\author{
UNIVERSIDADE DE SÃO PAULO \\ MUSEU DE ARQUEOLOGIA E ETNOLOGIA \\ PROGRAMA DE PÓS-GRADUAÇÃO EM ARQUEOLOGIA
}

\title{
MEIOS MÍSTICOS DE REPRODUÇÃO SOCIAL: ARTE E ESTILO NA CERÂMICA FUNERÁRIA DA AMAZÔNIA ANTIGA
}

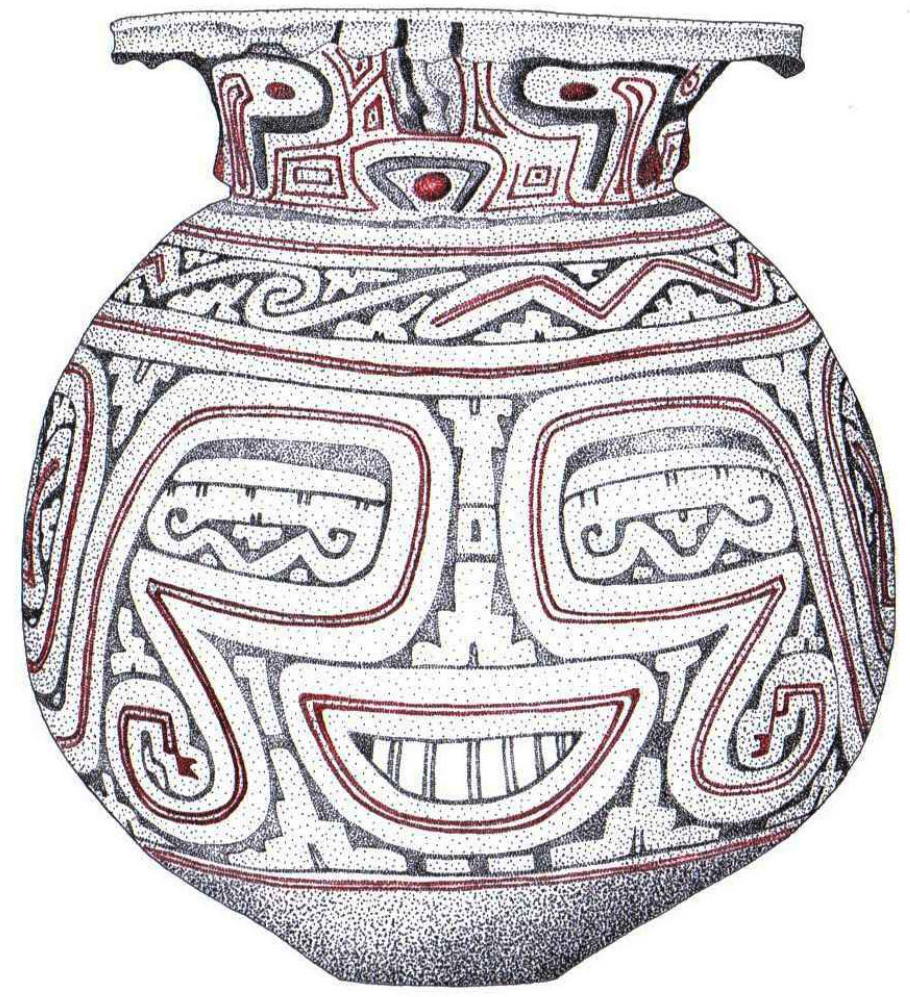

Cristiana Nunes Galvão de Barros Barreto

São Paulo 2008 


\section{UNIVERSIDADE DE SÃO PAULO MUSEU DE ARQUEOLOGIA E ETNOLOGIA PROGRAMA DE PÓS-GRADUAÇÃO EM ARQUEOLOGIA}

\section{MEIOS MÍSTICOS DE REPRODUÇÃO SOCIAL: ARTE E ESTILO NA CERÂMICA FUNERÁRIA DA AMAZÔNIA ANTIGA}

Cristiana Nunes Galvão de Barros Barreto

Tese apresentada ao Programa de Pós-Graduação em Arqueologia do Museu de Arqueologia e Etnologia da Universidade de São Paulo para obtenção do título de Doutor em Arqueologia.

Orientador: Prof. Dr. Paulo Antonio Dantas De Blasis

Linha de Pesquisa: Representações simbólicas em arqueologia 
a meus pais

pelo exemplo moral e acadêmico 


\section{A G R A DECIMENTOS ${ }^{1}$}

Muitas pessoas contribuíram de forma definitiva para o desenvolvimento das idéias aqui apresentadas. Gostaria de agradecer a todos e deixar aqui registrado o meu reconhecimento sem, no entanto, responsabilizá-los pelas reflexões e conclusões avançadas nesta tese, as quais foram geradas em um relativo isolamento acadêmico.

Vera Coelho foi a primeira pessoa a me ensinar a olhar potes de cerâmica, quando ainda no meu primeiro ano de faculdade, me passou a tarefa de analisar uma coleção de cerâmica xinguana. Foi então que descobri que os potes podiam ter cabeças, rabos, barrigas e, até mesmo, almas.

Coincidentemente, esta tese retoma temas que foram muito caros ao meu orientador do mestrado, Ulpiano Toledo Bezerra de Meneses, a quem serei sempre muito grata pelas profundas marcas intelectuais que deixou na minha formação acadêmica.

Meu interesse pela arqueologia amazônica foi despertado inicialmente por Irmhild Wüst, em uma perspectiva a partir do Brasil Central. Quando no departamento de antropologia da Universidade de Pittsburgh, Robert Drennan me incentivou a refletir sobre as implicações de minhas pesquisas nas aldeias circulares do Brasil Central para a arqueologia dos cacicados amazônicos. Desde que cursei o seu já legendário seminário de "Chiefdoms" tenho buscado os caminhos da pesquisa arqueológica para melhor entender porque e como as sociedades se tornam menos igualitárias e mais injustas. Passados muitos anos, me reencontrei refletindo sobre as mesmas questões timidamente esboçadas em um trabalho de fim de curso, no qual procurava relacionar as variações estilísticas da arte Olmeca a modelos explicativos para a rápida extinção desta cultura.

Foi também na Universidade de Pittsburgh que conheci Michael Heckenberger, colega e amigo desde então, e com quem a troca de idéias sobre a arqueologia da Amazônia tem sido constante e estimulante. Sou muito grata a seu incentivo moral para conclusão desta tese.

Devo minha entrada verdadeira na arqueologia amazônica a Eduardo Neves e seu generoso convite de parceria no projeto de livro e exposição, Unknown Amazon, realizado juntamente com Colin McEwan, no British Museum em 2000. Este projeto me proporcionou a visita a muitas das coleções européias e brasileiras aqui mencionadas, em memoráveis viagens da equipe curatorial, sempre documentadas pelo fino olhar e humor (não menos fino) do fotógrafo Fernando Chaves. Muitas de suas fotos são utilizadas aqui.

Com Eduardo aprendi não só a destrinchar e depurar a arqueologia das fases e tradições cerâmicas da Amazônia, mas sobretudo a entender aquelas teorias, nem sempre explícitas na literatura, que correlacionam estas fases e tradições a grupos etno-linguísticos. A produção científica do Projeto Amazônia

\footnotetext{
${ }^{1}$ Esta tese contou com o apoio financeiro da CAPES através da concessão de uma bolsa de doutorado a partir de abril de 2006.
} 
Central, por ele coordenado, e suas sínteses mais recentes sobre a arqueologia amazônica têm possibilitado um entendimento das dinâmicas de ocupação da região, sem o qual as reflexões aqui apresentadas não se sustentariam. Desde então, a convivência acadêmica e pessoal com Eduardo tem sido um estímulo definitivo, e certamente teria abandonado algumas das idéias bastante especulativas sobre a cerâmica marajoara, não fosse por seus comentários sempre muito positivos.

Devo a Colin McEwan a minha "iniciação" na leitura da iconografia marajoara, e às suas longas digressões durante nossas visitas às coleções. Com o seu olhar experiente e sua formação "lathrapiana" Colin me fez perceber o potencial do universo simbólico e ideológico imbuído nas cerâmicas para um entendimento verdadeiramente antropológico das sociedades ameríndias précoloniais.

O projeto Unknown Amazon, além de marcar minha sedução definitiva pela arqueologia amazônica, me possibilitou o contato e diálogo acadêmico com muitos estudiosos da área que de alguma forma influenciaram meu trabalho. Denise Schaan tem gerado muitas das idéias e hipóteses retrabalhadas nesta tese e a possibilidade de travar um diálogo acadêmico aberto com ela tem sido muito estimulante. Outros incentivos importantes vieram de Vera Guapindaia e sua contribuição sobre a cerâmica funerária; Edithe Pereira, e seu olhar sobre a arte rupestre e arte pré-histórica da Amazônia em geral; Juliana Machado, junto com a qual tive o prazer de me aventurar na história das expedições amazônicas e outros projetos curatoriais; e José Oliver, outro "lathrapiano" preocupado em repensar a arqueologia amazônica.

Ao lidar com a coleção do Instituto Cultural Banco Santos, o trabalho de coordenação curatorial de Ana Maria Leitão, e as discussões tanto com Julia Berra, na catalogação das peças, como com a equipe de restauro, coordenada por Gedley Braga e Angela Freitas, foram decisivos para entendermos, peça por peça, alguns dos princípios de decoração da cerâmica marajoara. A qualidade dos desenhos feitos por Julia e as imagens registradas por Denise Andrade permitiram que eu documentasse e ilustrasse muitas das observações aqui presentes.

Durante minha estadia em Oxford, Leslie Bethell me acolheu no Centre for Brazilian Studies, onde comecei a escrever sobre arte e arqueologia, e também apoiou minhas pesquisas sobre coleções amazônicas em museus britânicos.

No programa de doutorado do MAE, sou extremamente grata a Paulo A. D. De Blasis e a Eduardo Neves por acompanharem minhas hesitações nas mudanças de tema para a tese e oferecerem apoio incondicional às minhas decisões finais. Agradeço especialmente ao Paulé pelo seu incentivo e apoio enquanto orientador e por sua solidariedade de colega e amigo de longa data. Com ele, algumas conversas pelo longo corredor do MAE me ajudaram a explicitar melhor algumas das idéias aqui apresentadas.

Sou também muito grata à Fabíola Silva por sua leitura criteriosa do meu Memorial de qualificação e suas sugestões e orientações bibliográficas, ainda no início deste projeto. 
Cursar a disciplina "Antropologia da Arte" ministrada por Aristóteles Barcelos Neto no departamento de Antropologia da FFLCH me despertou para um novo entendimento da arte ameríndia amazônica. Tenho certeza de que se a leitura indigesta de "Art and Agency" de Alfred Gell, obra tão utilizada nesta tese, não tivesse se tornado prazerosa e estimulante sob a condução de Aristóteles, oferecendo suas próprias perspectivas teóricas, eu jamais teria sido capaz de aplicar muitos dos conceitos de Gell na análise do material arqueológico. $O$ curso de Aristóteles também me foi de grande valia para tecer o diálogo entre a etnologia e a arqueologia.

Agradeço igualmente à diretoria do MAE, José Luiz de Morais e Maria Cristina de Oliveira Bruno, pelo apoio institucional e por entenderem a importância em promover estudos científicos e curatoriais da coleção do Instituto Cultural Banco Santos, acolhida pelo museu em condições bastante peculiares, e também por me terem confiado esta tarefa com tanta segurança.

O banco de dados da coleção efetuado pela equipe do MAE serviu como base para as análises posteriores dos vasilhames e urnas funerárias. A assistência do estagiário Thiago Trindade, tanto na correção do banco de dados, como na análise dos vasilhames foi também crucial. No MAE, todo o pessoal do Serviço Técnico de Curadoria, sempre que possível, ajudou-me no acesso e manuseio das peças, ainda que questões de segurança e de logística de acondicionamento desta coleção não tenham sempre permitido condições ideais de análise. Sou muito grata à presteza de Wagner Souza no registro fotográfico de peças faltantes.

Nas ilustrações, contei com os serviços de Mendel Khan e Denise Dal Pino. Val de Moraes realizou os lindos desenhos em pontilhismo. Julia Kovensky me ajudou na formatação do banco de dados das urnas.

O recente Encontro Internacional de Arqueologia Amazônica em setembro último, em Belém, onde apresentei algumas idéias sobre o tema desta tese, proporcionou um fórum de debates e discussões informais muito ricos, em especial com Michael Heckenberger, Eduardo Neves, Stéphen Rostain, Manuel Arroyo-Kaolin, Renato Kipnis, Edithe Pereira, Vera Guapindaia, Fabíola Silva, Aristóteles Barcelos Neto, Juliana Salles Machado, Denise Gomes, entre outros.

Por fim, agradeço a meus pais, Célia e José, a meu marido Kurt e a meus filhos, Sofia e Thomas, pelo apoio, compreensão e paciência na longa e ansiosa espera pela conclusão deste projeto. 
página

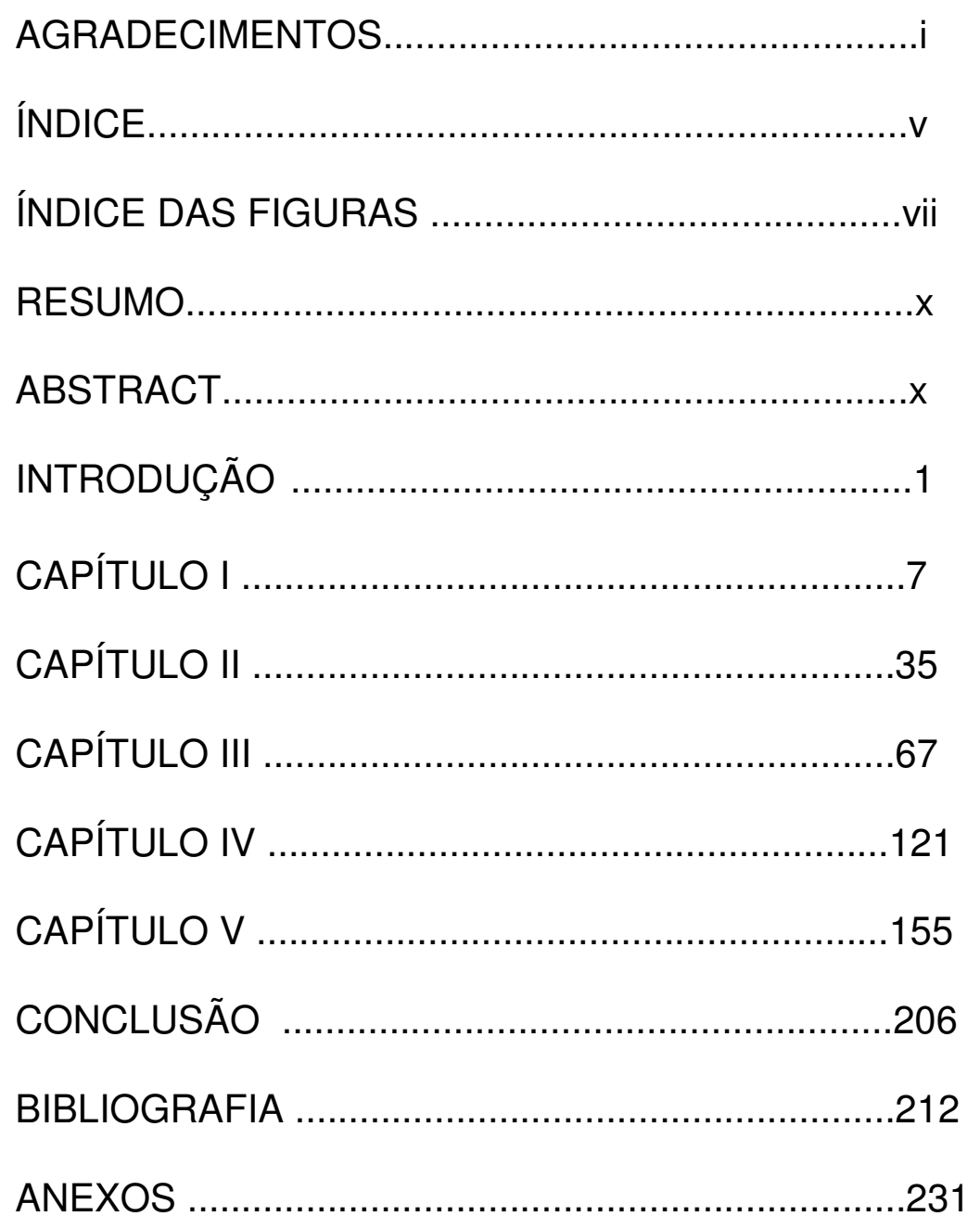


ÍNDICE

ÍNDICE DAS FIGURAS vii

RESUMO $\quad x$

ABSTRACT $x$

INTRODUÇÃO

1. Histórico da pesquisa 1

2. Delimitação do tema 2

3. Organização dos capítulos 4

\section{CAPÍTULO |}

ARTE, ARQUEOLOGIA E TRANSFORMAÇÕES SOCIAIS NA AMAZÔNIA PRÉ-COLONIAL 7

1. A arqueologia dos cacicados na Amazônia pré-colonial 7

2. Arte e estilo na arqueologia da Amazônia 16

3. De Lévi-Strauss a Alfred Gell: a antropologia da arte

4. Lições da etnologia: estilo, cultura material e ritual 30

\section{CAPÍTULO II}

\section{RITUAIS FUNERÁRIOS E OS MEIOS MÍSTICOS} DE REPRODUÇÃO SOCIAL NA AMAZÔNIA

1. Arqueologia, rituais funerários e complexidade social 35

2. Rituais funerários e ancestralidade $\quad 37$

3. Rituais funerários na Amazônia indígena 39

4. Bases para uma teoria sobre a morte e o sobrenatural 42

5. Entre o visível e o invisível 46

6. Os meios místicos de reprodução social 52

O ritual funerário Bororo: a força da expressão estética 52

O ritual funerário Kuarup: a reafirmação de estruturas
hierárquicas

7. Para uma (etno)arqueologia de objetos funerários 64

\section{CAPÍTULO III}

ARQUEOLOGIA DAS URNAS FUNERÁRIAS DA AMAZÔNIA 67

1. Artefatos como categorias conceituais: o recorte "urnas funerárias" 67

2. Urnas funerárias e enterramentos secundários na Amazônia 72

$\begin{array}{ll}\text { As urnas da fase Marajoara } & 74\end{array}$

As urnas Aruã $\quad 76$

$\begin{array}{ll}\text { As urnas Caviana } & 78\end{array}$

As urnas Maracá $\quad 80$

As urnas Mazagão $\quad 82$

As urnas Aristé $\quad 83$ 
As urnas Paredão $\quad 85$

As urnas Guarita $\quad 87$

As urnas Caimito $\quad 90$

3. Permanências e variações estilísticas regionais 94

4. Urnas funerárias: estilo e estratificação social 99

5. Fluxo e interação regional 107

6. Fluxo e complexidade social 112

7. Para um modelo de variabilidade regional 115

\section{CAPÍTULO IV}

O ESTILO DA CERÂMICA CERIMONIAL MARAJOARA

1. A análise estilística da cerâmica marajoara da coleção ICBS-MAE 121

Objetivos da análise

121

O universo de análise

123

2. A cerâmica cerimonial Marajoara 127

$\begin{array}{ll}\text { Urnas, vasos e recipientes } & 127\end{array}$

Os atributos observados 131

3. As tecnologias de encantamento da cerâmica marajoara 136

Figuras icônicas e "abstratas" 136

Os planos de composição 139

Ritmo e movimento 141

Eixos de simetria e a (des)construção de corpos 144

O princípio de representação desdobrado 146

4. Entre emblemas e ídolos: uma arte de sociedades de máscaras 152

O DESPERTAR DAS ALMAS: A ARTE FUNERÁRIA MARAJOARA 155

1. Uma classificação das urnas da coleção ICBS-MAE 155

2. As urnas do Grupo 1

Elementos de animação: corporalidade, sentidos e agência 166 Corpo e alma $\quad 171$

Representação desdobrada e magia 174

Representação desdobrada e síntese 177

Os elementos variáveis 179

Entre o visual e o ritual $\quad 182$

3. As urnas do Grupo 2

4. As urnas do Grupo $3 \quad 193$

5. As urnas do Grupo 4

6. Síntese dos resultados da análise das urnas 203

CONCLUSÃO 206

$\begin{array}{ll}\text { BIBLIOGRAFIA } & 212\end{array}$

ANEXOS 231

1. Composição da coleção ICBS-MAE 231

2. Catálogo das urnas funerárias da coleção ICBS-MAE 235 


\section{ÍNDICE DE FIGURAS}

Figura 2.1 Estatueta lítica da região dos rios Tapajós-Trombetas $\quad 50$

Figura 2.2. Três momentos do Kuarup 61

Figura 3.1 Escavações dirigidas por W. Farabee no aterro Camutins $\quad 67$

Figura 3.2 Formas de algumas urnas marajoara 75

Figura 3.3 Urnas Aruã conforme documentado por Meggers e Evans $\quad 77$

Figura 3.4 Urnas ditas "Caviana” $\quad 79$

Figura 3.5 Urnas Maracá $\quad 81$

Figura 3.6 Urnas Mazagão

Figura 3.7 Urnas Aristé. $\quad 84$

Figura 3.8 Formas características das urnas Paredão 86

Figura 3.9 Urnas da sub-tradição Guarita 88

Figura 3.10 Distribuição dos diferentes estilos de urnas do Horizonte Policromo da Amazônia 90

$\begin{array}{ll}\text { Figura 3.11 Vasilhame do complexo Caimito } & 91\end{array}$

Figura 3.12 Urnas antropomorfas da fase rio Napo, Equador 93

Figura 3.13 Urnas e estatuetas antropomorfas 110

Figura 3.14 Urna Maracá e estatueta marajora 111

Figura 3.15 Muiraquitãs em cerâmica, fase marajoara 114

$\begin{array}{ll}\text { Figura 4.1 Prato marajoara da coleção ICBS-MAE } & 121\end{array}$

Figura 4.2 Pequenas tigelas da coleção ICBS-MAE 132

Figura 4.3 Tigelas da coleção ICBS-MAE 133

Figura 4.4 Peças da coleção ICBS-MAE com o motivo do
"rosto sorridente."

Figura 4.5 Exemplo de vasilhame com três campos de decoração 
Figura 4.6 Exemplo de falsa simetria em urna funerária

Figura 4.7 Vasilha antropomorfa 145

Figura 4.8 Exemplo de representação desdobrada 146

Figura 4.9 Exemplo de composição de figura desdobrada 147

Figura 4.10 Desenho sobre papel de mulher Kadiweu replicando a pintura facial. $\quad 148$

Figura 4.11 Tigela com desenhos desdobrados. 149

Figura 4.12 Etapas de desdobramento das imagens. 150

Figura 4.13 Eixos de simetria e formação de imagem "encadeada." 150

Figura 4.14 Eixo de simetria das figuras na superfície externa da vasilha.

Figura 5.1 Variações nos elementos constitutivos da figura principal nas urnas do grupo 1

Figura 5.2 Exemplos de possíveis urnas "femininas" e "masculinas"

Figura 5.3 Detalhe das faces da figura nas urnas do grupo 1

Figura 5.4 Alargadores de orelha em cerâmica da coleção ICBS-MAE 164

Figura 5.5 Urna da coleção Carlos Estevão de Oliveira 166

Figura 5.6 Bonecos laterais em urnas do grupo 1

Figura 5.7 Urna funerária com figura de olho no bojo ICBS-MAE 1192173

Figura 5.8 Eixo de simetria para a representação desdobrada nas urnas marajoara

Figura 5.9 As quatro faces de uma urna do grupo 1

Figura 5.10 - Urna ICBS-MAE 1601

Figura 5.11 Decoração da superfície externa da borda da urna ICBS-MAE 1840

Figura 5.12 Urna ICBS-MAE 1598

Figura 5.13 Desenho da urna ICBS-MAE 1839 
Figura 5.13 Figuras zoomorfas pintadas no bojo das urnas do grupo $1 \quad 178$

Figura 5.14 Figura antropomorfa estilizada em bojo de urna do grupo 1180

Figura 5.15 Motivos em faixa frontal das urnas do grupo 1

Figura 5.16 Sequência da confecção das urnas ICBS-MAE 1597 e 1830185

Figura 5.17 Os quatro lados das urnas ICBS-MAE 1597 e $1830 \quad 186$

$\begin{array}{ll}\text { Figura } 5.18 \text { Urnas do grupo } 2 & 187\end{array}$

Figura 5.19 Perfil mostrando posicionamento das urnas escavadas por Meggers e Evans no sítio Monte Carmelo 189

Figura 5.20 Urna encontrada por Schaan no aterro Belém 189

Figura 5.21 "Frente" e "lado" da urna 1619

Figura 5.22 Urna da coleção do Museu de Arte

Pré-colombiana Barbier-Mueller 192

Figura 5.23 Urna ICBS-MAE 1620

Figura 5.24 a) Urna da coleção Barbier-Mueller e b) Urna do acervo do Museu Nacional da UFRJ

Figura 5.25 Urna documentada em Palmatary 195

Figura 5.26 Tangas cerâmicas decoradas 196

Figura 5.27 Urnas Pacoval Inciso documentada em Palmatary 197

Figura 5.28 Urna com "barriga e umbigo" 200

Figura 5.29 Urna ICBS-MAE 326

Figura 5.30 Urna "Pacoval Inciso" do acervo do Museu Etnológico de Berlim 


\section{RES U M O}

O presente trabalho propõe um enfoque na arte e no estilo da cerâmica arqueológica funerária da Amazônia com 0 objetivo de aprofundar 0 entendimento sobre as formas de organização social e as dinâmicas précoloniais de ocupação humana da região. Utilizando-nos de conceitos da antropologia social e da antropologia da arte sobre estilo e agência, analisamos os objetos rituais funerários enquanto mediadores e transformadores das relações sociais. Uma incursão exploratória na etnologia de rituais funerários, em particular nas implicações do perspectivismo ameríndio sobre as concepções de humanidade, ancestralidade, morte, corpo e alma na Amazônia, somada a um breve panorama da variabilidade estilística das urnas antropomorfas das diferentes tradições e fases cerâmicas arqueológicas, propomos alguns parâmetros comparativos para a correlação entre estilos funerários e formas de reprodução social. Os parâmetros propostos são então verificados para o caso particular de um conjunto de urnas funerárias da fase marajoara. Concluímos que a cerâmica ritual e, em particular a funerária, apresenta um enorme potencial analítico para resolvermos algumas incongruências epistemológicas que tem se apresentado entre a arqueologia e a etnologia da Amazônia, notadamente sobre os diferentes princípios de organização social das sociedades do passado e do presente.

Palavras chave: arqueologia da Amazônia; arte e arqueologia, estilo e arqueologia, arqueologia da morte, rituais funerários

\section{A B S T R A C T}

This dissertation proposes a focus on the art and style of archeological funerary vessels from Amazonia to improve understanding of patterns of social organization and pre-colonial change in the human occupation of the region. Drawing from concepts about style and agency in social anthropology and the anthropology of art, we analyze objects in funerary rituals as mediators and transformers of social relations. An exploratory incursion into the ethnology of funerary rituals, especially the implications of Amerindian perspectivist conceptions of humanity, ancestry, death and soul in Amazonia, and a summary comparative panorama of the stylistic variation of anthropomorphic urns from different archaeological ceramic traditions and phases, we propose some comparative parameters for correlations between funerary styles and forms of social reproduction. These parameters are then examined for the particular case of funerary vessels from the Marajoara phase. We conclude that ritual ceramics, especially funerary ceramics, presents an enormous analytical potential for resolving epistemological incongruences that have appeared in Amazonian archaeology and ethnology, notably that of different principles of social organization in the past and present.

Keywords: Amazonian archaeology, art and archaeology, style and archaeology, death archaeology, funerary rituals. 
Despertar a alma: este é, dizem-nos, o fim último da arte, o efeito que ela pode provocar.

G. W. Hegel

O Belo na Arte, Curso de Estética 


\section{N T R O D U Ç Ã O}

\section{Histórico da pesquisa}

Esta tese tem uma história um pouco diferente dos tradicionais trabalhos acadêmicos. As reflexões sobre a cerâmica marajoara aqui apresentadas não foram geradas em um laboratório de análises de material arqueológico proveniente de escavações, como costumeiro, mas sim em empreitadas curatoriais de diferentes naturezas: visitas a coleções museológicas, seleção de peças para exposições, orientações para restauro e expografias; produção de imagens e textos para catálogos, além das observações sempre surpreendentes sobre o impacto visual causado pelas peças sobre o público em geral.

Este contato íntimo com as peças mais exuberantes e bem preservadas da arqueologia amazônica, aos poucos foi possibilitando um entendimento bastante intuitivo de algumas recorrências e princípios básicos de composição da cerâmica arqueológica desta região, e em particular, da cerâmica marajoara. Quando, em 2002, a oportunidade de curar a enorme coleção de arqueologia amazônica reunida pelo Instituto Cultural Banco Santos se apresentou, nos debruçamos sobre ela de forma a transformar este conhecimento intuitivo em conhecimento científico, tarefa esta bastante complicada, vistos os interesses divergentes daquela instituição que sempre privilegiou o potencial expositivo de suas coleções. Mas, graças ao apoio buscado junto ao IPHAN, e membros da equipe museológica do Instituto, conseguimos garantir uma abordagem mais científica, tanto na documentação como na catalogação do material, agregando as informações disponíveis na literatura acadêmica especializada, e ao mesmo tempo abrindo a coleção para a interlocução com pesquisadores da área. Este lento e minucioso trabalho foi interrompido com o fechamento do Instituto e a transferência da coleção para o MAE.

Foi a partir da disponibilização da coleção no MAE que vimos a oportunidade de transformá-la em objeto de estudo para um projeto acadêmicocientífico de doutoramento, propondo então ao programa de pós-graduação do museu uma mudança temática bastante radical (de um projeto sobre a 
arqueologia das aldeias circulares do Brasil Central, para um estudo estilístico de cerâmica marajoara).

\section{Delimitação do Tema}

A correlação entre princípios estilísticos observados na cultura material de uma sociedade e suas formas de sociabilidade é um tema clássico da arqueologia desde os seus primórdios, mas que vem sendo repensado a partir de um recente e renovado interesse da antropologia em estudos de cultura material e de uma nova antropologia da arte (Conkey, 1990; Morphy, 1994; Gosden, 2001). A idéia de explorar este tipo correlações na cerâmica amazônica, e a delimitação de um tema mais específico para se trabalhar com a referida coleção, levou em consideração, inicialmente, o aproveitamento máximo de alguns potenciais exibidos pela própria coleção, entre eles, a grande quantidade de objetos cerâmicos da fase marajoara, decorados e inteiros. Pensamos então em aprofundar o tema da representação do corpo na cerâmica, tema este de fácil inserção dentro do cenário teórico da atual antropologia amazônica, onde a "construção da pessoa" e a "fabricação do corpo" entre as sociedades indígenas já constituem temas bem desenvolvidos (Viveiros de Castro, Seeger e da Matta, 1979). Além do mais, vislumbramos a possibilidade de se contrapor uma perspectiva arqueológica sobre as formas de "materialização do corpo" a uma perspectiva etnológica sobre a "inconstância da alma selvagem" (Viveiros de Castro, 2002). Para tal, isolamos provisoriamente duas categorias de objetos que representam corpos tridimensionalmente e que são numericamente expressivas na coleção: as urnas funerárias e as estatuetas antropomorfas da fase marajoara.

As análises destes objetos engendraram algumas dificuldades metodológicas inerentes ao trabalho com coleções desprovidas de uma contextualização arqueológica precisa, sobretudo quanto aos atributos funcionais dos objetos. Urnas funerárias ou recipientes para fermentação de bebidas? Ídolos ou chocalhos antropomorfos, ou ambos? Tentamos evitar a corriqueira, mas pouco segura associação entre cerâmica "decorada" e uma natureza necessariamente "cerimonial", categoria classificatória bastante 
freqüente nas análises cerâmicas arqueológicas, mas pouco qualificada. Ao invés, procuramos algumas âncoras conceituais e alguns parâmetros de variabilidade, tanto na etnologia, como na arqueologia da região, de forma a fazer com que os princípios estilísticos identificados nestes objetos pudessem servir para aprofundar e construir novas maneiras de se entender as formas de sociabilidade das populações pré-coloniais da Amazônia.

Ao explorarmos o universo etnográfico dos rituais funerários das sociedades indígenas amazônicas e dos contextos funerários documentados pela arqueologia, percebemos que, em ambos os lados, o vasto e rico material já levantado apontava para questões de relevância fundamental para se entender formas e graus de complexidade social e organização política destas sociedades, uma vez que muitas destas formas e relações de hierarquia e poder estão relacionadas às concepções de ancestralidade, de vida e morte, e de corpo e alma.

Por outro lado, o universo contextual das estatuetas na etnografia e na arqueologia da região se mostrou bem menos conhecido, apesar de alguns estudos clássicos na etnografia Karajá (como os de Baldus,1936; Hartman, 1973; Chiara,1970; e mais recentemente Campos, 2007), e do artigo de ReichelDolmatoff (1961) sobre a estatuária Cuna da Colômbia, oferecerem parâmetros documentais e interpretativos pontuais. Além disso, na Amazônia pré-colonial, o universo das estatuetas, marajoaras e tapajônicas, já tinha sido explorado Roosevelt (1988) e Schaan (2001b) a partir de questões mais relacionadas à identidade de gênero do que a formas de organização social. Também já tínhamos explicitado estas questões de identidade e gênero a partir de algumas estatuetas da coleção Instituto Cultural Banco Santos (Barreto, 2003 e 2004).

Por estes motivos, deixamos em suspenso o estudo das estatuetas da coleção, e escolhemos a cerâmica funerária como o objeto propriamente de estudo para esta tese. Isto posto, estamos convencidos de que a cerâmica da fase marajoara deve ser estudada enquanto um sistema que engloba várias categorias conceituais de objetos, cuja relação entre as categorias encerra muitos dos princípios estilísticos aqui identificados. Assim sendo, a relação entre urnas funerárias antropomorfas e a estatuária não foi ignorada nesta tese. 


\section{Organização dos capítulos}

No capítulo inicial, intitulado Arte, Arqueologia, e Transformações Sociais na Amazônia Antiga justificamos a relevância dos temas escolhidos, apresentamos as principais inspirações teóricas, assim como as implicações das teorias para as abordagens metodológicas empregadas. Aqui, a arqueologia dos cacicados da Amazônia é revisitada no sentido de avaliar as diferentes formas com que as características estéticas e tecno-estilísticas dos artefatos foram utilizadas para construir argumentos a favor ou contra 0 desenvolvimento de sociedades complexas na Amazônia pré-colonial.

Apontamos algumas discrepâncias entre esta arqueologia de cacicados e as teorias advindas da etnologia, que desde as "sociedades contra o Estado" de Clastres, até as sociedades instáveis do perspectivismo amazônico de Viveiros de Castro, parecem apontar formas de sociabilidade mais igualitárias. Introduzimos a idéia de que o estudo dos estilos e da arte, de uma forma dinâmica, isto é na sua variabilidade regional e temporal e, sobretudo, na esfera dos objetos rituais, possa constituir uma ponte para um diálogo entre a arqueologia e a etnologia, em direção a uma visão consensual.

A partir das antropologias da arte praticadas por Lévi-Strauss e Alfred Gell, explicitamos algumas das teorias utilizadas em nossas análises: respectivamente, sobre a função social da arte e a teoria de agência dos objetos. Destas teorias decorre nossa escolha por uma definição operacional de estilo, conforme proposta por Peter Roe, e por um método de análise descritivo e indutivo, de identificação de recorrências para a definição dos princípios estilísticos sob os quais foram concebidos os artefatos. Outras questões metodológicas, levantadas a partir do conhecimento etnográfico do mundo da mágica ritual, também são aqui anunciadas.

No segundo capítulo, intitulado Rituais Funerários e os Meios Místicos de Reprodução Social na Amazônia desenvolvemos algumas das implicações da etnologia de rituais funerários na Amazônia para a análise arqueológica de objetos funerários. Em particular examinamos os funerais enquanto momentos 
de forte produção estética direcionada tanto para a reprodução como para a transformação de formas tradicionais de sociabilidade.

Concepções ameríndias sobre a morte e o sobrenatural constituem as bases para diferenciar rituais voltados para a ressocialização dos mortos e aqueles voltados para reafirmar as estruturas hierárquicas dadas pela ancestralidade.

Retomamos as seqüências dos ritos em dois casos de ritual funerário bem estudados na etnologia amazônica, o ritual funerário Bororo, e o Kuarup, observando em cada seqüência, o papel dos objetos envolvidos, os contextos de intenções à sua volta, e a agência e protagonismo destes objetos, desde sua criação até o seu descarte. Propõe-se assim algumas idéias em direção a uma etno-arqueologia dos rituais funerários que possa ser utilizada como parâmetro interpretativo da cerâmica funerária arqueológica da Amazônia.

No terceiro capítulo, intitulado Arqueologia das Urnas Funerárias da Amazônia, construímos um panorama sobre as urnas funerárias na arqueologia da Amazônia, em especial, no que diz respeito às variações estilísticas e diferentes maneiras de representar corpos humanos. Da baixa Amazônia, até os contrafortes andinos, estabelece-se diferentes graus de variabilidade na representação humana, possivelmente correlacionados à posição das diferentes sociedades em relação aos fluxos inter-regionais, aos diferentes estilos de se demarcar a diferenciação social entre os indivíduos e, finalmente, às diferentes maneiras de se legitimar autoridade e poder. Propõe-se que esta variabilidade também seja resultante da variabilidade etno-linguística dos povos que ocuparam a região antes do contato, particularmente da história de expansão das populações proto-Aruaque e proto-Tupi. A partir disso, constrói-se um modelo preditivo polarizado entre dois tipos de sociedades, com graus de variabilidade estilística e formas de representação humana na cerâmica funerária correspondentes.

No quarto capítulo, intitulado 0 Estilo da Cerâmica Cerimonial Marajoara especificamos a abordagem metodológica para a definição de uma cerâmica cerimonial marajoara e o trabalho de análise desenvolvido com os vasilhames da coleção do Instituto Cultural Banco Santos no MAE. Alguns 
princípios estilísticos gerais à cerâmica marajoara são apresentados como resultado das análises, sobretudo, aqueles que podem ser identificados como definidores de uma arte de sociedades de máscaras, conforme definido por Lévi-Strauss, e as suas "tecnologias de encantamento".

No quinto e último capítulo, intitulado O Despertar das Almas: as Urnas Funerárias Marajoara apresentamos uma tipologia das urnas funerárias marajoara, onde os tipos variam entre um modelo constituído nos moldes reconhecidos pela literatura da antropologia da religião de construção de ídolos, e outro, cuja função emblemática parece ser mais predominante. Colocamos a hipótese de que o estilo funerário marajoara pode ser resultante de uma busca pela conciliação entre uma relação de identificação emblemática e pertencimento a uma identidade marajoara coletiva perante o mundo exterior, e uma relação de idolatria de entidades míticas ancestrais, ou sobrenaturais, que reforçaria a rivalidade entre grupos internos à sociedade marajoara.

Esta hipótese pode explicar algumas das discrepâncias observadas entre as cerâmicas funerárias marajoara e as demais urnas funerárias conhecidas para Tradição Polícroma no restante da Amazônia, freqüentemente associadas às populações proto-Tupi, e talvez elucide os processos que levaram à extinção da sociedade marajoara por volta de 1400 d.C., ou sua absorção por povos subseqüentes.

$\mathrm{Na}$ Conclusão apontamos o potencial explicativo das teorias sobre 0 perspectivismo ameríndio para a arqueologia. Retomamos o modelo apresentado no terceiro capítulo para o caso específico da cerâmica funerária marajoara, e tecemos algumas considerações finais quanto à posição dos cacicados de Marajó entre os dois pólos do modelo proposto e sua inserção no quadro de transformações regionais quando de sua decadência. 


\section{A PíTULO I}

\section{ARTE, ARQUEOLOGIA E TRANSFORMAÇÕES SOCIAIS NA AMAZÔNIA PRÉ-COLONIAL}

Our cosmovision is based upon our science; the Indians' is based upon their knowledge. Of course, we want to continue in our world which, for better or for worse, is our creation. But in order to live in it, here, today, tomorrow and in the future, we need the Indian's knowledge. And here I am referring not only to the practical knowledge of the Indians, to the sort of things a peasant knows. What I am trying to say is that the Indians' way of life reveals to us the possibility of a separate strategy of cultural development; in other words, it presents us with alternatives on an intellectual level and on a philosophical level. We should keep in mind these alternative cognitive models.

Gerardo Reichel-Dolmatoff

(I Congresso Internacional de Etnobiologia, Belém1988)

\section{A arqueologia dos cacicados na Amazônia pré-colonial}

Há meio século atrás, Betty Meggers e Clifford Evans inauguraram o debate sobre a existência de sociedades complexas na Amazônia pré-colonial a partir da constatação da complexidade técnico-estilística da cerâmica da fase marajoara. Desde então, o passado pré-colonial da Amazônia tem sido objeto de debates acirrados entre modelos concorrentes, dentro de uma longa e cíclica história de interpretações, a qual, desde tempos coloniais, tem oscilado entre um passado de grandes civilizações perdidas, e outro menos glorioso, de sociedades simples, pequenas, e "primitivas », talvez mais próximas das atuais (Barreto e Machado 2001; Neves, 1999).

As pesquisas arqueológicas, amparadas da etno-história e da história oral indígena, têm trabalhado em torno de dois cenários bastante distintos, nos quais variam, sobretudo, o grau de complexidade social e o tamanho das populações amazônicas pré-coloniais. Oscilam assim entre um sistema de grandes cacicados rivais que teriam emergido rapidamente durante o milênio que antecede a chegada dos europeus, integrados através de extensas redes de trocas e alianças de guerra, (Lathrap, 1970; Carneiro, 1981, 1998; Roosevelt, 1980; 1999; Heckenberger, 2005; Heckenberger et al. 1999, 2001; Neves, 2004; Schaan, 2004; Stahl, 2002, Whitehead,1994) e outro sistema de sociedades 
tribais menores, as quais teriam atingido há milênios um estado de equilíbrio adaptativo na floresta tropical que perduraria até os nossos dias (Meggers, 2001, para uma síntese).

Muitos dos argumentos deste debate são relativos à organização social e à economia destas sociedades e, sobretudo, à sustentabilidade da floresta tropical e às possibilidades de manejo de recursos naturais, isto é, às limitações ou potenciais ecológicos para o desenvolvimento de um ou outro tipo de formação social. Desta forma, a interpretação dos registros arqueológicos tem privilegiado aqueles aspectos que podem ser considerados verdadeiras "assinaturas" de um ou outro sistema, assim como a dimensão e a duração dos assentamentos e a própria dinâmica de formação do registro arqueológico, como os padrões de formação de terra preta e de descarte da cerâmica (Neves et al 2004; Machado, 2005).

Mais recentemente, um novo cenário vem sido proposto por Neves a partir de suas pesquisas na Amazônia Central (Neves, 2008). Neves parte da premissa de que as sociedades do período pré-colonial mais tardio eram cíclicas, com períodos alternados de centralização e descentralização política, para explicar porque, em algumas áreas, como em Santarém e no alto Xingu, as sociedades parecem ter passado por um alto grau de centralização e hierarquia social, deixando vestígios de enormes assentamentos quase urbanos (Roosevelt, 1999; Heckenberger et al, 2008), enquanto que em outras, como ao longo da costa das Guianas, não foram registradas quaisquer evidencias de formação cacicados complexos (Boomert ,2004; Rostain and Versteeg, 2004). É possível, contudo, que estas diferenças se devam simplesmente a processos de ocupação destas áreas por sociedades culturalmente distintas, de expansão, colonização de novas áreas e interação entre elas, prenunciando a diversidade lingüística e cultural até hoje presente na região.

De qualquer forma, as propostas de Neves deslocam a discussão sobre a existência ou não de complexidade social na Amazônia, para um entendimento mais aprofundado das diferentes maneiras com que sociedades se apropriaram do espaço, demarcaram seus territórios, interagiram entre si, em diferentes modos e graus de complexidade social. 
De fato, o que parece não ser questionado pelos proponentes destes diferentes cenários é a diversidade cultural que parece surgir, sobretudo no baixo Amazonas, durante o primeiro milênio da era cristã. Estas culturas, desenvolvidas localmente ou não, são reconhecidas principalmente pelos diferentes estilos de cerâmica e sítios funerários. Uma grande variedade de artefatos cerâmicos decorados ocorre nestes sítios, denotando um crescente investimento na produção de objetos para usos rituais ou cerimoniais. É esta cerâmica que têm servido de guia principal para a classificação dos sítios nas principais tradições arqueológicas da região, principalmente as diferentes fases e estilos da chamada Tradição Polícroma da Amazônia, conforme inicialmente estabelecidos por Meggers (1961).

Além da cerâmica mortuária, e especificamente das urnas funerárias, outros objetos cerâmicos como tigelas, pratos, vasos e estatuetas altamente decorados, assim como alguns raros objetos líticos esculpidos, como os muiraquitãs e os "ídolos" de pedra, chamam há tempos a atenção dos arqueólogos por sua elaboração técnica e estética, e foram, na verdade, o primeiro motivo para se pensar na presença de sociedades mais complexas na Amazônia, dando origem às primeiras hipóteses de imigração de povos oriundos de regiões vizinhas (tais quais os Andes ou o Caribe).

O que representa esta essa profusão quase repentina de objetos decorados com estilos regionais diversificados? Seria o resultado de uma rápida transformação de pequenas sociedades tribais em grandes cacicados rivais, onde a intensificação de rituais e de cerimônias legitimaria novas estruturas de poder, ou simplesmente o deslocamento de sociedades ceramistas mais complexas oriundas de regiões vizinhas para a região amazônica? Seria a complexidade maior da cerâmica um reflexo de um fenômeno regional mais amplo, com a formação de redes de troca mais extensas?

Estas são questões ainda pouco exploradas no debate atual que, como apontamos acima, enfoca mais os potenciais econômicos e os padrões de assentamentos do que a produção de artefatos propriamente dita, e sua circulação. 
Assim, ainda que a arqueologia da região tenha inicialmente tratado da cerâmica como um possível marcador de complexidade social, a relação entre a produção de objetos mais elaborados e formas de organização social mais complexas, mesmo que proposta por alguns arqueólogos para casos específicos, como o fez Roosevelt $(1988,1992)$ para Marajó, é uma relação que ainda não foi formalmente formulada enquanto uma teoria para a Amazônia e, portanto, tampouco foi verificada. A questão fundamental sobre o porquê do aparecimento desta cerâmica mais elaborada, permanece assim em aberto e está intimamente ligada a toda uma longa discussão sobre a própria origem das tradições cerâmicas da Amazônia e em especial da Tradição Polícroma, onde a profusão de objetos decorados parece ser mais intensa, e a crescente diversidade de estilos.

Alguns destes "novos" objetos que surgem no período em questão já foram interpretados como símbolos ou insígnias de prestígio e poder entre chefes e elites locais e parecem ter sido objeto de circulação e troca por toda a Amazônia, como é o caso de pingentes e adornos de nefrita e jadeíta, mais comumente conhecidos como muiraquitãs, encontrados por toda a região amazônica, Orinoco e Caribe, mas com apenas alguns centros de fabricação regionais (Boomert, 1987).

Talvez, mais importante do que os usos e a circulação regional destes objetos, seja o fato de que eles nos confirmam que, a partir de um certo momento, durante o milênio que antecede a colonização, algumas sociedades pré-coloniais amazônicas estavam de fato integradas a extensas redes regionais e é possível que esta integração esteja relacionada às mudanças nas indústrias cerâmicas com a diversificação de estilos regionais e a intensificação de objetos decorados.

Roe (1995:41) alerta para o papel do contexto geográfico e social do que ele denomina de "efeitos de interação" na cultura material. De acordo com este pesquisador, uma vez que estilos codificam informação, o acesso de uma sociedade a um maior fluxo de informação, em um cenário que favoreça a interação com outras sociedades, pode aumentar a complexidade estilística e a rapidez dos ciclos estilísticos. Talvez, este seja o melhor argumento disponível 
na literatura sobre estilos que possa explicar o porquê a diversidade estilística apareça na região do baixo Amazonas e estuário, uma região cujos atributos geográficos não só favorece a interação entre as diferentes sociedades ribeirinhas ao longo dos rios e ilhas estuarinas, mas que também propiciava contato via marítima com diferentes povos da costa Norte e Nordeste da América do Sul e ilhas do Circum-Caribe.

A grande questão que resta a ser resolvida, contudo, é a da relação entre o maior fluxo de informação, e a decorrente diversidade estilística, e as mudanças na organização social destas sociedades pré-coloniais.

Neste sentido, é interessante lembrar que juntamente com o surgimento de cerâmicas mais elaboradas e da circulação de objetos de prestígio, indicações arqueológicas do surgimento de sociedades mais centralizadas e hierárquicas tem sido a alta densidade de ocupação dos sítios arqueológicos que sugere uma organização social de assentamentos em grandes aldeias mais permanentes.

Além disso, este processo é acompanhado muitas vezes por profundas intervenções na paisagem natural - em alguns casos, de forma a reverter determinadas limitações ambientais -- para o estabelecimento de grandes populações na região, e possibilitar uma integração regional. A formação de "terras pretas" ricas para o cultivo (Petersen et all., 2001), a construção de estradas e valas de proteção (Heckenberger, 1996), ou a ereção de aterros artificiais como em Marajó (Schaan, 2004) sugerem mudanças na organização social destas sociedades na sua capacidade de mobilização de mão de obra e uma política necessariamente mais centralizada para a coordenação destes trabalhos.

Ainda que seja desconhecida a dinâmica de formação destes cacicados, sabemos que alguns deles desapareceram antes mesmo da conquista, como é o caso dos cacicados de Marajó (Schaan, 2001a), mas outros perduraram até o contato com os europeus, como o dos Tapajós em Santarém (Gomes, 2001), e acabaram se desintegrando rapidamente em conseqüência do contato. 
Assim, se hoje o pêndulo da pré-história amazônica parece estar mais próximo dos cacicados complexos, pouco se sabe ainda como estes teriam se formado, quão estáveis estas formações sociais eram, sobretudo, como estas sociedades se transformaram durante e após a colonização européia.

Se uma das questões mais importantes na atual antropologia das terras baixas da América do Sul é justamente a de se entender a natureza e magnitude das mudanças ocorridas entre as sociedades antigas do passado pré-colonial e aquelas historicamente conhecidas e etnograficamente estudadas (Neves et al., 2001), na Amazônia, esta ponte entre a arqueologia e a etnologia nem sempre é possível, pois os materiais trabalhados de cada lado deste grande divisor de águas - o contato com os brancos e seus conseqüentes efeitos - nem sempre são comparáveis.

Do ponto de vista antropológico, e especificamente para a questão de quão diferentes das atuais eram as sociedades indígenas do passado, o debate se torna ainda mais relevante se extrapolar o âmbito meramente arqueológico, e dialogar com outras questões, trabalhadas tanto pela etno-história como pela antropologia social, sobre dinâmicas específicas de transformação das sociedades indígenas, e especificamente teorias de desenvolvimento social.

Recentemente, a arqueologia dos antigos cacicados Amazônicos tem gerado um certo desconforto com interpretações arqueológicas que propõem um cenário para o passado tão diferente do atual, como o faz Heckenberger (1999, 2003 e 2008), de forma que as sociedades indígenas contemporâneas são, dentro de uma ótica evolucionista, facilmente reduzidas a meras sociedades devoluídas e, portanto, facilmente "descartáveis", como alerta Viveiros de Castro (2002:340).

É preciso reconhecer que por trás deste desconforto existem contradições reais entre a visão etnográfica e a arqueológica, como também apontou Viveiros de Castro (2002:194) contrapondo, por exemplo, o cenário arqueológico de sociedades centralizadas em cacicados agrícolas (como, por exemplo, sugeriu Roosevelt em 1991), a certas características dominantes das sociedades indígenas contemporâneas, como a enorme importância ideológica conferida à caça, a generalizada concepção das relações com a natureza que 
privilegia interações simbólicas e sociais com o mundo animal (e não vegetal), ou ainda a ideologia de predação ontológica como um regime de constituição de identidades coletivas, características estas que casariam mal com regimes ideológicos associados à agricultura e à centralização política.

Além disso, estas ideologias apontam para uma instabilidade estrutural das instituições e sistemas de poder, onde uma chefia desprovida de autoridade, e a guerra enquanto prática para a busca de autonomia, conforme 0 modelo de "sociedades contra o Estado" de Clastres (1974) são incompatíveis com os modelos de cacicados complexos propostos pelos arqueólogos.

Estariam os arqueólogos completamente equivocados quanto à natureza das sociedades pré-coloniais, ou teriam estas mesmas sociedades se transformado a tal ponto que seus traços essenciais não seriam mais reconhecíveis nas sociedades indígenas contemporâneas? Estariam os arqueólogos e etnólogos construindo modelos excessivamente generalizantes para sociedades organizadas a partir de diferentes princípios de liderança, autoridade, chefia e hierarquia social?

Este paradoxo exemplifica como o conhecimento das sociedades contemporâneas pode questionar de forma positiva as hipóteses e modelos arqueológicos postulados para o passado, contrariamente a uma visão bastante em voga entre os arqueólogos contemporâneos que alertam contra os perigos de qualquer projeção analógica do presente para o passado (Gosden, 1999).

Ao contrário, parece-nos que a estratégia fundamental a ser avançada por ambas as disciplinas seria o estabelecimento de pontes analíticas entre 0 passado e o presente que permitam entender as verdadeiras mudanças no ethos das sociedades amazônicas. Acreditamos que um passo nesta direção pode ser dado justamente através do que conhecemos dos universos estéticos e ideológicos das sociedades indígenas da Amazônia, do passado e do presente.

Se na arqueologia lidamos essencialmente com variações da cultura material no tempo e espaço para determinarmos diferentes sociedades, o que estas variações nos dizem sobre as dinâmicas de transformações de 
sociedades tribais em outras mais complexas e todas as tensões sociais inerentes a estas mudanças?

Da mesma forma, podemos nos perguntar porquê, através dos séculos, mesmo após o desmantelamento destas sociedades enquanto cacicados autônomos, alguns elementos destas estéticas parecem ter permanecido inalterados como, por exemplo, certos motivos decorativos, enquanto outros foram extremamente transformados, recriados, quando não desapareceram por completo? $\mathrm{O}$ que nos dizem os estudos etnográficos sobre a integridade e continuidade de padrões estéticos diante das mudanças mais recentes observadas na cultura material ?

Se os estudos da cultura material indígena para os períodos durante e pós-contato refletem sempre uma história de perda e abandono de determinadas práticas, de substituição de técnicas e materiais tradicionais por outros modernos, eles também deixam claro que, apesar das transformações ocorridas, as sociedades indígenas continuam a conceber seus objetos dentro de padrões estéticos carregados de significados simbólicos, inclusive daqueles referentes às tensões e contradições trazidas pela própria experiência de contato (Van Velthem, 1999, 2000).

$\mathrm{Na}$ verdade, o terreno dos estilos artísticos, e especificamente a relação entre universos simbólicos e a cultura material, tem sido um terreno bastante visitado na antropologia amazônica, quer em uma visão mais generalizante (como as de Rivière 1969, Lopes da Silva 1991; Ribeiro 1989, Vidal 1992, Roe 1995) quer em estudos particulares, sobre a cultura material, grafismo e decoração corporal em sociedades específicas (Overing,1989; Reichel Dolmatoff 1961,1985; Müller, 1990; Van Velthem, 1995; Gow ,1999; Lagrou, 2007, entre outros).

Por outro lado, na arqueologia amazônica, os estudos iconográficos dos estilos regionais de cerâmicas têm também se aprofundado (Schaan, 1997) ainda que o uso de estilo enquanto categoria analítica varie entre os arqueólogos, concorda-se que estilos artísticos são instrumentos de comunicação e demarcam (intencionalmente ou não) comunidades e fronteiras 
sociais, políticas e ideológicas (Binford, 1989; Conkey e Hastorf ,1990; Earle, 1990; Braun, 1995; Wobst,1977; Wiessner, 1990).

Portanto, de ambos os lados, parece haver um consenso de que a estética de fabricação e decoração das coisas reflete não só as diferentes maneiras indígenas de conceber seus mundos, mas também suas transformações. Parece haver igual consenso sobre a importância desta estética decorativa, seja dos objetos ou de corpos humanos, enquanto linguagem visual que reforça a vida social e espiritual, o que parece ser uma característica comum em sociedades tribais sem escrita, particularmente em situações de transição (Guiart, 1990).

Assim sendo, o que nos resta compreender melhor é como estas estéticas expressam as mudanças pelas quais passaram as sociedades indígenas da Amazônia nestes últimos dois milênios, onde uma longa história de profundas modificações sociais, de sociedades tribais para cacicados précoloniais mais hierarquizados, de sociedades desmanteladas pela colonização para as sociedades indígenas contemporâneas, complexamente integradas às sociedades nacionais que as envolvem.

Alguns antropólogos observam que a simbologia associada aos mitos que estruturam o universo dos povos indígenas da América do sul se diferenciam de acordo com o grau de hierarquização destas sociedades. Roe (1982), por exemplo, propõe que na América do Sul, a tendência a antropomorfização do mundo é mais forte entre sociedades hierarquizadas e etnocêntricas de Estados (em oposição à sociedades tribais ou cacicados), citando como exemplo a cosmologia Aymara-Quetchua, onde as montanhas tem cabeças, ombro, peito e pernas. Esta visão antropocêntrica do mundo é aparentemente mais sutil em cacicados complexos (como as culturas Kogi e Warao). Entre os povos menos estratificados da floresta tropical, os símbolos naturais utilizados seriam mais generalizados, onde humanos se misturam às criaturas míticas, animais, e espíritos em uma forma mais igualitária.

A arqueologia mostra que, na Amazônia pré-colonial, é justamente entre as sociedades que parecem ter atingido os níveis mais complexos e hierarquizados de organização social que surgiram as representações de 
animais e humanos, onde estes se misturam formando criaturas míticas como, por exemplo, nas figuras duais representadas na cerâmica Tapajônica.

Portanto, parece-nos que não se trata de identificar elementos de uma estética de sociedades tribais diferenciada de outra de sociedades mais complexas, e assim por diante, mas entender como estes modelos mentais do mundo, presentes na cultura material, expressam mudanças na forma em que estes mundos são organizados.

\section{Arte e estilo na arqueologia na Amazônia}

$\mathrm{Na}$ arqueologia das terras baixas da América do Sul, algumas regiões, como a Amazônia, se sobressaem não só pela profusão de estilos artísticos, mas também pela grande quantidade de objetos decorados, de provável natureza cerimonial. Os estilos decorativos, sobretudo das cerâmicas, desde cedo chamou a atenção de pesquisadores como Charles Hartt, Ferreira Penna, Emílio Goeldi e outros, mas quase sempre as análises deste material ficaram restritas a estudos descritivos, classificatórios e tentativas casuais de interpretação de símbolos (do grafismo e formas de representação na cerâmica). As interpretações foram sempre bastante especulativas e, por isso, provisórias, sempre no aguardo e de um maior conhecimento dos contextos arqueológicos das peças. A ausência de teorias que permitissem relacionar manifestações artísticas a processos históricos e sociais também contribuiu para o caráter especulativo das interpretações propostas. Talvez o melhor exemplo de tentativas deste tipo seja a obra de Frederico Barata (1952) - Arqueologia, As artes plásticas no Brasil - cujas interpretações propostas para as manifestações artísticas pré-coloniais na Amazônia careciam do contexto histórico-cultural fornecido pelas primeiras pesquisas arqueológicas sistemáticas iniciadas por Meggers e Evans na Amazônia durante a mesma década da publicação.

Os estudos de Palmatary sobre as cerâmicas Tapajônica e Marajoara (Palmatary, 1939 e 1950), em seu enorme esforço de compreensão e sistematização de repertórios cerâmicos, propondo tipologias baseadas em formas, técnicas e motivos decorativos, de certa forma abriram caminhos 
importantes para a confecção de tipologias cerâmicas que futuramente embasariam as proposições de fases e estilos das diferentes tradições cerâmicas arqueológicas da Amazônia.

Desde então, os estilos, definidos pelos atributos "técnicas de fabricação", "formas e dimensões de objetos cerâmicos", e seus "padrões decorativos", passam a formar o tripé de sustentação das tipologias cerâmicas na Amazônia. Contudo, a maneira como a distribuição no tempo e no espaço destes diferentes estilos cerâmicos são usados para a identificação de diferentes unidades sócioculturais (em geral referidas por diferentes termos como "tradição", "fase", estilo" ou "cultura arqueológica") correspondem mais a um recurso metodológico analítico do que a um entendimento dos diversos universos estilísticos.

É importante explicitar o pressuposto que sustenta esta metodologia classificatória, o de que os diferentes estilos da cerâmica correspondem a códigos culturais compartilhados por diferentes grupos sociais, separados no espaço, no tempo ou em ambos. Nesta abordagem, a correspondência direta entre estilo artístico e identidade cultural é assumida a priori, e estilo é concebido como um atributo passivo, isto é como um produto cultural, uma marca que é reproduzida através das gerações, sendo assim mantida conscientemente ou não ao longo de um determinado tempo por determinadas comunidades.

$\mathrm{Na}$ arqueologia amazônica, desde as tipologias propostas por Meggers e Evans (1957), que a relação entre estilo e identidade cultural serviu de base para análises com contornos bastante funcionalistas, privilegiando aqueles aspectos relativos às técnicas de fabricação e usos utilitários da cerâmica que pudessem informar sobre padrões de subsistência e modos adaptativos na floresta tropical, e deixando de lado os aspectos mais simbólicos e ideológicos que a cerâmica poderia deixar transparecer na reconstituição destas antigas culturas.

Contudo, por trás da análise funcionalista da cerâmica, a obra de Meggers e Evans é pautada por uma preocupação maior, que é situar as sociedades antigas estudadas dentro de determinados padrões de 
desenvolvimento cultural e grau de complexidade social esperados para 0 ambiente da floresta tropical.

"If we are to trace the Tropical Forest Pattern of culture backward through time, it has to be done through the medium of pottery. For this to be done adequately and accurately, it is necessary to understand the functional associations that pottery has not only in terms of its method of manufacture and its use, but also in the broader perspective of its significance as indicative of the subsistence level and sociopolitical attainments of the culture." (Meggers e Evans, 1957:24).

É justamente com base nos estilos cerâmicos e, sobretudo, no argumento de que a cerâmica da fase Marajoara se sobressai estilisticamente do restante das cerâmicas das outras fases, que Meggers e Evans construíram seu argumento de que a sociedade que produziu a cerâmica da fase Marajoara exibiria um nível de organização social mais complexo, diferente do padrão definido como o "Tropical Forest Pattern".

Mesmo que a situação da fase Marajoara em relação às demais fases e estilos da Tradição Polícroma da Amazônia permaneça uma questão em aberto, ainda bastante discutida entre os arqueólogos que tentam mapear as origens e desenvolvimentos desta tradição ao longo da bacia amazônica, é preciso reconhecer que apesar do alto grau de ornamentação da cerâmica, ou "complex and time-consuming techniques of pottery ornamentation" (Meggers e Evans 1957: 605), ter sido o principal critério utilizado Meggers e Evans para separar a cerâmica Marajoara do restante, a relação determinante entre o grau de ornamentação da cerâmica e grau de complexidade social não foi trabalhada e permanece como um pressuposto implícito na obra de Meggers ${ }^{1}$.

Mais especificamente, Meggers e Evans se basearam na quantidade e grande número de combinações de técnicas decorativas identificadas na cerâmica da fase marajoara para argumentar pela complexidade social da sociedade que a produziu (Meggers e Evans, 1957: 410-411).

Assim, para destrinchar a complexidade da cerâmica marajoara, ao invés de explorar a variabilidade dos motivos e seus possíveis significados simbólicos,

\footnotetext{
${ }^{1}$ Este pressuposto parece ter sido perpetuado de forma igualmente implícita em todos os desdobramentos da influência de Meggers na arqueologia amazônica, especialmente nas pesquisas subseqüentes do PRONAPABA coordenadas por Simões $(1972,1983)$.
} 
eles teceram toda uma metodologia de classificação em torno das técnicas de execução da decoração. Criou assim uma escala de complexidade para diferentes tipos cerâmicos, de acordo com o número de técnicas combinadas em uma mesma peça, e estabelecendo que certas técnicas, por serem mais trabalhosas (time-consuming) como a excisão, estariam no topo da escala, enquanto outras, de execução mais rápida, como o escovado, na base da escala. O pressuposto implícito é de que certas técnicas exigem maior grau de especialização e capacidade artesanal (craft skills) por parte do artista do que outras. Meggers poderia então ter proposto que certas técnicas consistiriam em uma "tecnologia de prestígio" (Hayden, 1998), ou atribuir outros significados sociais ao emprego das diferentes técnicas, dentro de uma enorme gama possível de classificação dos sistemas tecnológicos (conforme apontado por Machado, 2007). Contudo, ao ignorar os conteúdos simbólicos associados a estas técnicas, suas tipologias e seriações da cerâmica marajoara serviram apenas para testar e confirmar a hipótese de declínio gradual da complexidade cerâmica como sinal de declínio gradual da própria sociedade marajoara. Os subseqüentes trabalhos e Meggers demonstram que, a longo prazo, ela esteve menos interessada em destrinchar as formas de organização social e tipo de hierarquia da sociedade marajoara, e mais preocupada com questões de adaptação, de forma a argumentar pela impossibilidade da floresta tropical sustentar sociedades maiores, estáveis e mais complexas e pela necessária origem externa da sociedade marajoara e seu gradual declínio nos trópicos da baixa Amazônia.

Para se entender as origens destes estilos amazônicos mais complexos, procurou-se paralelos em outras partes das Américas, apontando-se semelhanças de estilos no oeste e noroeste da América do Sul, partes da América Central e Caribe estendendo-se até áreas dos Estados Unidos, como o Mississipi (Palmatary, 1950; Meggers e Evans, 1957).

Assim, tidos como combinações de atributos formais, estilos artísticos não só são usados para definir tradições culturais diferentes, mas também seus atributos isolados (como, por exemplo, o antiplástico, ou a policromia) são usados para retraçar origens regionais, migrações e contatos entre diferentes 
culturas (como o fizeram Nordenskiold, 1930, Palmatary 1950, Meggers e Evans 1957, e Brochado 1980, 1984, para a Amazônia).

A decomposição dos estilos cerâmicos em diferentes traços culturais, acompanharam de certa forma as tendências difusionistas presentes em toda a arqueologia da América do Sul até os anos 1980's. Resultaram desta abordagem, uma arqueologia de "horizontes", "tradições" e "fases" como as inicialmente propostas por Meggers e Evans para organizar os conhecimentos sobre a ocupação pré-colonial da floresta tropical (Meggers, 1961; Evans e Meggers, 1968). As próprias denominações das tradições, tais quais hachuradazonada, inciso-ponteada e polícroma, isto é, essencialmente a partir dos atributos técnicos da ornamentação da cerâmica, é testemunho desta prioridade dada aos atributos formais da cerâmica em detrimento dos conteúdos simbólicos.

A abordagem de Roosevelt à cerâmica marajoara veio mudar definitivamente este cenário, ao propor não só o surgimento local de sociedades complexas, mas também uma aparente correlação entre certos padrões decorativos da cerâmica e complexidade social, Roosevelt, apostando na possibilidade de práticas de agricultura intensiva na ilha terem promovido crescimento populacional e conseqüente hierarquização, identifica uma mudança na arte local da ênfase na figuração de animais para a de humanos:

"The importance of human imagery may also have been enhanced when population growth made fertile cultivable land more valuable and its control and exploitation by human labor factors requiring ideological justification, through appeal to ancestral rights. Further more, humans may have become more important than animals in shamanic symbolism in the process of development of chiefly religion focused on deified, elite ancestors". (Roosevelt, 1991:89).

Ainda que muitos aspectos do modelo proposto por Roosevelt nunca tenham sido documentados por evidências arqueológicas, como a idéia de uma sociedade agrária, ou uma substituição cronológica na iconografia cerâmica de figuras animais para humanas, a idéia da arte cerâmica enquanto fator de legitimação ideológica para cultos ancestrais foi posteriormente retomada por Schaan $(1997,2004)$, assim como nesta tese, mais especificamente para contextos funerários. 
Em relação às abordagens tanto de Meggers como de Roosevelt, nas últimas décadas, a arqueologia tem proposto um outro tipo de abordagem que concebe estilos artísticos de forma mais ativa. Parte-se do princípio de que arte e artefatos concretizam as maneiras em que indivíduos percebem e organizam a realidade. O estilo artístico é então visto como um meio ativo de comunicação e interação, o qual através da experiência estética, indivíduos ou grupos negociam, definem, afirmam, negam ou impõem relações sociais (Wobst, 1977; Hodder, 1982; Conkey, 1990; Carr e Nietzel, 1995). A arte e, conseqüentemente, os artefatos são então vistos como transformadores, e não apenas como um produto passivo.

$\mathrm{Na}$ arqueologia das terras baixas, antes mesmo deste renovado interesse por estilos, alguns arqueólogos como, por exemplo, Lathrap e seus alunos, propuseram que a Amazônia foi um centro de inovação cultural, com invenções técnicas críticas, como a cerâmica e a tecelagem (especificamente o tear dito "amazônico »), criando estilos artísticos próprios que acabam por se espalhar por toda a região.

São estilos presentes na iconografia de decoração dos objetos, uma iconografia identificada essencialmente como religiosa, zoomórfica, com base em práticas alucinógenas e xamanísticas, utilizada em rituais para a comunicação com o mundo sobrenatural (Lathrap, 1970). É um estilo, portanto, que envolve mais do que o compartilhamento de idéias entre grupos sociais, é um estilo que pode ser replicador de uma ideologia.

É a partir desta idéia de estilos artísticos amazônicos, ou um estilo panamazônico, que a simbologia presente nos objetos arqueológicos e etnográficos pode ser relacionada ao um corpo de mitos e narrativas indígenas e que seu papel enquanto agente de reprodução e transformação da cultura pode ser estudado no passado e no presente (Peter Roe, 1982; Reichel-Dolmatoff, 1978; DeBoer, 1984). Na Amazônia, a repetida representação mais ou menos estilizada de determinados animais como, por exemplo, a cobra ou a onça, juntamente com personagens humanos que povoam as narrativas mitológicas é uma constante na decoração dos objetos, passado e presente. Pode-se falar 
assim de uma arte indígena amazônica geral, com variações regionais, ou estilos regionais.

Estas teorias são de certa forma compatíveis com a idéia de que as sociedades indígenas da Amazônia tecem suas relações sociais dentro de uma forma particular de se conceber o outro (seja este humano, animal, espírito, artefato, etc...), maneira esta denominada "perspectivismo ameríndio" por Viveiros de Castro, com base em recorrentes referências na etnografia amazônica de que a forma manifesta de cada ser é apenas um envoltório (uma roupa) a esconder uma outra forma interna, espiritual, visível apenas por seres da mesma espécie, ou seres trans-específicos, como os xamãs (Viveiros de Castro, 2005a, 2005b, 2008). Este mundo altamente transformacional (Rivière, 1994) típico das culturas amazônicas tradicionais, é certamente o que Lathrap e seus colaboradores apreenderam nos vestígios materiais que definem um estilo pan-amazônico.

A convergência de idéias entre arqueólogos e etnólogos sobre uma arte pan-amazônica esbarra, no entanto, em fenômenos problemáticos para a arqueologia, sobretudo no que diz respeito ao caráter invisível, imaterial, ou "virtual" de alguns atributos "relativamente típicos do modo de existência e manifestações de espíritos" nesta concepção pan-Amazônica, ainda que esta noção de "espírito" possa corresponder exatamente a uma intensa multiplicidade de expressões artísticas (Viveiros de Castro, 2004:4).

De forma geral, na América pré-colombiana, a intensificação de expressões artísticas e a emergência de diferentes estilos artísticos tem sido associada a mudanças de estrutura social. Desde Willey (1962) que arqueólogos tem reconhecido o papel organizador da arte, como nas culturas Olmeca e Chavin, ou no Mississipi e no Sudoeste norteamericano (Earle 1990; Plog, 1990), onde estilos minimamente relacionados acabam por unir regiões previamente isoladas e separadas politicamente, formando unidades políticas mais complexas.

Em muitos casos, o surgimento de grandes estilos artísticos, concomitante ao aumento de atividades cerimoniais, tem sido associado a processos de transformação de sociedades igualitárias para estruturas mais 
hierárquicas, onde os objetos e sua iconografia servem para legitimar novas estruturas de poder e reforçar posições de prestígio, sobretudo associando as novas elites com o mundo ancestral e sobrenatural através dos mitos (veja por exemplos os estudos de Earle (1990) no Havaí e na área Olmeca e de Helms(1986) na Colômbia e no Panamá.

A partir desta perspectiva os diferentes estilos da cerâmica arqueológica na Amazônia podem adquirir um novo significado, e podem ser entendidos não mais como formados por influências de outros estilos de outras regiões, mas como elementos ativos de processos de transformação dos indivíduos e das sociedades pré-coloniais.

Com a formulação de novas teorias sobre como manifestações artísticas se relacionam a processos históricos em uma variedade de sociedades ameríndias, e, sobretudo, com o avanço das pesquisas arqueológicas que permitem melhor entender os contextos de fabricação e uso daqueles objetos arqueológicos até então conhecidos apenas por sua elaboração estética, podese dizer que uma nova arqueologia do estilo é possível na Amazônia.

Alguns estudos arqueológicos têm-se voltado à iconografia de determinadas culturas arqueológicas amazônicas em específico, (vide os estudos de Schaan (1997, 2001a, 2001b, 2004) com a cerâmica da fase Marajoara, e os de Gomes (2001) com a cerâmica Tapajônica). Estas iconografias são estudadas enquanto linguagens simbólicas, as quais, juntamente com outros dados do contexto arqueológico, podem informar sobre as dinâmicas históricas, sociais e ideológicas destas antigas sociedades amazônicas.

$\mathrm{Na}$ cerâmica arqueológica amazônica a necessidade de reafirmar modelos mentais do universo mitológico e dos personagens que ele contém através da arte cerâmica parece surgir de forma consistente a partir do primeiro milênio de nossa era, sempre através de formas de representação que parecem obedecer regras extremamente rígidas e complexas, algumas delas já bem documentadas em estudos como os de Schaan (1997). 
Por outro lado, estudos de etno-arqueologia junto a sociedades indígenas contemporâneas têm revelado as diferentes dimensões simbólicas que podem adquirir a fabricação e usos da cerâmica, assim como suas formas e grafismos decorativos, mostrando como representações mais estilizadas de elementos da natureza também carregam significados mitológicos (DeBoer, 1984: Silva,2003).

Estes avanços permitem repensar o papel das artes nas sociedades amazônicas antigas, sobretudo em regiões e culturas específicas. Contudo, falta ainda uma visão geral de como esta arte cerâmica pode nos ajudar a compreender as transformações pelas quais passaram estas sociedades nos últimos séculos ao nível regional mais amplo; de como os diferentes estilos encontrados na arqueologia da região se relacionam entre si e definem processos de interação e mudança.

Com os estudos recentes da iconografia encontrada na cerâmica arqueológica aprendemos que representações figurativas, sobretudos de figuras humanas e animais, parecem ter sido bem mais freqüentes no passado précolonial, como demonstra a profusão de estatuetas, as urnas funerárias antropomorfas e os apliques e apêndices decorativos em forma de seres humanos e animais que povoam a cerâmica de várias culturas arqueológicas da Amazônia.

Esse figurativismo contrasta marcadamente com as representações menos realistas (às vezes ditas "abstratas") de elementos da natureza, notadamente mais estilizadas e geometrizantes, encontradas nos materiais etnográficos históricos e contemporâneos, em uma larga gama de suportes que incluem instrumentos, trançados, máscaras, bancos, corpos humanos, além também da cerâmica. Exibem uma linguagem simbólica mais codificada, de leitura mais restrita, destinada aos membros daquela comunidade específica ou grupo cultural apenas, e a partir da qual a possibilidade de uma leitura mais universal do seu significado simbólico parece ter sido abandonada.

Algumas raras exceções de um figurativismo mais realista, como o encontrado nas "bonecas" karajá ou nos bancos zoomorfos xinguanos, correspondem justamente àqueles objetos hoje feitos para venda aos turistas ou comércio de artesanato, para uma apreciação por um "público" externo, mais 
genérico, o que reforça a idéia de que o uso de uma linguagem estética figurativa mais realista busca comunicar idéias para o mundo externo àquela cultura específica. Em tempos pré-coloniais, um figurativismo mais naturalista parece corresponder à necessidade de se manter uma linguagem extra-regional, ainda que com suas variações particulares. Qual o papel desta linguagem panamazônica no passado pré-colonial destas sociedades indígenas? Estaria ela voltada para a promoção de uma maior interação entre os povos ao longo de toda a bacia amazônica?

Esta tese propõe adiantar um pouco estas questões tomando um caminho diverso, mas complementar ao da análise simbólica da iconografia dos objetos já explorada sobretudo para a cerâmica marajoara e tapajônica. Este caminho diverso consiste em transferir a ênfase da análise do significado simbólico dos objetos para a agência dos objetos, isto é investigar a capacidade destes objetos de intermediarem ações sociais. Nesta perspectiva, questiona-se menos o que o objeto representa e mais o que ele "faz" e como "age" na rede de relações sociais destas antigas culturas.

Por isso, a esfera de agências dos objetos aqui escolhida, foi a esfera dos rituais funerários, onde ao mesmo tempo que valores tradicionais são reatualizados através de manifestações artísticas de variada natureza, eles podem também ser transformados.

\section{De Lévi-Strauss a Alfred Gell: a antropologia da arte a favor da arqueologia}

Esta tese propõe pensar como a arte, em objetos funerários na Amazônia pré-colonial, gera "coeficientes" de reprodução sócio-política e vice-versa, mostrando a complexidade das relações sociais. Inspira-se assim em dois corpos teóricos que definem arte e estilo e correlacionam estes conceitos com formas de organização social.

Um que gira em torno das reflexões de Lévi-Strauss sobre a arte dos povos de tradição oral (sem escrita), entre os quais as expressões estéticas são um meio importante de significar, comunicar e sintetizar o conhecimento. Em Lévi-Strauss a arte é uma manifestação privilegiada para entendermos como 
estes povos se apropriam da natureza como fonte de conhecimento e inspiração (Hénaff, 1991; Vidal, 1999; Passeti, 2008).

Na obra de Lévi-Strauss, identificamos três conceitos para descrever esta relação entre arte e sociedade cujas implicações para a análise arqueológica das cerâmicas amazônicas nos pareceram relevantes para definir a abordagem metodológica aqui utilizada. $\mathrm{O}$ primeiro diz respeito à idéia de $\underline{\text { estilo, }}$ que pode ser definido nesta perspectiva como expressões concretas de princípios fundamentais construídos e construtores de processos específicos de pensamento e sociabilidade. Para identificar estes princípios fundamentais, LéviStrauss sugere que se use o método indutivo, que consiste em recolher com muita paciência os dados etnográficos e, a partir das recorrências observadas, colocar em evidência as estruturas a partir de detalhes muito precisos. (Esta definição de estilo aparece na obra de Lévi-Strauss desde a Antropologia Estrutural, mas também fica evidente em vários dos seus estudos de caso, como no capítulo intitulado "Uma sociedade indígena e seu estilo" em Tristes Trópicos (1967 [1955]) assim como na Via das Máscaras (1979).

O segundo conceito sobre arte que surge na obra de Lévi-Strauss é o de sistema de comunicação, o que the confere certa estabilidade e tradição. Contudo, diferentemente da linguagem, a arte é um sistema baseado na relação material entre significante e significado, pois "há uma mimese do objeto nas formas que o representam" e é isso que confere inteligibilidade à arte. Ou seja, é através da experiência sensorial que a arte é apreendida. A partir deste sistema de comunicação sensorial, pode-se pensar no fluxo de idéias ou mensagens que ele produz em termos de seus diferentes componentes: o referente, o contexto, o código, a mensagem e o destinatário (Lévi-Strauss, 1990, 1997). Na antropologia da arte e na arqueologia, muitas outras abordagens operacionais e terminologias têm surgido para a análise de expressões estéticas (Morphy,1994; Gosden, 2001), como, por exemplo, a que propôs Alfred Gell em "Art and Agency" (nos termos de artista, protótipo, índice e receptor), mas o importante aqui é retermos a idéia de que a arte pode analisada enquanto um sistema de significados (Morphy, 1996), idéia esta fortemente retomada pela antropologia partir da década de 1990 (Coote e Shelton, 1992; Weiner,1996). 
Em terceiro lugar, está a idéia de que a arte tem uma função social e de que é possível correlacionar formas recorrentes de representação visual a tipos de estrutura social, sem necessariamente lançar mão de argumentos históricos ou difusionistas. Esta idéia de Lévi-Strauss, primeiramente apresentada na sua Antropologia Estrutural é retomada e, de certa forma modificada, ao longo de sua obra, reconhecendo que a maneira específica como um tipo de sociedade se diz através de formas plásticas determinadas, ainda que de forma invertida ou idealizada, está diretamente ligada aos mitos, ritos, e relações de poder. Isso se deve ao fato de que estas formas plásticas são passíveis de transformações homólogas às verificadas nas relações de transformação da mensagem, como nas funções sociais ou religiosas que exercem. (Passeti, 2008: 233).

É a partir desta idéia de que os objetos artísticos podem ser analisados enquanto veículos de negociação e poder, que a teoria de agência, em sua versão artística, foi desenvolvida por Alfred Gell. A pergunta predominante presente na obra de Gell é a de como e o quê a arte é capaz de mobilizar em termos sociais.

A base epistêmica da teoria de Gell é inspirada no deconstrucionismo melanésio de Strathern (1988) e na economia do dom formulada por Mauss (1923), na qual os artefatos são partes destacadas das pessoas nos processos de transação. Inspira-se também na idéia de pessoa distribuída (the fractal person) tal qual proposta por Roy Wagner (1991) também para a Melanésia. Porém, Gell leva esta formulação mais adiante considerando os objetos de arte como pessoas (índices), independentemente se eles estão situados em processos de troca ou transação.

Barcelos Neto, transpondo a teoria de Gell para a Amazônia, lançou a hipótese de que, se na Melanésia a idéia de distribuição da pessoa ocorre por meio da troca de artefatos (como, por exemplo no Kula), na Amazônia ela se dá através de rituais, os quais, entre outras coisas, mobilizam seres (corpos, pessoas e espíritos) através da produção e uso de determinados artefatos.

Ao estudar a fabricação e a pintura de máscaras entre os Waujá, Barcelos Neto identifica uma certa compulsão decorativa na fabricação de objetos rituais enquanto uma série de ações voltadas para a redistribuição de 
mitos. A compulsão de fabricação de objetos é em si a tentativa de recompor determinadas figuras míticas "síntese".

A função de síntese do conhecimento é também observada por Els Lagrou em seus estudos sobre a arte Kaxinawá, igualmente dotada de uma "compulsão decorativa". Aludindo à noção de estilo de Peter Roe (conforme apresentamos abaixo), Lagrou sublinha a correspondência entre estilo artístico e estilo de pensamento, pois, uma vez que para os ameríndios o universo é transformativo, isso implicaria que a visão pode, repentinamente, mudar diante de nossos olhos. O mundo é composto de muitos mundos, e estes diversos mundos são pensados enquanto simultâneos e em contato, embora nem sempre perceptíveis. O papel da arte seria, portanto, o de comunicar uma percepção sintética dessa simultaneidade das diferentes realidades (Lagrou, 2007:149).

A cerâmica marajoara parece ter um estilo igualmente "compulsivo" ao recobrir cada centímetro das superfícies dos objetos cerâmicos com grafismos extremamente elaborados. É sobre a qualidade de agente, não somente dos grafismos, mas dos próprios artefatos, que nos concentramos aqui, como objetos repositórios de intenção e ação, como pessoa ou ser replicado, ou "distribuído" (na terminologia de Gell), como personagens integrantes do ritual que têm o poder de reatualizar mitos, crenças, e valores ideológicos, e não apenas como símbolos ou objetos que representam pessoas ou seres sobrenaturais. Nos interessa assim a "magia" do objeto, seu poder de fazer 0 ritual acontecer e de the conferir maior intensidade.

Para tal, utilizaremos na análise dos objetos algumas características do que Gell denominou "tecnologias de encantamento", isto é um sistema tecnológico para expressões artísticas que exercem fascínio, encantamento e, portanto, poder, justamente pela dificuldade de se explicar como determinados objetos foram criados. Trata-se, portanto, de entender como um sistema de conhecimento de técnicas de produção eficazes age dentro de uma complexa rede social de intenções e necessidades coletivas, tornando a arte essencial à reprodução e à transformação de valores sociais (Gell, 1992:43). 
Com isto, Gell propõe uma ruptura com as preocupações meramente estéticas da antropologia da arte, mas também foge do que ele chama do "sociologismo" de Bourdieu, no qual, de acordo com Gell, nunca se olha o objeto de arte em si, como um produto da criatividade humana, mas apenas seu poder de demarcar distinções sociais. Também foge da abordagem iconográfica, mais estruturalista, que trata a arte como uma espécie de escrita, a qual em vez de considerar o objeto apresentado, privilegia a análise dos símbolos nele representados.

Gell acredita que é possível estudar e entender as "tecnologias de encantamento" das diferentes sociedades através de uma análise integrada dos contextos sociais do objeto em questão e de seus atributos estilísticos formais. Algumas das análises que apresenta em Art and Agency privilegiam a relação entre vários tipos de objetos, como os diferentes componentes de um sistema particular de técnicas de encantamento.

A abordagem de Gell começa a ser aplicada na análise de materiais arqueológicos pré-colombianos, como o fizeram Saunders (2003) e Quilter (2007), com resultados bastante frutíferos, sobretudo para materiais de contextos arqueológicos já bem estudados.

De certa forma, as análises de Gell se aproximam muito das abordagens arqueológicas sistêmicas de interpretação de artefatos tais quais inicialmente propostas por Walter Taylor no seu "conjunctive approach" (Taylor 1983) e mais tarde retomada pela arqueologia processual. Contudo, se na arqueologia a relação entre os diferentes objetos de uma mesma cultura é bastante enfatizada, falta ao arqueólogo, a observação direta dos contextos sociais em que eles são concebidos, produzidos, utilizados, negociados, venerados e etc...

Por isso, uma decorrência metodológica desta abordagem teórica, é a proposta desta tese em analisar categorias de objetos (e suas relações com outras categorias de objetos) à luz de determinados conhecimentos etnográficos, especificamente referentes às esferas rituais funerárias entre sociedades indígenas amazônicas. 
Por mais que reconheçamos as diferenças cosmológicas entre sociedades indígenas da Amazônia, do passado e do presente, o estudo de temas tais quais os sistemas ontológicos, o xamanismo e suas formas rituais e a mitologia indígena amazônica, permitem hoje teorias mais generalizantes como as propostas por Eduardo Viveiros de Castro (2001) sobre o perspectivismo ameríndio na Amazônia, ou por Carlos Fausto (2007) sobre a antropologia funerária dos sistemas animísticos amazônicos (Arhem, 2002); sobre a dualidade da arte ameríndia amazônica proposta por Elsje Lagrou (2002) e outras as quais nos referimos no capítulo seguinte. Estas teorias podem nos servir como um pano de fundo supostamente comum a todas as sociedades amazônicas, ou uma medida para explicar a variabilidade descrita para as diferentes sociedades estudadas pelos etnólogos, e contra a qual projetamos a análise de determinadas categorias de objetos arqueológicos. Não se trata, portanto, de fazer uso de analogias etnográficas, para analisar contextos arqueológicos, mas de utilizarmos um corpo de teorias e generalizações geradas com base na observação etnográfica de sociedades indígenas amazônicas e seu potencial explicativo, o que chamamos acima de lições da etnologia ameríndia, para organizarmos a análise de um conjunto de objetos arqueológicos.

\section{Lições da etnologia: estilo, cultura material e ritual}

Outra decorrência metodológica de nossas inspirações teóricas é a escolha de uma definição operacional de estilo artístico, ou simplesmente estilo, gerada a partir da observação de diferentes sistemas estilísticos, que incorpora tanto a perspectiva levistraussiana de estilo, enquanto um sistema de significados, como a perspectiva gelliana sobre formas de agência e tecnologias de encantamento.

Por isso, adotamos a definição de estilo desenvolvida por Peter Roe em vários de seus trabalhos sobre arte e cosmologia amazônica (Roe,1982), mas formalmente construído e generalizado para estudos arqueológicos e etnográficos em geral, em "Style, Society, Myth and Structure" (Roe, 1995). De acordo com Roe: 
"Style can be analyzed as an aspect of culture, which is a system of ideas that underlies the behavior of individuals in society. Culture and style in this ideational sense, arise out of a feedback process between individuals; their cognitive structures, drives, and senses; and the learned environment, which encompasses physical, biotic, and socially significant components. Culture and style do not emanate upward from the individual, nor trickle down from some reified superorganic, but instead are negotiated realities, simultaneously process and product. Individual intent interacts with the properties of raw materials, knowledge of craft processes, and the social context." (Roe, 1995:28)

Ainda que bastante abrangente, esta definição de estilo nos pareceu bastante operacional na medida em que Roe especifica quais são os elementos envolvidos neste processo de negociação entre a criação individual e as condições específicas dadas pela sociedade. Os elementos especificados por Roe são: (a) reconhecibilidade, ou seja, o estilo deve ser identificado enquanto tal por características que Ihe são peculiares; (b) virtuosidade; no sentido de que o estilo pode extrapolar os requisitos necessários à função instrumental do objeto; (c) mídia, isto é, estilo requer sempre um suporte, um veículo, mesmo que este seja apenas um recurso somático; (d) contextualidade, ou seja sua reconhecibilidade depende do contexto a sua volta, podendo ser induzida ou não por este contexto; (e) seletividade, isto é, o estilo é constituído por uma série de escolhas ou seleções de dadas alternativas conhecidas por trás das quais residem intenções (conscientes ou não); (f) natureza normativa, isto é, é uma maneira recorrente de estruturar e apresentar forma ou processo que reflete expectativas entre o artista e seu público; (g) variabilidade limitada, definida por um corpus único e singular; (h) capacidade de afetar emocionalmente ou sensitivamente. Em síntese:

Style is an intentional structured system of selecting certain dimensions of form, process, or principle, function, significance, and affect from among known, alternate possibilities to create pleasing variability within a behavioral-artifactual corpus. Style is both the process of creating information through differentiation, so that it is recognizably evocative of a specific cultural context, and a way of circumscribing choice via the imposition of a frame within which creation or recombination occurs. (Roe, 1995:31).

Nem todas estas qualidades de estilo podem ser identificadas no registro arqueológico. Mas reconhecibilidade, seletividade, virtuosidade e variabilidade constituem estão na base da maior parte das inferências arqueológicas sobre estilo. 
Alguns arqueólogos sugerem que somente a partir de analogias etnográficas é que a arqueologia pode interpretar as representações simbólicas da arte pré-colombiana. MacDonald (1972), por exemplo, ao associar a iconografia da cerâmica tapajônica (Santarém) e, sobretudo, os animais nela representados, a mitos compartilhados entre grupos indígenas Carib, argumenta que a partir destes mitos atuais pode-se entender como os antigos Tapajós ordenavam seu universo no passado.

Contudo, como vimos, nem sempre a analogia etnográfica dentro de um contexto de continuidade histórica é possível, e outras dimensões dos estilos artísticos arqueológicos devem exploradas, como apontamos acima na relação entre formas de representação e processos de mudança social.

Além disso, sabemos que boa parte da mitologia amazônica lida com causas e conseqüências da forma/aparência específica que tomam diferentes agentes, todos concebidos enquanto essencialmente instáveis e ambíguos em relação aos atributos humanos e não-humanos de uma ontologia perspectivista (Viveiros de Castro, 2004, 2005a), complicando assim consideravelmente a leitura arqueológica.

Especificamente no caso da Amazônia, e para avançarmos na questão de quão diferentes eram as sociedades indígenas pré-coloniais das atuais, nos parece que um novo olhar sobre a arte e estilos artísticos das tradições arqueológicas pode contribuir para algumas respostas, se acompanhadas pela experiência etnográfica com os domínios simbólicos de sistemas específicos de arte, representação e comunicação através da cultura material, e em particular da cerâmica, que parece ser um universo de estudo comum à etnografia e à arqueologia.

Em primeiro lugar é preciso partir das lições da etnologia sobre o visível e o invisível no mundo ritual ameríndio, como apontou Lagrou (2007). Ainda que haja um certo consenso de que os rituais são momentos particulares em que a reatualização ou reordenação do cosmos incorre muitas vezes na multiplicação de objetos rituais como forma de intensificação e extensão dos agentes naturais e sobrenaturais (as máscaras talvez sejam o exemplo mais evidente deste fenômeno). Contudo, estes entes multiplicados ou estas pessoas distribuídas, 
nem sempre os são de forma material e tangível. Mas autores como Barcelos Neto e Lagrou, reconhecem que os artefatos se encontram no cruzamento entre noções de pessoa e de corporalidade(s) e a partir da análise que tecem sobre sua atuação nas redes de interações sociais entre pessoas e entre corpos, surgem generalizações que podem ser estendidas para a análise de artefatos arqueológicos.

A segunda lição fundamental da etnologia ameríndia é que não parece haver um padrão que nos sirva de guia para elegermos o que é um objeto ritual, podendo estes ser artefatos muito simples e pouco trabalhados. Às vezes nem sequer são artefatos, no sentido estrito do termo, isto é, materiais alterados na forma e aparência pela ação humana. Podem ser objetos sem decoração, ou objetos com funções utilitárias específicas, tais quais bancos ou raladores de mandioca, e que são integrados em rituais específicos incorporando significados simbólicos diferentes. Mas, o inverso não é verdadeiro, isto é, aqueles objetos que demandam uma maior maestria artística, quer na sua composição quer na sua decoração, são, em geral, objetos fabricados para uso ritual. As regras não são rígidas, mas oferecem algum parâmetro para a arqueologia.

Outro fato que dificulta a consideração de artefatos arqueológicos em um sistema mais amplo de produção ritual, é de que dispomos provavelmente de apenas uma parcela da variada gama de objetos rituais observadas na etnologia da Amazônia, da qual constam uma série de materiais perecíveis em plumas, palha, algodão, e madeira, os quais raramente se preservam em contextos arqueológicos.

Está claro que a análise de uma estética ameríndia da Amazônia que faça uma ponte entre o passado e o presente não deve se restringir ao mundo dos objetos. É também possível identificá-la no domínio da construção da paisagem, isto é na estética espacial dos assentamentos, dos monumentos ou de intervenções humanas no meio ambiente em geral, como sugere Heckenberger (2005:252) que identifica uma "estética cultural" de construtividade e monumentalidade próprias aos povos xinguanos, por exemplo. Contudo, nem sempre os testemunhos arqueológicos desta estética da paisagem foram preservados ou podem ser identificados em seu "projeto 
original", uma vez que a paisagem (sobretudo nos trópicos amazônicos) se transforma inexoravelmente com o tempo, com ou sem a ação humana.

Deste ponto de vista, a cerâmica funerária, assim como a estatuária e a arte rupestre, é um objeto privilegiado para o estudo destes universos estéticos, pois apesar de representar apenas uma pequena parcela dos suportes materiais possíveis das expressões estéticas, ela constitui uma das poucas categorias de objetos que são concebidos e construídos para perdurarem no tempo, talvez para a eternidade, diferentemente dos artefatos mais efêmeros confeccionados para o uso cotidiano, ou em materiais menos duradouros. Contrastam também com a linguagem estética da decoração corporal que tem uma duração mais circunstancial.

De maneira geral, o domínio das atividades cerimoniais, em especial os rituais de passagem, também se sobressai como contexto privilegiado para estes estudos, por ser nas cerimônias que as sociedades indígenas atualizam suas crenças e concepções do mundo, constituindo-se em momentos de alta produção estética. Os rituais funerários, em particular, combinam este potencial analítico da produção estética, com atividades que deixam muitas marcas e testemunhos materiais passíveis de estudo pela arqueologia. Por isso, elegemos as urnas cerâmicas funerárias da Amazônia pré-colonial, como principal objeto de análise, neste trabalho, entre outras categorias de cerâmica cerimonial.

Em suma, este trabalho propõe um esforço metodológico na direção de um diálogo entre a arqueologia e a etnologia das sociedades amazônicas, em um terreno no qual o casamento entre uma perspectiva histórica de longo prazo, inerente à visão arqueológica, e a riqueza e complexidade da etnografia disponível sobre a produção estética e ritual, talvez represente um caminho surpreendentemente revelador no entendimento das mudanças ocorridas nas sociedades indígenas da Amazônia entre o passado e o presente. 


\section{RITUAIS FUNERÁRIOS e OS MEIOS MÍSTICOS DE REPRODUÇÃO SOCIAL NA AMAZÔNIA}

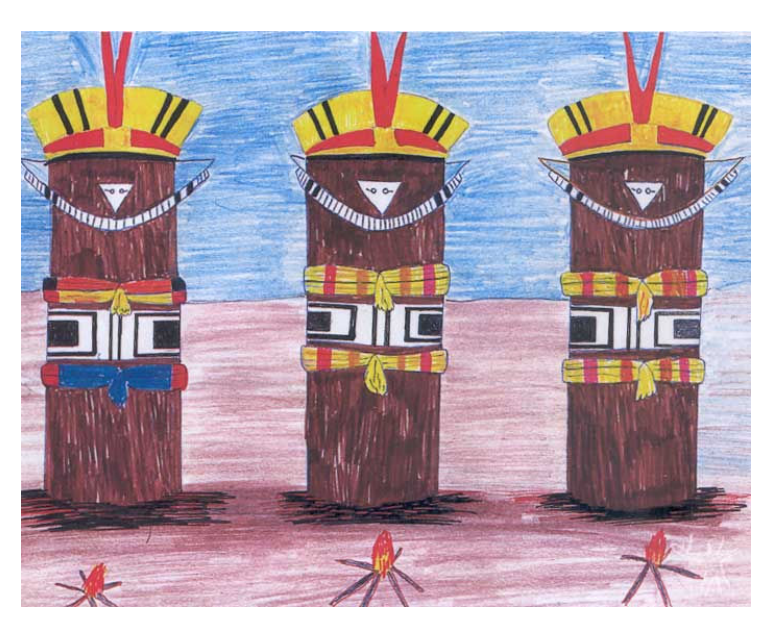

"Segundo Maivotsiním, o criador, os toros de madeira sempre deveriam virar gente. Isso quer dizer que os índios jamais poderiam desaparecer, seriam eternos. Quando alguém morresse, bastaria fazer o Kuarup para ele voltar à vida. Maivoitsiním, porém tinha proibido relações entre casais no primeiro Kuarup, e isso não foi obedecido. Zangado, disse que os desobedientes não reviveriam mais na terra, só no Ivát, a aldeia celestial, onde a alma do índio perdura após a morte."

Lenda da criação xinguana narrada a Claudio e Orlando Villas Boas (1990:33)

\section{Arqueologia, rituais funerários e complexidade social}

Tradicionalmente, na arqueologia, o estudo de práticas funerárias constitui um terreno privilegiado para se entender aspectos de organização social, em específico, o grau de estratificação social, as bases sócio-políticas das relações de prestígio e poder, além das ideologias e crenças que legitimam estas relações.

Em geral, parte-se da premissa que as relações sociais são reproduzidas nos rituais realizados para a disposição dos mortos, sobretudo naquilo que diferenciam os indivíduos entre si ou que simbolizam o pertencimento de um indivíduo a um determinado grupo social. As oferendas, os diferentes tratamentos dados aos restos mortais, os objetos associados, as formas de enterramento em si, a geografia dos cemitérios, as maneiras de se segregar o sagrado do profano, enfim, muitos elementos materiais, espaciais e visuais 
constituem importantes indicadores arqueológicos para se inferir a estrutura social de uma sociedade (Parker Pearson, 1999).

Além disso, em sociedades hierárquicas, bastante atenção é dada a alguns aspectos que podem refletir concepções cosmológicas simbólicas e políticas sobre a relação entre os vivos e os mortos, ou ainda, entre os vivos e seus ancestrais, uma vez que a relação com os antepassados pode ser conscientemente utilizada por líderes ou grupos sociais com maior poder para legitimar seu prestígio ou negociar relações de poder (David e Kramer, 2001).

Também é comum em sociedades mais complexas que cultos à ancestrais se realizem através de construções funerárias cerimoniais, monumentos, túmulos, ou outras intervenções físicas na paisagem, que combinam a imponência simbólica do monumento e sua associação ao ancestral à demonstração pública de poder de controle e mobilização de força de trabalho para a sua edificação. Na América pré-colombiana, tanto nas sociedades formativas do Mississipi, da Mesoamérica e dos Andes, como nos Estados e Impérios que se sucederam, a construção de monumentos funerários (mounds, templos, pirâmides e etc.) é um elemento importante para a implantação de sistemas sociais mais complexos e hierárquicos (Earle, 1991; Drennan, 1991).

Nas Américas, conforme bem observado por Heckenberger, modelos baseados na concentração de poder através do controle e manipulação da força de trabalho e de recursos simbólicos parecem ser mais adequados do que aqueles baseados na história do desenvolvimento de Estados ocidentais, onde o controle sobre inovações tecnológicas e a produtividade econômica geram sociedades mais hierárquicas e complexas (Heckenberger, 2003:48).

Assim, evidências de rituais funerários em que se afirmam diferenças hierárquicas, através do controle de espaços e de monumentos e objetos rituais associados a ancestrais divinos, podem ser elementos essenciais para 0 reconhecimento da presença de sociedades mais complexas no passado précolonial da Amazônia. 


\section{Rituais funerários e ancestralidade}

Muitos arqueólogos que trabalham com práticas mortuárias, como por exemplo, Hodder (1982) e Parker Pearson (1999), alertam para o fato de que, em contextos rituais funerários, as sociedades nem sempre reproduzem relações sociais do seu cotidiano, mas sim relações que são idealizadas, que não existem na prática, ou ainda que se realizam apenas em circunstâncias especiais. Portanto, é preciso estabelecer desde o início de nossas análises que, ao lidar com materiais arqueológicos ligados a rituais funerários, estamos trabalhando em um terreno de representação das relações sociais, representação esta que reflete concepções de vida, de morte e da relação com ancestrais, de acordo com modelos cosmológicos particulares.

O estudo antropológico de rituais funerários nos ensina que, enquanto um fenômeno cultural, a morte não é apenas a cessação da vida física; é antes, como Vernant tão aptamente colocou, uma transformação na qual o morto é tanto $\mathrm{o}$ instrumento quanto o objeto, é uma transmutação do sujeito que toma lugar no corpo e por meio dele (Vernant, 1985:65; Taylor, 1993:655). Rituais funerários são portanto o momento em que esta transformação acontece, onde uma nova identidade é conferida ao morto, seja a de ancestral a ser relembrado, venerado ou simplesmente de alguma forma ainda presente no mundo dos vivos, mesmo que estas transformações visem apenas demarcar sua separação do mundo dos vivos ou preparar para o seu esquecimento.

Hodder, a partir de seus estudos sobre práticas mortuárias entre os Nuba no Sudão (Hodder,1982), propõe que a intensidade das transformações do mundo dos mortos estaria positivamente correlacionada com o grau de complexidade social da comunidade em geral, chamando a atenção para os tipos de ideologia ou sistemas de pensamento que regem os rituais funerários.

$\mathrm{Na}$ etnoarqueologia, as teorias que associam rituais funerários a mudanças sociais indicam que estes se tornam arenas bastante eficazes para o que Parker Pearson chama de "social advertisement", isto é da divulgação e afirmação de novas configurações sociais, podendo ocorrer de forma propositalmente deliberada onde mudanças nas relações de poder resultam em 
re-ordenamentos de status e consolidação de novas posições (Parker Pearson 1999:12; David e Kramer, 2001:385).

Na mesma linha, Nicholas David (1992) ao fazer uma etnoarqueologia das práticas mortuárias entre sociedades tribais africanas, propõe que retomemos uma visão hertziana dos rituais funerários. Discípulo de Durkheim, Hertz (1960 [1907]), inaugurou a sociologia mortuária de sociedades tribais, em particular aquelas com enterramentos secundários, construindo sua teoria ao redor das práticas sobrepostas e interrelacionadas voltadas para (1) o cadáver, (2) a alma, e (3) a comunidade de sobreviventes. Sua análise enfocava particularmente o ritual funerário como a expressão de interdependência destes três elementos, e mais especificamente o que ele denominou o "período intermediário" ou estágio liminar entre a vida e a morte.

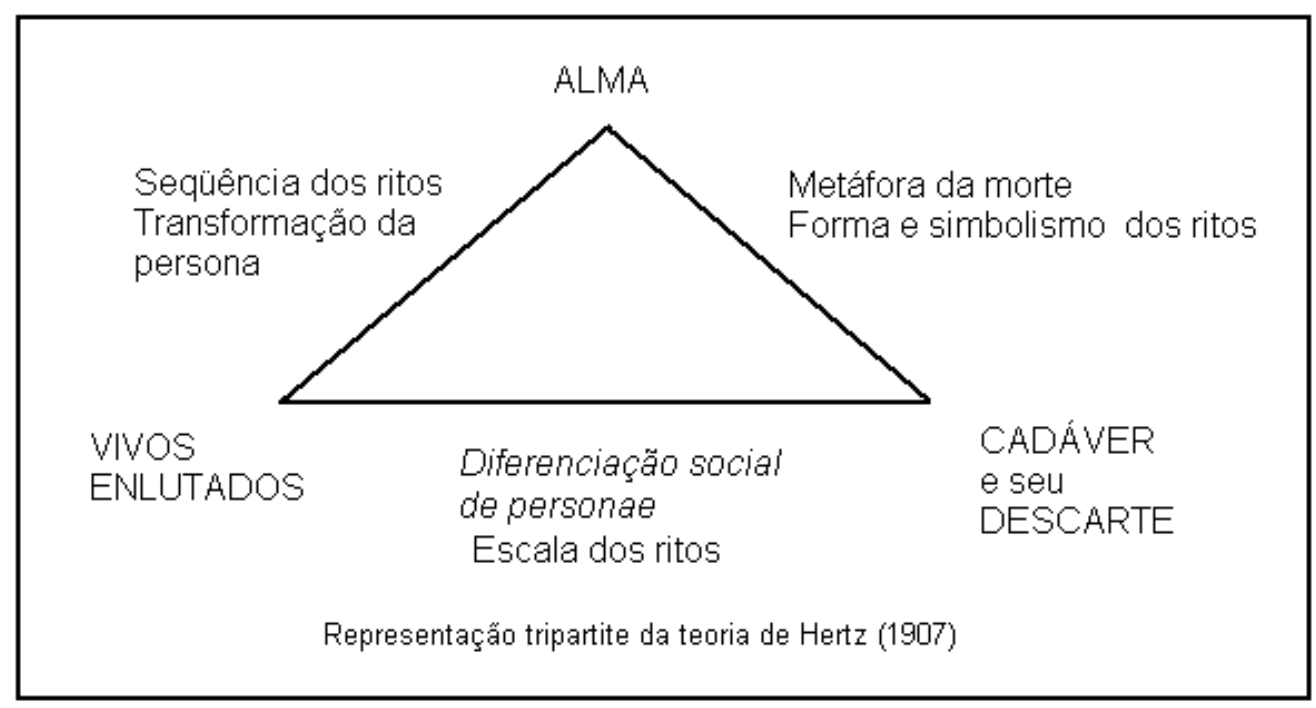

De acordo com David (1992), arqueólogos dispensaram muita atenção à relação entre os "vivos e enlutados" e a "disposição final do cadáver" enquanto determinante da escala do ritual e diferenciação social, com correlações diretas entre o grau de elaboração dos enterramentos e a posição social dos indivíduos. Contudo, o outro lado do triângulo herztiano, isto é, a relação entre os vivos e os mortos que recria, através dos rituais, as contradições inerentes às relações de dominação e poder teria sido pouco estudado. 
Os rituais funerários em geral, e os sepultamentos secundários em particular, envolvem uma série de estágios até a disposição final dos remanescentes humanos. Durante os rituais, elementos mediadores entre os vivos e os mortos dão forma às possíveis transformações e transmutações do indivíduo que se foi e do eventual surgimento do novo ser ou espírito que dele possa emanar. Elementos sensoriais, sobretudo os visuais e aqueles que funcionam como ativadores de memória, tais quais cantos, danças, esculturas, pinturas, túmulos, monumentos, e etc., mais ou menos elaborados, são criados e construídos dentro de linguagens e estéticas próprias, compartilhadas pela sociedade, para realizar a transformação ou a transmutação do morto.

Assim, o ritual funerário tem um poder criativo em termos de performances e de percepção. Como já afirmava Mary Douglas em Pureza e perigo (1966), assim como a fala é capaz de criar pensamentos, os rituais podem criar percepção. Os rituais, e a cultura material neles gerada, fornecem um foco, um método mnemônico e uma possibilidade de controle da experiência (Novaes, 2006).

\section{Rituais funerários na Amazônia indígena}

Toda abordagem mais conceitual às questões de significação do estilo decorativo ou da iconografia dos artefatos indígenas nos conduz a questões cosmológicas ligadas à organização do mundo indígena (Overing,1996; Lagrou, 2005). Por isso, acreditamos que a análise estilística das urnas marajoara pode acrescentar novos dados ao debate sobre complexidade social na Amazônia pré-colonial, sobretudo quando se observa a quase total ausência da fabricação de objetos rituais funerários muito elaborados, e especificamente o total desaparecimento de rituais que envolvem enterramentos secundários em urnas cerâmicas entre as sociedades indígenas contemporâneas da Amazônia.

Como observou Anne Christine Taylor, tornou-se comum na etnologia amazônica observar a ausência de qualquer fenômeno que se assemelhe a cultos ancestrais, à falta de memória genealógica, a aparente pobreza e simplicidade da maioria dos rituais funerários (ao menos, na Amazônia 
ocidental) assim como a escassez generalizada de cemitérios, túmulos ou qualquer espaço marcadamente duradouro associado aos mortos. Ao contrário, longe de se enfatizar uma continuidade entre o mundo dos vivos e o dos ancestrais e cultuar e reverenciar a memória dos últimos, em nomes, épicos ou monumentos, os ameríndios das terras baixas dedicam mais tempo e atividades se "desfazendo" dos mortos, esquecendo seus nomes e feitos, e enfatizando seu afastamento do mundo dos vivos (Taylor, 1993: 653).

Os ciclos de rituais funerários das sociedades indígenas das terras baixas parecem variar bastante na duração e seqüência de práticas observadas (lutos, tabus, preparação de comidas, ornamentação corporal, cantos, choros, danças), da parafernália material envolvida nos rituais (adornos, cestos, máscaras, urnas funerárias e outros objetos variados) e formas de tratamento do corpo e despojamento do cadáver, (putrefação, moqueamento, cremação, enterramento, canibalismo, etc...). Também variam, de acordo com as cosmologias particulares, os sujeitos nos quais os mortos são transformados e as instâncias naturais e sobrenaturais que eles virão a ocupar ao final do ciclo funerário, quer seja em espectro invisível, ser sobrenatural, ou outro.

Mas o que parece peculiar e comum às muitas culturas amazônicas, é a ênfase radical dada à descontinuidade reflexiva entre os mortos e os vivos, e a recorrente transformação do morto em outro ser, não humano, isto é, ocupando uma outra instância cosmológica, às vezes referida como a aldeia dos mortos, uma espécie de sociedade paralela, mas na qual os mortos permanecem acessíveis e próximos, presentes como vizinhos ou como "alter egos". Esta sociedade paralela, é tomada como parceira essencial da sociedade dos vivos, estando as duas intrinsecamente ligadas por uma complexa rede de interações. A relação dialética de alteridade e, sobretudo, de contraposição ao mundo dos vivos é portanto o que rege a transformação dos mortos em seres diferentes e na qual se espelham conflitos e modelos alternativos de organização social ao mundo dos vivos.

"Thus, Amazonian groups transform their dead quite systematically into paradigms of sociological foreignness, and it is their relation to this alterity, rather than the fate of the dead as such, that really engages in their interest. Indeed, 
the dead are often used to build alternative models based on values absent from, or at odds with, the social organization of the living" (Taylor, 1993: 654).

Os Piaroa, por exemplo, se organizam em grupos endogâmicos locais, territoriais, mas projetam sobre seus mortos um elaborado sistema de organização social de clãs e metades que os faz parecer uma versão fantasma de grupos Gê e Bororo do Brasil Central, e que nada tem a ver com os do Piaroa. De acordo com Overing (1993) é a tensão entre os dois modelos que está na base da filosofia social dos Piaroa.

Carneiro da Cunha (1978) observa que os Krahó vivem em oposição ao mundo dos mortos: enquanto os vivos moram na aldeia à luz do sol, os mortos vivem na floresta e o sol deles é a lua, e assim concomitantemente.

Els Lagrou observa a importância desta relação de alteridade e identidade com os mortos que para os Kaxinawá chega ao extremo na medida em que "estar doente" ou "morrer" significa não só um processo transformativo de perda do "eu", mas a finalização de um processo de constante transformação que será completado somente após a morte, quando então os humanos se transformam em seres imortais capazes de conviver com aqueles que representam o pólo extremo e absoluto do perigo, como a onça ou o temível deus canibal - Inka. Embora esta figura mítica se comporte como uma ameaça aos vivos, ela também se torna um "cônjuge e força civilizatória para os Kaxinawá, agora mortos, que se tornariam iguais a ele, isto é, bonitos e luminosos como o eterno Inka, habitante do mundo celeste. Os Kaxinawá, enquanto vivos, são presas potenciais do Inka, mas quando mortos e vivendo nas aldeias celestes, são alimentados por este" (Lagrou, 2002:33-34).

Anne Christine Taylor chama a atenção para como os Jívaro Ashuar exemplificam este dilema amazônico em relação aos mortos, entre uma surpreendente eficácia em apagar seus mortos da memória e ao mesmo tempo mantê-los presentes e ressocializá-los em constantes parceiros em relações de alteridade e identidade (Taylor, 1996).

Conklin (1993), generalizando a partir das diferentes visões de morte e dos diversos rituais funerários amazônicos, conclui que existem paralelos 
evidentes no sentido de que estas sociedades tendem a conceber a morte como uma maneira de reproduzir e dar continuidade à vida social.

Where European and other traditions see a radical split between life and death, many native Amazonians do not. Durkheim treated death as a rupture in the social fabric that must be mended in order for social life to continue. In contrast, Amazonian systems often view death as integral to social life and its reproduction. Death brings not only loss and the imperative to repair what has been destroyed in society, but also positive opportunities to renew the sources of society and life itself. (Conklin, 1993:55).

Assim, os rituais funerários na Amazônia tendem a produzir manifestações artísticas ou imagens regenerativas, focadas em certos temas que refletem o pensamento ameríndio sobre sociabilidade, isto é, a relação entre humanos, animais e seres sobrenaturais, organizada a partir de seus atributos transformacionais e regras de comensalidade.

\section{Bases para uma teoria sobre a morte e o sobrenatural}

Ainda que muitos debates tenham se estabelecido entre etnólogos de grupos Tupi sobre suas ontologias e filosofias de alteridade, ao estudar as práticas funerárias e os significados dos rituais antropofágicos e canibalísticos típicos destas sociedades, parece haver uma certa concordância que tais rituais são uma forma de re-socializar os mortos, criando outros laços de parentesco e afinidade. $\mathrm{Na}$ verdade, muito do que tem sido escrito sobre o perspectivismo ameríndio tem se embasado na etnologia destes povos.

Pode-se dizer que foi com o livro de Eduardo Viveiros de Castro, Araweté, de 1986, que uma nova fase se iniciou nos estudos sobre a morte nas culturas das terras baixas da América do Sul. Esse livro foi a primeira grande análise comparativa sobre o complexo conceitual do exocanibalismo dos grupos Tupi, contextualizado pela elaborada etnografia de uma de suas versões contemporâneas, a dos Araweté. O livro influenciou e inspirou etnólogos das terras baixas não só na realização de estudos sobre a morte, como também sobre outras categorias de análise (pessoa, gênero, organização social, guerra e cosmologia). Especificamente em um seminário sobre a concepção da morte na região das terras baixas sul-americanas, realizado em Oxford, em 1989, 
foram então desenvolvidas idéias centrais de Viveiros de Castro, tais como a de que a morte é principalmente um assunto de predação, e acompanhando a lógica indígena, Viveiros de Castro fez do ato de comer - mais precisamente dos atos de caçar, matar, cozinhar e comer - o fato central da análise sociológica. Posteriormente, esse quadro analítico veio a ser conhecido como "a economia simbólica da predação". (Viveiros de Castro, 1992b; 1993; Rivière 1993).

As recentes teorias geradas desde então sobre ontologias ameríndias tem revelado uma nova maneira de olhar para a relação entre humanos e não humanos Descola $(1986,2005)$ e Viveiros de Castro $(2002,2005 a)$ dentro da já cunhada linha de estudos realizados por alunos e colegas de Viveiros de Castro, aprofundando, de modo crítico, os muitos argumentos formulados por este autor, à luz de etnografias densas e originais (por exemplo, Vilaça ,1992, 1993 e Gonçalves, 1993).

A principal premissa é que na ontologia ameríndia a intencionalidade e a consciência reflexiva não são atributos exclusivos do ser humano, mas estão potencialmente presentes em todos os seres do cosmos. Em outras palavras, animais, plantas, deuses e espíritos são pessoas em potencial e podem ocupar uma posição de sujeito em suas relações com os humanos. Esta indistinção ontológica gera uma série de problemas etnográficos e teóricos, incluindo o que nos concerne aqui, a relação entre os humanos e os animais na morte e no pós morte, e a própria concepção de pessoa e a construção de sua identidade para o mundo pós morte. Estas teorias focam no corpo como o principal lugar da identidade.

Segundo Viveiros de Castro, tipicamente, os humanos, em condições normais vêem os humanos como humanos e os animais como animais; mas os animais e outras subjetividades que povoam o universo - deuses, espíritos, mortos, habitantes de outros níveis cósmicos, plantas, objetos e artefatos - nos vêem como não-humanos e a si como humanos.

"Em suma os animais são gente, ou se vêem como pessoas. Tal concepção está quase sempre associada à idéia de que a forma manifesta de cada espécie é um envoltório (uma "roupa") a esconder uma forma interna humana, normalmente visível apenas aos olhos da própria espécie ou de certos 
seres trans-específicos, como os xamãs....Teríamos então à primeira vista, uma distinção entre uma essência antropomorfa de tipo espiritual, comum aos seres animados, e uma aparência corporal variável, característica de cada espécie, mas que não seria um atributo fixo, e sim uma roupa trocável e descartável. $A$ noção de 'roupa' é, com efeito, uma das expressões privilegiadas da metamorfose - espíritos, mortos e xamãs que assumem formas animais, bichos que viram outros bichos, humanos que são inadvertidamente mudados em animais -, processo onipresente no "mundo altamente transformacional" (Riviere 1994) proposto para as culturas amazônicas”. (Viveiros de Castro, 2002:351)

Esta natureza transformacional dos seres, expressa na instável materialização e visualização da roupagem ou do corpo tem evidentes implicações para as transformações do indivíduo na doença e na morte.

Na verdade, a morte também é um momento transformacional em si, e na ordem da ontogênese ameríndia, os espectros dos mortos, não são mais humanos, assim como os animais, que também foram humanos em tempos prístinos, deixaram de sê-lo. Por isso,

"não é de surpreender que, enquanto imagens definidas por sua disjunção relativamente a um corpo humano, os mortos sejam atraídos pelos corpos animais; é por isso que, na Amazônia, morrer é transformar-se em um animal: se as almas dos animais são concebidas como tendo uma forma corporal humana prístina, é lógico que as almas dos humanos sejam concebidas como tendo um corpo animal póstumo, ou como entrando em um corpo animal que será eventualmente morto e comido pelos viventes. "(Viveiros de Castro, 2008:21).

Em um artigo de Carlos Fausto com implicações bastante generalizantes, embasado em dados sobre 53 grupos ameríndios das terras baixas, ele identifica a predação como uma característica específica da ontologia Amazônica dentro do contexto mais amplo que ele denomina de tradição Siberoameríndia, Enquanto na América do Norte e na Sibéria a relação entre os humanos e animais seria resolvida por uma série de negociações entre 0 predador e a presa, na Amazônia, a predação seria um vetor trans-específico de sociabilidade, isto é, humanos e animais estão imersos em um sistema sociocosmológico no qual a direção da predação e a produção do parentesco estão em constante disputa. Segundo Fausto, tanto a predação, como a comensalidade são formas de se produzir pessoas e sociabilidade na Amazônia 
ameríndia. Assim, a doença e a morte de um ser humano, aos olhos de seus parentes, quase sempre equivalem à sua captura por algum animal predador. As transformações do corpo doente são decorrências da captura de sua alma pelo predador. Do ponto de vista do agressor não humano, no entanto, a doença e a morte correspondem à transformação de uma outra pessoa em parente (Fausto, 2007:498).

Muitos são os exemplos de rituais voltados para se restabelecer 0 equilíbrio original do cosmos, diante de situações de crises causadas por motivos variados, inclusive doenças e mortes, em que os membros ancestrais e entidades do mundo dos mortos em geral são evocados e chamados para reafirmar ou restabelecer as estruturas sociais originais.

Barcelos Neto descreve como o ritual Apapaatai entre os Waujá, onde estes seres monstruosos são alimentados pelos donos do ritual, aqueles ameaçados por doenças, restabelecem assim a sua forma humana. Demonstra como a reprodução política da ordem social via tais rituais, em que uma relação de "predação" (rapto da alma, doença) é transformada em uma relação de "produção" (sociopolítica). A descontinuidade ontológica entre humanos e nãohumanos, ao ser suspensa por meio dos adoecimentos graves e rituais xamânicos, oferece uma economia simbólica do poder, que constitui o eixo central na socialidade Waujá. (Barcelos Neto, 2001b).

Mas chamam a atenção alguns rituais funerários particularmente complexos, os quais constituem ao mesmo tempo momentos de enorme força de expressão estética, seja por meio dos cantos, danças, ornamentos usados e objetos fabricados para estas ocasiões, e momentos nos quais os mortos são evocados para restabelecerem o sentido e a ordem da comunidade.

Do ponto de vista da arqueologia, interessa, é claro, olhar a produção material desta estética, entender as motivações e as maneiras com que os objetos são produzidos, seus atributos rituais, isto é as magias e encantamentos que eles exercem e, sobretudo, a relação entre seus atributos visuais e rituais.

Porém, em se tratando de sociedades ameríndias, um problema maior se coloca, e que também é próprio da arqueologia, que é o de lidarmos apenas 
com a cultura material e visível, filtrando involuntariamente nosso objeto de estudo, os rituais funerários, de forma a separar o visível do invisível, o material do virtual, justamente em sociedades onde pessoas, animais, objetos, almas e espíritos transitam constantemente entre os dois estados, podendo inclusive serem multiplicados de forma virtual.

\section{Entre o visível e o invisível}

Retomando os exemplo do ritual dos apapaatai entre os Waujá, Barcelos Neto observa como as imagens dão existência a coisas que inexistem, ou vivificam, materializam e presentificam seres que já existem mas que só podem ser vistos a partir da sua "decoração".

Para os Waujá, a imagem vivifica aquilo que se confeccionou ou desenhou, esta é uma das razões pelas quais produzir objetos artísticos nessa sociedade é algo tão sério e perigoso, e está reservado, mas não exclusivamente, a pessoas que mantêm alguma relação privilegiada com 0 « sobrenatural »." (Barcelos Neto, 2001:147)

Viveiros de Castro, em um seminário sobre a natureza dos espíritos em cosmologias autóctones das Américas (Viveiros de Castro, 2004) enfoca justamente o caráter virtual e a condição de relativa invisibilidade, transparência e opacidade de seres mitológicos, das almas humanas e de espíritos animais, nas cosmologias amazônicas. Esta condição virtual dos seres míticos, geralmente aparece como definida em tempos pré-cosmologicos, quando as diferenças entre as espécies ainda não apresentavam contornos definidos, o que é fundamental para entendermos não só a reversibilidade desta condição em tempos atuais, explicando o regime de metamorfose dos espíritos e seres, podendo ser materializados assumindo diversas roupagens ou corpos, como também a capacidade de se multiplicarem e se manifestarem em diferentes corpos ou objetos ao mesmo tempo.

Viveiros de Castro parte de uma narrativa de Davi Kopenawa do mito de origem ianomami sobre os espíritos e xamãs, para identificar noções semelhantes de virtualidade de entidades mitológicas em outras cosmologias amazônicas; cita diversos estudos de caso onde transparece a noção de seres ancestrais míticos em um estado amorfo, ou virtual, como entre os Yekuana da 
Venezuela ou Barasana do Vaupés, e outros, indicando que o modo de existência e manifestação dos espíritos é um traço pan-amazônico, correspondendo sempre a uma "intensa multiplicidade virtual" (Viveiros de Castro, 2004).

Em muitas sociedades, como os Barasana, o poder terapêutico/ patogênico dos xamãs ou dos feiticeiros, isto é, daqueles que podem prevenir ou causar doenças e morte nos humanos, reside justamente na sua capacidade de guardar esta condição primitiva de transmutação entre as espécies, de metamorfose entre diferentes estados e de trânsito entre diferentes instancias espirituais.

Assim, uma questão importante que se coloca para entendermos os rituais funerários amazônicos, e em particular o sentido da produção das urnas funerárias, é a de como conciliar esta noção de espiritualidade e sobrenatureza, definida enquanto uma intensa instabilidade, reversibilidade e multiplicidade de formas e aparências em suas manifestações, com a intencionalidade expressa nas urnas funerárias de materializar de forma permanente e duradoura imagens de seres estreitamente associados ao mundo mitológico e ancestral das antigas sociedades amazônicas.

Talvez, tendo em vista o pensamento perspectivo ameríndio, seja necessário buscar nas formas de fazer (técnicas e contextos de produção) e no estilo da produção estética visual, a solução para que o invisível e o instável sejam expressos visual e materialmente enquanto tal, questão à qual voltaremos no decorrer das análises estilísticas das urnas. Por ora, seria importante salientar o risco que se incorreria em analisar iconografias ameríndias enquanto meras representações ou ilustrações de um conhecimento denotativo sobre o mundo, ao se ignorar que este conhecimento está mais na maneira escolhida de representar e ilustrar, e menos nos elementos representados e ilustrados em si.

Além disso, esta instabilidade transformacional do perspectivismo ameríndio dá margem a argumentos como o de Sztutman (2005) que, retomando Viveiros de Castro, a correlaciona com empecilhos a formas de organização social e política mais estáveis e, portanto, mais complexas. Mais precisamente, Sztutman reconhece no trânsito cósmico próprio à cosmovisão 
perspectivista um impedimento à fixação do poder político em uma só pessoa, como o chefe ou o xamã, pois só poderia constituir-se sobre uma unidade identitária estável. Na Amazônia, a função xamânica seria oposta à do chefesacerdote (como nas das sociedades andinas e mesomaericanas), cuja função representativa implica na existência de um grupo humano não ameaçado por mudanças de perspectiva advindas da incorporação de subjetividades diversas (Sztutman, 2005:79).

Esta oposição entre xamãs e chefes sacerdotes, é retomada por Viveiros de Castro, a partir dos conceitos propostos por Stephen Hugh-Jones de xamãs horizontais e verticais. No xamanismo horizontal, os "xamãs são especialistas com poderes que derivam da inspiração e do carisma, e cuja atuação é voltada para o exterior" através da guerra. Seus principais interlocutores são os animais predadores, que causam a morte e a doença. No xamanismo vertical, tem-se "os mestres cerimoniais, guardiães pacíficos de um conhecimento esotérico e precioso, especialistas na condução a bom termo dos processos de reprodução das relações internas ao grupo (iniciação, nominação, funerais)". Estes estão mais próximos dos chefes-sacerdotes.

A tese de Viveiros de Castro é que, na Amazônia indígena, o xamanismo horizontal é a forma mais antiga de xamanismo, permanecendo operativa até hoje,

... "ao modo de um resíduo que bloqueia a constituição de chefaturas ou Estados dotados de uma interioridade metafísica acabada. ... Todo morto continua um pouco bicho; todo bicho continua um pouco gente. A humanidade permanece imanente, reabsorvendo uma boa maioria dos focos de transcendência que emergem incessantemente por toda parte do vasto tecido do socius amazônico. O xamã horizontal amazônico marca, em sua onipresença na região, a impossibilidade de coincidência perfeita entre poder político e potência cósmica, dificultando assim a elaboração de um sistema sacrificial de tipo clássico. A instituição do sacrifício assinala a captura do xamanismo pelo Estado. O fim da bricolagem cosmológica do xamã, o começo da engenharia teológica do sacerdote. (Viveiros de Castro, 2008:.22)

O "turning point" que teria transformado o xamanismo horizontal de sociedades mais igualitárias, em um xamanismo sacerdotal de sociedades mais hierárquicas, teria sido o surgimento de valores como a ancestralidade, os quais enfatizam a continuidade diacrônica entre vivos e mortos. Neste outro modo, os 
humanos, após a morte, continuariam assumindo formas humanas, ou mesmo, sobre-humanas.

Em suma, a predação e o perspectivismo, dado o "perigo" da perda de identidade (cosmológica e social) que engendram, seriam um impedimento para a constituição de unidades políticas estáveis, ao passo que uma cosmopolítica na qual a pessoa ou grupo são constituídos por transmissão de potência em linhagens ancestrais, permitiria a estabilização de unidades identitárias, como argumenta Heckenberger para o caso das sociedades xinguanas no passado.

Especificamente no que diz respeito ao papel das artes visuais no universo transformativo do mundo ameríndio em geral, a questão que se coloca, em princípio, é se ela vem realimentar a instabilidade, ou se ao contrário, ela surge no sentido de possibilitar uma maior unidade e estabilidade política.

Neste sentido, seria a arte produzida em momentos de reatualização de cosmologias, como são os rituais funerários, uma forma de compensar a instabilidade do universo cosmológico ameríndio, trazendo visibilidade ao invisível, durabilidade ao efêmero, unidade à multiplicidade de formas ou corpos em que os seres se manifestam?

Em um mundo em que os sujeitos nem sempre são perceptíveis, ou são visualmente instáveis, podendo mudar diante de nossa visão, se replicar em diferentes mundos, e adquirir roupagens distintas, seria o papel da arte o de comunicar uma percepção sintética dessa simultaneidade, como propõe Els Lagrou ao analisar o estilo de pensamento perspectivo na arte dos Kaxinawá? (Lagrou, 2002:44)

A idéia de síntese do pensamento transformacional amazônico parece se aplicar de forma bastante coerente a alguns objetos arqueológicos amazônicos, cuja função ainda é pouco conhecida, mas cujos atributos físicos parecem indicar usos rituais. Tanto objetos líticos, que representam figuras híbridas, meio animal, meio humanas, ou figuras humanas sendo dominadas por animais, como as estatuetas estilo "alter-ego" da área do Tapajós-Trombetas (Aires da Fonseca, 2008), ou ainda a cerâmica com figuras duais da cerâmica Santarém, que representam humanos ou pássaros, dependendo do ângulo em que são 
observadas (Gomes, 2001), parecem ilustrar de forma visual e material a noção de corpo como lugar para constantes transformações.

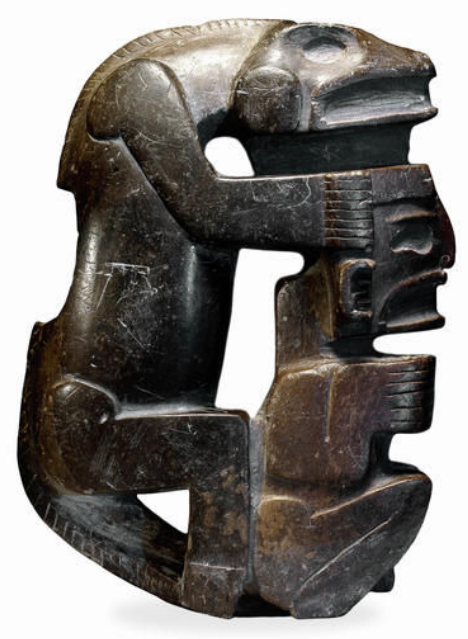

Figura 2.1

Estatueta lítica da região dos rios Tapajós-Trombetas, coleta de Curt Nimuendaju, Acervo do Museu Etnográfico de Goteborg, Suécia (altura: 17,8 cm)

Já no mundo da cultura material documentada etnograficamente nos rituais, esta natureza transformacional dos objetos não é tão evidente. Talvez isso se deva ao fato de que, apesar de vários autores americanistas já terem ressaltado a importância que tomam os sentidos e as propriedades sensíveis dos seres e dos objetos no seio de teorias socio-cosmológicas ameríndias (notadamente Levi-Strauss 1964, 1967; Lagrou 2007; Seeger 1981; Viveiros de Castro), poucos são os autores que se debruçaram sobre os objetos rituais tentando correlacionar seus atributos físicos, ou sua "corporalidade", a seus poderes mágicos, como o faz Barcelos Neto (2008).

Em resumo, Barcelos Neto propõe uma divisão fundamental no sistema de objetos rituais amazônicos, partindo da observação de que algumas das propriedades sensíveis dos objetos - tal qual brilho, dureza, cor, cheiro ou emissão de sons, assim como a forma - determinam a agência que lhes é imputada e suas capacidades de transformação. De acordo com suas comparações entre objetos rituais andinos e amazônicos, na Amazônia, tanto os 
objetos antropomorfos (ainda que não representem apenas o que é humano), como os objetos duráveis, parecem ter uma maior capacidade de "retenção" do estatuto de pessoa através do exercício de suas capacidades e agência (sejam elas de cura, de adivinhação, de propiciação ou de encantamento). Objetos cujo ciclo de vida ultrapassa a vida de um ser humano ou de uma geração, se revestem de uma importância mágica extrema. Barcelos Neto, cita, em particular, os objetos duros, como os em pedra, osso ou madeira, que podem emitir sons e assumir formas equivalentes a partes do corpo humano (as flautas em osso Tukano ou em madeira dura dos Waujá).

"Insistons sur l'hypothese selon laquelle ce rôle de premier plan est lié à la capacité de ces objets de faire des choses dont les humains ne sont pas capables. Ajoutons 'a cela le fait qu'ils vivent plus longtemps que les humains, c'est à dire que les objets impérissables créent une continuité sur le long terme entre les dimensions du temps, de l'espace et des persones, c'est pourquoi ils seraient miraculeux, divinatoires et capables de produire d'autres personnes. " (Barcelos Neto, 2008:127).

As implicações desta hipótese de Barcelos Neto para a arqueologia de objetos rituais são bastante instigadoras, na medida em que características físicas, tais quais durabilidade, dureza e forma, são observáveis nos registros arqueológicos que lidam, na Amazônia, justamente apenas com aqueles objetos mais duráveis. Em especial para o estudo das urnas funerárias cerâmicas, estes atributos tornariam estes objetos não apenas vetores de mediação (entre vivos e mortos), mas assumiriam também capacidades de transformação de pessoas.

Apresentamos a seguir uma breve uma releitura de dois ciclos funerários bastante bem estudados na literatura etnográfica das terras baixas, atendo-nos às diferentes dimensões rituais e intencionalidades das ações que resultam em expressões visuais e materiais. O primeiro, o ritual funerário Bororo, é um ritual mais voltado para a reafirmação de identidades e restabelecimento do equilíbrio cosmológico interno, restrito à comunidade da aldeia, enquanto que o Kuarup, é um ritual inter-aldeias, voltado para a reafirmação de hierarquias sociais e representação identitária perante a uma comunidade multi-étnica. 


\section{Os meios místicos de reprodução social}

\section{O ritual funerário Bororo: a força da expressão estética}

O ritual funerário Bororo talvez seja um dos mais estudados na etnografia das terras baixas. Bem como mostrou Viertler em $A$ refeição das almas (1991) têm implicações culturais, políticas e econômicas para a sociedade Bororo. Ë um ritual que nos parece particularmente interessante para ilustrar uma situação onde a força da expressão estética coletiva constrói simbolicamente realidades virtuais, espirituais, vitais para manutenção e continuidade da comunidade. É um ritual voltado para a reafirmação da estrutura social interna à aldeia.

Do ponto de vista da arqueologia, é interessante porque relaciona referências espaciais e temporais, assim como outros elementos materiais e visuais, a realidades imateriais, não acessíveis diretamente à observação arqueológica.

Desde o anúncio da morte de uma pessoa até o enterro definitivo de seus ossos, a seqüência ritual constrói simbolicamente uma arena para o encontro de todos os vivos com todos os mortos perante a transformação do morto em alma e da escolha de um representante do morto entre os vivos. Silvia Caiuby Novaes observa como isto se dá de forma cuidadosamente elaborada pelos Bororo ao longo dos ritos funerários por meio de processos simbólicos focados no corpo do indivíduo morto e que envolvem a mímese e o contato. É esta arte mimética que articula o real ao realmente construído, ou seja, que transforma o morto em alma, que recria relações entre o morto e sua comunidade e restabelece 0 equilíbrio da sociedade Bororo.

Para os Bororo, a morte é o resultado da ação do bope, uma entidade sobrenatural envolvida em todos os processos de criação e transformação, como o nascimento, a puberdade e a morte. Quando uma pessoa morre, sua alma passa a habitar o corpo de certos animais, como a onça pintada, a onça parda, a jaguatirica.

A morte desencadeia um longo ciclo de transformações que devem ser controladas e vividas ritualmente. A primeira delas é "figurar bem aquilo que será desfigurado", isto é, a imagem da identidade do morto. O corpo do 
moribundo é todo decorado de modo a tornar visíveis as marcas de pertencimento clânico: os cabelos são cortados do modo tradicional, o corpo é untado com urucum, o rosto pintado e a cabeça ornamentada com os adornos plumários de seu clã. Uma vez morto, isto é, tendo perdido o sopro vital, seu rosto é coberto por uma bandeja de palha, para que transformado em alma, não seja visto por mulheres e crianças. Observe-se aqui a tensão entre o que deve se tornar visível (a identidade clânica do morto) e o que não pode ser visto (a alma).

O processo de desfiguração se inicia então quando o corpo do morto é enterrado em cova rasa, sistematicamente regada para acelerar o processo de decomposição, e seus pertences são destruídos. Entre a morte de um indivíduo e a ornamentação de seus ossos, que serão depois definitivamente enterrados, passam-se de dois a três meses. Um tempo longo, em que os grandes rituais são realizados.

Findo o processo de desfiguração, um homem será escolhido para representar o morto. Todo ornamentado, seu corpo é inteiramente recoberto de penugens e pinturas, tendo em sua cabeça um enorme cocar de penas e a face coberta por uma viseira de penas amarelas. No pátio da aldeia já não é um homem que dança, mas sim a alma nova que, com suas evoluções, se apresenta ao mundo dos vivos.

Ao dançar no pátio central, o representante do morto carrega um pertence do morto que o identifica (um arco para um homem; um cesto para uma mulher; um brinquedo para uma criança). Observa-se aqui a relação de contigüidade e contato entre a pessoa representada e seu representante através de um único objeto (já que os outros foram destruídos) enquanto elo de ligação entre os diferentes estados de transformação do morto.

Os ossos do morto constituem então o único elemento material de continuidade entre o indivíduo morto e sua nova identidade ancestral. Os ossos são lavados no rio e ornamentados ao som de cantos, choro ritual e junto à escarificação das mulheres. Este é o momento mais solene do funeral. Os ossos pintados são colocados dentro de um grande cesto feito especialmente para a ocasião, amarrado com cabelos de parentes do morto, enquanto um xamã das 
almas evoca a alma do morto para que ela ocupe a nova morada; todas as outras almas são também evocadas para facilitar sua entrada na aldeia dos mortos. A mãe ritual do morto carrega o cesto por toda a aldeia e para sua casa. Alguns dias depois o cesto é levado a uma baía onde é enterrado definitivamente. Observe a escolha da palha, material perecível, para encerrar os ossos que serão definitivamente retirados do universo da aldeia. $O$ foco material do funeral deixa então de ser os ossos do indivíduo morto para se voltar à sua alma.

Corroborando a ontologia perspectivista, de acordo com os Bororo, alma dos mortos abriga-se em corpos de animais. Assim, o luto só termina quando o representante do morto consegue caçar um felino e ofertar seus dentes, garras e couro aos parentes dele. Ao morrer, o animal perde seu sopro vital e se aloja em uma cabacinha mortuária fabricada especialmente pelo pai do morto e que será tocada pelo caçador em todos os funerais. A caça do felino representa assim a recuperação da alma transformada, "digerida", recuperada e guardada na cabacinha mortuária. A partir de então, ela passará a ser evocada enquanto integrante do mundo ancestral nos rituais funerários. Observe-se aqui que a alma, ou sopro vital, não é concebida como totalmente virtual e imaterial, uma vez que pode ser transferida do corpo humano ou animal para um recipiente, no caso a cabacinha, um recipiente bastante simples, sem decoração, mas que propicia um novo corpo, isto é uma forma material, que permite inclusive que a alma seja tocada em futuros rituais.

É interessante notar que ao longo do ciclo funerário, a transformação do morto em alma ancestral passa pela separação de seu corpo (representado pelos ossos) de sua alma (o sopro encerrado na cabacinha). Esta separação, assim como o descarte do corpo e a preservação ou transformação da alma eternizada depende, no processo ritual, dos recipientes, cesto e cabaça para confiná-los espacialmente. No caso do cesto funerário que contém os ossos decorados e arrumados de forma a reproduzir a ordem anatômica de um corpo, ele é decorado não só de forma emblemática, representando seu clã, mas também é amarrado com cabelos de parentes falecidos. O contato e a aproximação entre objetos que do morto e seu grupo acabam representando 
todo o universo do morto que deve ser esquecido, enterrado, submerso em uma lagoa sagrada. Já a cabaça que abriga a alma ancestral simplesmente dá materialidade e visibilidade a algo que deve ser invocado nos rituais funerários, a ancestralidade.

O papel dos recipientes, portanto, é duplo: encerrar a identidade dos restos mortais que devem ser descartados, e preservar, dar continuidade, à alma ou espírito ancestral de forma a poder ser invocados quando necessário.

Ao analisarmos os objetos funerários arqueológicos, em especial as urnas funerárias, devemos portanto estar atentos a estes tipos de agência conferida aos recipientes funerários, isto é a fabricação de novos corpos, novas almas, e sobretudo estabelecer a continuidade e o diálogo entre o mundo dos vivos e o mundo dos mortos.

Além disso, vemos a importância do funeral como momento de criação estética. Novaes destaca o funeral como um ciclo de criação estética e reafirmação do conhecimento em que "os sentidos do mundo passam pelos sentidos do corpo". É um momento em que o conhecimento é reproduzido através da "experiência sensível dos corpos, ações sobre o corpo, manipulações simbólicas e literais (escarificações) sobre os corpos, fabricação de novos corpos". (Novaes, 2006:312).

Esta fabricação de novos corpos é de certa forma materializada e tornada visível por uma ampla produção objetos (roupas cerimoniais, pintura corporal, objetos emplumados ou de plumas, viseiras, pregos, o cesto funerário, a decoração dos ossos, a cabaça, e etc.), juntamente com outras imateriais (cantos, choros, danças, comidas, bebidas, cigarros, etc.).

As implicações para o estudo da cerâmica funerária são duas. Primeiro, 0 fato de que a produção de objetos funerários faz parte de um sistema bastante complexo e diversificado de produção estética em geral, material e imaterial. Em segundo, o fato de que a cultura se reafirma pela fabricação de corpos, não só os dos indivíduos mortos, mas de todos os participantes do ritual funerário como uma maneira de tornar visível o conhecimento do sobrenatural. Assim, a presença de cerâmicas em forma de corpos de animais ou humanos em 
contextos funerários, presença esta bastante comum na Amazônia pré-colonial, pode ser interpretada de forma mais ampla como uma estratégia de construção de corpos em práticas rituais fundamentais para a reafirmação de cosmologias próprias, em particular de concepções sobre a vida e a morte, ancestrais e sobrenatureza.

\section{O ritual funerário Kuarup: a reafirmação de estruturas hierárquicas}

A noção de morte e as relações com ancestrais entre os diferentes povos que tradicionalmente habitam o Alto Xingu guardam em comum o longo ciclo ritual do Kuarup, uma cerimônia funerária, que envolve mitos de criação da humanidade, a classificação hierárquica nos grupos, a iniciação das jovens e as relações entre as aldeias dos diferentes povos

Assim como o ritual funerário Bororo, o Kuarup já foi amplamente descrito, interpretado e revisitado na literatura etnográfica, e em suas diferentes versões étnicas. Aqui, vamos nos ater apenas às práticas funerárias e ao simbolismo da comunicação ritual com implicações diretas para a interpretação arqueológica de cerâmicas funerárias. Em especial, as descrições de Agostinho (1974) e Robert Carneiro (1993) e os recentes estudos de Heckenberger (1996) entre os Kuikuro e de Barcelos Neto (2001) entre os Waujá, mais preocupados (cada qual à sua maneira) com a cultura material e sistemas estéticos e simbólicos xinguanos, serviram de guia para esta breve releitura.

No alto Xingu, a mais profunda expressão de diferenciação social entre chefes e o restante da comunidade se dá, não quando os jovens são iniciados como adultos e futuros chefes, mas quando os chefes recém-mortos são homenageados na cerimônia do Kuarup. Em síntese, a cerimônia recria o nascimento dos chefes ancestrais por meio de alusões metafóricas, simultaneamente através de cantos, danças e objetos, e a construção de um ou mais protótipos dos ancestrais, espécies de ídolos construídos com o tronco Kuarup, a mesma madeira com que o herói mítico fez as mulheres, entre as quais a mãe dos gêmeos, Sol e Lua, arquétipos e autores da humanidade atual. Em homenagem a essa mulher foi celebrada a primeira festa dos mortos, que é 
a mais importante do Alto Xingu e que consiste, portanto, em uma reencenação da criação primordial.

De acordo com Heckenberger, os xinguanos ou, mais especificamente, os Aruaque, localizariam a potência social no interior da sua sociedade, literalmente, no centro da praça onde estão enterrados os chefes ancestrais mais importantes, e onde a ação propriamente política se dá nos grandes rituais intertribais (e não nas divinações xamânicas realizadas dentro de casa). Assim ele enfatiza a diferença, na sociedade xinguana, dos papéis de chefe e xamã, mas associa o poder do chefe ao que poderíamos chamar, parafraseando Santos-Granero (1986) de "meios místicos de reprodução social". É a ligação genealógica mais direta com os ancestrais míticos que legitima a posição do chefe, o que leva Heckenberger a qualificar como "sagrada" sua autoridade; esta ligação é confirmada e mantida pelo controle dos rituais iniciatórios e funerários de chefes, quando se afirmaria o ciclo de transmissão de substância divina dentro da linhagem de alto status. Através do Kuarup (2005:288).

Enquanto um ritual inter-étnico, o Kuarup realiza-se no final da estação seca cada vez que se torna necessário homenagear os mortos, "levar" o luto aos parentes vivos e também, reavivar as energias da sociedade como tal e firmar as alianças entre os diferentes povos. Assim, além das danças e dos cantos rituais funerários, desfilam, ao redor do troncos dos defuntos, meninos que logo terão as orelhas perfuradas e receberão novos nomes; moças em período de reclusão pubertária serão apresentadas aos visitantes e finalmente a festa termina com a luta do huka-huka, competição desportiva que consagra os novos "campeões", ideal de toda a masculinidade na região do Alto Xingu.

Quanto aos rituais funerários propriamente ditos, tanto os chefes de aldeia, como os chefes das casas, os anetï, (membros de um grupo social hereditário de maior status), têm uma forma diferenciada de sepultamento. Enquanto os corpos dos mortos comuns são enterrados diretamente na terra, apenas envoltos por uma rede e recobertos por uma esteira, os dos chefes são enterrados em uma espécie de câmara funerária, formado por duas covas e um túnel subterrâneo. Os corpos são colocados em uma rede cujos punhos são amarrados a postes de madeira fincados nas covas. As bocas das covas são 
recobertas com esteiras e panelas de cerâmica emborcadas. Uma cerca baixa em forma de ampulheta é construída em volta do sepultamento com pequenos postes da mesma madeira que os postes memoriais usados no Kuarup. A cerca é deixada no local durante algumas semanas, para depois serem arrancadas e jogadas fora.

No caso dos anetï o enterro formal não termina aí. Alguns meses depois, uma seqüencia de rituais se desenrola em torno do sepultamento ao longo de uma semana ou mais, durante a estação das chuvas quando se colhe o pequi (visto este fruto ser usado para a bebida da festa). Após as cerimônias funerárias internas à aldeia ditas (egitse em kuikuro), pode-se então celebrar uma cerimônia inter-aldeias maior, o Kuarup propriamente dito, onde se celebra a morte de um ou mais anetïs falecidos. Um anetï morto é comemorado apenas uma vez em um Kuarup inter-aldeias, mas a ocasião desta comemoração pode variar consideravelmente, podendo se passar até vinte anos após a sua morte.

Assim, apesar do ciclo funerário xinguano não envolver enterramentos secundários, ele guarda de certa forma uma estrutura também em dois tempos para aqueles indivíduos de maior status. Um primeiro tempo em que se desfaz do corpo do morto, enterrando-o, e um segundo tempo que é a grande cerimônia funerária propriamente dita. Muitos traços da cerimônia doméstica, interna à aldeia, também fazem parte da grande cerimônia inter-aldeias, como as canções, o tocar dos maracás, o fumar ritual dos xamãs, as danças cantadas e animadas, o tocar de flautas e a luta huka-huka.

Assim como entre os Bororo, são momentos de uma grande produção estética. Contudo no Kuarup inter-aldeias, esta produção é ainda maior, incluindo uma larga gama de objetos para a troca de presentes entre chefes e indivíduos da aldeia anfitriã e as dos convidados: cintos, colares, diademas, potes e etc. que são produzidos exclusivamente para esta finalidade. A aldeia anfitriã também é responsável pela produção de grandes quantidades de comida e bebida para seus hóspedes, iniciada com vários meses de antecedência.

Do ponto de vista da produção de objetos funerários, uma diferença importante entre o funeral doméstico e o Kuarup é a produção e decoração dos 
postes de madeira, que representam e memorizam os anetïs mortos e que é exclusiva ao Kuarup.

Os postes de madeira, metaforicamente decorados como corpos de xinguanos, tem por função representar os mortos homenageados e abrigar suas almas, mas também servem para reencenar o mito de criação dos humanos, segundo o qual foi obra de um demiurgo que deu vida a toras de madeira dispostas em um gabinete de reclusão, ao soprar-lhes fumaça de tabaco. De acordo com Carneiro (1993:418) os Kuikuro acreditam que as almas dos mortos moram em uma aldeia localizada no céu e, quando da cerimônia, à noite, as almas dos anetï que estão sendo celebrados descem do céu e "entram" nos postes dedicados a eles. Outros registros falam que as almas "ficam junto" aos postes na última noite do rito. As almas dos não anetï também podem descer à terra para assistir às festividades.

Este momento de "materialização" dos ancestrais ou de tornar visíveis as almas dos falecidos através de um objeto ou figura, proporcionado pelos postes decorados, é o que aqui nos interessa focar na medida em que se podem estabelecer paralelos com as urnas funerárias e a produção de figuras antropomorfas em contextos funerários arqueológicos em geral. É importante, portanto, entendermos como se dá a fabricação dos postes memoriais e como eles agem enquanto foco principal da cerimônia do Kuarup.

A sequência da preparação dos postes pode ser vistas nas imagens registradas por Rubem Pereira de Ávila em um Kuarup realizadas na aldeia Kamaiurá do Ipawu em 1994 (Figura 2.2).

A madeira escolhida é a mesma utilizada para as covas e a cerca do enterramento, a madeira referida no mito de origem xinguano e pertencente à espécie denominada Kuarup entre os Kamaiurá, dando o nome à cerimônia inter-aldeias. Vem da árvore considerada "chefe" entre todas as árvores da floresta e portanto é natural que seja associada com os chefes da aldeia. Ela é também é usada na construção das casas de chefe, para os postes centrais. Portanto, os postes, em sua essência material, representam desde o início o princípio de hierarquia social xinguana. 
Alguns dias antes do Kuarup, são cortados os troncos para os postes memoriais, com cerca de $2 \mathrm{~m}$ de altura e 40 a $45 \mathrm{~cm}$ de diâmetro. Agostinho relata que, como o diâmetro do tronco da árvore cortada é variável, as seções mais grossas são reservadas para os postes dos anetï de maior status. Trazidos para a aldeia, eles são fincados na terra para serem pintados. Segundo Agostinho (1974:89), os Kamaiurá, Waujá e Mehinaku decoram seus postes em buracos temporários, fora da aldeia, enquanto os Kuikuro, Kalapalo e Nahuquamatipuis decoram-no dentro da casa-dos-homens. Aqui também, este momento de criação figurativa, ou de refiguração do ancestral, não pode ser visto pelas mulheres. Depois de pintados eles são levados para o centro da aldeia, onde se desenrolará a cerimônia com choros, cantos, danças.

Os postes são decorados, como corpos humanos, corpos xinguanos, com desenhos geométricos em preto e branco típicos de cada etnia, assim como as pinturas corporais. A pintura é feita em uma secção do poste de aproximadamente $40 \mathrm{~cm}$ que é descascada e, inicialmente, pintada de branco, como um engobo. A seguir, nesta área a ser pintada, delimita-se uma faixa central, que será pintada de vermelho, e que define o eixo de simetria de todo 0 tronco, na frente e atrás dele, separando os desenhos simétricos em preto pintados nas laterais. Na parte frontal, bem acima desta faixa central, um 


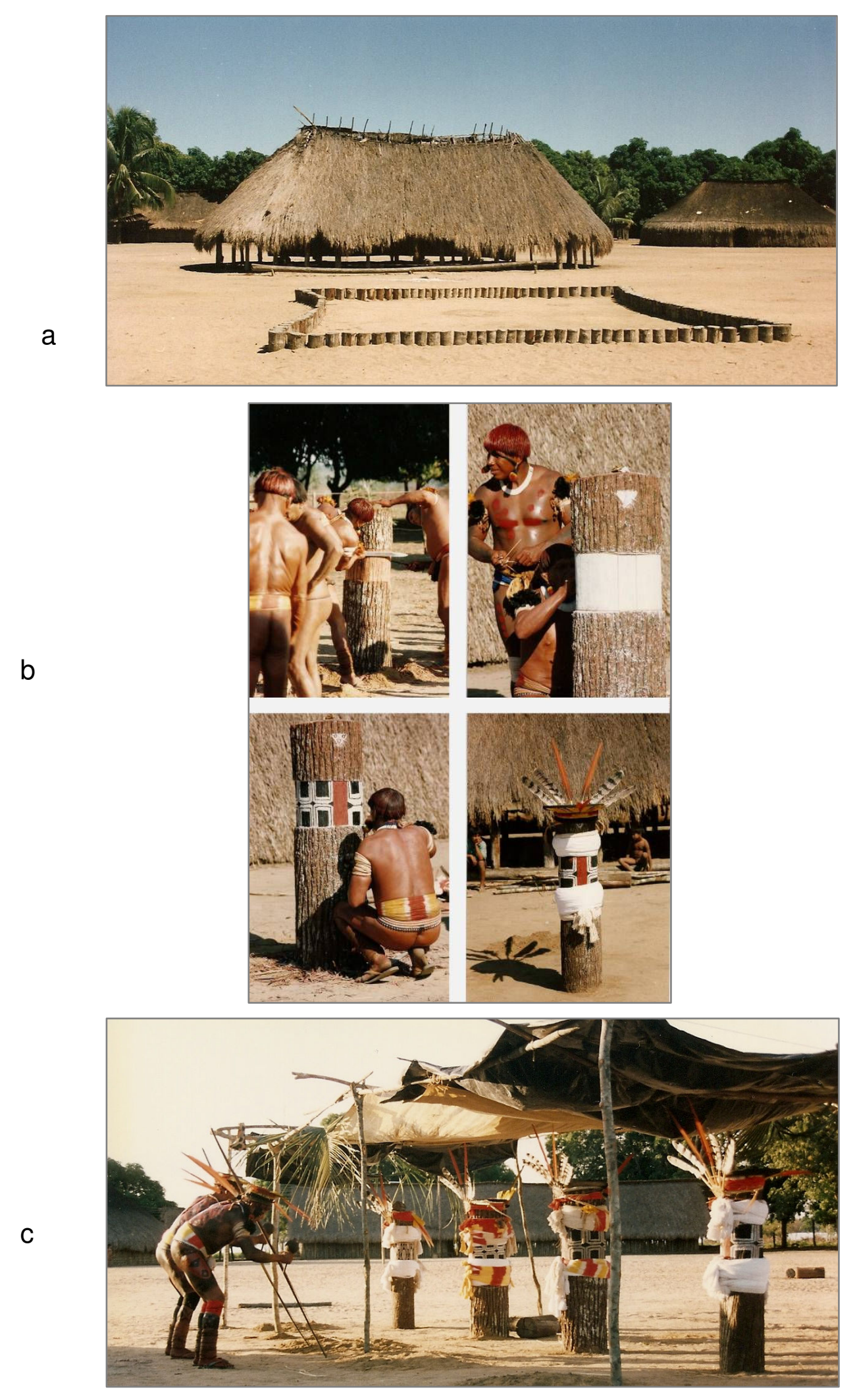

Figura 2.2.

Três momentos do Kuarup:

a) Demarcação da área de enterro primário;

b) Decoração dos postes;

c) Chefes tocam e dançam para os mortos 
pequeno triângulo branco, com olhos e boca desenhados em preto, indica um rosto de forma estilizada. Os motivos dos desenhos em preto sobre branco variam, havendo uma variedade de nomes para cada um.

Finalizada a pintura, os troncos são levados para o centro da aldeia, onde o restante da decoração é finalizada por seus parentes e afins. São colocados cintos masculinos de algodão, um grande colar de caramujo abaixo do rosto, adornos plumários na lateral e, no topo, um diadema de penas de gavião real e arara.

Os troncos são colocados um do lado do outro e não parece haver diferenças individuais, mas alguns autores observaram a colocação de chumaços de algodão sem fiar na parte superior para indicar o gênero masculino. Além da indicação de gênero, a indicação de status também é observada na colocação daqueles troncos mais grossos, correspondendo aos falecidos mais importantes, no centro do conjunto de postes, e os menos importantes nas pontas. Há, portanto, uma hierarquia concêntrica do status.

É diante dos postes assim decorados que, primeiramente, os parentes dos falecidos, e em seguida os chefes e integrantes das aldeias visitantes revezam-se nos choros e danças rituais. Tradicionalmente, este é o momento também em que se reconta o mito do Kuarup.

Quando começa a escurecer, acende-se um fogo diante de cada poste, os xamãs da aldeia trazem seus banquinhos para perto dos postes, acendem seus cigarros e fumam e cantam alternadamente. As fogueiras são constantemente reabastecidas por cada uma das delegações das aldeias visitantes. É neste momento que as almas se escondem juntos aos postes, e que adquirem sua magia: como a alma de uma pessoa morta é considerada extremamente perigosa, podendo causar doenças e morte, elas devem ser muito cautelosas para ficarem discretamente escondidas da visão dos vivos. É também neste momento que os postes, por encerrarem as almas, começam a ser tratados e protegidos como se fossem as almas em si.

Segundo Carneiro "as almas dos anetïs mortos nunca são diretamente invocadas ou propiciadas, mas pensam-se nelas com solicitude, e a razão pela 
qual se fazem as fogueiras na frente dos postes de quarup (sic) é para evitar que as almas, que estão residindo temporariamente dentro deles, sintam frio". Um informante kamayurá chegou a comentar que um poste Kuarup poderia "tremer de frio" caso não fosse aceso o fogo (Carneiro 1993: 418-419). Segundo Agostinho (1974: 96) a manutenção de um fogo durante a noite em frente aos postes seria para impedi-los de se transformarem em mamaés, espíritos. Portanto, neste caso, após a morte, as almas dos humanos não ocupam ou nem transformam em animais, tampouco em entes sobrenaturais, mas continuam humanas.

Durante a noite, um xamã ocasionalmente sopra fumaça de tabaco sobre o poste, pois sem isso o poste poderia "chorar". Ainda como proteção aos postes, durante a cerimônia inter-aldeias, um abrigo é construído para eles, o qual, segundo um informante yawalapiti impede que o sereno caia nos espíritos que ficam dentro dos postes, "incomodando-os". Agostinho (1974:95) diz que o abrigo também protege os postes do calor do dia. Nos postes do Kuarup kamayurá, um disco de cerâmica, ou uma base de vasilhame cerâmico é colocada sobre cada poste, para impedir que a seiva da madeira saia do poste 0 que provocaria a morte do dono do Kuarup.

A festa dos mortos termina na manhã seguinte. Quando surge a madrugada, os fogos são apagados e as cinzas e carvões devem imperativamente ser enterrados, sob o risco de as almas ficarem vagando pela aldeia. Somente após o enterramento destes é que os responsáveis pelo ritual podem se retirar e que as almas dos anetïs celebrados ficam livres para voltar à sua aldeia no mundo dos mortos, embora não necessitem fazer isso.

Terminada a parte funerária do Kuarup, seguem-se então as lutas e a elas a cerimônia de apresentação das jovens reclusas, o tocar de flautas, e a troca de presentes. Apesar de não serem mais o foco da festa, os postes Kuarup são mantidos no pátio da aldeia até o término do ritual. Ao se retirarem os visitantes ficam com alguns dos adornos dos postes. Após sua partida, o dono principal do Kuarup manda então que os postes sejam arrancados e jogados no rio ou lago mais próximo. Todas as almas que andaram ao redor da aldeia podem então voltar à aldeia dos mortos. 


\section{Para uma (etno)arqueologia de objetos funerários}

Os dois exemplos de rituais funerários aqui relatados guardam algumas características comuns em relação à produção e agência de objetos funerários que, sem dúvida, estão também presentes entre muitos outros povos indígenas das terras baixas. O paralelo mais importante é o caráter regenerativo comum a todas as manifestações estéticas, incluindo as materiais e visuais.

A primeira delas é que os objetos em questão, os "recipientes" funerários no caso Bororo (como o cesto e a cabaça), e os postes Kuarup no caso xinguano, são todos objetos cuja fabricação em si impõe ritmo e estrutura na seqüencia de eventos do ritual, muitas vezes demarcando eles próprios dois tempos diferentes, como é comum aos funerais com enterros secundários, um tempo em que se desfigura e se desfaz dos restos materiais do falecido, e outro tempo em que se lida com a alma do falecido de forma a assegurar a continuidade de convivência com os vivos enquanto ancestral que habita um mundo sobrenatural.

Em segundo lugar, são objetos que propiciam um foco espacial e visual durante as cerimônias. É diante deles que boa parte dos choros, cantos e danças ocorre. São assim objetos que possuem um ciclo de vida, sendo ativados ou desativados, conforme o ciclo do próprio ritual. Os objetos se tornam protagonistas sobretudo durante o momento em que se estabelece laços sociais com o falecido enquanto ancestral, enquanto ingressando ou habitando um mundo contíguo porém diferente do mundo dos mortos.

A escolha dos materiais (palha, madeira e cabaça) são de certa forma congruentes com a hipótese de Barcelos Neto. O mais durável, a cabaça, é escolhida para perdurar e ser utilizada em outros rituais, enquanto que tanto 0 cesto funerário, como os postes serão simplesmente descartados, não necessariamente destruídos fisicamente, mas apenas jogados no rio ou lagoa, para ficarem fora da arena de visão e da circulação da aldeia. No caso xinguano, a destruição sistemática dos restos das fogueiras, incluindo 0 enterramento das cinzas, é o que parece "desativar" a agência dos postes. 
A agência destes objetos depende de sua visibilidade e, quase sempre do contato físico com os participantes, como no caso da cabacinha bororo precisar ser tocada para reavivar a alma nela encerrada, ou os xamãs se apoiarem nos postes Kuarup, ou assoprarem fumaça, enquanto cantam no momento em que as almas vêm ocupá-los.

Tanto o descarte dos objetos, o enterramento das cinzas, como a relevância destes objetos estarem visíveis ou não, poderem ser tocados ou não, nos faz questionar em que medida o enterramento proposital de objetos, sem destruí-los, tais quais as urnas funerárias, tornando-os invisíveis e intocáveis, poderia ser uma ação para simplesmente impedir a interferência humana na agência destes objetos.

E o que fazem estes objetos? Seus poderes "mágicos", ou o seu protagonismo, recai, como previsto por Barcelos Neto, nas suas qualidades de fazer coisas as quais os humanos não são capazes, tais quais propiciarem a separação entre a essência material e imaterial da pessoa, entre os ossos e a alma/espírito, servindo, cada qual à sua maneira de invólucro ou recipiente. No caso dos postes Kuarup, uma vez acesos os fogos diante deles, eles propiciam a vinda das almas à aldeia, fornecendo-lhe ao mesmo tempo um corpo para os falecidos serem celebrados, e uma proteção a possíveis males causados pela visão de suas almas.

Em ambos os casos, estes são os objetos (no caso, cesto funerário e postes) que servem de suporte para símbolos emblemáticos de suas identidades sociais e culturais, tanto para demarcar a posição social do indivíduo dentro da aldeia, como para reafirmar elementos compartilhados por toda a comunidade, bororo ou xinguana. No caso xinguano, os postes são a objetificação simbólica e ritual da estrutura hierárquica, que em si é renovada durante o ritual.

Contudo, os postes Kuarup são os únicos objetos que assumem abertamente a condição de pessoa, sendo construídos enquanto corpos e decorados com adornos corporais (pintura, cintos e plumária) e, a partir de um certo momento, passam a ser tratados enquanto pessoas - são aquecidos para não sentirem frio, são protegidos do sereno e do sol e outras ações para que os 
postes não se aborreçam ou não chorem. Os postes, objetos inanimados, passam assim a ser "animados" por um processo que envolve tanto a confecção dos postes em si enquanto "corpos" a serem ocupados pelas almas dos mortos, como pelo que se passa em volta dos postes, durante todo o ritual.

São também os únicos que cumprem a função de representar seus mortos para além da comunidade interna, isto é, perante as outras aldeias e os outros povos, servindo de foco para um ritual de socialização regional.

A pergunta que decorre de nossas observações, é se as urnas funerárias cerâmicas fabricadas pelas sociedades indígenas pré-coloniais da Amazônia poderiam ter desempenhado papeis semelhantes a estes objetos presentes nas cerimônias funerárias aqui enfocadas. Para respondermos à esta pergunta, nos voltamos às urnas arqueológicas propriamente ditas. 


\section{A ARQUEOLOGIA DAS URNAS FUNERÁRIAS NA AMAZÔNIA}

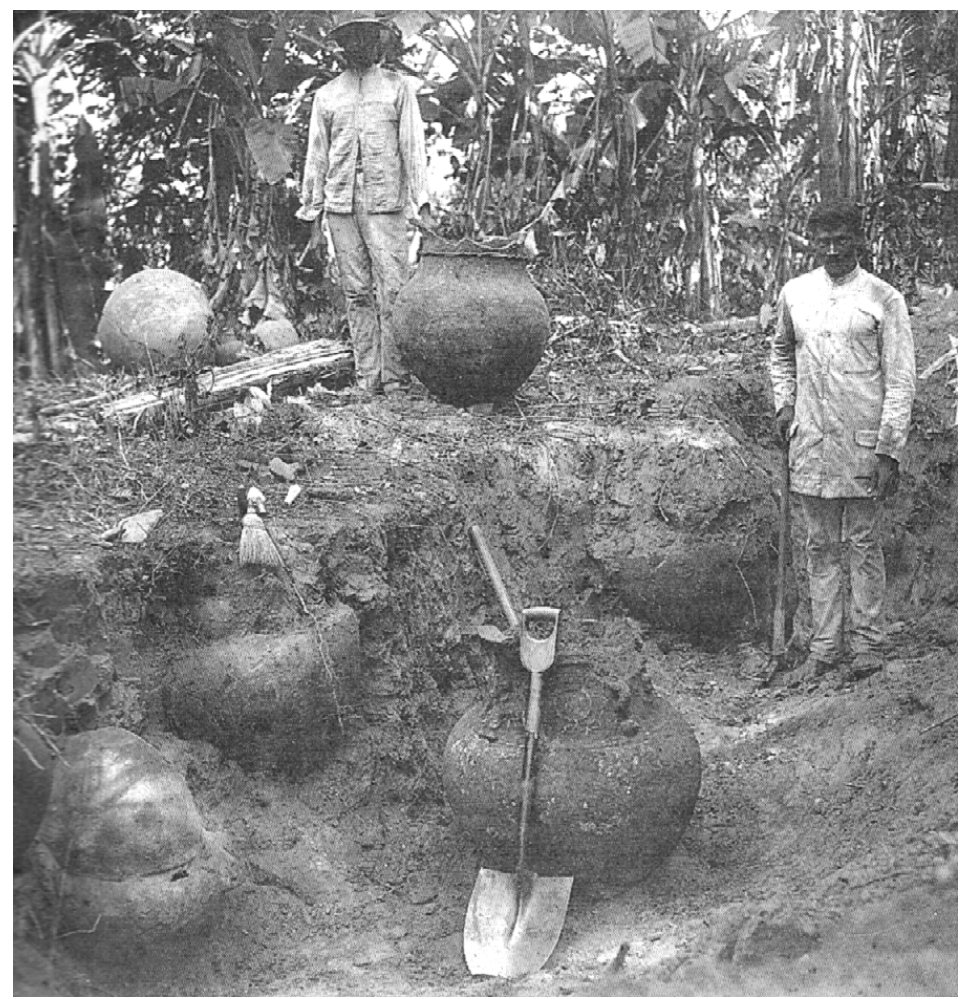

Figura 3.1

Escavações dirigidas por W. Farabee no aterro Camutins,

Ilha de Marajó, 1915 (Arquivo: University of Pennsylvania Museum)

The major proposition is that artifacts, as objects created and interpreted by people, embody the organizational principles of human categorization processes. ... The variability of objects is significant as a major source of evidence for the study of the society, the artifactual environment being one of the main products of social action. It is anticipated, therefore, that an understanding of the forces which created artifactual variability can also contribute towards an understanding of the social. (Miller, 1985:1).

\section{Artefatos como categorias conceituais: o recorte "urnas funerárias"}

A citação acima de Daniel Miller em seu artigo "Artifacts as categories" descreve bem nossa proposta de estudar urnas funerárias, e sua variabilidade, enquanto uma categoria de artefatos que nos informa sobre os princípios tradicionais de organização de uma sociedade. Em particular, como a variabilidade com que são construídas, e os padrões estéticos e tecnoestilísticos empregados, informam sobre as forças sociais e religiosas ativas nas 
sociedades que as produziram. Como vimos, o universo dos objetos funerários, por envolver a relação com seres ancestrais e domínios sagrados é um universo privilegiado para o estudo arqueológico da agência de objetos. Por isso, dentre as categorias de objetos cerâmicos presentes no registro arqueológico, escolhemos as urnas funerárias.

Neste trabalho, nossa análise se debruça sobre um conjunto de urnas funerárias da Amazônia pré-colonial, enquanto um elemento ilustrativo de como se dá a fabricação das pessoas e seus corpos entres as sociedades da Amazônia pré-colonial, enquanto um elemento mediador entre os vivos e os mortos, e possivelmente, enquanto um elemento cuja agência pode ser transformadora de relações sociais. As urnas da fase marajoara são aqui consideradas objetos rituais funerários dentro de um contexto dinâmico de sociedades em mudança tanto no quadro regional mais amplo de formação e interação de cacicados na Amazônia, como em seu papel de reatualizar valores tradicionais internos de cada sociedade.

Aqui, o foco na categoria de objeto "uma funerária", enquanto elemento integrante de rituais funerários e mediador de relações sociais, nos permite, logo de início, considerar estes objetos como testemunhos de um evento maior do que o simples enterramento de restos mortais. A própria natureza dos enterramentos, isto é enterramentos secundários, nos remete a um ciclo funerário bastante longo, e demarcado por dois processos, o de desintegração do cadáver e separação dos ossos, e o de preparação dos ossos e despojamento final.

Como vimos, este ciclo funerário demarcado em dois tempos é bastante recorrente na etnografia de sociedades tribais, quase sempre correspondendo a dois momentos distintos de um ciclo no qual primeiro se desfaz a identidade do indivíduo morto e dos laços deste para com sua comunidade, para, em um segundo momento, transformá-lo em outro indivíduo ou espírito, conferindo-lhe uma nova identidade e estabelecendo relações sociais de outra natureza com o mundo dos mortos, isto é, o momento da transmutação do morto propriamente dito ao qual se refere Vernant. Vimos o exemplo do ritual funerário Bororo analisado por Sylvia Caiuby Novaes que identifica estes momentos de 
"desfiguração" e "refiguração" do mundo e empresta de Taussig (1999) o conceito de "defacement" para explicar o momento de desintegração dos corpos, e "refiguration", o momento de força criativa para a manutenção e continuidade da comunidade, isto é o momento de articular o real às novas identidades simbolicamente construídas (Novaes, 2006).

Voltando às urnas cerâmicas, temos também que considerar de início a escolha em se preservar os restos mortais neste tipo de recipiente, muitos deles correspondendo a elaboradas peças de grande porte, testemunhando uma grande dedicação artesanal e domínio técnico na sua confecção. A escolha deste tipo de recipiente demonstra não só a intenção de preservação dos ossos ali depositados, mas também da durabilidade e visibilidade deste novo "invólucro" ou "roupagem" construída para os mortos, com a intenção de imprimir forma e imagem a sua nova identidade, que passa, nas urnas, sobretudo por meio da percepção visual.

A escolha por um material relativamente resistente e durável, como a cerâmica, ao invés de outros mais efêmeros e perecíveis, como os trançados de fibras, mais comum na Amazônia atual, talvez possa ser entendida como uma intenção de perenizar determinadas identidades ancestrais, ou ao menos tornar possível que sejam revisitadas periodicamente, quando da realização de ritos funerários que estabelecem relações com o mundo dos mortos. Além disso, pode estar relacionado também a valores simbólicos associados ao barro e à cerâmica, seus poderes mágicos dentro de uma classificação êmica dos objetos relacionada às qualidades de dureza e durabilidade, como observou Barcelos Neto entre os Waujá.

As imagens pintadas ou esculpidas nas urnas são evidências de que não somente as urnas eram feitas para serem vistas, mas também que elas poderiam tornar visível e palpável, talvez durante os próprios rituais funerários, aquilo que em outras circunstâncias não os seriam. Em sociedades tribais em geral, e em particular na Amazônia, rituais xamanísticos tornam visíveis signos exteriores de estados interiores. Assim, espíritos, almas, ou outros seres sobrenaturais passam de uma relativa invisibilidade e adquirem forma e imagem 
através de máscaras, roupagens, pinturas corporais e outros artefatos, muitas vezes por intermédio de visões do xamã em estados alterados ou em sonhos.

Assim, uma das questões que guiaram nossa análise das informações etnográficas e arqueológicas disponíveis, e especificamente sobre enterramentos secundários em urnas, é justamente a de considerar a hipótese de que as urnas representam uma manifestação material e visual de seres sobrenaturais, isto é um corpo, uma aparência, uma roupagem para entidades que seriam em outras circunstâncias invisíveis e imateriais.

Por conseguinte, podemos considerar a confecção de urnas cerâmicas e seus atributos imagéticos como imbuídos de uma intencionalidade que vai além da simples preservação dos restos mortais de indivíduos e adquire o sentido de propiciar a presença constante e eterna de seres sobrenaturais no local de enterramento dos mortos. Pode se pensar nas urnas como corpos construídos através dos quais estas entidades sobrenaturais poderiam se manifestar a qualquer momento.

Se a etnografia dos rituais funerários de sociedades indígenas das terras baixas nos dá a dimensão destes rituais como fundamentais para a reprodução de cosmologias particulares, tanto em relação à ordem das coisas e pessoas dentro de suas comunidades, como no estabelecimento de relações de identidade e alteridade com o mundo externo, a arqueologia, que lida com poucos testemunhos materiais destes rituais, depende ainda de um entendimento das práticas funerárias bastante especulativo.

Os relatos etnográficos também deixam clara a importância de como estes rituais se estruturam, desde os preparativos até a sua finalização, e de como a duração e segmentação temporal das várias performances, das pessoas envolvidas nos diferentes momentos, e de todo um sistema de produção e multiplicação de expressões artísticas, cantos, danças, objetos, e etc., correspondendo a estágios e necessidades distintas de socialização entre os integrantes da mesma comunidade, entre estes e outros externos, entre o mundo dos vivos os e dos ancestrais e entre o mundo dos vivos e do sobrenatural em geral. 
Também fica claro que os rituais funerários pertencem àquelas práticas culturais mais arraigadas aos valores e crenças tradicionais destas sociedades indígenas, inclusive porque re-estabelece vínculos com seu passado, tanto com os seus personagens ancestrais recentes, como com os personagens de seus mitos de origem.

Rituais funerários, e de maneira geral, a forma como estas sociedades lidam com seus mortos, constituem assim um objeto de estudo privilegiado para a arqueologia amazônica, na medida em que representam um traço cultural estrutural destas sociedades, e estariam menos propensos a variações e mudanças frente a eventos de ordem conjuntural, como o contato com outros grupos, conflitos, guerras, alianças, participação em redes de troca e outras, de natureza temporária.

Contudo, poucos arqueólogos da Amazônia se dedicaram ao estudo mais sistemático das práticas funerárias em período pré-colonial, apesar do fato de que uma grande proporção dos vestígios materiais venha de sítios cemitérios ou de outros contextos funerários. As exceções são a pesquisa de Guapindaia, que documentou sistematicamente os cemitérios Maracá (2001), no Amapá, e as hipóteses propostas por Schaan para enterramentos em urnas por ela escavados em Marajó (2003b).

Deve-se admitir também que tanto Meggers e Evans (1957 e 1965) como Hilbert (1968) consideraram algumas características dos padrões de sepultamento, ainda que de forma menos diagnóstica do que as propriedades da cerâmica em si, para propor tanto a filiação de complexos cerâmicos às diferentes fases e tradições cerâmicas, como também para explicar suas possíveis movimentações ao longo da bacia Amazônica.

Em nenhum destes casos, contudo, o foco das análises recaiu sobre aquelas características dos sepultamentos que poderiam informar sobre a simbologia dos rituais funerários enquanto meio de reafirmar estruturas sociais ou cosmologias específicas.

Outras sínteses da arqueologia amazônica, como a extensa cronologia proposta por Brochado e Lathrap (1982), privilegiaram determinados atributos da 
cerâmica, como a forma, e o estilo da cerâmica utilitária, por estarem mais relacionados a aspectos adaptativos, como dieta, tecnologias de preparação de alimentos e regras de etiqueta de consumo, e por acreditarem que estes elementos culturais são extremamente conservadores (Brochado e Lathrap, 1982:14). Indicadores de cosmologias específicas e práticas rituais, como a cerâmica funerária não foram considerados na sua organização das seqüências de ocupação da Amazônia.

A nosso ver, um bom começo, seria entendermos a distribuição cultural e as especificidades de enterramentos secundários na Amazônia pré-colonial e como se configuram as urnas em termos estilísticos. Uma síntese do que se conhece sobre as urnas cerâmicas em si, como elas foram construídas, com quais finalidades específicas, e como foram utilizadas e descartadas fornece assim um contexto geral dentro do qual podemos então desvendar a agência destes objetos nos rituais funerários.

\section{Urnas funerárias e enterramentos secundários na Amazônia pré-colonial}

De maneira geral, o sepultamento em urnas cerâmicas foi registrado em muitas sociedades indígenas da América do Sul, sendo bastante comum entre muitos povos ceramistas das terras baixas. Contudo, o enterramento secundário em urnas, parece estar mais circunscrito à Amazônia, e algumas áreas da Bolívia, Colômbia, Venezuela, e litoral das Guianas, e nas áreas litorâneas ocupadas por povos falantes de línguas do tronco Tupiguarani. Na Amazônia, está documentada etnograficamente entre os Karajá e povos do baixo Xingu, entre os Omágua e Cocama e outros povos de língua Tupi desta área do alto Solimões, mas onde também os Shipibo-Conibo, falantes de línguas Pano o praticam.

Para o período pré-colonial, o enterramento secundário em urnas cerâmicas, enquanto uma tradição pan-amazônica, está associado, dentro do quadro cronológico inicialmente proposto por Meggers em 1965, à dispersão da Tradição Polícroma (então sugerida entre 600 a 1300 d. C.), manifestando-se desde os contrafortes andinos, no Peru, Equador e Colômbia, até a área 
estuarina, em diversos estilos ou fases regionais. As mais antigas urnas com sepultamentos secundários até agora conhecidas, parecem ser justamente as da fase marajoara, hoje com datações entre 400 e 1400 d.C. (Meggers e Dannon, 1988; Roosevelt 1991; Schaan, 2004).

É também na área entre Marajó e Guianas que a maior diversidade de estilos aparece correlacionada a um florescimento bastante tardio de diferentes culturas arqueológicas, algumas perdurando até a época de contato, como as urnas encontradas em cemitérios Aruã (nas ilhas de Mexiana e Caviana), Mazagão e Maracá (no leste do Amapá), e a fase Aristé (norte do Amapá e Guiana Francesa). Nem todos os complexos cerâmicos destas culturas foram associados à Tradição Polícroma ou a povos de língua Tupiguarani. Segundo Neves (2008: 371), as ocupações entre o norte do Amapá e a costa do Surinam certamente foram habitadas pelos ancestrais dos povos Palikur e Lokono, de fala Aruaque e tanto a localização geográfica destes sítios, como a cronologia, sugerem aportes compartilhados por povos da região circum caribenha em geral. Contudo, está claro, tanto pela contemporaneidade dos registros arqueológicos, como pela semelhança entre traços estilísticos da cerâmica, que esta era uma área com grande interação regional.

Nesta área, os sepultamentos em urnas variam consideravelmente em seus contextos arqueológicos. Em Marajó, na fase marajoara, estão associados à construção de tesos ao longo dos igarapés e rios, construídos enquanto densos cemitérios em diferentes estágios; nos cemitérios Aruã, as urnas eram semi-enterradas em locais altos e protegidos nas áreas florestadas das ilhas de Mexiana e Caviana; as urnas Maracá, no Amapá, eram depositadas à superfície dos cemitérios localizados dentro de grutas e abrigos rochosos; e as urnas Aristé, eram colocadas dentro de verdadeiras câmaras funerárias, largos poços escavadas no solo e tampados com lages de pedra entre outras localizações. 


\section{As urnas da fase marajoara}

Os enterramentos em urna da fase marajoara foram detalhadamente descritos nos relatos de escavações realizadas por Derby (1879), Ferreira Penna (1879), Farabee (1921), Meggers e Evans (1957), Roosevelt (1991) e Schaan (2005). Apesar dos muitos dados publicados, ainda é ambígua a relação entre os cemitérios com enterramentos em urnas, as áreas de habitação e a ocorrência de outros enterramentos diretos.

De acordo com estes relatos de escavação as estruturas funerárias revelaram muitas variações de tamanho, forma e decoração das urnas e oferendas associadas, tanto na distribuição horizontal como vertical dos sítios, indicando grande variabilidade nas práticas mortuárias, tanto geograficamente como cronologicamente.

Entre os padrões observados está o fato de que os enterramentos em urnas ocorrem quase sempre concentrados em uma área específica do teso, em geral nos tesos mais altos, apresentando uma gama de artefatos associados (pequenas vasilhas, tangas, contas de colar e lâminas de machado em pedra). Dentro destas estruturas funerárias, a cerâmica associada - urnas e vasilhas para oferendas - pode ou não ser decorada. As urnas podem conter restos humanos de um ou mais indivíduos, com ossos inteiros ou cremados, em geral sendo tampadas com vasilhas emborcadas. Alguns vasilhames com restos humanos encaixados dentro de urnas maiores. Além disso, alguns restos humanos aparecem exumados diretamente no solo, em torno de alguns enterramentos em urna. (Voltaremos mais adiante às interpretações já avançadas para estes padrões de enterramento).

É nesta fase que as urnas ocorrem na maior variedade de tamanhos, formas, motivos e técnicas decorativas. Não há na literatura arqueológica, uma tipologia específica para as urnas funerárias da fase marajoara, mas sim as tipologias propostas para a cerâmica desta fase em geral e que levam em conta sobretudo variações de forma e decoração'. As urnas, isto é, aqueles

\footnotetext{
${ }^{1}$ A tese de Joanne Magalis (Magalis, 1975) que faz a seriação de algumas urnas antropomórficas pintadas não inclui como variável a forma geral das urnas, uma vez que todas
} 
recipientes descritos contendo restos humanos em contextos funerários, ocorrem praticamente sob todas as categorias de formas descritas para os tipos de vasilhames de boca mais constrita e maiores dimensões, sendo algumas mais predominantes, conforme quadro abaixo, mas de acordo com Schaan as urnas apresentam marcantes características estilísticas locais, "denotando identidades sociopolíticas e limites territoriais, e não, diferenças temporais" (2007:83). Algumas das formas e estilos de urnas marajoara podem ser vistas na figura abaixo.

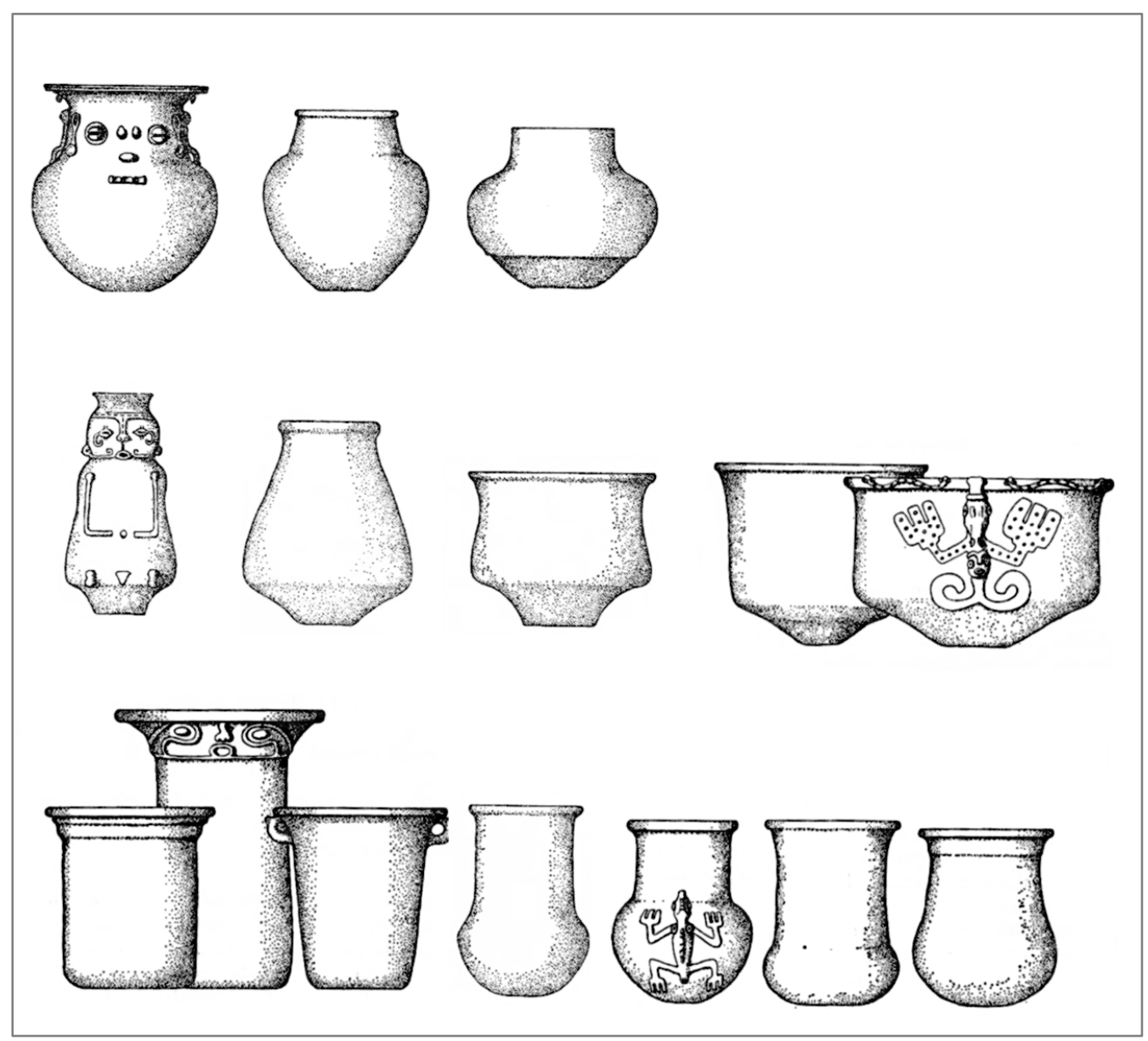

Figura 3.2

Formas de algumas urnas marajoaras dos sub-estilos Joanes Pintado, Camutins, Pacoval e Arari Vermelho de acordo com as tipologias de Meggers e Evans (1957). 


\section{As urnas Aruã}

O material cerâmico desta fase, provavelmente contemporânea e posterior à Marajoara, correspondendo às populações aruaques encontradas nas ilhas estuarinas quando dos primeiros contatos com os Europeus, foi identificado por Nimuendaju (em 1923) e por Meggers e Evans (em 1947) nas suas escavações tanto no Amapá, como nas ilhas de Marajó, Caviana e Mexiana. Devido a diferenças tanto nos padrões de assentamento como na cerâmica entre os sítios mais antigos do Amapá e os mais recentes encontrados nas ilhas é possível que se trate de duas culturas distintas, como sugeriu Nimuendaju em 1923 (2004: 101).

Os cemitérios foram registrados apenas nas ilhas de Mexiana e Caviana - ao todo foram registrados 5 em Mexiana e 14 em Caviana (Nimuendaju, 2004; Meggers e Evans 1957:465) - ocorrem nas áreas florestadas, mais interioranas, elevadas e secas, afastados dos sítios habitação destas ilhas. De acordo com Meggers e Evans densos cemitérios foram formados pela deposição de urnas funerárias à superfície ou em buracos rasos, não chegando serem realmente enterradas. Nimuendaju descreveu estes cemitérios da seguinte maneira:

Geralmente as urnas contêm apenas um esqueleto, apesar de ocasionalmente haver dois esqueletos. Os ossos, ao menos os maiores, são freqüentemente pintados de vermelho com urucum...Normalmente os ossos longos são colocados verticalmente contra a parede da urna em uma pilha. $O$ crânio é colocado sobre os ossos menores; o maxilar inferior é sempre destacado. (Nimuendaju, 1923 citado em Meggers e Evans, 1957:524, tradução minha).

As oferendas mortuárias mais comuns são pequenas vasilhas colocadas ao lado da urna, estatuetas cerâmicas, pequenas pedras polidas, lâminas de machado, contas e pendentes de pedra verde, e contas européias nos sítios mais recentes. As urnas variam entre 30 e $80 \mathrm{~cm}$ de altura e são quase sempre sem decoração, ou apenas com uma faixa de círculos impressa e/ou ungulação sobre fino aplique em rolete. As formas apresentam quase todas bojos globulares, variando na altura e constrição do pescoço. Algumas poucas urnas são antropomorfas, com corpos mais tubulares, e aberturas laterais. 

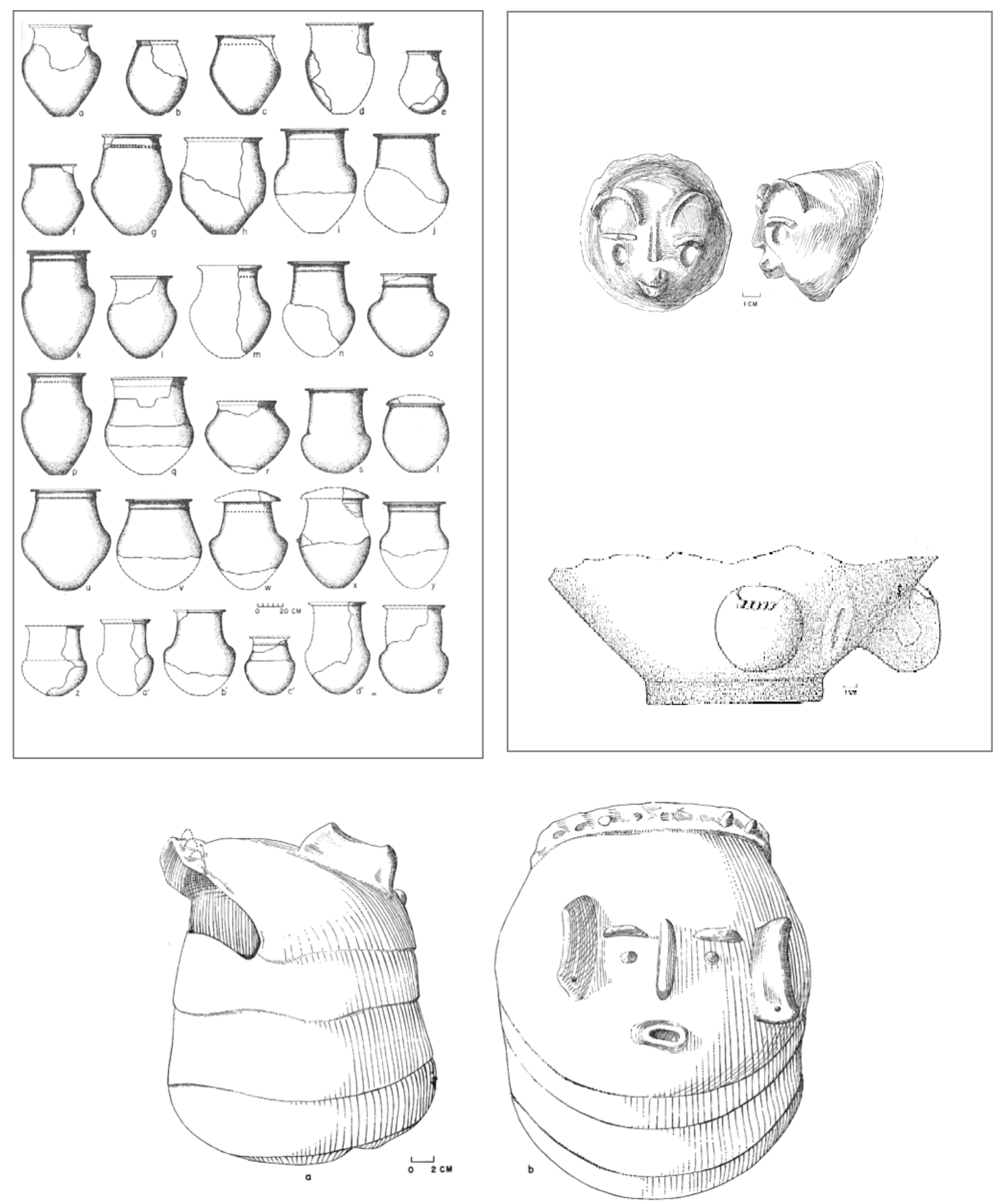

Figura 3.3

Urnas Aruã conforme documentado por Meggers e Evans (1957: 467, 485, 489, e 501): Ao alto, formas reconstituídas de urnas funerárias do cemitério Fundo das Panellas, na ilha de Caviana; ao lado, apêndices e base de urna antropomorfa; abaixo, urna com abertura lateral. 


\section{As urnas Caviana}

Ainda na ilha de Caviana, aparecem cemitérios cujas urnas têm sido descritas como do estlilo ou cultura "Caviana", e talvez corresponda à variante identificada por Nimuendaju quando de suas escavações, associando-a ao material encontrado sobretudo no sítio de Rebordello (vide Nimuendaju 2004, prancha 189: 362). Praticamente todas as urnas deste estilo são provenientes de pilhagens e constam de coleções particulares ${ }^{1}$. Tanto para Eduardo Neves (Museo Barbier-Mueller, 2003) como para Stéphen Rostain (comunicação pessoal), este estilo aparece como uma entidade híbrida, uma mistura entre a policromia da fase marajoara e a antropomofia das urnas Maracá, e também da cerâmica Aristé para Rostain.

As urnas medem entre 40 e $70 \mathrm{~cm}$ de altura, e representam corpos humanos sentados sobre bancos. Apresentam corpos tubulares ou fálicos, com braços e mão modelados em apliques sobre o corpo enquanto as pernas flexionadas são modeladas em maior volume destacadas do corpo, com os pés apoiados ao solo. Os bancos, em formato retangular, fornecem apoio ao corpo da urna. As tampas, em forma de cuia, representam as cabeças, com olhos, nariz, boca e outros elementos em apliques modelados. No corpo, há sempre a representação dos genitais.

Tanto a modelagem do corpo da urna quanto os apliques, conferem grande naturalismo às figuras humanas representadas, às vezes com uma decoração pintada bastante elaborada, cuja distribuição pelo corpo remete às práticas de pintura corporal.

\footnotetext{
${ }^{1}$ Duas destas urnas são conhecidas na coleção do Museu Babier-Mueller de Arte Précolombiana em Barcelona e foram publicadas em catálogos do museu $(2002,2003) \mathrm{A}$ proveniência de Caviana é incerta, apesar da seguinte nota publicada no catálogo de 2002: "Lors de l'exposition de cette pièce et la suivante en 1992, um visiteur nommé Carlos Delgado nous a laissé une note disant qu'um propriétaire terrien de la petite ile de Caviana, au nord de Marajó, possédait une urne absolument identique, trouvée sous ses terres » (2002:84). Outras 5 urnas são conhecidas em uma coleção particular formada pelo suíço Gerard Geiger (falecido em 2003) e publicadas no catálogo "Au coeur de l'Amerique pré-colombienne, Collection Gerard Geiger, 5 Continents Editions, Milão, 2003). Sobre estas, a proveniência de Caviana também é incerta, apesar de serem apresentadas sob esta categoria no catálogo.
} 
Infelizmente não há mais informações sobre os contextos de depósito arqueológico destas urnas e tampouco de seus conteúdos funerários. No entanto, a boa conservação dos exemplares conhecidos pode ser uma indicação de que as urnas não eram enterradas, mas apenas depositadas à superfície de lugares mais protegidos da ilha, a exemplo dos outros cemitérios aí conhecidos.
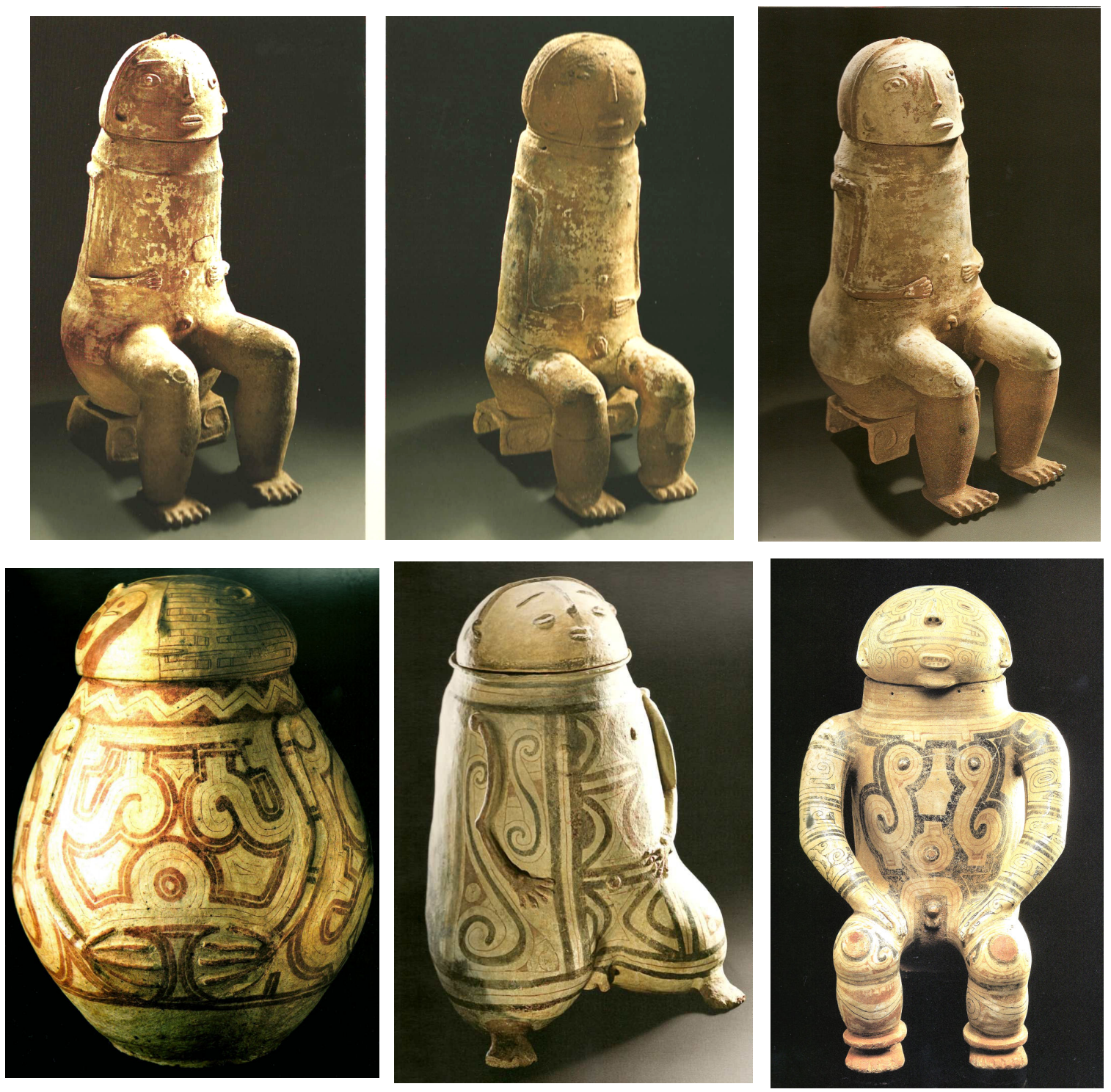

\section{Figura 3.4}

Urnas ditas "Caviana".

Acima, três urnas da coleção Geiger, Suiça (Geiger, 2003, alturas variam entre 71 e $73 \mathrm{~cm}$ ). Abaixo, à esquerda, urna de coleção particular, Suíça (Schoepf, 1995; altura: $60 \mathrm{~cm}$ ) ; ao centro, urna da coleção Geiger; altura $55 \mathrm{~cm}$ ); à direita, urna da coleção Barbier-Mueller (2002; altura 63 $\mathrm{cm})$. 


\section{As urnas Maracá}

As principais informações sobre os cemitérios e urnas Maracá provêm das coletas de Ferreira Penna (1877), Lima Guedes (1897, 1898), e publicações de Emílio Goeldi (1900) no final do século XIX, das coletas de Nimuendajú em 1915 e Farabee (1921), e das escavações de Vera Guapindaia nos anos 1980's (Guapindaia e Machado 1997, Guapindaia 2001; Souza et al, 2001.)

Não se sabe ao certo quando se dá o início da ocupação correspondente a este estilo, mas ele parece ter perdurado até pouco após o contato com europeus, como atestam as contas de vidro encontradas em algumas urnas.

Os cemitérios se distribuem nas regiões mais altas e protegidas do vale do Rio Maracá (sul do Amapá), em abrigos rochosos e cavernas de formatos e dimensões variadas. As urnas estão depositadas à superfície, em número, distribuição e formatos variados.

As urnas mais comuns são as antropomorfas, em figuras humanas sentadas sobre bancos, com os braços flexionados e mãos apoiadas sobre os joelhos. Variam entre 20 e $85 \mathrm{~cm}$ de altura. $O$ antropomorfismo aqui é mais estilizado, com corpos mais tubulares, braços e pernas destacadas do corpo, também mais tubulares. As tampas que formam as cabeças podem ser trapezoidais ou semi-esféricas, apresentando furos para amarração junto à borda do corpo. Na parte superior das tampas um disco plano apresenta decoração plástica. Na cabeça e no corpo, a decoração com incisões, apliques modelados e pintura em branco, amarelo e preto, representa adornos e pinturas corporais. Via de regra, o sexo da urna é indicado pela representação modelada de seus genitais. Ao longo das costas, uma aplique vertical com incisões horizontais, forma uma saliência semelhante às vértebras de uma coluna vertebral. Existem também urnas zoomorfas, igualmente decoradas e com tampas, e urnas tubulares simples, sem decoração.

Os ossos humanos de apenas um indivíduo, uma vez decorados, eram colocados dentro da urna de forma padronizada. Traços de resina e furos de amarração parecem indicar que a tampa era selada e amarrada ao corpo da urna. 
Os estudos de Vera Guapindaia indicam que tanto o sexo como a idade dos indivíduos, inferidos pelos vestígios ósseos, apresentam correspondência com o sexo e tamanho das urnas, tendo sido, portanto, feitas "sob medida".
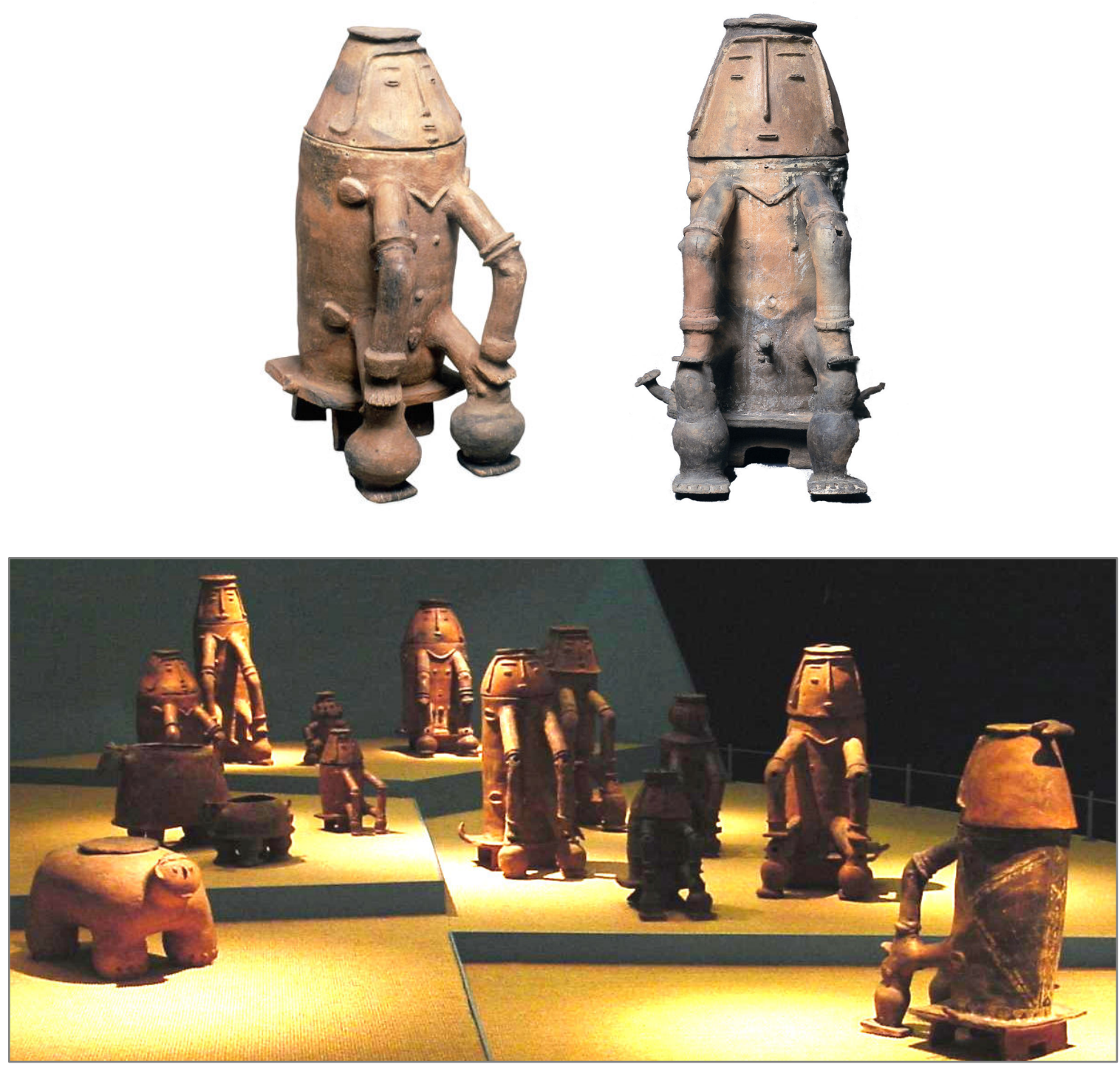

Figura 3.5

Urnas Maracá. Acima, urna feminina do Museu Etnológico de Berlim (altura: $55 \mathrm{~cm}$ ) e e urna masculina do MPEG (altura: $67 \mathrm{~cm}$ )

Abaixo, conjunto de urnas antropomorfas e zoomorfas 


\section{As urnas Mazagão}

Ao norte do Rio Maracá, a cerâmica da fase Mazagão, encontrada ao sul do rio Amapari-Araguari e nos rios Jarí e Vilanova, no Amapá, foi considerada a fase irmã da cultura Aristé, localizada mais ao norte do Amapá, por Meggers e Evans (1957:102). Contudo, trata-se de um complexo cerâmico ainda bastante desconhecido, com variantes na decoração incisa que a aproximam da Tradição Inciso Ponteada e formas e temperos da pasta que lembram tanto a fase marajoara quanto a cerâmica Maracá. Aqui também a presença de contas de vidro indica uma cronologia tardia, dos períodos pré e pós-contato.

Aqui as urnas também apresentam traços antropomorfos, porém ainda mais esquematizados que nas urnas Maracá. Duas formas distintas, uma mais tubular e outra mais globular levam apenas alguns apliques compondo um rosto. Uma urna globular, assim como na fase marajoara, apresenta rostos em duas faces simetricamente opostas. Uma urna antropomorfa com figura sentada sobre banco testemunha (segundo Meggers e Evans), uma influência tardia da cultura Maracá.
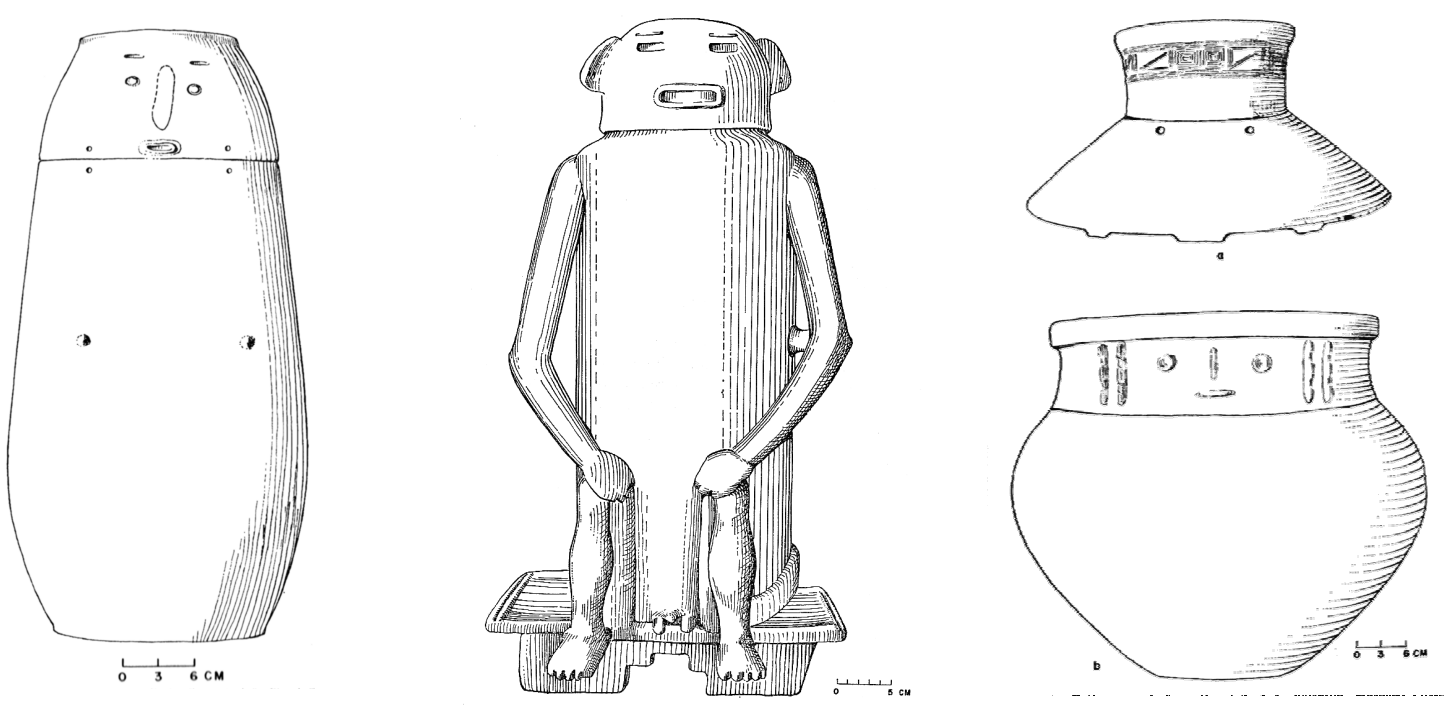

Figura 3.6

Urnas Mazagão documentadas em Meggers e Evans (1957:52,61,63).

( $A$ urna do meio foi desenhada a partir de reconstituição parcial) 
As urnas encontradas em dois sítios cemitérios registrados por Meggers e Evans (Piçacá e Valentim) apresentavam-se em concentrações no topo de colinas. As urnas variam entre formas tubulares e globulares, e são encontradas parcialmente enterradas, cobertas com tampas. Além das urnas contendo ossos tratados e, mais raramente, contas de colar e lâminas de machado, os enterramentos secundários compõem-se ainda de pequenas tigelas depositadas próximas às urnas.

\section{As urnas Aristé}

As informações sobre a cerâmica desta fase provêm sobretudo das escavações de Emílio Goeldi no sítio Cunaní (Goeldi, 1900), Nimuendaju em Calçoene e outros sítios (2004); da análise de coleções por Meggers e Evans (1957) mas sobretudo, das pesquisas de Stephen Rostain na Guiana Francesa (1994). A cerâmica desta fase ocorre em sítios distribuídos entre os rios Amapari-Araguari ao sul e Approuage ao norte, já na Guiana Francesa. A sequência cronológica é bastante longa e foi divida por Rostain em Aristé antigo (de 600 a 1350 d. C.) e Aristé tardio (de 1350 a 1750 d.C.). Pesquisas mais recentes estão sendo conduzidas no Amapá área por Mariana Petry Cabral e João Darcy de Moura Saldanha, mas os resultados ainda não foram publicados.

Ao todo são conhecidos 32 cemitérios, sendo 21 no Amapá e 11 na Guiana Francesa. Urnas cerâmicas com enterramentos secundários foram encontradas tanto no interior de câmaras subterrâneas em poços escavados em forma de bota e recobertos por lages de pedra, em grutas e abrigos rochosos, ou ainda semi enterradas no solo, em geral no tpo de colinas. (Rostain, 1994).

As formas das urnas são bastante complexas, com bases conoidais truncadas, corpos semiglobulares divididos em zonas horizontais delimitadas por roletes em relevo, mudanças de motivos decorativos pintados, e uma ou mais constrições próximas à borda. Rostos são representados em um lado da urna, por olhos, nariz e boca modelados próximos à borda e braços por apliques modelados ao longo do corpo. As tampas ultrapassam as bordas, parecendo assim chapéus sobre as figuras humanas representadas pelas urnas. Os 
motivos decorativos são pintados em vermelho sobre um engobo amarelado, e incluem uma variedade de formas geométricas tais quais faixas onduladas, espirais, escalonados, vírgulas e reticulados.

Nas estruturas subterrâneas e grutas as urnas são encontradas juntamente com uma variedade de outros recipientes decorados (vasos e tigelas). Os ossos no interior das urnas correspondem a apenas um indivíduo e são geralmente decorados.

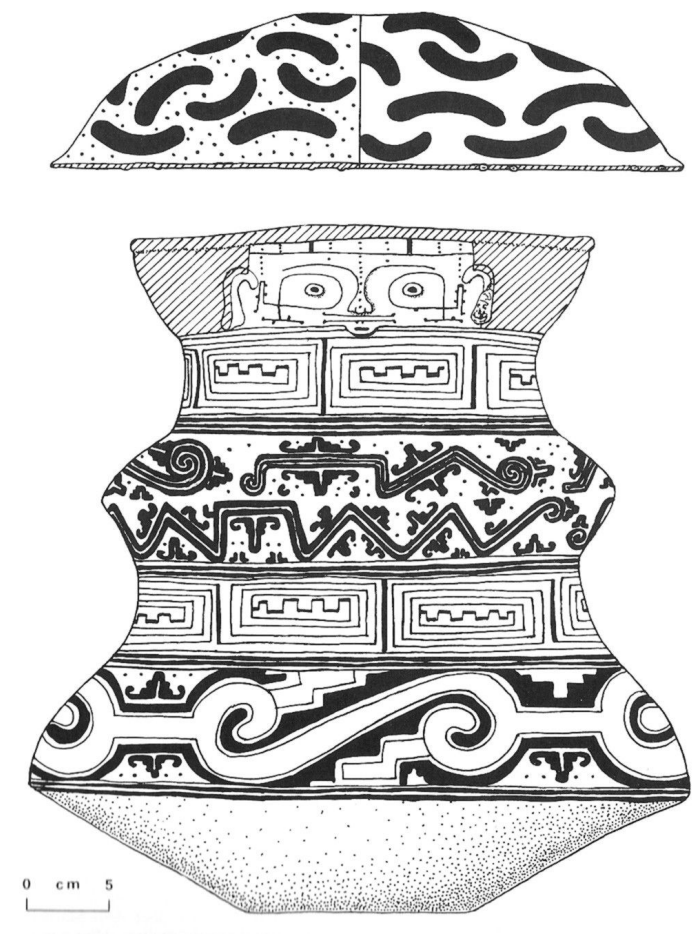

a

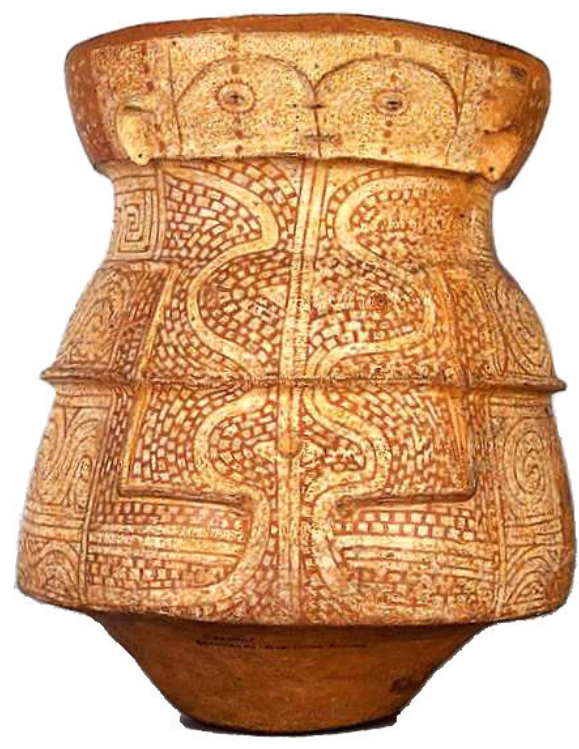

b

Figura 3.7

Urnas Aristé

a) Urna do período Aristé tardio, sítio cemitério em caverna Trou Biche,Guiana Francesa (altura $42 \mathrm{~cm}$; o desenho da tampa na metade esquerda indica a decoração de sua face interna), apud Rostain, 1994:67 );

b) Urna Aristé do cemitério Cunani, Amapá, escavado por Emílio Goeldi (altura $55 \mathrm{~cm}$ ). Acervo MPEG. 
Remontando o rio Amazonas, as ocorrências de estilos ou fases cerâmicas com enterramentos secundários em urnas cerâmicas parecem ser interrompidas ao longo da área de distribuição da cerâmica Santarém e Konduri e outras variantes relacionadas à Tradição Inciso Ponteada, entre a foz do rio Xingu e a cidade de Parintins. Isto talvez se deva ao fato de que as culturas relacionadas a estas cerâmicas praticassem os enterramentos diretos e/ou cremação dos mortos. Nimuendaju descreve ainda a prática de mumificação para os índios Tapajós que habitam esta área.

Na cerâmica Santarém, que é contemporânea aos complexos cerâmicos do baixo vale e Guianas, existem, contudo, grandes vasos antropomorfos que poderiam ter servido para a inumação de restos humanos cremados.

\section{As urnas Paredão}

É na Amazônia central que voltam a aparecer os enterramentos secundários em urnas cerâmicas, associadas às fases Paredão e Guarita. A cerâmica da fase Paredão está associada a um horizonte cronológico mais antigo, o da Tradição Borda Incisa, horizonte este datado inicialmente entre 100 e 800 d. C. na Amazônia, e comumente relacionado aos povos de língua Aruaque.

Contudo, a fase Paredão é uma manifestação bastante tardia na Amazônia central, datada aproximadamente entre os séculos VII e XII d. C. (Moraes, 2006; Neves, 2008; Lima, 2008) e, portanto, de certa forma contemporânea a outras fases da Tradição Polícroma com urnas cerâmicas. De fato, de acordo com as mais recentes interpretações sobre este complexo cerâmico na Amazônia central (Moraes, 2006:175-176; e Lima, 2008:370), a fase Paredão, parece ter sido uma evolução da fase Manacapuru, com mudanças na cerâmica provavelmente resultantes do encontro destes povos de língua Aruaque com povos de língua Tupi que surgem na área por volta de 1200 d. C., representados pela fase Guarita da Tradição Polícroma.

Moraes identifica um longo período de "convivência" entre estes dois complexos cerâmicos que resulta em mudanças tanto nos antiplásticos (com a 
inclusão do caco moído típico da Tradição Polícroma), como nas técnicas de fabricação do material Paredão. Perguntamo-nos se a ocorrência de urnas funerárias com enterramentos secundários na fase Paredão também não teria sido mais uma influência da Tradição Polícroma ou resultado desta longa convivência.

Curiosamente, a fase Paredão, além das urnas cerâmicas, apresenta também, como inovação, a construção de montículos. Apesar da associação entre urnas e montículos ser bastante sugestiva de um "pacote" cultural de práticas funerárias, de acordo com Moraes (2006:175) os montículos parecem estar correlacionados a contextos habitacionais, e não funerários.

As urnas Paredão são bastante características: são grandes (até $1 \mathrm{~m}$ de altura) e volumosas, com bojos cordiformes ou piriformes, e gargalo e ombros bem acentuados. Sobre estes, dois apliques em lados simetricamente opostos são modelados em forma de cabeças humanas ou cabeças animais mais estilizadas. Geralmente são tampadas com alguidares emborcados.
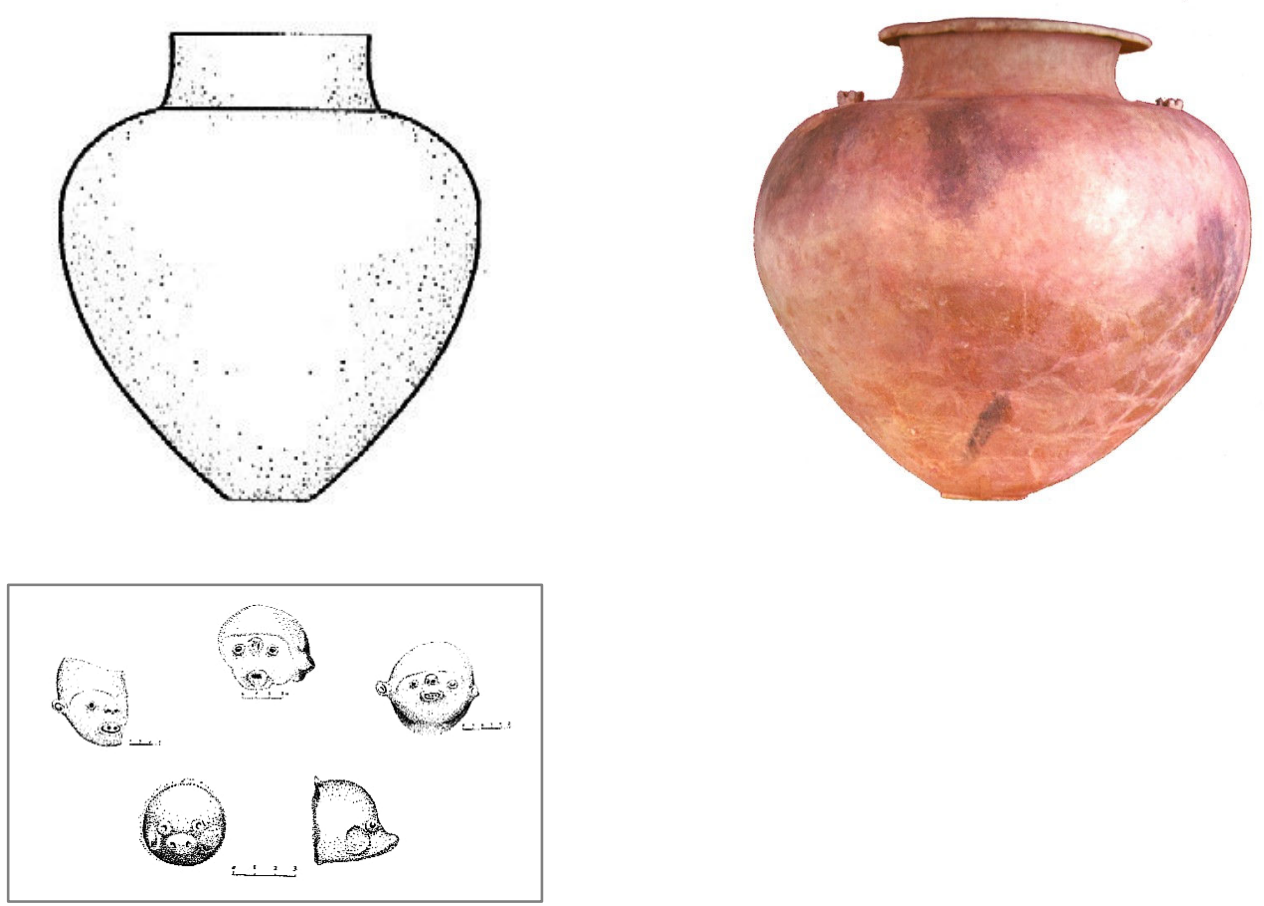

\section{Figura 3.8}

Formas características das urnas Paredão e apêndices laterais (desenhos: apud Lima, 2008: 514 e 515; foto: Urna coletada em Lages, AM por Simões, 1968, altura: $76 \mathrm{~cm}$, acervo MPEG) 


\section{As urnas Guarita}

$\mathrm{Na}$ Amazônia central, a presença de enterramentos secundários em urnas continua com as urnas da chamada sub-tradição Guarita (Evans e Meggers,1968) englobando vários estilos regionais e associada a Tradição Polícroma. Apresenta uma distribuição geográfica muito extensa, desde 0 cemitério de Miracangüera em Silves (onde as datas mais antigas remontam ao século VIII d.C), até o médio e alto Solimões (surgindo aí no século XII), e ao longo de afluentes do Amazonas e Solimões, como o Madeira, Uatumã, Negro e Japurá-Caquetá, na fronteira com a Colômbia. Na literatura, encontramos várias denominações regionais para este complexo cerâmico, que podem ser resumidas, de acordo com Neves (2006:61), em: Miracangüera (em Silves, Itacoatiara e Urucurituba); Borba (no baixo Madeira); Guarita (em Manaus e baixo rio Negro, Manacapuru, Codajás e Coari); Tefé (no médio Solimões), São Joaquim e Pirapitinga (no alto Solimões), Zebu (na região de Letícia, Colômbia) e Nofurei (no rio Caquetá, em Araracuara, Colômbia). Contudo, urnas inteiras desta sub-tradição são mais conhecidas nas suas variantes Miracangüera e Guarita.

Neves acredita que a introdução destas cerâmicas polícromas está correlacionada a mudanças no padrão de ocupação humana da área, provavelmente decorrentes de conflitos bélicos, com mais movimentações de contingentes populacionais menores, e a construção de estruturas defensivas em aldeias, tais quais fossos e paliçadas. (Neves, 2008:372)

Este complexo cerâmico parece ter perdurado até o contato e foi associado aos Omágua e Cocama descritos pelos primeiros cronistas do Amazonas. De acordo com Neves (2006:63), as datas indicam uma movimentação e dispersão da Amazônia central em direção ao alto Amazonas e Solimões, 

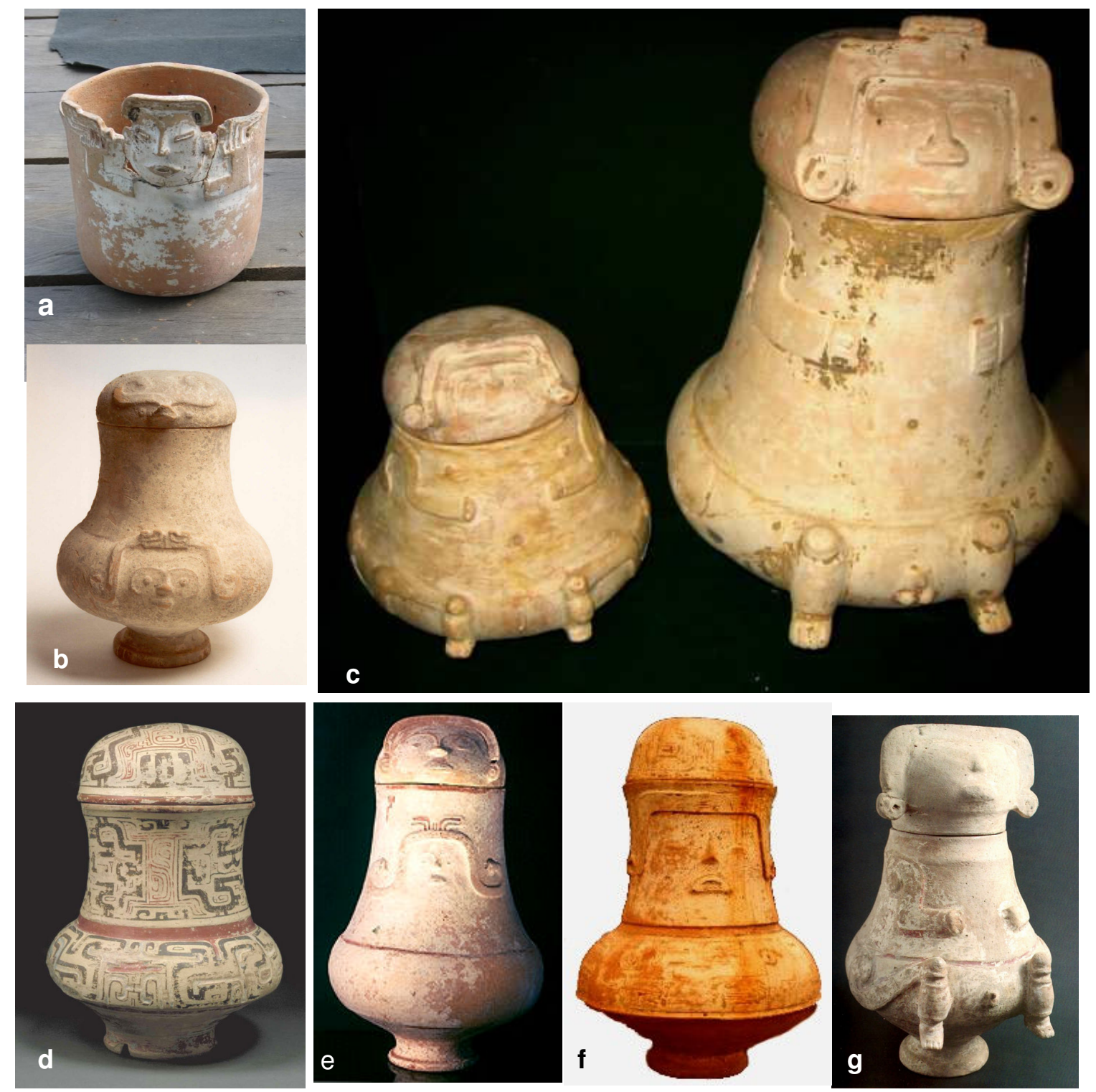

Figura 3.9

Urnas da sub-tradição Guarita

a) Urna documentada por Kazuo Tanahara, em área do rio Solimões entre Codajás e Coari, AM. b) Urna da coleção do Museu de Arte Précolombiana Barbier-Mueller, Barcelona, (proveniência desconhecida, altura: $43 \mathrm{~cm}$ ).

c) Urnas encontradas nos arredores de Urucurituba, AM.

d) Urna acervo do Instituto Geográfico e Histórico de Manaus (proveniência desconhecida, altura $60 \mathrm{~cm})$.

e) Urna da coleção ICBS-MAE (proveniência desconhecida, altura: $62 \mathrm{~cm}$ )

f) Urna encontrada nos arredores de Urucurituba, AM.

g) Urna encontrada em Nova Olinda, margem direira do R.Madeira, AM 
As urnas Guarita variam entre 25 e $80 \mathrm{~cm}$ de altura e apresentam formas mais ou menos tubulares, ou com bojo globular, às vezes carenado, e pescoço alongado. Apresentam sempre um engobo branco, e pintura vermelha e preta, às vezes sobre incisões acanaladas. As bases podem ser em pedestal, ou arredondadas, com o fundo anelar e plano. Um rosto é representado por apliques modelados ou no bojo ou na tampa, ou em ambos. A tampa pode ser uma simples tigela emborcada, ou apresentar mais detalhes plásticos. Em geral, são feitas na mesma medida da borda da urna, proporcionando um encaixe perfeito.

O rosto é sempre contornado por um aplique em forma de faixa que termina nos lados em espirais, círculos, ou forma de cabeça de cobra, na altura das orelhas, parecendo brincos. Braços e pernas, quando representados, aparecem mais colados ao corpo. As pernas são flexionadas, como se 0 indivíduo estivesse sentado, e os pés são por vezes protuberantes. O sexo, quando indicado, é representado por apliques arredondados (três protuberâncias para o masculino, e uma protuberância partida para o feminino). Existem ainda urnas com tampa em formatos similares, mas sem decoração plástica formando rosto ou membros, apenas faixas acanaladas e pintadas mais estilizadas.

Evans e Meggers acreditavam que o rosto emoldurado poderia ser uma característica estrutural das urnas do horizonte policromo na Amazônia, com variantes no restante e decoração das urnas. O mapa abaixo mostra a distribuição das urnas no horizonte então mapeado (Evans e Meggers, 1968), onde se incluem também as urnas da fase Caimito (no Peru) e rio Napo (no Equador). 


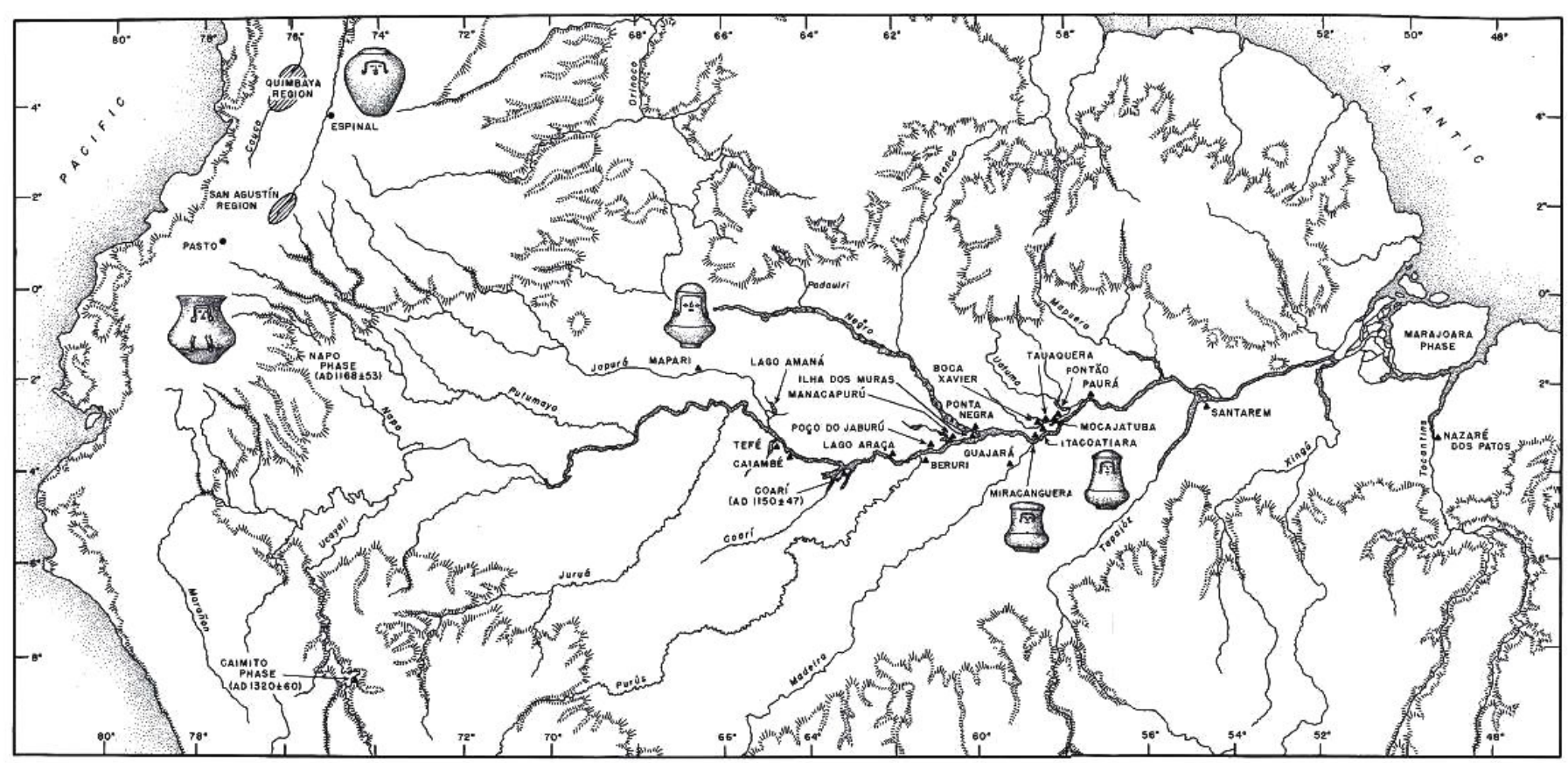

Figura 3.10

Distribuição dos diferentes estilos de urnas do Horizonte Polícromo da Amazônia, conforme proposto por Evans e Meggers em 1968, quando de suas pesquisas no vale do Rio Napo. (apud, Evans e Meggers, 1968: 94)

\section{As urnas Caimito}

No alto Amazonas ocorrências da Tradição Polícroma continuam pelo rio Ucayali, no Peru, na chamada fase Caimito, datada em torno de 1300 d.C. e provavelmente correspondendo à ocupação dos índios Cocama, documentada historicamente (Lathrap, 1970; Morales Chocano, 2000).

É interessante notar que, em período anterior, este vale teria sido ocupado por grupos de língua pano, ou multi-étnicos, com uma cerâmica igualmente polícroma e com enterramentos secundários em urnas. Estes grupos de língua pano teriam tido continuidade na área com os Shipibo e Conibo, conhecidos histórica e etnograficamente. De acordo com Morales Chocano, as investigações de Lathrap (1970), De Boer, Roe e Raymond (1075), Myers (2002) no Ucayali central e os no baixo Ucayali e Samiria (2002), indicam uma intricada rede de interações entre a Tradição Polícroma e outra tradição ceramista multi- 
étnica denominada Pacacocha (incluindo estes grupos de língua pano). Ele sugere que a Tradição Polícroma seria aí mais antiga (2002:68), mas alerta para o fato de que muitas interrogações permanecem sem respostas quanto às correlações entre complexos cerâmicos e grupos lingüísticos, assim como a associação dos enterros em urnas a uma ou outra tradição ceramista e a natureza das relações Shipibo-Conibo-Cocama.

Lathrap (1970:147) descreve urnas funerárias antropomorfas para extensos sítios desta fase no lago Imaríacocha no médio Ucayali apresentando corpos cilíndricos com os genitais indicados em relevo e complexos desenhos em preto sobre branco. A cabeça era provavelmente representada na tampa da urna. Outras apresentam o rosto característico no bojo do vasilhame.

Nos sítios estudados neste vale os enterramentos em urna se estendem por áreas de 1000 metros quadrados, correspondendo a assentamentos habitacionais sob os quais eram enterradas as urnas.

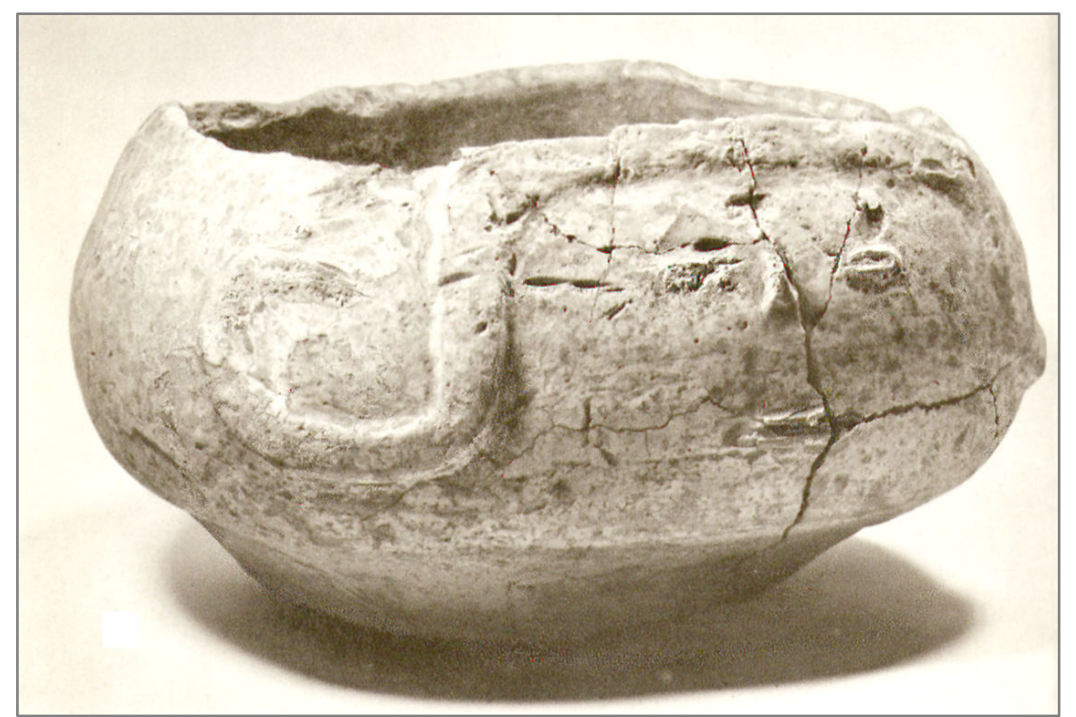

Figura 3.11

Vasilhame do complexo Caimito. Sítio Caimito, Imaríacocha, Peru. Traços de pintura vermelha e preta sobre engobo branco. Acervo Museo Nacional de Antropologia e Arqueologia, Lima. (diâmetro: 23,5 cm), apud Lathrap (1970:pr.41). 


\section{As urnas rio Napo}

A ocorrência mais a Leste da Tradição Polícroma com enterramentos secundários em urnas foi identificada por Evans e Meggers (1968) no vale do rio Napo, ao Leste do Equador, também já bastante próximo aos contrafortes andinos. Esta fase está datada aproximadamente entre os séculos XII e XV d. C. Neste vale, grupos Omagua, de língua Tupi, foram registrados desde o século XVI e tanto Lathrap como Meggers concordam com esta associação entre a cerâmica e a etnia.

Apesar dos vários sítios investigados por Meggers na área próxima à fronteira peruana, nenhuma urna antropomorfa foi encontrada in situ. De acordo com Meggers e Evans (1968:36), um grande número de urnas foram encontradas em contextos habitacionais e outras em lugares isolados. Quase todas foram observadas em museus locais, no Equador e no Peru, resultantes de achados fortuitos e, por isso, nem sempre a proveniência exata pode ser comprovada. Os dados compilados sobre estes achados aumentam a distribuição geográfica da cerâmica da fase Napo, assim como a diversidade de formas de urnas encontradas. A partir de uma amostra de 15 urnas inteiras, Evans e Meggers identificaram três tipos básicos, de acordo com a localização da abertura na urna. Segundo os autores, a elevação das formas em relevo, o estilo dos rostos, e o grau de realismo ou estilização foram consideradas variáveis independentes (Meggers e Evans, 1968:52).

- Tipo A: A abertura se localiza no topo da cabeça da urna; o corpo é cilíndrico ou globular, a base é plana ou levemente côncava. Os membros se projetam destacados do corpo ou em relevo parcial. (altura de um exemplar é 38 $\mathrm{cm})$.

- Tipo B: A abertura se localiza na base da urna. O rosto fica em um lado de uma cabeça hemisférica, mais separada do corpo cilíndrico por uma pequena constrição. A parte inferior da urna termina em curvatura interna da parede, com borda direta e lábios planos, deixando a parte central da "base" aberta. Os membros podem estar ausentes, mostrados em relevo, ou destacados do corpo. A altura de dois exemplares é de $23,5 \mathrm{~cm}$ e $48 \mathrm{~cm}$ respectivamente.

- Tipo C: A abertura se localiza no pescoço da urna, com a cabeça sendo removível enquanto tampa. A parede do corpo cilíndrico se curva internamente terminando em uma pequena constrição para o encaixe da tampa/cabeça. Os membros são representados em relevo descontínuo ou se projetam destacados do corpo. As pernas podem estar apenas sugeridas indicando posição ajoelhada 

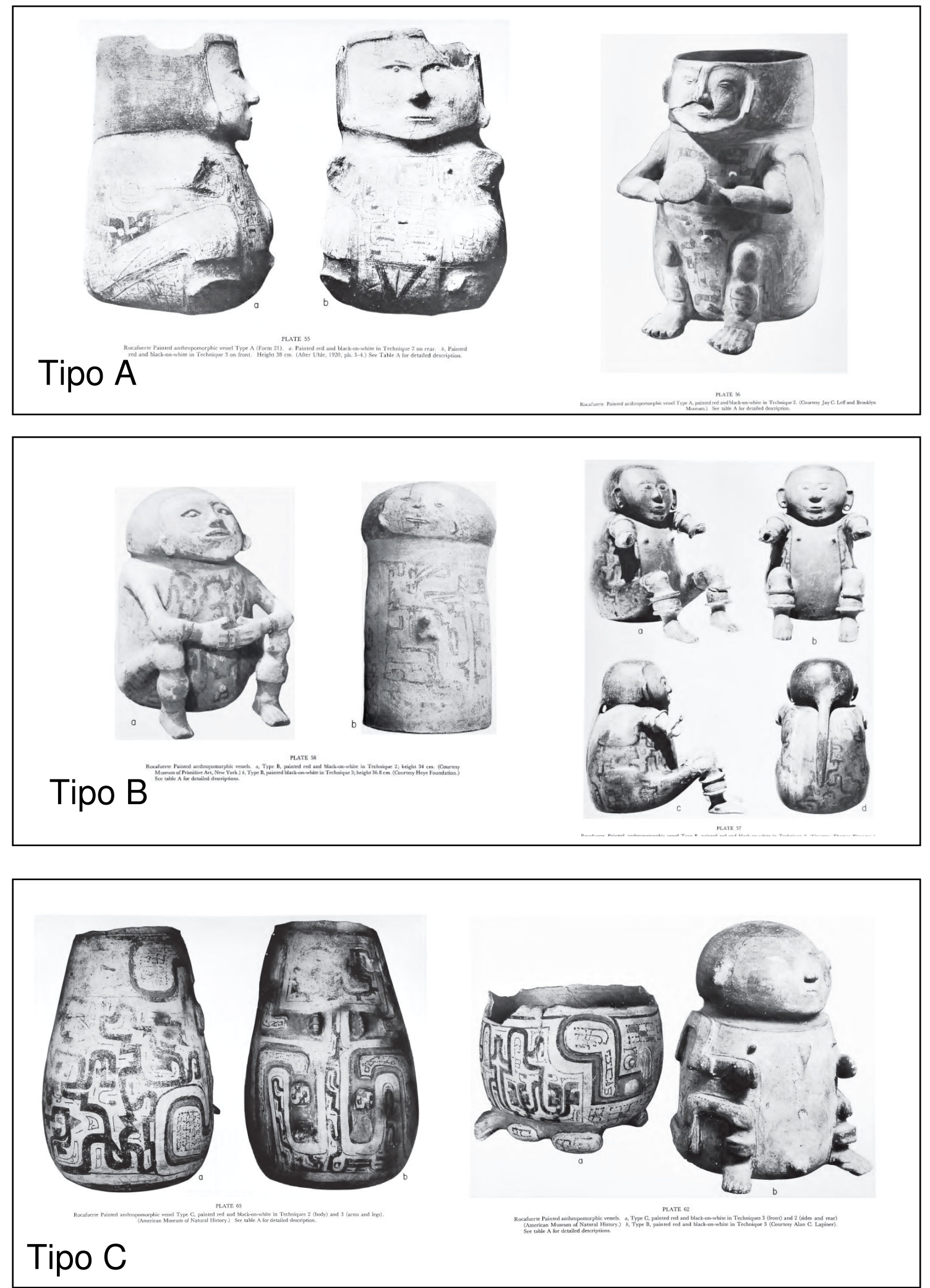

Figura 3.12

Urnas antropomorfas da fase rio Napo, Equador documentados por Evans e Meggers (1968) 
ou sentada. A altura de três exemplares são 15, 34.5 e $43 \mathrm{~cm}$ respectivamente, da base até o pescoço.

Algumas foram encontradas com os ossos preservados no interior e o pequeno tamanho de algumas indicam não só o enterramento secundário, mas também uma possível cremação incompleta dos ossos.

Curiosamente, parece ser nesta ponta tanto cronológica como geográfica da Tradição Polícroma que as urnas funerárias aparecem na sua maior diversidade de formas, com variações únicas como as aberturas na base, e também, uma maior variedade de técnicas decorativas de pintura e incisão nos motivos aplicados sobre os corpos, apresentando ainda como traço exclusivo, a pintura de motivos em negativo, isto é, com desenhos traçados em finas linhas e preenchimento do entorno, deixando a superfície sem pintura carregar os motivos predominantes.

\section{Permanências e variações estilísticas regionais}

O conjunto de urnas funerárias conhecidas para a Amazônia pré-colonial certamente exibe um grau de semelhança que compõe uma linguagem comum amazônica. O breve panorama aqui apresentado indica, sobretudo, uma longa permanência de aproximadamente 1200 anos da prática de enterramentos secundários em urnas cerâmicas antropomorfas, de uma ponta à outra da bacia amazônica. Algumas constantes, como as formas tubulares com tampa, a antropomorfia, sobretudo com a representação de uma face humana, a representação do corpo na posição sentada, a pintura corporal, a indicação do sexo, e motivos incisos e pintados em faixas, espirais, e representações de cobras, fazem parte desta linguagem pan-amazônica. São estes elementos que garantem uma das características fundamentais para se definir estilos particulares, isto é, aquilo que Roe chama de reconhecibilidade, ou a sua capacidade de ser identificado enquanto distinto de outros estilos (Roe: 1995:30).

Roe alerta para o fato de que é a visibilidade dos traços estilísticos, a maneira como eles se destacam sobre outros, do ponto de vista do observador 
(e não necessariamente do produtor), é que dão reconhecibilidade a um estilo particular. Assim, além dos traços elencados acima, há de se considerar também o fato de que muitos dos contextos em que são encontradas as urnas exibem algum aspecto que garantem sua preservação e sua visibilidade, associados a verdadeiros marcos da paisagem, marcos estes que podem ser naturais (como as grutas, abrigos, e topos de montanhas), ou construídos, como os tesos de Marajó, e os túmulos Aristé e que, portanto, podem atuar como um marcador de lugares sagrados (assim como os templos) onde se exibe as marcas estilísticas tradicionais e ancestrais das sociedade que os constroem.

Nos cemitérios Maracá, as urnas ficam em lugares protegidos (como abrigos e cavernas), e ao invés de serem enterradas, ficam expostas aos visitantes (Guapindaia, 2001). As urnas Aruã e Mazagão também não eram propriamente enterradas, mas eram colocadas em abrigos ou outros lugares protegidos, porém visíveis (Meggers e Evans, 1957).

Esta visibilidade intencional sugere fortemente a prática de uso da representação dos ancestrais enquanto marcadores de identidade política e cultural para o mundo exterior, isto é as outras sociedades amazônicas contemporâneas. Assim, os cemitérios, com suas urnas talvez nem sempre visíveis, mas certamente revisitáveis, podem, portanto, ter desempenhado funções emblemáticas de demarcação territorial para grupos externos, em uma instância de interações regionais.

Em uma instância ritual, local, eles podem ter funcionado como lugares cerimoniais, onde se não só eram celebrados rituais funerários, mas onde também se invocava o mundo ancestral e o mundo dos mortos em geral, como vimos ser comum nos rituais funerários, bororo, xinguanos e outros. $O$ fato de que muitas das urnas não fossem enterradas, mas apenas colocadas à superfície destes lugares, ou que fossem enterradas à sub-superfície sempre com tampas, de modo a preservar seus conteúdos e poderem ser rearranjadas parecem compatíveis com esta função cerimonial. Mesmo nos aterros da fase marajoara, onde as urna foram encontradas enterradas, Schaan observou que no aterro Belém por ela escavado, que a maior parte das urnas parece ter sido enterrada somente até a boca, de maneira que a tampa ficaria ao nível ou um 
pouco acima do nível do solo, permitindo acesso aos restos mortais dos antepassados. Além dos objetos encontrados dentro das urnas, poucos artefatos foram encontrados no local, indicando que havia a preocupação de manter o espaço funerário limpo de resíduos, provavelmente enquanto um espaço cerimonial (Schaan, 2003b).

A permanência temporal e a abrangência geográfica com que os traços estilísticos das urnas funerárias ocorrem na Amazônia parece também conferir uma certa unidade cosmológica aos povos fabricantes do que se convencionou chamar de cerâmica da Tradição Polícroma.

Se, no passado, a falta de dados cronológicos e a incerteza da associação entre os enterramentos e determinados complexos cerâmicos melhor identificados em contextos habitacionais tornavam ambígua a filiação cultural de enterramentos em urnas, hoje percebe-se que a correspondência entre a ocorrência de urnas antropomorfas e cerâmicas da Tradição Polícroma é quase absoluta na sua distribuição geográfica, ainda que por vezes não estejam claras as possíveis heranças, influências, ou trocas com complexos cerâmicos anteriores, como a cerâmica relacionada aos povos Aruaque na Amazônia central e como é o caso dos possíveis contatos entre os povos portadores desta tradição e outros da região sub-andina ou circum-caribenha em geral.

Se, como bem identificou Neves $(2006,2008)$, ainda não se pode afirmar se a dispersão da Tradição Polícroma pela Amazônia teria sido o resultado de uma verdadeira expansão demográfica com a colonização de novas áreas por grupos de fala tupi, ou de apenas processos de interação regional, com relações de troca e comércio que teriam difundido a cerâmica pela região, a prática de enterramentos secundários em urnas antropomorfas, parece indicar que esta dispersão não se limitou à adoção de alguns traços tecnológicos e estilísticos na fabricação das cerâmicas, mas se expressa também nas esferas rituais mais tradicionais.

Com isso, a associação entre a distribuição da cerâmica da Tradição Polícroma e povos de língua tupi parece se fortalecer, quando se adiciona este determinado padrão de enterramento à matriz cultural sugerida pelo binômio "cerâmica + língua". Resta saber, no entanto, se esta permanência cronológica 
e esta homogeneidade estilística, seria fruto de uma base cosmológica única, ou se ela é resultante de um longo processo de interação regional ao longo da bacia Amazônia, facilitado pela extensa rede fluvial.

Se tanto Meggers e Evans (1968) quanto Lathrap (1970) e Brochado (1984) já haviam sugerido o enterramento secundário em urnas antropomorfas como um traço diagnóstico da Tradição Polícroma, a variabilidade dos enterramentos secundários, e em particular as diferenças estilísticas entre as urnas, não foram utilizadas na construção de suas hipóteses nem para explicar o desenvolvimento territorial e cronológico destes complexos cerâmicos, nem a variabilidade interna da tradição.

Ao defender o desenvolvimento desta tradição a partir de uma origem na Amazônia Central por volta do início da era cristã, como postulava Lathrap (1970), Brochado se refere às urnas antropomorfas como um traço ainda ausente nos primórdios desta tradição. Brochado identifica uma mudança nas técnicas dos padrões decorativos (de acanalados para pintados), mas uma retenção das formas da sub-tradição Guarita:

"Later, the painting appeared on progressively more differentiated fields, but retained the characteristic scroll motifs, which were painted instead of incised. On the other hand, the relatively simple Central Amazonian range of vessel shapes did not change much and, there are no anthropomorphic burial urns" (Brochado, 1984: 320)."

No entanto, o modelo cardíaco de Lathrap de sucessivas levas de expansão de grupos proto-tupi a partir da Amazônia central desde o primeiro milênio antes de Cristo não se verificou com as subseqüentes pesquisas do PAC (Projeto Amazônia Central, Neves, 2003) e, portanto, a variabilidade estilística observada na cerâmica em geral, e nas urnas em particular, não parece estar relacionada à variação temporal e dispersão das supostas levas proto-tupi.

Outro fato interessante é que, do ponto de vista estilístico, tanto as formas das urnas, como as técnicas de tratamento e decoração de superfície, apresentam justamente maior variabilidade nas duas pontas do eixo leste-oeste da várzea amazônica do que na Amazônia central. Aí, as urnas da sub-tradição Guarita, apesar das diferentes ocorrências locais (incluindo nos afluentes ao 
norte e ao sul do Amazonas/Solimões) apresentam uma certa homogeneidade nas seguintes características:

a) formas gerais das urnas compostas, semi-globulares alongadas ou cilíndricas, com bases em pedestal, anelares ou cônicas;

b) tampas semi-esféricas feitas sob medida para a urna;

c) técnicas de representação humana, com rostos indicados por apliques que formam olhos, nariz e boca, aplicados no corpo ou tampa da urna e emoldurados por uma larga faixa modelada; braços junto ao corpo e pernas dobradas com pés salientes;

d) aplicação de pintura policroma preta e vermelha sobre engobo branco, em faixas largas intercaladas por linhas finas, às vezes acompanhando e sobreposta à decoração incisa e ou acanalada;

e) os motivos incisos e pintados em policromia formam espirais duplas, às vezes com as extremidades em forma de cabeça de cobra.

Já no alto Solimões, sobretudo no rio Napo, uma variedade de formas nas representações humanas resultam em uma ampla gama que varia entre corpos mais cilíndricos e tubulares até os mais globulares, com braços e pernas mais ou menos estilizados, completamente modelados e destacados do corpo ou apenas indicados em relevo, quando não estão ausentes. O grau de realismo também varia bastante, com algumas urnas exibindo ornamentos corporais, penteado, e pintura facial e corporal em detalhes.

Também já mencionamos as três diferentes localizações das aberturas das urnas, com um tipo de abertura na parte inferior da urna exclusiva a esta fase. Outra variação exclusiva é a representação da figura humana segurando entre as mãos um objeto circular (um pequeno escudo decorado, segundo Meggers e Evans).

É também nas urnas do rio Napo, que encontramos a maior diversidade de técnicas decorativas e maior variabilidade nas combinações empregadas, o que levou Meggers e Evans a definirem, para este complexo, um total de 18 tipos cerâmicos decorados. As urnas conhecidas se inserem no tipo Rocafuerte Pintado, onde um maior número de técnicas estão combinadas, as vezes em 
diferentes ordens de aplicação: incisão simples, incisão dupla, excisão, acanalado, pintura vermelha, pintura vermelha sobre branco, pintura preta sobre branco, pinturas preto e vermelha sobre branco, e mais cinco técnicas diferentes de aplicação da pintura (pontilhados, linhas finas, faixas, pintura em negativo e retoques).

Aqui também os motivos pintados variam entre faixas sinuosas intercaladas por linhas mais finas, escalonados, retângulos e círculos, e podem ser simétricos ou não.

Esta variabilidade de formas, técnicas e motivos só é comparável à da fase marajoara, onde a tipologia de Meggers e Evans (1957) definiu 14 tipos cerâmicos decorados, de acordo com as formas mais recorrentes e a gama de combinações das oito diferentes técnicas de decoração plástica identificadas nos vasilhames, todos eles com urnas funerárias. Em Marajó, contudo, a variação nas formas das urnas parece ser menor, assim como também o grau de realismo antropomorfo. Lá estão ausentes as urnas com membros destacados do corpo, com mãos pés modelados braços, forma esta de representação humana que ocorre na cerâmica Marajoara apenas nas estatuetas.

\section{Urnas funerárias, estilo e estratificação social}

Estes diferentes graus de a variabilidade regional observados nos estilos das urnas poderiam nos informar sobre diferenças na organização social destas sociedades ao longo do tempo?

A primeira pergunta a ser respondida é entendermos quem eram os indivíduos exumados nestas urnas. Apesar da falta de pesquisas sobre os contextos habitacionais e funerários, os enterramentos secundários em urnas parecem, pelo menos e alguns casos, demarcar um tratamento funerário reservado apenas a parte da população. Há contudo variação regional. Em alguns locais, parece ter sido uma prática mais freqüente, como atestam os sítios onde as urnas são encontradas em maior número, como em alguns cemitérios no médio e baixo vale (por exemplo, os sítios Fundo das Panellas, 
em Caviana, com 46 urnas, ou alguns sítios da Amazônia central, como o famoso cemitério de Miracanguera em que foram registradas dezenas de urnas). Mas muitas vezes ocorrem também em poucos números, em contextos habitacionais ou em ocorrências isoladas.

Assim, parece haver variações regionais, entre uma prática reservada a determinados indivíduos, que poderiam ser aqueles com papeis sociais individualmente diferenciados (como o chefe ou o xamã), ou a grupos de indivíduos, que poderiam corresponder a elites locais.

Particularmente nos tesos da fase marajoara, os enterramentos parecem se organizar em concentrações compostas por um conjunto de urnas que podem variar em tamanho e decoração, às vezes umas dentro de outras, assim como outros objetos associados, vasilhas cerâmicas, líticos e até mesmo outros enterramentos diretos. A julgar pela intensidade da ocupação humana na parte leste da ilha durante a fase marajoara, fica claro que nem todos os indivíduos eram sepultados em urnas cerâmicas.

Schaan interpretou os enterramentos em urnas da fase marajoara enquanto uma prática reservada a indivíduos pertencentes a uma elite social, ou seja, àqueles indivíduos pertencendo a grupos de descendência ou linhagens com maior prestígio e, por isso, os enterramentos ocorreriam em grupos, formando densas estruturas funerárias, com vários corpos ali inumados. 0 enterramento secundário de indivíduos nestas áreas especiais enfatizaria assim o pertencimento do indivíduo a um grupo ancestral particular, demonstrando e reafirmando os laços genealógicos em cerimônias funerárias, de forma a conferir maior status ao falecido e à nova geração que se segue.

De acordo, o elemento chave para tecer estes elos de identidade com ancestrais seria a iconografia das cerâmicas decoradas, onde o estilo das urnas indicaria o pertencimento do indivíduo a um determinado grupo de parentesco.

"Earle (1990:3) points out that this "active" component of style is especially apparent in chiefdoms, where some "elements of style", as in objects used in ceremonial display, are chosen purposefully to signal social relationships and group membership". In Marajoara funerary vessels, this would be accomplished by demonstrating genealogical ties to ancestors on the iconography, in order to 
empower the new generations. In this sense, funerary vessel style was likely to reinforce genealogy and tradition". (Schaan 2004: 362).

Assim, as variações de estilo (tanto na pintura, como nas formas de representação humana) corresponderiam a uma gama de elementos emblemáticos de determinados grupos sociais, tais quais clãs ou linhagens. De acordo, o pertencimento do indivíduo enterrado a um determinado grupo da elite local se daria através de uma associação espacial a um agrupamento de urnas decoradas e outros objetos de prestígio, delimitados espacialmente, e não necessariamente do seu enterro secundário em uma urna decorada com aqueles motivos emblemáticos. Isto, de certa forma explicaria a ocorrência de urnas não decoradas, de enterramentos diretos, e mesmo a ocorrência de ossos de mais de um indivíduo por urna nestas estruturas funerárias.

Esta visão pressupõe um modelo de organização social com base em uma hierarquia determinada por descendência genealógica, ou seja, uma hierarquia voltada para grupos de descendência, isto é para um status "herdado", em contraposição a uma hierarquia de indivíduos, voltada para um tipo de status conquistado ou adquirido por ações individuais. Confrontando os dados obtidos através da pesquisa nos aterros dos Camutins com os dados produzidos por outros pesquisadores, Schaan conclui que:

"o padrão hierárquico observado é mais marcado pela distinção entre a elite e pessoas comuns do que por diferenças entre membros da elite. A falta de ênfase em monumentos pessoais e o uso de enterramentos similares para um grande número de membros da elite indica que o domínio político e econômico sobre o rio Camutins, marcado pela construção de aterros e culto aos antepassados buscava legitimar uma elite que se afirmava enquanto grupo, não por personalidades individuais. Os dados são consistentes com o que Renfrew (1974) chamou de cacicados orientados para o grupo, em que o poder emana de um grupo social, não de indivíduos." (Schaan, 2003b:9)

Contudo, neste esquema proposto por Schaan, é difícil explicar a grande variabilidade de formas, estilos, dimensões e tipos de inumação de cada sepultamento individual. Se o princípio predominante de sociabilidade era 0 pertencimento a um grupo social ou a linhagens ancestrais, deveria se esperar formas mais padronizadas de enterramentos. Curiosamente, Schaan explica a variabilidade entre as urnas de uma mesma estrutura funerária como relacionada a diferenças de gênero e idade entre os indivíduos, mas, ao nosso 
ver, também poderiam denotar diferenças de status e prestígio adquiridos por merecimento. (No capítulo seguinte, nossas análises estilísticas de urnas marajoara tentam resolver esta ambigüidade.)

De qualquer forma, as implicações das interpretações sugeridas por Schaan, aproximam a sociedade marajoara a um modelo particular de sociedades mais estratificadas, semelhante ao que Heckenberger identificou no alto Xingu como um sistema de chefatura teocrática, conceito que fora usado por Oberg para descrever sociedades Aruaque do sudoeste amazônico (apud Heckenberger, 2005:332), por Julian Steward e Louis Faron (1959) para sociedades Aruaque das Antilhas (os Taïno), para as chefaturas mesoamericanas e, finalmente, por Sahlins, para as chefaturas polinésias. Segundo (Heckenberger, 2005:42), este sistema hierárquico (que hoje estaria involuído) no alto Xingu, se caracteriza pelo fato de que é a ligação genealógica mais direta com os ancestrais míticos que justifica a posição do chefe e que the confere uma autoridade sagrada; esta ligação é confirmada e mantida pelo controle dos rituais iniciatórios e funerários de chefes, quando se afirmaria 0 ciclo de transmissão de substância divina dentro da linhagem de alto status. É justamente este status que é reverenciado e reafirmado nas cerimônias funerárias do Kuarup, descritas no capítulo anterior.

Este modelo, que como já anunciamos anteriormente, contrasta com o ethos mais instável de predação e do conflito como princípios básicos de ordenação da vida social e construção da sociabilidade, não se verifica nas sociedades indígenas atuais, especialmente entre os Jívaro, Caribe, Pano e Tupi, onde o canibalismo e a guerra definem status e prestígio (Hill e SantosGranero, 2002:18).

De fato, trabalhos recentes sobre povos de língua e/ou cultura Aruaque, compilados no volume organizado por Jonathan Hill e Fernando Santos-Granero (2002), que contém, aliás, um ensaio de Heckenberger, parecem concordar quanto à especificidade Aruaque no que se refere a um princípio ontológico fundamental: enquanto em certas sociedades a pessoa se constitui (torna-se potente) pela apreensão de qualidades pertencentes a seres estrangeiros (Viveiros de Castro, 2002; Vilaça, 2000; entre outros), os xinguanos ou, mais 
especificamente, os Aruaque, localizariam a potência social no interior da sua sociedade, literalmente, no centro da praça onde estão enterrados os chefes ancestrais mais importantes, onde se realizam as cerimônias do Kuarup, e onde os postes enfeitados que abrigam a alma destes importantes ancestrais são transformados em ídolos.

Da mesma forma, na antiga sociedade marajoara, de acordo com a proposta de Schaan, para se demarcar o status diferenciado de um indivíduo da elite local, ele deveria ser enterrado no solo sagrado junto aos chefes ancestrais.

Se os padrões de enterramento observados por Schaan nos tesos de Marajó realmente indicam que esta sociedade se aproximava mais do que foi descrito por Hill e Santos-Granero como um ethos Aruaque, e não a grupos Tupi e Guarani como propuseram Lathrap e Brochado, é uma questão que deverá se resolver ao longo de diferentes linhas de pesquisa. O estudo estilístico que aproxima as cerâmicas arqueológicas Tupiguarani e Marajoara, conforme proposto por Lima (2005) é uma delas. Por outro lado, Schaan (2007: 85) argumenta que a cerâmica da fase marajoara tanto difere do restante das cerâmicas polícromas da Amazônia, por ser mais antiga e mais complexa, como também parece ter sido produzida por sociedades com graus e princípios de estratificação social distintos das sociedades Tupis conhecidas etnograficamente.

Voltando às urnas funerárias, já observamos que urnas as encontradas nas estruturas funerárias da fase marajoara exibem um menor grau de realismo antropomorfo. De forma geral não parecem representar um determinado indivíduo em particular, mas alguns "modelos" estilizados, replicados em diferentes dimensões e padrões decorativos, provavelmente representando entidades míticas. Isto, de certa forma, é bastante congruente com o modelo de Schaan para explicar o padrão funerário das elites locais, na medida em que confirma a ênfase em figuras emblemáticas de identificação grupal e não em indivíduos em particular. (No capítulo seguinte, nossas análises estilísticas das urnas abordam em detalhes esta questão.)

Este, contudo, não parece ser o caso das urnas encontradas em outros cemitérios, onde há uma correspondência mais precisa entre os atributos 
formais das urnas e indivíduos específicos. Quanto mais realistas as representações antropomorfas, mais detalhes são observados relativos à identidade do indivíduo representado, tais como as indicações relativas ao sexo, com a representação dos órgãos genitais, da identidade grupal e social com pinturas corporais específicas aplicadas aos corpos e demais ornamentações corporais (brincos, braçadeiras, tornozeleiras, colares, e adornos de cabeça) representando possivelmente insígnias de status e poder.

Nota-se, por exemplo, que apesar de a indicação do sexo estar sempre presente nas urnas antropomorfas, em algumas culturas parece haver uma real correspondência entre o sexo das urnas e o dos indivíduos nelas enterrados, como nas urnas Maracá (Guapindaia, 2001), enquanto que em outras, como nas urnas Marajoara, onde mais de um indivíduo pode ser enterrado em uma só urna, o sexo da figura antropomorfa representada é, de acordo com Schaan 2004, sempre feminino. Mas, a nosso ver, esta identificação do sexo das urnas marajoara é ainda bastante especulativa. Mesmo assim, a partir destas e outras evidências alguns arqueólogos chegaram mesmo a levantar hipóteses sobre uma maior importância do papel das mulheres em Marajó à época pré-colonial, e mais especificamente uma organização social em matriarcados (Roosevelt, 1988) ou em linhagens ancestrais femininas (Schaan, 2001b e 2003). Isto também vem reforçar a idéia de que a antropomorfia das urnas marajoara seria a replicação de um modelo único de algum personagem mítico ancestral, e não corresponderia à representação dos indivíduos nela inumados, mas, tais quais os postes kuarup, teriam uma função mais próxima da idolatria.

Outro elemento de variabilidade das urnas ao longo da bacia amazônica, é a representação de indivíduos sentados sobre bancos, objeto este que tem sido interpretado como uma insígnia de diferenciação de indivíduos masculinos de maior prestigio, como os chefes e xamãs, usados sobretudo durante rituais. Entre algumas sociedades indígenas do noroeste da Amazônia, é um objeto não só associado a rituais xamanísticos (como entre os Tukano), mas também, juntamente com outros objetos, o banco, e o ato de se sentar em um banco, remete a vários mitos de origem da humanidade e rituais de comunicação com um mundo espiritual dos seres ancestrais (Ribeiro, 1989; McEwan, 2001; 
Barreto, 2006). A construção de urnas sobre os bancos, poderiam assim ter dupla função: elevar e isolar do solo os restos mortais encerrados nas urnas, e indicar o caráter sagrado e cerimonial do espaço onde as urnas estão depositadas, deixando claro que os indivíduos ali representados ocupam um papel de destaque na sociedade.

Enquanto nas urnas Maracá e Caviana, os bancos são modelados formando a base das urnas, em outras, há apenas a indicação das pernas dobradas como alusão a uma posição sentada. Nas urnas Maracá os bancos apresentam apêndices nas laterais, de um lado representando uma cabeça (humana ou animal) e do outro, uma cauda, formando assim um animal com características bastante ambíguas, (contrastando com os bancos zoomorfos talhados em madeira hoje no Alto Xingu, onde os atributos formais permitem reconhecer perfeitamente o animal representado). Na superfície do banco, incisões formam por vezes padrões geométricos que lembram os motivos de trançados de palha, como se os bancos estivessem recobertos por esteiras, ou podem corresponder a algum motivo emblemático do grupo social ao qual pertencem.

Nas urnas Caviana, os bancos não apresentam os apêndices zoomorfos, mas alguma decoração na parte frontal, assemelhando-se formalmente mais aos bancos hoje produzidos em pelos Wayana-Apalai também no Amapá.

É interessante notar que tanto no caso das urnas Maracá, como das urnas Caviana, os bancos não são um objeto de uso exclusivo dos homens, ainda que em um contexto bastante ritual como o funerário. Isto poderia ser interpretado como um indício de um papel mais importante das mulheres nestas antigas sociedades, indo de encontro a algumas teorias que propõem a existência de sociedades matriarcais na antiga Amazônia1. Por outro lado, existem casos documentados na etnografia amazônica de xamãs mulheres, como entre os Shipibo-Conibo da Amazônia peruana (Colpron, 2005).

Muitas urnas da sub-tradição Guarita, apesar de não exibirem bancos, apresentam bases em pedestal, às vezes, conjuntamente com pernas dobradas,

\footnotetext{
${ }^{1}$ Anna Roosevelt (1988 e 1991) chegou a formular a teoria de matriarcados marajoaras a partir de uma análise da cerâmica arqueológica.
} 
cumprindo o mesmo papel de base elevada do solo. Contudo, não é possível estabelecer qualquer correlação estilística entre bancos e bases em pedestal além destas especulações.

Dentro destas considerações sobre o papel dos bancos como marcadores de individuais de prestígio e status, que bancos arqueológicos foram registrados em varias sociedades das terras baixas da América do Sul, variando em porte, estatura e decoração: existem os verdadeiros "tronos" esculpidos em pedra, encontrados dentro de grandes estruturas arquitetônicas (possivelmente antigos templos ou palácios) como os famosos bancos da cultura Manteña da costa do Equador (800-1500 d.C.) e outros bancos em pedra não menos imponentes de antigas culturas do Panamá e da Costa Rica; mas também existem os pequenos bancos circulares de cerâmica, cujos restos são encontrados em algumas culturas pré-incaicas do Equador e Peru (como Narrío e La Tolita) e que aparecem também na Amazônia, a exemplo dos próprios bancos da fase marajoara (McEwan, 2001).

Se o grau de detalhamento individual na representação antropomorfa das urnas é maior naquelas do rio Napo, aí, contudo, elas não apresentam indivíduos sentados sobre bancos, mas apenas a indicação da posição sentada. Morales Chocano (2000: 86) interpreta a posição de pernas dobradas como uma posição de parto, em vez de sentada, e vê nas urnas antropomorfas a replicação de um mesmo personagem feminino evocando o nascimento de uma nova vida. Contudo, nos parece bastante evidente de que há uma variação entre ambos os sexos representados, conforme se pode observar nas imagens apresentadas acima e que, portanto, a posição flexionada das pernas não necessariamente indica a posição de parto.

Ao contrário, tanto a variabilidade das formas antropomorfas das urnas, quanto o maior grau de detalhamento e realismo de algumas delas, nos leva a supor que, neste caso do rio Napo, as urnas provavelmente eram construídas de forma individualizada, de acordo com as características da pessoa nela inumada, incluindo os atributos simbólicos de prestígio e status, tanto na posição corporal do indivíduo representado, como na sua ornamentação. 
Acreditamos, que as diferenças entre os estilos regionais podem assim fornecer informações importantes sobre os diferentes graus e formas de expressar a estratificação social ao nível grupal e individual.

\section{Fluxo e interação regional}

Curiosamente, se para Meggers e Evans, em sua perspectiva adaptacionista, a única maneira para explicar a complexidade da cerâmica da fase marajoara era a migração para o baixo Amazonas a partir de algum centro onde a cerâmica já estivesse igualmente desenvolvida, a complexidade da cerâmica Policroma no alto vale, já nos contrafortes andinos, não oferecia qualquer incongruência do ponto de vista histórico-cultural.

A diversidade das formas, das técnicas de decoração e dos motivos incisos e pintados aplicados sobre as urnas não parece estar necessariamente relacionada a estilos regionais particulares, ou a determinadas fases temporais, mas a uma maior ou menor rigidez no uso dos elementos básicos de um repertório estilístico pan-amazônico, e a uma maior ou menor permeabilidade dos padrões estilísticos regionais face à interação com outros complexos cerâmicos.

$\mathrm{Na}$ análise estilística inter-regional, o conceito de fluxo de informação, ou de significados, pode ser uma ferramenta metodológica eficaz para entendermos a gramática da variabilidade regional expressa nas urnas antropomorfas da Amazônia.

De acordo com Peter Roe (1995), ao estudar a variabilidade estilística da cerâmica Shipibo, a localização das comunidades ao longo da rede fluvial, o acesso de uma sociedade ao fluxo de informação em uma determinada posição geográfica pode definir o grau de complexidade e a rapidez com que ciclos estilísticos ocorrem.

"The main rivers are avenues of ideas. The close juxtaposition of groups provides a "high density" information system composed of different styles that are borrowed more freely. Stylistic heterogeneity results. ...Since social interaction is greatest on the main river, more stylistic elements are available there for recombination". (Roe, 1995: 41). 
Esta correlação depende, é claro, da natureza do contato em que se dá o fluxo de informação, a qual, no caso da cerâmica, pode se realizar através de redes de troca, interações cerimoniais esporádicas, casamentos que impliquem no deslocamento de ceramistas entre comunidades, entre outras formas de contato.

O conceito de fluxo, também tem sido utilizado para se analisar a formação de sociedades multi-étnicas, como o fez Lux Vidal para estudar a circulação de tradições dentro ou através das diferentes sociedades indígenas do Oiapoque. De acordo com Vidal (1999) este conceito (conforme proposto por Hannerz (1997) e Barth (1995) dá ênfase ao caráter não estrutural, dinâmico e virtual na constituição das culturas. No caso das sociedades indígenas do Oiapoque, Vidal identificou um código gráfico (grafismos abertos e fechados) que representam a marca de um estilo misturado, aplicado a objetos tanto de uso cotidiano, quanto a objetos rituais sagrados. A partir de sociedades que compartilham muitos traços comuns, mas que se diferenciam entre si, e uma em relação às outras, dependendo do contexto, o código gráfico permitiu desvendar os processos de circulação e padronização de aspectos cosmogônicos e simbólicos.

A nosso ver, o conceito de fluxo de significados, assim como foi aplicado por Vidal, permite entender as semelhanças e recorrências estilísticas em termos de processos de interação que resultam em emulação, empréstimo e apropriação entre diferentes culturas regionais, sem termos de recorrer forçosamente à reconstituições difusionistas, como encontradas em Meggers e Evans e Lathrap e , onde a distribuição geográfica de elementos estilísticos é sempre vista como movimentação de levas migratórias.

Por outro lado, determinados processos históricos não podem ser ignorados. Para tal, são particularmente iluminadores estudos sobre a transformação da cerâmica ao longo de processos de fusão de grupos etnolinguísticos distintos, como o fez, por exemplo, Gerard Collomb com as coleções históricas da cerâmica Kali'na (ou Galibi), um povo de língua Carib, que até hoje habita o litoral das Guianas e do Amapá. Collomb demonstrou que o estilo da cerâmica atual não remete a uma etnicidade única, fechada em si 
mesma, mas é o resultado de influências e interações dos Kali'na com outros grupos, antes e depois da chegada dos europeus. A análise de uma seqüência histórica desta cerâmica possibilitou assim retraçar a complexa história de interações entre sociedades indígenas desta região e identificar processos de formação de novas identidades étnicas claramente expressos nos estilos de decoração da cerâmica, como a combinação de motivos e técnicas de pintura em um mesmo vasilhame, às vezes separadas nas áreas internas e externas dos vasilhames, ou a segmentação das superfícies dos vasilhames de modo a combinar diferentes estilos e ao mesmo tempo mantê-los separados (Collomb 2003).

Assim como com a cerâmica Kali'na, a variação de estilos regionais nas urnas funerárias amazônicas pode ilustrar como as práticas rituais funerárias e, sobretudo, as formas de representação do mundo, neste caso do mundo ancestral expressa nas urnas, podem estar intimamente relacionadas a processos históricos específicos, como a necessidade de demarcação de poderes regionais através da legitimação de suas identidades com o mundo ancestral, ou seja, relacionada especificamente à formação de cacicados e a uma dinâmica de interação regional própria, quer através de redes de troca quer através da competição e da guerra.

Voltando às urnas antropomorfas da Amazônia, algumas recorrências parecem indicar processos de fluxo ou circulação de significados em elementos independentes, onde dimensões, formas, técnicas de decoração, e motivos figurativos podem trafegar separadamente, independente de padrões rígidos de combinações específicas entre eles.

Dois exemplos específicos desta independência de elementos estilísticos podem ser identificados ao longo da bacia amazônica. O primeiro diz respeito às formas antropomorfas mais ou menos realistas das urnas. Na fase marajoara não são encontradas urnas com o grau de realismo antropomorfo na forma observado em outras áreas, com os braços e pernas bem destacados do corpo, sendo esta forma reservada a peças menores, como as estatuetas e alguns apêndices antropomorfos (inclusive das urnas) abundantes na cerâmica desta fase. Na verdade, muitas das urnas antropomorfas replicam formas observadas 
nas estatuetas da fase marajoara e vasilhas antropomorfas da cerâmica Santarém. Além disso, percebe-se que tanto as estatuetas da fase marajoara como as urnas antropomorfas do médio e alto Amazonas apresentam a mesma gama de variação entre formas tubulares fálicas e formas onde os membros são mais destacados dando maior realismo à figuração humana.

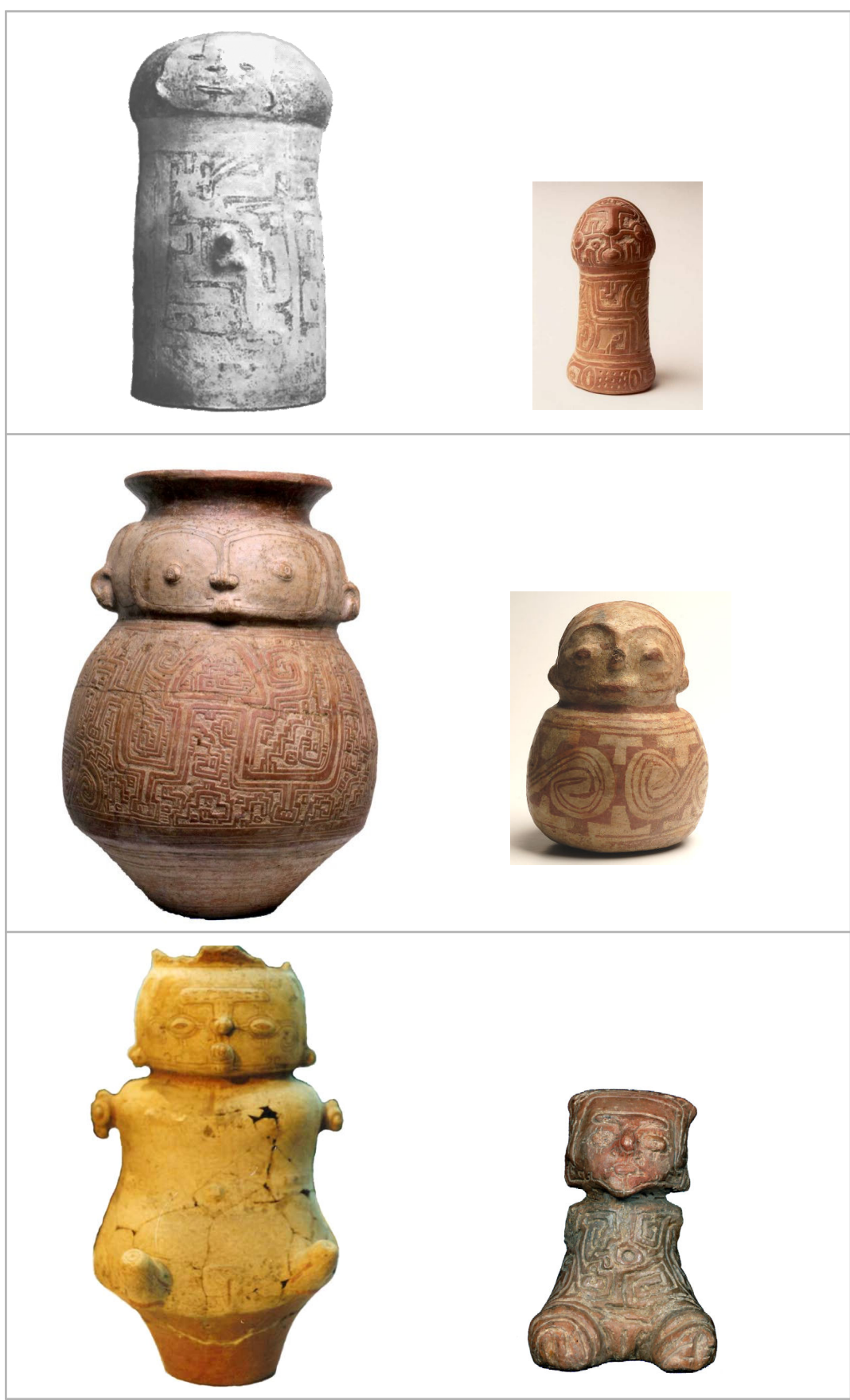

Figura 3.13

Urnas e estatuetas antropomorfas

A esquerda: Urna tubular da fase rio Napo; urna globular da fase Marajoara (acervo Museu Nacional UFRJ); urna antropomorfa da fase Marajoara, estilo Pacoval Inciso (acervo do MUPORC, UFSC). À direita: estatuetachocalho em forma fálica (acervo MAE, USP); estatueta chocalho pintada globular (altura: $13 \mathrm{~cm}$, coleção ICBSMAE); estatueta incisaexcisa antropomorfa (altura: $14,5 \mathrm{~cm}$, coleção ICBS-MAE), todas da fase Marajoara. 
Assim, entre urnas funerárias e estatuetas, as formas se replicam, independentemente das dimensões em que são materializadas e, mais importante, de suas funções rituais. Em se tratando de representações tridimensionais de figuras humanas, não seriam surpreendentes as semelhanças entre as formas de representação encontradas nas estatuetas e nas urnas, mas a perspectiva de que as urnas podem ser vistas como estatuetas aumentadas, ou vice-versa, isto é as estatuetas podem ser vistas como miniaturas de urnas é bastante sugestiva do tipo de reapropriação de elementos estilísticos que podem ter ocorrido ao longo da bacia amazônica nas diferentes esferas de interação regional.

Este fenômeno de reapropriação de formas simbólicas com alterações de dimensões, parece também ocorrer em outros objetos ligados à representação humana, como as estatuetas líticas encontradas na área do Tapajós-Trombetas (provavelmente relacionadas à cultura Konduri) que parecem replicar em dimensoões diminutas e portáveis as grandes estátuas líticas da cultura San Augustin do alto vale do Rio Magdalena, na Colômbia (Reichel-Dolmatoff, 1972, e Aires Fonseca Jr., 2007)

Outro exemplo da independência no fluxo de elementos estilísticos pode ser encontrado em dois atributos das urnas antropomorfas Maracá, o aplique reticulado nas costas da urna que indicam uma coluna vertebral, e a aplicação de motivo geométrico no topo da cabeça, também presentes em estatuetas da fase marajoara.

Figura 3.14

Urna Maracá e estatueta marajora. Vista dorsal mostrando saliência "vertebral".

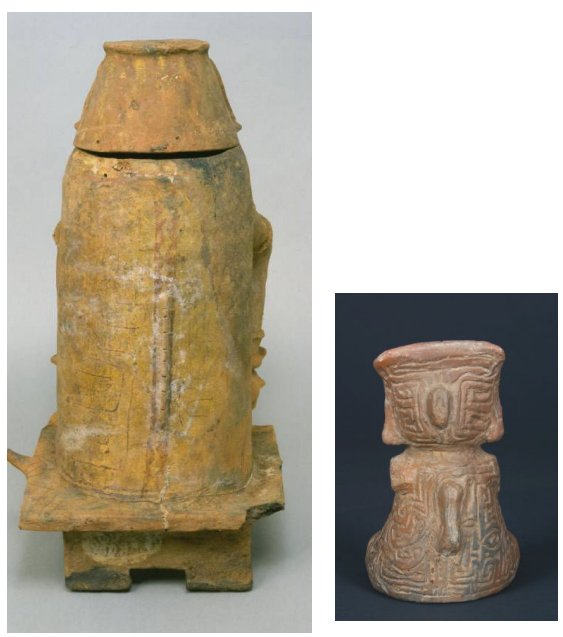


Algumas técnicas específicas, como as incisões sobre pintura e retoque posterior de pintura sobre a incisão, encontrada no tipo denominado por Meggers e Evans como Pacoval inciso na fase marajoara sobre vasilhames que não são antropomorfos é recorrente na cerâmica do rio Napo, sobre urnas antropomorfas, formando, inclusive, padrões geométricos bastante semelhantes.

Assim, parece haver uma certa independência de elementos de representação que migram tanto entre categorias de objetos (como das estatuetas para as urnas) como também entre diferentes complexos cerâmicos regionais, denotando uma alta intensidade de fluxo de técnicas e símbolos.

Em síntese, o que percebemos é que o maior ou menor grau de variabilidade se dá através de um maior ou menor número de combinações de elementos que podem ser usados independentemente de outros.

O fato de que a variabilidade seja maior tanto no baixo, como no alto Amazonas, nos faz pensar que a localização geográfica destas culturas, propiciando um contato com um maior número de complexos cerâmicos e universos estéticos distintos, pode ter favorecido um maior fluxo de elementos estilísticos.

\section{Fluxo e complexidade social na Amazônia pré-colonial}

O fluxo de elementos estilísticos das urnas antropomorfas, assim como da cerâmica em geral, também pode ser analisado em termos de apropriações de símbolos de prestígios e poder, dentro de uma dinâmica de hierarquias regionais onde ocorrem processos de empréstimo, emulação, imitação e modificação de símbolos externos que possuem um componente de prestígio. A partir da definição de Miller de emulação, isto é, o desejo de imitar ou copiar um grupo que está no poder e a adoção de produtos ou estilos associados a este grupo (1985:185).

Neste sentido, é possível que no caso dos exemplos citados acima urnas/ estatuetas cerâmicas antropomorfas e estátuas/estatuetas líticas possam representar uma emulação de centros de poder regionais mais 
hegemônicos. Seriam as formas antropomorfas das urnas funerárias encontradas naqueles complexos cerâmicos mais recentes do médio e alto Amazonas emulações das estatuetas antropomorfas da fase marajoara mais antiga, e os sepultamentos secundários nestas urnas poderiam representar um esforço de legitimação de prestigio de elites locais emulando uma origem ancestral marajoara?

Sabemos como a participação e o controle em redes de troca, o acesso a materiais exóticos ou a mais elementos estilísticos (como apontou Roe), pode colaborar para o estabelecimento de hierarquias regionais (Shortman and Urban, 1992).

Especificamente para a fase marajoara, alguns elementos comprovam sua participação em pelo menos algumas redes por onde circulam objetos exóticos, provavelmente utilizados como insígnias de prestígio e poder, como os muiraquitãs e objetos de pedra verde em geral (contas de colar e pingentes). Estes objetos, juntamente com outros instrumentos líticos, lâminas de machado e polidores de cerâmica, são encontrados associados a enterramentos secundários, provavelmente como oferendas mortuárias ou como bens pessoais da pessoa ali enterrada.

De acordo com Boomert (1987) os objetos de pedra verde encontrados no baixo Amazonas parecem ter sido objeto de circulação e troca por todo o norte da América do Sul. São encontrados por toda a região amazônica, Orinoco e Caribe, mas com apenas alguns centros de fabricação regionais, Fontes etnohistóricas relatam que os Tapajós fabricavam e trocavam sua fina cerâmica, redes, bancos de madeira e muiraquitãs, contas e estatuetas. Uma vez que os muiraquitãs são mais recorrentes na região do Tapajós-Trombetas, antigo território dos Tapajós, é provável que eles controlassem uma importante rota de comércio destes bens no baixo Amazonas. Estas peças em nefrita ou jadeíta, com perfurações para amarração com cordões, eram provavelmente utilizadas como adornos de cabeça por mulheres, e podem ter várias formas, representando diferentes animais, contudo, os batráqueos parecem mais freqüentes. 
Os muiraquitãs registrados em Marajó são raros, atestando que se os povos que habitavam a ilha participavam da rede de circulação destes objetos, eles certamente representavam um item raro, de difícil acesso e por isso valioso, assim como outros ornamentos em pedra verde, como as contas de colar, pingentes e labretes. Contudo, são conhecidas muitas peças cerâmicas que replicam tanto os labretes como os muiraquitãs em forma de sapo, estes, com as mesmas perfurações para amarração, sendo provavelmente eram usados igualmente como adornos de cabeça. Os exemplares destes "muiraquitãs" cerâmicos parecem ser bem mais numerosos, demonstrando assim um típico processo de emulação e multiplicação de um símbolo de poder e prestígio, que acabou por transformar seu caráter exclusivo em um item de fácil acesso e replicação. Não sabemos se estas "imitações baratas" de muiraquitãs, uma vez popularizadas, teriam esvaziado o significado simbólico imbuído nos muiraquitãs verdadeiros relativo ao poder de controle de redes regionais, mas é possível que este tipo de processo de emulação no fluxo de objetos e de elementos estilísticos fizessem parte da dinâmica de competição entre cacicados rivais.

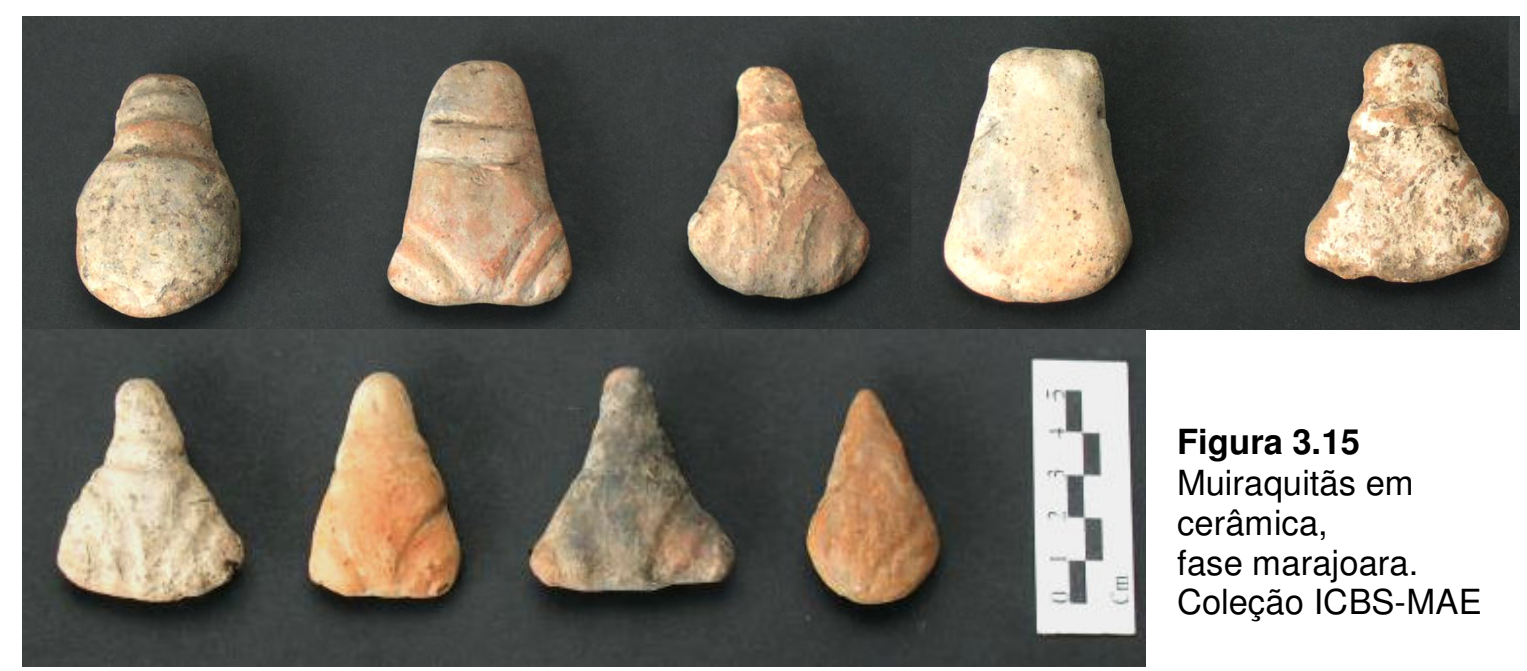



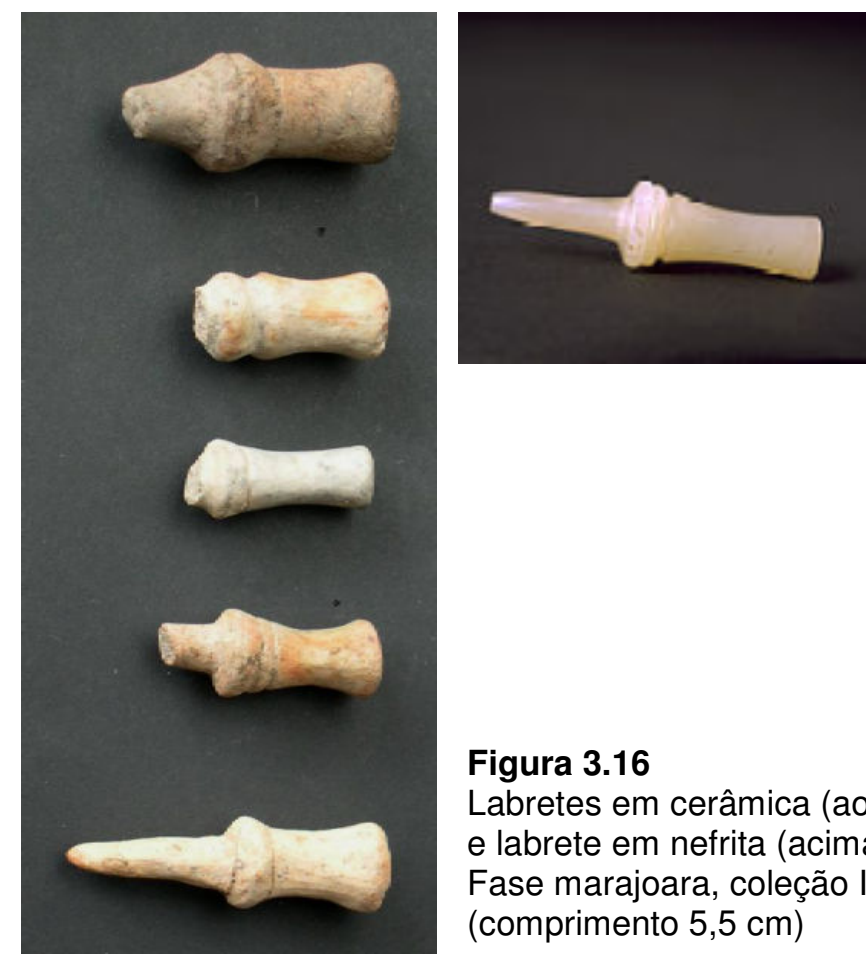

Figura 3.16

Labretes em cerâmica (ao lado)

e labrete em nefrita (acima),

Fase marajoara, coleção ICBS-MAE.

(comprimento $5,5 \mathrm{~cm}$ )

\section{Para um modelo de variabilidade regional das urnas funerárias}

Concluímos que as diferenças entre estilos regionais nas urnas funerárias da Amazônia podem fornecer informações importantes sobre os diferentes graus e formas de complexidade social atingidos pelos antigos cacicados amazônicos. De modo geral, a análise da variabilidade nas formas de representação humana destacou basicamente dois modelos de concepção de urnas antropomorfas e que, a nosso ver, correspondem também a diferentes maneiras de se conceber a fabricação da identidade humana, a relação entre alma e corpo, e a relação com a diferenciação social entre as pessoas.

De um lado tem-se o modelo $(A)$ de urna funerária que replica uma mesma figura humana (ou híbrida), apresentando algumas características que são recorrentes, tais quais as figuras emblemáticas que aparecem nas urnas mais estilizadas de formas globulares da fase marajoara, de sexo sempre feminino; ou a face replicada sobre as tampas ou corpos das urnas Guarita, também com formas bastante estilizadas, representação esta que pode corresponder a uma figura mítica ancestral, comum a estas sociedades. De 
outro lado, temos um modelo (B) de urna antropomorfa bem mais variável, que pode ser extremamente realista de representação humana, exibindo detalhes que parecem corresponder a uma representação específica do indivíduo nela exumado, como, por exemplo, as urnas Maracá, onde tamanho e gênero das urnas correspondem a idade e sexo dos indivíduos inumados, e as do rio Napo, que exibem insígnias de status individuais.

Se estes modelos de concepção de urnas antropomorfas estão de fato relacionados a diferentes formas de legitimação e transferência de status e prestígio entre elites ou lideranças locais, ainda é uma suposição bastante especulativa. Faltam ainda muitas outras evidências contextuais, tanto sobre as estruturas funerárias em si, como um melhor controle da variabilidade destas formas de representação humana nas cronologias de ocupação regional, para aprofundarmos esta correlação, mas por ora, enquanto um recurso heurístico para a formulação de hipóteses, propomos no quadro abaixo, alguns eixos de alinhamento e contraposição entre estes dois modelos de concepção de urnas ( $A$ e B) e possíveis correspondências a modelos etnográficos de sociedades indígenas amazônicas quanto às formas de constituição de identidades, hierarquia social, transmissão de poder, chefias e lideranças.

Para os modelos de sociedades indígenas, utilizamos as contraposições identificadas por Vanzolini Figueiredo (2006) entre os modelos propostos para as sociedades Aruaque (Heckenberger, 2005; Hill e Santos-Granero, 2002) e para sociedades Tupi (Viveiros de Castro, 2002, e Vilaça, 2002; entre outros). Para as relações entre as formas perspectivas amazônicas e a relação com os mortos, utilizamos especialmente as várias versões do texto de Viveiros de Castro sobre xamanismo transversal, onde ele desenvolve a idéia de que, na Amazônia, a morte demarca a descontinuidade de uma forma humana pristina, e que portanto, as almas dos humanos, são concebidas como tendo um corpo animal póstumo, ou como entrando em um corpo animal. Já em sociedades com um xamanismo vertical, ou mais próximas das chefaturas teocráticas, os mortos humanos passam a ser vistos mais como humanos, do que como mortos, e há uma continuidade na forma humana entre a vida e a morte, ou mesmo, uma passagem para uma forma sobrehumana. (Viveiros de Castro, 2005b e 2008). 


\begin{tabular}{|c|c|c|}
\hline $\begin{array}{c}\text { Urnas } \\
\text { funerárias }\end{array}$ & MODELO A & MODELO B \\
\hline $\begin{array}{l}\text { Formas de } \\
\text { representação } \\
\text { humana }\end{array}$ & $\begin{array}{l}\text { Figuras idealizadas, mais } \\
\text { estilizadas, maior grau de } \\
\text { reconhecibilidade. }\end{array}$ & $\begin{array}{l}\text { Figuras antropomorfas } \\
\text { individualizadas, podem ser mais } \\
\text { ou menos estilizadas. } \\
\text { Ocorrem figuras zoomorfas }\end{array}$ \\
\hline $\begin{array}{l}\text { Variabilidade } \\
\text { estilística }\end{array}$ & $\begin{array}{l}\text { Maior padronização das formas } \\
\text { das urnas, e recorrências } \\
\text { estilísticas bem demarcadas. }\end{array}$ & $\begin{array}{l}\text { Grande variabilidade estilística e } \\
\text { de formas de representação. }\end{array}$ \\
\hline $\begin{array}{l}\text { Conceito de } \\
\text { fabricação da } \\
\text { pessoa }\end{array}$ & $\begin{array}{l}\text { A fabricação do corpo tem um } \\
\text { modelo estável, ancestral e } \\
\text { sagrado e que pode ser } \\
\text { distribuído através de réplicas }\end{array}$ & $\begin{array}{l}\text { A fabricação do corpo é uma } \\
\text { tentativa de fixar a identidade } \\
\text { humana perante a capacidade de } \\
\text { transmutação da alma em } \\
\text { diferentes corpos }\end{array}$ \\
\hline Cemitérios & $\begin{array}{l}\text { Lugares onde realizam cerimônias } \\
\text { coletivas / rituais funerários com } \\
\text { enterros secundários dos "nobres" }\end{array}$ & $\begin{array}{l}\text { Ocorrem enterramentos } \\
\text { individuais, não necessariamente } \\
\text { em cemitérios coletivos }\end{array}$ \\
\hline $\begin{array}{l}\text { Concepções } \\
\text { sobre a vida e a } \\
\text { morte }\end{array}$ & $\begin{array}{l}\text { A morte é a fixação de uma forma } \\
\text { pristina humana ou sobre- } \\
\text { humana. } \\
\text { Há continuidade diacrônica entre } \\
\text { vivos e mortos. } \\
\text { As almas humanas tomam a } \\
\text { forma de uma figura genérica da } \\
\text { humanidade prístina. }\end{array}$ & $\begin{array}{l}\text { A morte marca a desumanização } \\
\text { das almas humanas. } \\
\text { As almas humanas póstumas } \\
\text { tomam a forma de animais. }\end{array}$ \\
\hline $\begin{array}{l}\text { Elementos } \\
\text { constitutivos } \\
\text { das identidades } \\
\text { / ontologias }\end{array}$ & $\begin{array}{l}\text { Relação com ancestrais míticos. } \\
\text { Poder ritual. }\end{array}$ & $\begin{array}{l}\text { Conflito. } \\
\text { Predação. }\end{array}$ \\
\hline $\begin{array}{l}\text { Locais e meios } \\
\text { de ação e } \\
\text { decisão política }\end{array}$ & $\begin{array}{l}\text { Grandes rituais } \\
\text { Inter-tribais, coletivos, na praça } \\
\text { central da aldeia. }\end{array}$ & $\begin{array}{l}\text { Divinações xamânicas realizadas } \\
\text { dentro de casa. }\end{array}$ \\
\hline $\begin{array}{l}\text { Figuras de } \\
\text { maior prestígio/ } \\
\text { autoridade }\end{array}$ & $\begin{array}{l}\text { Chefe imbuído de uma autoridade } \\
\text { sagrada transmitida por linhas } \\
\text { ancestrais. } \\
\text { "Xamã vertical" ou sacerdote. }\end{array}$ & $\begin{array}{l}\text { O xamã é a figura de maior } \\
\text { prestígio de acordo com seus } \\
\text { poderes de cura e divinação, } \\
\text { "Xamã horizontal". }\end{array}$ \\
\hline $\begin{array}{l}\text { Transmissão da } \\
\text { chefia }\end{array}$ & Por genealogia ancestral. & $\begin{array}{l}\text { Por merecimento ou conquista } \\
\text { individual. }\end{array}$ \\
\hline $\begin{array}{l}\text { Sociabilidade } \\
\text { inter-tribal }\end{array}$ & $\begin{array}{l}\text { Relações pacíficas de comércio e } \\
\text { troca cerimonial. }\end{array}$ & Guerra e canibalismo. \\
\hline $\begin{array}{l}\text { Modelos } \\
\text { etnográficos }\end{array}$ & $\begin{array}{l}\text { (proto) Aruaque } \\
\text { Tukano + sociedades multi- } \\
\text { étnicas do noroeste amazônico (?) }\end{array}$ & (proto) Tupi, Pano Jívaro \\
\hline $\begin{array}{l}\text { Modelos de } \\
\text { cacicados }\end{array}$ & Chefaturas "teocráticas" & Chefaturas tribais \\
\hline $\begin{array}{l}\text { Estratificação } \\
\text { social }\end{array}$ & $\begin{array}{l}\text { Sociedades mais hierarquizadas e } \\
\text { mais estáveis; } \\
\text { Hierarquias entre grupos de } \\
\text { descendência; sociedades } \\
\text { abertas, pluri-étnicas. }\end{array}$ & $\begin{array}{l}\text { Sociedades menos } \\
\text { hierarquizadas e chefaturas mais } \\
\text { instáveis, fechadas e autônomas. }\end{array}$ \\
\hline
\end{tabular}


Para além das diferenças entre estilos de representação humana e variabilidade, as semelhanças encontradas entre os estilos regionais têm sido interpretadas ora como coincidências, ora como evidência de contato e interação entre estas sociedades, uma vez que redes de troca testemunhadas pela distribuição de certos objetos poderiam ter impulsionado também a adoção de formas plásticas e grafismos. Contudo, a recorrência das figuras e grafismos representados pode também denotar uma base mitológica minimamente comum, cujo processo histórico precisa ainda ser melhor documentado arqueologicamente.

Nesta linha, alguns processos históricos melhor conhecidos em escala mais localizada talvez possam elucidar a relação entre estilos artísticos e transformações sociais na região amazônica como um todo. Por exemplo, estudos sobre variações estilísticas ao longo da fase marajoara, revelaram que ao invés de se correlacionarem a diferenças cronológicas, como previamente sugerido (Magalis,1975; Meggers e Evans,1957; Roosevelt,1991), estas variações estilísticas resultaram de uma rápida expansão geográfica da cultura Marajoara pela ilha, em um período de 100 a 200 anos, e uma segregação de sub-estilos teria surgido para demarcar centros regionais autônomos que interagiam ou competiam entre si (Schaan, 2003). No capítulo seguinte, nos deteremos na análise estilística mais detalhada das urnas marajoara para a verificação desta correlação.

Da mesma forma, o aparecimento durante o primeiro milênio d.C. de práticas de enterramento em urnas cerâmicas antropomórficas decoradas por toda a bacia amazônica pode ser visto como o surgimento de uma linguagem comum, usada de forma identitária por toda a região amazônica para se demarcar centros de poder regionais (chefaturas ou cacicados) através dos diferentes estilos da cerâmica funerária.

É interessante notar que a representação humana em urnas funerárias cerâmicas, uma tradição regional tão disseminada na Amazônia pré-colonial, e apesar de continuada durante os primeiros tempos de contato (como atestam as 
contas de vidro européias encontradas em urnas Maracá), parece ter sido abandonada por completo entre as sociedades indígenas ao longo da história.

Seu abandono certamente não se deve ao abandono da fabricação da cerâmica, uma vez que algumas sociedades amazônicas (como por ex. os Waujá, ou os Karajá) mantiveram esta prática até hoje, mantendo também seus diferentes estilos de forma e decoração. A importância do mundo ancestral entre as sociedades indígenas contemporâneas tampouco diminuiu, como denotam a prática de rituais funerários aqui revisitados

É possível que certas práticas contemporâneas, como, por exemplo, a representação do morto nos postes kuarup, no Alto Xingu, possa ser vista como uma reminiscência das urnas antropomorfas funerárias do passado pré-colonial. Esta clara relação entre hierarquia social e ancestralidade, observada ainda hoje entre as sociedades xinguanas, teria tido sua origem nos processos précoloniais de transformação social que originaram os estilos regionais de urnas funerárias?

O abandono da prática de enterramentos em urnas funerárias enquanto demarcadores de identidade de poderes regionais é certamente compatível com aquilo que conhecemos sobre as mudanças sócio-políticas que sofreram os cacicados amazônicos após os primeiros anos de colonização, em que a dizimação populacional e a reintegração de poderes regionais em redes de comércio e guerras coloniais reorganizam suas identidades sócio-políticas (Porro, 1994, Whitehead, 1992).

Whitehead descreve como, durante a colonização, determinadas sociedades ameríndias do nordeste da América do Sul que representavam poderes regionais bastante centralizados acabaram por se "tribalizar" por terem sido reduzidas demográfica e militarmente ou por terem estabelecido relações de dependência política e econômica com os governos europeus. Além disso, documenta como novas identidades étnicas e tribais foram gradualmente moldadas pela lenta e tênue expansão e contração dos Estados coloniais, concluindo que nenhum grupo indígena moderno desta área pode ser tomado como exemplo de padrões pré-coloniais de existência, pressuposto este que 
considera ingênuo quando postulado por arqueólogos e etnógrafos (Whitehead, 1992: 134-135).

No entanto, se uma certa prudência é necessária no exercício da comparação entre as culturas que a arqueologia revela e as sociedades que a etnografia observa, sobretudo no que diz respeito a suas identidades culturais, suas histórias de transformação entre o passado pré-colonial aos dias de hoje podem ser recuperadas através de testemunhos materiais que refletem estas mudanças identitárias, notadamente, nos estilos de suas cerâmicas. 


\section{A P ÍT U L O I V \\ O ESTILO DA CERÂMICA CERIMONIAL MARAJOARA}

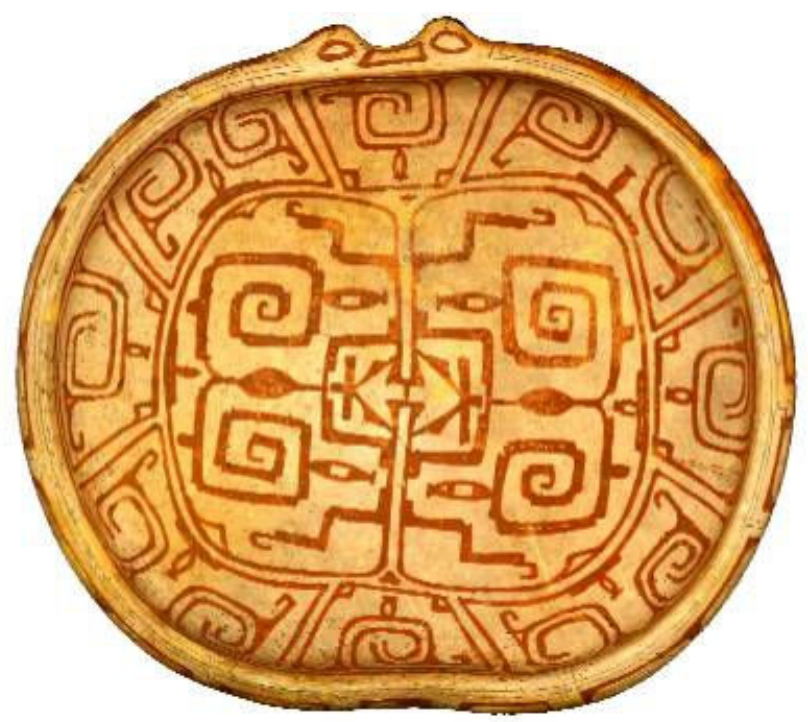

Figura 4.1

Prato marajoara da coleção ICBS-MAE (dimensões: 30,5 x $34 \mathrm{~cm}$ )

\section{A análise estilística da cerâmica marajoara da coleção ICBS-MAE}

\section{Os objetivos da análise}

Nos capítulos anteriores foram levantados alguns aspectos estruturais e contextuais dos rituais funerários e da cerâmica mortuária determinantes para delimitarmos os objetivos da análise estilística da cerâmica marajoara e suas urnas.

Primeiramente, está o fato de que a arte, tanto quanto os mitos, sintetiza conceitos e conhecimento, mas, mais especificamente, pode materializá-los, fixar referências plásticas e visuais, e assim conferir estabilidade e tradição a formas de sociabilidade reconhecidamente típicas de um universo relacional. $E$ dado que nestas sociedades, rituais funerários são a esfera por excelência de reprodução destas formas de sociabilidade, supõe-se que os princípios 
estilísticos que regem a cerâmica funerária marajoara, devem de alguma forma, refletir os princípios organizadores da sociedade.

Dada a possibilidade de objetos funerários operarem como demarcadores de territórios sagrados e como emblemas de hierarquias ancestrais, é particularmente importante explorar a agência das urnas funerárias enquanto objetos mediadores entre os vivos e o mundo ancestral, e enquanto legitimadores de poder e status herdados.

Dadas a distribuição e a variabilidade estilística observadas ao longo de uma extensa tradição de enterramentos secundários em urnas, e a possibilidade destas estarem relacionadas a diferentes formas de interação e intensidade de fluxos regionais, é preciso, estar atento a dinâmicas particulares de aquisição, apropriação e combinação de elementos estilísticos, e no caso de Marajó, ainda mais, vista a sua posição geográfica privilegiada para contatos externos.

Também visto que muitos aspectos da cerâmica marajoara tendem a destacá-la do restante das cerâmicas da tradição Policroma (é a mais antiga, a mais complexa, associada a aterros artificiais, etc...), é importante definir as bases de um estilo marajoara em termos não só dos atributos tecno-tipológioos, mas em termos de sua função ritual e das tecnologias de encantamento nela reconhecíveis.

Os objetivos da análise estilística portanto podem ser resumidos em:

- identificar os princípios de construção das urnas dentro de uma qualificação mais específica da complexidade da cerâmica marajoara em termos estilísticos;

- isolar recorrências que definam o estilo marajoara, e em especial das urnas, em termos dos efeitos sensoriais e estéticos que ela proporciona (aquilo que Roe chama de "affect" em sua definição de estilo), e outros elementos mnemônicos, ou marcas referenciais, tais quais padrões gráficos, emblemas, personagens, etc...), essenciais a reconhecibilidade do estilo;

- identificar possíveis sobreposições entre os significados simbólicos dos objetos cerâmicos sua função ritual.

- explorar diferentes tipos de agência das urnas enquanto objetos rituais. 


\section{O universo de análise}

A cerâmica marajoara e, em particular as urnas funerárias, são conhecidas em muitas coleções, de museus e particulares. Estes objetos foram coletados em diferentes circunstâncias, desde o século XIX, quer em escavações sistemáticas, quer pelos moradores e fazendeiros da ilha. Assim, um número bastante alto de urnas inteiras ou semi- inteiras está registrado em museus através do mundo:

\section{No Brasil:}

. Museu Paraense Emílio Goeldi, Belém

. Museu do Estado do Pará, Belém

. Museu do Marajó, Pará

. Museu Nacional da UFRJ, Rio de Janeiro

. Museu do Estado do Pernambuco, Recife

. Museu U. P. O. R. C. da UFSC, Florianópolis (coleção Tom Wildi)

. Museu de Arqueologia e Etnologia da USP, São Paulo

Nos E.U.A.

. University of Michigan Museum, Ann Arbor (Coleção J.B. Steere, 1871)

. Peabody Museum of American Archaeology and Ethnography, Harvard University, Cambridge , (Coleção O. A. Derby, 1876);

. University Museum, University of, Pennsylvania, Philadelphia

(Coleção W. Farabee, 1914-1915)

. The Brooklyn Museum ( Coleção D. Holdridge, 1931-1932)

. American Museum of Natural History, Nova lorque (Coleções C. Hartt, 1879; A. Lange, 1913; A. Roosevelt, 1980's)

. Museum of American Indian, Heyes Foundation, Nova lorque

. Museum of American Indian, Smithsonian, Washington (Coleções Meggers and Evans)

. Field Museum of Natural History, Chicago (Coleções Farabee e Anna Roosevelt)

\section{Na Europa:}

. Etnografiska Museet, Gotemburgo, (Coleção Nimuendaju, 1920)

. Volkerkunde Museum, Berlin , (Coleção Antonio Mordini, 1926-1927) 
Museo Nationale de Antropologia e Etnologia, Florença (Coleção Antonio Mordini, 1926-1927)

. Statens Etnografiska Museet, Estocolmo (Coleção Antonio Mordini, 19261927)

. Museum fur Volkerkunde, Vienna, (permuta com Museu Nacional, 1950)

. Musée et Institut d'Ethnographie, Geneva

. Museo Ethnográfico Luigi Pigorini, Roma

. Museu Nacional de Etnologia, Lisboa, (Coleção F. Bandeira, 1960's)

. Museu Barbier-Mueller de Arte Pré-Colombiana, Barcelona

. Cambridge University Museum of Archaeology and Ethnology

Imagens e estudos sobre urnas funerárias marajoara foram publicadas principalmente por Palmatary (1950), que fez um apanhado sistemático de todas as coleções brasileiras e norte-americanas, Meggers e Evans (1957) que publicou materiais escavados em suas pesquisas e anteriores, Magalis (1975) que realizou a seriação de uma amostra de 100 urnas de coleções brasileiras, norte-americanas e européias (mas, infelizmente sem ilustrações das urnas), e as pesquisas mais recentes de Roosevelt e Schaan, que publicaram apenas alguns exemplares de urnas, não chegando a publicar catálogos com todas as peças encontradas.

Em nossas análises, utilizaremos principalmente as urnas provenientes da coleção reunida pelo Instituto Cultural Banco Santos (ICBS) entre 2002 e 2004, hoje sob a guarda do Museu de Arqueologia e Etnologia da USP, nunca antes estudadas, e cujo inventário apresentamos em anexo. Ao longo das discussões, acrescentamos observações sobre peças provenientes de outras coleções por nós conhecidas, notadamente as brasileiras e as européias, dentre as que mencionamos acima.

A coleção do ICBS é uma coleção de peças arqueológicas da Amazônia constituída através da incorporação de diversas coleções menores e peças avulsas de colecionadores particulares. Na maior parte, são peças que foram reunidas por fazendeiros da ilha de Marajó, e que foram sendo encontradas e armazenadas nas fazendas, mas que não foram coletadas em escavações 
sistemáticas. Portanto, são peças descontextualizadas quanto a sua proveniência e estruturas arqueológicas.

Na tentativa de recuperarmos o máximo possível de informações sobre a proveniência das peças, realizamos um trabalho de localização das fazendas onde estas peças foram encontradas, a partir dos nomes dos colecionadores antigos que constavam nos registros de proveniência do Instituto Cultural Banco Santos, e com isso pudemos associar algumas coleções a sítios, ou conjuntos de sítios conhecidos na ilha. Pudemos assim verificar que a maior parte da cerâmica marajoara é proveniente das coleções das famílias Dacier (Coleção Graciete), Teixeira (Coleção Gisela e Silvia Teixeira) e do fazendeiro Luis Otávio, talvez o maior colecionador da ilha, o qual, por muitos anos, praticou escavações amadoras, tendo falecido em 2003. (O catálogo das urnas estudadas em anexo indica, sempre que possível, a coleção de origem). Pudemos verificar que estes colecionadores são todos moradores da região do alto rio Anajás, e mais especificamente dos conjuntos de tesos conhecidos como Monte Carmelo e os Camutins, uma área já bastante estudada arqueologicamente. De maneira geral estes são sítios estão já bastante erodidos e vêm sofrendo destruição por intempérie e pilhagens há mais de um século.

Três tesos em Monte Carmelo foram registrados e escavados por Meggers e Evans em 1949, tendo já sido visitados anteriormente por Steere em 1879, e por Holdridge em 1931. (Meggers e Evans, 1957). Posteriormente, um dos três tesos, o sítio de Guajará foi também escavado por Roosevelt onde foram obtidas três datações, entre 615 d. C., 890 d. C. e 1275 d. C., interpretadas como pertencentes a duas sub-fases: Camutins (Ca. 400-700 d.C.) e Guajará (700-1100 d.C.). (Roosevelt ,1991:187 e 314, tabela 5.1).

Os tesos Os Camutins, são certamente os maiores e mais conhecidos de Marajó, constituindo um conjunto de cerca de 40 aterros em uma área de aproximadamente $10 \mathrm{~km} 2$ ao longo do igarapé Os Camutins, afluente do rio Anajás. Estes sítios foram registrados desde 1867 por von Martius e foram visitados e ou escavados por Ferreira Penna (Hartt, 1885), Orville Derby (1879), W.C. Farabee (1921) que escavou o aterro então chamado de Magno (hoje dito 
Belém), Sandoval Lage (1944) e Hilbert (1952) que descreveu peças provenientes de 17 tesos.

Meggers e Evans registraram 20 sítios e escavaram o topo do maior deles, Camutins (ou M1) descrevendo duas estruturas funerárias. Estes sítios foram retomados pelas pesquisas de Schaan, que escavou dois tesos (Camutins e Belém, ou M1 e M17 respectivamente) e cujos resultados estão em sua tese de PhD (Schaan, 2004). As datas obtidas situam-se entre 660 e 995 d.C. para Camutins e entre 680 e 1030 d. C. para Belém. Neste último, uma estrutura funerária contendo 24 urnas foi comparada às estruturas funerárias encontradas por Meggers e Evans em Camutins, e é com base nestes dados que Schaan propôs suas hipóteses sobre os significados dos enterramentos em urnas da fase marajoara.

Grande parte das urnas aqui analisadas faz parte deste contexto arqueológico. Certamente correspondem ao período chamado de "clássico" da fase marajoara, entre 700 e 1100 d. C., caracterizado por Schaan como um período de prosperidade, multiplicação de cacicados e expansão de uma ideologia religiosa por toda a ilha. (Schaan, 2004:264).

Infelizmente não pudemos incorporar em nossas análises outras inferências cronológicas sobre a variabilidade do material proveniente destes sítios, uma vez que as seriações propostas por Meggers e Evans (1957) e Magalis (1975) são discordantes, e embasadas em atributos distintos. Enquanto Meggers e Evans trabalham com atributos relativos às técnicas e formas, Magalis privilegia os elementos estilísticos. Além disso, Schaan refuta ambas as seriações, colocando a hipótese de que a variabilidade dos tipos cerâmicos encontrada nestes sítios refletem menos diferenças temporais, e mais diferentes graus de fluxo de ceramistas (ou mulheres) enquanto portadoras de estilos distintos (Schaan, 2004).

A isto acrescentamos outro fator que dificultaria o reconhecimento de variações estilísticas na cerâmica funerária ao longo do tempo: o fato de que se está lidando com um sistema de combinação de técnicas, formas plásticas e grafismos que são em si associados a valores de ancestralidade e que, portanto, é de se esperar que estilos particularmente mais antigos fossem 
recuperados, replicados ou transformados intencionalmente. Assim, tais atributos não constituiriam bons "guias" cronológicos, a menos que se reconheça a gramática destes processos de emulação estilística.

Comparativamente às coleções arqueológicas disponíveis para o estudo de urnas funerárias amazônicas, a coleção analisada reúne um número excepcionalmente alto de recipientes inteiros, ou quase inteiros e, além disso, apresenta um alto índice de objetos com superfícies decoradas, em especial as grandes urnas, com a pintura policrômica também particularmente bem conservada. Este conjunto excepcional de objetos inteiros e com a totalidade dos motivos decorativos presentes, nos permitiu estender a análise estilística de elementos iconográficos para além da simples identificação e tipologia de determinados elementos isolados, o que é comumente feito a partir de fragmentos ou de peças fragmentadas, e abordar o projeto de composição da cada peça na sua integridade, aprofundando a análise das diferentes partes em relação ao todo, ou dos diferentes campos em cada urna, privilegiando o projeto da urna na sua individualidade.

Além disso, como foi possível recuperar muitos dos projetos "originais" de urnas funerárias na sua integridade e, portanto, perceber, a partir da contraposição dos elementos constantes aos que variam, as características gerais que estão na essência da composição desta categoria de objeto na fase marajoara e que acreditamos teve um papel importante nos rituais funerários locais.

\section{A cerâmica cerimonial marajoara}

\section{Urnas, vasos e recipientes}

A primeira dificuldade encontrada devido à descontextualização arqueológica da coleção foi a própria seleção das peças cuja função de "urna funerária" poderia ser inferida apenas através dos atributos formais do vasilhame. Além das 69 peças aqui analisadas, a coleção conta com outros 61 vasilhames classificados como "vasos", cujas formas, mais alongadas e com boca constrita, em muito se assemelham às das urnas. 
Constatamos que na literatura da arqueologia marajoara não existe de fato uma definição tipológica precisa daqueles vasilhames descritos enquanto urnas funerárias e que, na verdade, o termo "urna" é geralmente utilizado para descrever os vasilhames encontrados nos contextos funerários contendo restos humanos, mas está ausente nas tipologias de atributos formais de vasilhames.

Nas tipologias avançadas por Meggers e Evans, as "urnas" se enquadram assim em uma série de formas de vasilhames definidos para cada tipo (tecnoestilístico), correspondendo, em geral, às formas que ocorrem em maiores dimensões. O termo inglês "jar" (traduzido como "vaso") é utilizado de maneira genérica para todas estas formas, com exceção da forma de no. 14 do tipo Joanes Pintado, à qual os autores se referem como "funerary jars" (Meggers e Evans, 1957:162), apesar de muitas outras formas estarem documentadas nos desenhos que acompanham suas descrições das estruturas funerárias.

Verificamos que a tipologia cerâmica de Meggers, para organizar os diferentes tipos e suas variações, privilegiou os atributos técnicas de tratamento de superfície e forma do vasilhame, nesta ordem hierárquica, deixando em segundo plano os motivos executados e sua distribuição no vasilhame, o que ficaria dificultado por uma amostra com uma grande quantidade de fragmentos (e não peças inteiras) a partir dos quais estes atributos nem sempre poderiam ser observados.

No sistema de classificação de vasilhames do material escavado e descrito por Schaan para os aterros Camutins e Belém, as formas foram igualmente privilegiadas para se deduzir diferenciações de função e propor sua classificação em três grupos distintos: vasilhames para a preparação de alimentos ("food processing vessels"); vasilhames para beber e estocar líquidos (containers for drinking and storage"); e vasilhames para servir ("serving vessels"). As formas das urnas funerárias descritas para estes sítios corresponderiam aqui também àquelas que ocorrem em maiores dimensões no segundo grupo, o de vasilhames para beber e estocar líquidos, em particular as formas de no. XXVI, XXVII e XXVIII (Schaan, 2004:287-288).

Contudo, um teste inicial de ambas as tipologias baseadas na forma dos vasilhames contra a variabilidade das formas registradas nos grandes vasos ou 
urnas da coleção ICBS-MAE não apresentou correspondência entre os tipos propostos e formas encontradas. Surpreendentemente, os vasilhames da coleção apresentaram uma variabilidade de formas muito maior do que as descritas tanto por Meggers e Evans como por Schaan, o que provavelmente se deve a dois fatores. Um fator metodológico, isto é, ao fato de que as tipologias foram concebidas baseadas na reconstituição de formas a partir de muitos fragmentos de bordas e bases e alguns poucos vasilhames inteiros, e que uma amostra maior de vasilhames inteiros, tal qual a amostra da coleção ICBS-MAE, apresentaria variações formais de difícil reconstituição através apenas de fragmentos. Outro fator, de ordem mais conceitual, é o fato de que as tipologias foram construídas para dar conta da variabilidade encontrada na maior parte do material escavado que, em ambos os casos, corresponde à cerâmica utilitária, e que, provavelmente, a cerâmica ritual apresenta outros parâmetros de variabilidade.

Neste sentido, o sistema de classificação da cerâmica marajoara proposto por Roosevelt, no qual ela separa a cerâmica cerimonial (utilizada em contextos rituais e funerários) da cerâmica utilitária (para se processar e servir alimentos), parece mais apropriado para uma análise de materiais cerâmicos descontextualizados, em particular das urnas funerárias. Roosevelt registrou uma maior variabilidade e complexidade nas formas, técnicas e acabamento dos vasilhames da cerâmica cerimonial escavada no Teso dos Bichos, um sítio mais a leste na ilha de Marajó, que integra outros grupos de sítios ao longo do rio Arari. Para este material, Roosevelt chega a argumentar que a cerâmica cerimonial teria sido feita não só para usos distintos reservados às elites locais, mas também por um grupo mais especializado de ceramistas (Roosevelt, 1991:370).

Dentre as características apontadas por Roosevelt para a cerâmica cerimonial estão:

- superfícies mais bem alisadas e polidas;

- modelagens figurativas mais apuradas;

- decoração incisa-excisa aplicada nas paredes externas de forma mais fina e complexa, freqüentemente combinada com pintura vermelha e branca; 
- pintura policrômica figurativa mais apurada;

- formas com contornos mais complexos, carenadas, e por vezes formando silhuetas excêntricas ou efígies;

- as bordas são mais grossas, angulares e complexas, e são freqüentemente decoradas com adornos figurando humanos e animais;

- as bases são mais complexas, incluindo bases em pedestal.

Apesar de Roosevelt ter identificado a distribuição exclusiva da cerâmica cerimonial em sítios não habitacionais, incluindo os cemitérios, tanto Meggers como Schaan descrevem também cerâmicas mais simples, não decoradas, encontradas nas estruturas funerárias e utilizadas inclusive como urnas. Assim, mesmo que haja uma diferença de concepção e de execução de uma cerâmica cerimonial, não sabemos ao certo se as cerâmicas depositadas nas estruturas funerárias marajoara, em especial as urnas funerárias, tenham sido fabricadas especialmente para este propósito ou se, pelo menos em alguns casos, cerâmicas utilitárias tenham sido re-aproveitadas para fins funerários.

$\mathrm{Na}$ Amazônia, existem registros etnográficos de cerâmicas que são fabricadas sem decoração para uma determinada função e que podem ser posteriormente decoradas para serem usadas para fins cerimoniais ou rituais, e são assim re-usadas e re-pintadas conforme a ocasião, tal como nos relata Lagrou para a cerâmica Kaxinawá:

Assim como nem sempre e nem todos os corpos são pintados, também nem todos os objetos keneya têm desenho. Panelas para cozinhar comida não são pintadas, mas pratos para servir comida podem sê-lo. A pintura é associada a uma fase de novidade na vida do objeto ou da pessoa, uma fase na qual é desejável enfatizar a superfície lisa e perfeita do corpo em questão. O desenho chama a atenção para as novidades na experiência visual, que anunciam eventos cruciais da vida. O desenho desaparece com o uso e só é refeito por ocasião de uma festa. Assim, coisas com o desenho ocupam um lugar especial na cultura Kaxinawá, como em outras culturas do ocidente amazônico. (Lagrou, 2002:40).

De qualquer forma, parece claro que a presença ou ausência de decoração nos vasilhames em si, não é um indicador exclusivo para definir a cerâmica enquanto cerimonial e, muito menos, funerária, e que um conjunto mais complexo de atributos deve ser considerado. 


\section{Os atributos observados ${ }^{1}$}

Foi com base no conjunto de atributos formais indicados por Roosevelt e naqueles descritos para os recipientes funerários individualmente documentados por Meggers e Evans e por Schaan para os sítios do alto Anajás, que procedemos à análise de uma gama bastante extensa de atributos formais de todos os vasilhames decorados da coleção ICBS-MAE para separar aqueles que pudessem ser classificados como urnas funerárias. A presença ou ausência destes atributos foram inicialmente registrados de forma descritiva, pois, em se tratando de peças descontextualizadas, cujos critérios de coleta e formação de coleção foram provavelmente a boa conservação e presença de decoração nas peças, desde o início de nossas análises, nos pareceu inapropriado empregar a qualquer metodologia quantitativa, mesmo sendo esta uma amostra bastante volumosa.

Os atributos observados nos vasilhames foram:

\section{Dimensões}

Forma/contorno do vasilhame

Acabamento da superfície

Motivos decorativos e representação figurativa:

- técnicas empregadas (pintura, incisão, excisão, incisão e excisão, modelagem, modelagem e pintura);

- localização na peça: bojo, pescoço, borda externa, borda interna, alça;

- ocorrência em pares simétricos

Tipo de motivo decorativo: linhas duplas, reticulado, ondas, espirais, espirais duplas, ziguezagues, círculos, retângulos, lozangos, escalonados, cruzes, outro;

Tipo de representações figurativas: (assim denominados a título de identificação)

- coruja/mulher, cobra, lagarto, morcego, escorpião, macaco, figura antropomorfa genérica, rosto sorridente, olho, boca, tridígito, outro.

Esta análise inicial de vasilhames inteiros evidenciou algumas possibilidades de associações entre técnicas e motivos, imprevistas nas tipologias disponíveis, e que dificilmente seriam contempladas em uma análise

\footnotetext{
${ }^{1}$ Esta análise da presença e ausência dos atributos aqui mencionados em vasilhames da coleção ICBS-MAE, foi realizada com todos os vasilhames da coleção, incluindo urnas, vasos, tigelas e pratos, em um total de 354 peças. Resultados parciais desta análise foram apresentados no I Encontro de Arqueologia Amazônica, em setembro de 2008 em Belém.
} 
multivariada destes atributos em coleções formadas por fragmentos. Algumas das associações observadas foram:

a) Os mesmos motivos, ou motivos muito semelhantes, podem ser aplicados no mesmo vasilhame, mas serem executados em técnicas diferentes. Isto ocorre em recipientes abertos, em que as superfícies tanto interna como externa são visíveis e com a utilização de técnicas diferentes em cada uma. Isto indica a importância do modo de fazer não só como uma técnica de aplicação de um motivo ou figura, mas talvez também como marca de um estilo, na qual o meio (ou a mídia) pode ser tão importante quanto a mensagem. Isto é, o fato de um vasilhame ser pintado pode ser tão relevante quanto a figura ou o motivo pintado à sua superfície. Percebemos que quando os mesmo motivos são aplicados com diferentes técnicas de acordo com a superfície, há uma preferência pela pintura nas superfícies internas. Talvez isto se deva à função do vasilhame, mas, como veremos adiante, esta preferência certamente está relacionada a princípios mais gerais do estilo marajoara relativos aos planos internos e externos, invisíveis e visíveis dos objetos.

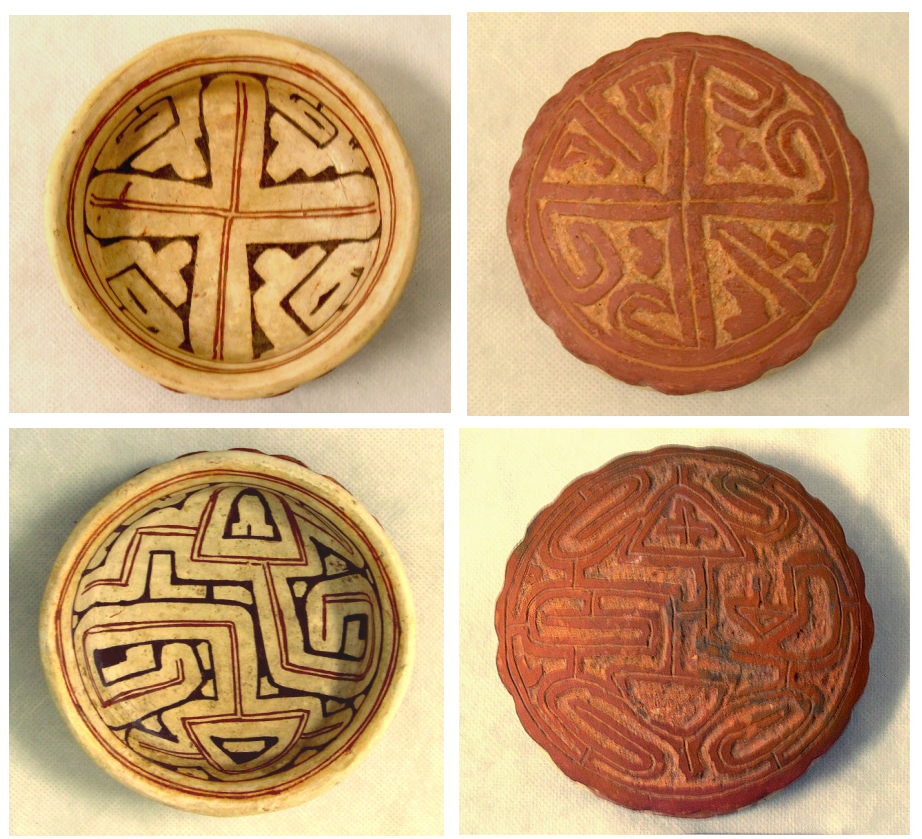

Figura 4.2

Pequenas tigelas da coleção ICBS-MAE com os mesmos motivos na superfície interna pintada e na superfície externa incisa-excisa. Peças de no. 646 (diâmetro: 11,8 cm) e 645 (diâmetro: 13,5) 
b) Desenhos com traços formais diferentes podem resultar em efeitos visuais semelhantes, inclusive executados em técnicas diferentes, como a pintura e a excisão. Motivos formalmente distintos, mas semelhantes (que com certeza seriam classificados em categorias distintas se observados apenas em fragmentos) nos indicam a importância de outras variáveis na percepção dos padrões, tais quais a visibilidade do gesto na pintura, ou o os efeitos de ritmo, de movimento, de repetição e simetria nos diferentes de campos decorativos.

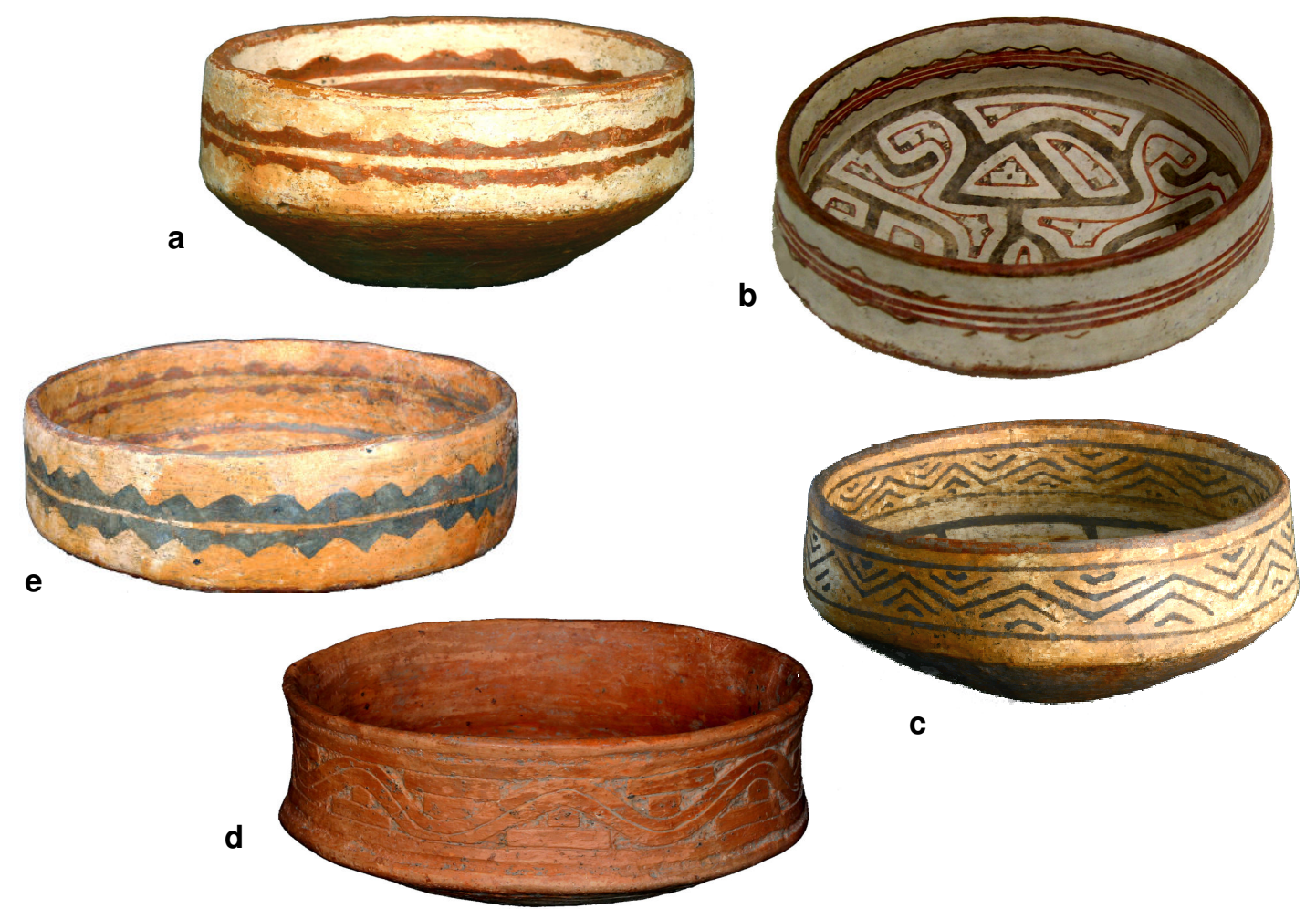

Figura 4.3

Tigelas da coleção ICBS-MAE

a) 1575: tigela com pintura vermelha sobre engobo branco (alt.: $4,8 \mathrm{~cm}$; diâmetro: $10,4 \mathrm{~cm}$ ); b) 653 tigela com linhas vermelhas paralelas e linha preta em zig-zag (altura: 9 $\mathrm{cm}$; diâm. $20 \mathrm{~cm}$ ); c) 693: tigela pintada com motivos em zig-zag (altura: $9 \mathrm{~cm}$; diâmetro: $20 \mathrm{~cm}$ ); d) 708: tigela excisa (altura: $9 \mathrm{~cm}$; diam.: $20 \mathrm{~cm}$ ); e) 324: tigela com pintura preta e vermelha sobre engobo alaranjado (altura: $7,5 \mathrm{~cm}$; diâmetro: $19 \mathrm{~cm}$ ). 
c) Alguns motivos são aplicados em objetos de formas e função distintas, enquanto outros são exclusivos a determinados objetos. Percebe-se uma independência relativa entre formas, técnicas, figuras e motivos geométricos na maneira em que estes elementos se combinam, apesar de um repertório bastante rígido, bem delimitado, e preciso.

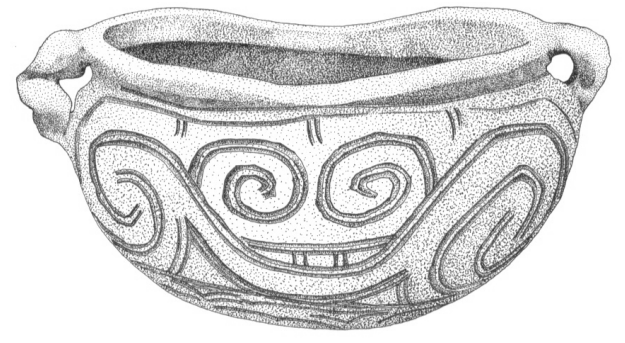

a

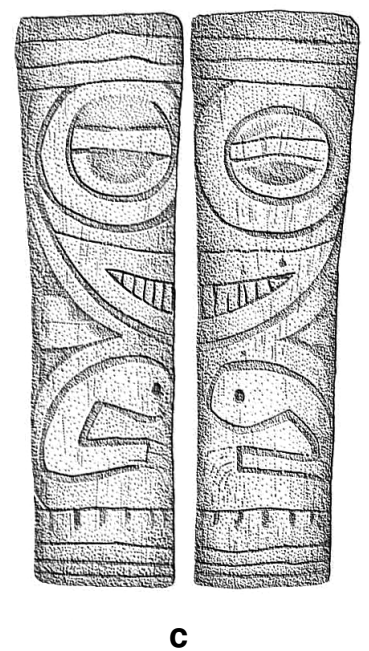

C

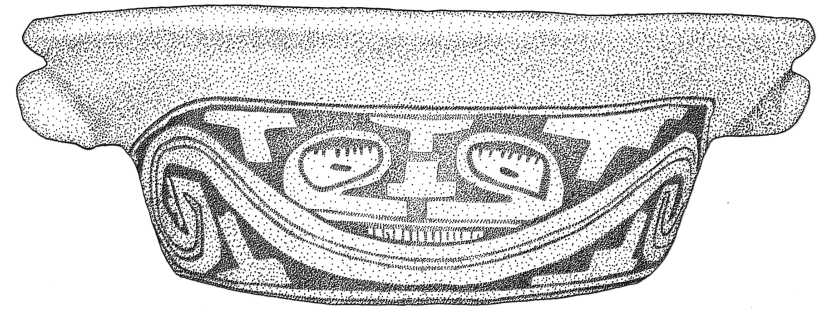

b

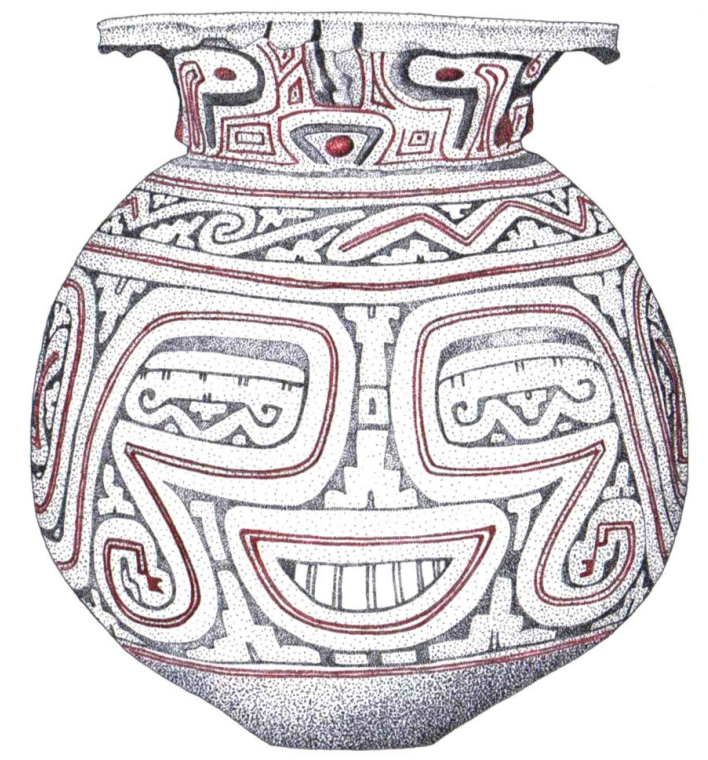

d

Figura 4.4

Peças da coleção ICBS-MAE com o motivo do "rosto sorridente"

a) 675: pequena tigela com decoração incisa (alt.:7cm; largura: $14 \mathrm{~cm}$ )

b) 655: pequena tigela com decoração pintada (alt:: 7cm; largura: $21 \mathrm{~cm}$ )

c) 740: osso longo cortado com motivos incisos (as duas faces foram desenhadas lado a lado; comprimento: $7 \mathrm{~cm}$; diâmetro: $2,5 \mathrm{~cm}$ )

d) 1633: urna funerária pintada (altura: $51,5 \mathrm{~cm}$; diâmetro do bojo: $48 \mathrm{~cm}$ ) 
Assim, ao tentar mapear as associações entre maneiras de fazer, motivos e formas deparamo-nos com dificuldades metodológicas consideráveis na definição de associações recorrentes entre cada um destes elementos.

Percebemos outros atributos estilísticos que não seriam visíveis em uma análise quantitativa multivariada, como geralmente se faz com amostras de fragmentos cerâmicos, e que poderiam ser mais relevantes para uma analise da cerâmica cerimonial funerária. São elementos próprios a toda a gama de objetos cerâmicos decorados da fase marajoara e que dizem respeito à estruturação dos campos decorativos, aos efeitos de ritmo, forma e movimento, enfim, a recursos pictóricos de uma linguagem visual marajoara que não haviam sido contemplados em análises anteriores ${ }^{1}$. Enfim percebemos que a compilação de signos e suas formas de execução, como privilegiadas nas tipologias e estudos da cerâmica marajoara disponíveis na literatura arqueológica, não dariam conta de descrever estes elementos. Por isso mesmo, e apesar de serem atributos que extrapolam a cerâmica funerária e podem ser observados na cerâmica marajoara decorada como um todo, consideramos importante apresentá-los aqui, como mais um recurso para a análise das urnas funerárias.

Partimos da idéia de que a decoração de objetos é um componente de uma "tecnologia social", ou uma "tecnologia de encantamento" nos termos definidos por Alfred Gell (1992 e 1998:66) para entender a intenção dos efeitos visuais almejados e as formas de conferir agência aos objetos na cerâmica decorada marajoara. Identificamos assim alguns recursos tecnoestilísticos que propiciam um engajamento entre o objeto (índice) e os indivíduos que o observam (receptores), definidos por Gell como "captivation", "attachment", "animation" e outros. São efeitos que além de provocar experiências sensoriais, exercem controle sobre a maneira como o observador se relaciona com identidades sociais que são representadas de diferentes maneiras na decoração do objeto.

\footnotetext{
${ }^{1}$ É necessário apontar que no caso dos estudos iconográficos da cerâmica marajoara realizados por Schaan, a autora explicitou a escolha de trabalhar com unidades mínimas de significação de forma isolada: "É importante salientar que essas unidades não foram isoladas a partir de um método de análise formal como propõe Shepard (1976), mas buscando as estruturas mínimas, independente do local e posição onde aparecem nas vasilhas...Sendo assim não consideramos a posição formal relativa das unidades dentro do conjunto, mas isolamos unidades as partir da comparação entre os diversos contextos onde elas estão presentes"( Shaan, 2007:179).
} 


\section{As tecnologias de encantamento da cerâmica marajoara}

Figuras icônicas e "abstratas"

Ao contrário do grafismo geométrico com formas "abstratas" comum na arte gráfica dos ameríndios da Amazônia, a cerâmica marajoara se sobressai por um grande número de representações mais figurativas, onde se reconhecem figuras humanas e animais. Por isso, Schaan denominou a arte marajoara como icônica, fazendo uma distinção entre signos icônicos (que guardam uma semelhança com o objeto que representa) e símbolos que podem ser construídos a partir da simplificação de um signo icônico, mas que, freqüentemente são construídos a partir de mais de um referente, constituindose numa condensação de sentidos reconhecíveis apenas intuitivamente, ou mesmo irreconhecíveis quando fora de seus contextos (Schaan, 1997:53)

As análises iconográficas realizadas por Schaan identificaram signos gráficos que podem corresponder a unidades mínimas significantes, em geral inspirados e estilizados a partir de figuras antropomorfas ou zoomorfas, tais quais a pele de serpente, as patas de lagarto, ou o rabo de escorpião (Schaan,1997:182). Com certeza, estes signos, constituíam uma linguagem visual icônica com um claro objetivo mnemônico. Outros signos, segundo a autora, não são passíveis de interpretação, por terem sido tão simplificados de forma a perderem sua "iconicidade" e se tornam assim figuras abstratas para 0 arqueólogo.

Os estudos dos sistemas de representação entre sociedades indígenas constituem um amplo e complexo universo (Munn,1966), cujos contornos não pretendemos abordar aqui. Por ora, basta-nos indicar alguns estudos de grafismos indígenas como os de Munn (1973) entre os Walbiri, os de Van Velthem (1995) entre os Wayana e os de Ribeiro (1987) entre os Kaiabi, que apontaram para o fato de que aquilo que para o observador externo, no caso 0 arqueólogo, representam apenas padrões "abstratos", são na realidade desenhos figurativos, já que estariam dando forma, através de um traço definidor, a conceitos mentais abstratos. São representações iconográficas de 
conceitos ligados a personagens e fatos mitológicos e às suas cosmologias, em geral complementados por outras formas de expressões verbais nas suas tradições orais.

A partir disso, achamos bastante útil a idéia avançada por Alfred Gell, de que toda representação visual é icônica (e portanto é diferente de um código de convenções), mas o que realmente interessa ao antropólogo ou ao arqueólogo, é o grau de semelhança com o que está sendo representado, e o grau de reconhecibilidade por parte do observador, pois são estes elementos que definem e controlam o tipo de percepção e de relação almejada pelo artista entre o observador e as entidades ali representadas ou constituídas. Além disso, Gell traz para a discussão o fato de que o reconhecimento da entidade ali constituída, nem sempre ocorre de forma espontânea, podendo ser induzido de várias maneiras (Gell, 1998). Esta proposta de Gell de se deslocar a análise de uma descrição semântica dos ícones ou símbolos utilizados para um entendimento da relação entre o objeto e o observador é assim exemplificado:

"A picture of an existing thing resembles that thing in enough respects to be recognized as a depiction model of it. A depiction of an imaginary thing (a god, for instance) resembles the picture that believers in that god have in their minds as to the god's appearance... The fact that 'the picture that people have in their minds' of the god's appearance is actually derived from their memories of images which purport to represent this appearance does not matter. What matters to me is only that people believe that the god, as agent, 'caused' the image (index), as patient, to assume a particular appearance" (Gell 1998:25) ${ }^{1}$.

$\mathrm{Na}$ cerâmica marajoara percebemos diferentes maneiras de se controlar a reconhecibilidade de determinados ícones. Algumas figuras sofrem alterações de múltiplas naturezas (deformações, recortes, inversões cromáticas, desdobramentos, reflexões, simplificações) como, por exemplo, as simplificações identificadas por Schaan (1997:180-181). Estas são utilizadas

\footnotetext{
${ }^{1}$ Aqui está implícita uma crítica dirigida aos modelos lingüísticos e às estratégias de decomposição de representações visuais em elementos ou unidades constituintes, na esperança de se conseguir construir uma "gramática visual" tal qual uma linguagem escrita, a partir de signos gráficos. Mas, como o próprio autor argumenta, linhas, círculos e ovais, não são fonemas visuais, uma vez que eles representam ou estão no lugar de coisas, ou partes de coisas, mesmo que reduzidos a suas estruturas geométricas básicas. É portanto diferente das letras de um alfabeto: a letra d de "dog" não faz parte de um cachorro, enquanto que qualquer linha que faça parte de um desenho de um cachorro representa alguma parte de um cachorro. (Gell, 1998:164165)
} 
tanto de forma isolada, como em conjunto, na formação de padrões repetitivos ou na composição de outras figuras.

Outras figuras são reproduzidas dentro de padrões extremamente rígidos de replicação, mesmo quando executados em objetos de diferentes funções, materiais, tamanhos, formatos, curvaturas e etc., como por exemplo a figura do rosto sorridente aplicada em diferentes peças e em diferentes técnicas. Estas são aplicadas de forma independente ou em pares, mantendo sempre sua unicidade.

A cerâmica marajoara compõe um jogo entre estes dois usos de imagens, que aparecem freqüentemente combinados na mesma peça, mas muitas vezes constituídas de duas maneiras distintas, plástica e graficamente. Nossa hipótese é que este estilo "misto" de decoração de objetos cerâmicos busca a conciliar dois tipos de relação do observador com as entidades ali representadas: uma forma emblemática de identificação com entidades sociais, e outra forma sacralizada de culto ou idolatria de entidades míticas e/ou sobrenaturais. ${ }^{1}$

De acordo com esta hipótese, aquelas figuras mais intensamente transformadas, seriam usadas para a de identificação de elementos emblemáticos de identidades sociais (tais quais grupos de parentesco, linhagens, grupos corporativos, facções políticas locais, ou mesmo elementos de identidades externas à sociedade marajoara), possivelmente visando o reconhecimento por parte do observador de relações de interação e mesmo de dominação, através de diferentes formas de apropriação dos símbolos emblemáticos que representam estes grupos sociais. Isto viria a explicar as múltiplas formas de transformação como manipulações de seus significados identitários, onde apenas um mínimo de reconhecibilidade das figuras icônicas seria almejado.

Já os elementos direcionados às relações de culto e idolatria buscam a engajar os observadores em contextos cerimoniais coletivos, onde o máximo de reconhecibilidade das entidades representadas seria importante para reproduzir,

\footnotetext{
${ }^{1}$ Aqui referimo-nos a idolatria no sentido de ídolo definido por Gell, isto é, onde o ídolo não é um retrato de um deus, mas é o corpo do deus na forma de um artefato (Gell, 1997:99).
} 
fixar e compartilhar visualmente uma mesma imagem por todos indivíduos participantes. Aqui podemos incluir não somente as figuras gráficas, os desenhos, mas também as formas de fazer, isto é, as técnicas de construção das figuras (pintura, incisão, incisão-excisão, modelagem) já que estas também se apresentam pouco misturadas e executadas dentro de uma gama bem restrita de variabilidade. $O$ mesmo pode ser observado quanto às formas plásticas de determinados objetos, incluindo as formas de apliques e apêndices modelados. (No entanto, talvez algumas técnicas mais misturadas, como os retoques de pintura sobre linhas excisas, possam ser o resultado de modificações intencionais sobre padrões emblemáticos pré-existentes).

Alguns dos princípios identificados na composição, ordenação, transformação e recombinação de imagens gráficas nos vasilhames marajoara são descritos a seguir.

\section{Os planos de composição}

Boa parte dos vasilhames decorados apresenta delimitações formais bem visíveis quanto à extensão dos campos (áreas) de aplicação da decoração, em geral indicadas por uma ou mais linhas pintadas ou incisas. As tangas marajoara, objetos que são bastante planos e portanto quase bidimensionais, talvez sejam a expressão máxima desta característica, com faixas pintadas em motivos geométricos bem delimitadas por linhas .

Nos objetos tridimensionais, existe uma coincidência bastante grande, entre pontos de inflexão do contorno da cerâmica e estas delimitações por linhas, separando assim o bojo globular de um vaso, do seu pescoço com paredes mais retas, e este de sua borda, com ainda outro grau de inflexão. Este é também um recurso bastante comum na arte cerâmica em geral, de forma a não extrapolar os motivos gráficos sobre planos com diferentes curvaturas, sob o risco de causar deformações nos mesmos. Trata-se, portanto, de uma técnica estilística para que se garanta uma certa harmonia entre as formas plásticas e gráficas utilizadas, mas que muitas vezes é também aproveitado para uma organização dos diferentes temas combinados no mesmo vasilhame. 
$\mathrm{Na}$ cerâmica da fase marajoara, este recurso é também utilizado com a peculiaridade de quase sempre manter os mesmo eixos de simetria utilizados para a organização dos grafismos nos diferentes campos (ou planos) de decoração.

Observe-se, por exemplo, na vasilha ilustrada abaixo (figura 4.12, ICBSMAE 1606) a demarcação entre as paredes laterais e o fundo da vasilha por linhas contínuas e faixa pontilhada. O mesmo desenho encadeado das paredes laterais é reproduzido na superfície externa desta vasilha, onde a curvatura e extensão da parede são as mesmas. Na superfície circular e côncava do fundo da vasilha, outro motivo gráfico é aplicado, uma figura simétrica cujo posicionamento central coincide com os mesmo eixos de simetria refletida das figuras nas paredes laterais.

Percebemos assim que apesar de muitos dos motivos gráficos aplicados sobre as formas tridimensionais, serem formados por diferentes recortes $\mathrm{e}$ recombinações de figuras icônicas, formando padrões encadeados ou figuras simétricas que se repetem, elas ainda guardam uma certa independência quando são ordenadas no objeto tridimensional. O seu alinhamento ao longo dos mesmos eixos de simetria, que pode ser o de um corpo humano ou o de um vasilhame tridimensional, contribui para conferir unidade ao todo, promovendo integração visual entre os diferentes campos decorativos que "conversam" assim entre si, através de um mesmo princípio de ordenação.

De certa forma, esta composição dos campos decorativos dos vasilhames difere daquela identificada por Müller entre os Asurini, onde a aplicação dos desenhos, existentes abstratamente em um plano supostamente infinito, são projetados sobre a cerâmica de maneira a recortá-los sobre a forma tridimensional do objeto (Müller, 1993). Ao contrário da cerâmica marajoara, um encadeamento infinito dos desenhos é adaptado à forma geral do vasilhame, utilizando-se as técnicas de ampliação e repetição contínua ou variação cíclica, onde os limites, começo ou fim, são imperceptíveis, ou melhor, inexistentes, conceitualmente, e nada têm a ver com as extremidades e limites do próprio objeto. 
Por este motivo, na arte marajoara são necessárias não só as linhas de delimitação dos diferentes campos, por vezes muitas e intercaladas em preto e vermelho, ou grossas e finas, como múltiplas molduras para cada figura ou tema, mas também elementos de ligação ou conexão entre as diferentes figuras, conferindo, não só unidade ao todo, mas também ritmo e movimento.

\section{Ritmo e movimento}

A cerâmica marajoara é repleta de efeitos de ritmo e movimento. $O$ olhar, ao tentar acompanhar uma mesma figura ou motivo ao longo das paredes do vasilhame, é levado a percorrer toda a sua volta ou circunferência, a seguir espirais ou zigue-zagues que vão de cima a baixo da peça; a procurar a continuidade de algumas figuras em outros lados ou superfícies, enfim é captado de diferentes maneiras a destacar unidades dentro de um emaranhado de signos, que, à primeira vista, pode parecer bastante confuso e labiríntico. Certamente alguns símbolos com função mnemônica eram mais imediatamente reconhecíveis por indivíduos conhecedores desta linguagem, mas a maneira como estes símbolos estão dispostos nas paredes dos vasilhames apresentam uma clara intenção de atrair um olhar mais demorado, constituindo aquilo que Gell denominou de "mind-traps", ou armadilhas para se capturar a mente do observador, na composição de padrões gráficos complexos.

Em geral, é a maneira como as figuras são repetidas, encadeadas e justapostas que aumentam o grau de complexidade do padrão. De acordo com Gell, a formação de padrões complexos está intimamente associada à intenção de não só captar a atenção mais demorada do observador, ou de diminuir a velocidade e mesmo impedir a compreensão do todo, mas também de estabelecer uma relação entre o observador e o objeto marcada pela frustração de se apropriar ou possuir o conhecimento necessário à reconstrução do todo. (Gell, 1998:80). O exemplo máximo de uso de padrões complexos para estabelecer este tipo de relação, é o uso apotropaico de motivos labirínticos (tais quais os labirintos celtas ou medievais) concebidos como obstáculos ou redes protetoras contra ações maléficas que tentam atingir o interior de pessoas, recipientes ou templos. 
$\mathrm{Na}$ formação de padrões complexos, Gell identificou basicamente quatro tipos de movimentos a partir de alterações e repetições de formas: reflexão (que chamamos aqui de desdobramento), que é o deslocamento da mesma figura de forma espelhada; (2) translação, que é o deslocamento da mesma figura sem qualquer modificação; (3) rotação, que é o deslocamento da mesma figura virada em um determinado ângulo; (4) reflexão transladada, que é o deslocamento da mesma da mesma figura seguido de outro deslocamento da mesma figura espelhada.

1. Reflexão

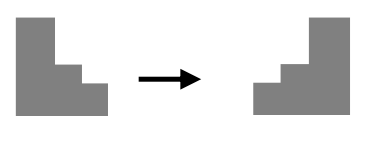

2. Translação

3. Rotação

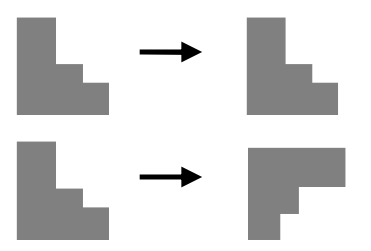

4. Translação com

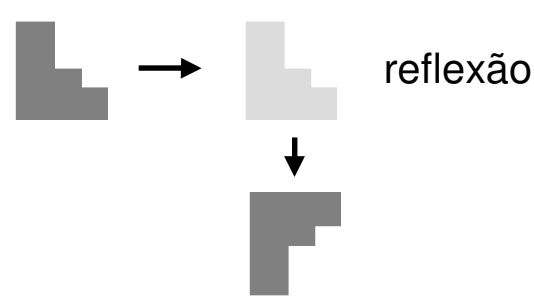

De acordo com Gell, é a percepção destes movimentos que, cognitivamente falando, é a fonte da animação das formas ou figuras. Não se trata de uma ilusão, de um fenômeno puramente subjetivo, mas da percepção por parte do observador da agência imbuída nas alterações das formas.

No grafismo marajoara, a reflexão (movimentos 1 e 4 ) a partir de eixos de simetria ortogonais é o movimento mais freqüente, como descrevemos na seção seguinte, mas todos os movimentos são utilizados, sobretudo na composição de faixas, ou frisas, ao longo de formas tridimensionais globulares ou cilíndricas. Nestas, uma combinação de formas alternadas bastante comum, é o encadeamento de espirais duplas por translação, ponteadas por formas em $T$ em reflexão transladada. Enquanto as espirais em formato arredondado levam o olhar a um movimento fluido horizontal em zigue-zague ou em ondas ( $\sim \sim$ ), 
as figuras em $\mathrm{T}$, em formato angular, levam o olhar a um movimento pontuado vertical ( T T T T ), causando assim ritmo e movimento simultaneamente. $O$ contraste entre formas arredondadas e formas angulares é também útil para prolongar o movimento do olhar e da percepção do movimento como um todo.

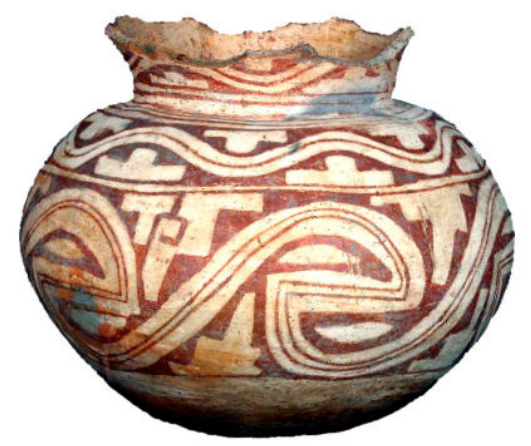

Figura 4.5

Exemplo de vasilhame com três campos de decoração delimitados por linhas horizontais contendo padrões semelhantes. ICBS-MAE 1193 (altura: $27 \mathrm{~cm}$, diâmetro 34,7 cm)

Outro recurso bastante utilizado para demorar o olhar, é o de desencontrar o alinhamento dos motivos desenhados nos diferentes campos ou faixas delimitados, às vezes com falsas simetrias, criando ritmos e movimentos independentes para cada campo. Neste caso a harmonia do todo é conseguida com o uso das mesmas figuras, ou de figuras semelhantes, na composição dos padrões formados nos diferentes campos, alterando apenas a extensão ou dimensão das figuras, como na peça ICBS-MAE 1193 ilustrada acima.

Em outros casos, os motivos delimitados nos diferentes campos parecem se alternar na forma como dialogam entre si, ora alinhando-se em uma superfície, ora se desalinhando em outra, chamando a atenção assim para a independência das diferentes partes em relação ao todo 

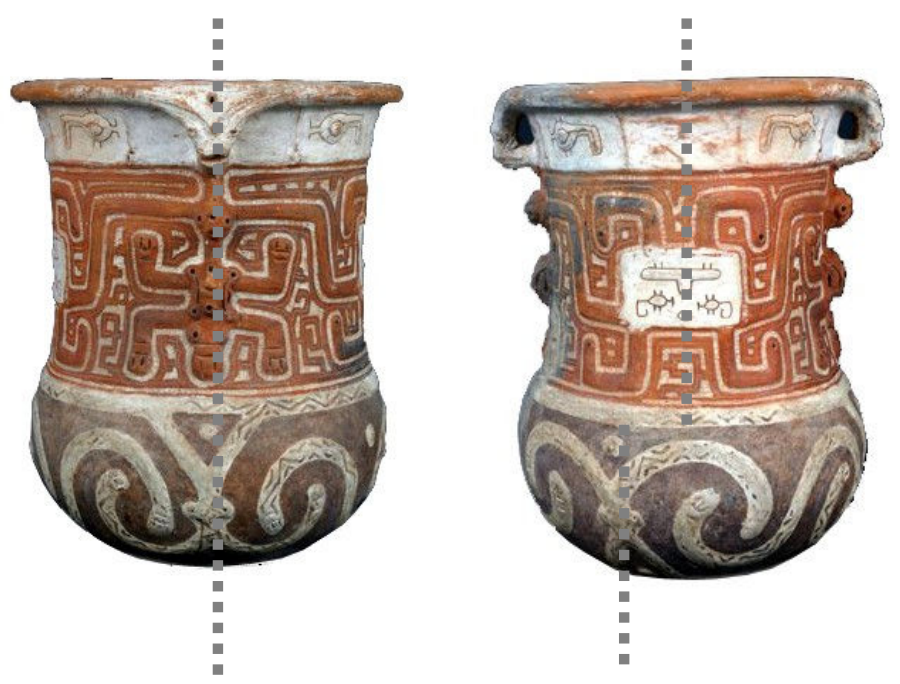

Figura 4.6

Exemplo de falsa simetria em urna funerária com três campos decorativos delimitados. Observese o alinhamento (em uma face) e o desalinhamento (em outra face) do padrão formado por figuras de cobras/ espirais duplas no campo inferior em relação à simetria dos campos superiores. ICBS-MAE 1620 (altura: 51,5 cm; diâmetro: $27 \mathrm{~cm}$ ).

\section{Eixos de simetria e a (des)construção de corpos}

Em toda a cerâmica da fase marajoara eixos de simetria binária são bem demarcados. Os vasillhames e os bancos, em particular, em oposição às estatuetas e outros objetos, são freqüentemente repartidos em metades ou quadrantes na organização dos campos decorativos, sendo as divisões tripartites mais raras. Os motivos parecem assim replicados nestas divisões, às vezes bem demarcadas por linhas pintadas ou incisas, outras vezes se evidenciando apenas pela distribuição dos motivos na superfície. Schaan já havia observado a simetria do duplo na cerâmica marajoara, com a replicação de elementos sempre em pares, em particular as representações de humanos e animais, argumentando que isto seria uma conseqüência de uma visão de mundo perspectivista:

"I suggest that to speak of the paired order of things may mean that any given element in the cosmos has its double, which is not necessarily its opposite. The pairs are not merely opposed, but can also be conceived as being complementary. They are part of the same order of things but offer different perspectives on dimensions of the same reality. ... they respected this dual perspective, within which an understanding of the other is an indispensable way of seeing the world"...(Schaan, 2001a:127-128). 
A nosso ver esta simetria está relacionada a dois princípios distintos. Um, é a construção de vasilhames enquanto corpos humanos ou animais, e que portanto replicam a própria simetria dos corpos. A exemplo da cerâmica zoomorfa Waujá, os pratos, tigelas e vasos marajoara são construídos ao longo de um eixo cabeça-cauda, com as duas metades laterais espelhadas. Isto fica bastante claro naqueles recipientes onde um apêndice na ponta deste eixo representa uma cabeça, o bojo do vasilhame correspondendo ao ventre ou englobando todos os quatro membros, distribuídos cada um em um quadrante, às vezes representados de forma bastante estilizada, em espirais ou tridentes. O corpo se amolda assim à forma oval ou arredondada do vasilhame cujos motivos decorativos emulam a sua simetria bilateral.

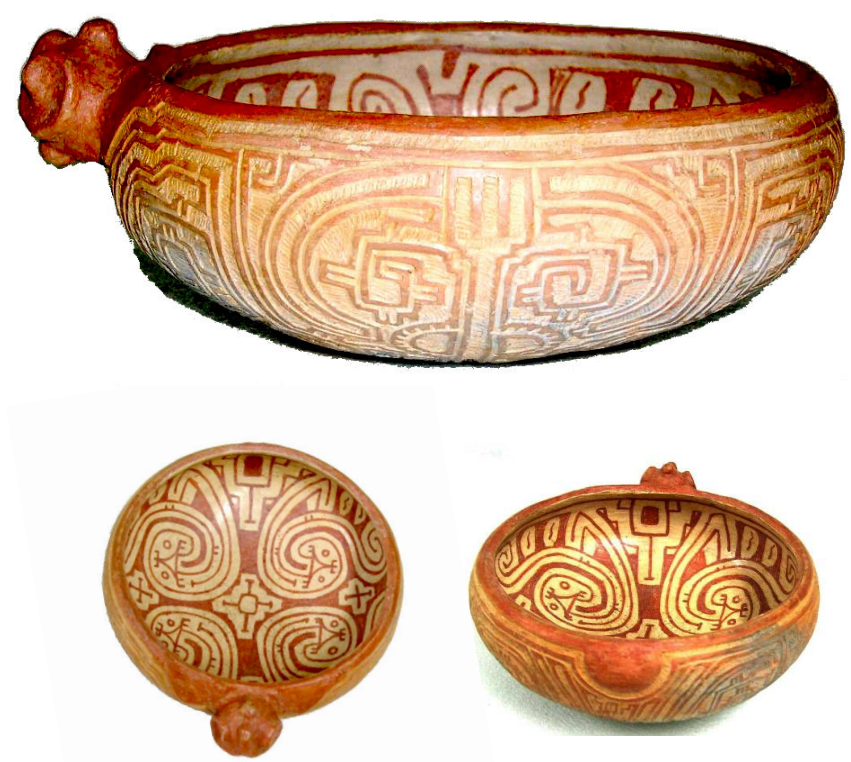

\section{Figura 4.7}

Vasilha antropomorfa. ICBS-MAE 654 (altura: $9 \mathrm{~cm}$; diâmetro da boca:19,2 cm)

É possível ainda que diferentes maneiras de executar os desenhos destes corpos nas duas superfícies do vasilhame, interna e externa, correspondam também a diferentes códigos de representação das partes internas do corpo (as entranhas, propriamente ditas) e da superfície externa (pele), em um jogo visual entre dentro/fora do vasilhame e partes 
invisíveis/visíveis do corpo. Apesar de ser esta ainda uma hipótese bastante especulativa, ela certamente seria bastante sugestiva para analisarmos as urnas funerárias, em particular a correlação entre esta oposição e outra dada pelo binômio alma/corpo.

\section{O princípio de representação desdobrada (split representation)}

Outro princípio presente na cerâmica marajoara é o que chamamos aqui de "representação desdobrada", termo este mais conhecido em inglês como "split representation", conforme cunhado por Franz Boas em 1900 (Jonaitis, 1995:13) ou em francês, como "représentation dédoublée", conforme retomado por Lévi-Strauss em sua Antropologia Estrutural em 1958 (1967:269). O termo, conforme inicialmente usado por Boas para analisar a arte dos ameríndios do Noroeste do Pacífico, se refere a uma maneira específica de representação bidimensional de animais em superfícies tridimensionais, partindo do princípio observado acima de distorcer ou estilizar seus corpos para que "caibam" na superfície decorada. Na representação desdobrada, a transformação do sujeito representado, vai além da distorção e estilização, repartindo ao meio o corpo de acordo com um eixo de simetria, e recombinando as duas metades de diferentes formas na mesma superfície.

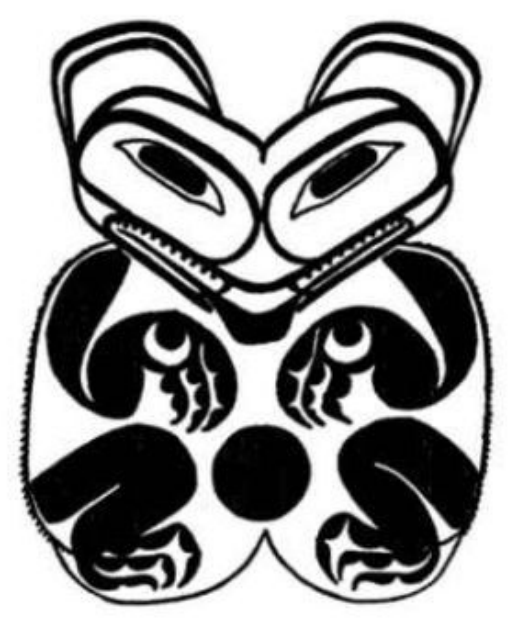

No caso específico da arte ameríndia do Noroeste do pacífico, o corte do corpo é feito no plano perpendicular à superfície frontal, da cabeça à cauda, isto é, separando os dois lados do corpo em perfis, que são achatados, e reunidos face a face. Formam assim representações que, se dobradas ao meio, apresentam os dois perfis idênticos, espelhados, e quando desdobradas, compõem uma única figura vista de frente.

Figura 4.8

Exemplo de representação desdobrada observada por Boas em desenho de urso sobre uma casa Tsimshiam, o círculo central correspondendo à entrada da casa. (apud Jonaitis,1995:81) 
Este tipo de representação desdobrada onde dois perfis compõem uma vista frontal, foi também denominado de "Janus-faced image" por Gell (1998:195) na arte da Polinésia.

Este mesmo princípio aplicado à representação bidimensional de corpos humanos ou animais ou motivos geométricos em superfícies tridimensionais foi identificado na arte de várias outras culturas "tribais", por Lévi-Strauss, como na tatuagem Maori da Nova Zelândia, nos bronzes do Neolítico chinês, e na pintura corporal dos Kadiweu. O eixo de simetria, a transformação pela qual passam as metades, e a maneira de reuní-las em uma única superfície parecem variar culturalmente.

Outra transformação comum na representação desdobrada de corpos humanos e animais é aquela encontrada na arte medieval dos povos normandos do norte da Europa, ou na arte tribal africana, onde os desenhos são também denominados de "chain-type drawings", encadeados, onde apenas uma parte do corpo é desdobrada na perspectiva lateral e replicada simetricamente, enquanto a outra, na perspectiva frontal, é utilizada para unir os dois perfis, conforme documentado por Deregowski (1970). Em geral, neste caso, o desdobramento separa a cabeça do corpo, formando assim animais com um corpo e duas cabeças, ou ao contrário, com uma cabeça unida a dois corpos simetricamente refletidos. Esta técnica é bastante usada na composição de objetos semi-ciculares ou anelares, com as duas cabeças em geral se encontrando em um lado do objeto e o corpo formando o anel, como observado por Boas nos chapéus e pulseiras Haida (Boas,1897).

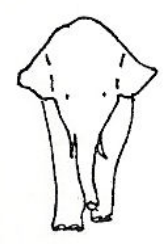

a

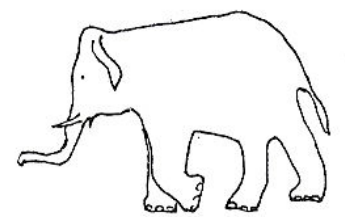

b

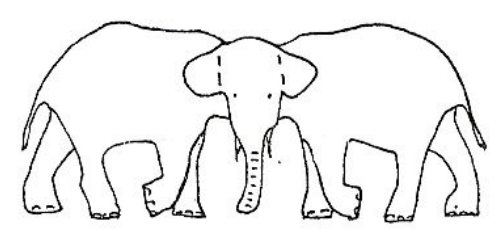

C

Figura 4.9

Exemplo de composição de figura desdobrada (c) a partir de duas perspectivas:

(a) frontal; (b) lateral. Deregowski (1970: 23) 
$\mathrm{Na}$ pintura facial dos Kadiweu, Lévi-Strauss identificou um tipo de representação desdobrada de dois motivos geométricos bastante complexa, com dois eixos de simetria perpendiculares, um vertical no centro do rosto, e outro horizontal, na altura dos olhos e, portanto, deslocado do centro, dividindo o rosto em dois quadrantes superiores menores, e dois quadrantes inferiores maiores. Os quadrantes são, por sua vez, divididos diagonalmente ao meio, formando um padrão ligeiramente assimétrico de oito bandas triangulares com motivos alternados, re-unidas onde os eixos de simetria se cruzam. Deslocamento e desdobramento são assim os princípios que regem a arte Kadiweu, cujos vasos cerâmicos são decorados de maneira similar. ${ }^{1}$

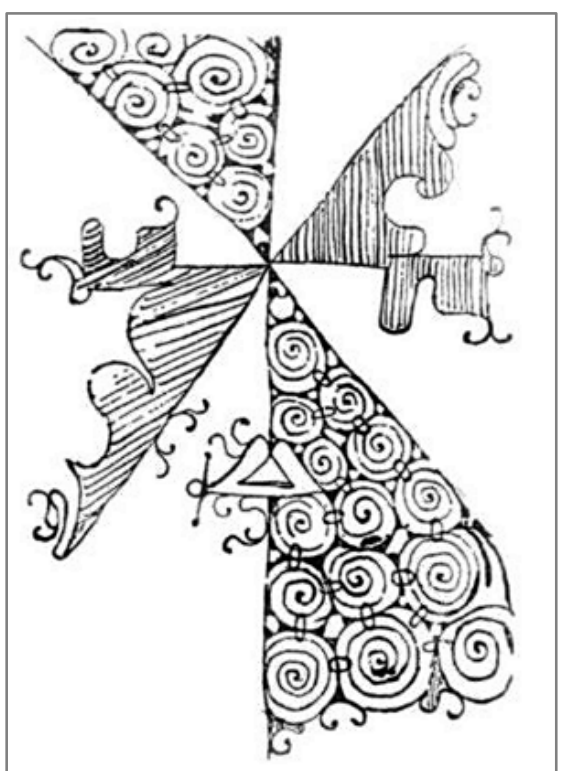

As figuras assim recortadas, sejam elas de corpos humanos, ou motivos geométricos, podem girar sobre vários eixos de simetria simultaneamente, os motivos podem sofrer transformações variadas (distorções e reflexões são as mais comuns), e serem reunidos em diferentes orientações, criando padrões de maior ou menor grau de complexidade.

\section{Figura 4.10}

Desenho sobre papel de mulher Kadiweu replicando a pintura facial, onde a representação de dois motivos geométricos é desdobrada ao longo de dois eixos simultaneamente. Observe-se o eixo de simetria horizontal ligeiramente deslocado, na altura dos olhos (Lévi-Strauss, 1967: 280)

\footnotetext{
${ }^{1}$ Lévi-Strauss diferencia a decoração facial da decoração corporal e dos vasos cerâmicos entre os Kadiweu, definindo a primeira (facial) como um estilo simbólico, com função semelhante às mascaras, e a segunda (corpos e vasilhames cerâmicos) como um estilo decorativo propriamente dito. Contudo, segundo nossas observações, os desenhos sobre a cerâmica tradicional Kadiweu são construídos seguindo regras, similares, ainda que mais simples, também desdobrando os motivos.
} 
Na cerâmica marajoara, princípios semelhantes de desdobramento foram visivelmente aplicados na composição dos motivos pintados e incisos, sobretudo daqueles motivos icônicos, representando corpos humanos e animais.

Os eixos de simetria, um ou dois, são sempre centrais e perpendiculares entre si, formando metades ou quadrantes com motivos replicados e que são reunidos no centro, onde os eixos de simetria se cruzam. Este centro, por vezes é mesmo representado por uma cruz, indicando onde os dois eixos de simetria se encontram. Observe-se, por exemplo, as figuras pintadas na vasilha ilustrada abaixo.
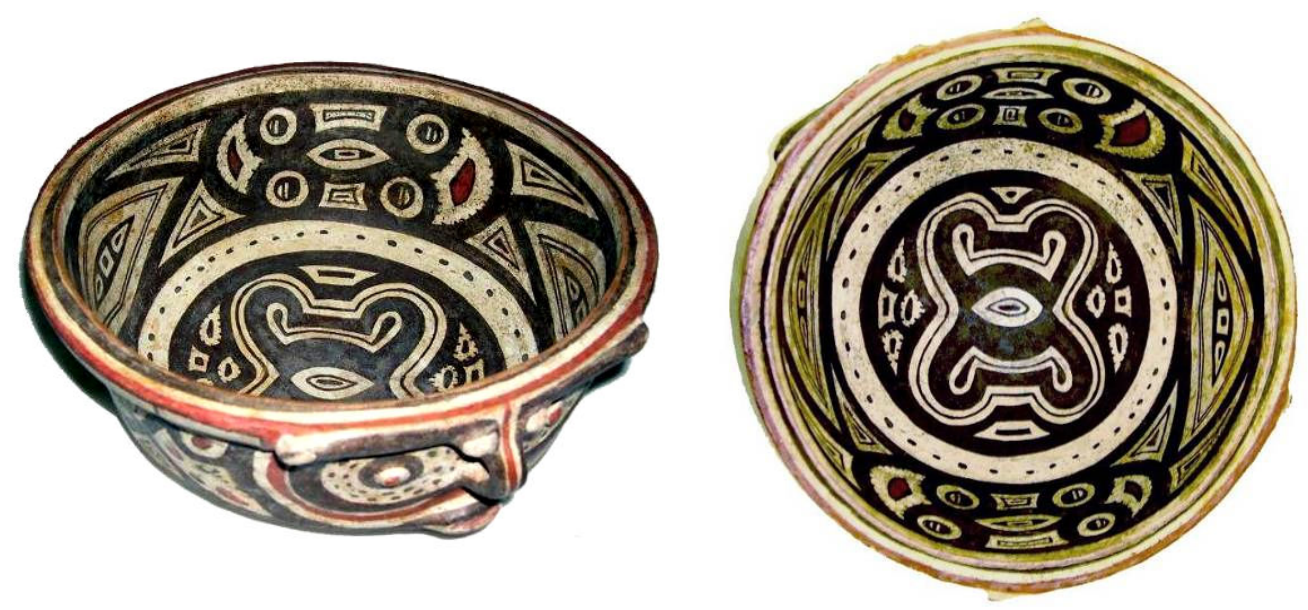

Figura 4.11

Tigela com desenhos desdobrados.

ICBS-MAE, no. 1606 (altura: $10 \mathrm{~cm}$, diâmetro da boca: $27 \mathrm{~cm}$ )

Aqui, alguns dos tipos de desdobramento de figuras indicados acima foram aplicados simultaneamente, usando-se três eixos de simetria distintos. A figura que ocupa as paredes laterais internas foi desdobrada ao longo de um eixo simétrico horizontal, e reunida no centro do corpo, de modo a compor um corpo losangular com duas cabeças, como um desenho encadeado. 
a

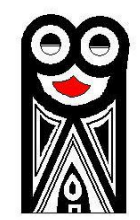

b

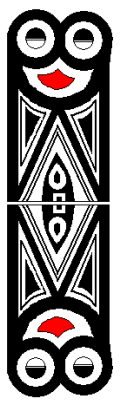

C

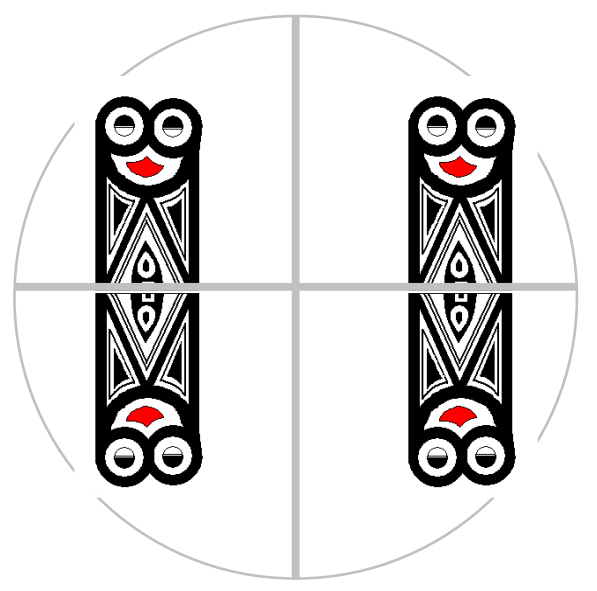

Figura 4.12

Etapas de desdobramento das imagens

Esta figura com duas cabeças é também desdobrada ao longo de um eixo simétrico vertical, de modo a espelhar esta figura nas duas metades da parte interna da vasilha, na curvatura de sua parede lateral. As cabeças, ao serem justapostas, acabam assim formando uma segunda cabeça, composta por um par de olhos e o elemento de junção / integração no encontro das figuras.
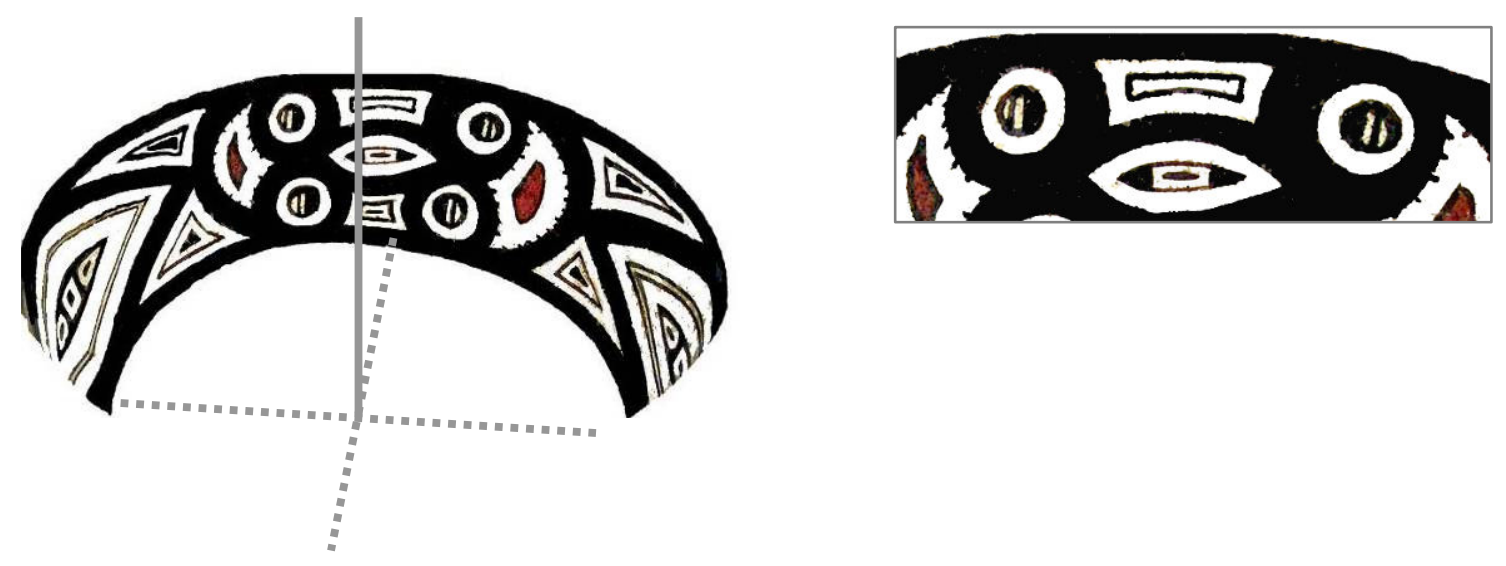

Figura 4.13

Eixos de simetria e formação de imagem "encadeada" 
As metades e quadrantes da decoração da vasilha se estruturam assim em torno de três eixos de simetria, conformando-se à tridimensionalidade do todo.

A superfície externa da vasilha alia a decoração plástica que emula um rosto, como elemento predominante, ladeado por decoração gráfica semelhante à das paredes laterais. Ambas as representações (plástica e gráfica) se estruturam também em pares simetricamente refletidos, ou desdobrados, mas segundo um eixo de simetria horizontal ligeiramente desalinhado do eixo de simetria horizontal da superfície interna da vasilha.
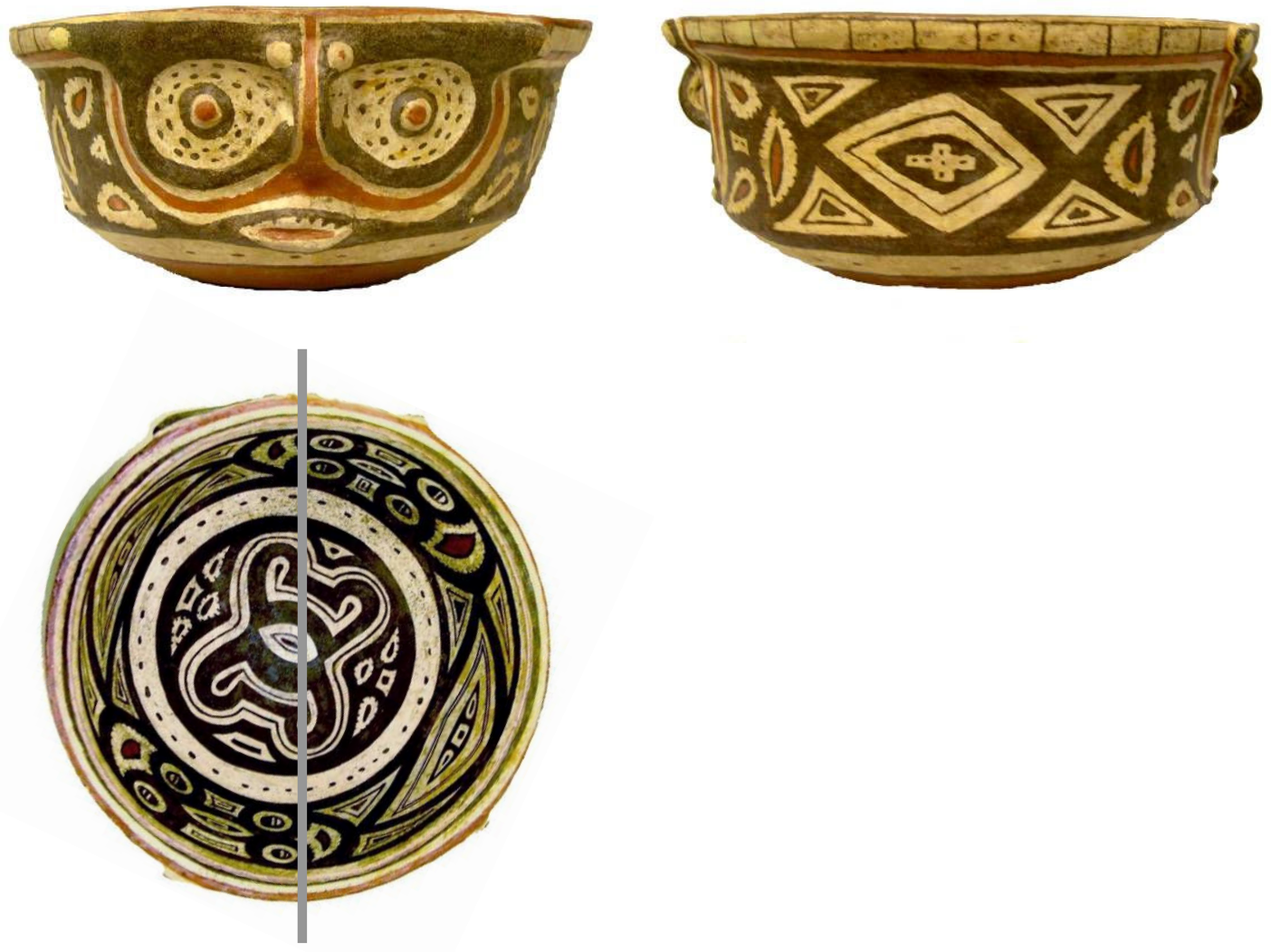

Figura 4.14

Eixo de simetria das figuras na superfície externa da vasilha.

No fundo da vasilha, a figura central, lembra a seção transversal de uma coluna vertebral, e o oval com retângulo no centro é usado nas peças antropomorfas para indicar uma vagina. O mesmo símbolo oval é usado para conectar as cabeças das figuras desdobradas laterais formando uma boca. Esta 
multiplicidade de perspectivas, aliada à transformação de símbolos em novos elementos, é também bastante característica do estilo marajoara e certamente contribuem para uma maior complexidade na relação entre o objeto e seu observador. Contudo, nem todos os elementos são transformáveis ou intercambiáveis, sendo alguns deles retidos, provavelmente para efeito de reconhecibilidade.

Voltaremos a estes elementos de retenção, na descrição das urnas funerárias, mas por ora, é importante indicar que os elementos mais utilizados para a retenção da reconhecibilidade dos referentes originais recaem sobre determinadas partes decompostas de corpos humanos ou animais, tais quais os olhos, as mãos/patas e os dedos/dígitos, e outros órgãos sexuais, tais quais mamilos, vaginas e falos, certamente e, não por acaso, todos eles órgãos sensoriais.

Antes de adentrarmos o universo da cerâmica funerária, é necessário retomarmos algumas das implicações identificadas por Lévi-Strauss e por Gell nas formas de representação desdobrada.

\section{Entre emblemas e ídolos: uma arte de sociedades de máscaras}

Para Lévi-Strauss, a representação desdobrada não se explica apenas enquanto única maneira de adaptar figuras de corpos de animais às superfícies curvas de objetos tridimensionais, como o propôs Boas, uma vez que existem maneiras alternativas de fazê-lo. O desdobramento da representação constitui um caso particular de aplicação de uma arte gráfica ao objeto tridimensional, isto é, quando a superfície tridimensional em questão só adquire significado com a decoração. Utilizando-se da noção de máscara enquanto chave para a compreensão deste tipo de representação, Lévi-Strauss defende então que a representação desdobrada não é utilizada apenas em qualquer cultura a máscaras, onde estas atuariam como um meio de encarnação de personagens em determinados rituais, mas particularmente naquelas sociedades em que as máscaras e as pessoas que as usam são indissociáveis, tanto fisicamente quanto socialmente, como é o caso da pintura facial Kadiweu e da tatuagem 
Maori. São aquelas sociedades em que os indivíduos são definidos e hierarquizados pela posição que ocupam em linhagens genealógicas de privilégios, insígnias e prestígios, e que por intermédio das máscaras associam a hierarquia social à ancestralidade. Conclui assim:

"L'independence réciproque de l'élément plastique et de l'élément graphique correspond au jeu plus souple entre l'ordre social et l'ordre surnaturel, comme le dédoublement de la répresentation exprime I 'adhérence stricte de I 'acteur a son rôle, et du rang social aux mythes, au culte et aux 'pedigrees'. Cette adhérence est si rigoureuse que, pour dissocier l'individu de son personnage, il faut le reduire en lambeaux 》. (Lévi-Strauss, 1967:292).

Segundo ele, é no seio das sociedades que tipicamente competem por credenciais genealógicas, associando indivíduos humanos a seres sobrenaturais ou deuses, como foi o caso dos Kadiweu (nos quais reconhece traços testemunhos de uma ordem social mais complexa no passado), das tribos ameríndias do Noroeste do Pacífico, das sociedades arcaicas do leste asiático e das sociedades de chefia da Polinésia. Nestas últimas, esta correlação foi endossada tanto por Gombrich (1984:262-70), como por Gell (1998:213).

Juntamente com a representação por desdobramento, incluindo a representação de seres vistos de frente por dois perfis, Lévi-Strauss identifica outros traços estilísticos comuns à arte das sociedades de máscaras, a saber: estilização intensa; esquematização ou simbolismo, que se exprimem pela acentuação de traços característicos ou da adição de atributos significativos; deslocamento dos detalhes arbitrariamente isolados no conjunto; simetria muito elaborada que freqüentemente coloca em evidência assimetrias de detalhe; transformação ilógica de detalhes em novos elementos; e por fim, uma representação mais "intelectual" do que intuitiva, com o esqueleto ou os órgãos internos se sobressaindo na representação do corpo.

Alguns destes elementos são retomados por Gell na análise estilística da arte da Polinésia para a constituição da agência de ídolos e imagens, e algumas das técnicas de encantamento para propiciar relações específicas entre 0 público e os ídolos (Gell, 1992 e 1993) 
Muitos destes elementos, reconhecíveis na cerâmica decorada marajoara, podem constituir parâmetros iniciais para se definir uma cerâmica ritual ou cerimonial marajoara. As implicações das colocações de Lévi-Strauss e Gell para compreendermos os sentidos desta cerâmica cerimonial estão necessariamente no fato de que os objetos cerâmicos, em sua plasticidade e grafismos característicos, não devem ser tomados apenas enquanto suportes para símbolos que representam conceitos acerca do mundo e de seres humanos, animais ou sobrenaturais, mas enquanto índices de agência, agência esta provavelmente de natureza hierárquica, ancestral e essencialmente política.

Retomando a hipótese apresentada mais acima, que considera o estilo da arte marajoara enquanto uma busca pela conciliação entre uma relação de identificação emblemática a determinados grupos sociais e uma relação de idolatria de entidades míticas ou sobrenaturais, poderíamos assim especificar a sobreposição destes dois eixos de coerência da arte marajoara naquilo que Lévi-Strauss identificou como os aspectos indissociáveis de algumas culturas de máscara: o indivíduo e a máscara; o ator e seu papel; o meio e a mensagem, a posição hierárquica do indivíduo e ancestrais sagrados; e neste caso, o objeto cerâmico emblemático e entidades sobrenaturais/mitológicas que legitimam a posição dos indivíduos na sociedade como um todo.

Nas urnas funerárias, por elas constituírem o meio por excelência tanto de (re)significação de identidades individuais através do corpo da pessoa inumada, como de reatualização de crenças sobre a ancestralidade, ambos os elementos emblemáticos e de idolatria deveriam estar presentes e mais facilmente reconhecíveis, do ponto de vista de uma análise arqueológica e estilística. 


\section{APÍTULO V}

\section{O DESPERTAR DAS ALMAS: A ARTE FUNERÁRIA MARAJOARA}

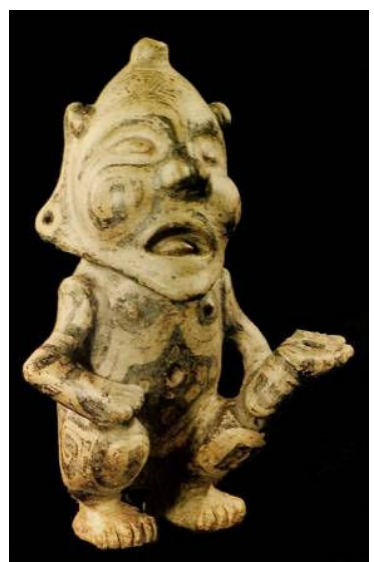

«...les conexions magiques, comme les illusions d'optique, n'existent que dans la conscience des hommes, et nous demandons à l'investigation scientifique de nous en faire connaître les raisons... »

Claude Lévi-Strauss, 1958:294

\section{Uma classificação das urnas da coleção ICBS-MAE}

Com base nas descrições de Meggers e Evans (1957) e de Schaan (2004) dos vasilhames escavados em contextos funerários, dos elementos indicados por Roosevelt (1991) para a cerâmica cerimonial marajoara, e dos princípios estilísticos apontados acima, foram selecionadas as 68 peças aqui analisadas. Contudo, é possível que tenham escapado à nossa seleção os vasos de cerâmica utilitária, não decorada, que porventura tenham sido reutilizados como urnas funerárias, e que neste caso, não teríamos como reconhecer este uso.

Das 68 peças selecionadas, 24 encontram-se completas, isto é, com toda a borda presente, ainda que algumas tenham sido parcialmente reconstituídas em processos variados de restauro. Outras 36 estão praticamente inteiras, apenas com a borda faltante. Um inventário descritivo destas peças é apresentado no Anexo 2.

Observamos que a ausência e fragmentação da borda de alguns tipos de urna é uma constante em todas as coleções de cerâmica da fase marajoara, sobretudo nos vasilhames que apresentam um pescoço constrito ou vertical com bordas inclinadas externamente ou extrovertidas. Isto certamente se deve a um fator de conservação destes vasilhames que ao serem indevidamente retirados 
dos solos pelas bordas, ou ao aflorarem na superfície dos sítios, foram afetados por ações antrópicas diversas, apresentando fraturas nas partes mais superficiais das peças ao longo do ponto de inflexão mais frágil do vasilhame, entre o pescoço e a borda, arrancando assim a borda das peças.

Contudo, é provável que esta fragmentação se deva também ao modo de deposição das urnas nos cemitérios, uma vez que alguns vasilhames evidenciados e escavados em seus contextos originais, inclusive tampados com outros vasilhames ou tigelas emborcadas, também estavam com as bordas fragmentadas e ausentes. Em alguns casos, as bordas correspondentes foram encontradas próximas a outros vasilhames, em setores distintos da estrutura funerária, denotando remanejamento proposital destas partes. ${ }^{1}$

Conforme já aventado por Schaan (2004:199), este padrão de fragmentação e, sobretudo, a ausência das bordas, pode indicar que as urnas não eram enterradas por completo, mas somente até a altura do pescoço. As bordas extrovertidas ficariam assim expostas, sobre a qual se apoiava uma tampa, e poderiam eventualmente se fragmentar enquanto estivessem expostas.

Com exceção das bordas fragmentadas, em geral, as urnas da coleção ICBS-MAE são peças excepcionalmente bem conservadas, não só na sua estrutura, mas também nos acabamentos de superfície, incluindo a pintura, quase sempre policrômica, os apêndices e apliques. Algumas poucas peças sofreram perdas de pintura, conservando apenas o engobo branco, e outras ainda perderam alguns apliques, o que às vezes impossibilitou as análises de identificação e localização de motivos e figuras no conjunto da peça.

É preciso relatar ainda que, em algumas peças, onde estava claro que os apliques ocorriam em pares, em posições simetricamente opostas da urna, alguns apliques faltantes foram simplesmente replicados pelo restauro, de forma a se ter uma melhor idéia do conjunto geral da peça. Outras reconstituições, tanto da policromia, de bordas, ou de apliques, também foram realizadas, mas

\footnotetext{
${ }^{1}$ Veja, por exemplo, as urnas evidenciadas por Meggers e Evans em Camutins - $\mathrm{K}$ e N no enterramento J-14 (Meggers e Evans, 1957:270 e 276) e as urnas evidenciadas por Schaan, no aterro Belém de nos. 5,6,9,11 e 21 (Schaan, 2004: 229-231).
} 
sempre apenas em casos em que havia indicações seguras para reconstituí$\operatorname{los}^{1}$.

A partir da analise formal dos atributos observados em todos os vasilhames e das características estilísticas listadas acima, organizamos este conjunto de urnas em grupos bastante consistentes quanto às recorrências de alguns elementos determinantes. Estes, dizem menos respeito aos atributos normalmente utilizados nas tipologias, tais quais formas e técnicas de decoração, e mais à maneira de estruturar a peça como um todo em torno de temas ou figuras específicas, da organização de diferentes planos e campos decorativos, e da distribuição de determinados motivos, executados em diferentes técnicas, de acordo como os planos e campos decorativos criados e dos efeitos de percepção visual almejados.

$\mathrm{Na}$ verdade, percebemos que a forma do vasilhame é importante, na medida em que transgride ou supera o princípio geral do estilo marajoara de simular a forma de corpos humanos ou animais. Neste sentido, há uma distinção fundamental com implicações para a agência das urnas: aquelas formas que replicam um personagem em específico; e as formas que são concebidas, também segundo um conceito genérico de corpo, e cuja criação de campos bem delimitados para a aplicação gráfica de determinadas figuras parece predominar.

Neste sentido, algumas variações de forma parecem menos relevantes do que outras, e vistas dentro sistemas tipológicos sem correlacioná-lo com os significados simbólicos, estas variações acabariam por separar em tipos distintos urnas que foram concebidas dentro de um mesmo princípio de construção de corpos ou vasilhames.

Grupo 1: São 30 urnas que se distinguem de todo o restante das outras pelo fato que seu corpo constitui um personagem específico; apresenta uma variação modal em suas dimensões, podendo ser sub-divididas em pequenas

\footnotetext{
${ }^{1}$ Uma boa parte desta coleção foi objeto de processos variados de restauro enquanto ainda estava sob a guarda do ICBS, obedecendo a critérios científicos e ao destino então planejado para a coleção, que era essencialmente expositivo.. Os projetos de restauro foram coordenados pelos conservadores Gedley Braga e Angela Freitas, sob minha curadoria. Um relatório detalhado das intervenções realizadas em cada peça encontra-se depositado no setor de documentação do MAE.
} 
(14 urnas com menos de $50 \mathrm{~cm}$ de altura) e grandes (16 urnas com mais de 50 $\mathrm{cm}$ de altura). Este grupo apresenta alguma variabilidade na forma e grafismos, mas um alto grau de reconhecibilidade pela sua estrutura geral, composta por elementos plásticos e pintados que lhes são exclusivos.

Grupo 2: São 12 urnas com dimensões médias, formas globulares, e técnicas e grafismos extremamente semelhantes. Apresentam grafismos sempre pintados, Alguns destes grafismos circulam entre outras categorias de objetos cerâmicos marajoara, principalmente o que retrata um rosto com boca sorridente.

Grupo 3 : São 16 urnas que apresentam uma organização de campos decorativos coincidentes com a estrutura formal da urna, com combinações de técnicas semelhantes: sempre pintura e incisão na borda; motivos espiralados inciso-excisos no pescoço, associados a um elemento (lagarto) em relevo; e espirais duplas pintadas no bojo. Neste grupo, existem duas variações de forma e dimensões: urnas maiores, com bojos mais globulares (3 urnas), e urnas médias, com corpos mais tubulares (13 urnas).

Grupo 4: São 5 urnas médias ou pequenas, que apresentam a mesma forma com base cônica carenada e decoração incisa com pintura e retoques. Apresentam-se em dois modos: com elementos plásticos e incisos que the conferem antropomorfia, ou com figuras formando motivos padronizados contínuos.

\begin{tabular}{|c|c|c|c|}
\hline GRUPO & $\begin{array}{l}\text { Menores } \\
\text { (menos que } 50 \mathrm{~cm} \text { de altura) }\end{array}$ & $\begin{array}{l}\text { Maiores } \\
\text { (mais que } 50 \mathrm{~cm} \text { de altura) }\end{array}$ & $\begin{array}{l}\text { TOTAL } \\
68\end{array}$ \\
\hline 1 & $\begin{array}{l}0307-0817-1192-1194- \\
1556-1588-1605-1610- \\
1612-1614-1624-1625- \\
1626-1627\end{array}$ & $\begin{array}{l}1583-1584-1585-1586- \\
1587-1596-1597-1598- \\
1590-1591-1592-1596- \\
1601-1602-1603-1839-1840\end{array}$ & 31 \\
\hline 2 & $\begin{array}{l}0277-0292-0293-0294 \\
1193-1201-1600-1604- \\
1619-1615-1616-1633-\end{array}$ & & 12 \\
\hline 3 & $\begin{array}{l}0336-0382-0470-1196 \\
1198-1200-1562-1618 \\
1620-1621-1623-1628 \\
1634-\end{array}$ & $1594-1608-1629$ & 16 \\
\hline 4 & $\begin{array}{l}0326-0760-1176 \\
1611-\mathrm{sn}\end{array}$ & & 5 \\
\hline $\begin{array}{l}\text { Não } \\
\text { classificadas }\end{array}$ & $\begin{array}{l}1599-1609-1613- \\
1617\end{array}$ & & 4 \\
\hline
\end{tabular}


Passamos a seguir à descrição e observações resultantes da analise das urnas do Grupo 1, em primeiro lugar, e dos outros grupos em seguida. $\mathrm{Na}$ descrição destes grupos, sempre que possível, indicamos também urnas documentadas em outras coleções que podem se enquadrar em cada um deles.

\section{As urnas do GRUPO 1}

As urnas do grupo 1 são as mais numerosas e talvez as mais conhecidas da fase marajoara, tendo se tornado o símbolo comumente usado para esta cultura. Exemplares deste tipo de

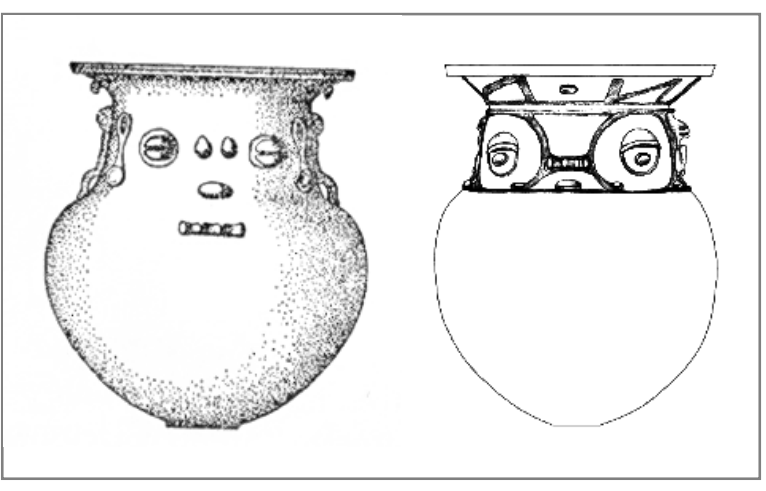
urna estão documentados em Palmatary (1950: pranchas 88-89,93-95, diversas coleções); Meggers e Evans (1957: prancha 76, coleção MPEG); Roosevelt (1991: 46-47, coleções MPEG, University of Pennsylvania Museum, Brooklyn Museum; e família Teixeira). Também observamos outros exemplares deste tipo de urna em todas as coleções nacionais, americanas e européias.

Magalis (1975) procedeu à seriação de elementos decorativos em uma amostra de 60 urnas deste tipo, trabalhando com praticamente todas as peças inteiras conhecidas até então ${ }^{1}$. Isto significa que as 30 urnas aqui analisadas aumentam em $50 \%$ a amostra para este tipo de urnas.

São urnas que apresentam formas muito recorrentes, correspondendo a variações daquela descrita por Meggers e Evans para "'funerary jars" do tipo Joanes Pintado. Apresentam bojos mais ou menos globulares, pescoço constrito vertical ou inclinado interno, e bordas inclinadas externamente ou extrovertidas, e reforçadas externamente. A base é em geral plana ou arredondada e sua superfície depende bastante da forma do bojo, o qual, próximo à base, pode ser mais ou menos cônico ou piriforme $O$ bojo pode também ser mais cordiforme,

\footnotetext{
${ }^{1}$ Não foram incluídas nas análises de Magalis nem as coleções particulares brasileiras, nem as coleções européias do Museu Nacional de Etnologia em Lisboa e do Museu de Arte Précolombiana Barbier- Mueller de Barcelona.
} 
com ombros acentuados por apliques laterais e outras variantes apresentam um volume achatado, com secção transversal mais ovalada e menos globular.

Este tipo de urna ocorre em geral em dois intervalos de tamanho. Entre todas as urnas publicadas deste tipo registramos uma variação entre 26 e 110 $\mathrm{cm}$ de altura. Na coleção ICBS-MAE, as 30 urnas aqui classificadas neste grupo ocorrem sobretudo nos intervalos entre 26 e $55 \mathrm{~cm}$ de altura, e entre 70 e $90 \mathrm{~cm}$ de altura.

\section{Distribuição das 30 urnas do grupo 1 por intervalos de altura}

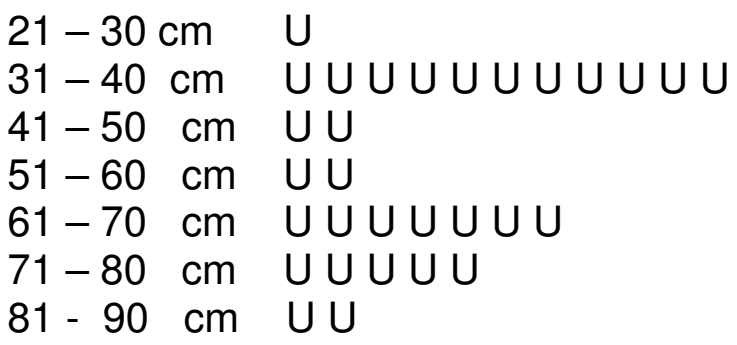

A variação no tamanho acompanha também uma variação nos detalhes da urna, as maiores apresentando um maior número de atributos decorativos plásticos. Muitos dos apêndices presentes nas urnas maiores, certamente serviam para facilitar o manuseio e transporte das mesmas, propiciando melhor preensão e apoio. As urnas que se aproximam de uma altura de 1 metro, são bastante pesadas, mesmo vazias, sendo necessário, ao menos, duas pessoas fortes para seu transporte.

Alguns dos primeiros pesquisadores a encontrarem estas grandes urnas supuseram que os indivíduos eram inumados diretamente nelas, constituindo um enterramento primário, devido a disposição de ossos ainda articulados (Farabee, 1921). Mas pesquisas posteriores demonstram um padrão de enterramentos secundários e cremação combinados.

Nestas urnas identificamos recorrências estruturais, isto é elementos que não só se repetem em todas elas, dentro de uma gama mínima de variação formal, mas que são elementos plásticos e gráficos constitutivos de um modelo de urna. Outros elementos apresentam um maior grau de variabilidade, podendo 
ou não estar presentes e, portanto, não foram considerados elementos constitutivos deste modelo.

Este modelo de urna se destaca de todos os outros por sua composição ser estruturada na figura predominante de um ser zoomorfo antropomorfizado (pássaro/humano), que ocorre sempre em pares simetricamente opostos, e cujos atributos físicos são sinalizados por elementos essencialmente plásticos, isto é pela própria forma das paredes da urna e outros em relevo, formados por apliques e apêndices modelados. Alguns atributos restantes são ainda adicionados em pintura vermelha e preta sobre 0 engobo branco. Diferentemente das urnas dos outros grupos, estas constituem em todo o seu volume o corpo desta figura predominante.

As faces ocupam o pescoço da urna, enquanto no bojo são representados os membros superiores dobrados, evidenciando mãos/patas com três ou quatro dígitos. Nas faces predominam grandes olhos redondos, com pálpebras semi-cerradas e salientes, nariz e boca em relevo, emolduradas por faixas em $\mathrm{T}$ (às vezes interpretadas como sobrancelhas).
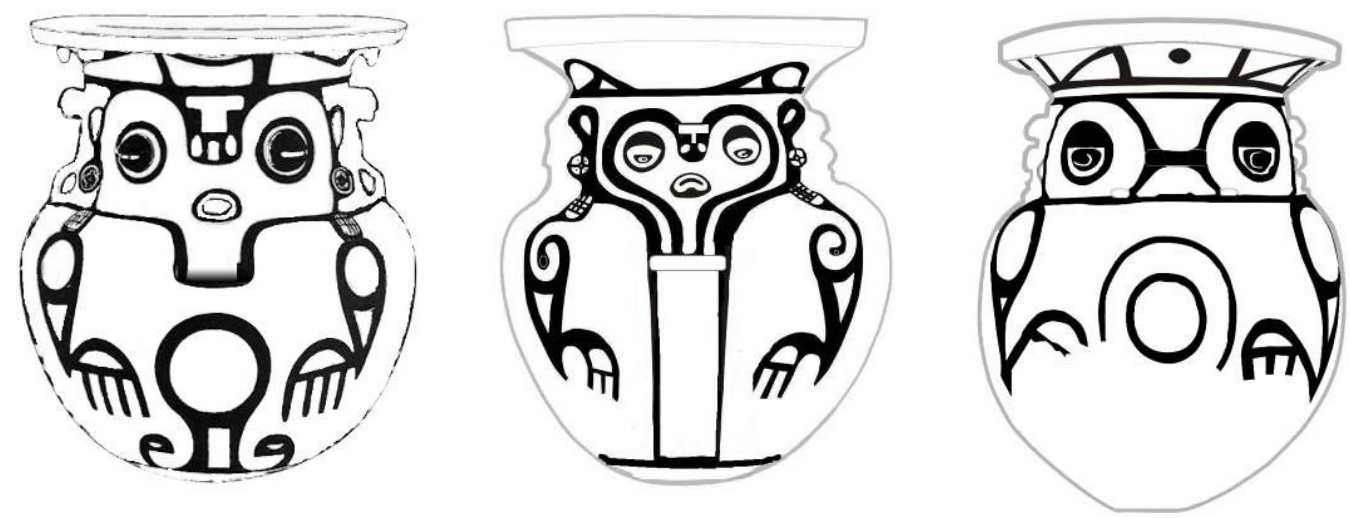

Figura 5.1

Variações nos elementos constitutivos da figura principal nas urnas do grupo 1.

A única superfície que talvez não componha o corpo deste personagem é o plano formado pela superfície externa da borda, ao qual voltaremos mais adiante. 
Vários autores reconheceram nesta figura traços ornitomorfos. (Roosevelt,1991; Schaan, 2001a). A partir do formato geral da urna, da articulação dos membros, da posição e número dos dígitos, da forma dos olhos e narinas Schaan identificou traços de coruja ou harpia (gavião-real) (Schaan 1997:142). O gavião-real está no topo da cadeia alimentar, e não têm nenhum predador natural a não ser o homem. Sua predileção alimentar está nos pequenos mamíferos, bugios e preguiças, mas consome também moluscos, crustáceos e peixes e até serpentes, lagartos e alguns pássaros. Pode atingir $1,15 \mathrm{~m}$ de comprimento e $2,5 \mathrm{~m}$ de envergadura. As corujas também são aves caçadoras eficientes, graças à visão extremamente aguçada e seus movimentos rápidos, podendo girar a sua cabeça em até $270^{\circ}$. São portanto aves que ocupam uma elevada posição na hierarquia ontológica da comensalidade, tão marcada pelo ethos da predação nas sociedades indígenas amazônicas.

Schaan também sugere uma associação metafórica entre a coruja, ou o gavião-real, conhecidos por engolir animais inteiros e regurgitar apenas seus ossos, com o descarnamento e a separação dos ossos de um enterro secundário necessários ao "renascimento" ou "regurgitação" do indivíduo (2001a:120)

Outro fato interessante está no comportamento reprodutivo das corujas: o macho se aproxima da fêmea, com uma presa entre as garras. Se ela aceitar o presente, dá-se o acasalamento. Ë possível assim que estas urnas recriem cenas de sedução para o acasalamento e reprodução, uma vez que em muitas delas, a parte central do bojo, entre as patas dianteiras pintadas, é ocupada por faixas que delimitam figuras de animais diversos, incluindo cobras e macacos. Outras vezes, esta parte central do bojo, apresenta círculos preenchidos, o que tem sido interpretado como uma representação do útero ou de um estado de gravidez deste personagem (Schaan,2001a). Poderiam também indicar a ave chocando sua cria (as corujas e harpias em geral põem dois ovos, dos quais só um é fertilizado).

Abaixo da faixa central ou círculo, próximo à base da urna, é freqüente a presença de um símbolo oval ou retangular, ao qual Schaan atribui a representação da vagina, indicando o sexo feminino, mas este nem sempre está 
presente. $\mathrm{Na}$ verdade, Schaan considera todas estas urnas como representações de um ser sempre do gênero feminino, mas não encontramos muitas evidências para esta generalização. Ao contrário, é possível que a representação de ambos os gêneros estejam presentes, pois parece haver uma certa recorrência nas urnas que apresentam círculos (úteros ou ovos) associados aos ovais ou retângulos (vaginas) por um lado, e as urnas com faixas centrais sem os ovais e retângulos, conforme as urnas ilustradas abaixo. Contudo, não dispomos de um grande número de urnas com estes elementos da base bem conservados, que pudessem nos confirmar estas associações.
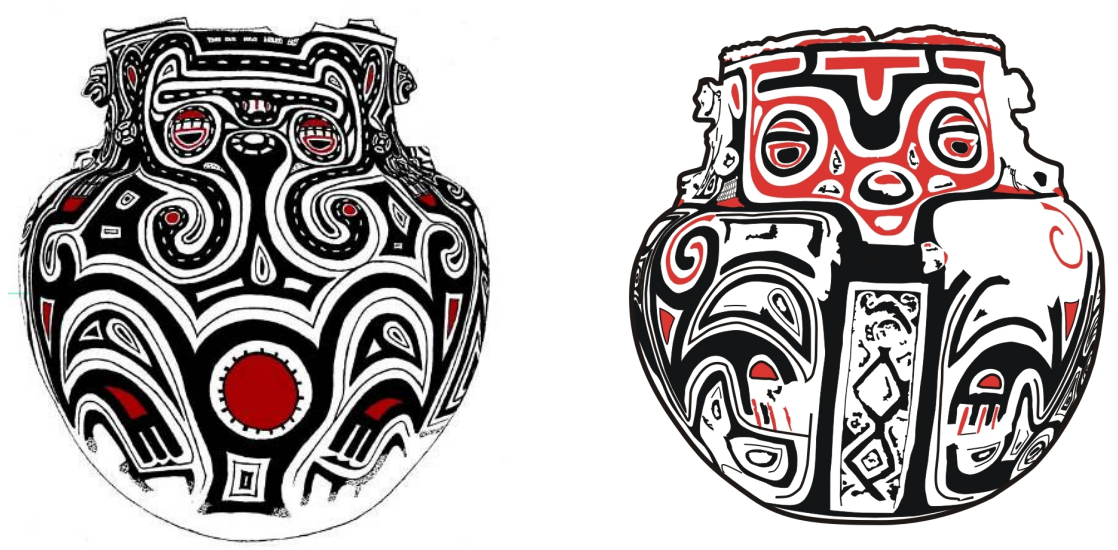

\section{Figura 5.2}

Exemplos de possíveis urnas "femininas", com representação de útero ou ovo entre as patas, e "masculinas", com representação de presa entre as patas (no caso, duas cobras entrelaçadas formando um padrão de losangos).

De acordo com Magalis, os círculos cheios, ou umbigos, poderiam representar o genital feminino, enquanto que alguns dos círculos preenchidos com rostos, seriam o feto. Mas, acaba por concluir que as urnas são femininas:

...the urns themselves are symbolically female. The representations of fertility and birth found upon urns intended for the burial of the dead are significant clues which can be used to interpret Marajoara religion" (1975:193)

Nas urnas de maior dimensão, esta figura apresenta também algumas características de um ser humano ornamentado, com adornos tais quais os alargadores de orelhas e brincos que, na verdade, são pendentes em cordão pendurados nos lóbulos das orelhas (tassels em inglês), formando um laço acima da orelha e plumas pendendo abaixo da orelha, repousando sobre o bojo 
da urna. Evans e Meggers (1957:416) acreditam ser este um traço diagnóstico de culturas do Chaco boliviano (de acordo com a distribuição mapeada por Nordenskiold) e da costa do Peru (por estarem presentes nos tecidos aí encontrados).
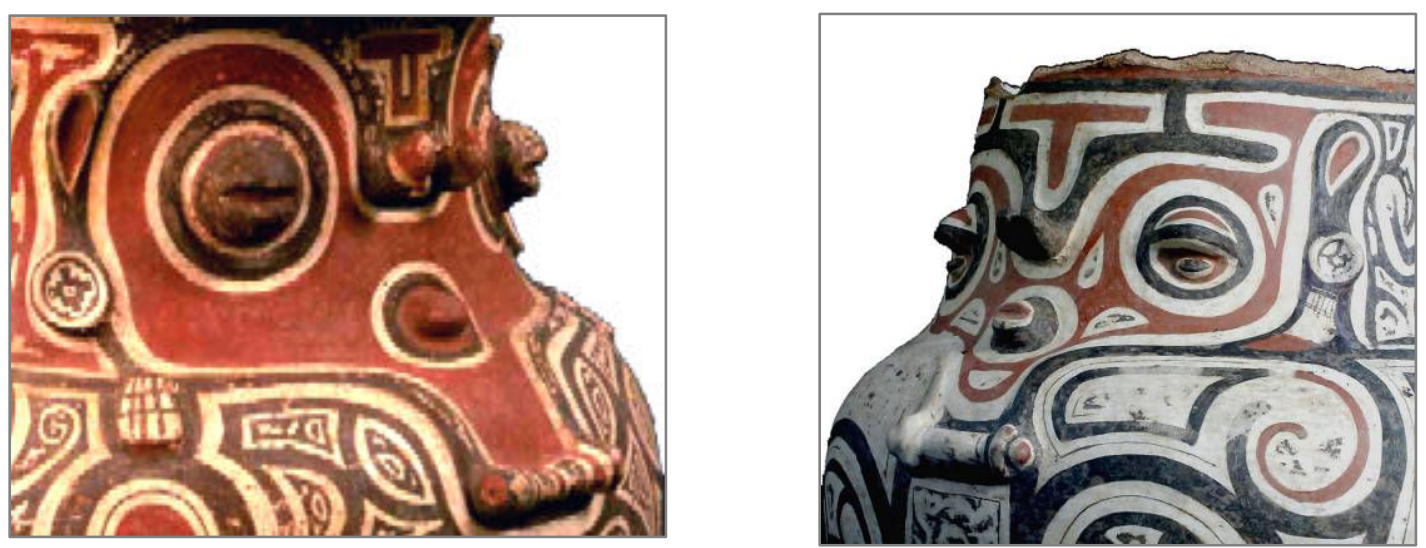

Figura 5.3

Detalhe das faces da figura representada nas urnas do grupo 1, mostrando alargador de orelha, brinco, e adorno cilíndrico sobre o peito. Urnas do acervo do Museu Paraense Emílio Goeldi (altura: $84 \mathrm{~cm}$; diâmetro: $70 \mathrm{~cm}$ ) e ICBS-MAE 1602 (altura:78 cm; diâmetro: 74cm).

$\mathrm{Na}$ coleção ICBS-MAE, identificamos 20 alargadores de orelha em cerâmica, alguns dos quais com restos de pintura ou decoração incisa semelhantes aos retratados nas urnas, indicando que este tipo de adorno deve ter sido de uso bastante freqüente.

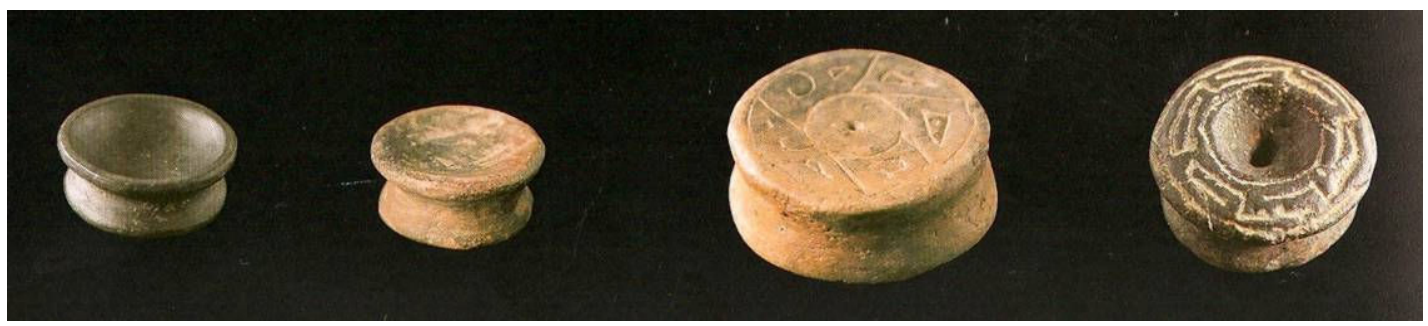

Figura 5.4

Alargadores de orelha em cerâmica da coleção ICBS-MAE.

(diâmetros variam entre 2,4 e 3,4 cm)

Um cilindro que parece estar pendurado horizontalmente no pescoço desta figura é aplicado sobre o bojo das urnas maiores. Este é quase sempre perfurado em ambas as extremidades. Possui algumas saliências que parecem 
indicar amarrações. Poderiam corresponder a adornos semelhantes aos cilindros de quarto, usados pelos chefes de alguns grupos do Noroeste amazônico, notadamente os Tukano, como uma insígnia de prestígio. Ainda na coleção ICBS-MAE foram identificados dois ossos longos trabalhados, com decoração incisa formando padrões semelhantes aos encontrados na cerâmica da fase marajoara, um deles desenhado na figura 4.2c, pag.134. É possível, portanto, que os cilindros representados nas urnas correspondessem a estes artefatos em osso e que, assim como os alargadores, também fossem portados por indivíduos marajoara. ${ }^{1}$

Estes são os elementos mais recorrentes que dão forma e constituem o corpo desta urna/personagem antropo/zoomorfo, muitos dos quais nos parecem elementos típicos de artefatos concebidos enquanto ídolos. É interessante notar que, neste caso, é improvável que estes recipientes tenham sido confeccionados para outros fins e, só depois, reutilizados como urnas. Note-se, por exemplo, que em algumas urnas a forma do rosto não é só constituída pela adição de apliques e apêndices, ou pela pintura, mas é realmente obtida na confecção das paredes da urna, moldando, a partir da superfície interna, algumas das formas que devem aparecer em relevo e que portanto configura a confecção da urna enquanto um corpo, já na etapa "pré-decoração" de confecção da urna.

Este é o caso da urna ilustrada abaixo, que apesar de um pouco divergente do modelo de rosto para as urnas deste grupo, mostra bem a modelagem das paredes na altura do pescoço formando bochechas inchadas, remetendo ao movimento de sopro pela personagem.

\footnotetext{
${ }^{1}$ Reichel-Dolmatoff interpreta algumas figuras retratadas em peças do Museu do Ouro (Bogotá) com cilindros semelhantes, enquanto ossos longos de aves utilizados como inaladores para substâncias alucinógenas. Uma peça semelhante aos dois ossos trabalhados encontrados na coleção ICBS foi exposta na Mostra do Redescobrimento, módulo Artes Indígenas (Aguilar, 2000:197). Aparentemente, esta peça integra a coleção de objetos Tupinambá do sec. XVI hoje no Museu Nacional da Dinamarca.
} 


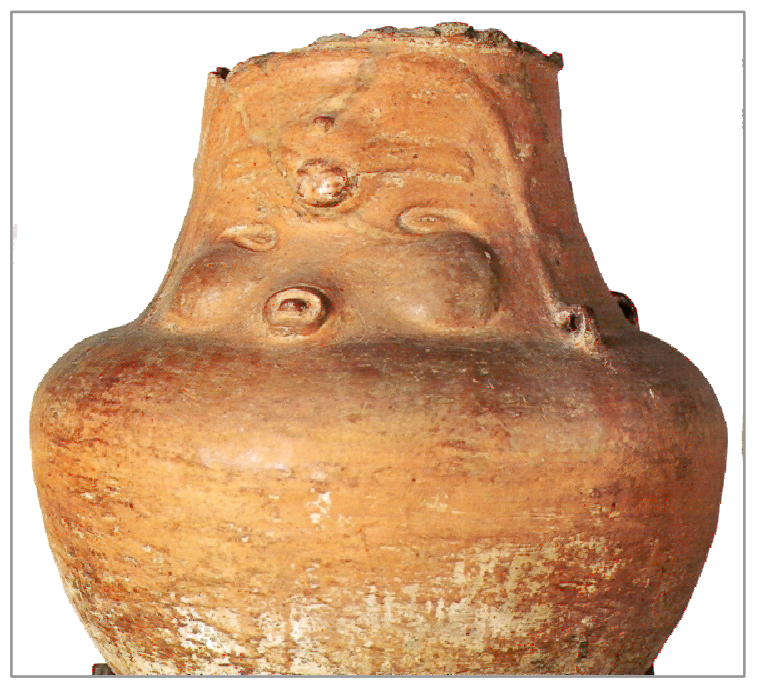

Figura 5.5

Urna da coleção Carlos Estevão de Oliveira, Museu do Estado do Pernambuco altura (borda fragmentada): $106 \mathrm{~cm}$; diâmetro máximo: $90 \mathrm{~cm}$

\section{Elementos de animação: corporalidade, sentidos e agência}

Olhos, nariz, boca, sobrancelha, orelha, adornos e por vezes mamilos, são todos elementos que também são constituídos plasticamente, com a adição de matéria, com apêndices e apliques. Entre os diferentes exemplares deste tipo de urna, existe uma grande variação no grau de saliência destes elementos em relevo, como se a parede da urna constituísse um plano através do qual estes

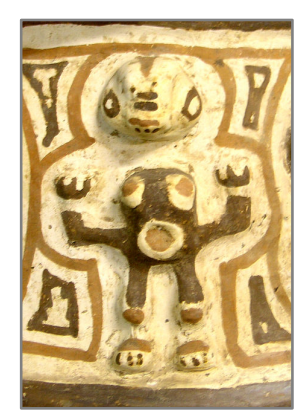
elementos pudessem transitar de dentro para fora da urna, ou entre a superfície interna e a externa, ficando ora mais expostos e visíveis e ora mais retraídos ou embutidos no interior da urna.

O mesmo acontece com os pequenos bonecos antropomorfizados nas duas laterais da urna, que podem estar completamente salientes, como uma estatueta colada à parede

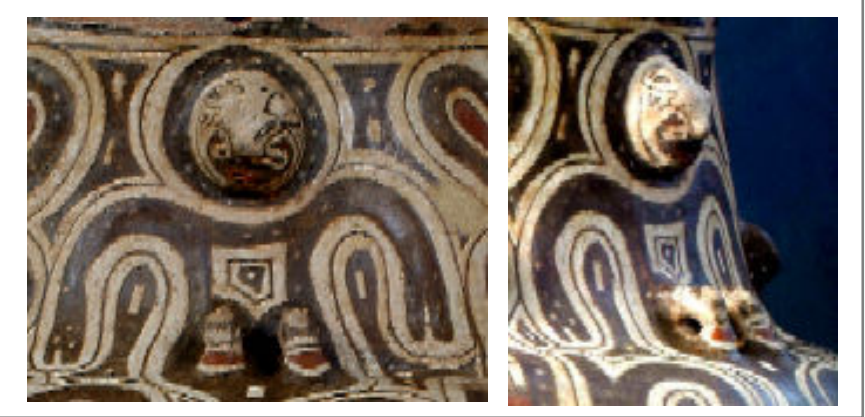
da urna, ou apresentar apenas o rosto e joelhos salientes, com 0 restante do corpo "afundados " dentro da urna.

Figura 5.6

Bonecos laterais em urnas do grupo 1. 
A presença predominante no rosto é a dos olhos: são volumes salientes que saltam na direção do observador e sempre emoldurados por sucessivas linhas e faixas alternadas e contrastantes em preto e vermelho sobre branco, sinalizando um alvo para o olhar. Quer os olhos sejam construídos com a pálpebra semi-cerrada, retratando cílios e por vezes uma plumagem preta salpicada de branco, quer sejam mais arredondados e arregalados, os olhos atraem o olhar do observador por se destacarem do plano definido pelas paredes da urna.

A importância dos olhos foi observada por Gell em diversos tipos de ídolos enquanto típicos elementos de animação de objetos inanimados por promoverem uma intensa interação entre o devoto e o ídolo, entre sujeito e objeto. Olhar e ser olhado cria uma ponte de reciprocidade e inter-subjetividade entre os dois:

"Eye contact, mutual looking, is a basic mechanism for intersubjectivity because to look into another's eyes is not just to see the other, but to see the other seeing you. Eye contact prompts self-awareness of how one appears to the other, at which point one sees oneself 'from the outside' as if one were an object (or an idol)." (Gell, 1998:120)

De acordo, este tipo de reciprocidade causado por uma oscilação ótica (o olhar e o ser olhado) acaba por desmanchar as fronteiras físicas entre o ídolo e seu devoto, o qual atinge assim um estado de união com o ídolo. Os olhos promovem então a animação do ídolo, pois o sentido da visão não só estimula os outros sentidos (como o de tocar e ouvir), mas também provocam no devoto determinados estados psicológicos, tais quais a consciência de si enquanto sujeito e o estado de união com um deus, ajudando assim a reforçar a própria devoção (Gell 1998:117-118).

É preciso esclarecer que a base da idolatria a que se refere Gell não está no fato do devoto acreditar que o ídolo tenha vida própria e sentidos, pois a imagem ou objeto é em geral percebida como ser inanimado, mas justamente pela surpresa causada pela agência de um ser inanimado.

A antropomorfia de seres inanimados é outro recurso comum na construção da idolatria de objetos apontado por muitos autores que trabalham tanto na linha da antropologia simbólica como da cognitiva, desde o clássico 
estudo de Gombrich (1979), e didaticamente ilustrado na reconstrução de rituais funerários na arqueologia Maya por Gillespie (2001). A base intencional da antropomorfização de objetos está não só nos efeitos de animação do objeto, conferindo-Ihe órgãos de sentido, mas, sobretudo, no estabelecimento de uma relação de identificação entre o ídolo e o devoto, nos seus atributos físicos.

No caso destas urnas, no entanto, a antropomorfização não se dá pelos atributos físicos humanos, mas por atributos culturais, através do uso de adornos que são exclusivos aos humanos (alargadores, brincos e pendentes) e possivelmente restritos a apenas alguns humanos, enquanto insígnias de prestígio. Pode-se assim dizer que as urnas não são "antropomorfizadas", mas sim "humanizadas" com estes elementos. Além disso, a associação de atributos físicos de um animal, reconhecidamente superior quanto às suas habilidades predadoras, a possíveis insígnias de prestígio social entre os humanos, especifica uma relação entre a capacidade transformacional, ou de trânsito entre os dois mundos (animal e humano) e sua posição social diferenciada, superior.

As características do personagem assim construído, e sua relação de olhar e ser olhado com o indivíduo que a observa, são em tudo compatível com o que a teoria perspectivista prevê na relação entre humanos e animais e entre seres humanos e seus ancestrais. Primeiramente, para os ameríndios, "o referencial comum a todos os seres da natureza não é o homem enquanto espécie, mas a humanidade enquanto condição "(Descola, 1986:120). Esta humanidade, por ser considerada a forma originária e ancestral de todos os seres, é retida enquanto uma essência humano-espiritual, independentemente das diferentes roupagens ou corpos que hoje ocupam. Os adornos podem assim sinalizar esta condição humana ancestral.

Por outro lado, diferentemente de uma relação entre essência e aparência, as roupas ou corpos que recobrem esta essência humana, não são meros disfarces (ou máscaras), são o "equipamento distintivo, dotado das afecções e capacidades que definem cada animal", definindo o ponto de vista da perspectividade e exercendo funções distintas na economia da predação, como 
define Viveiros de Castro (2002:394) ${ }^{1}$. No caso das urnas, é a forma dos corpos de aves predadoras (corujas ou harpias) que confere um ponto de vista e uma posição específica na relação entre predador e presa. Conferem-lhe as habilidades superiores de visão e caça destes animais.

Pode-se pensar neste personagem coruja/harpia enquanto uma figura apotropaica, que estaria em estado de vigília, protegendo a urna e o morto dos perigos predatórios de outros animais, mas por que sua vez pode estar sujeita à predação pelos humanos.

Os seres mitológicos cuja forma, nome e comportamento misturam atributos humanos e não humanos, tem sido interpretados na teoria perspectivista, enquanto indicadores da existência de contextos comuns de intercomunicabilidade, entre o mundo animal e humano. De acordo com Viveiros de Castro, estes seres mitológicos são, de certa forma, xamãs, com suas qualidades trans-específicas. (Viveiros de Castro, 2002:354)

Nas análises iconográficas de Reichel-Dolmatoff sobre a ourivesaria précolombiana do Museo del Oro, um dos elementos mais comuns que caracteriza o que ele denomina a "arte xamânica" amazônica, são justamente as figuras híbridas, pássaros/humanos. Segundo ele são figuras que representam a capacidade dos xamãs em dissociarem seus espíritos de seus corpos para "voar", e penetrar outras dimensões do cosmos, uma ação que "simboliza a morte seguida pelo renascimento em um estado de conhecimento ...que é adquirido a partir de uma outra dimensão cognitiva" (1990:26). A figura neste estado de vôo xamânico é em essência um pássaro, mas é humanizado por portar um cinto, uma máscara, um chocalho, adornos plumários variados, ou ainda um tubo em osso de pássaro (para inalar alucinógenos). É freqüentemente acompanhado de animais auxiliares, tais quais felinos que servem de guias, e pássaros, batráquios e répteis, animais hoje considerados

\footnotetext{
${ }^{1}$ De acordo, o perspectivismo amazônico "parece incidir mais freqüentemente sobre espécies como os grandes predadores e carniceiros, tais como o jaguar, a sucuri, os urubus ou a harpia, bem como sobre as presas típicas dos humanos, tais quais o pecari, os macacos, os peixes, os veados e as antas. Pois uma das dimensões básicas, talvez mesmo a dimensão constitutiva, das inversões perspectivas diz respeito aos estatutos relativos e relacionais do predador e da presa" (Viveiros de Castro, 2002: 353).
} 
por alguns povos indígenas da Colômbia epítomes de dois mundos (água e terra; noite e dia; seco e molhado, etc...). Richard Cooke, identificou os mesmos animais antropomorfizados na decoração da cerâmica polícroma do Panamá e nas peças em metal do Panamá e Costa Rica, exibindo um grau de uniformidade cognitiva com povos indígenas atuais que, segundo ele, justificam a analogia com as práticas xamânicas atuais para se entender seus significados (Cooke, 1998:101).

A coruja e o gavião estão presentes em vários mitos amazônicos, e não raro relacionados à propiciação da visão após a morte, como descreve Descola para os Ashuar:

Segundo a interpretação mais freqüente, o wakan deixa o corpo pouco antes da morte para se trans formar num Iwianch que ia assombrar a casa até a completa dissolução das carnes do defunto, quando então o wakan-Iwianch se metamorfoseia em animal. ....Dizem ainda que o wakan gosta de se encarnar nas corujas e nos bicos-encarnados a fim de recuperar a visão, já que ele é considerado cego a partir do momento em que abandona o corpo. Assim, este pássaros emprestariam seus olhos aos mortos e não é raro que um achuar, ao ouvir um bico-encarnado assobiar o seu pees-pees característico, comece a resmungar abaixando a a cabeça: "Vá incomodar quem Ihe enfeitiçou!" Descola (2006:411).

Da mesma forma, as urnas marajoaras, replicando os mitos, reiteram assim dois princípios básicos do perspectivismo amazônico: a valorização simbólica da caça e a importância do xamanismo. Mas ao construir e materializar o corpo deste personagem ancestral, mítico, híbrido, e com poderes xamanísticos, as urnas adquirem outra função (além da de síntese do conhecimento mitológico): trazem para o ritual funerário a perspectiva transespecífica do xamã, onde a relação estabelecida pelo olhar e o ato de ser olhado, é subjetivada pela "capacidade" da urna de se comunicar tanto com os humanos quanto com os animais predadores. Absorvem assim a mágica do xamanismo perante o olhar dos humanos. ${ }^{1}$

\footnotetext{
${ }^{1}$ Vale a pena citar aqui algumas objeções tecidas por Santos-Granero (2007:117) à concepção "visocêntrica" do perspectivismo em relação aos outros sentidos: "o papel dos diferentes sentidos nas relações intra e interespecíficas e, em segundo lugar, a questão da consciência dos seres - consciência tanto de que almas encorporadas e desencorporadas têm diferentes capacidades sensórias como de que a percepção tem um caráter perspectivo. $A$ dimensão sensorial do fenômeno do perspectivismo não foi explorada por seus estudiosos, exceto no que concerne à afirmação de que os ameríndios atribuem a animais, espíritos e outros seres não humanos as mesmas faculdades cognitivas e sensoriais que eles, ameríndios,
} 


\section{Corpo e alma}

Se os elementos plásticos da urna definem um personagem com qualidades e perspectivas específicas, isto se dá principalmente através da mimese de elementos reconhecíveis em seu corpo (como alguns dos atributos animais e os adornos). Contudo, a constituição do ídolo não se dá apenas na construção de um corpo (com olhos, boca, etc...), mas também com a delimitação de um espaço interno que é envolto pelo corpo. É o contraste dentro/fora, ou essência/aparência, invisível/visível que, segundo Gell, pode conferir algo espiritual ao núcleo do objeto-ídolo, como uma mente, uma alma, um espírito ou um ego, e o torna assim capaz de pensar, ter intenções, etc. (Gell 1998:129-130).

Muitos rituais de idolatria giram em torno de objetos com cavidades internas, enquanto repositórios de intenção, ou objetos que são guardados dentro de recipientes e camadas de envoltórios diversos (tecidos, relicários, oratórios, arcas, ou mesmo os recintos arquitetônicos dos templos), e envolvem uma seqüência de ações relacionadas a desembrulhar, descobrir e expor o núcleo do objeto, de forma a ativar, ou reavivar os poderes espirituais do ídolo. Lembra-nos a cabacinha Bororo, onde a alma do falecido é encerrada após o seu funeral, podendo ser invocada, posteriormente, a partir do toque, ou os postes Kuarup que são "acesos" com um fogo próximo e pela fumaça assoprada da boca dos xamãs.

No perspectivismo ameríndio, são justamente os corpos que constroem esta relação entre o externo e o interno, o material e o imaterial, o corpo, que define a perspectiva, e a alma que lhe confere potência. Alguns autores, como Santos-Granero, vêem na dimensão espiritual o lócus da capacidade de transmutação dos seres:

"a noção ameríndia de que o mundo material é o invólucro de certa dimensão espiritual, importante fonte de conhecimento extraordinário, parece

possuem (e.g. Viveiros de Castro, 1998, p. 474). Esses autores têm posto o foco sobretudo na visão e em como diferentes tipos de seres "vêem" outros seres. Alguém poderia argumentar que a noção de perspectiva é sinônimo de ponto de vista, o que, portanto, justificaria o foco na visão. Entretanto, dada a ênfase na "condição encorporada" da perspectiva e na noção de corpo como "feixe de afecções e capacidades", esperar-se-ia uma perspectiva menos "visocêntrica" da própria perspectiva". 
ser tão generalizada nas terras baixas sul-americanas quanto a idéia de que tal dimensão espiritual só pode ser percebida pela alma, ou vitalidade, de uma pessoa. Até mesmo povos ameríndios que dizem que o conhecimento tem sempre um caráter encorporado põem-se de acordo quanto ao fato de a dimensão espiritual do mundo só poder ser apreendida por meio de componentes não corpóreos da pessoa: "Para que alguém possa ver a verdadeira natureza das gentes e das coisas que compõem o mundo natural diz Kensinger (1995, p. 240) em referência aos Kaxinawá -, deve também entender bedu yushin, o espírito do olho, às vezes também chamado de o real espírito, yushin kuin". (Santos-Granero, 2006:105)

Em outras palavras, o poder da magia, ou dos xamãs, o que thes possibilita ver e se comunicar com todos os seres como um semelhante, reside menos na sua capacidade transformacional corpórea (a mudança de invólucro seria apenas um recurso de ilusão "cenográfica", uma aparência), e mais na sua alma, que é a verdadeira fonte de conhecimento extraordinário. Mas para ver a verdadeira natureza das gentes, é necessário não só o treinamento espiritual para a aquisição deste conhecimento extraordinário, mas também, é preciso estar dotado de olhos. Por isso, encontramos em algumas sociedades amazônicas uma sobreposição entre uma entidade espiritual e os olhos, como o "espírito do olho", dos Kaxinawá.

Nas urnas funerárias, além do papel predominante dos olhos, e de olhos particularmente eficientes, como os das corujas ou harpias, da reflexão dos olhos nos vários planos da urna, alguns indícios desta sobreposição olhos/alma, se traduzem também na utilização da figura de um olho, posicionada no bojo da urna, isto é, no lugar onde possivelmente se retratam órgãos internos (como o útero) ou seres no interior de ventres grávidos (ovos ou fetos).

\footnotetext{
${ }^{1}$ Esta protagonismo da espiritualidade sobre a corporalidade é colocado de uma maneira bastante distinta por Eduardo Viveiros de Castro: "Ser capaz de ocupar o ponto de vista é sem dúvida uma potência da alma, e os não humanos são sujeitos na medida em que têm (ou são) um espírito; mas a diferença entre os pontos de vista - e um ponto de vista não é senão diferença - não está na alma." Está, segundo o autor, no corpo, e é assim definido: "O que estou chamando de corpo, portanto, não é sinônimo de fisiologia distintiva ou anatomia característica; é um conjunto de maneiras ou modos de ser que constituem um habitus. Entre a subjetividade formal das almas e a materialidade substancial dos organismos, há esse plano central que é o corpo como feixe de afecções e capacidades, e que é a origem da perspectiva". (Viveiros de Castro, 2002:380).
} 

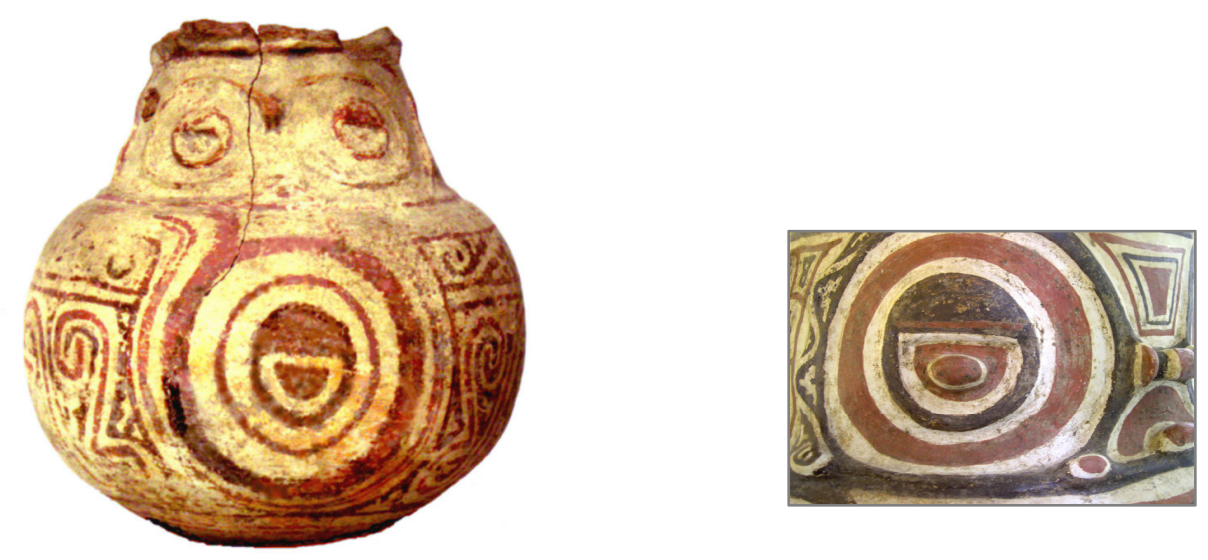

Figura 5.7

Urna funerária com figura de olho no bojo ICBS-MAE 1192 (altura: $35 \mathrm{~cm}$; diâmetro: 34cm) e detalhe de um olho da urna 1840.

Mas talvez a sobreposição mais significativa entre espiritualidade e corporalidade, esteja na ação dada pela função propriamente dita do objeto enquanto recipiente funerário: conter os restos mortais de determinados indivíduos, associando-os a algum tipo de espiritualidade, alma, ou capacidade extraordinária, dada pela corporalidade do personagem constituído pela urna. A associação se dá de forma metonímica, isto é, por uma espacialidade coincidente entre a alma do personagem ídolo e os restos materiais dos indivíduos. Seria por demais especulativo especificarmos aqui qual a intenção mais precisa por trás desta ação, mas tanto a relação entre corporalidade e espiritualidade dada pelo perspectivismo amazônico, como a prática comum de construir corpos envoltórios para sacralizar objetos, sugerem-nos a intenção de provocar uma transmutação do indivíduo inumado dotando-o de uma nova identidade, trans-específica, nem animal nem humana, talvez sobre-natural e, por isso, sagrada.

A associação se dá de forma metonímica, por contigüidade ou coincidência espacial, o que parece ser compatível com a forma como os cemitérios estariam espacialmente organizados nos aterros marajoara, onde, de acordo com as descrições de Schaan, vimos que as estruturas funerárias se organizam espacialmente em agrupamentos de urnas decoradas e outros objetos de prestígio. 


\section{Representação desdobrada e magia}

O personagem híbrido assim constituído é duplicado em dois lados simetricamente opostos das urnas. Se pensarmos então nas urnas enquanto corpos, verificamos que estes corpos são desdobrados, constituindo duas frentes, mas partilhando do mesmo interior (ou das mesmas costas e interior invisíveis). A face frontal é assim refletida a partir de um plano vertical, que corta a urna de cima a baixo em duas metades idênticas.
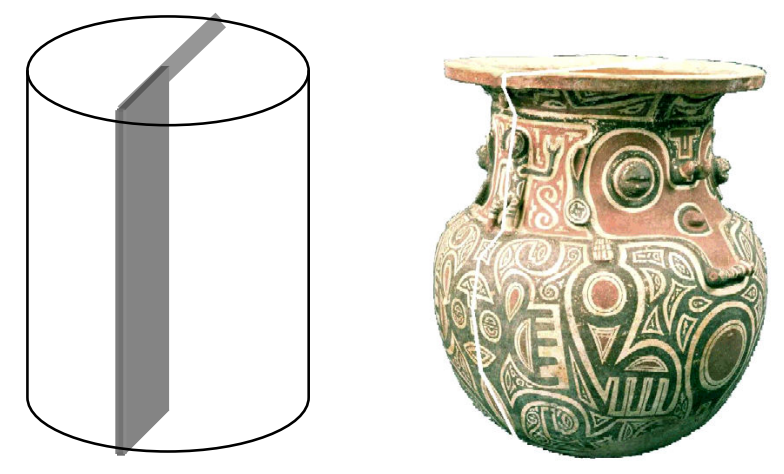

Figura 5.8

Eixo de simetria para a representação desdobrada nas urnas marajoara

Mas, como é característico na cerâmica marajoara, uma vez unidas estas duas metades, a junção dos perfis laterais formam novas "frentes", através da justaposição dos olhos.

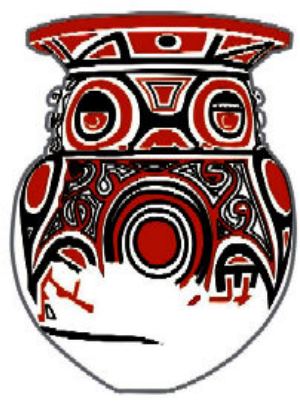

a

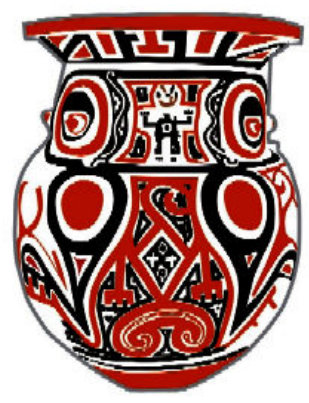

b

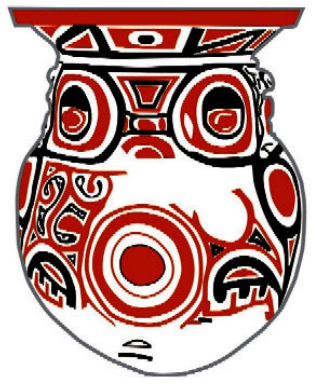

C

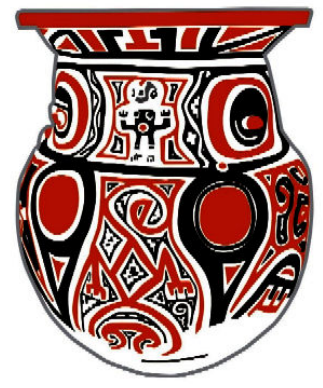

d

Figura 5.9

As quatro faces de uma urna do grupo 1. Note-se os elementos das faces b e c também posicionados em lados simetricamente opostos. 
Desta forma, de qualquer "lado" em que a urna é vista, é possível sempre se deparar com um par de olhos. A junção destes perfis que formam uma nova vista frontal apresenta alguns elementos de ligação, alguns estruturais, como os pequenos "bonecos" modelados aplicados no pescoço da urna, situados entre os olhos, e outras variáveis, como alguns grafismos que figuram animais ou formas labirínticas no bojo da urna. Estes elementos são também posicionados em pares simetricamente opostos, obedecendo ao mesmo princípio de reflexão dos outros lados da urna.

Em alguns casos, a intenção em se formar novas faces nestas laterais das urnas fica mais evidente na secção ovalada (em vez de globular) dada à forma geral da urna, aproximando assim os dois olhos, conforme a urna ilustrada abaixo. Em relação à forma globular mais freqüente, a vista frontal do personagem, é não só refletida na parede simetricamente oposta, mas foi também aumentada na sua largura, formando inclusive ombros salientes nas suas laterais. Ao serem re-unidas, seus dois perfis não só formam uma nova face, mas os ombros salientes transformam-se em uma grande protuberância mamilar na parte superior do bojo.
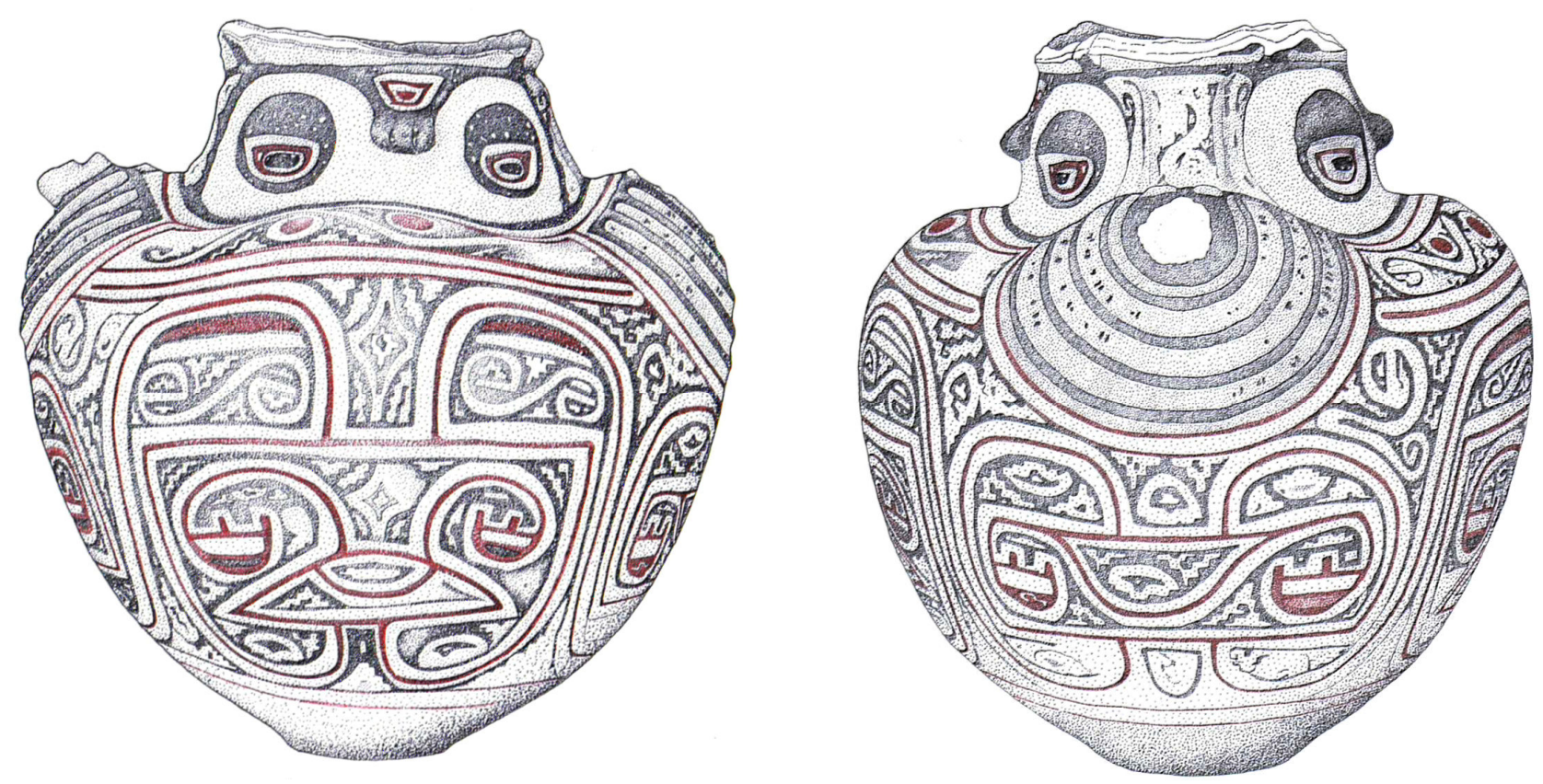

Figura 5.10 - Urna ICBS-MAE 1601. altura (borda fragmentada): $54 \mathrm{~cm}$; comprimento: $52,5 \mathrm{~cm}$; largura: $46 \mathrm{~cm}^{1}$

\footnotetext{
${ }^{1}$ Apesar de mais rara, esta forma de urna está também documentada em McEwan, Barreto e Neves (2001:128).
} 
Particularmente interessante para entendermos o princípio de duplicação ou reflexão das figuras nestas urnas, está a observação de Gell, sobre o estilo da representação desdobrada na arte das ilhas Marquesas para os etua, um ídolo apotropaico, que na passagem de sua imagem gráfica para objetos tridimensionais é representada sem costas, mas com duas frentes espelhadas e reunidas em um só objeto (Gell, 1998:190). Segundo ele, a parte frontal do ídolo, constitui a forma canônica ritual, olhando para as pessoas e, portanto, é assim replicada para conferir legitimidade estilística e eficácia ao princípio ritual do ídolo. A imagem do ídolo assim executada, não é a representação do ídolo, mas constitui o ídolo em si.

"One cannot see God from the back, because if he is not watching us, he is not God. In the same way Marquesan art cannot permit motifs to be witnessed, so to speak, at a disadvantage,just as it was sacrilege, in the Marquesas as in most Polynesian societies, to approach, or pass by the back of a chief' (1998:192)

Nas urnas marajoaras, tanto os elementos que se encontram na junção dos perfis, como o tipo de deformação plástica da forma da urna 1601, tem um papel semelhante ao identificado por Lévi-Strauss na assimetria (ou deslocamento) da representação desdobrada do Kadiweu: a de assegurar a distinção das figuras originais, ou canônicas, nos termos de Gell.

Assim, retomando o paralelo de Lévi-Strauss de que, neste caso, as imagens, ou máscaras, não representam seres sobrenaturais, mas constituem estes seres em si e que, portanto, a forma como são constituídos deve obedecer a sua forma canônica, como proposto por Gell, aqui poderíamos identificar talvez não tanto uma forma canônica, mas sobretudo, um ponto de vista, uma perspectiva particular, a de um ser híbrido, trans-específico, com poderes mágicos semelhantes ao do xamã. Desta forma, de qualquer lado que este personagem seja olhado, ele pode ver e se comunicar tanto com os animais quanto com os humanos e exercer sua magia. Neste caso, a forma de idolatria deste personagem aqui proposta, não passaria pela veneração de uma imagem, fixada em uma forma canônica, mas pelas suas características constitutivas, as quais Ihe conferem qualidades específicas, sobretudo através da ação do olhar. 


\section{Representação desdobrada e síntese}

Se os planos do pescoço e bojo da urna correspondem aos elementos constitutivos deste personagem, o plano da borda e, por vezes o do lábio da urna, parecem compor uma síntese da sua estrutura simétrica e predominância de alguns elementos tais quais os olhos.

Seguindo o estilo marajoara de delimitar campos, a superfície externa da borda é delimitada e separada do pescoço da urna por linhas e faixas paralelas pintadas e em relevo, marcando a mudança de inflexão das paredes. Mas, diferentemente de outros vasilhames onde a delimitação dos diferentes campos confere-lhe certa independência no alinhamento e simetria dos motivos, aqui o relevo e grafismo aplicados na borda replicam de forma refletida, diminuída e estilizada a estrutura de simetria de toda a urna e elementos do pescoço e parte superior do bojo.
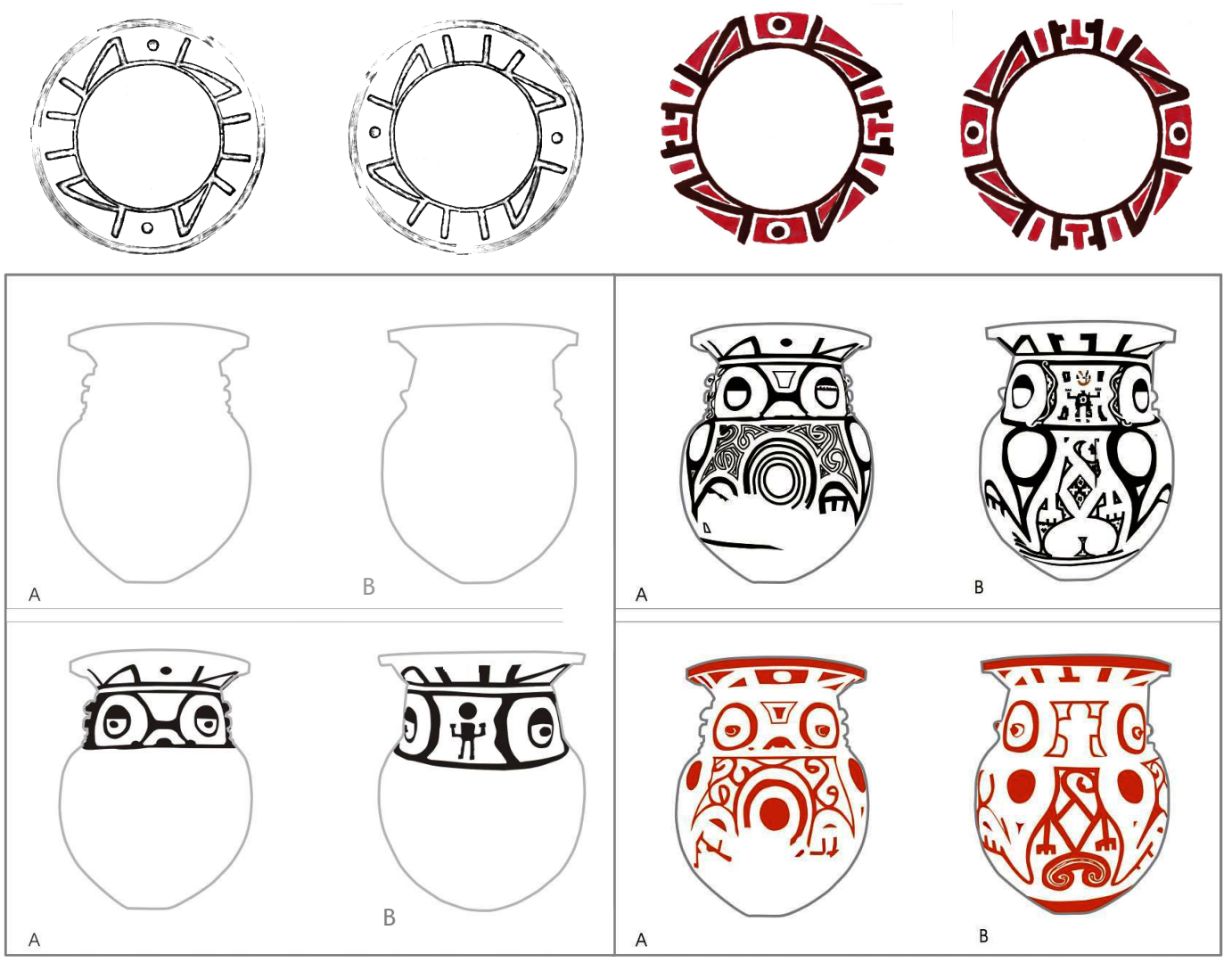

Figura 5.11

Decoração da superfície externa da borda da urna ICBS-MAE 1840. À esquerda, contorno e apenas os elementos em relevo nas faces $\mathrm{A}$ e $\mathrm{B}$; à direita apenas a decoração pintada em preto (acima) e em vermelho (abaixo) sobre engobo branco. 
Na urna 1840 na figura acima, por exemplo, um pequeno círculo central espelha o grande círculo do bojo, assim como na sua lateral uma forma $T$ espelha o boneco que se encontra logo abaixo. As linhas pretas, que no pescoço da urna delimitam os olhos, e no bojo, delimitam a área entre as patas, são reproduzidas nas bordas alinhando as mesmas divisórias. A borda reúne assim a síntese de toda a composição da urna e seus principais elementos estruturais.

$\mathrm{Na}$ urna 1598, onde os olhos são mais salientes, suas formas arredondadas aparecem refletidas nas bordas como se fossem sombras

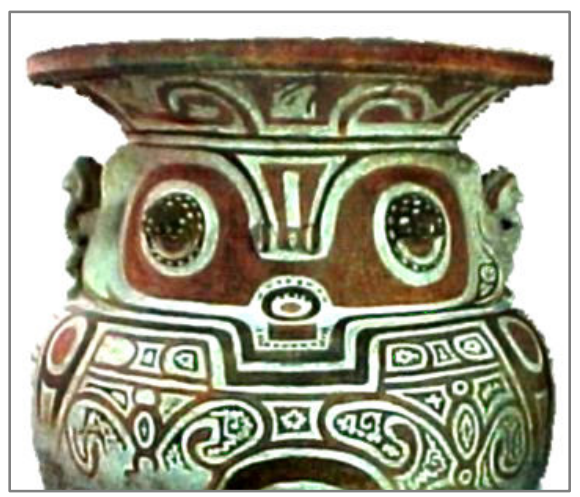
projetadas de baixo para cima. O mesmo acontece no lábio espesso e plano da urna 1839, onde a estrutura simétrica da urna é sintetizada por apenas alguns riscos verticais e campos em cores alternadas, como se sua complexidade fosse filtrada para reproduzida projetada sobre este pequeno plano do lábio.

Figura 5.12

Urna ICBS-MAE 1598

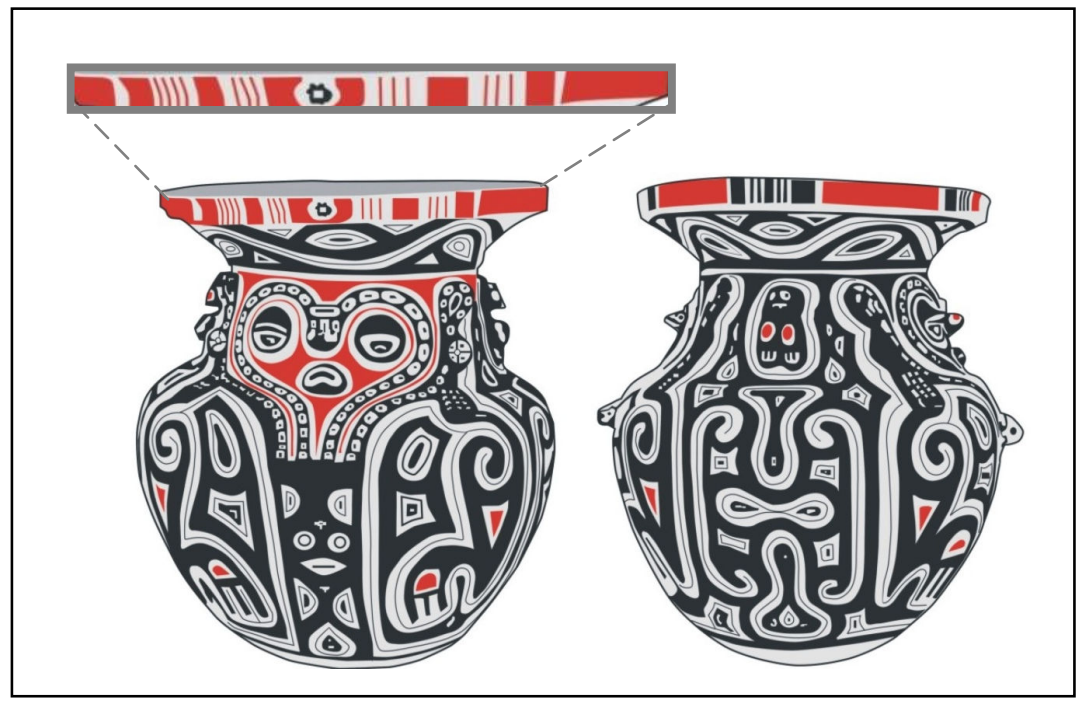

Figura 5.13

Desenho da urna ICBS-MAE 1839, com decoração pintada no lábio ampliada. 
A função desta reflexividade sintética da estrutura da urna nas bordas e lábios, pode se dever ao fato de que as bordas fragmentadas eram realocadas nos espaços funerários marajoara, talvez exercendo alguma função mnemônica do personagem por ela encarnado associando espacialmente determinados indivíduos ali enterrados.

\section{Os elementos variáveis}

Se os elementos estruturais da urna constituem um personagem mítico, ancestral, dotado de uma magia que pode emanar literalmente de todos os seus lados, o que podemos dizer daqueles elementos que identificamos como variáveis, isto é, que não são tão recorrentes de forma a fazer parte dos modelos conceitual para este tipo de urna?

Alguns destes elementos são reconhecíveis enquanto seres animais, e parecem geralmente no bojo da urna, abaixo do pequeno boneco em relevo no pescoço. Alguns aparecem de ponta cabeça, outros em posição sentada, ou com as pernas abertas, exibindo seus genitais. É possível que sejam referências fetos ou a cenas de parto.

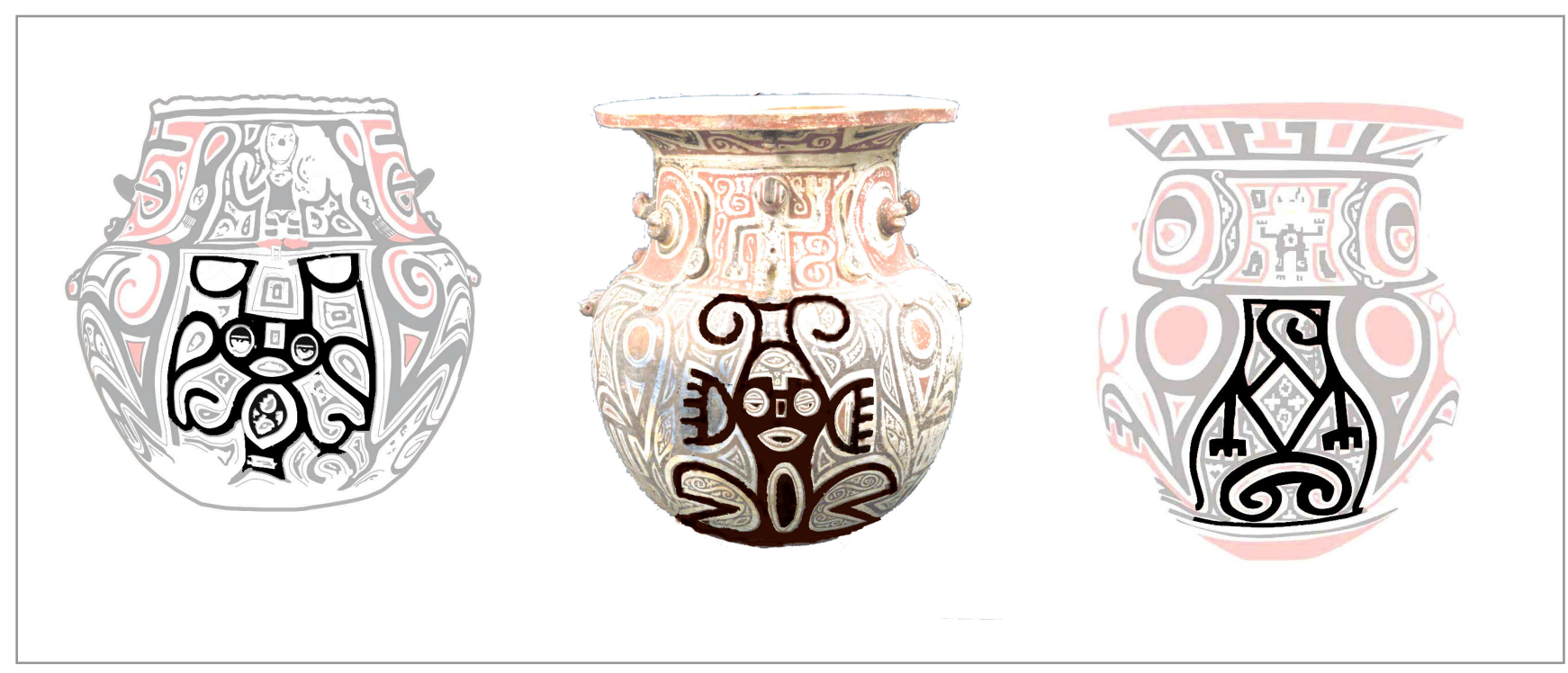

Figura 5.13

Figuras zoomorfas pintadas no bojo das urnas do grupo 1. 
Já nas urnas menores, eles aparecem mais esquematizados, e podem ser corpos de animais simplificados, retendo alguns elementos indicativos de olhos, boca e garras. Estes são desenhos que aparecem em outros tipos de urnas, assim como em outros vasilhames e não parecem ser exclusivos à contextos funerários.

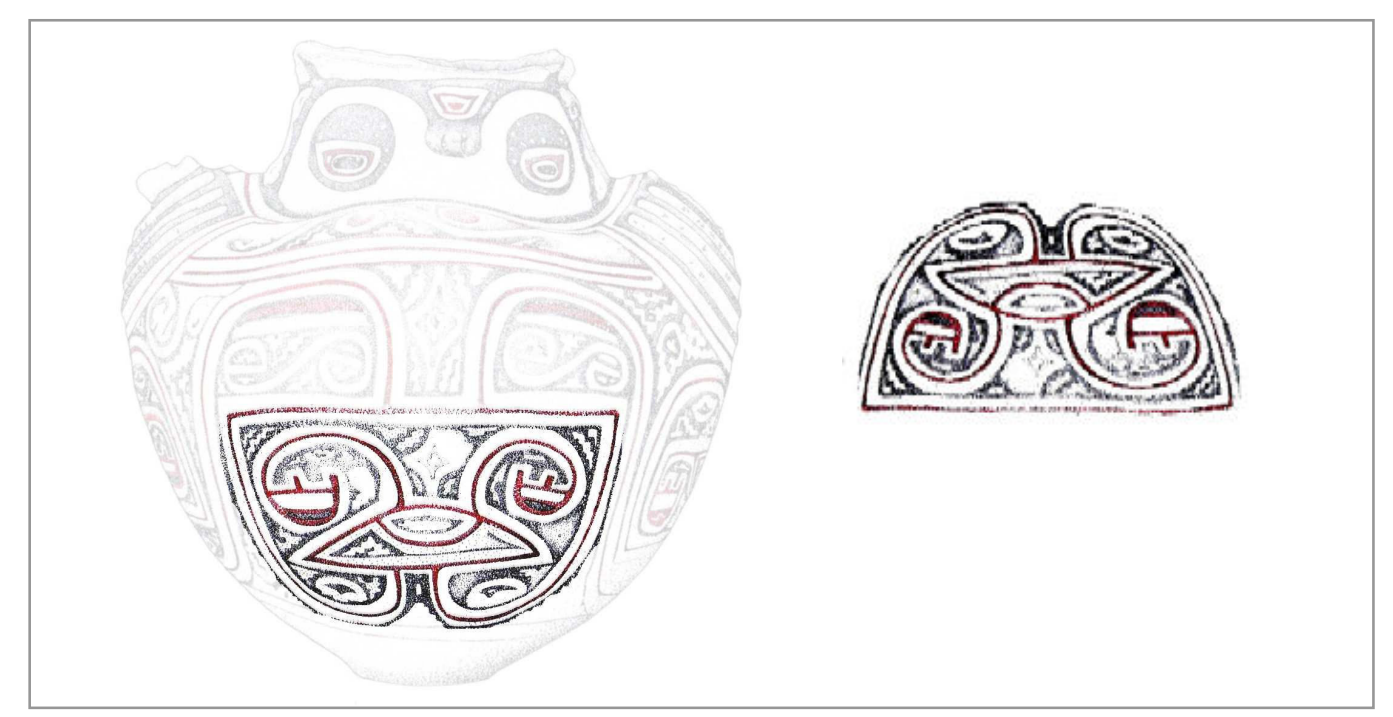

Figura 5.14

Figura antropomorfa estilizada em bojo de urna do grupo 1.

Nas áreas centrais das urnas maiores, entre as patas da figura principal, existem os já aludidos círculos, que podem também ser formados da mesma maneira que os olhos, com uma pálpebra semi-cerrada, ou ainda apresentar pequenos traços irradiantes à sua volta (o que Magalis chama de "umbigos peludos", mas que Schaan interpreta como útero), os quais parecem mesmo evocar a fertilidade e reprodução, como já sugerido por ambas as autoras.

Nas urnas que apresentam uma faixa central no ventre do personagem híbrido, os motivos parecem mais recorrentes. Identificamos ao menos três motivos, cada qual se repetindo em pelo menos três urnas:

- as linhas em zigue-zague, que podem ser duas linhas entrecruzadas formando losangos, ou apenas uma com pontos nas laterais; 
- os "medalhões", que podem ser grandes e com figuras de preenchimento em forma de espirais duplas; ou apenas pequenos círculos ovalados com molduras pontilhadas.

- as faces compostas por dois olhos circulares e uma boca oval.

Estes motivos aparecem também em outros objetos, alguns de forma mais recorrente do que outros.
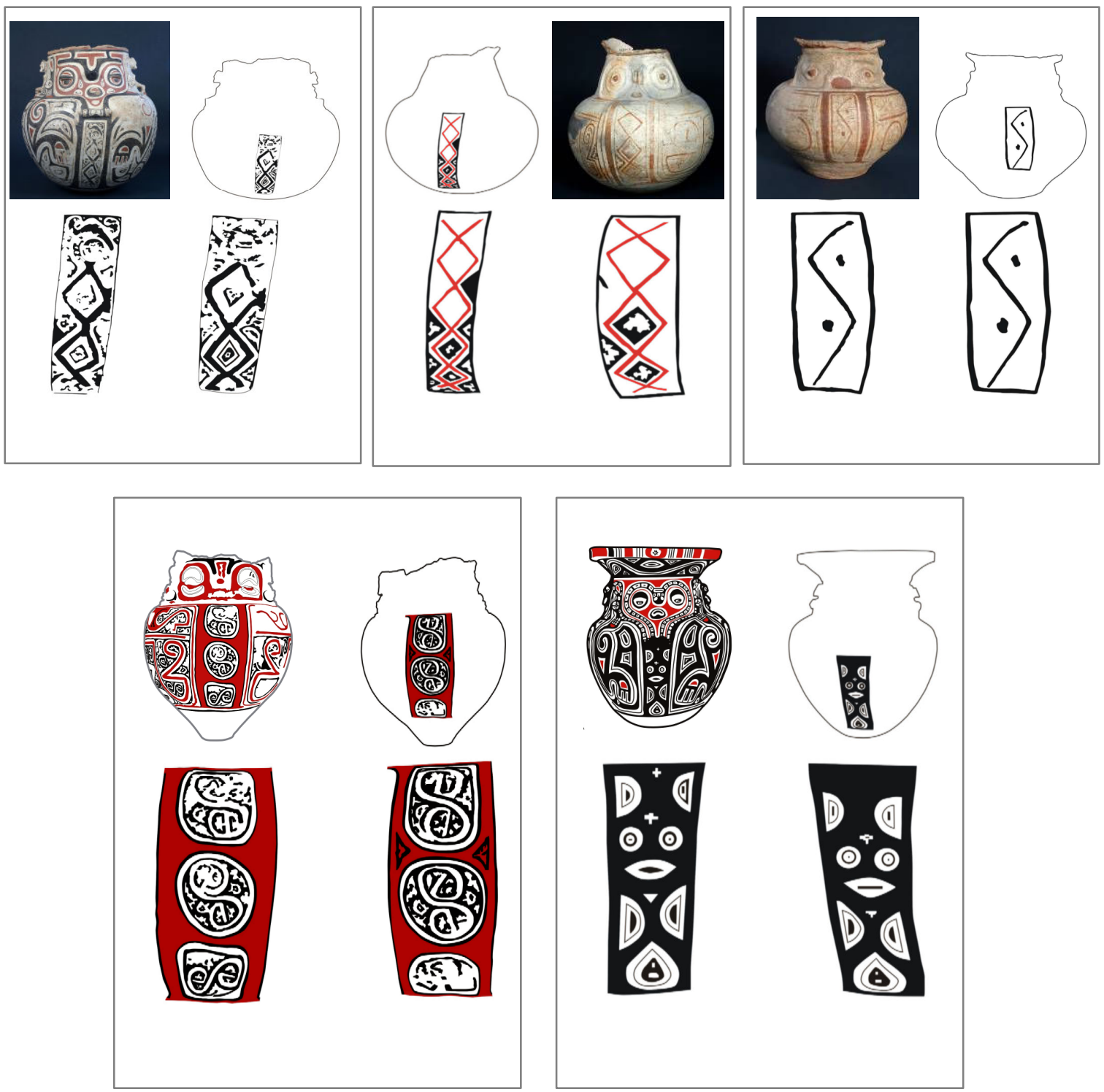

Figura 5.15

Motivos em faixa frontal das urnas do grupo 1. 
Estas figuras constituem assim um repertório fixo de referentes. Nossa hipótese, a cerca destes motivos que são exibidos entre as presas da personagem principal é que, estes sim, são marcas, no sentido usado por Vidal (1999), desenhos emblemáticos que remetem a determinadas identidades sociais, possivelmente definidas por linhagens genealógicas e, por isso, são recorrentes, inclusive sobre outros objetos cerimoniais. Os emblemas, ou marcas, seriam aqui sacralizados quando carregados e exibidos pelas figurasídolo.

Assim, interpretado, este primeiro grupo de urnas parece se conformar bem à idéia de Schaan sobre os cemitérios de Marajó associados espacialmente em torno de urnas decoradas com figuras emblemáticas das diferentes facções da elite local, dando ênfase à identificação grupal e não a diferenças individuais particulares. Contudo, suas observações não especificam os mecanismos através dos quais estas figuras retransmitem status, prestígio e poder, aos indivíduos ali enterrados.

No estilo marajoara, de acordo com os padrões de reconhecibilidade e variabilidade observados, emblemas parecem circular por uma larga gama de objetos, mas somente as urnas aqui descritas, através de seus "poderes mágicos" fazem com que eles sejam sacralizados e venerados. Aí reside a agência propriamente dita destes objetos.

\section{Entre o visual e o ritual}

Finalmente, podemos concluir que os elementos constitutivos deste modelo de urna se aproximam mais do modelo A proposto no capítulo anterior, na qual a urna corresponde à fabricação de um corpo a partir de um modelo corporal bastante estável, correspondendo a uma figura mítica, ancestral, que pode ser distribuída através de sua replicação em locais sagrados.

O processo de sacralização em si, se dá pela reafirmação da continuidade entre vivos e mortos, com as almas humanas tomando a forma (ou o corpo) deste personagem da humanidade pristina. Este personagem porta emblemas, símbolos, que o diferenciam de outros humanos e especificam sua 
origem, sua história. Assim, de certa forma, cumprem muitas funções rituais semelhantes aos postes Kuarup: propiciam um corpo para as almas, e representam uma identidade comunitária específica e tradicional perante outras; reatualiza o conhecimento sobre as origens e reprodução social da comunidade.

Muitos dos paralelos que podem ser estabelecidos entre as funções rituais das urnas marajoaras e dos postes kuarup, são relevantes para os arqueólogos na medida em que se traduzem em ações que resultam na produção material e visual: a escolha da matéria prima em si, como a de uma madeira com significados míticos; a maneira ritual como os postes são transformados em seres animados, através da sua decoração; a pintura, que privilegia a simetria do corpo humano, (inclusive com o recurso pictórico de contraste de cores, onde a faixa central vermelha define a simetria, e os motivos gráficos emblemáticos do grupo são aplicados em preto e branco nas laterais); a maneira como os postes são enfeitados com os adornos corporais (colar, plumárias e etc.) de forma a humanizá-los; a forma circular e sua decoração que permite que os postes se assemelhem a pessoas de qualquer ângulo que sejam vistos; a maneira como são dispostos no pátio central, obedecendo um princípio espacial de centralidade hierárquica; e finalmente, a maneira como se invocam as almas dos mortos celebrados para que ocupem estes corpos, através de ações diversas a seu redor.

Da mesma forma, podemos imaginar que a própria confecção da urna, ou sua decoração, se desse já de maneira ritualizada, definindo um tempo, uma seqüencia de ações por parte de determinadas pessoas. Parte desta seqüencia, pode ser inferida a partir de uma leitura arqueológica das técnicas de execução e aplicação da decoração.

1) A constituição plástica da urna em si, que envolveria desde a aquisição da argila, seu tratamento, e a modelagem de suas paredes e apliques. Para a confecção das urnas maiores, seria necessário um tempo consideravelmente maior, uma vez que partes das paredes, bordas e apliques só poderiam ser adicionados em etapas intercaladas por outras de secagem, de forma a propiciar uma base de sustentação mais sólida. Boa parte das deformações pré-queima observadas se devem justamente à 
esta dificuldade técnica. A adição de apliques é uma etapa determinante para a definição dos eixos de simetria e separação dos campos de decoração que serão completados com a pintura..

2) A segunda etapa envolveria a queima, o que provavelmente ocorria em fornos semi-abertos, vistas as manchas de oxidação freqüentes; (ambas Roosevelt (1991) e Schaan (2004) abordam em detalhes a questão da obtenção de argila e da queima em fornos.

3) A terceira etapa envolveria a decoração da superfície da urna já constituída na sua forma geral, e é possível que isto já fosse realizado em um espaço ritual próprio, talvez na área do cemitério, e envolveria a participação de artesãos especializados, assim como indivíduos relacionados ao morto que compartilhasses os mesmo símbolos identitários. Esta etapa tem uma seqüencia bem definida de execução na seguinte ordem: (ilustradas nas pranchas seguintes)

- aplicação do engobo branco;

- pintura de linhas grossas ou faixas que delimitam campos; pintura sobre ou em volta dos apliques, ressaltando a organização dos eixos de simetria e elementos em relevo tais quais os olhos;

- composição do corpo da figura principal (rosto, membros e suas articulações, "úteros"e faixas centrais, através de linhas grossas;

- composição de elementos secundários (motivos das faixas centrais; e figuras nas "junções laterais");

- elementos de preenchimento e de ligação que se encaixam ou "emanam" das linhas de definição dos elementos usando preto e vermelho alternadamente.

4) A quarta etapa, envolvendo as urnas, seria a que consistiria no rito funerário propriamente dito, isto é, na deposição dos restos funerários e objetos associados dentro da urna, e seu fechamento com tampas ou tigelas emborcadas. Aqui, provavelmente membros da comunidade se engajariam em danças, cantos, choros e etc. em volta da urna. 

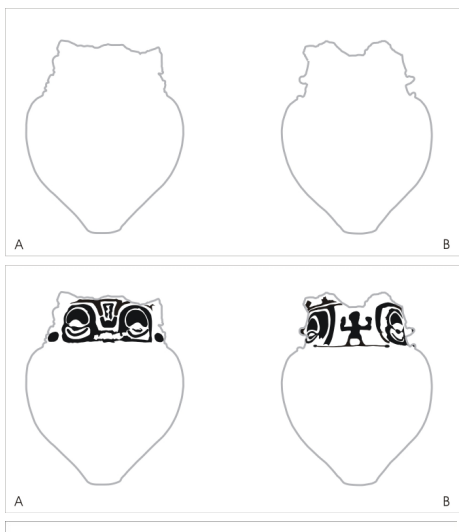

.웜ㅇ.

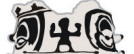

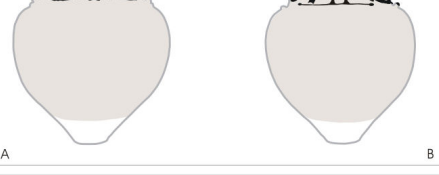

\section{(정.}
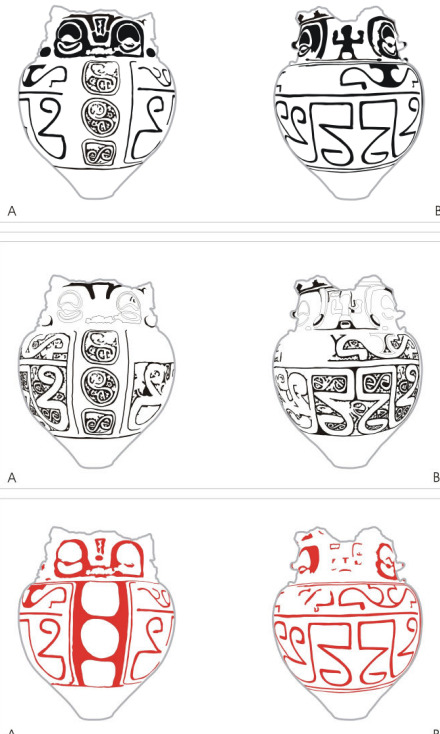

1

2

3

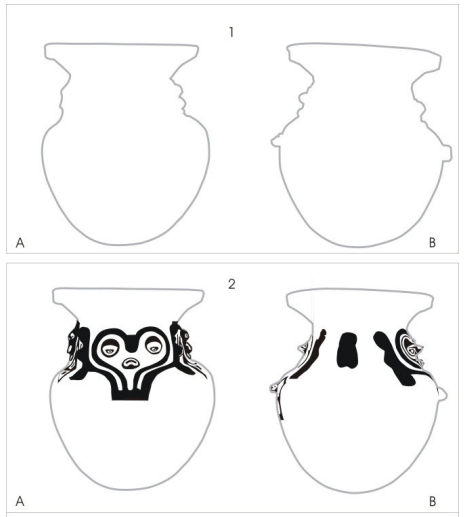

4
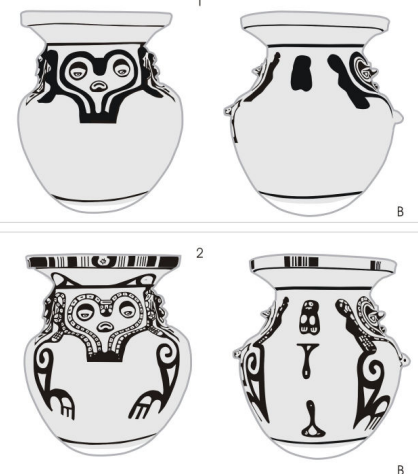

5

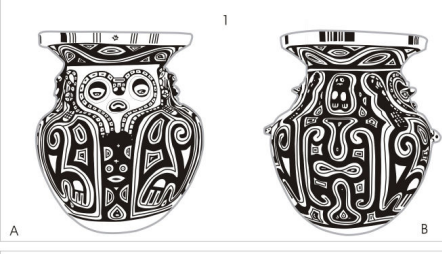

6

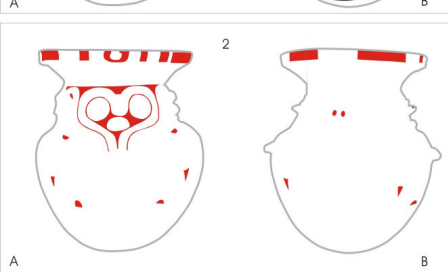

\section{Figura 5.16}

Sequência da confecção das urnas ICBS-MAE 1597 e 1830

1) Modelagem da base, paredes, e borda com sobreposição de roletes

2) Colocação dos elementos de relevo em apliques e apêndices

3) Preparação da superfície para pintura (alisamento e engobo), e divisão dos campos decorativos com faixas e linhas

4) Composição da figura principal com pintura sobre o relevo e sobre o bojo

5) e 6) Composição de elementos secundários e de preenchimento usando duas cores alternadamente 

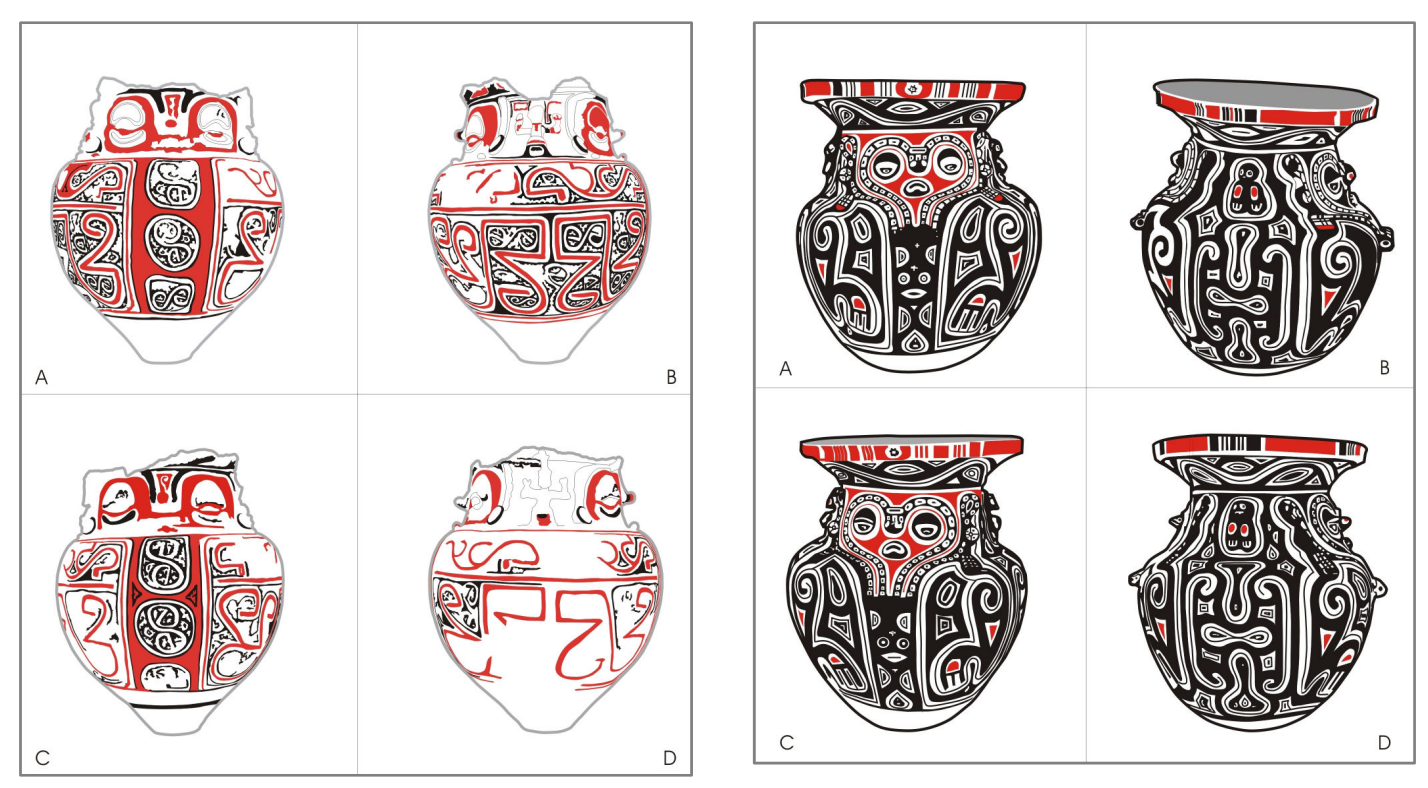

Figura 5.17

Os quatro lados das urnas ICBS-MAE 1597 e 1830

Certamente, muito do que é mobilizado durante rituais funerários, se dá fora da arena visual e sensorial do ritual em si, inclusive as intenções e ações intermediadas pelo personagem/urna aqui descrito. Mas estas certamente promoviam um foco espacial e material importante para a organização do ritual. 


\section{As urnas do GRUPO 2}

As urnas do grupo 2 são as que apresentam menos variabilidade interna. Apresentam um bojo globular, com base plana. O pescoço é constrito, curto, reto ou inclinado externo; as bordas são extrovertidas e reforçadas externamente, com lábios planos. As dimensões variam pouco, com uma altura média entre 35 a 45

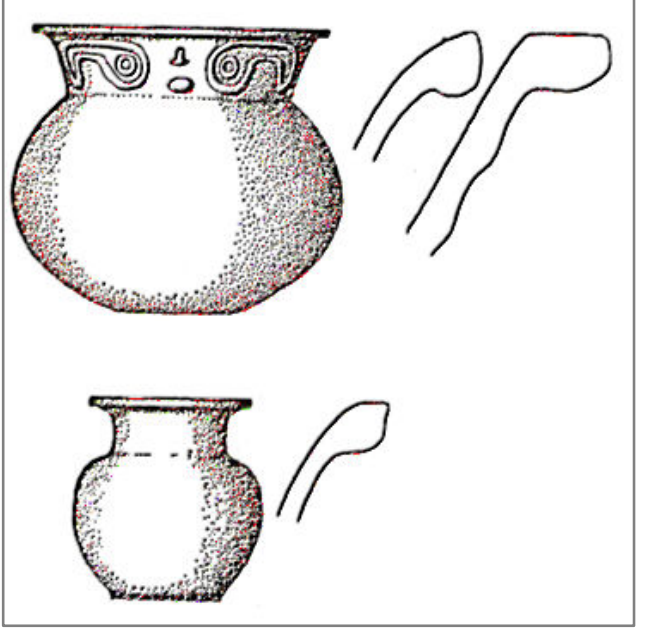
$\mathrm{cm}$. Correspondem às formas 11 e 13 descritas por Meggers e Evans para a cerâmica do tipo Joanes Pintada (Meggers e Evans, 1957:360).

Há poucos elementos em relevo: algumas saliências ao longo da borda, às vezes formam pequenas alças entre a borda e o pescoço. No pescoço, dois apliques finos ovais formam olhos (em forma estilizada de escorpião, ou de cabeça de cobra) e mais abaixo, outro aplique forma uma boca triangular ou oval.

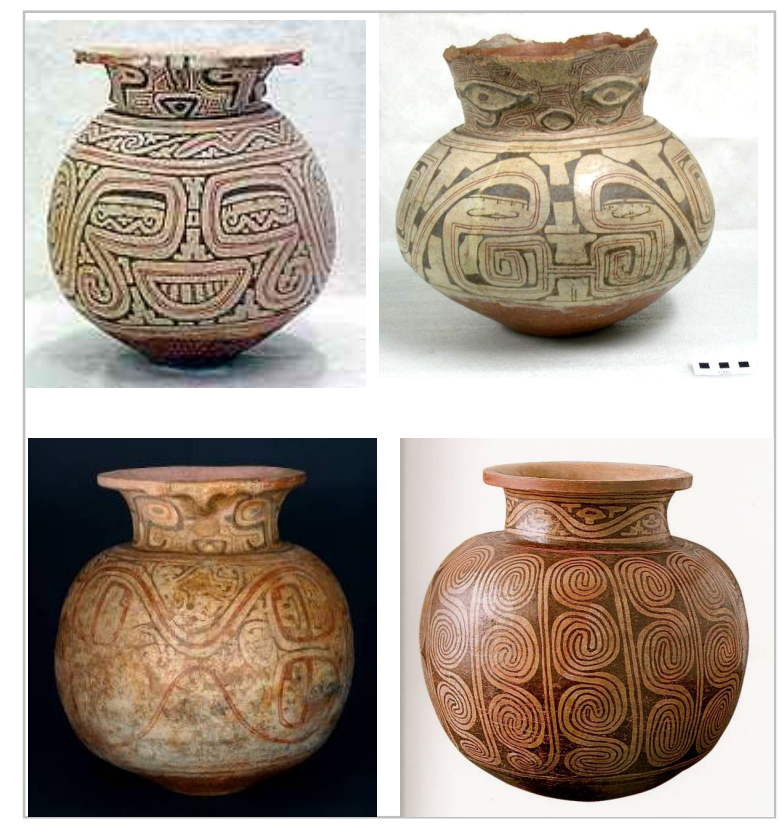

Figura 5.18

Urnas do grupo 2.

Em sentido horário: ICBS-MAE 1633, 1619, 1604 e 1600. 
A decoração pintada é sempre em vermelho e preto, ou apenas preto, sobre um engobo branco (ou creme), com um acabamento de superfície particularmente bem executado: as superfícies são brilhantes, os traços da pintura são finos e precisos, com linhas duplas ou triplas. O campo do pescoço da urna, em torno dos olhos, é freqüentemente recoberto por um padrão de linhas vermelhas paralelas e finas, como em uma pintura facial. No bojo, as figuras sobressaem-se na pintura muitas vezes por um efeito negativo, isto é, o motivo é todo contornado por áreas pretas e deixando o fundo do engobo branco formar o desenho.

No bojo da urna, o grafismo mais comum é o motivo do rosto com boca sorridente, mas outras variações deste rosto aparecem sem a indicação dos dentes, como na urna 1619. Assim como nas urnas do grupo 1, algumas delas ocorrem com todo o bojo recoberto por um padrão contínuo de espirais entrelaçadas, em linhas pretas sobre branco, como a urna 1604.

Urnas semelhantes estão documentadas em Palmatary (1950: pr.86 a , 87 b, e 78 a). Meggers e Evans documentaram uma urna deste tipo em uma estrutura funerária no aterro 1 , do sítio J-14 (Monte Carmelo), ao longo do rio Anajás. Nesta urna foram encontrados ossos humanos sem sinais de queima, e um fragmento de borda de um grande recipiente sem decoração, com diâmetro original de $54 \mathrm{~cm}$. A urna estava tampada por uma pequena tigela emborcada e encaixada dentro do pescoço da urna, com decoração incisa-excisa.(Meggers e Evans, 1957:267). Trata-se da urna J representada na ilustração da escavação abaixo na (figura 5.19). ${ }^{1}$

\footnotetext{
${ }^{1}$ A figura abaixo foi redesenhada a partir da figura em Meggers e Evans (1957:261), com perfil estratigráfico mais abrangente do cemitério, com $4 \mathrm{~m}$ extensão. Este recorte pode dar a falsa idéia de centralidade da urna $L$ (grupo 1), e da associação da urna $J$ em relação a uma área "central" do cemitério, mas na verdade, todo este grupo de urnas faz parte de um conjunto maior.
} 


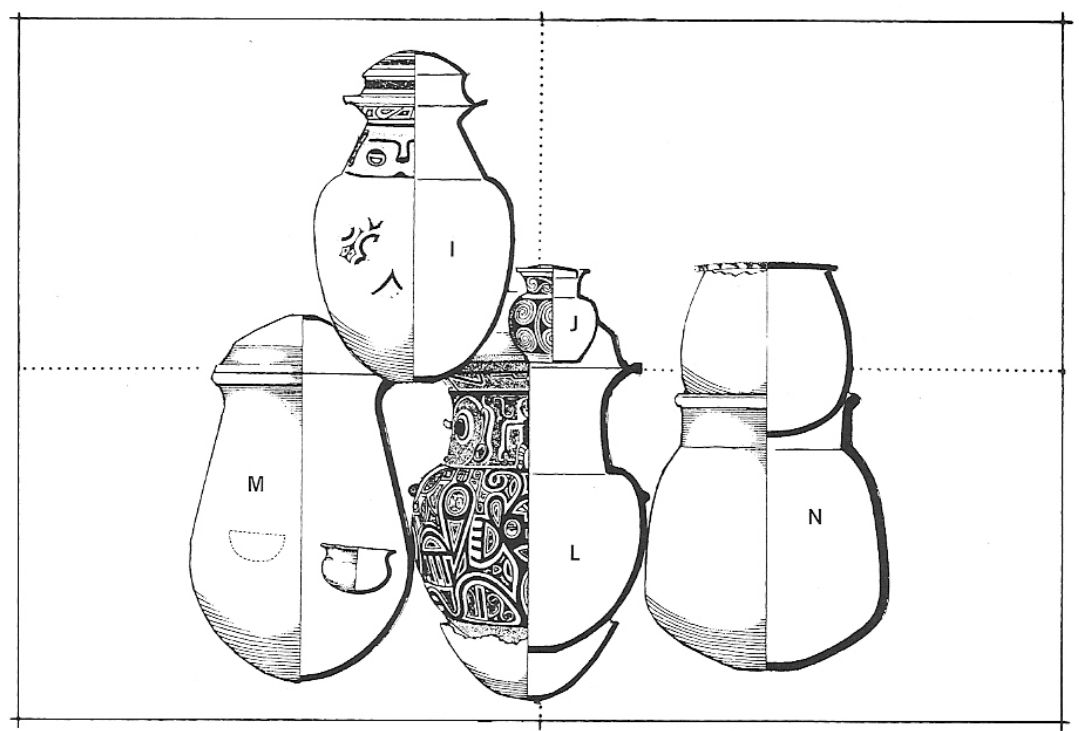

Figura 5.19

Perfil mostrando posicionamento das urnas escavadas por Meggers e Evans no sítio Monte Carmelo. (redesenho em MacEwan et al 2000:117)

Schaan (2004:369) também encontrou urnas deste tipo nos aterros Belém (sítio M-17) e nos Camutins, todas com a figura do rosto sorridente, tema este que ela identifica como um dos mais duradouros ao longo do período clássico marajoara ( 700-1100 d.C.).
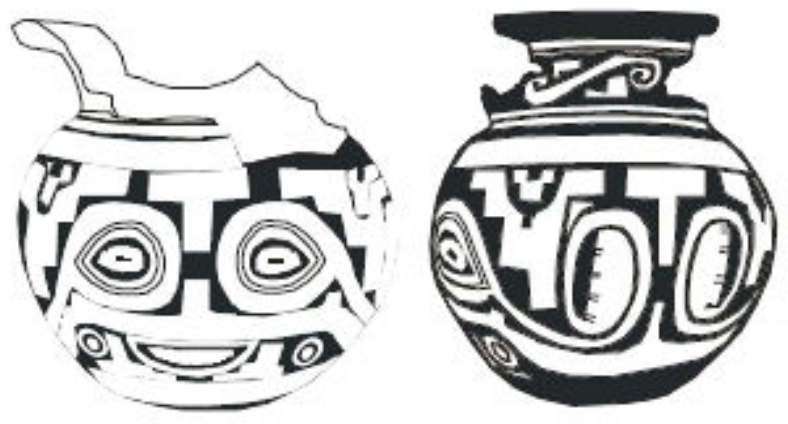

Figura 5.20

Urna encontrada por Schaan no aterro Belém

(apud Schaan, 2004: 369) 

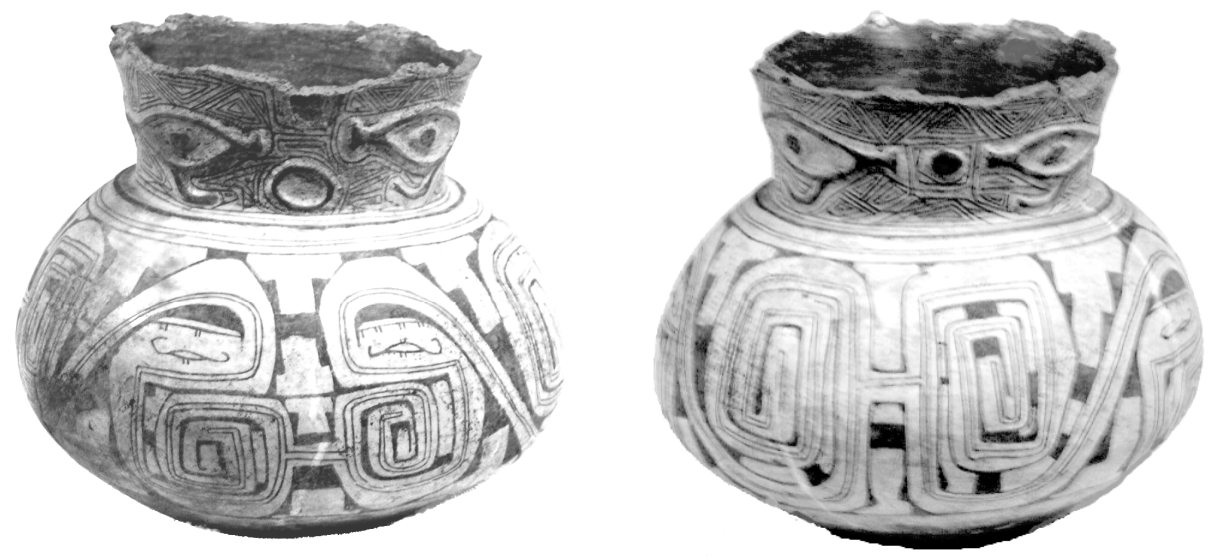

Figura 5.21

"Frente" e "lado" da urna 1619 (altura: $25 \mathrm{~cm}$ )

É possível que este modelo de concepção de urna, seja uma versão menor e simplificada das urnas do grupo 1. As formas são semelhantes, assim como a divisão dos campos decorativos e a composição de um rosto nas paredes do pescoço. Apresentam a mesma simetria reflexiva, com um rosto de cada lado, mas com a junção formando outro rosto, nem sempre tão harmoniosa.

Duas diferenças nos parecem fundamentais. Primeiro, o fato de que a composição plástica e gráfica da urna, como um todo, não compõe uma entidade única, com características corporais específicas, com alto grau de reconhecibilidade, como a urna coruja/humano do grupo 1. Aqui, embora o rosto composto no pescoço da urna sirva para engajar o olhar com um efeito semelhante às urnas do grupo, o corpo deste rosto não parece se estender para o restante da urna. Além disso, não há os elementos necessários para reconhecer os "equipamentos", ou capacidades de um corpo, como os olhos de coruja, ou os brincos dos humanos, que the conferisse uma perspectiva específica. Ao contrário, aqui, os olhos e bocas, não parecem obedecer a um padrão: podem ser formados a partir de diferentes figuras gráficas (ovais, círculos, triângulos, ou a forma de peixe, de cabeça de cobra, de escorpião estilizado, etc.). Em certos casos, eles nem mesmo estão presentes. Assim, a 
urna não parece constituir um corpo, ou envoltório, para potencializar as almas dos humanos depois de mortas, assim como as urnas do grupo $1 .$.

Uma outra diferença, que é uma decorrência desta primeira, está na independência que parece haver entre os diferentes campos decorativos formados pela borda e o bojo. O desalinhamento da simetria entre o grafismo do pescoço e o do bojo (conforme se percebe na figura acima), indica que um não compõe o todo junto com o outro, ou um não faz parte do outro. Assim, o efeito de engajamento do olhar nos "olhos" da urna, fica aqui dividido entre um contato com os olhos que estão no pescoço, e um outro rosto composto pelo grafismo do bojo. Assim, não há um "esqueleto" estrutural, com alguns elementos localizados variáveis, mas apenas divisões recorrentes, onde se inserem elementos variáveis de um mesmo repertório finito, assim como, os outros objetos decorados marajoara.

Concluímos, de que apesar destas urnas representarem uma versão estilizada, ou mesmo miniaturizada das urnas do grupos 1, elas não parecem ter a mesma função ritual, de "sacralização das almas", conforme sugerido acima, guardando apenas sua característica emblemática, de referente de identidades grupais ou sociais específicas.

Contudo, um exemplar de urna da coleção Barbier Mueller (Barcelona), nos faz indagar, se as urnas aqui agrupadas, não seriam uma versão menor e simplificada de um outro tipo de urna com as mesmas características do grupo 1 (figura 5.22).

Nesta peça, que parece uma versão "monumentalizada" das urnas do grupo 2, percebemos que alguns elementos em relevo da figura formada no pescoço da urna se estendem pelo bojo, indicando assim o restante do corpo pertencente ao rosto acima. São membros que descem pelas laterais do bojo terminando em patas ou garras com três dígitos. Nas linhas "laterais", de junção das duas faces refletidas da urna, dois grandes apêndices globulares em forma de cabeça animal, que em muito lembram os volumes das urnas Paredão. Não fica claro, no entanto, se os membros com os tridígitos não poderiam pertencer a estas figuras laterais. 

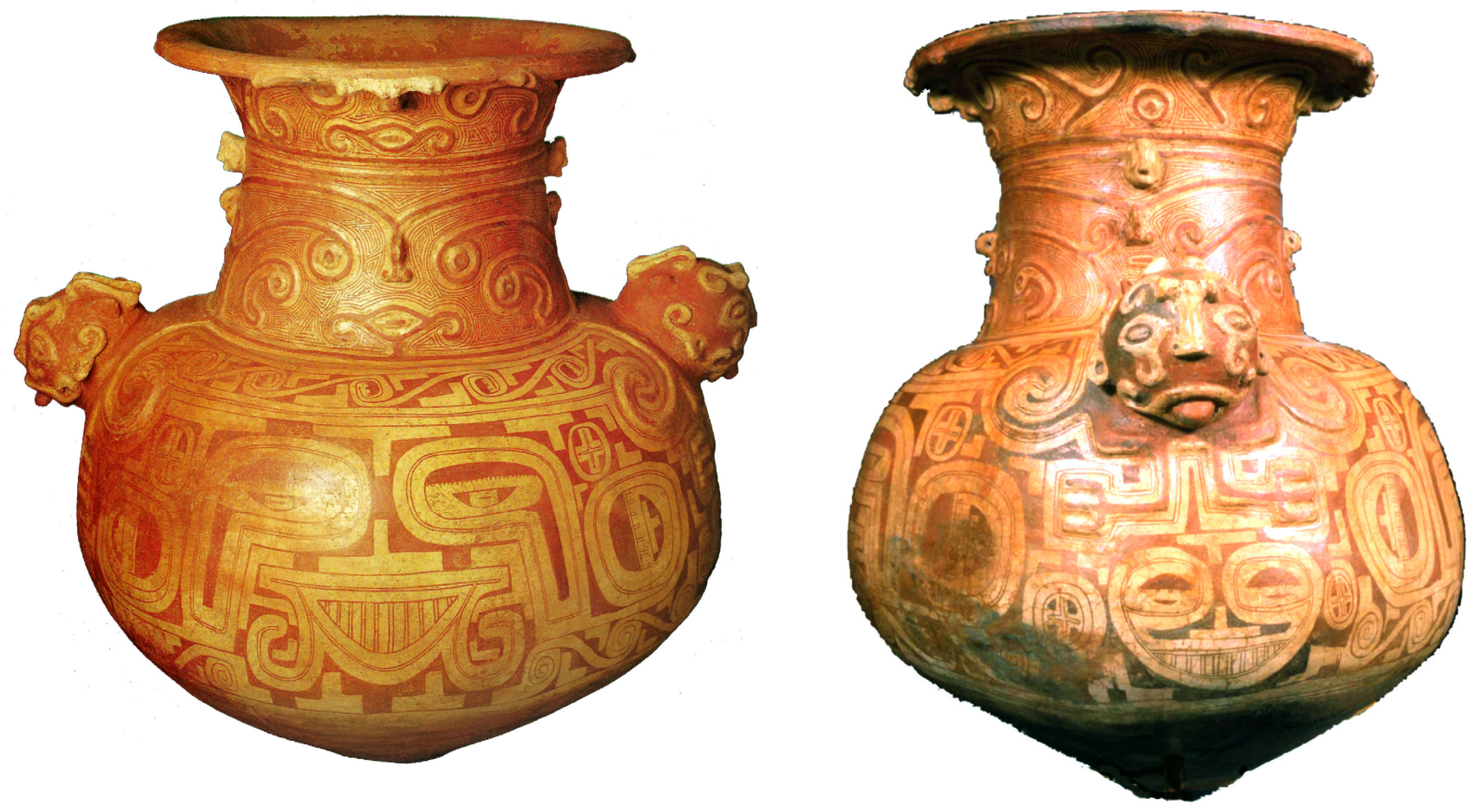

Figura 5.22

Urna da coleção do Museu de Arte Pré-colombiana Barbier Mueller, (altura: $91 \mathrm{~cm}$ )

Outra urna semelhante, sem os apêndices laterais, da coleção do University Museum (Pennsylvania) está documentada em Palmatary (1950:pr.96b), o que nos leva a pensar em uma variabilidade maior, talvez relacionada à distribuição cronológica das urnas ao longo dos 500 anos da fase marajoara, onde alguns tipos de urnas, a partir de um modelo original, passaram por processos de perda ou de estilização de elementos mais elaborados, ou, ao contrário, por momentos de incorporação destes elementos, por emulação de outros estilos externos. 


\section{As urnas do GRUPO 3}

Estas também ocorrem em duas versões: maiores e com bojos mais globulares, e menores e mais tubulares. Sua principal característica é o longo pescoço cilíndrico com decoração incisa

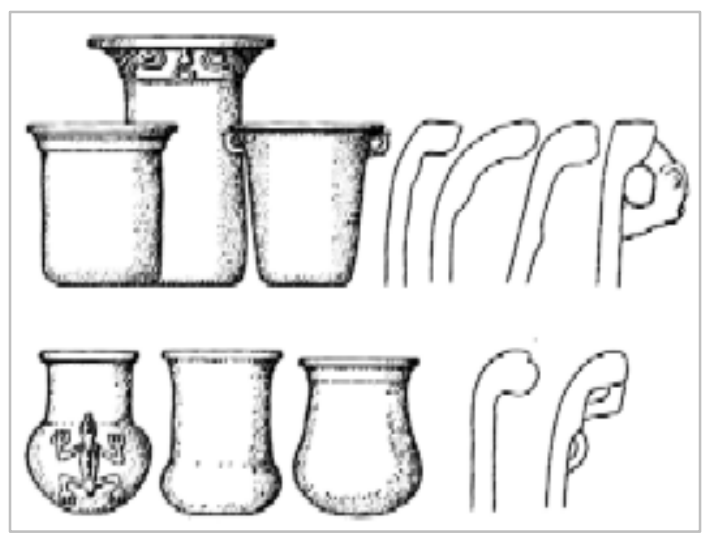
e excisa, onde apliques em geral reproduzem duas figuras distintas, simetricamente refletidas nos quatro lados da urna. A figura de um animal réptil, com os quatro membros abertos e tridígitos, interpretada por Schaan como um jacaré ou lagarto (Schaan, 1997:148); e outra figura, de difícil associação a qualquer animal, com um rosto quadrado, com membros e antenas irradiando deste quadrado.

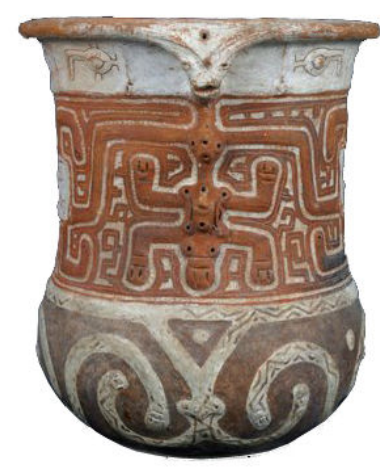

a

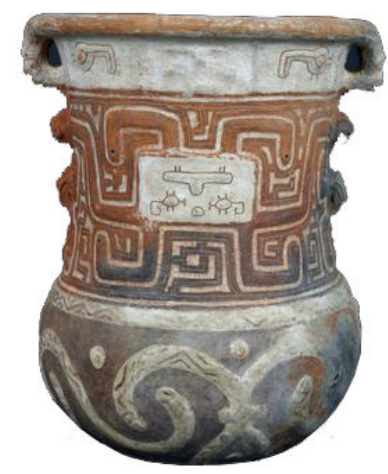

b

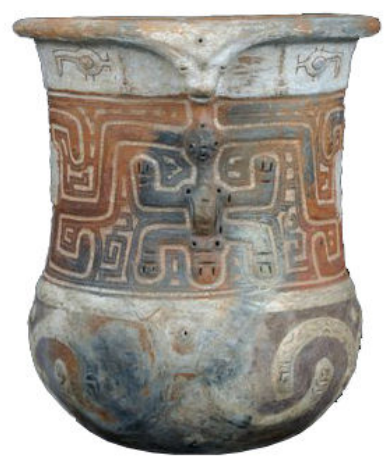

C

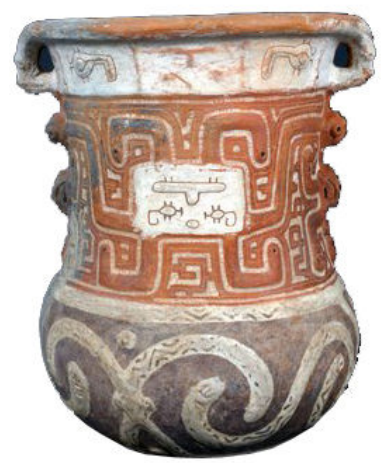

d

Figura 5.23

Urna ICBS-MAE 1620 (altura: $38 \mathrm{~cm}$ )

Esta combinação de fundo inciso-exciso com apliques destas duas formas podem aparecer de varias maneiras, isoladamente ou junto com outros tipos de decoração de três maneiras:

1) ocupando toda a extensão das paredes, da borda, até base (como na peça 1621); 
2) combinada com uma borda pintada com incisões, formando um rosto (peça 1628);

3) com borda e bojo pintados e incisos, sempre com motivos de cobras entrelaçadas na parte inferior, (como a peça 1620 acima).

Estas combinações possíveis deixam claro como a divisão tripartite da urna, entre borda, pescoço, e bojo, definem campos independentes para motivos que podem ou não estar combinados. Cada motivo, por sua vez é sempre executado na mesma técnica e sempre ocupa um mesmo campo nesta divisão. Os rostos pintados e incisos sempre nas bordas, os lagartos sobre decoração incisa-excisa sempre no pescoço, e as espirais duplas, ou cobras, pintadas sempre na base.

Outras urnas com esta combinação de técnica e apliques estão documentadas em Palmatary (1950: pr. 53, 54, 57, 75 a, 60 e 61), mas com formas mais globulares. Meggers e Evans (1957:118) descrevem este tipo de urnas como Arari Vermelho Exciso-inciso com duplo engobo, nas formas 6, 7, e 8.e pranchas 60 a 63).

Os modelos maiores exibem as mesmas características de combinações possíveis, como ilustrado nas urnas do Museu Nacional (UFRJ) e Barbier Mueller abaixo.
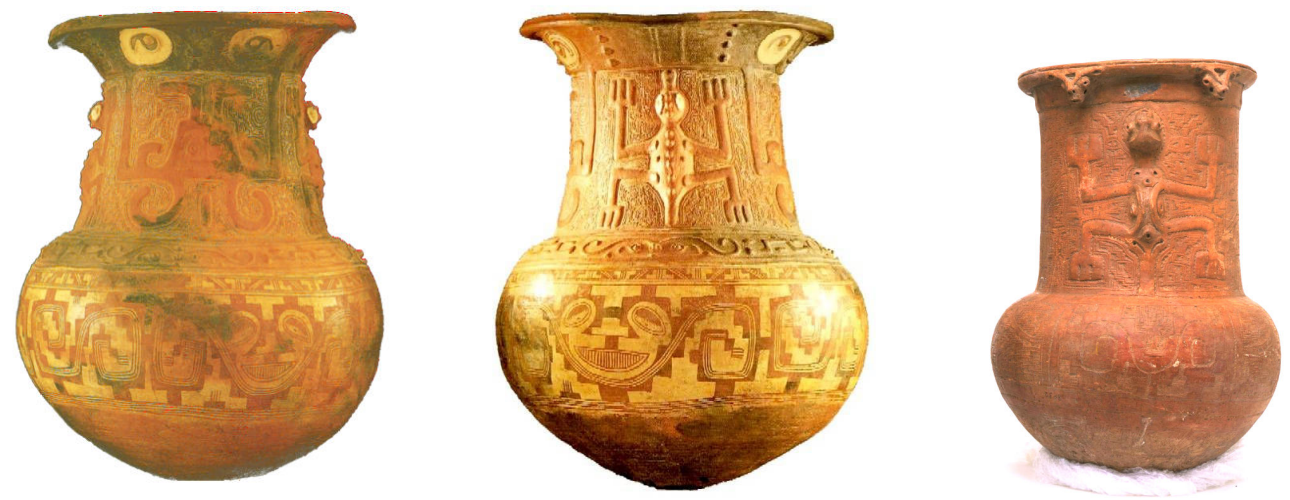

a

b

Figura 5.24

a) Urna da coleção Barbier-Mueller (altura: $100 \mathrm{~cm}$ )

b) Urna do acervo do Museu Nacional da UFRJ (altura aprox.: $80 \mathrm{~cm}$ ) 
Em outro exemplar da coleção Barbier Mueller (figura 5.24 acima), as espirais duplas, ou cobras entrelaçadas do bojo foram combinadas com o rosto sorridente das urnas do grupo 3, demonstrando assim que os motivos se combinam por compartilhar a mesma posição dentro da divisão tripartite vertical da urna.

Alguns exemplares de outras coleções apresentam uma distorção proposital na forma geral da urna, criando um pescoço exageradamente longo, o que confirma a idéia de que esta porção tubular da urna tem uma importância simbólica em si.

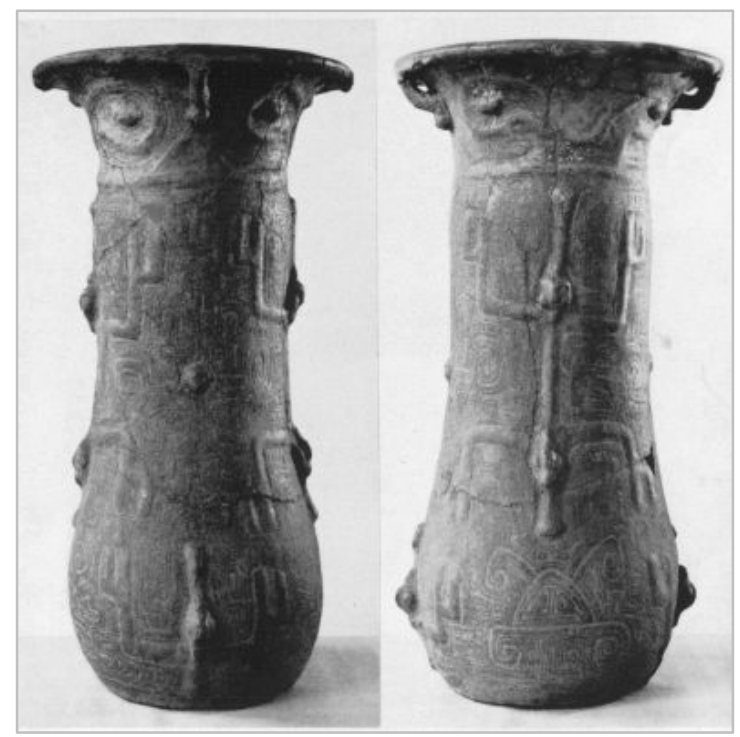

\section{Figura 5.25}

Urna documentada em Palmatary 1950:407 (Rio Camutins, altura: 59cm.) Acervo University Museum (Pennsylvania).

Em resumo, para as urnas dos grupos 2 e 3, percebemos que não são urnas propriamente antropomorfas, constituindo um corpo, com vabeça e membros, mas que o princípio estrutural, que se repete em todas elas, é a divisão em secções horizontais que correspondem às superfícies com diferentes curvaturas da urna: borda, pescoço e bojo. São estes campos que organizam a combinação de técnicas e motivos, a partir de repertórios limitados, e regras rígidas de localização: espirais, cobras, rostos sorridentes pintados, em baixo; lagartos e entidade com antenas, aplicados sobre superfície excisa-incisa, no meio; e olhos ou rostos genéricos, pintados e incisos, em cima. A variabilidade 
se dá na dimensão das peças, e no número de motivos reconhecíveis combinados, sendo comum que, as que apresentam um maior número de motivos combinados, estejam entre as maiores.

Os três campos decorativos assim definidos apresentam também uma ordem de recorrência, estando em primeiro lugar, os olhos nas bordas, quase sempre presentes, enquanto os outros, em outros campos, são mais variáveis. Este princípio de variabilidade diferenciada por campo decorativo está presente em outros artefatos da fase Marajoara, sendo mais facilmente reconhecível nas tangas decoradas. Nestas, uma faixa superior apresenta um motivo em triângulos e retângulos sempre recorrente; abaixo desta, uma segunda faixa apresenta uma variação entre três ou quatro motivos recorrentes, enquanto 0 campo triangular formado pelo restante da tanga, apresenta sempre motivos únicos, apesar de formados por elementos gráficos semelhantes.
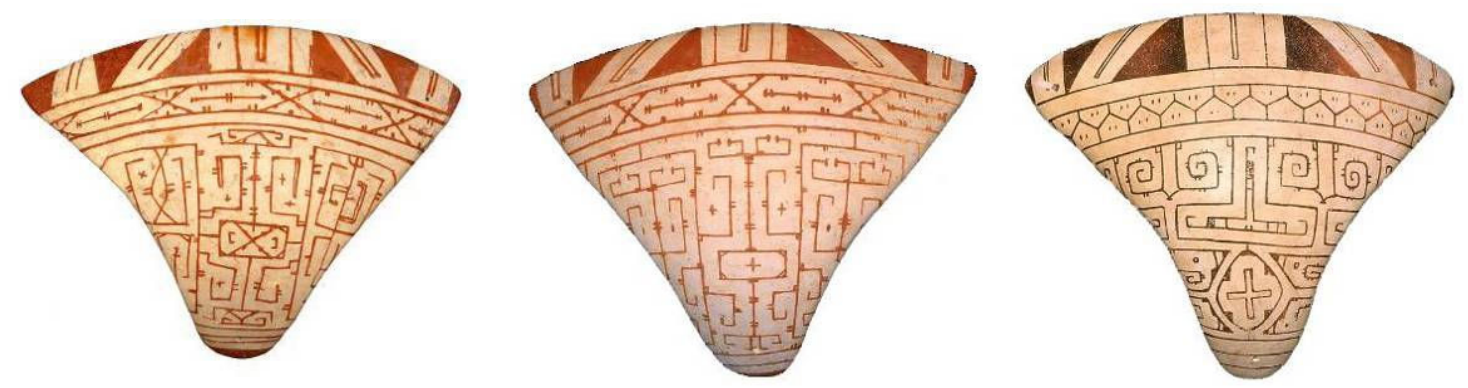

Figura 5.26

Tangas cerâmicas decoradas

ICBS-MAE (altura 13cm; larguras: de 12 a $14,5 \mathrm{~cm}$ )

Esta hierarquização na variabilidade dos campos ou faixas delimitadas ocorre de maneira semelhante nas urnas. Assim, se é verdade que os motivos deste repertório têm uma função emblemática, de identificar facções da elite local (como propôs Schaan), ou mais genericamente como aqui colocado, simplesmente identificando pertencimento a determinados grupos sociais, a maneira ordenada destes elementos, obedecendo a regras rígidas de combinação e exclusividade, indicam que se está lidando com a representação de identidades múltiplas, algumas excludentes entre si, e outras, possivelmente 
cumulativas. Se os diferentes motivos são indicadores de gênero, idade, aldeia de origem, clãs, linhagens, grupos corporativos, ou insígnias de status e prestígio, é difícil especificar, mas o fato de que eles estão combinados em diferentes graus de recorrência e exclusividade é compatível com modelos de composição multi-étnica de sociedades "misturadas", como o estilo identificado por Vidal (1999) entre os índios do norte do Amapá, ou de sociedades com um passado marcado por complexos processos de fusão étnica, como identificado na cerâmica Galibi por Collomb no litoral das Guianas (Collomb, 2000).

Enfim, o que nos parece mais provável, é que este estilo de "mistura controlada" seja o resultado de um intenso fluxo de "marcas", quer localizado em Marajó, quer aberto a outras redes regionais. Poderia se pensar ainda em um intenso processo de rivalidade entre diferentes grupos, com constante apropriação e emulação de estilos, mas dentro de regras minimamente convencionais, para garantir sua reconhecibilidade.

\section{As urnas do GRUPO 4}

As urnas do grupo 4, são raras na coleção ICBS. Correspondem ao que Meggers e Evans classificaram como o tipo Pacoval Inciso nas suas formas 8, 9 e 11

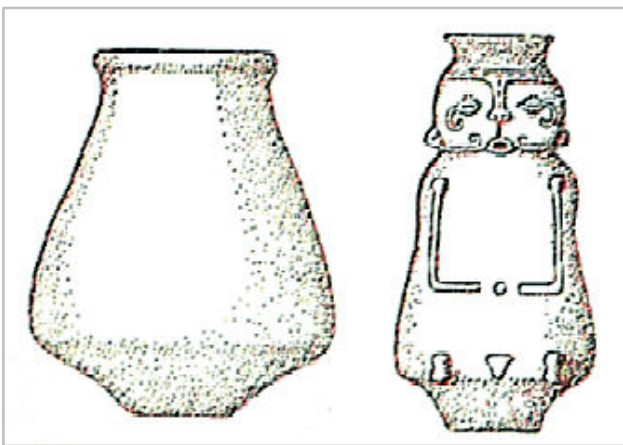
(Meggers e Evans, 1957:368 e pr.78). Estão documentadas também em Palmatary (1950: pranchas19e, 22 b,22c,22d, 23c,23d,23f; 29, 30 a, 33 e 34).

Figura 5.27

Urnas Pacoval Inciso documentada em Palmatary, 1950 (391-392). (altura da urna antropomorfa: $77 \mathrm{~cm}$ ).
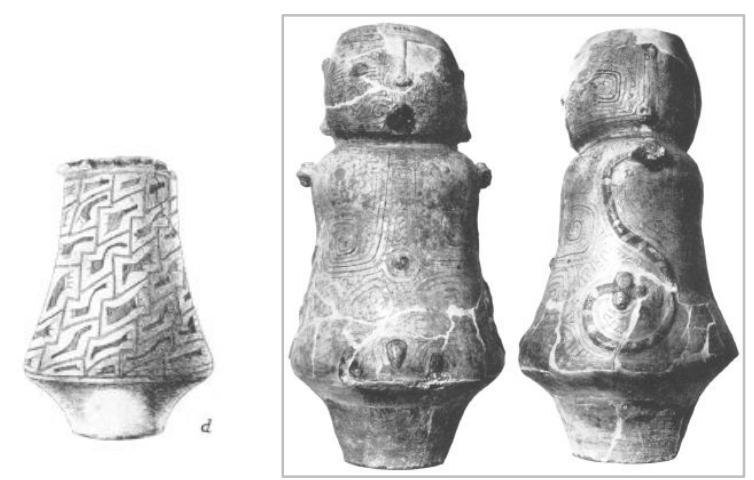
Estas urnas ocorrem em duas formas básicas. Uma é a das urnas ilustradas acima, com base conoidal truncada. Esta forma, com a base conoidal, só ocorre exclusivamente associada ao tipo de decoração finamente incisa, às vezes com linhas duplas paralelas e reticuladas, com pintura vermelha sobre as incisões. Apresentam toda a superfície externa recoberta por um padrão geométrico, com formas em $\mathrm{Z}$ ou $\mathrm{S}$ encadeadas, também comum em outros recipientes. Nesta forma, algumas urnas são modeladas constituindo um corpo humano, com constrição na altura do pescoço e cabeça modelada. Quando antropomorfizadas, as incisões compõem detalhes do corpo, com um par de grandes espirais no bojo indicando as pernas, e uma série de formas concêntricas em torno de botões aplicados que formam umbigo, mamilos, e outros apliques que compõem olhos, boca, nariz e sobrancelhas em forma de T ou $V$, no rosto, além dos membros e genitais, no bojo. Nem sempre há sinalização do genital, mas quando há, parece corresponder sempre ao sexo feminino (ou um triângulo púbico ou retângulo com fenda), mas alguns exemplares exibem apenas uma saliência circular, da mesma maneira que mamilos e umbigos são representados. Por vezes pernas são indicadas por elementos em relevo, sobressaindo-se do bojo próximo à base.

Estas urnas verdadeiramente antropomorfas se assemelham muito às formas plásticas encontradas nas urnas Guarita, com apliques laterais em forma de cobra indicando os braços, e os pés elevados como se o indivíduo estivesse sentado, com as pernas dobradas, e os pés acima da base.

Uma outra forma, com o corpo mais tubular e a base mais arredondada, também é construída à imagem de um corpo humano, podendo também apresentar um topo com cabeça, ou ser mais curta, provavelmente levando uma tampa em forma de cabeça.

Nenhuma das características que compõem o corpo humano emula membros ou outras partes de animais, mas são comuns os apliques em forma de cobra ou cabeça de ave nas laterais, formando braços, e os olhos serem compostos a partir de incisões em forma de escorpião. A figura humana não apresenta grande variabilidade nos seus traços humanos, apenas na forma 
geral da urna e dimensões (os exemplares inteiros com dimensões registradas variam entre 77 e $22 \mathrm{~cm}$ de altura).

A figura humana assim constituída perece ser sempre a mesma e na mesma posição corporal. Apenas um exemplar conhecido apresenta esta figura com braços destacados e as duas mãos sobrepostas sobre a boca (exemplar do acervo do American Museum of Natural History, Palmatary: Pr.27a, Roosevelt 1990:352, fig. A). A forma da cabeça, mais quadrangular, com ênfase nos lóbulos perfurados das orelhas, e a posição das mãos sobre a boca, é bastante característica das estatuetas antropomorfas tapajônicas e das pequenas figuras humanas modeladas em cariátides. Distinguem-se assim das estatuetas marajoara, as quais apesar de comporem corpos com traços humanos bem reconhecíveis, apresentam cabeças em formas mais arredondadas e fálicas.

A maneira de se compor a forma humana remete assim a várias características de outras urnas antropomorfas amazônicas. Magalis observou semelhanças estilísticas tanto com a cerâmica tapajônica como com alguns elementos das urnas Maracá (Magalis, 1975:262), além daqueles por nós observados que remetem às urnas Guarita, como a forma geral da base e as cobras laterais formando braços.

O mais interessante nestas urnas, é que quando em seu modo antropomórfico, alguns exemplares são construídos como estátuas (são as efígies às quais se refere Roosevelt, 1991:53), com frente e costas, sem a tradicional reflexão ou desdobramento em duas frentes, tão característicos do estilo marajoara. Os exemplares da coleção ICBS-MAE são assim construídos. Quando vistas de perfil, percebe-se uma marcada assimetria no seu bojo, formando uma barriga com umbigo. 

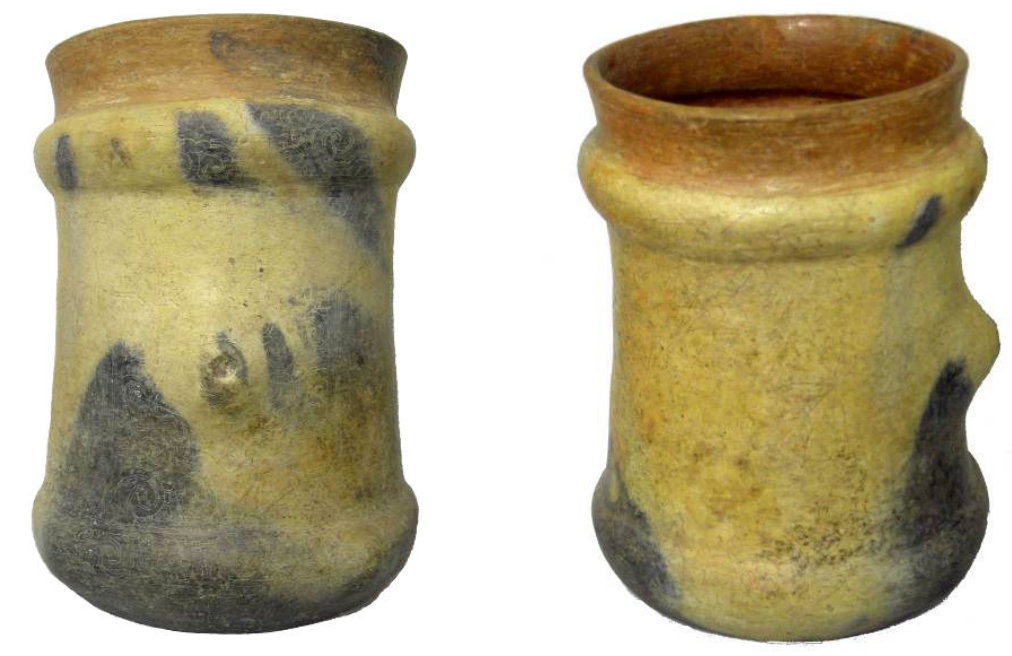

Figura 5.28

Urna com "barriga e umbigo"

ICBS-MAE 0760 (altura: $36 \mathrm{~cm}$; diâmetro da borda: $24 \mathrm{~cm}$ )
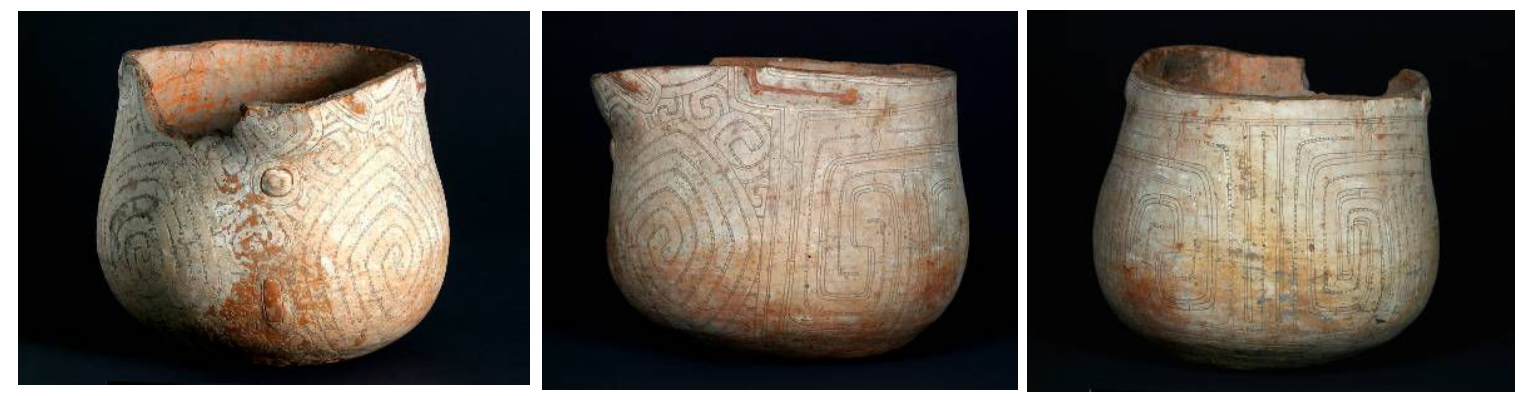

Figura 5.29:

Urna ICBS-MAE 326; altura (fragmentada):18cm; profundidade: $23 \mathrm{~cm}$, largura: $19 \mathrm{~cm}$

Outros exemplares destas urnas "Pacoval", tanto documentados por Schaan (2007:82) e observados por nós nas coleções do Museu Paraense Emílio Goeldi e do Etnologishes Museum de Berlim (McEwan et al. 2000: 121,122) apresentam, no entanto, o tradicional desdobramento em duas "frentes". Neste caso, a junção destas frentes não parece formar outra figura, constituindo um caso "mal resolvido" de representação desdobrada. 

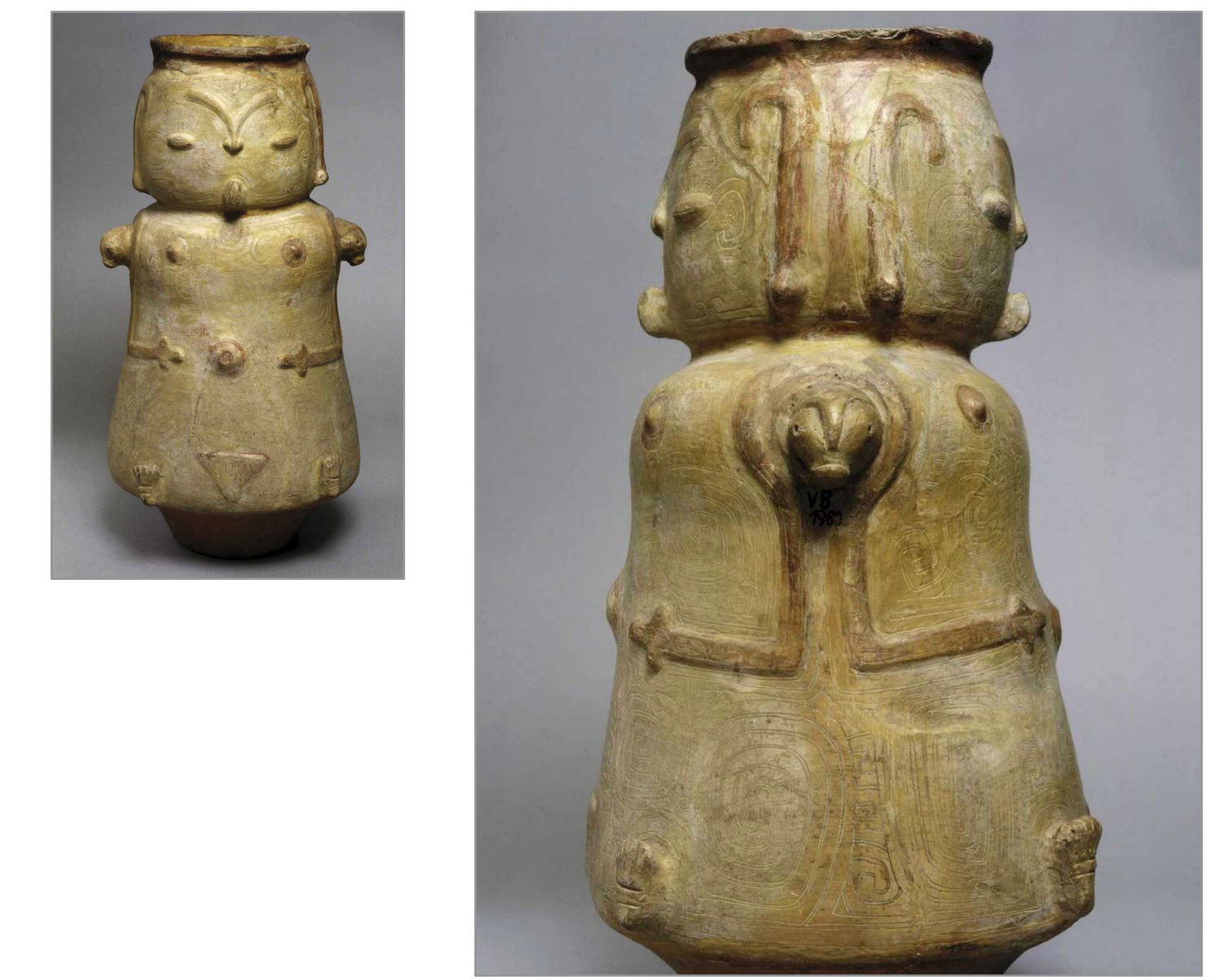

Figura 5:30

Urna "Pacoval Inciso" do acervo do Museu Etnológico de Berlim (altura $65 \mathrm{~cm}$; largura: $33 \mathrm{~cm}$ )

A cerâmica do estilo "Pacoval" foi considerada por Meggers uma das variantes mais antigas da fase Marajoara (Meggers e Evans, 1957: 370), enquanto que a seriação dos elementos estilísticos efetuada por Magalis (1975) coloca-o na outra extremidade cronológica da fase. Isto talvez se deva a uma regionalização deste sub-estilo dentro da ilha, mais comum nos sítios próximos ao lago Arari, sobretudo sob a forma de urnas funerárias. Nos sítios do rio Anajás, este estilo é muito raro, ou virtualmente ausente. Assim, a discordância quanto à cronologia deste estilo se deve mais ao fato de Meggers considerar os sítios em área de savana, próximos do lago Arari, os mais antigos, e não propriamente à interpretação das seqüencias estilísticas.

As datações indicam que sítios nestas duas áreas foram contemporâneos por ao menos 600 anos, e é com base nestas evidências que Schaan argumenta que as especificidades estilísticas estariam denotando identidades 
sociopolíticas e limites territoriais locais, em vez de diferenças temporais (2007:83). Contudo, não há datações absolutas para este tipo de urna em específico.

Mesmo que os vários estilos de urnas tenham sido de fato contemporâneos, é preciso reconhecer que, mesmo regionalizados, eles não permanecem estanques e são passíveis de emulação e transformação. A transformação de um modelo de urna, que replica de uma forma mais "amazônica" os corpos humanos, com frente e costas, como no estilo que parece ser característico aos sítios do lago Arari, em um outro modelo com uma figura mais estilizada e desdobrada em duas frentes, à maneira dos sítios de Monte Carmelo e Os Camutins, pode ser identificada como uma "adaptação local" de um estilo externo. Infelizmente, desconhecemos a proveniência dos exemplares das urnas desdobradas do estilo Pacoval e, por isso, é impossível precisar se, neste caso, o princípio tão arraigado na cerâmica marajoara da representação desdobrada estaria sendo abandonado em detrimento da emulação de um estilo "estrangeiro", que reproduz os corpos humanos sem desdobrá-los, ou se ao contrário, este estilo mais realista de representação estaria sendo executado de uma forma adaptada aos princípios da cerâmica cerimonial marajoara.

As semelhanças deste estilo de urna em particular com outras externas a Marajó, juntamente com as implicações postuladas no capítulo anterior sobre os diferentes modelos de urna e suas associações a determinadas etnias e padrões de organização social, nos faz pensar que as transformações estilísticas estivessem ocorrendo em Marajó, não só em decorrência de rivalidades internas (como defende Schaan), mas estivessem sendo provocadas principalmente por grandes mudanças nas redes de interação regional ao longo da bacia Amazônia, na qual, a sociedade marajoara se colocava em posição geograficamente vantajosa.

Isto talvez explique as múltiplas tentativas de correlações que já foram avançadas pelos diferentes estudiosos da cerâmica marajoara a estilos externos a Marajó e nos indique que a chave para entendermos os princípios de percepção marajoara pode estar na tensão entre uma linguagem pan- 
amazônica que possibilita o fluxo de estilos ao longo de toda a bacia amazônica e a forma como são reconhecidos, emulados, transformados e conformados às suas próprias formas de afirmação de identidades locais pelas sociedades da ilha.

Mudanças na adoção de um ou outro modelo de urna funerária (provavelmente de maneira bem mais gradual e menos polarizada como aqui colocamos), em Marajó, como no restante da Amazônia, podem ter sido provocadas pelas mudanças identificadas por Neves para o início do segundo milênio de nossa era, de alguma forma relacionada à expansão de populações de fala Tupi e da própria cerâmica policroma, ao aumento de deslocamentos territoriais e interações belicosas, e ao aparecimento, por volta de 1400 d.C. de sociedades mutli-étnicas (Hornborg, 2005; e Whitehead, 1994), semelhantes às que se preservaram no noroeste amazônico e no alto Xingu (Neves, 2008).

Em conclusão, o estilo marajoara de fabricar suas cerâmicas, sepultar seus mortos, e reafirmar suas tradições ancestrais, pode ter sido abalado pelo contato ou confronto com sociedades cujos princípios ideológicos de transferência de autoridade e legitimação de poder fossem fundamentalmente distintos, embasados em outros valores espirituais, diante dos quais as tecnologias perderiam seus "encantamentos" e os rituais perderiam seus "ídolos ancestrais", e seus meios místicos de reprodução social se tornariam inoperantes.

\section{Síntese dos resultados da análise das urnas}

A análise das urnas apresentada neste capítulo primeiramente identificou uma variabilidade nos princípios de composição estrutural das urnas de forma a agrupá-las em quatro conjuntos distintos. Vista a proveniência da coleção (com uma maioria de peças proveniente da região do alto Anajás é possível que a maior quantidade de urnas do grupo 1 reflita a regionalização estilística deste grupo, em geral identificado como sub-estilo, ou tipo, Joanes Pintado. 
Este grupo de urnas apresentou um conjunto de princípios estilísticos de construção e decoração muito recorrentes, executados de forma mais completa nas urnas de maior dimensão:

a) a replicação de uma mesma concepção corporal em torno de características zoo/antropomorfas, com ênfase em órgão sensoriais (olhos, boca, mamilos, etc.) de um personagem sobrehumano;

b) recursos estilísticos direcionados para a animação e idolatria de imagens;

c) recursos estilísticos que conferem magia aos objetos;

d) recursos estilísticos que sintetizam a estrutura e conceito geral do objeto em apenas parte do objeto;

e) o uso variável de motivos e desenhos a partir de um repertório finito, provavelmente usados como emblemas.

Estes elementos combinados nos fizeram alinhar estas urnas dentro do modelo A proposto no capítulo III, isto é, urnas cuja agência é assegurar a continuidade da perspectiva humana para o mundo pós-morte, através da associação dos restos mortais do indivíduo com o corpo de um personagem ancestral. De acordo com o esquema proposto, esta concepção de urna seria adotada por sociedades entre as quais os funerais são celebrados em grandes rituais, com foco visual em objetos-ídolos que representam tanto a identidade cultural da comunidade como celebra e atualiza as hierarquias sociais internas.

Outras urnas da coleção (grupos 2 e 3) não apresentam os mesmos princípios de concepção e função ritual, mas retêm suas qualidades de suporte para a veiculação de símbolos ou emblemas, combinados em regras estilísticas bem específicas. Provavelmente serviam como objetos para associar e identificar o pertencimento de indivíduos a diferentes grupos sociais, provavelmente relacionados a narrativas míticas.

Finalmente, as urnas do grupo 4 parecem constituir um modelo de urna antropomórfica funerária mais comum em outras áreas da Amazônia, como as urnas da sub-tradição Guarita da Amazônia central. A sua presença em duas versões, uma mais "amazônica", representando o corpo de forma mais naturalística; e outra mais "marajoara", representando o corpo desdobrado, 
revela o fluxo de informação entre a sociedade marajoara e outras áreas da Amazônia, e ilustra uma maneira de emular e adaptar concepções externas de urna funerária ao estilo marajoara local.

Em síntese, identificamos alguns elementos de uma estética funerária particular a qual, acreditamos, é consistente com uma visão cosmológica amazônica tradicional no âmbito geral, mas é conflitante com alguns modelos que enfatizam a efemeridade dos objetos rituais e o despojamento e a simplicidade com que as sociedades indígenas amazônicas atuais se desfazem de seus mortos. Esta estética particular, faz transparecer uma sociedade extremamente preocupada em se manter conectada com seus ancestrais, e dedicada a uma constante produção de sínteses de reatualização de seus mitos, com óbvia intenção estabilizadora de uma tradição particular. Na criação de elementos mediadores entre os vivos e os mortos, a arte parece refletir uma complexa ciência no controle de veiculação, emulação e apropriação de símbolos internos e externos, talvez compensatória dos contextos regionais instáveis na qual a sociedade marajoara se inseria, como atestam as reconstruções das seqüências histórico-culturais do restante da Amazônia a partir do segundo milênio de nossa era. 


\section{O N C L U S ÃO}

Em arqueologia, categorias e tipologias são instrumentos de análise que visam, em última instância, reconstituir contextos históricos e suas dinâmicas de transformação a longo prazo. Neste sentido, as tipologias cerâmicas avançadas na arqueologia amazônica, resultando em fases, tradições, e complexos cerâmicos vêm possibilitando a reconstrução de seqüencias histórico-culturais pré-coloniais de forma bastante operacional. O que não está clara, é a relação entre estas categorias e as divisões etno-lingüísticas das populações amazônicas, conhecidas desde a colonização, o que nos remete a um problema clássico da arqueologia que é o da correspondência entre variabilidade cerâmica e a etnicidade, ou identidade cultural (Arnold, 1988; Jones, 1997).

O estudo estilístico da cerâmica, assim como o exercício exploratório aqui desenvolvido, são uma tentativa de abordarmos aquilo que Lévi-Strauss chamou dos modelos mentais que as sociedades fazem de si mesmas, isto é, de aproximar as categorias arqueológicas às categoria êmicas das sociedades estudadas. A linguagem, os mitos e a arte são um terreno fértil para tal, mas um terreno nem sempre observável para o arqueólogo.

No caso da Amazônia, o perspectivismo ameríndio, com seu foco na corporalidade e na visão (ou na maneira como os indivíduos vêem os outros e a si mesmos) como elementos definidores da sociabilidade pode ser a chave decodificadora entre o registro arqueológico observável, e os princípios que regem as categorias êmicas ameríndias, além de permitir lidar com uma certa gama já conhecida de variabilidade dos princípios perspectivistas entre as diferentes sociedades amazônicas e as identidade étnicas que representam.

O risco que se incorre, é sempre o de projetar uma interpretação sobre princípios observados no presente em sociedades do passado que possam ter sido fundamentalmente diferentes. Por isso, deve-se evitar a literalidade e a equivalência formal. Aqui procuramos utilizar o perspectivismo mais como fonte de inspiração para se formular um modelo de correspondência entre estilos de cerâmica funerária e estilos de sociabilidade, o qual, como qualquer modelo, é 
formulado em termos idealizados e cuja eficácia explanatória precisa ser verificada com casos concretos bem documentados.

No caso da cerâmica funerária marajoara, o perspectivismo permite entender particularmente bem as formas de representação de corpos, humanos e animais, a tensão sempre presente nestas sociedades ameríndias quanto à instabilidade destas formas, e o que a morte e a relação com os mortos significa em relação a esta instabilidade. As urnas funerárias, em suas formas humanas, animais ou híbridas podem assim ser vistas, de modo geral, como uma tentativa de assegurar após a morte a retenção de perspectivas e capacidades particulares através destes corpos. Contudo, se as concepções de morte variam de acordo com o tipo de sociedade, isto é, se para uns morrer é se transformar em animal, perdendo a identidade humana, enquanto para outros o importante é buscar a continuidade humana, ou ainda a transformação sobrehumana, o que deveríamos esperar de sociedades em transformação?

Concluímos, que no caso marajoara e sua cerâmica funerária, ao apresentar um estilo extremamente formalizado, com regras e repertórios bem definidos, sobretudo naquilo que Roe identifica como os elementos que transformam um estilo em uma tradição, estamos lidando com uma sociedade empenhada na produção de uma estabilidade no plano simbólico material e visual, através da sua cerâmica, que é bastante consistente por ao menos 600 anos. Além disso, na cerâmica funerária, identificamos urnas que cumprem funções rituais mais próximas de personagens-ídolo típicos de sociedades com xamanismo "vertical" ou das chefaturas teocráticas, do que das instáveis sociedades descritas atualmente pelos etnólogos da Amazônia.

De certa forma, isto é compatível com registros arqueológicos em outras partes da Amazônia de sociedades pré-coloniais com grande capacidade de mobilização social, sobretudo em termos de intervenções na paisagem tais quais as estruturas defensivas e estradas do alto Xingu, os aterros artificiais na Bolívia, as construções megalíticas do Amapá, e os geoglifos do Acre, que indicam a existência no passado de sociedades bem mais complexas e estáveis em termos de estruturas de poder e autoridade. 
Contudo, a fase Marajoara, também com seus aterros, se destaca do restante, pelo grau e natureza de sua complexidade cerâmica, a qual, acreditamos que se deva, ao menos em parte, à sua posição geográfica privilegiada para a participação em múltiplas redes de interação regional, absorvendo e "digerindo" uma ampla gama elementos estilísticos.

O desaparecimento da sociedade marajoara e sua bela cerâmica, poderia se explicar pelo processo denominado por Peter Roe de "mediadisplacement", isto é o processo observado entre sociedades que, ao se tornarem mais complexas, sua cerâmica, e objetos de representação pessoal (adereços) passam a se tornar inadequados para carregar mensagens de prestígio e poder. Ao invés disso, são substituídos por outros meios que não mais dependem de rituais promovidos por indivíduos face a face, mas através de uma relação mais indireta com os símbolos de poder, como, por exemplo, a arquitetura monumental. Roe identifica pelo menos dois casos de "deslocamento de mídia" bem documentados arqueologicamente: o caso da decadência de artefatos em metal entre os Incas (que ficam menos elaborados à medida que a arquitetura monumental aumenta); e também o caso dos cacicados Taïnos em Porto Rico, onde há transferência da cerâmica elaborada para monumentos esculpidos e gravados em pedra (1995:56).

São casos que deixam de ser "sociedades de máscara" nos termos de Lévi-Strauss, para se tornarem as "chefaturas teocráticas" de Sahlins, onde os xamãs "verticais" ou sacerdotes não mais encarnam os espíritos ou as divindades em si, mas se tornam agenciadores dos grandes rituais dedicados a estas entidades. É o processo a que Viveiros de Castro descreve como "o fim da bricolagem cosmológica do xamã, e o começo da engenharia teológica do sacerdote" (2008:22).

A caracterização estilística das urnas funerárias aqui apresentada é compatível com uma sociedade em transição nesta direção, isto é, para uma sociedade mais complexa, onde a cerâmica parece se configurar como uma mídia importante, o que é confirmado pela tese de Schaan de que há um intenso uso social da cerâmica, na produção de objetos rituais e para festas e cerimônias, associado às atividades produtivas de manejo hidráulico e de pesca 
intensiva, durante um período que se estende entre 700 e 1100 d.C. (Schaan, 2004) A partir de 1100 d.C. , apesar do estilo marajoara continuar a ser replicado por populações locais da ilha, a diminuição no fabrico da cerâmica cerimonial e a cessação dos aterros, marcam o início da decadência da fase marajoara. Não parece haver aqui, um abandono da cerâmica em detrimento da construção de aterros, mas ao contrário, uma concomitância bastante consistente, mas é uma relação que mereceria ser verificada através de um estudo mais detalhado da cronologia destes desenvolvimentos. Por ora, parece certo que a decadência da cerâmica demarca uma mudança estrutural nas bases da sociedade marajoara, revertendo de alguma forma a tendência que a aproximou ao modelo de chefaturas teocráticas. Talvez, isso se deva ao que Viveiros de Castro chamou de exopraxis do xamanismo, um "resíduo que bloqueia a constituição de chefaturas ou Estados dotados de uma interioridade metafísica acabada", e que, na Amazônia, permanece sempre operativo mesmo entre as sociedades mais hierárquicas. Segundo ele, este resíduo está na prática de um xamanismo voltado para o exterior, isto é:

"para o exterior do socius, que não está isenta de agressividade e de ambigüidade moral; seus interlocutores por excelência são os espíritos animais causadores de doenças (as quais são frequentemente concebidas como casos de vingança canibal por parte dos animais consumidos). Se alguém pode nascer aristocrata, ninguém morre imediatamente ancestral; não há puros ancestrais exceto no tempo pré-cosmológico e pré-corporal do mito - mas ali humanos e animais se comunicavam diretamente" (Viveiros de Castro, 2008:19).

É possível que este resíduo tivesse sido reavivado por mudanças e rearranjos no contexto regional da Amazônia causadas pela expansão de povos entre os quais tais princípios estivessem mais latentes, e que a exopraxis belicosa e canibal de povos proto-tupi vieram minar as bases ideológicas e rituais da sociedade marajoara, das quais a cerâmica, e em particular a cerâmica funerária, teria sido o principal agente estabilizador.

Seria esta a dinâmica dos ciclos alternados de centralização política identificados por Neves na ocupação da várzea amazônica a partir do segundo milênio d. C.?

Por mais que ainda que não saibamos exatamente quais são os processos étnicos e políticos por trás da expansão da Tradição Polícroma pela 
área da bacia amazônica, com uma distribuição tão vasta que vai do baixo Amazonas até praticamente o sopé dos Andes na Colômbia, Equador e Peru, existe uma dicotomia na cerâmica ainda muito pouco explorada pelos arqueólogos, por falta mesmo de estudos comparativos entre as diferentes áreas, que é o surgimento de uma linguagem cerâmica pan-amazônica, que integra técnicas e estilos locais em uma linguagem única, mas que, ao longo do tempo, mantém e aprofunda variações locais. O estudo comparativo da cerâmica funerária, assim como de outros objetos rituais e seus contextos podem assim identificar melhor esta dinâmica, no sentido de isolar características históricas e estruturais (tal qual o ethos de um xamanismo exoprático, proposto por Viveiros de Castro) e suas manifestações regionais ao longo do tempo.

Do ponto de vista metodológico, o exercício de análise estilística aqui desenvolvido de forma ainda bastante exploratória beneficiou-se em grande parte de uma perspectiva da antropologia da arte proposta por Gell na qual os objetos são encarados como pessoas, pela capacidade que adquirem em interrelacionar sujeitos, em interações pautadas em papéis de agência e paciência. Tais qualidades são dinâmicas e relacionais, variando de acordo com o ponto de vista adotado, e por isso talvez se ajuste particularmente bem a objetos fabricados por sociedades perspectivistas.

Mas para o arqueólogo, esta abordagem seria certamente enriquecida se embasadas por teorias de percepção visual que dão conta também do substrato coletivo e inconsciente de uma sociedade e da relação entre percepção visual, e crença advindas de pesquisas da filosofia da estética e da fenomenologia (Smith, 2001).

Por último, mas não menos importante, esperamos ter demonstrado o potencial analítico de coleções com objetos inteiros, mesmo que descontextualizados. Coleções deste tipo propiciam a análise não só dos objetos e de como foram executados, mas sobretudo, permitem recuperar o seu projeto "mental", e isolar os requisitos materiais e visuais que constituem as categorias conceituais do objeto ritual. As análises destes objetos inteiros complementam assim o largo conhecimento de que já dispõe a arqueologia 
amazônica sobre as características físicas da cerâmica e sua variabilidade. A partir de um melhor entendimento dos significados sociais desta variabilidade, talvez possamos construir uma verdadeira arqueologia de "sistemas tecnológicos", conforme proposto por Ingold (2001), incluindo-se neste sistema as " tecnologias de encantamento" dos objetos rituais.

$\mathrm{Na}$ arqueologia amazônica, e marajoara em particular, existe um grande quantidade de pequenas e grandes coleções semelhantes, com objetos inteiros e bem conservados, muitas vezes desconhecidas dos arqueólogos e outras vezes desprezadas por não serem provenientes de escavações científicas. Sem deixar de reconhecermos as limitações analíticas e interpretativas que esta descontextualização impõe, é preciso também que a comunidade científica se envolva na recuperação deste patrimônio, re-significando estes objetos dentro de uma prática científica responsável, que privilegie a análise de materiais já disponível em museus, antes de se iniciar novas pesquisas invasivas nos sítios arqueológicos.

Talvez o melhor uso que possamos fazer destes objetos descontextualizados seja mesmo o uso didático em belos livros e exposições, valendo-se de seus eternos poderes de encantamento, mas cabe ao arqueólogo fazê-lo de forma a mostrar ao público em geral a complexidade de um passado indígena ainda pouco conhecido.

Afinal, se a finalidade intrínseca da arte é o despertar das almas, como considerou Hegel, cabe ao arqueólogo fazer com que a arte marajoara e suas belas urnas funerárias continuem cumprindo seu fim. 


\section{B I B L I O G R A F I A}

\section{Agostinho, Pedro}

1974 Kwarì - Mito e Ritual no Alto Xingu. EPU, Edusp, São Paulo.

\section{Aguilar, Nelson (ed.)}

2000 Artes Indígenas. Catálogo da Mostra do Redescobrimento. Associação

Brasil 500 anos de Artes Visuais, Fundação Bienal, São Paulo.

Aires da Fonseca Jr., João

2007 Do século XIX ao XX : cartas e publicações sobre os ídolos de pedra Amazônicos, e-historia.

2008 As estatuetas líticas do baixo-Amazonas. Trabalho apresentado no primeiro Encontro Internacional de Arqueologia Amazônica, setembro de 2008, Belém.

\section{Arhem, Kaj}

2002 "Animals have culture too". Animism among the Tukanoans. Acta Americana, 10(2):22-28.

\section{Arnold, Dean E.}

1988 Ceramic Theory and Cultural Process. Cambridge University Press

Cambridge

\section{Baldus, Herbert}

1936 Licocos. Espelho, XXI, Rio de Janeiro.

\section{Barata, Frederico}

1952 Arqueologia. As Artes Plásticas no Brasil. Ediouro, Rio de Janeiro.

\section{Barcelos Neto, Aristóteles}

2001a Apontamentos para uma Iconografia Xinguana. In Os Povos do Alto Xingu, História e Cultura, organizado por B. Franchetto e M. Heckenberger, pp.193-218. Editora da Universidade Federal do Rio de Janeiro, Rio de Janeiro.

2001b O universo visual dos xamãs wauja (Alto Xingu), Journal de la Société des Américanistes, 87, pp. 137-160.

2002 A Arte dos Sonhos. Uma iconografia Ameríndia. Editora Assírio Alvim, Museu Nacional de Etnologia, Lisboa.

2008 Choses (in)visibles et (im)périssables. Temporalité et matérialité des objets rituels dans les Andes et en Amazonie. Gradhiva, no.8, n.s.

\section{Barreto, Cristiana}

1998 Brazilian Archaeology from a Brazilian Perspective, Antiquity 72 (277): 573582

2003 Le symbolisme sexuel et les femmes dans l'art de l'Amazonie ancienne. Kaos, Parcours du Monde, 2: 72-83. 
2004a Simbolismo sexual na Amazônia antiga: urnas, estatuetas e tangas marajoara. In Antes. Histórias da Pré-História, organizado por M. Dantas, pp. 84-99. Centro Cultural Banco do Brasil, São Paulo.

2004b Gifts from the past: The material culture of ancient Amazonia. In Amazonia, Native Traditions, editado por L.D. Grupioni, C. Barreto, pp. 115-129, BrasilConnects, São Paulo.

2005 Arte e Arqueologia na Amazônia Antiga. Centro de Estudos Brasileiros, Universidade de Oxford. Working Paper CBS-66-2005.

2005 a Art Précolombien et Archéologie. In Brésil Indien, les arts des Amérindiens du Brésil, editado por L.D.B. Grupioni, pp. 138-159. Réunion de Musées Nationaux, Paris.

2005 b Social complexity and inequality in ancient Amerindian societies: perspectives from the Brazilian lowlands. Centre for Brazilian Studies, University of Oxford, Working paper CBS-63-2005, 2005.

2006 Do chão profano aos bancos sagrados: uma arqueologia dos bancos indígenas da Amazônia. In Bancos Indígenas: entre a função e o rito, editado por A. Borges e C. Barreto, pp. 7-18. Museu da Casa Brasileira, São Paulo.

2006a Caminos de la desigualdad: Perspectivas desde las tierras bajas de Brasil. In Contra la tiranía del pensamiento tipológico, editado por C. Gnecco e C. Langebaek, pp. 1-30. Ediciones Uniandes, Bogotá.

\section{Barreto Cristiana e J. Machado}

2001 Exploring the Amazon, explaining the unknown. In McEwan, C., Barreto, C. e Neves, E. (orgs). Unknown Amazon, Nature in Culture in Ancient Brazil. pp. 232-250. British Museum Press, Londres.

\section{Barth, Fredrik}

1995 (1981) Process and form in social life: selected essays of Fredrik Barth. London: Routledge \& Kegan Paul.

\section{Binford, Lewis}

1989 Styles of style. Journal of Anthropological Archaeology, 8:51-67.

\section{Boas, Franz}

1955 (1897) Primitive Art. Dover Publications, Nova York.

\section{Boomert, Arie}

1987 Gifts of the Amazons: "Greenstone" Pendants and Beads as Items of Ceremonial Exchange in Amazonia. Antropológica 67:33-54.

2004 Koriabo and the Polychrome Tradition: The late-prehistoric era between the Orinoco and Amazon Mouths. In Late Ceramic Age Societies in the Eastern Caribbean, editado por A. Delpuech e C. Hofman. BAR International Series, Archeopress, Oxford.

Brochado, José P.

1980 The Social Ecology of Marajoara Culture. M.A. Thesis, University of Illinois. 
1984 An Ecological Model of the Spread of Pottery and Agriculture into Eastern South America. Ph.D. Dissertation. University of Illinois at UrbanaChampaign.

\section{Brochado, José P. e Donald Lathrap}

1982 Chronologies in the New World: Amazonia. Manuscrito não publicado e editado por José Oliver (1999).

\section{Braun, David P.}

1995 Style, Selection, and Historicity. In Style, Society, and Person:

Archaeological and Ethnological Perspectives, edited by C. Carr and J.E. Neitzel, pp. 123-141. Plenum Press, Nova York

Campos, Sandra C. La T. L.

2007 Bonecas Karajá. Modelando inovações, trasmitindo tradições. Tese de Doutorado apresentada ao depratamento de Cinências Sociais, PUC, São Paulo.

\section{Carneiro, Robert}

1981 The chiefdom as precursor to the state. In R. Kautz (org),_The transition to statehood in the New World, pp. 37-79. Cambridge University Press, Cambridge.

1993 Quarup, A Festa dos Mortos no Alto Xingu. In: Vera Coelho (org), Karl von den Steinen: Um século de Antropologia no Xingu, pp. 405-430. Edusp/FAPESP,São Paulo.

1998 What Happened at the Flashpoint? Conjectures on Chiefdom Formation at the Very Moment of Conception. In E. M. Redmond (org), Chiefdoms and Chieftaincy in the Americas, pp. 18-42. University Press of Florida, Gainesville.

\section{Carneiro da Cunha, Manuela}

1978 Os mortos e os outros. Hucitec, São Paulo.

Carr, Christopher e Jill Neitzel (eds.)

1995 Style, Society, and Person: Archaeological and Ethnological Perspectives Plenum, Nova York.

\section{Clastres, Pierre}

1979 La Société contre l'État. Recherches d'Anthropologie Politique. Les Éditions de Minuit, Paris.

\section{Collomb, Gérard}

2003 Réflexions sur un "style ethnique": La céramique Kali'na du littoral oriental des Guyanes. Journal de la Société des Américanistes, Cahier Guyanes, Paris.

\section{Colpron, Anne-Marie}

2005 Monopólio masculino do xamanismo amazônico: o contra-exemplo das mulheres xamã shipibo-conibo. Mana, vol.11, no.1, pp.95-128. 


\section{Conkey, Margaret}

1990 Experimenting with style and archaeology: some historical and theoretical issues. In: Conkey M. e Hastorf, C. (eds.) The Uses of Style in Archaeology, pp.5-17, New Directions in Archaeology series. Cambridge University Press, Cambridge.

Conkey, Margaret and C. Hastdorf (editores)

1990 The Uses of Style in Archaeology. Cambridge University Press, Cambridge.

\section{Conklin, Beth A.}

1993 Introduction: Visions of death in Amazonian Lives. The Latin American Anthropology Review_5(2):55-56.

1995 "Thus are our bodies, thus are our custom".: Mortuary Cannibalism in an Amazonian society. American Ethnologist 22:75-101.

2001 Consuming grief: Compassionate cannibalism in an Amazonian society. University of Texas Press, Austin.

\section{Cooke, Richard}

1998 The Felidae in Pre-Columbian Panama. A thematic approach to their imagery and symbolism. In Icons of Power. Feline symbolism in the Americas, editado por N. Saunders, pp.77-120. Routledge, Londres.

\section{Coote, Jeremy e Anthony Shelton (orgs)}

1992 Anthropology, Art and Aesthetics. Clarendon Press, Oxford.

\section{Crocker, Jon}

1985 Vital Souls. Bororo cosmology, natural symbolism, and shamanism. University of Arizona Press, Tucson.

\section{David, Nicholas}

1992 The archaeology of ideology: mortuary practices in the central Mandara highlands, northern Cameroon. In An African commitment: papers in honor of Peter Lewis Shinnie, editado por Judith Sterner e Nicholas David, pp. 181-210. Calgary University Press, Calgary.

\section{David, Nicholas e Carol Kramer}

2001 Mortuary practices, status, ideology, and systems of thought. In: Ethnoarchaeology in Action, editado por Nicholas David e Carol Kramer. Cambridge University Press, Cambridge.

\section{DeBoer, Warren R.}

1984 The Last Pottery Show: System and Sense in Ceramic Studies. In The Many Dimensions of Pottery: Ceramics in Archaeology and Anthropology, editado por A. C. Pritchard, pp. 529-571. Universitaet van Amsterdam, Amsterdam.

1991 The Decorative Burden: Design, Medium and Change. In Ceramic Ethnoarchaeology. Editado por W. Longacre, pp. 144-161. University of Arizona Press, Tucson. 
DeBoer, W. e D. Lathrap

1979. The Making and Breaking of Shipibo-Conibo Ceramics. In

Ethnoarchaeology, Editado por C. Kramer, pp. 102-138. Academic Press, Nova York

Delpuech, André e Corinne L. Hofman

2004 Late Ceramic Age Societies in the Eastern Caribbean. BAR International Series, 1273. Paris Monographs in American Archaeology 14. Archeopress, Oxford.

\section{Derby, Orville}

1879 The artificial mounds of the Island of Marajó. American Naturalist, 13:224229.

\section{Deregowski, Jan B.}

1970 A note on the possible determinant of "split representation" as an artistic style. International Journal of Psychology, 5(1):21-26.

\section{Derlon, Brigitte}

2007 Des « fétiches à clous » au Grand Verre de Duchampp. Une nouvelle théorie anthropologique de l'art. Le Débat, 147:124-135.

\section{Descola, Phillippe}

1986 La nature domestique. Simbolisme et praxis dans l'écologie des Ashuar. Éditions de la Maison des Sciences de l'Homme, Paris.

2006 As Lanças do Crepúsculo. Cosac Naify, São Paulo.

Douglas, Mary

1966 Purity and Danger. Routledge and Kegan Paul, Londres.

\section{Earle, Timothy}

1990 Style and iconography as legitimation in complex societies. In The Uses of Style in Archaeology, editado por M. Conkey e C. Hastorf, pp. 73-81, New Directions in Archaeology series. Cambridge University Press, Cambridge.

\section{Erikson, Philippe}

1986 Alterité, tatouage et anthropophagie chez les Pano: la belliqueuse quête du soi. Journal de la Société des Américanistes, LVII : 185-210.

1998 Uma singular pluralidade: a etno-história Pano. In História dos Índios no Brasil, editado por M. Carneiro da Cunha, pp. 239-253. Companhia das Letras, São Paulo.

\section{Evans, Clifford and Betty J. Meggers}

1968 Archaeological Investigations on the Río Napo, Eastern Ecuador. Smithsonian Contributions to Anthropology, vol. 6. Smithsonian Institution Press, Washington, D.C.

Farabee, William C.

1921 Explorations at the mouth of the Amazon. Museum Journal, 12:142-161. 


\section{Fausto, Carlos}

2001 Inimigos fiéis: História, guerra e xamanismo na Amazônia. EDUSP, São Paulo.

2007 Feasting on People. Eating Animals and Humans in Amazonia. Current Anthropology 48 (4):497-513.

Fernandes Dias, José A. B.

2000 Arte, Arte Î́ndia, Artes Indígenas. In Artes Indígenas, editado por N. Aguilar, Catálogo da Mostra do Redescobrimento, Associação Brasil 500 Anos Artes Visuais, São Paulo.

\section{Ferreira Penna, Domingos S.}

1879 Apontamentos sobre os ceramios do Pará. Archivos do Museu Nacional do Rio de Janeiro, 2:69-72.

Gell, Alfred

1992 The technology of enchantment and the enchantment of technology. In Anthropology, Art, and Aesthetics, editado por J.Coote e A. Shelton, pp. 40-67. Oxford University Press, Oxford.

1993 Wrapping in images:Tattooing in Polynesia. Oxford University Press, Oxford. 1998 Art and Agency: An Anthropological Theory. Clarendon Press, Oxford.

Geiger, Gérard (ed.)

2003 Au Coeur de I 'Amérique Précolombienne. Collection Gérard Geiger. 5 Continents Editions, Geneva.

\section{Green, Stanton W. e Pearlman Stephen}

1985 Frontiers, boundaries and open social systems. In The Archaeology of frontiers and boundaries, editado por S. Green e S. Pearlman, pp. 3-13. Academic Press, Nova York.

\section{Gillespie, Susan D.}

2001 Personhood, Agency, and Mortuary Ritual: A Case Study from the Ancient Maya. Journal of Anthropological Archaeology, 20 (1): 73-112.

\section{Gombrich, Ernst H.}

1962 Art and Illusion. Phaeidon, Londres.

1979 Ideals and Idols, Essays on Values in History and in Art. Phaeidon, Oxford. 1984 The Sense of Order. Phaeidon, Londres.

\section{Gomes, Denise}

2001 Santarém: Symbolism and Power in the Tropical Forest. In Unknown Amazon, Nature in Culture in Ancient Brazil, editado por C. McEwan, C. Barreto e E. Neves, pp. 134-154. The British Museum Press, Londres. 2002 A Cerâmica Arqueológica da Amazônia: Vasilhas da Coleção Tapajônica MAE-USP. Imprensa Oficial SP/Editora da Universidade de São Paulo, São Paulo. 
Gosden, Chris

1999 Anthropology \& Archaeolgy. A changing relationship. Routledge, Londres.

2001 Making Sense: Archaeology and Aesthetics. World Archaeology 33(2): 163167.

\section{Gow, Peter}

1999a A geometria do corpo. In A Outra Margem do Ocidente, editado por A. Novaes, pp. 299-316. Cia da Letras, São Paulo.

1999b Piro designs: Paintings and meaningful action in an Amazonian lived world. Journal of the Royal Anthropological Institute, n.s. 5:299-46.

Guapindaia, Vera L.C.

2001 Encountering the Ancestors: the Maracá funerary urns. In Unknown Amazon, Nature in Culture in Ancient Brazil, editado por C. McEwan, C. Barreto e E. Neves, pp. 156-174. The British Museum Press, Londres.

\section{Guapindaia, Vera L. C. e L. C. Machado}

1997 O Potencial Arqueológico da Região do Rio Maracá/lgarapé do Lago (AP). Boletim do Museu Paraense Emílio Goeldi, Belém, v. 13 n 1, p. 67-102.

\section{Guiart, Jean}

1985 Art as a mean of communication in pre-literate societies. In Art as a Means of Communication in Pre-literate Societies, The Proceedings of the W.I.S. on Primitive and Pre-Colombian Art, editado por E. Cohen e B. Danet , pp. 217-244, The Israel Museum, Jerusalém.

\section{Hannerz, Ulf}

1997 Fluxos, fronteiras, híbridos: palavras-chave da antropologia transnacional. Mana 3(1).

\section{Hartman, Günther}

1973 Litjoko. Puppen der Karaja, Bresilien. Museum fur Volkerkunde, Berlin.

\section{Hartt, Charles F.}

1871 Ancient Indian pottery from Marajó, Brazil. American Naturalist, 5.

1885 Contribuições para a ethnologia do valle do Amazonas. Archivos do Museu Nacional do Rio de Janeiro, 6.

\section{Hayden, Brian}

1997 Practical and prestige technologies: the evolution of material systems. Journal of Archaeological Method and Theory 5:1-55.

\section{Heckenberger, Michael. J.}

1999 O enigma das Grandes Cidades. Corpo Privado e Estado na Amazônia, In A Outra Margem do Ocidente. Brasil 500 anos: Experiência e Destino, editado por Adauto Novaes, pp. 125-52. Cia. das Letras, São Paulo.

2002 Rethinking the Arawakan Diaspora: hierarchy, regionality, and the Amazonian Formative. In Comparative Arawakan Histories, Rethinking Language Family and Culture Area in Amazonia, editado por Jonathan Hill 
e Fernando Santos-Granero, pp.99-122. University of Chicago Press, Urbana e Chicago.

2005 The Ecology of Power. Culture, Place, and Personhood in the Southern Amazon A.D. 1000-2000. Routledge, Nova York e Londres.

Heckenberger, Michael. J., J. Petersen, e E. Neves

1999 Village size and permanence in the Amazon: Two archaeological examples from Brazil. Latin American Antiquity 10:353-376.

2001 Of Lost Civilizations and Primitive Tribes, Amazonia: Reply to Meggers. Latin American Antiquity 12(3):328-333.

Heckenberger, Michael. J., A. Kuikuro, U. T. Kuikuro, J. C. Russel, M. Schmidt, C. Fausto e B. Franchetto

2003 Amazonia 1492: Pristine Forest or Cultural Parkland? Science 301:17101713.

Heckenberger, Michael J.; J. Christian Russell; Carlos Fausto; Joshua R. Toney; Morgan J. Schmidt; Edithe Pereira; Bruna Franchetto; Afukaka Kuikuro

2008 Pre-Columbian Urbanism, Anthropogenic Landscapes, and the Future of the Amazon. Science 321(29): 1214-1217

\section{Helms, Mary}

1986 Art Styles and Interaction Spheres in Central America and the Caribbean. Journal of Latin American Lore 12(1): 25-44.

Henaff, Marcel

1991 Claude Lévi-Strauss. Pierre Belfond, Paris.

Hertz, Robert

1907 Contribution à une étude sur la représentation collective de la mort. Année Sociologique 10: 48-137.

\section{Hilbert, Peter}

1952 Os tesos Marajoaras do Alto Camutins e a Atual Situação da Ilha de Pacoval, Arari. Instituto de Antropologia e Etnologia do Pará, 5. Belém.

1968 Archäologische Untersuchungen am Mittlern Amazonas. Dietrich Reimer Verlag, Berlin.

Hill, Jonathan D.

1993 Keepers of the Sacred Chants. The Poetics and Ritual Power in an Amazonian Society. The University of Arizona Press, Tucson/Londres.

\section{Hill, Jonathan e Fernando Santos-Granero}

2002 Comparative Arawakan Histories. Rethinking Language Family and Culture Area in Amazonia. University of Illinois Press. 
Hodder, Ian

1982 Symbols in action : ethnoarchaeological studies of material culture. Série "New studies in archaeology". Cambridge University Press, Cambridge Cambridge e Nova York.

\section{Hornborg, Alf}

2005 Ethnogenesis, regional integration, and ecology in prehistoric Amazonia: towards a systemic perspective. Current Anthropology, 46(4):589-620.

\section{Huntington, R. e P. Metcalf}

1991 Celebrations of Death : the Anthropology of Mortuary Ritual. 2a edição, Cambridge University Press, Cambridge e Nova York.

\section{Ingold, Tim}

1994 Companion encyclopaedia of anthropology: Humanity, culture and social life. Routledge, Londres.

2001 Beyond Art and Technology: The Anthropology of Skill. In Anthropological Perspectives on Technology, M. Schiffer (ed.), pp 17-31. University of New Mexico Press, Albuquerque.

2006 Rethinking the animate, a re-animating thought, Ethnos, 71(1): 9-20.

Jonaitis, Aldona (ed.)

1995 A Wealth of Thought. Franz Boas on Native American Art. University of Washington Press, Seattle e Londres.

\section{Jones, Sian}

1997 Archaeology of Ethnicity : Constructing Identities in the Past and Present. Routledge, Londres.

\section{Lagrou, Els M.}

2002 O que nos diz a arte Kaxinawá sobre a relação entre identidade e alteridade? Mana 8(1): 29-60.

2005 L'art des indiens du Brésil. Altérité, « authenticité » et « pouvoir actif ». In Brésil Indien : les arts de Amérindiens du Brésil, pp.68-87. Editado por L.D. Grupioni, Réunion des Musées Nacionaux, Paris.

2007 A fluidez da forma: arte, alteridade e agência em uma sociedade amazônica (Kaxinawa, Acre). TopBooks, Rio de Janeiro.

Lathrap, Donald. W.

1970a La Floresta Tropical y El Contexto Cultural de Chavín. In 100 Años de Arqueología en el Perú. Fuentes y Investigaciones para la Historia del Perú, 3 , editado por R. Ravines. Instituto de Estudios Peruanos: Edición de Petróleos del Perú, Lima.

1970b The Upper Amazon. Praeger, Nova York.

1973 The antiquity and importance of long-distance trade relationship in the moist tropics of pre-Columbian South America. World Archaeology 5:170-186.

\section{Lévi-Strauss, Claude}

1949 Les Structures Élémentaires de la Parenté. Mouton, Paris. 
1955 Tristes Tropiques, Éditions PLon, Paris.

1962 Le Totémisme Aujourd'hui. PUF, Paris.

1964 La Pensée Sauvage. Plon, Paris.

1967 (1958) Anthropologie Structurale. Éditions Plon, Paris.

1979 La Voie des Masques. Éditions Plon, Paris.

1984 Canibalisme et travestissement rituel. In Paroles Données, pp.141-149. Plon, Paris.

1990 Introductory Address. In Art as mean of communication in pre-literate societies, editado por Dan Eban. The Israel Museum, Jerusalém.

1997 Olhar, Escutar, Ler. São Paulo Companhia das Letras, São Paulo.

Lima, Helena P.

2008 História das Caretas. Tese de Doutorado, Museu de Arqueologia e Etnologia da Universidade de São Paulo.

Lima, Helena P.; E. G. Neves; J. B. Petersen

2006 A fase Açutuba: um novo complexo cerâmico na Amazônia Central. Arqueologia Suramericana 2(1):26-52.

\section{Lima, Tânia Andrade}

2005 Cerâmicas Tupiguarani e Marajoara. Elementos estruturais comuns. Ciência Hoje, 36(213):30-33.

\section{Lima, Tânia Stolze}

1996 O dois e seu múltiplo: reflexões sobre o perspectivismo em uma cosmologia Tupi. Mana, 2(2): 21-47.

\section{Lima Guedes, Aureliano P.}

1897 Relatório sobre uma missão ethnográfica e archeológica nos rios Maracá e Anauera-pucu. Boletim do Museu Paraense de História Natural e Ethnografia_2:42-64.

1898 Relatório sobre uma missão ethnografica e archeológica nos rios Maracá e Anauera-pucu (Guyana Brasileira) realizada pelo tenente-coronel Aureliano Pinto Lima Guedes. Julho a setembro de 1896. Boletim do Museu Paraense de História Natural e Ethnografia 2:46.

\section{Lopes da Silva, Aracy}

1991 Tradições, inovações, e criatividade: a análise comparativa de cosmologias vistas como processo". In Anuário Antropológico 90. Tempo Brasileiro, Rio de Janeiro.

\section{MacDonald, Regina}

1972 The order of things: an analysis of the ceramics from Santarém, Brazil. Journal of the Steward Anthropological Society_4(1):39-55.

\section{Machado, Juliana S.}

2005 Montículos artificiais na Amazônia central: um estudo de caso do sítio Hatahara, Amazonas. Dissertação de Mestrado, Museu de Arqueologia e Etnologia, Universidade de São Paulo. 
2007 Os significados dos sistemas tecnológicos: classificando e interpretando o vestígio cerâmico. Arqueología Suramericana, 3(1)..

Magalis, Joanne. E.

1975 A Seriation of Some Marajoara Painted Anthropomorphic Urns. Ph.D. Dissertation, University of Illinois.

Mauss, Marcel

1923 Essai sur le don: forme et raison de l'échange dans les societés archaïques. In Sociologie et Anthropologie, pp. 145-279. PUF, Paris.

\section{Meggers, Betty J.}

1961 An experimental formulation of horizon styles in the tropical forest of South America. In Essays in Pre-Columbian Art and Archaeology, editado por Samuel K. Lothrop, pp. 372-388. Harvard University Press, Cambridge.

1983 Lowland South America and the Antilles. In Ancient South Americans, editado por Justin Jennings, pp. 287-335. W. H. Freeman, San Francisco.

1993-95 Amazonia on the eve of European contact: ethnohistorical, ecological, and anthropological perspectives. Revista de Arqueología Americana 8: 91-115.

1996 Amazonia: Man and Culture in a Counterfeit Paradise (2a ed.). Aldine, Chicago.

2001 The mystery of the Marajoara: An Ecological solution. Amazoniana XVI (3/4):421-440.

Meggers, Betty e Evans, C.

1957 Archaeological Investigations at the Mouth of the Amazon. Bureau of American Ethnology, Bulletin 167. Smithsonian Institution Press.

1958 Archaeological Evidence of a Prehistoric Migration from the Rio Napo to the Mouth of the Amazon. In Migrations in New World Culture History, editado por Raymond H. Thompson, pp.9-19. University of Arizona Press, Tucson.

\section{Meggers, Betty e Jacques Danon}

1988 Identification and Implications of a Hiatus in the Archaeological Sequence on Marajó Island, Brazil. Journal of the Washington Academy of Sciences, 78(3):245-243.

\section{McAnany, Patricia A.}

1995 Living with the Ancestors: Kinship and Kingship in Ancient Maya Society. University of Texas Press, Austin.

\section{McEwan, Colin}

2001 Seats of Power: Axiality and Access to Invisible Worlds.. Unknown Amazon, editado por C. McEwan, C. Barreto e E. Neves, pp. 176-197. The British Museum Press, Londres.

McEwan, Colin, Barreto, Cristiana and Neves, Eduardo (editores)

2001 Unknown Amazon, Culture in Nature in ancient Brazil. The British Museum Press, Londres. 
Miller, Daniel

1985 Artifacts as categories. In Pottery and Social Strategy. Cambridge University Press, pp. 184-196, Cambridge.

1994 Artifacts and the meaning of things. In T. Ingold (ed.). Companion Encyclopedia of Anthropology, pp.396-419. Routledge, Londres.

Moraes, Claide de $\mathbf{P}$.

2006 A Arqueologia da Amazônia Central vista de uma perspectiva do Lago do Limão. Dissertação de Mestrado, Museu de Arqueologia e Etnologia, Universidade de São Paulo.

Morales Chacano, Daniel

2000 Las Poblaciones prehistoricas Amazonicas. Investigaciones Sociales, Estudios de Arqueologia, Ano IV, no. 6., Peru.

\section{Morphy, Howard}

1992 From dull to brilliant: the aesthetics of spiritual power amongst the Yolngu. In Anthropology, Art and Aesthetics, editado por J. Coote e A. Shelton. Clerendon Press, Oxford.

1994 The Anthropology of Art. In Companion Encyclopedia of Anthropology, pp.648-685. Routledge, Londres.

1996 Aesthetics is a cross-cultural category. In Key debates in Anthropology, editado por Tim Ingold, pp. 255-260. Routledge, Londres e Nova York.

\section{Museu Barbier-Mueller d'Art Precolombí}

2002 Amazonie Précolombienne dans les collections du Museo de Arte Precolombino Barbier-Mueller. Catálogo de exposição homônima com textos de Conceição G. Correia e Iris Barry. 5 Continents, Barcelona.

2003 Trésors de la céramique Précolombiènne dans les collections BarbierMueller. Catálogo de exposição homônima realizada em Barcelona e Genebra em 2003 e 2004. Museu Barbier-Mueller d'Art Precolombí, Barcelona.

\section{Müller, Regina $\mathbf{P}$.}

1990 Os Asurini do Xingu. História e Arte. Unicamp, Campinas.

\section{Munn, Nancy}

1966 Visual categories: an approach to the study of representational systems. American Anthropologist 68:936-50.

1973 Walbiri Iconography, Graphic Representation and Cultural Symbolism in a Central Australian Society. Cornell University Press, Ithaca.

Myers, Tom e M. S. Cipoletti (eds.)

2002 Art and artifacts in Amazonia. American Studies, 36, Verlag Anton Saurwein, Bonn. 
Neves, Eduardo G.

1999 Changing perspectives in Amazonian archaeology. In Archaeology in Latin America, editado por G. Politis e B. Alberti, pp.216-243. Routledge, Londres.

2003 Levantamento arqueológico da área de confluência dos rios Negro e Solimões, Estado do Amazonas: Continuidade das escavações, análise da composição química e montagem de um sistema de informações geográficas. Relatório enviado à Fundação de Amparo à Pesquisa do Estado de São Paulo, (FAPESP).

2004 Landscapes of Ancient Amazonia. In Amazonia, Native Traditions, editado por L. D. Grupioni e C. Barreto, pp. 95-111, BrasilConnects, São Paulo.

2006 Arqueologia da Amazônia. Jorge Zahar Editor, Rio de Janeiro.

2008 Ecology, Ceramic Chronology and Distribution, Long-term History, and Political Change in the Amazonian Floodplain. In Handbook of South American Archaeology, editado por Helaine Silverman e William Isbell, pp. 359-379. Springer, Nova York.

Neves, Eduardo G.; C. Barreto; C. McEwan

2001 Introduction. In McEwan, C. Barreto, e Neves, E. (orgs).Unknown Amazon, Nature in Culture in Ancient Brazil. pp. 14-19, British Museum Press, Londres.

Nimuendajú, Curt U.

2004 In Pursuit of a Past Amazon: Archaeological Researches in the Brazilian Guyana and in the Amazon Region (A posthumous work compiled and translated by Stig Rydén and Per Stenborg), editado por Per Stenborg. Etnologiska Studier 45, Gotemborg.

\section{Nordenskiold, Erland}

1930 Ars Americana. Vol.1. L'Archéologie du Bassin de l'Amazone. Les Éditions G. Van Oest, Paris.

\section{Novaes, Silvia Caiuby}

2006 Funerais entre os Bororo. Imagens da refiguração do mundo. Revista de Antropologia, USP, 49(1):284-315.

\section{Overing, Joanna}

1991 A estética da produção: o senso de comunidade entre os Cubeo e Piaroa. Revista de Antropologia 34.

1993 Death and the loss of civilized predation among the Piaroa. L'Homme,1268.

Palmatary, Helen. C.

1950 The pottery of Marajó Island, Brazil. Transactions of the American Philosophical Society, vol.39.

1960 The archaeology of the lower Tapajós. Transactions of the American Philosophical Society, nova série, vol.50. 


\section{Parker Pearson, Michael}

1999 The Archaeology of Death and Burial. Sutton Publishing, Stroud.

\section{Passeti, Dorothea V.}

2008 Lévi-Strauss, Antropologia e Arte: minúsculo - incomensurável. Edusp, Educ, São Paulo.

\section{Pessis, Anne-Marie e N. Guidon}

2000 Registros rupestres e caracterização das etnias pré-históricas. In Grafismo Indígena, Estudos de Antropologia Estética,editado por Lux Vidal, pp. 1934. Studio Nobel/Fapesp, São Paulo.

\section{Plog, Stephen}

1990 Sociopolitical implications of stylistic variation in the American Southwest. In The Uses of Style in Archaeology, editado por M. Conkey e C. Hastorf, pp.61-72. New Directions in Archaeology series. Cambridge University Press, Cambridge.

\section{Porro, Antonio}

1994 Social Organization and Political Power in the Amazon Floodplain: the Ethnohistorical Sources. In (org).Amazonian Indians from Prehistory to the Present: Anthropological Perspectives, editado por Anna Roosevelt, pp. 79-94. University of Arizona Press, Tucson.

\section{Quilter, Jeffrey}

2007 Representational Art in Ancient Peru and the Work of Alfred Gell. In Art's Agency and Art History, editado por R. Osborne e J. Tanner, pp. 135-157. Blackwell Publishing Ltd, Oxford.

\section{Reichel-Dolmatoff, Gerardo}

1961 Anthropomorphic figurines from Colombia, their magic and art. In Essays in pre-Columbian art and archaeology, editado por S. Lothrop. Harvard University Press.

1972 San Agustín: A Culture of Colombia. Praegen, Nova York.

1978 Beyond the Milky Way: Hallucinatory Imagery of the Tukano Indians. UCLA Latin American center Publications.

1985 Basketry as a Metaphor: Arts and Crafts of the Desana Indians of the Northwest Amazon. Occasional Papers of the Museum of Cultural History 5. University of California, Los Angeles.

1990 Orfevreria y Shamanismo: Un estudio iconográfico del Museo del Oro. Editorial Collina, Medellin.

\section{Renfrew, Collin}

1994 Towards a cognitive archaeology. In The ancient mind, editado por C. Renfrew e Zubrow, pp. 55-74. Cambridge University Press, Cambridge.

\section{Ribeiro, Berta}

1987 Desenhos semânticos e identidade étnica: o caso Kayabí. In Suma Etnológica Brasileira, vol. 3, pp. 265-286. Vozes/FINEP, Rio de Janeiro. 
1989 Arte Indígena. Linguagem Visual. Itatiaia/Edusp, Belo Horizonte.

1992 A mitologia pictórica dos Desâna. In Grafismo Indígena, Estudos de Antropologia Estética, editado por L. Vidal, pp.35-52. Studio Nobel/Fapesp, São Paulo.

Rivière, Peter

1969 Myth and material culture: Some symbolic interrrelations. In. Forms of Symbolic Action, editado por Spencer, pp. 151-166. University of Washington Press, Seattle.

Roe, Peter G.

1982 The Cosmic Zygote. Cosmology in the Amazon Basin. Rutgers University Press, New Brunswick.

1995 Style, Society, Myth, and Structure. In: Style, Society and Person, editado por C. Carr e J. Neitzel, pp.27-76. Plenum Press, Nova York e Londres.

Roosevelt, Anna C.

1988 Interpreting Certain Female Images in Prehistoric Art. In The Role of Gender in Precolumbian Art and Architecture, editado por V. Miller, Harvard University Press.1988.

1991 Moundbuilders of the Amazon : Geophysical Archaeology on Marajó Island, Brazil. Academic Press, San Diego.

1999 The Development of Prehistoric Complex Societies: Amazonia: a Tropical Forest. In Complex Polities in the Ancient Tropical World, editado por L. J. Lucero, pp. 13-33, Archaeological Papers of the American Anthropological Association 9, Washington D.C.

\section{Rostain, Stéphen}

2004 The French Guiana Coast: A Key Area in Prehistory between the Orinoco and Amazon Rivers. In Between St. Eustatius and the Guianas. Contributions to Caribbean Archaeology, editado por Aad Versteeg, pp.53-99. Publications of the St. Eustatius Historical Foundation, 3, St. Eustatius.

\section{Rostain, Stéphen e Aad Versteeg}

2004 The Arauquinoid Tradition in the Guianas. In A. Delpuech e C. Hofman (orgs). Late Ceramic Age Societies in the Eastern Caribbean, pp. 233250. Archaeopress, Oxford.

Sahlins, Marshall D.

1968 Tribesman. Prentice-Hall, Englewood Cliffs.

\section{Santos-Granero, Fernando}

1986 Power, ideology and the ritual of production in Lowland South America. Man (N.S.) 21 (4): 657-679.

2006 Vitalidades sensuais. Modos não corpóreos de sentir e conhecer na Amazônia indígena. Revista de Antropologia, 49(1):94-130 


\section{Saunders, Nicholas}

2003 Catching the light: technologies of enchantment and power in PreColumbian goldworking. In Gold and Power in Ancient Costa Rica, Panama, and Colombia, editado por J. Quilter e J. Hoopes, pp.15-47. Dumbarton Oaks Research Library and Collections, Washington.

\section{Schaan, Denise P.}

1997 A linguagem iconográfica da cerâmica Marajoara. Um estudo da arte préhistórica na llha de Marajó, Brasil (400-1300AD). Coleção arqueologia no. 3. Edipucrs, Porto Alegre.

2001a Into the labyrinths of Marajoara pottery: status and cultural identity in an Amazonian complex society. In Unknown Amazon, Nature in Culture in Ancient Brazil, editado por C. McEwan, C. Barreto e E.Neves, pp. 108133, British Museum Press, Londres.

2001b Estatuetas Marajoara: o Simbolismo de Identidades de Gênero em uma Sociedade Complexa Amazônica. Boletim do Museu Paraense Emílio Goeldi. Série Antropologia 17(2):23-63.

2003a A ceramista, seu pote e sua tanga: Identidade e significado em uma comunidade Marajoara. Trabalho apresentado na XII Congresso da Sociedade de Arqueologia Brasileira, São Paulo.

2003b Investigando gênero e organização social no espaço ritual e funerários Marajoara. Trabalho apresentado na XII Congresso da Sociedade de Arqueologia Brasileira, São Paulo.

2004 The Camutins Chiefdom. Rise and development of complex societies on Marajó Island, Brazilian Amazon. Tese de Ph.D., Universidade de Pittsburgh.

2007 Uma janela para a história pré-colonial da Amazônia: olhando além - e apesar - das fases e tradições. Boletim do Museu Paraense Emílio Goeldi. Ciências Humanas, Belém, v.2,n.1, pp.77-89.

\section{Schoepf, Daniel}

1995 Autoportraits du Nouveau Monde. Musée d'Ethnographie de Genève. Priuli \& Verlucca, Editori, Geneva.

Scott, Raymond; Warren R. Deboer; Peter G. Roe

1975 Cumancaya: a Peruvian ceramic tradition. Occasional papers no. 2, Department of Archaeology, University of Calgary.

\section{Seeger, Anthony}

1981 Nature and Society in Central Brazil: The Suyá Indians of Mato Grosso. Cambridge University Press, Cambridge.

Seeger, Anthony, Da Matta, R., Viveiros de Castro, E.

1979 A construção da pessoa nas sociedades indígenas brasileiras. Boletim do Museu Nacional, Série Antropologia, 32:2-19.

Shortman, Edward e P. Urban (eds.)

1992 Resources, Power and Interregional interaction. Springer, Nova York. 


\section{Silva, Fabíola A.}

2000 As tecnologias e seus significados. Tese de Doutorado. FFLCH, Universidade de São Paulo.

2003 Cultural Behaviors of Indigenous Populations and the Formation of the Archaeological Record in Amazonian Dark Earth: The Asurini Do Xingu Case Study. In Amazonian Dark Earths. Origin, Properties, Management. Editado por Norwell, pp.373-385. Academic Publishers, Kluwer.

Smith, A. D.

2001 Perception and Belief Source, Philosophy and Phenomenological Research, Vol. 62(2): 283-309

Souza, Sheila M.; Guapindaia, Vera L. C. ; Carvalho, C. R.

2001 A Necrópole Maracá e os Problemas Interpretativos em um Cemitério Sem Enterramentos. Boletim do Museu Paraense Emílio Goeldi, Belém, v. 17, n. 2, p. $479-520$.

Stahl, Peter W.,

2002 Paradigms in paradise: Revising standard Amazonian prehistory. The Review of Archaeology, 23 (2): 39-51.

\section{Steward, Julian e Louis Faron}

1959 Native Peoples of South America. McGraw-Hill,Nova York.

\section{Strathern, Marilyn}

1988 The gender of the gift. University of California Press, Berkeley.

\section{Streiff, Ruth}

1966 Catalogue des céramiques du Marajó au Musée d'ethonographie de Genève. Bulletin de la Société Suisse des Américanistes.

\section{Sztutman, Renato}

2005 O Profeta e o Principal: a ação política ameríndia e seus personagens. Tese de Doutorado, FFLCH, Universidade de São Paulo.

\section{Taussig, Michael}

1993 Mimesis and alterity. A particular history of the senses. Routledge, Nova York, Londres.

1999 Defacement. Public secrecy and the labor of the negative. Stanford University Press, Stanford.

\section{Taylor, Anne Christine}

1993 Remembering to Forget: Identity, mourning and memory among the Jivaro. Man, New Series. Vol. 28, No. 4, PP. 653-678.

1996 The Soul's Body and its States: An Amazonian Perspective on the Nature of Being Human", Journal of the Royal Anthropological Institute, vol. 2: 201-15. 


\section{Taylor, Walter}

1983 (1948) A Study of Archaeology. Southern Illinois University at Carbondale, Center for Archaeological Investigations, Carbondale.

\section{Van Velthem, Lucia $\mathrm{H}$.}

1995 O Belo é a Fera: a estética da produção e da predação entre os Wayana. Tese de Doutorado, Universidade de São Paulo.

1999 Feitos por inimigos: os brancos e seus bens na representação Wayana do contato. In Pacificando o Branco, editado por B. Albert e A.Ramos.

2000 Em outros tempos e nos tempos atuais: arte indígena. In Artes Indígenas, ed. por N. Aguilar, pp. 58-90. Catálogo da Mostra do Redescobrimento, Associação Brasil 500 Anos Artes Visuais, São Paulo.

\section{Vanzolini Figueiredo, Marina}

2006 Centralização e Faccionalismo: imagens da política no Alto Xingu.

Dissertação de Mestrado, Programa de Pós-graduação em Antropologia, Universidade Federal do Rio de Janeiro.

\section{Vernant, Jean P.}

1985 La belle mort et le cadavre outragé. In La mort dans les sociétés anciennes, editado por G. Gnoli e J.P. Vernant. Cambridge University Press ; Editions de la Maison des Sciences de l'Homme, Paris.

\section{Vidal, Lux (ed.)}

1992 Grafismo Indígena. Estudos de Antropologia Estética. Studio Nobel/Fapesp/Edusp, São Paulo.

1999 O Modelo e a Marca, ou o Estilo dos "Misturados". Cosmologia, História e Estética entre os povos indígenas do Uaçá. Revista de Antropologia, 42:1-2, São Paulo.

2001 Artes indígenas e seus múltiplos mundos. Revista do Patrimônio Histórico e Artístico Nacional, IPHAN, 29:11-41.

Viertler, Renate B.

1991 A refeição das almas. Hucitec/Edusp, São Paulo

\section{Vilaça, Aparecida}

1992 Comendo como gente: formas do canibalismo wari. Editora da UFRJ, Rio de Janeiro.

1993 O canibalismo funerário pakaa-nova: etnografia. In Amazônia: Etnologia e História Indígena, editado por E. V. de Castro e M.C. Cunha, pp.285-310. NHII, USP, FAPESP.

\section{Villas Boas, Orlando e C. Villas Boas}

1990 Território Tribal. In Xingu, Território Tribal. Ediado por M. Bisiliat e O. e C. Villas Boas, pp. 13-60. Cultura Editores Assicados, São Paulo.

\section{Viveiros de Castro, Eduardo}

1987 A fabricação do corpo na sociedade xinguana. In Sociedades Indígenas e Indigenismo no Brasil, pp. 31-41. Ed. Marco Zero, Rio de Janeiro. 
2002 A Inconstância da Alma Selvagem. Cosac \& Naif, São Paulo.

2004 The forest of mirrors: a few notes on the ontology of Amazonian spirits. Texto apresentado no Simpósio "La nature des esprits: humains et non-humains dans les cosmologies autochtones des Amériques" (F. Laugrand, coord.). Quebéc, Université Laval. (manuscrito)

2005a O solo etnográfico do perspectivismo (1). In A Onça e a diferença. Wikipédia.

2005b Chamanismo y sacrifício: um comentário amazônico. In Chamanismo y Sacrifício, Perspectivas arqueológicas y etnológicas em sociedades indígenas de América Del Sur, editado por J.P. Chaumeil, R.P. Camacho e J.F. Bouchard. Instituto Francês de Estúdios Andinos, Bogotá, D.C.

2008 Xamanismo transversal: Lévi-Strauss e a cosmopolítica amazônica. Versão manuscrita, ampliada do texto "Xamanismo e sacrifício" In $A$ inconstância da alma selvagem, pp. 457-472. Cosac \& Naify, São Paulo.

\section{Wagner, Roy}

1991 The Fractal Person. In Big Men and Great Men: Personifications of Power in Melanesia, editado por M. Strathern e M. Godelier, pp. 159-173. Cambridge University, Press, Cambridge.

\section{Weiner, James F.}

1996 Aesthetics is a cross-cultural category. In Key Debates in Anthropology, editado por Tim Ingold. Routledge, Nova York.

\section{Whitehead, Neil}

1994 The ancient Amerindian policies of the Amazon, the Orinoco, and the Atlantic Coast: a preliminary analysis of their passage from antiquity to extinction. In Amazonian Indians from Prehistory to the Present: Anthropological Perspectives, editado por Anna C. Roosevelt, pp. 33-53. University of Arizona Press, Tucson.

\section{Willey, Gordon}

1962 The early great styles and the rise of pre-Columbian civilizations. American Anthropologist 64:1-14.

\section{Wiessner, Polly}

1989 Style and Changing Relations between the Individual and Society. In The Meaning of Things: Material Culture and Symbolic Expressions, editado por lan Hodder, pp. 56-63. Unwin Hyman, Londres.

1990 Is there a unity to style? In The Uses of Style in Archaeology, editado por Conkey e C. Hastorf, pp. 105-121. Cambridge University Press, Cambridge.

\section{Wobst, H. Martin}

1977 Stylistic behavior and information exchange. In For the Director; Research Essays in the Honor of James B. Griffin, editado por C. Cleland, pp. 317142. Museum of Anthropology Anthropological Papers, Paper 61. University of Michigan, Ann Arbor. 


\section{A N EXO1}

COMPOSIÇÃO DA COLEÇÃO INSTITUTO CULTURAL BANCO SANTOS POR TIPOS DE ARTEFATOS E TRADIÇÕES CULTURAIS*

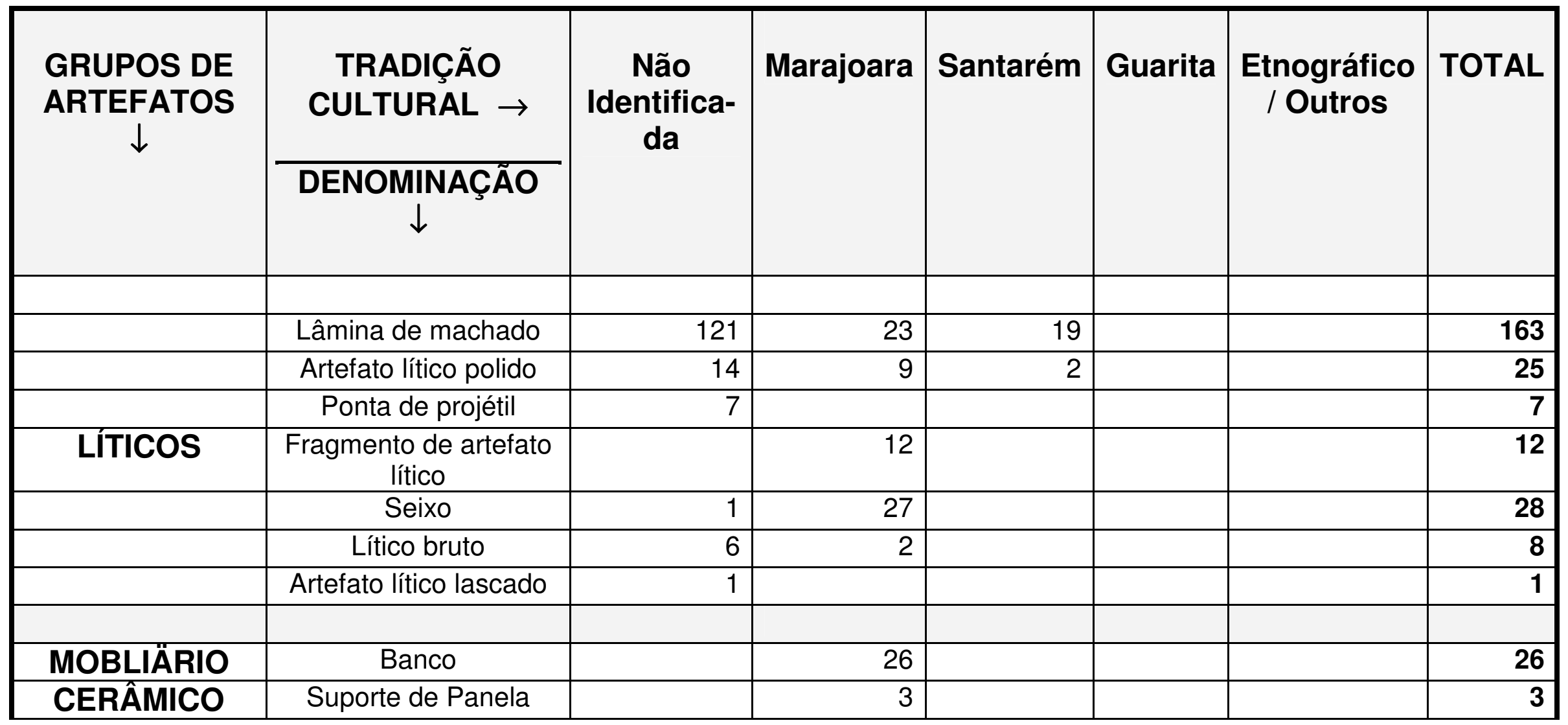




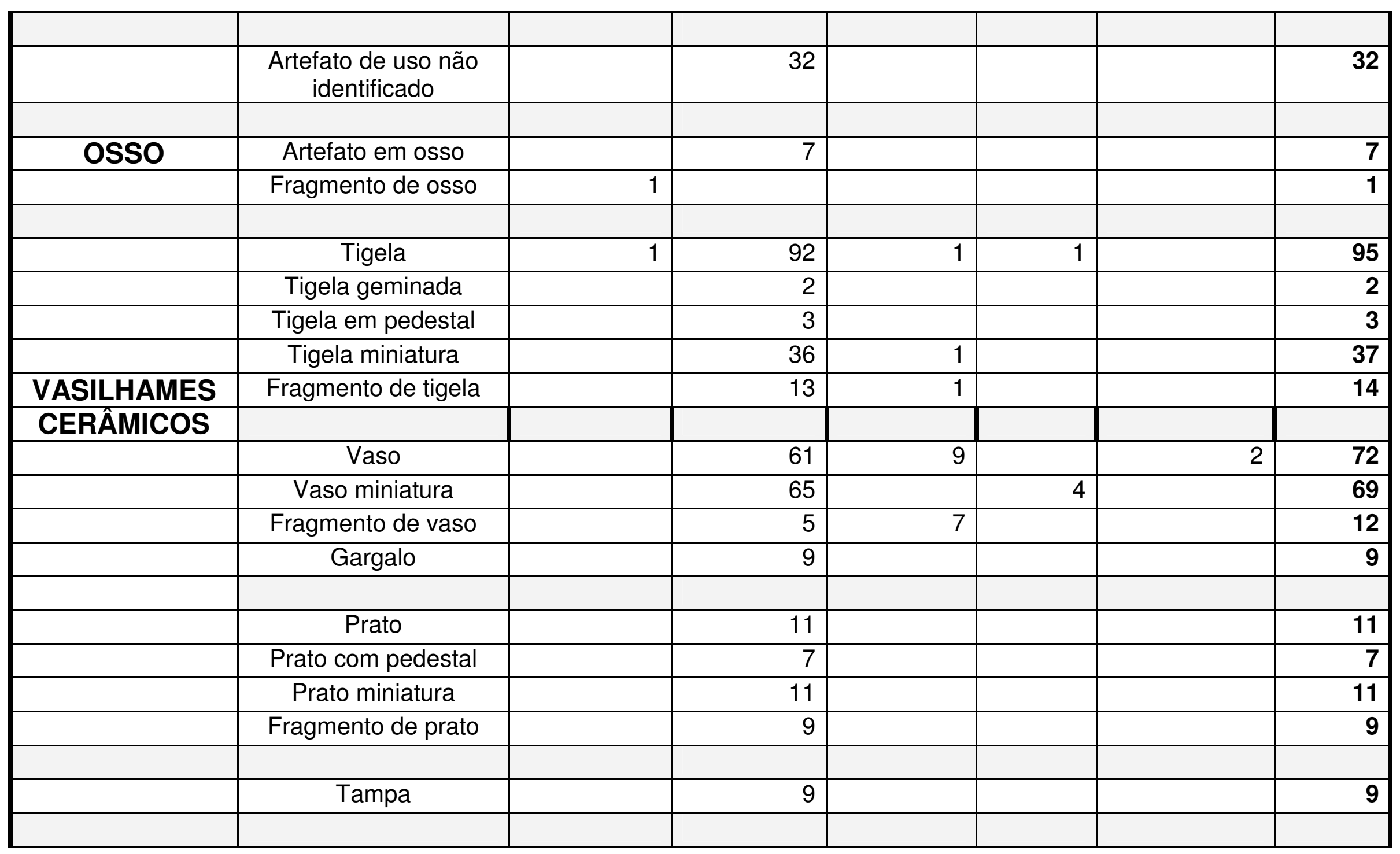




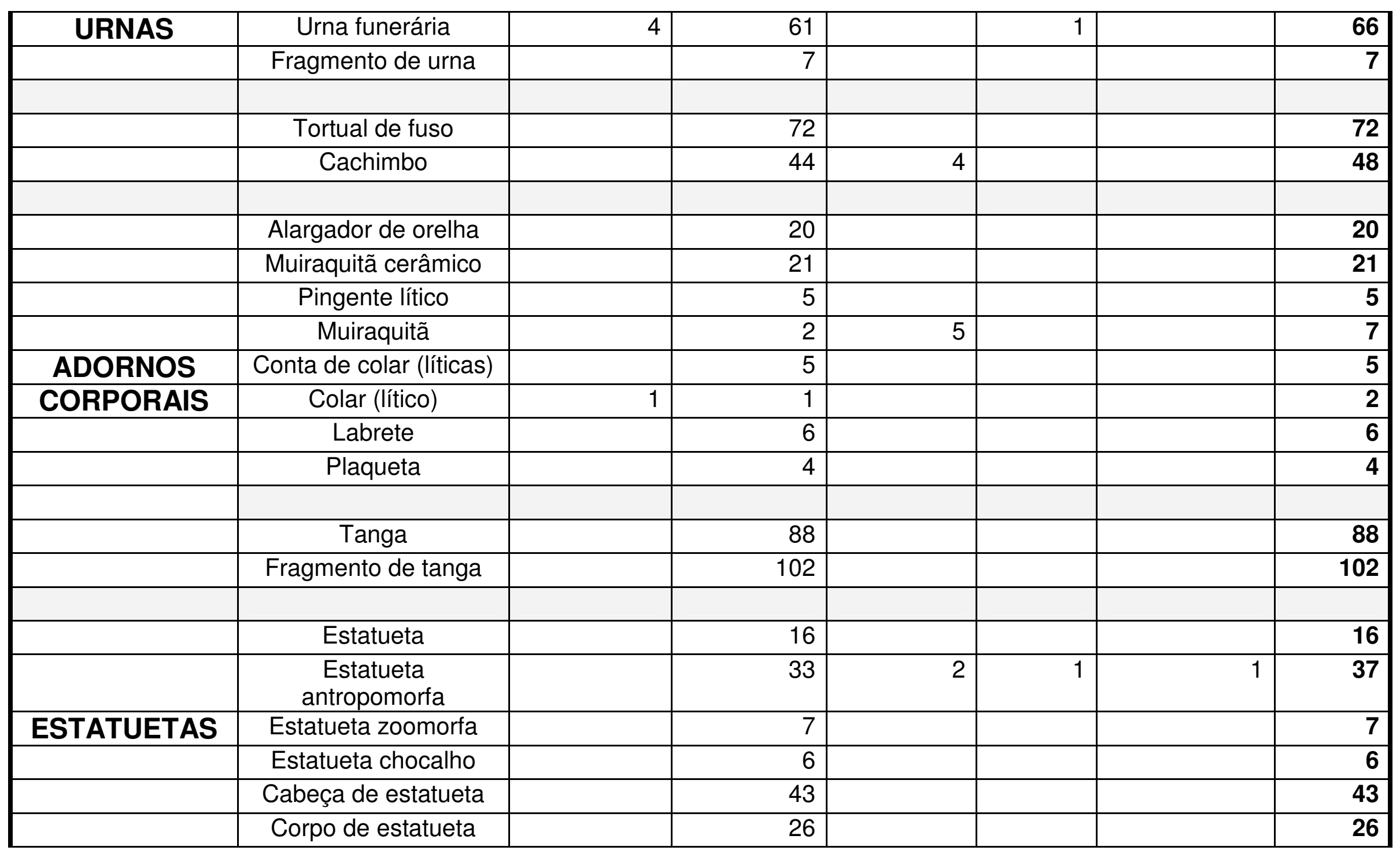




\begin{tabular}{|c|c|c|c|c|c|c|c|}
\hline & Pé de estatueta & & 7 & & 2 & & 9 \\
\hline & $\begin{array}{l}\text { Fragmento de } \\
\text { estatueta }\end{array}$ & & 6 & & & & 6 \\
\hline & Estatueta lítica & 1 & & 1 & & & 2 \\
\hline & & & & & & & \\
\hline & Apêndice & & 73 & 37 & & & 110 \\
\hline & Fragmento cerâmico & 72 & 47 & 277 & & & 396 \\
\hline \multirow[t]{6}{*}{$\begin{array}{l}\text { FRAGMENTOS } \\
\text { CERÂMICOS }\end{array}$} & $\begin{array}{c}\text { Fragmento de } \\
\text { cerâmica decorada }\end{array}$ & & 41 & 82 & & & 123 \\
\hline & Fragmento de borda & 1 & 54 & 51 & & & 106 \\
\hline & Base em pedestal & & 7 & 3 & & & 10 \\
\hline & Fragmento de base & & 4 & 2 & & & 6 \\
\hline & & & & & & & \\
\hline & TOTAL & 231 & 1282 & 504 & 09 & 03 & 2029 \\
\hline
\end{tabular}

* Tabela elaborada a partir do banco de dados realizado pela equipe do MAE quando do acolhimento da coleção ICBS em 2005 e modificado por Cristiana Barreto em julho de 2007 
Anexo 2 


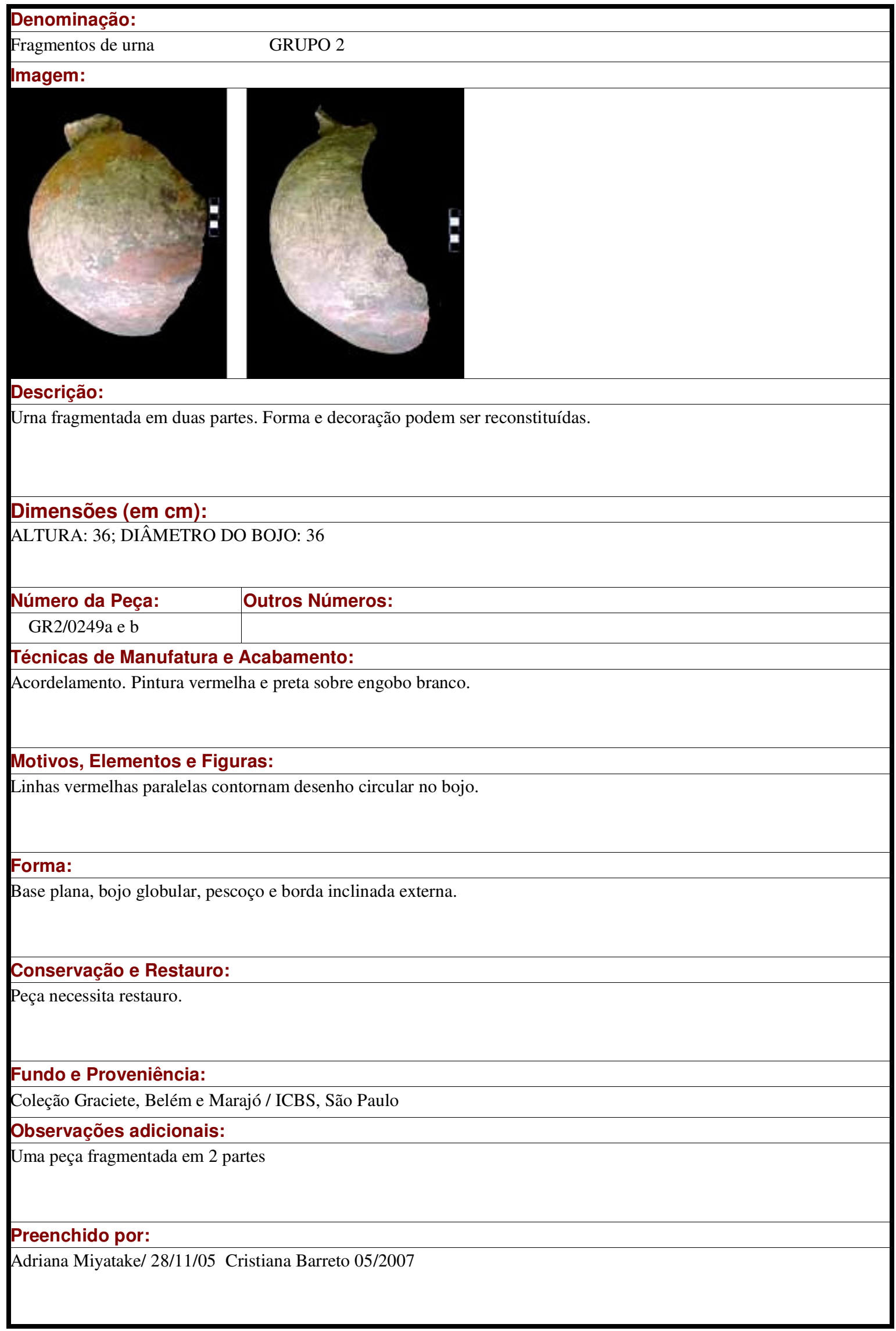




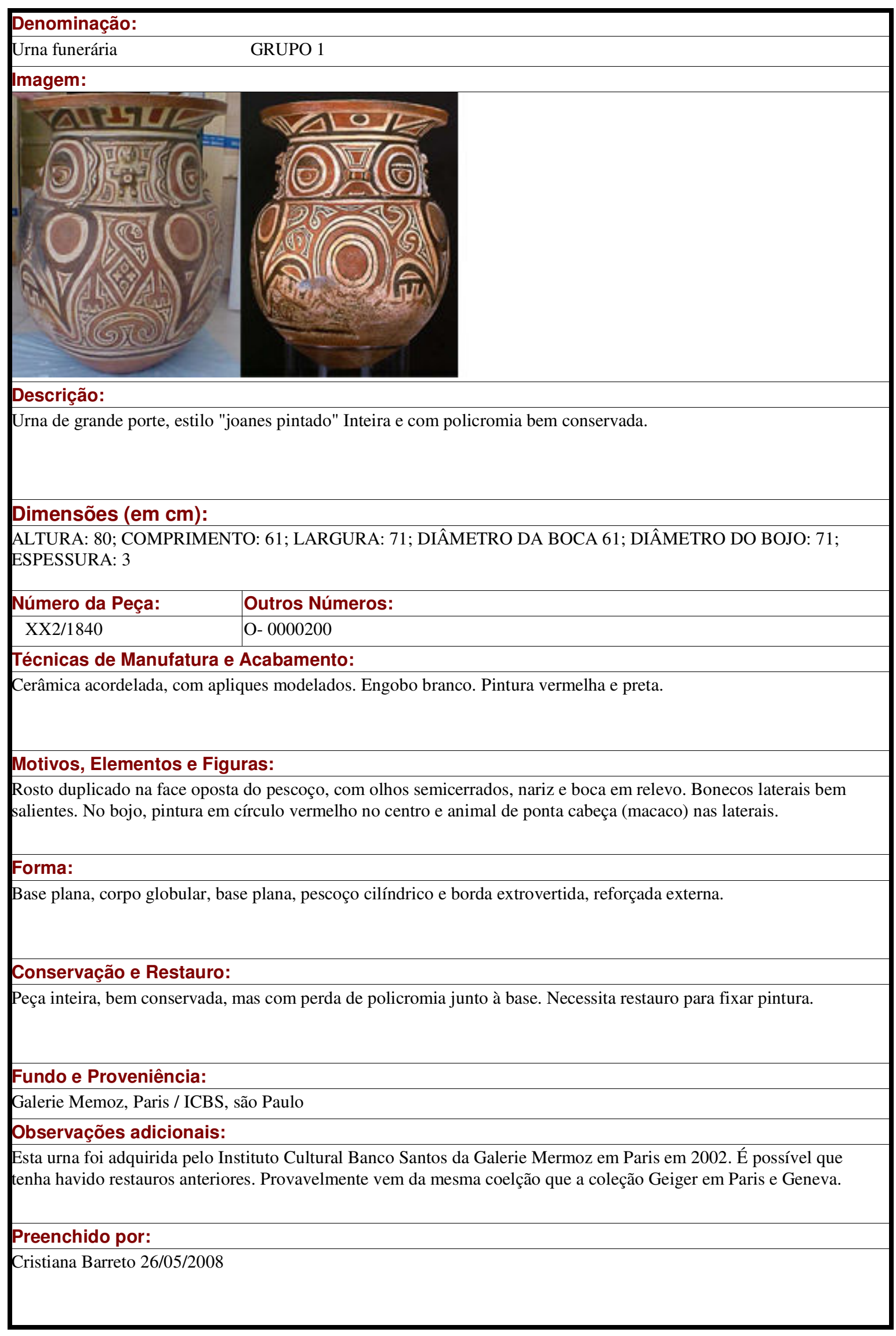




\begin{tabular}{|c|c|}
\hline \multicolumn{2}{|l|}{ Denominação: } \\
\hline Urna funerária & GRUPO 1 \\
\hline \multicolumn{2}{|l|}{ Imagem: } \\
\hline \multicolumn{2}{|c|}{ 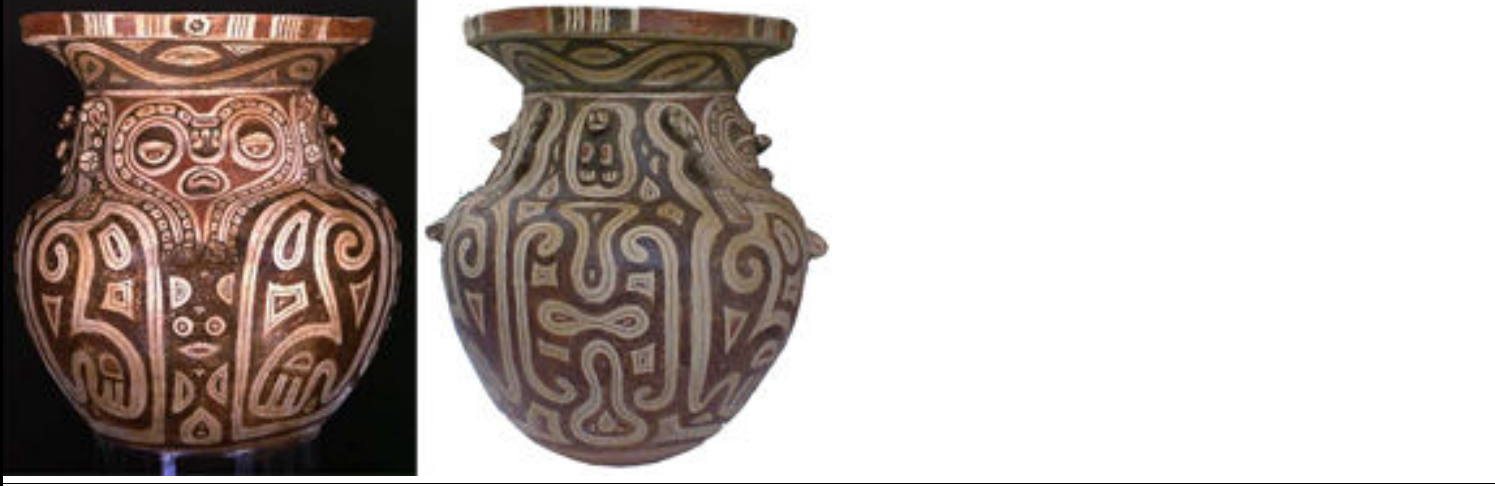 } \\
\hline \multicolumn{2}{|c|}{ Descrição: } \\
\hline \multicolumn{2}{|c|}{ Urna funerária do tipo "joanes pintado". Peça de grande porte, inteira, com a borda completa. } \\
\hline \multicolumn{2}{|c|}{ Dimensões (em cm): } \\
\hline \multicolumn{2}{|c|}{ ALTURA: 62; COMPRIMENTO: 64; LARGURA: 81; ESPESSURA: 3} \\
\hline Número da Peça: & Outros Números: \\
\hline $\mathrm{XX} 2 / 1839$ & O-0000199 \\
\hline \multicolumn{2}{|c|}{ Técnicas de Manufatura e Acabamento: } \\
\hline \multicolumn{2}{|c|}{ Acordelamento. Apliques modelados. Engobo branco. Pintura vermelha e preta. } \\
\hline \multicolumn{2}{|c|}{ Motivos, Elementos e Figuras: } \\
\hline \multicolumn{2}{|c|}{$\begin{array}{l}\text { Rosto duplicado nas faces opostas do pescoço com olhos semicerrados, nariz, boca, orelhas e brincos em relevo. } \\
\text { Bonecos laterais pouco detalhados. Cilindro horizntal em relevo perfurado. Faixa central com rosto no meio, ladeada } \\
\text { por membros e garras. }\end{array}$} \\
\hline \multicolumn{2}{|l|}{ Forma: } \\
\hline \multicolumn{2}{|c|}{$\begin{array}{l}\text { Base estreita e plana, corpo globular tendendo a piriforme, pescoço inclinado interno, borda longa e extrovertida. } \\
\text { Motivo em faixa ondulada na borda reflete os olhos do plano abaixo. Lábios planos com pintura, }\end{array}$} \\
\hline \multicolumn{2}{|c|}{ Conservação e Restauro: } \\
\hline \multicolumn{2}{|c|}{ Possivelmente restaurada antes de ir para o ICBS. } \\
\hline \multicolumn{2}{|l|}{ Fundo e Proveniência: } \\
\hline \multicolumn{2}{|c|}{ Galerie Mermoz, Paris / ICBS, São Paulo } \\
\hline \multicolumn{2}{|c|}{ Observações adicionais: } \\
\hline \multicolumn{2}{|c|}{ Possivelmente esta urna provêm da mesma coleção "Geiger" na Suíça, com mais materiais arqueológicos da Amazônia. } \\
\hline \multicolumn{2}{|l|}{ Preenchido por: } \\
\hline Cristiana Barreto 03/2008 & \\
\hline
\end{tabular}




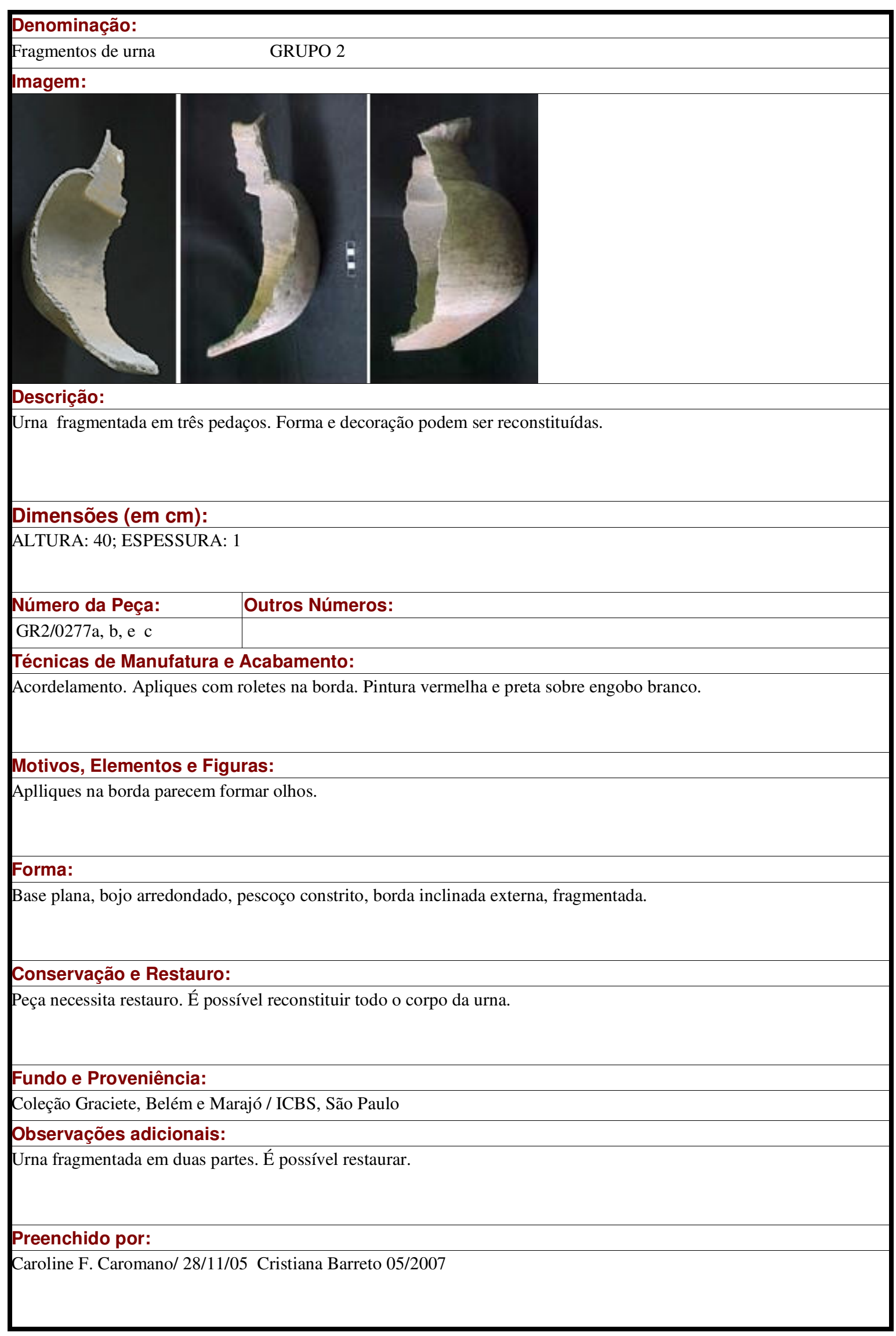




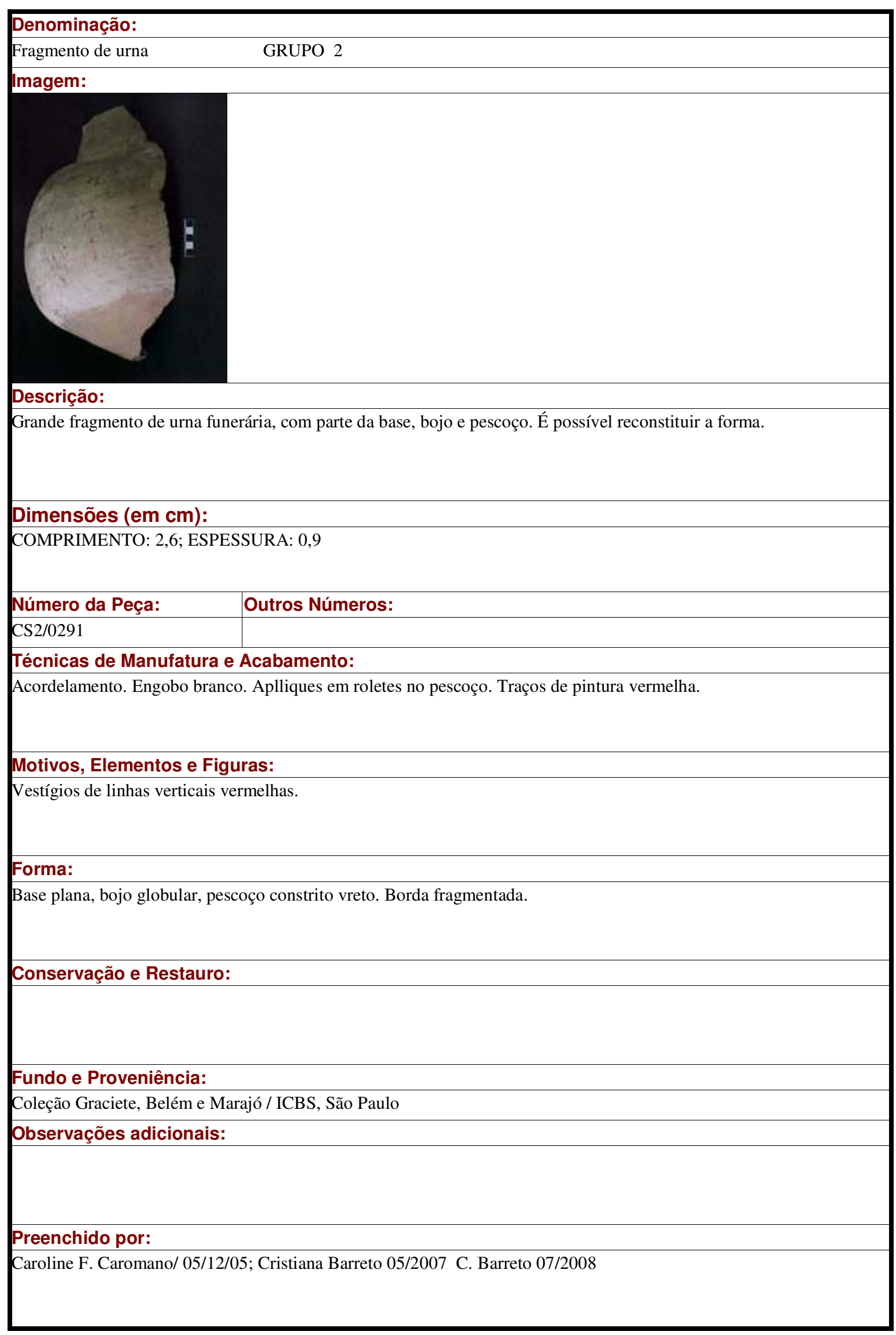




\section{Denominação:}

Urna funerária GRUPO 2

Imagem:

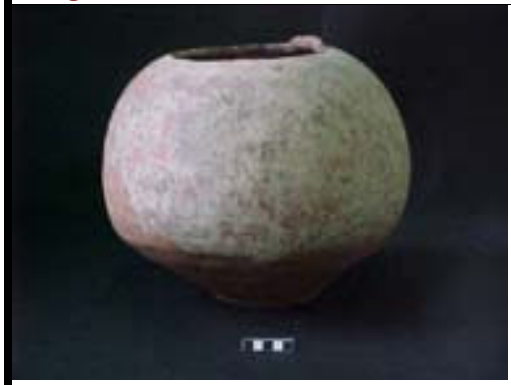

\section{Descrição:}

Urna de pequeno porte, com borda fragmentada e pintura erodida.

\section{Dimensões (em cm):}

ALTURA: 29; DIÂMETRO DO BOJO: 56

Número da Peça: $\quad$ Outros Números:

GR2/0292

Técnicas de Manufatura e Acabamento:

Acordelamento. Alisamento, engobo branco e pintura vermelha.

Motivos, Elementos e Figuras:

Não é possivel identificar os motivos.

Forma:

Base pequena e plana, bojo globular tendendo a piriforme, pescoço constrito fragmentado na junção com o bojo.

Conservação e Restauro:

Fundo e Proveniência:

Coleção Graciete, Belém e Marajó / ICBS, São Paulo

Observações adicionais:

Preenchido por:

Adriana Miyatake 29/11/05 Cristiana Barreto 05/2007 


\section{Denominação:}

Urna funerária GRUPO 2

Imagem:

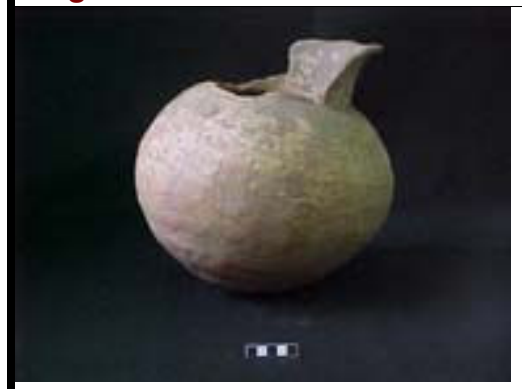

\section{Descrição:}

Urna de pequeno porte, com parte do pescoço e borda fragmentada. Pintura bem erodida.

\section{Dimensões (em cm):}

ALTURA: 30; DIÂMETRO DO BOJO: 48

Número da Peça: $\quad$ Outros Números:

GR2/0293

Técnicas de Manufatura e Acabamento:

Acordelamento. Engob branco, pintura vermelha e preta no bojo e pescoço.

Motivos, Elementos e Figuras:

Linhas paralelas entre pescoço e bojo. Desenhos em zigue-zague.

\section{Forma:}

Base plana, bojo globular, pescoço constrito, borda extrovertida, fragmentada.

\section{Conservação e Restauro:}

Necessita limpeza e restauro.

Fundo e Proveniência:

Coleção Graciete, Belém e Marajó / ICBS, São Paulo

Observações adicionais:

Preenchido por:

Adriana Miyatake 29/11/05 Cristiana Barreto 05/2007 


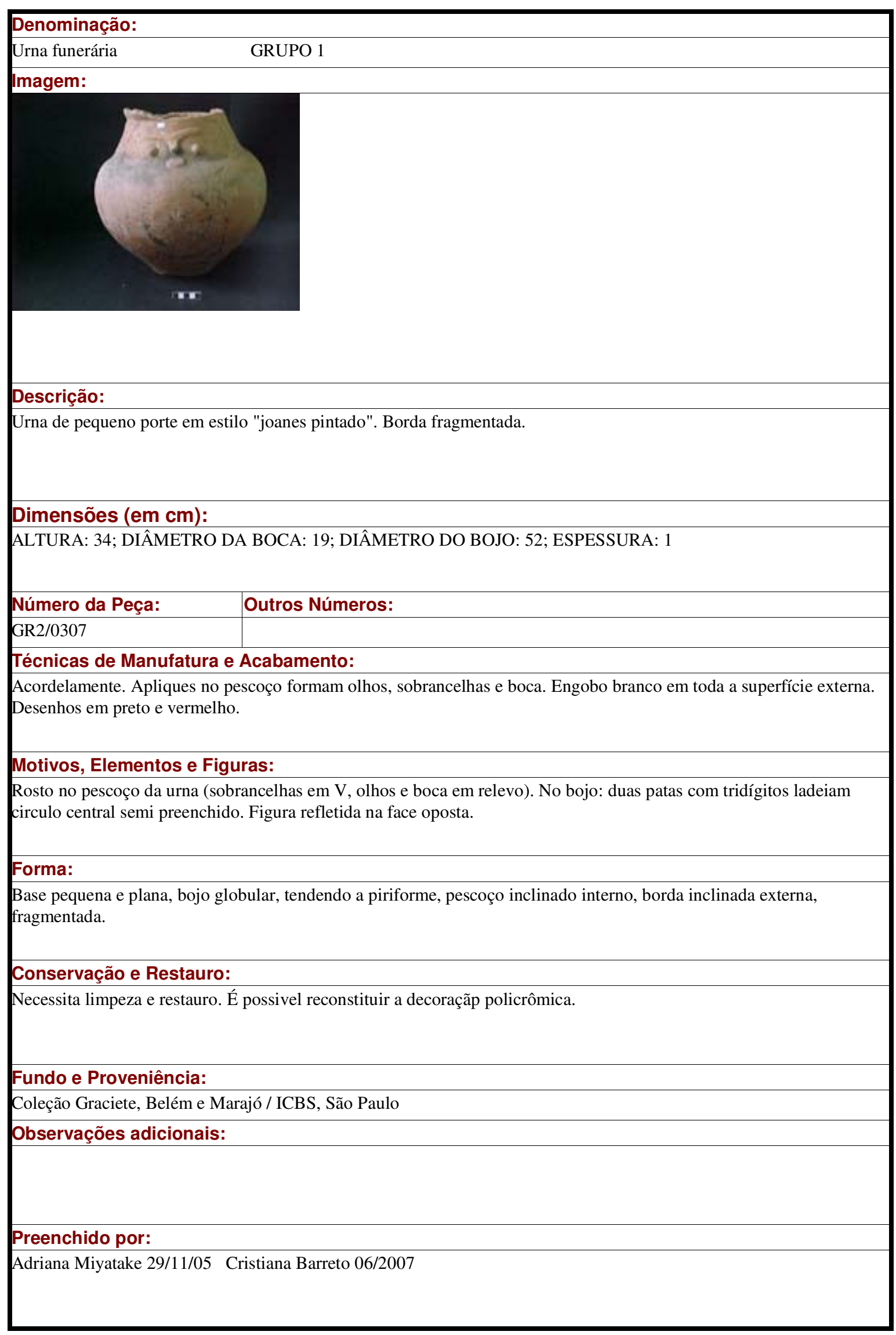




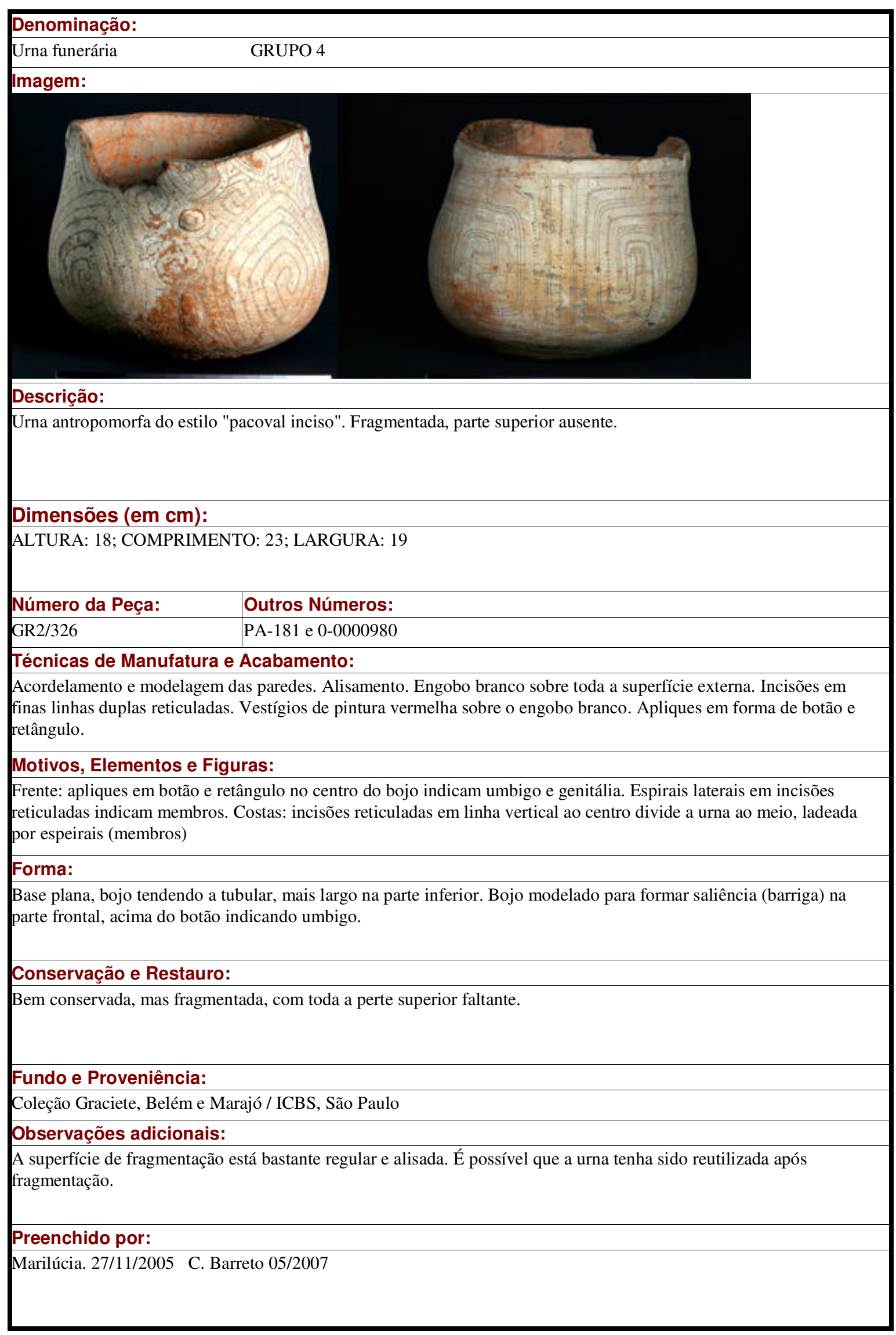




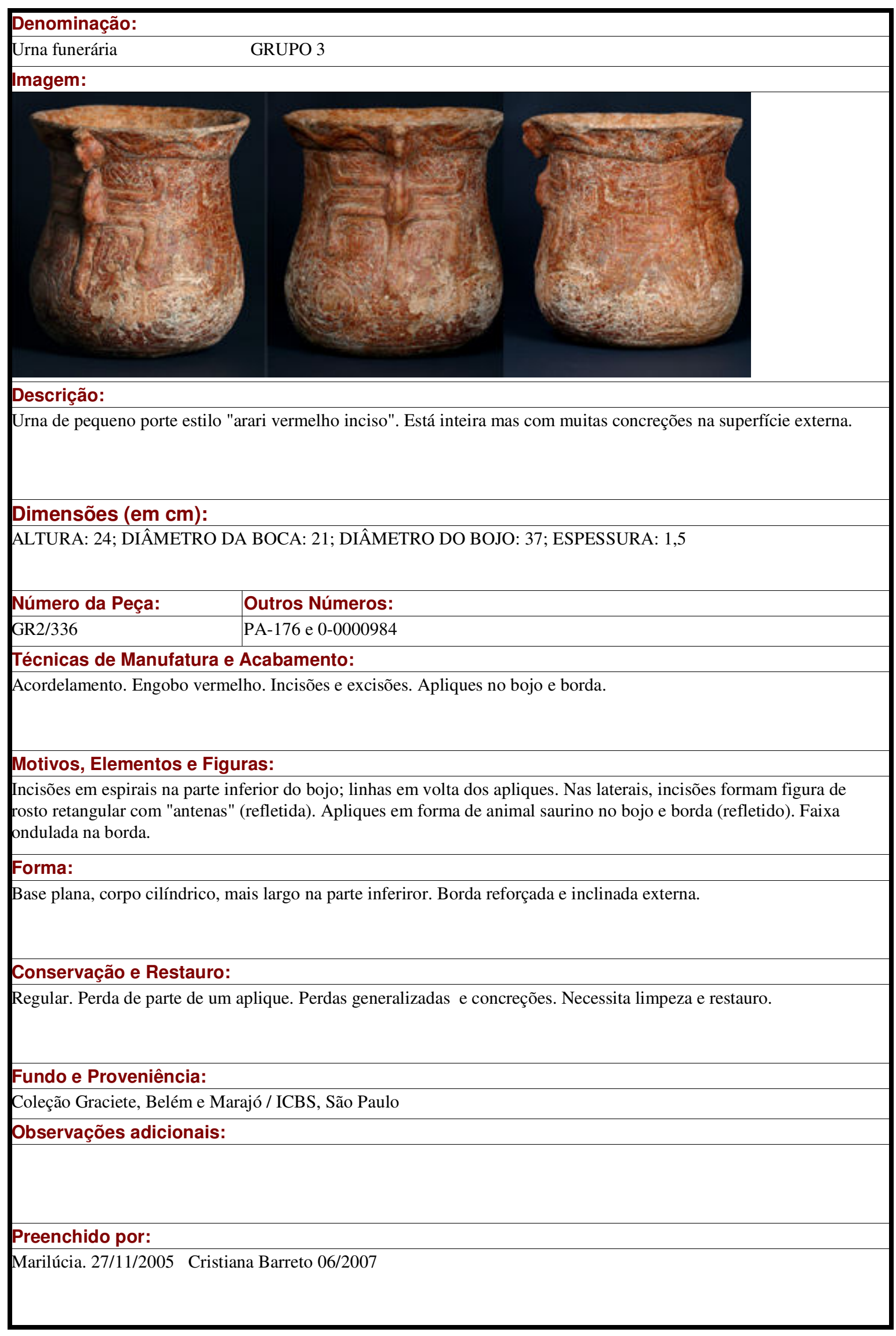




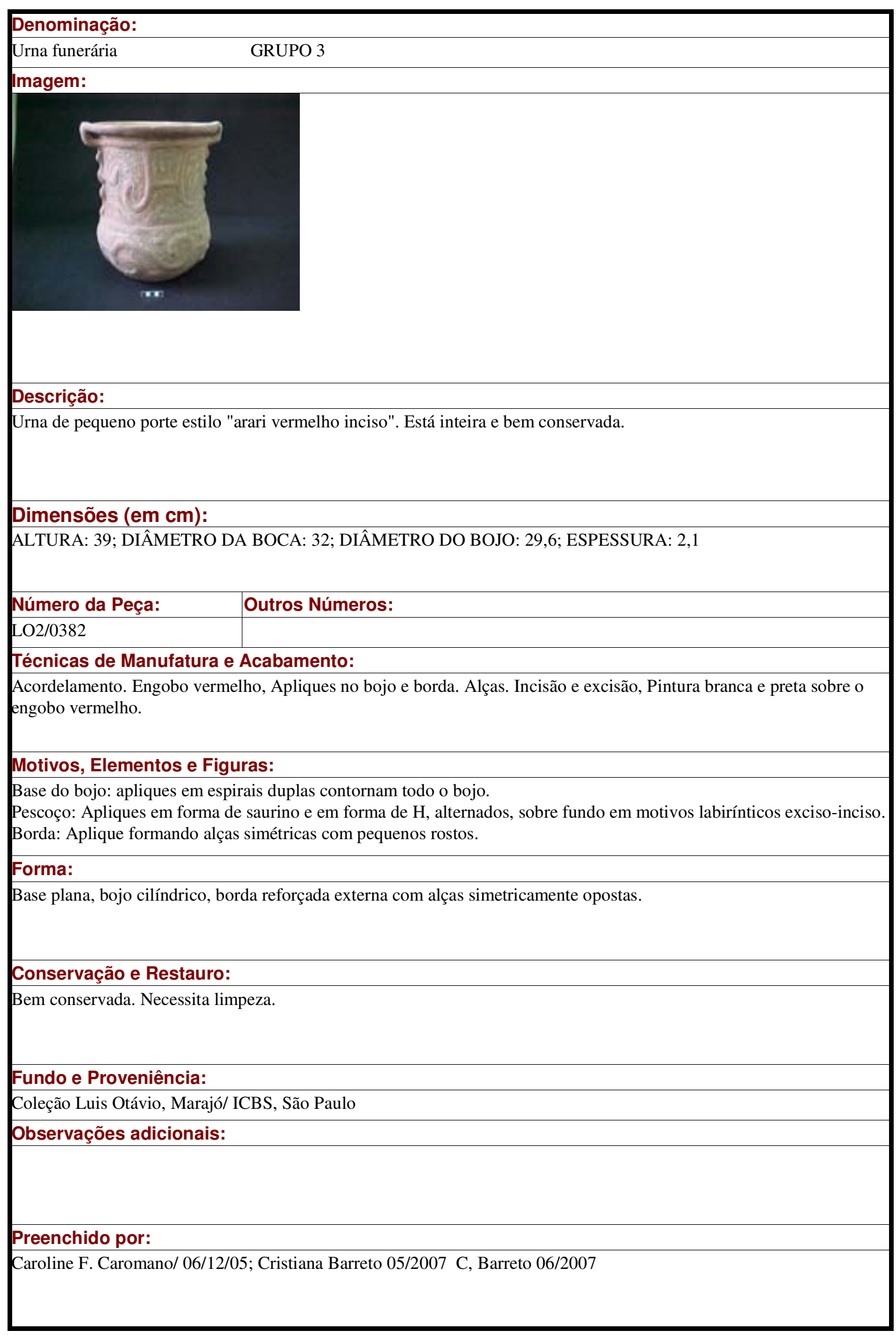




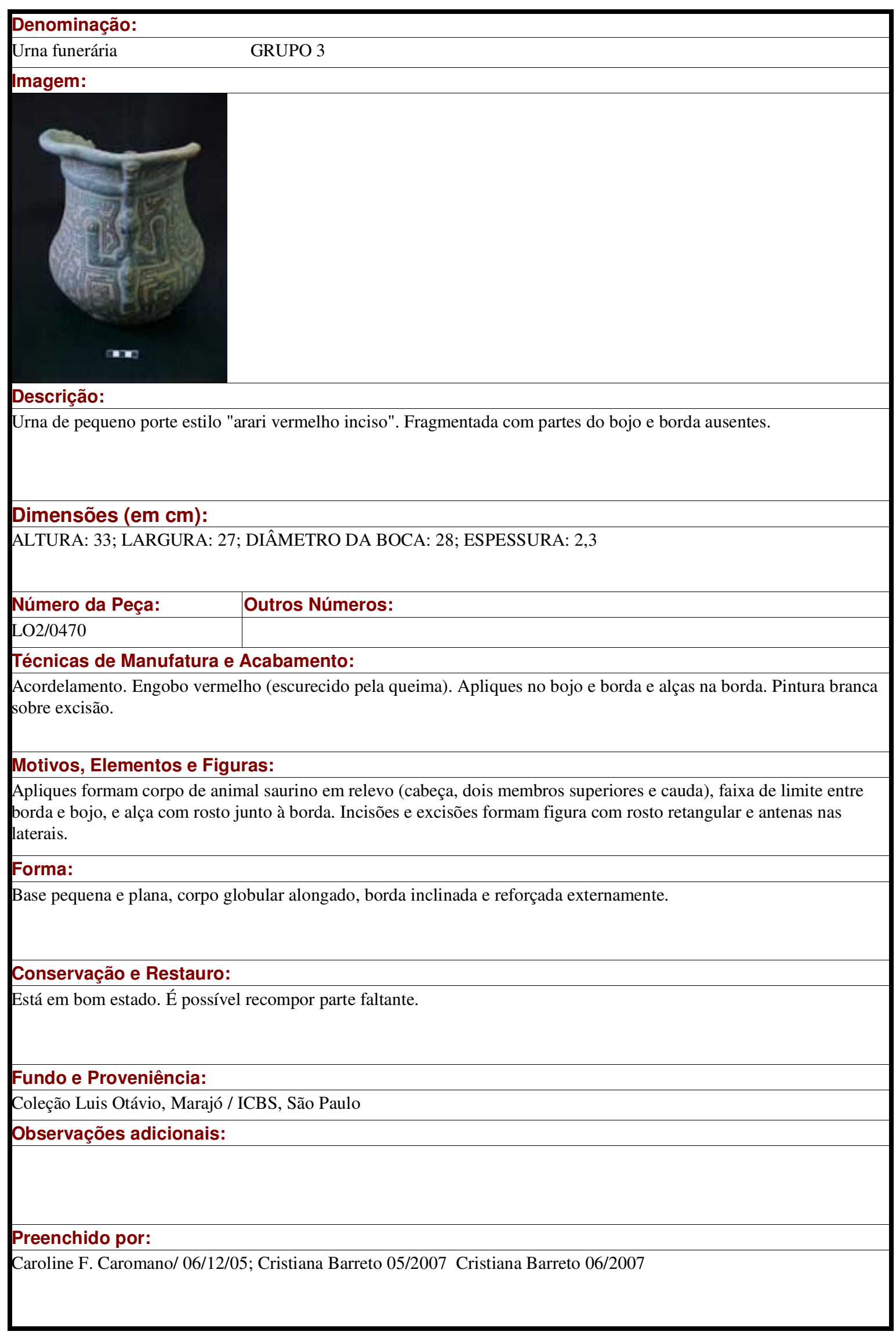




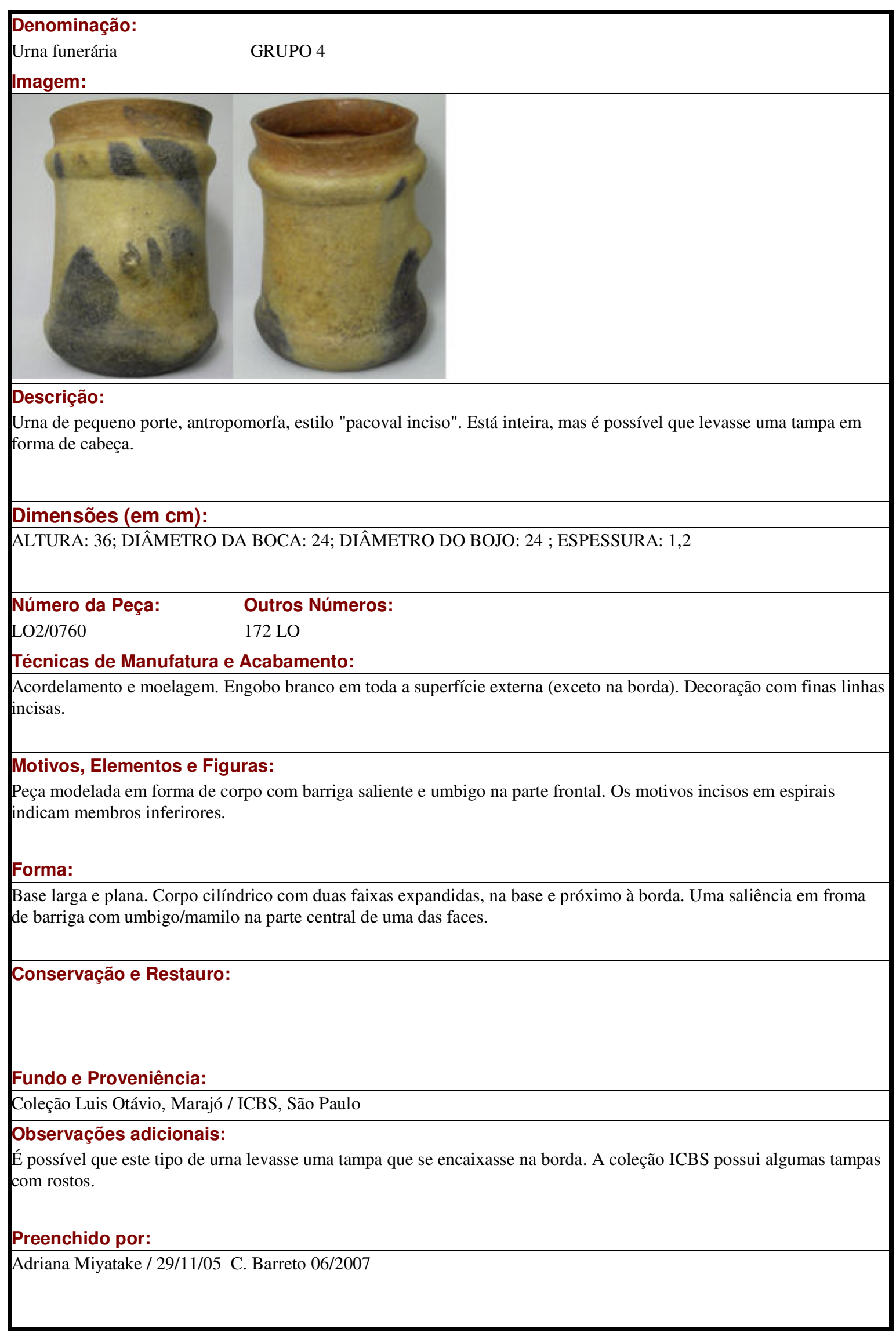




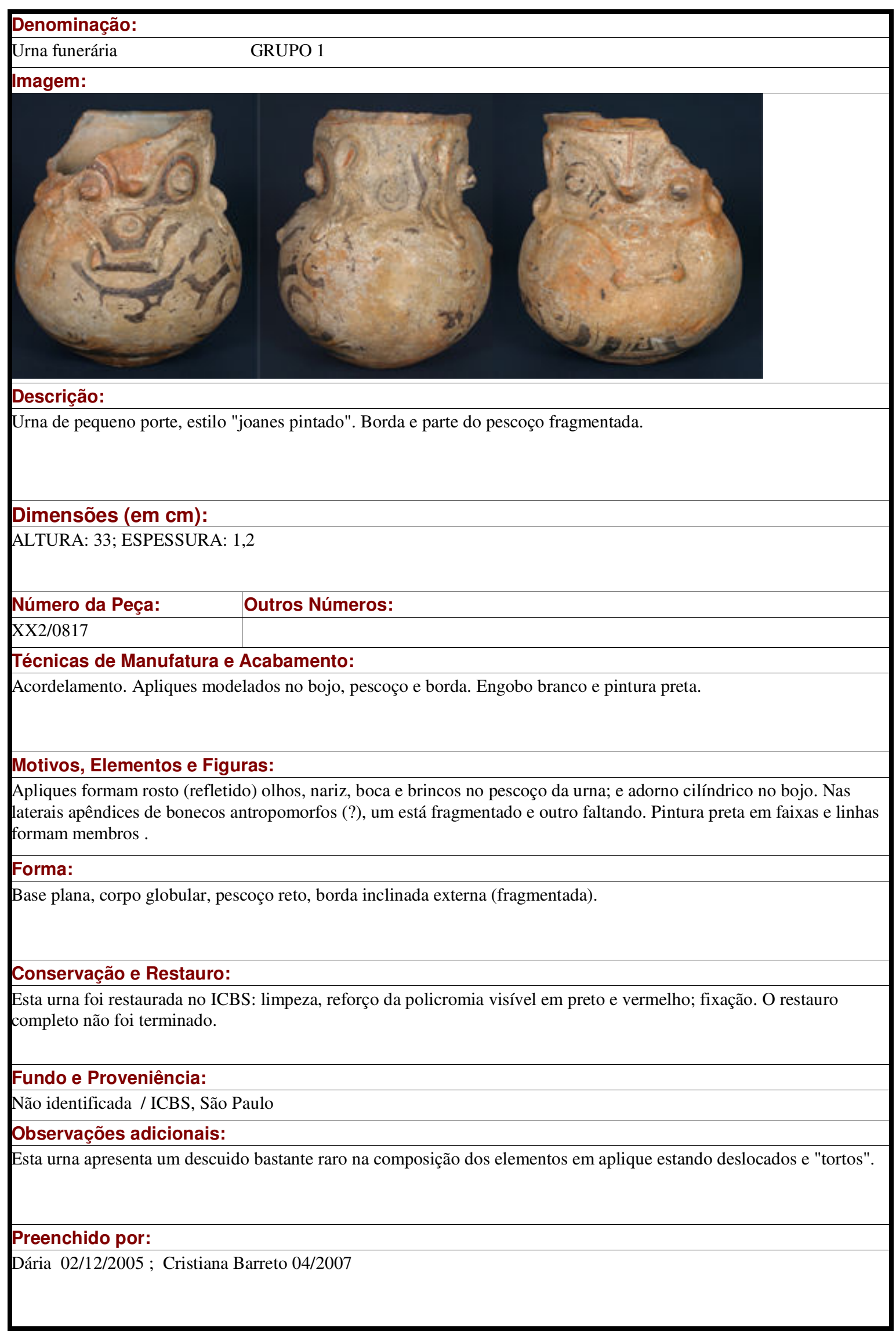




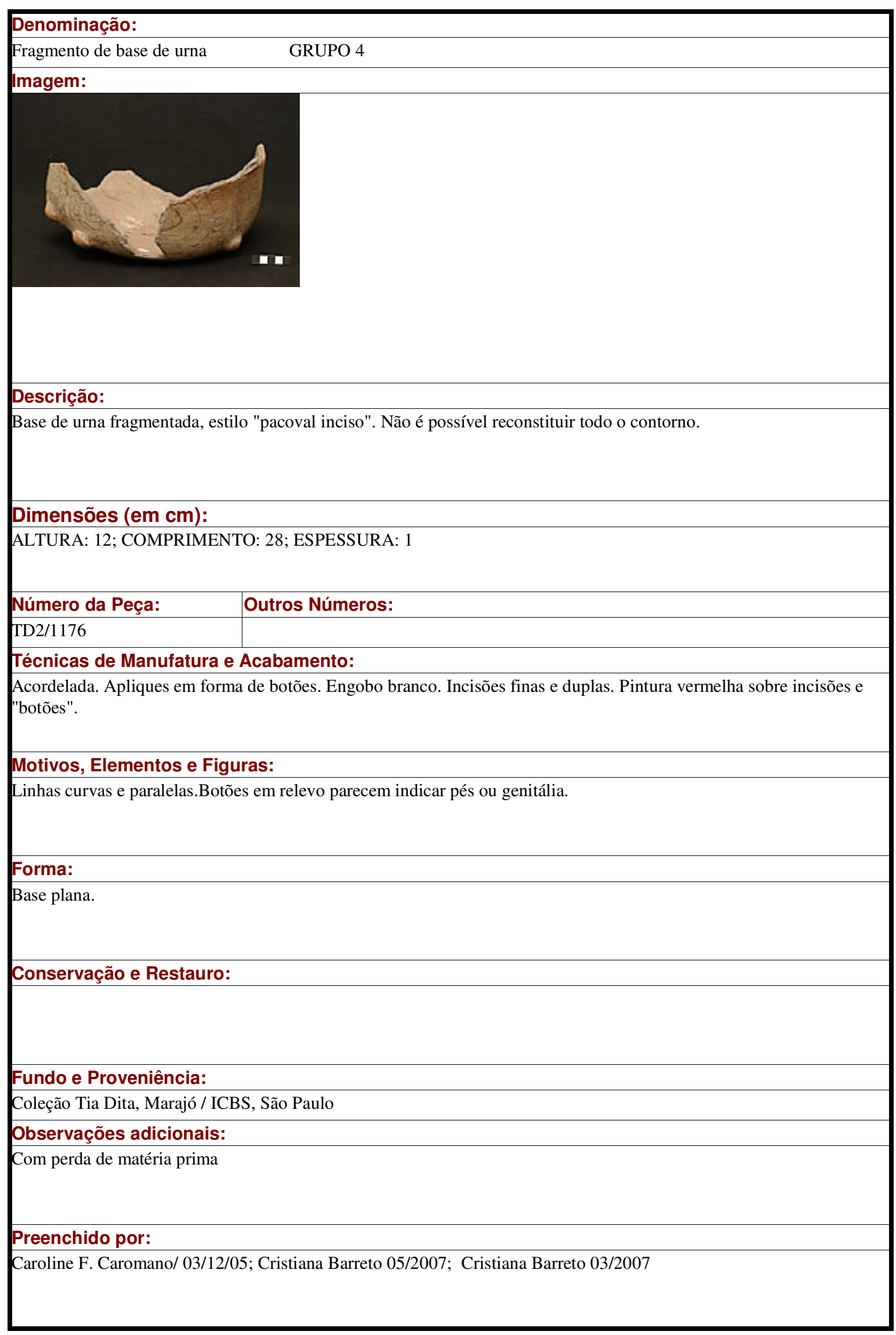




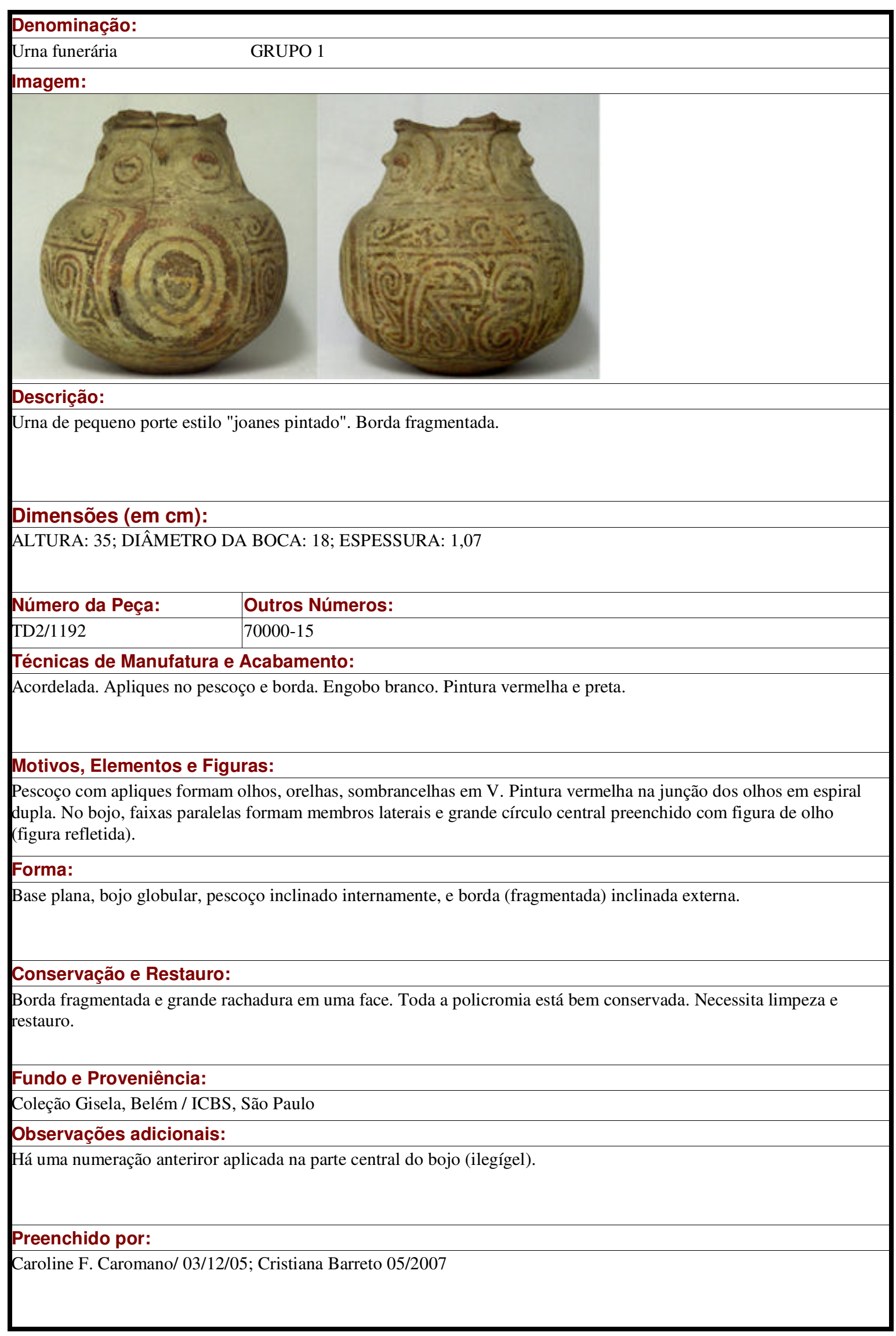




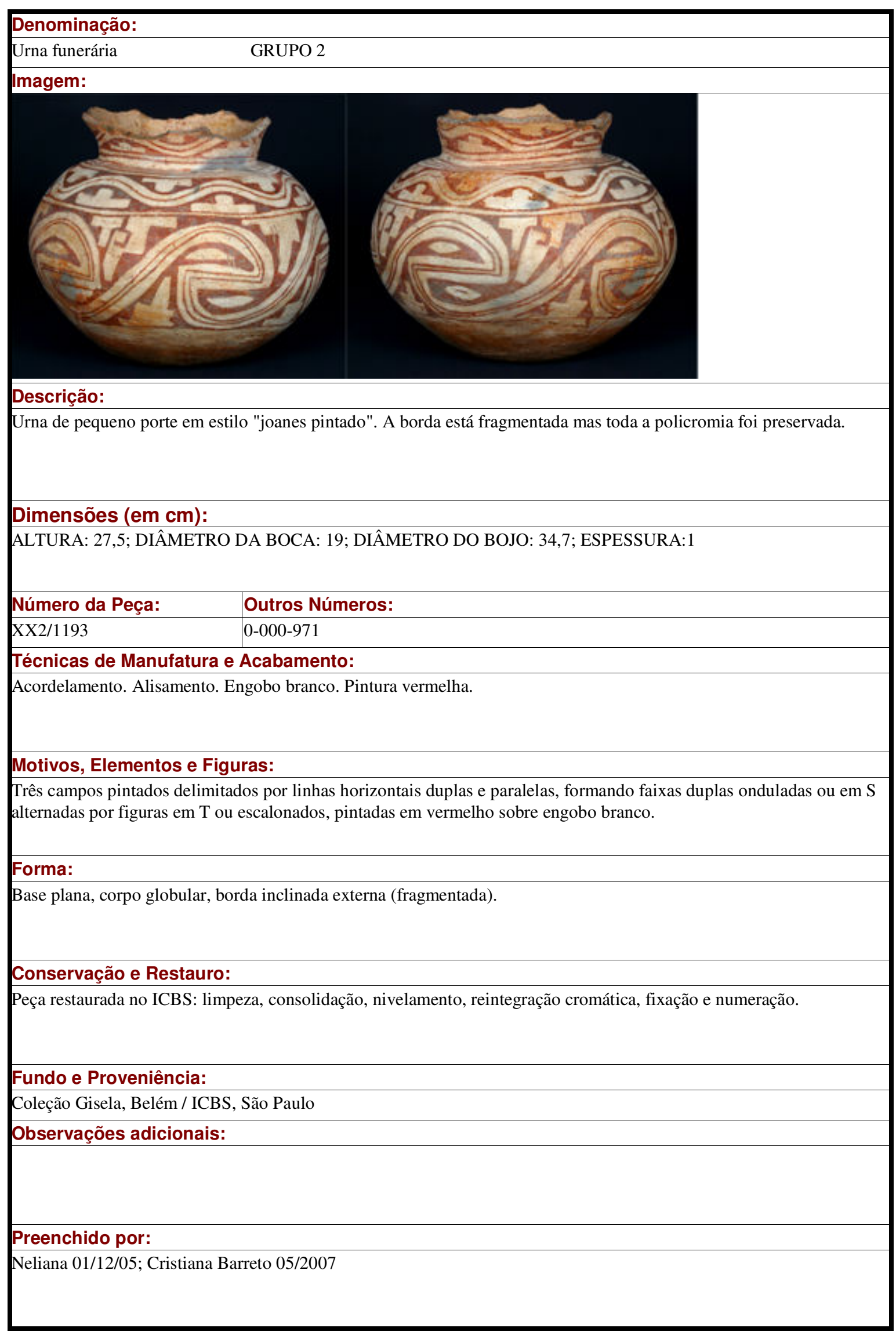




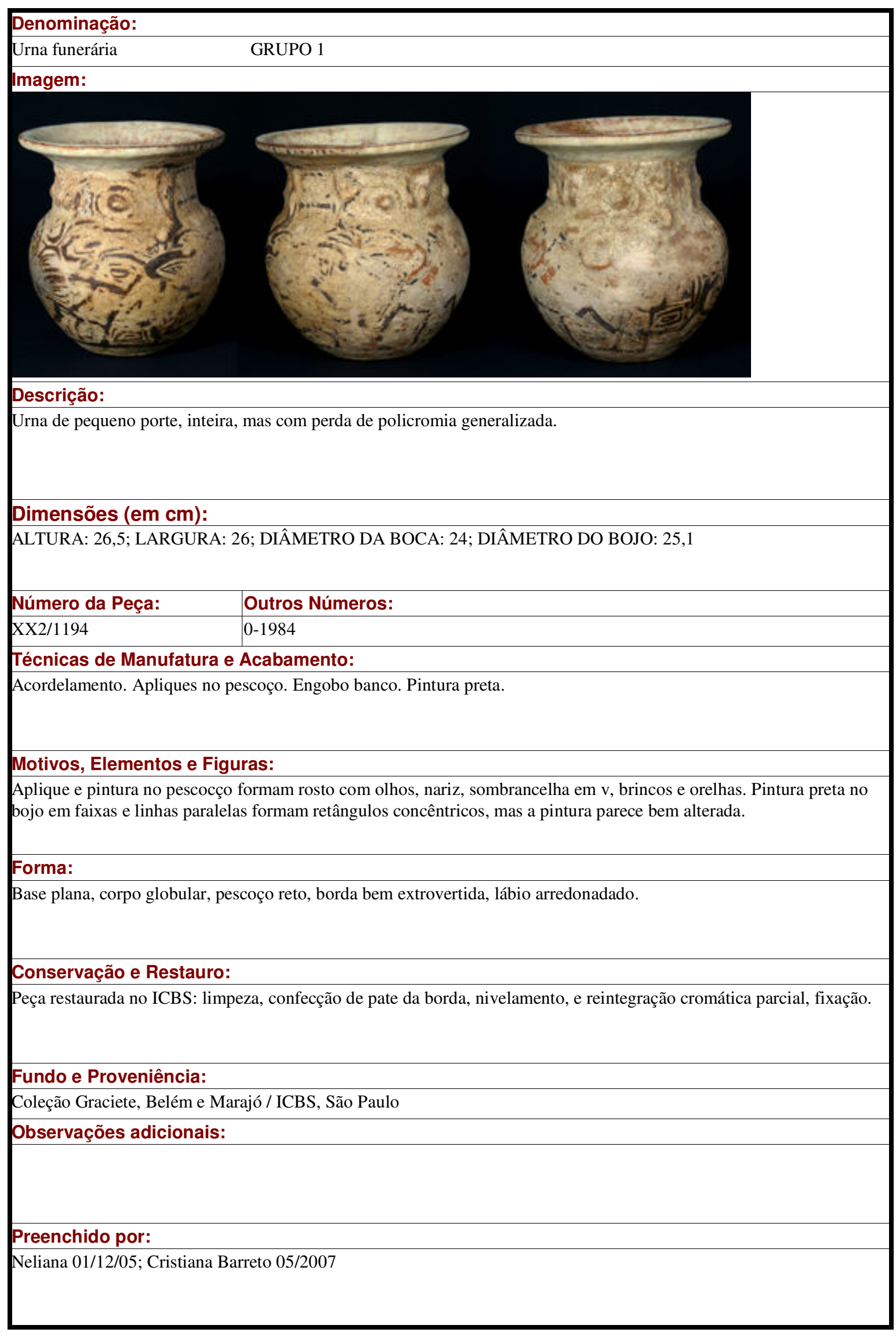




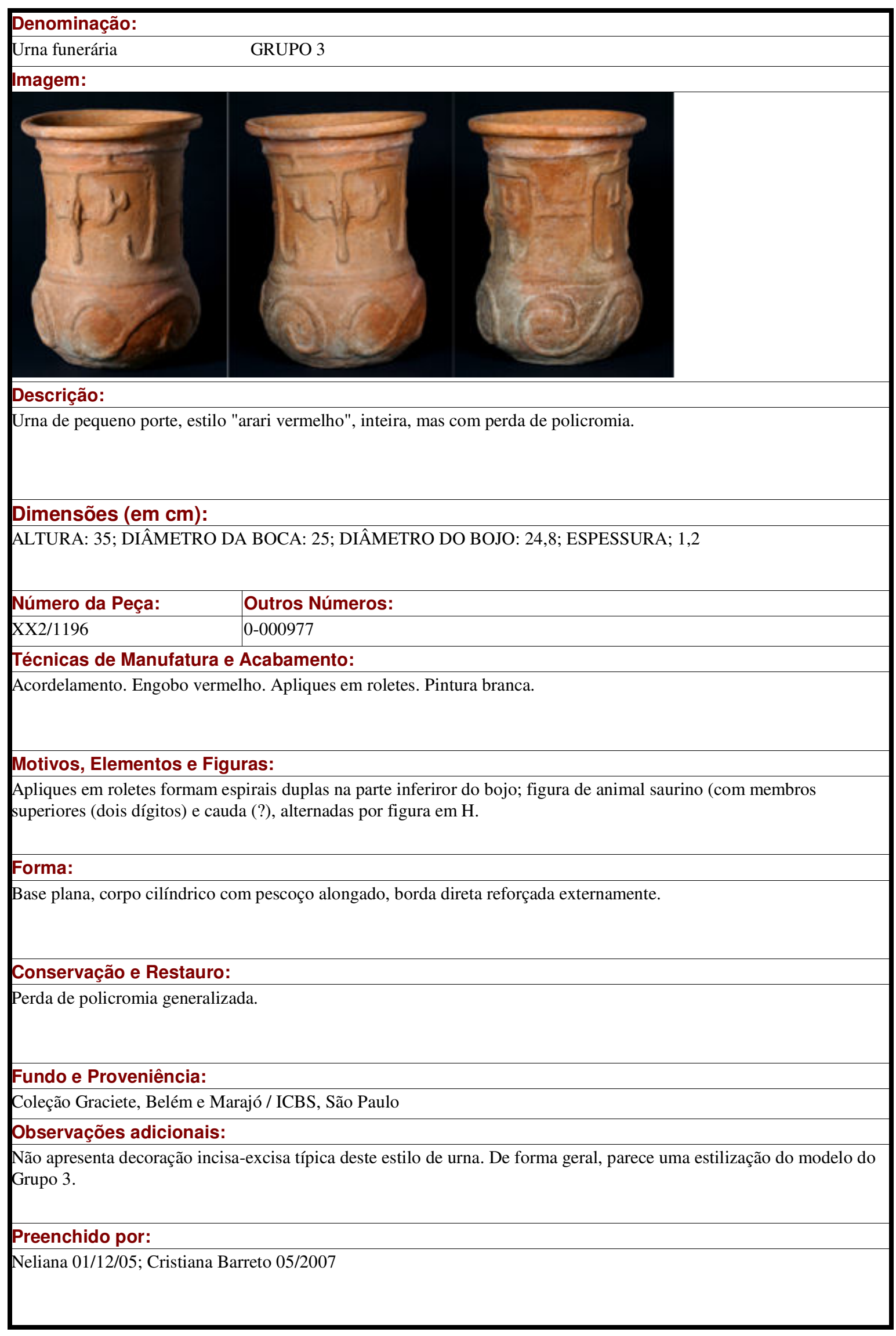




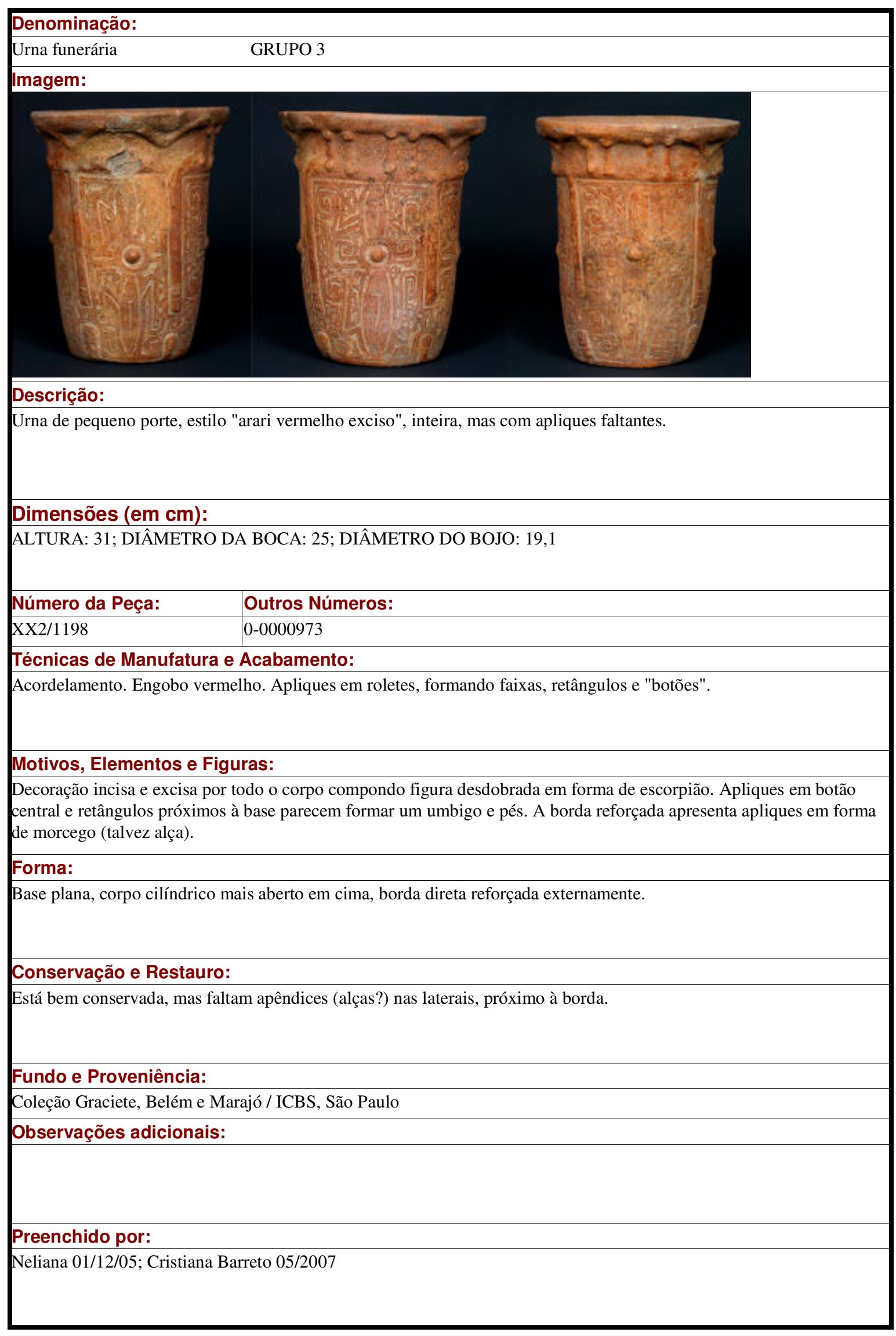




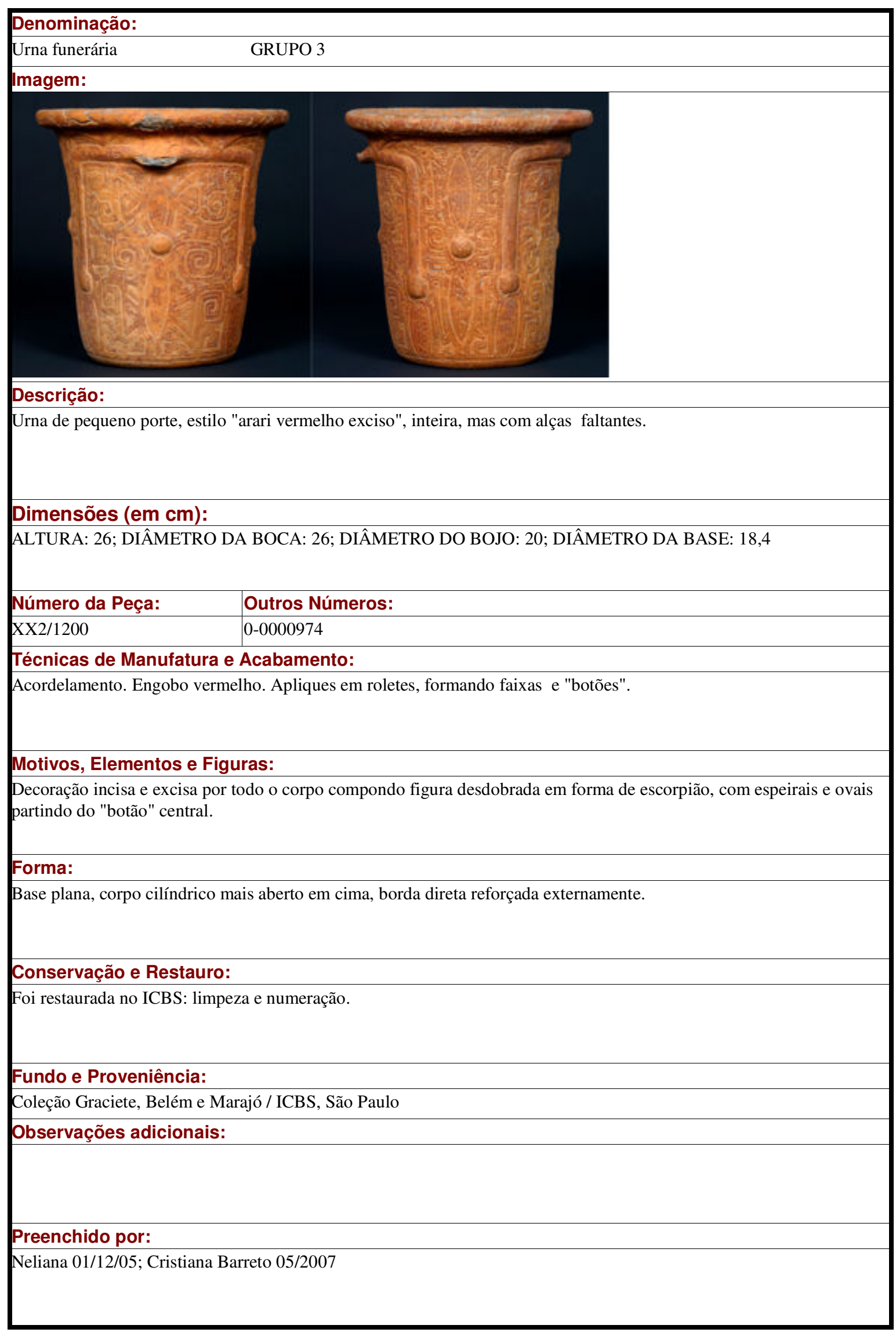




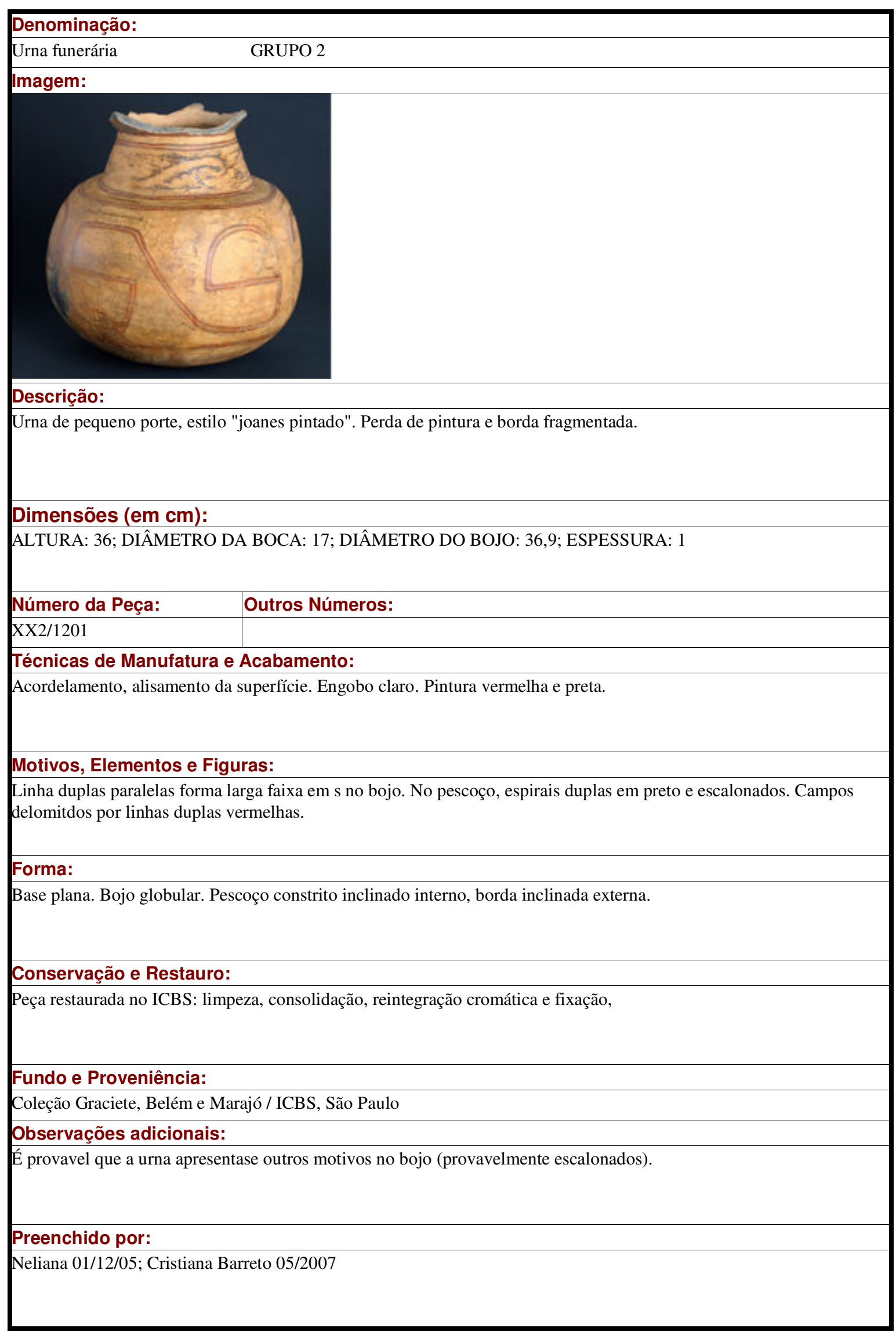




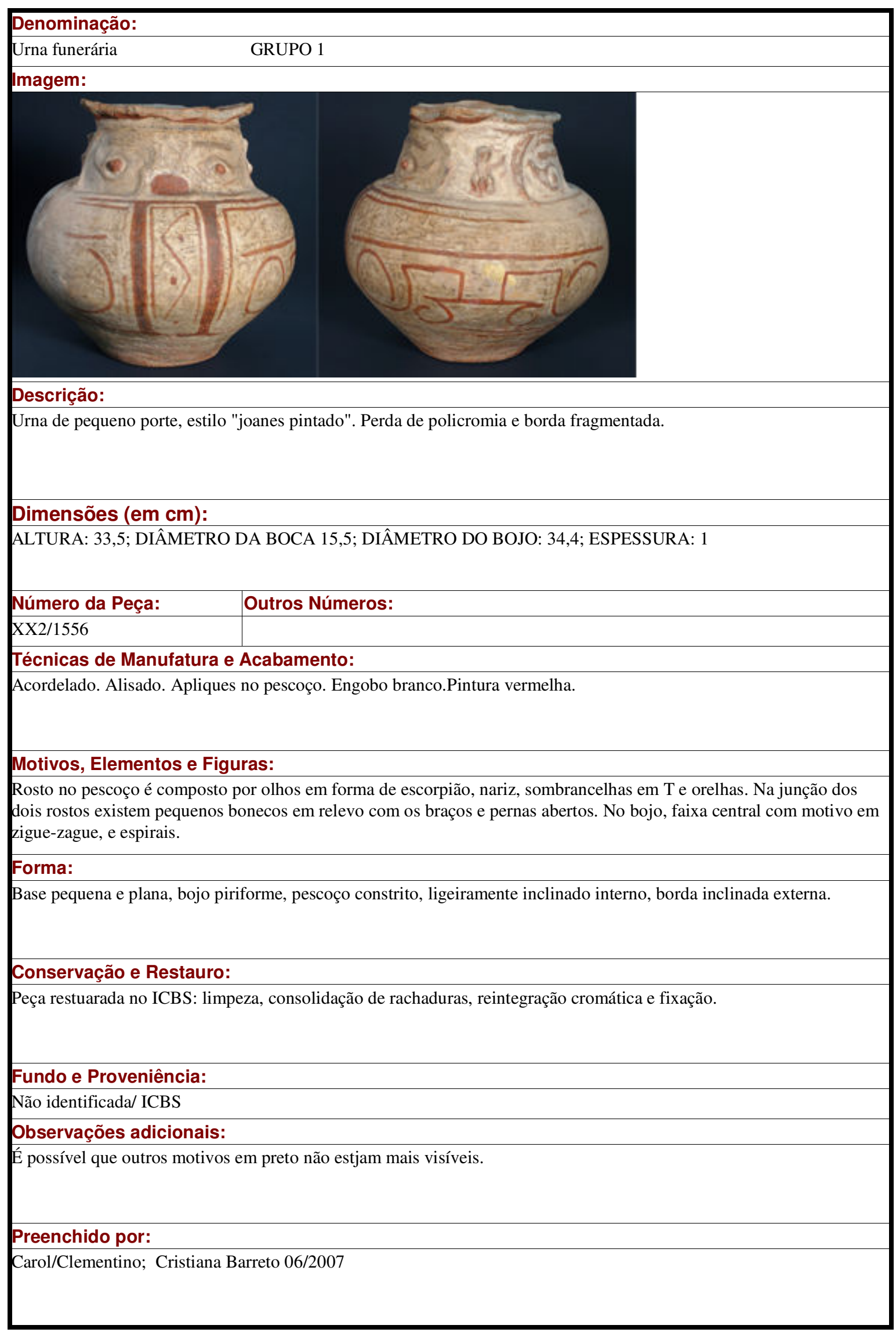




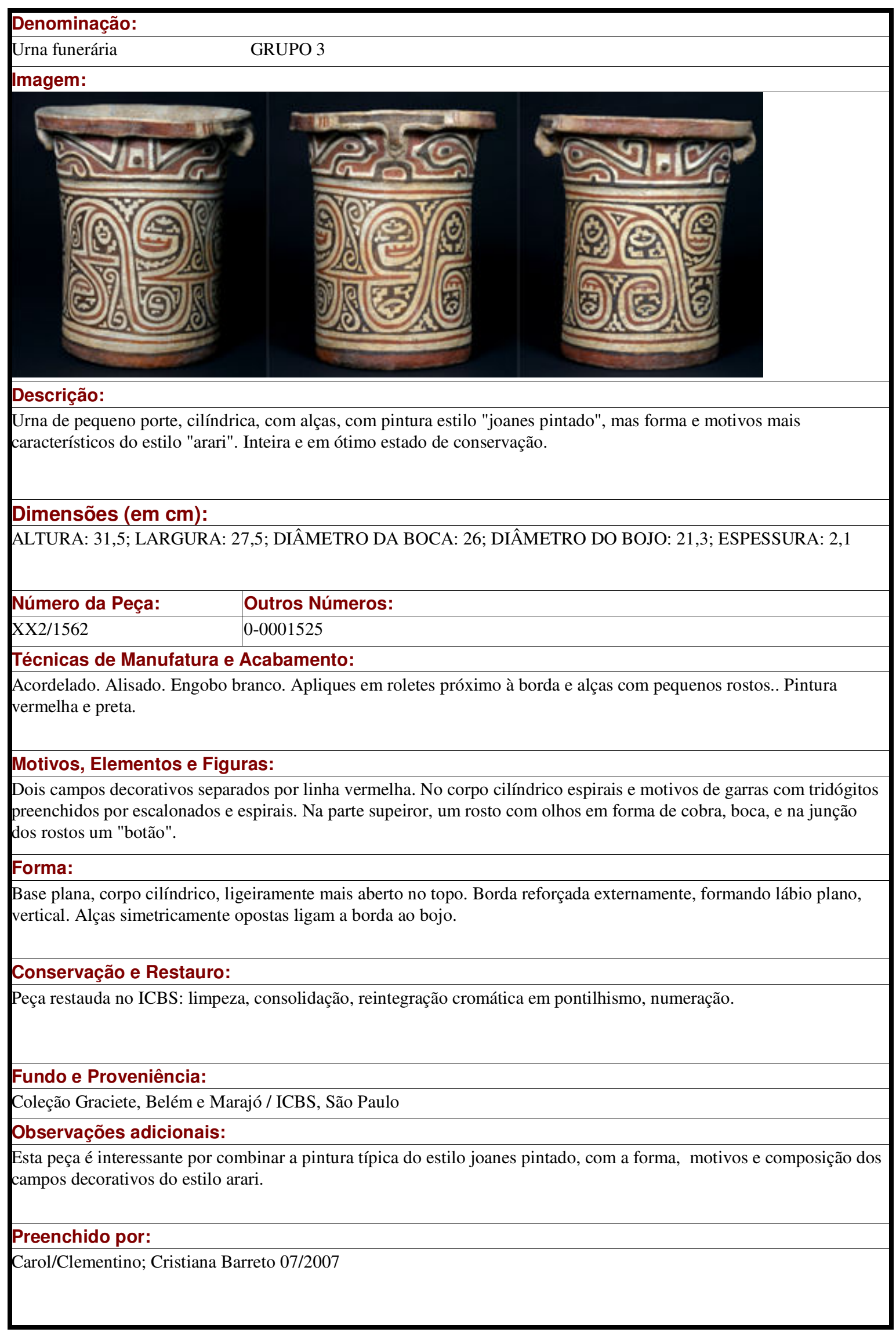




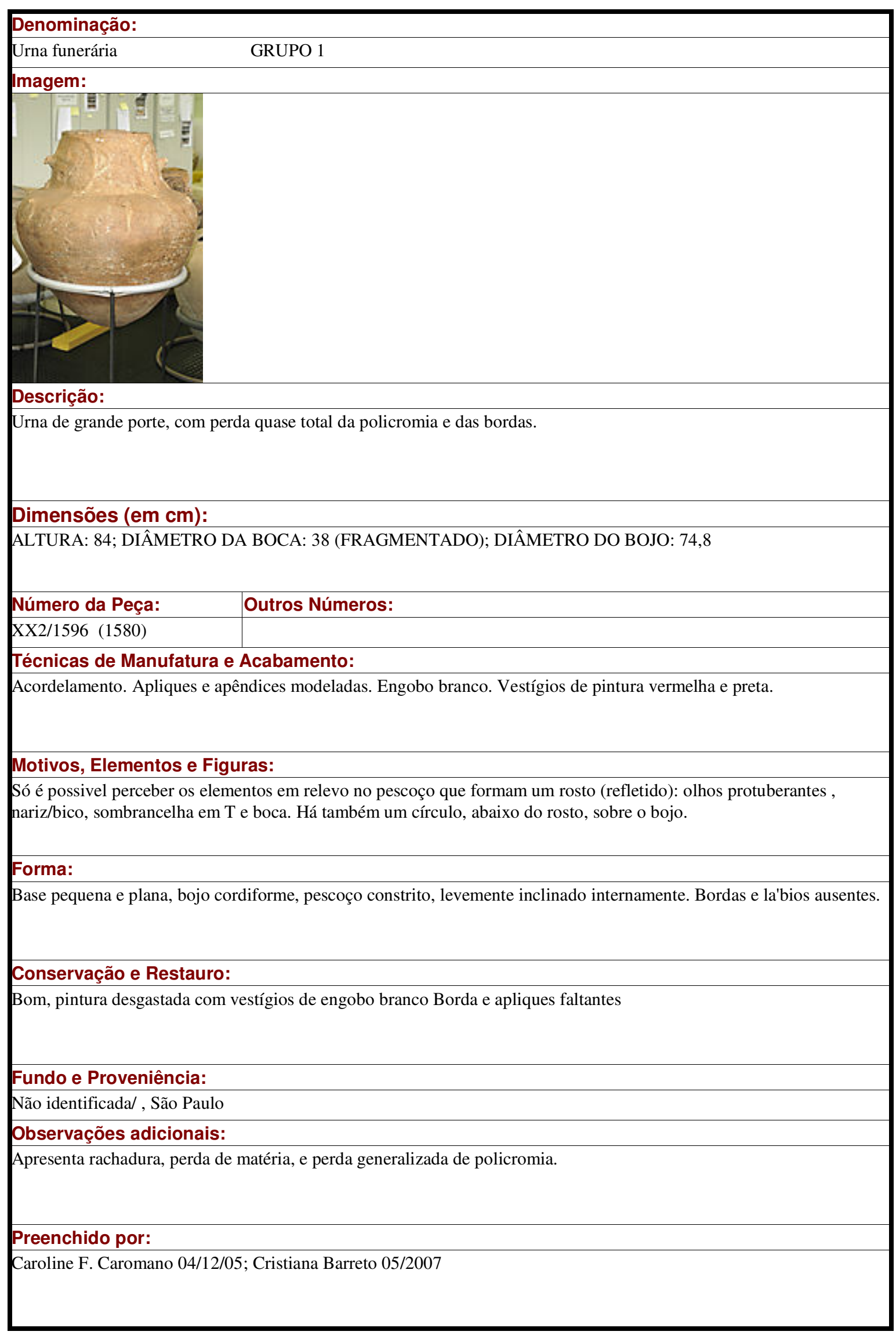




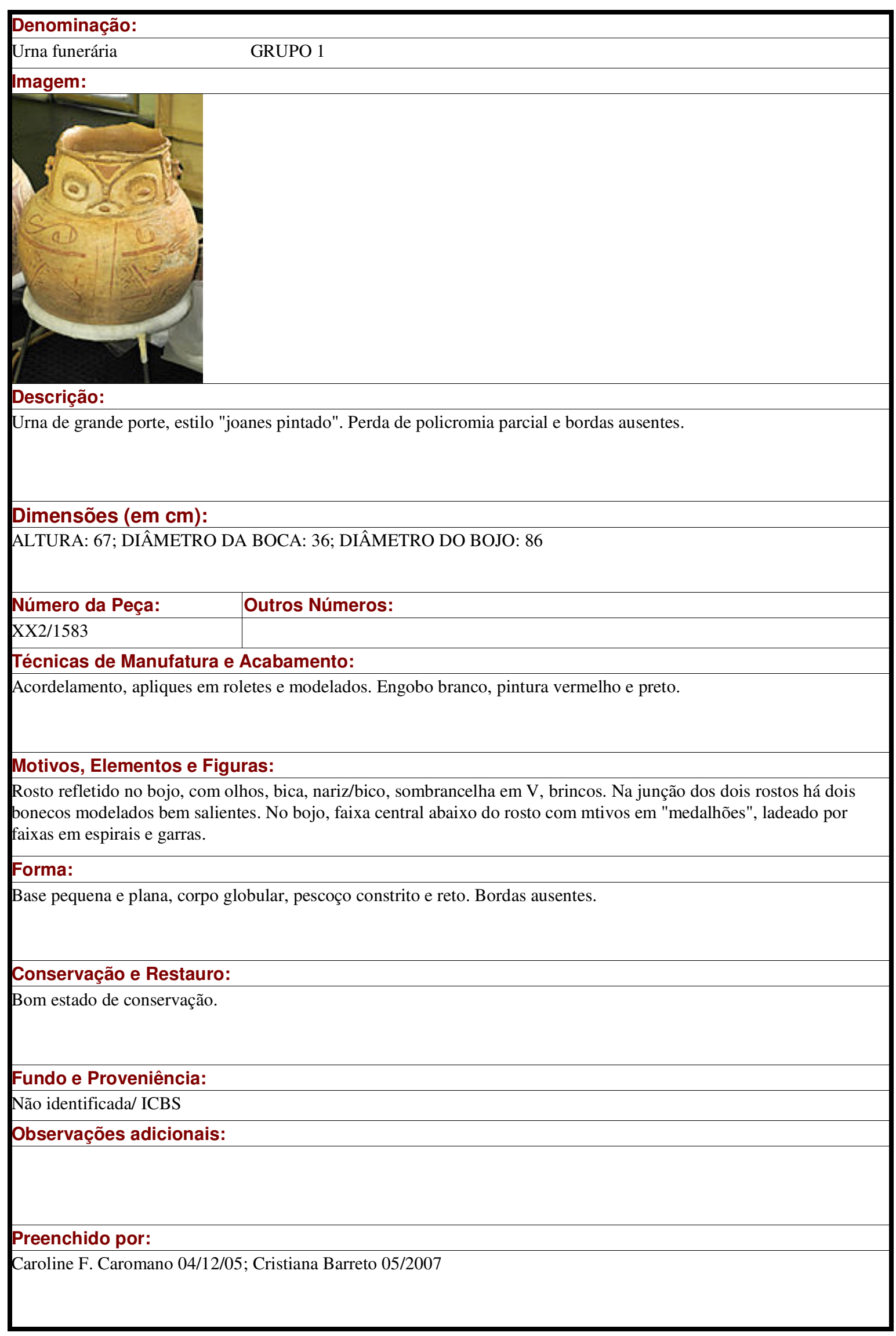




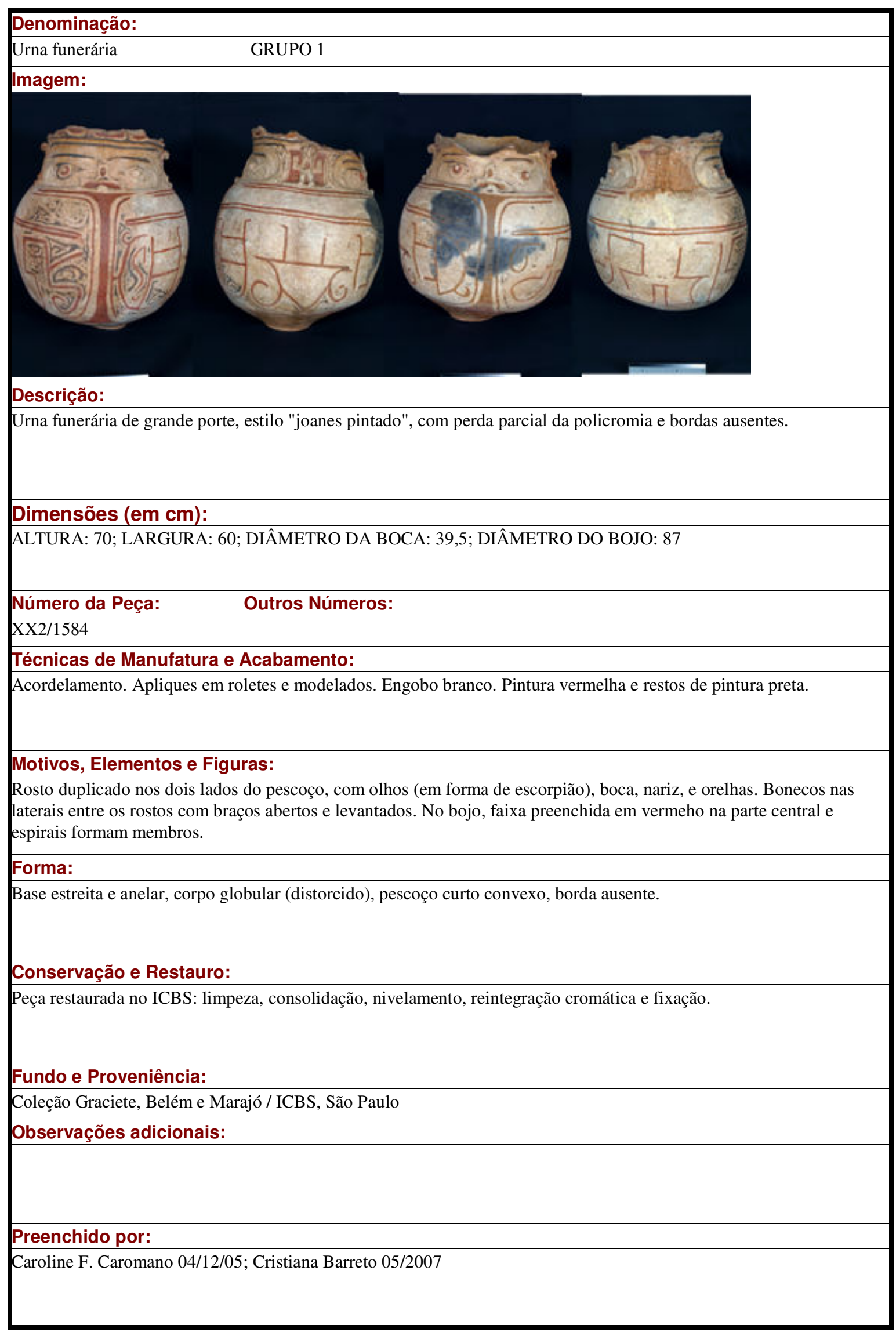




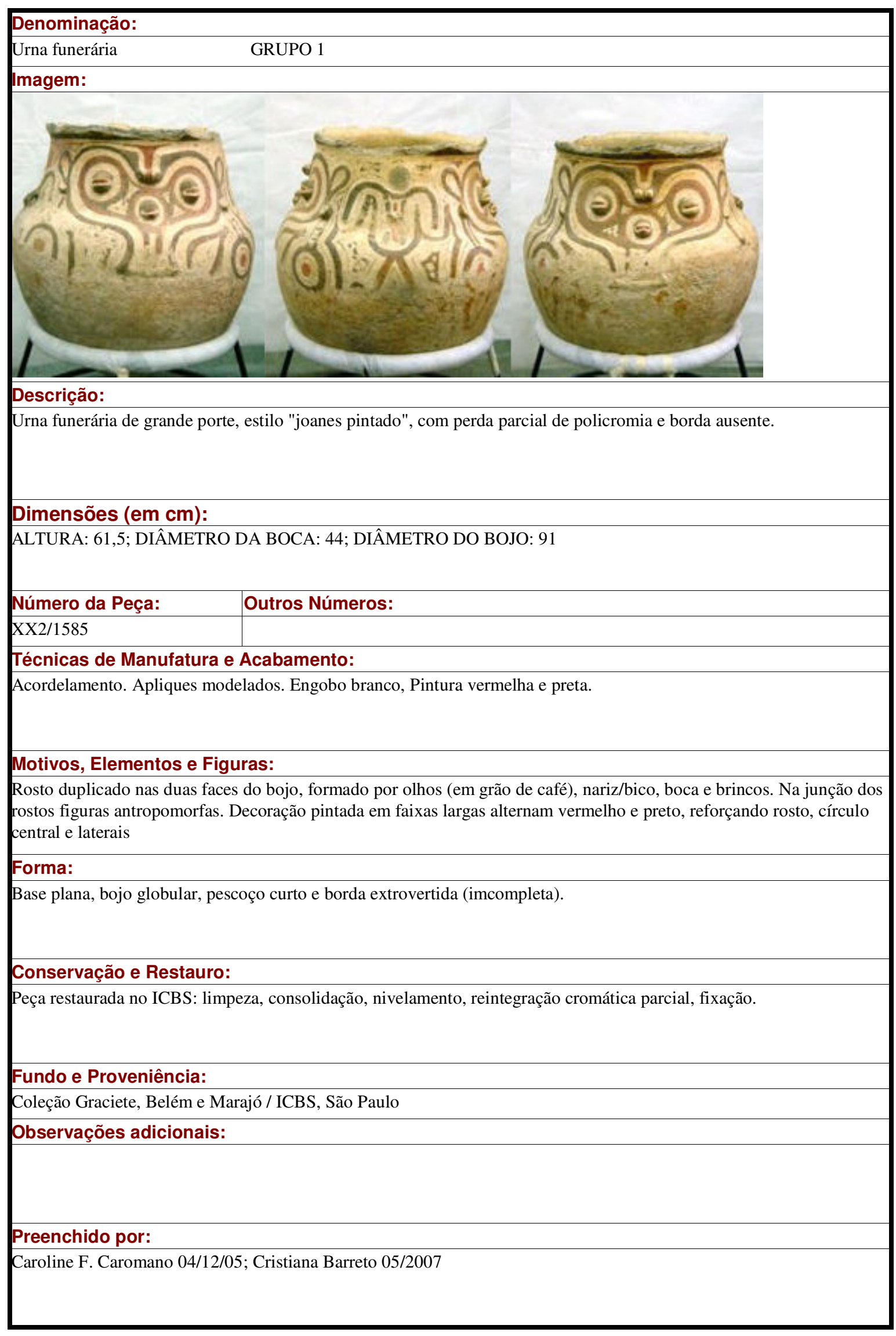




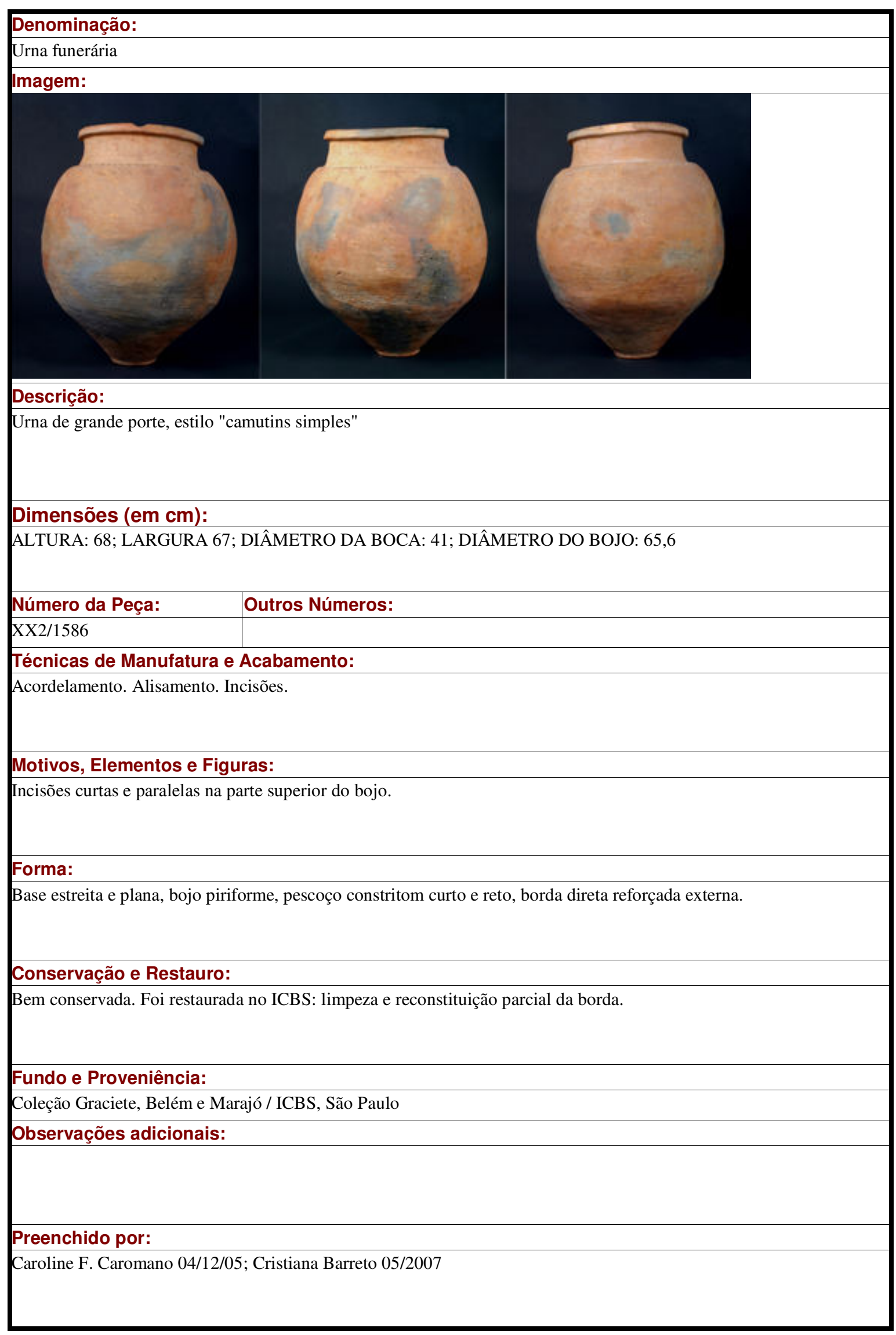




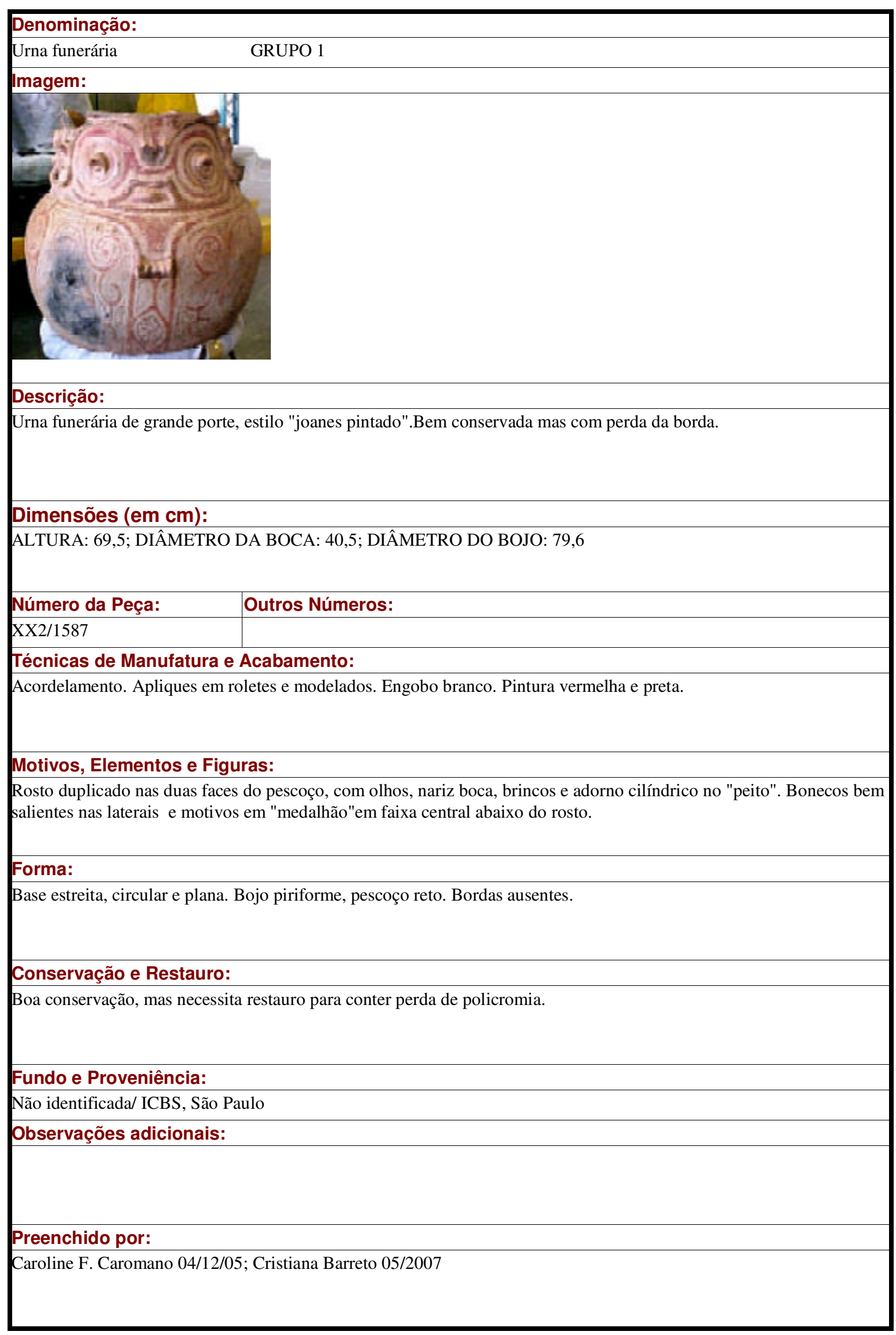




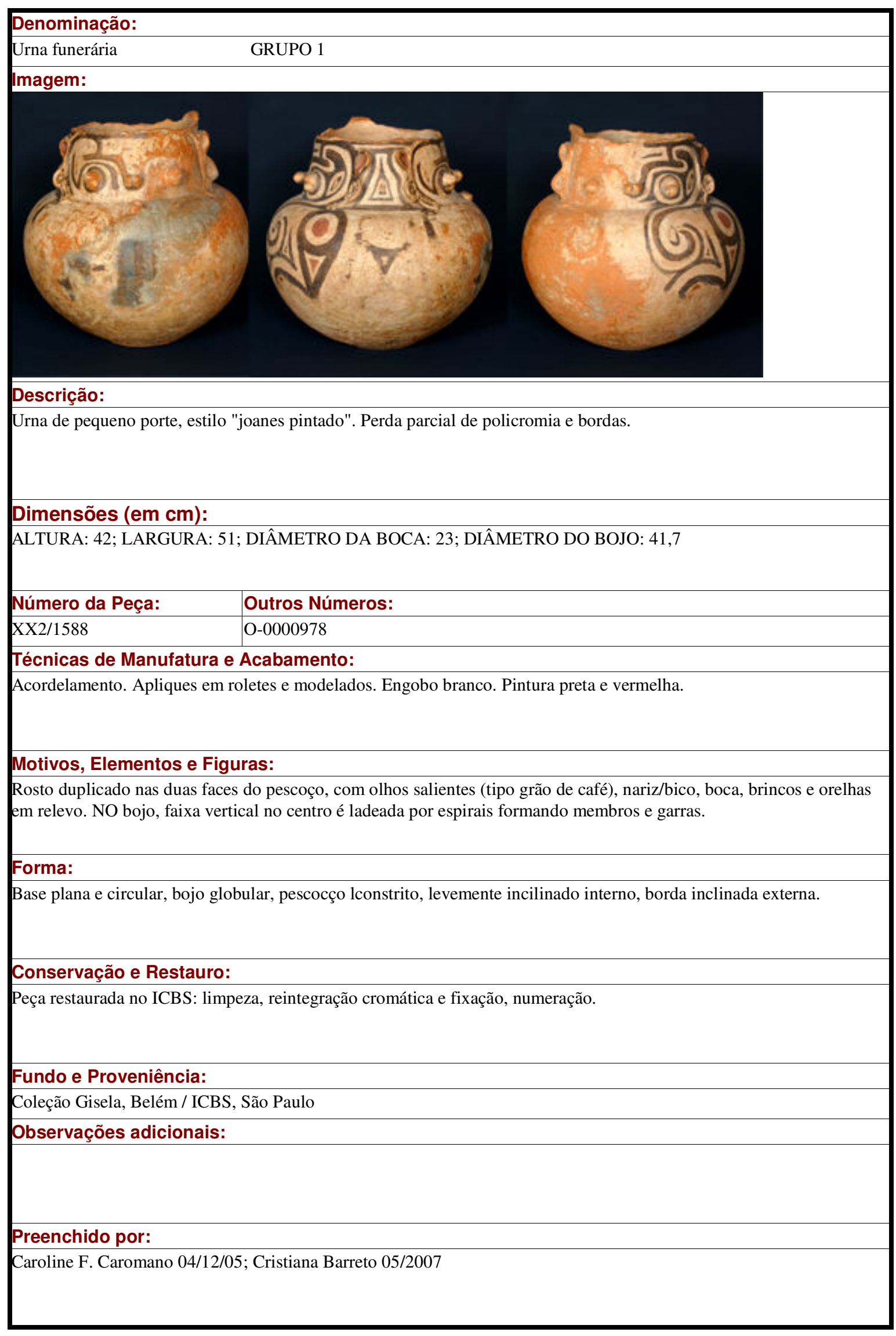




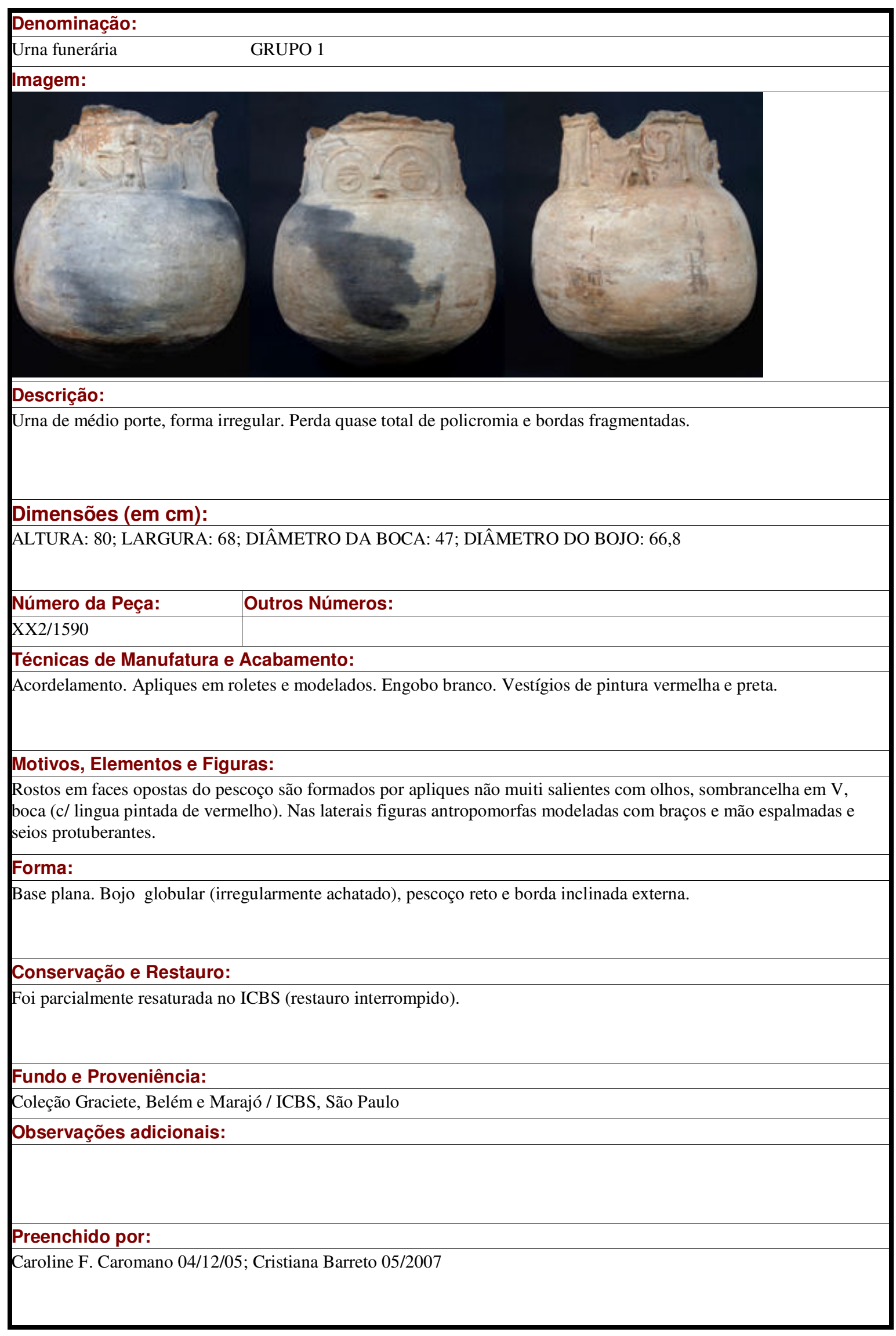




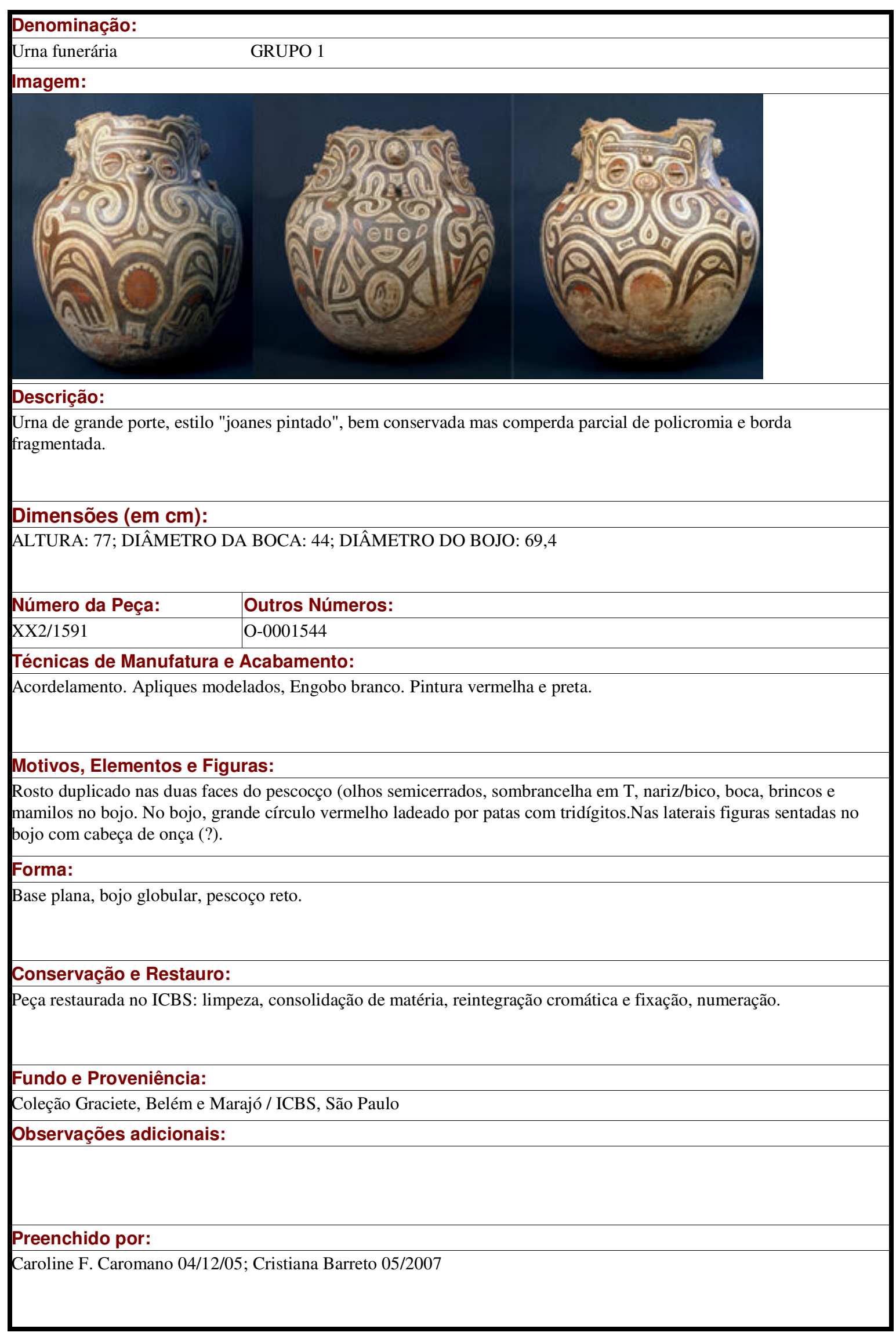




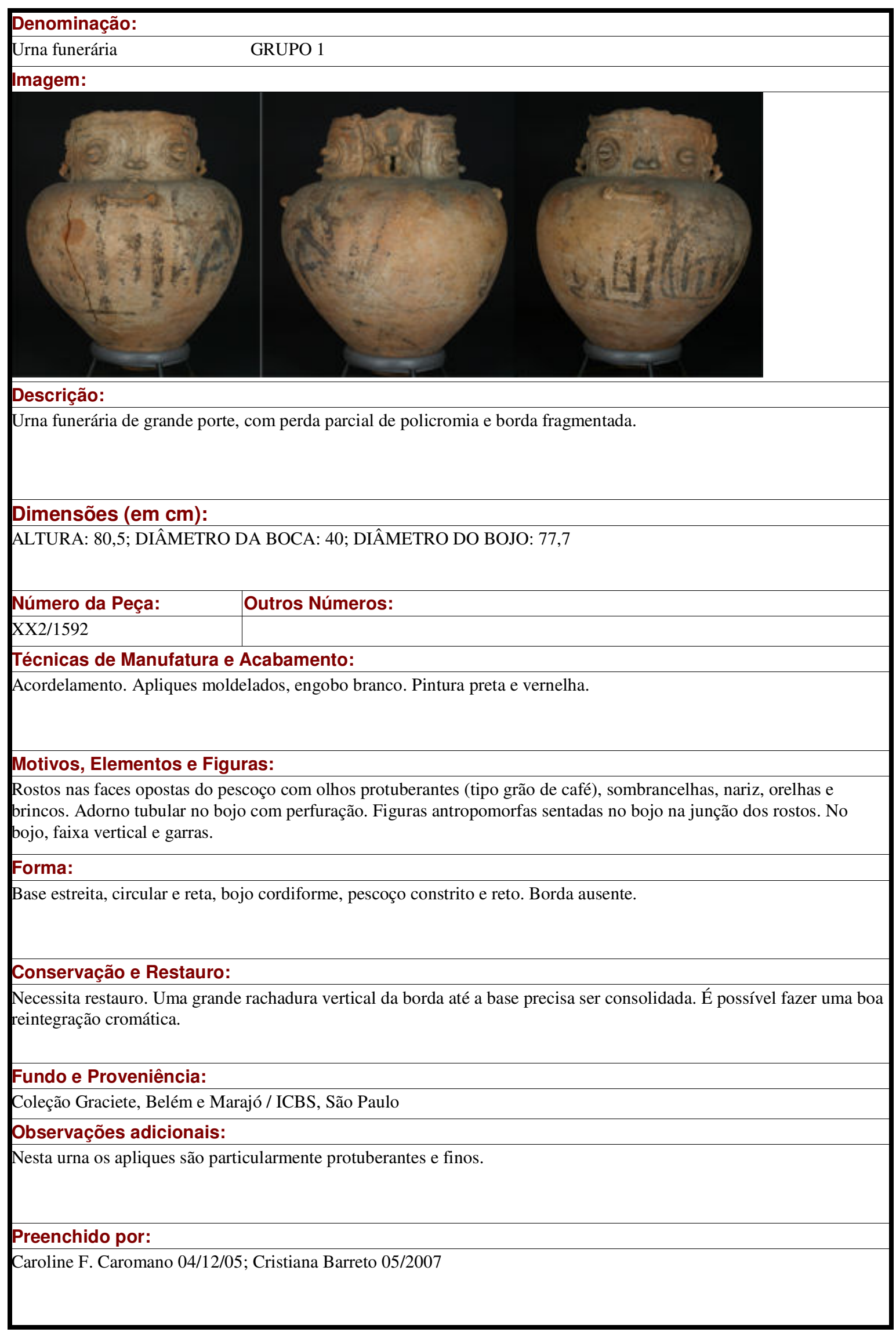




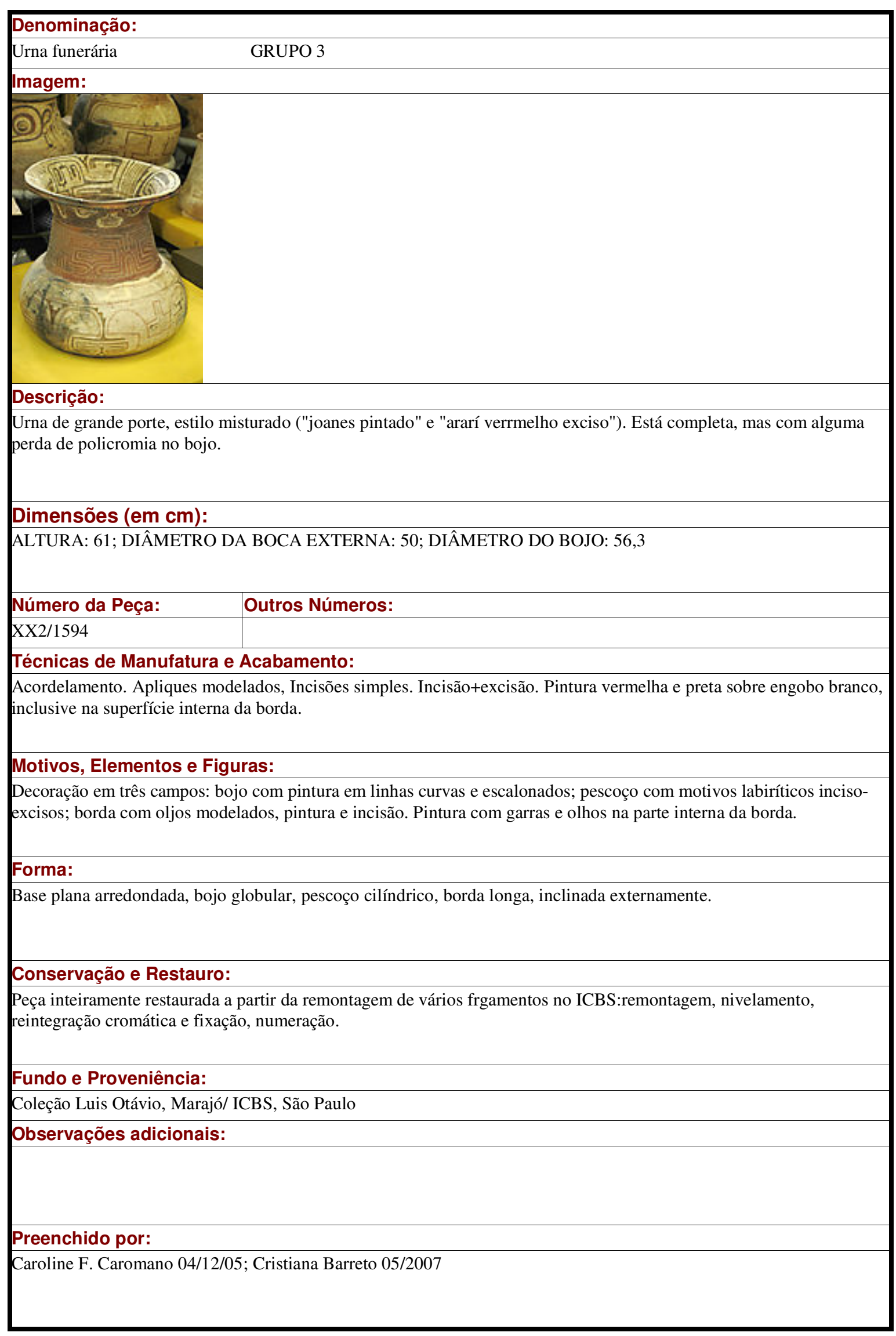




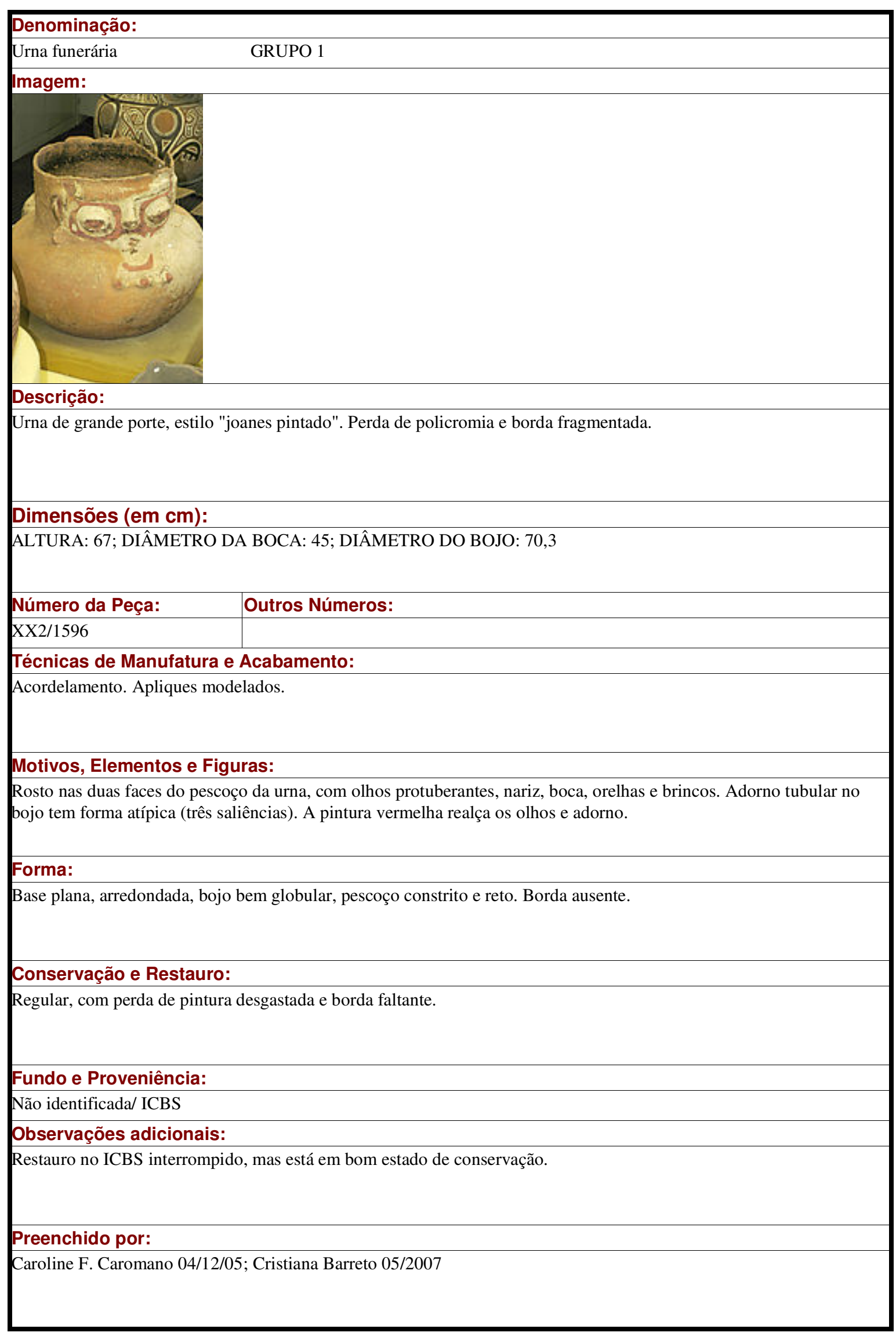




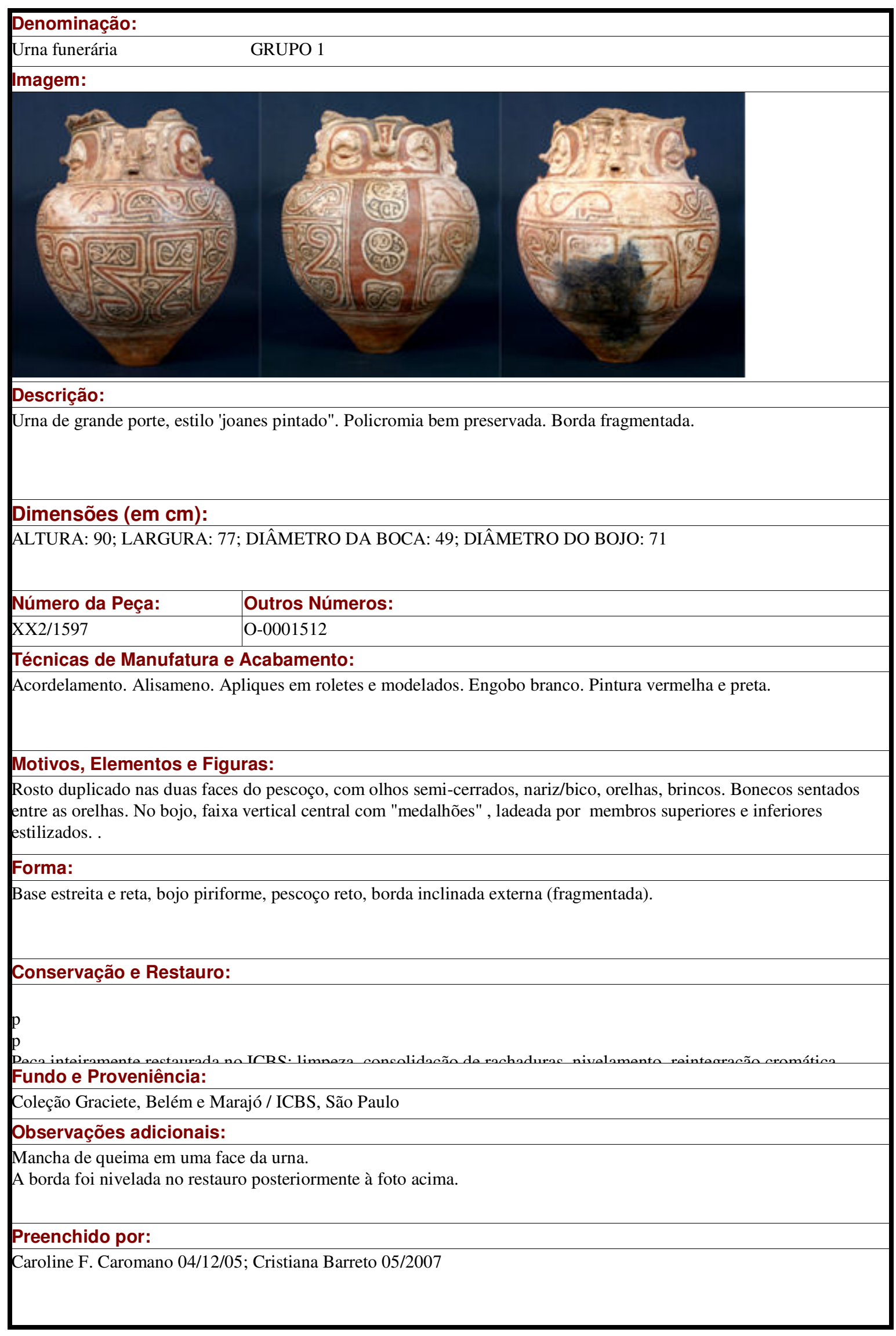




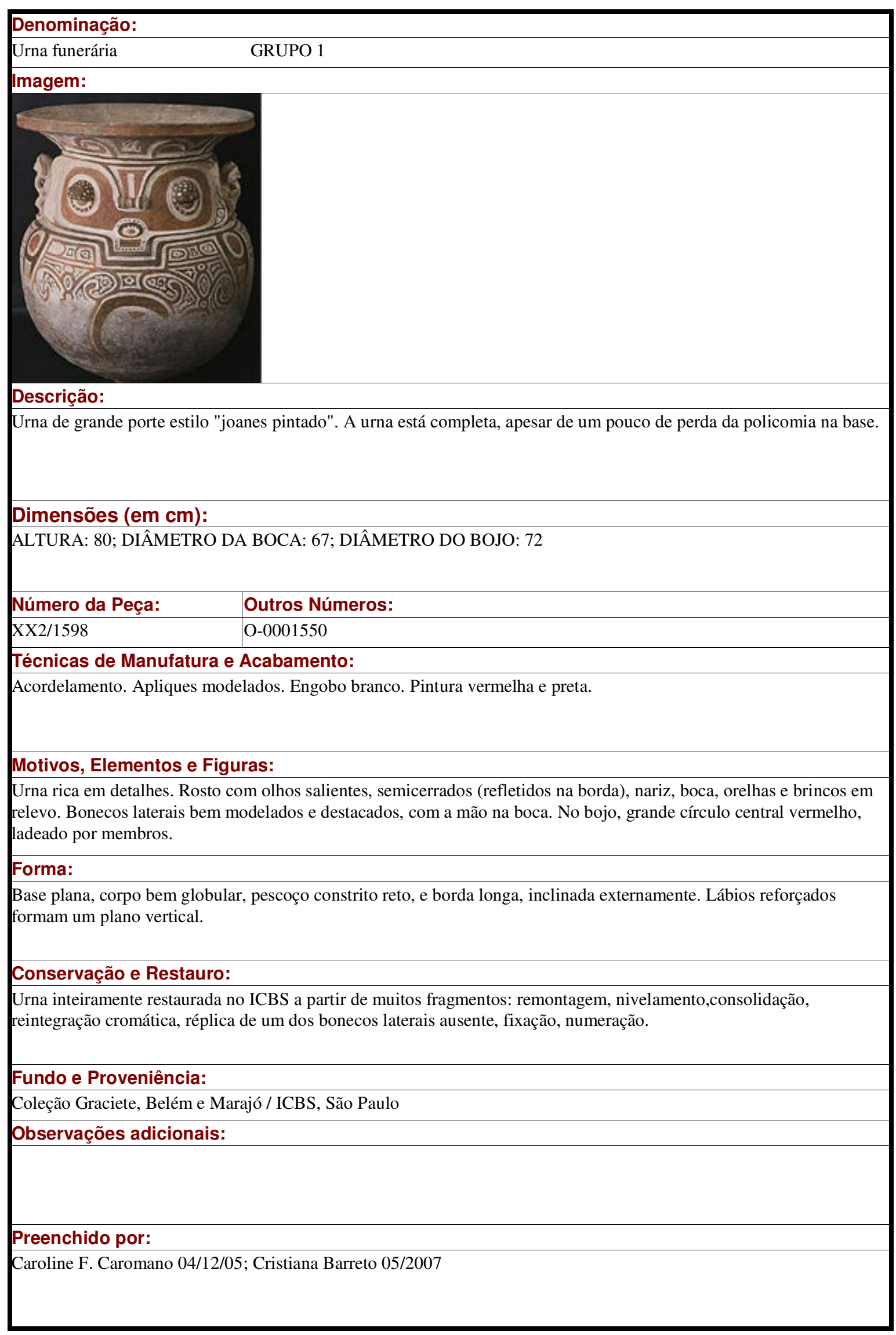




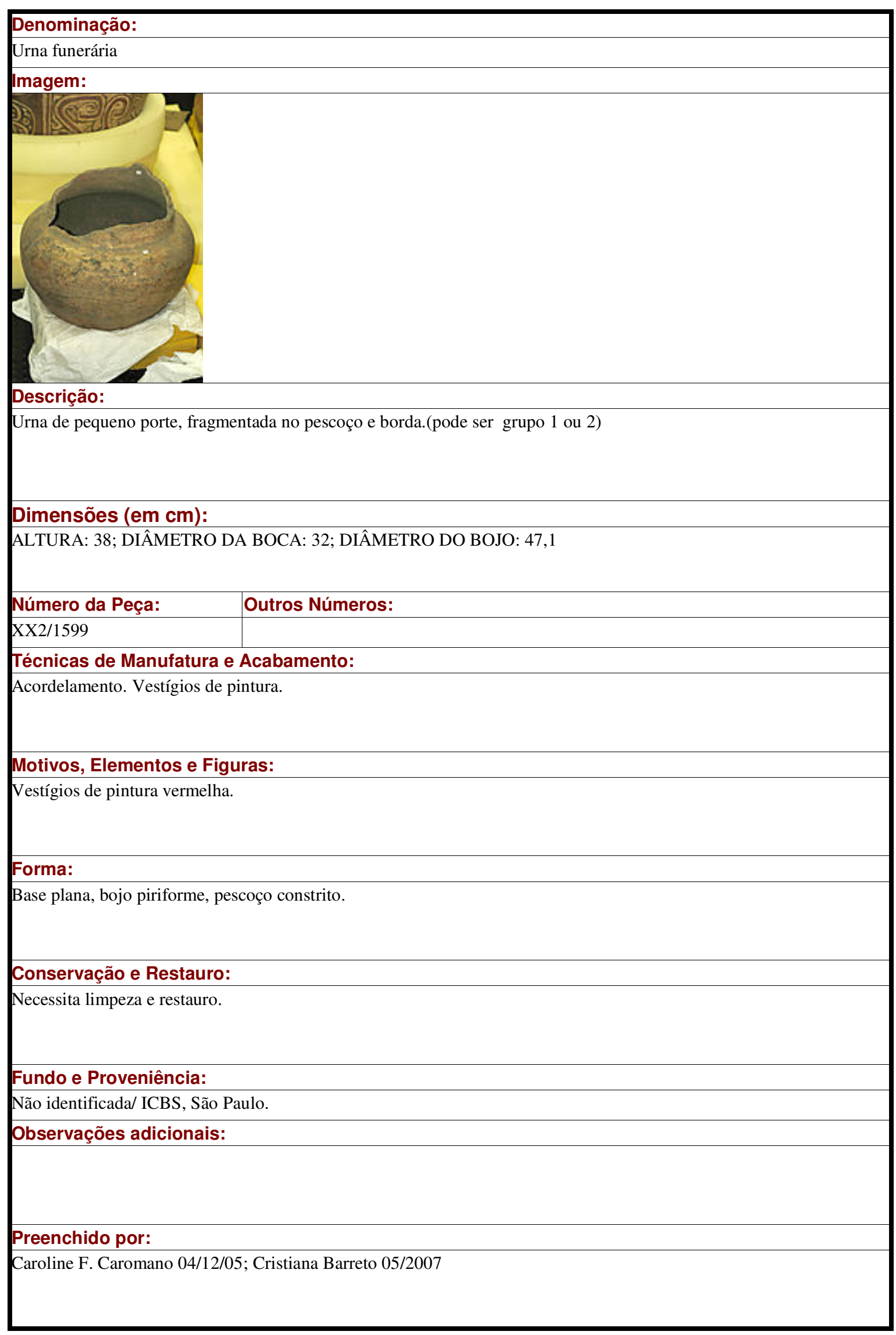




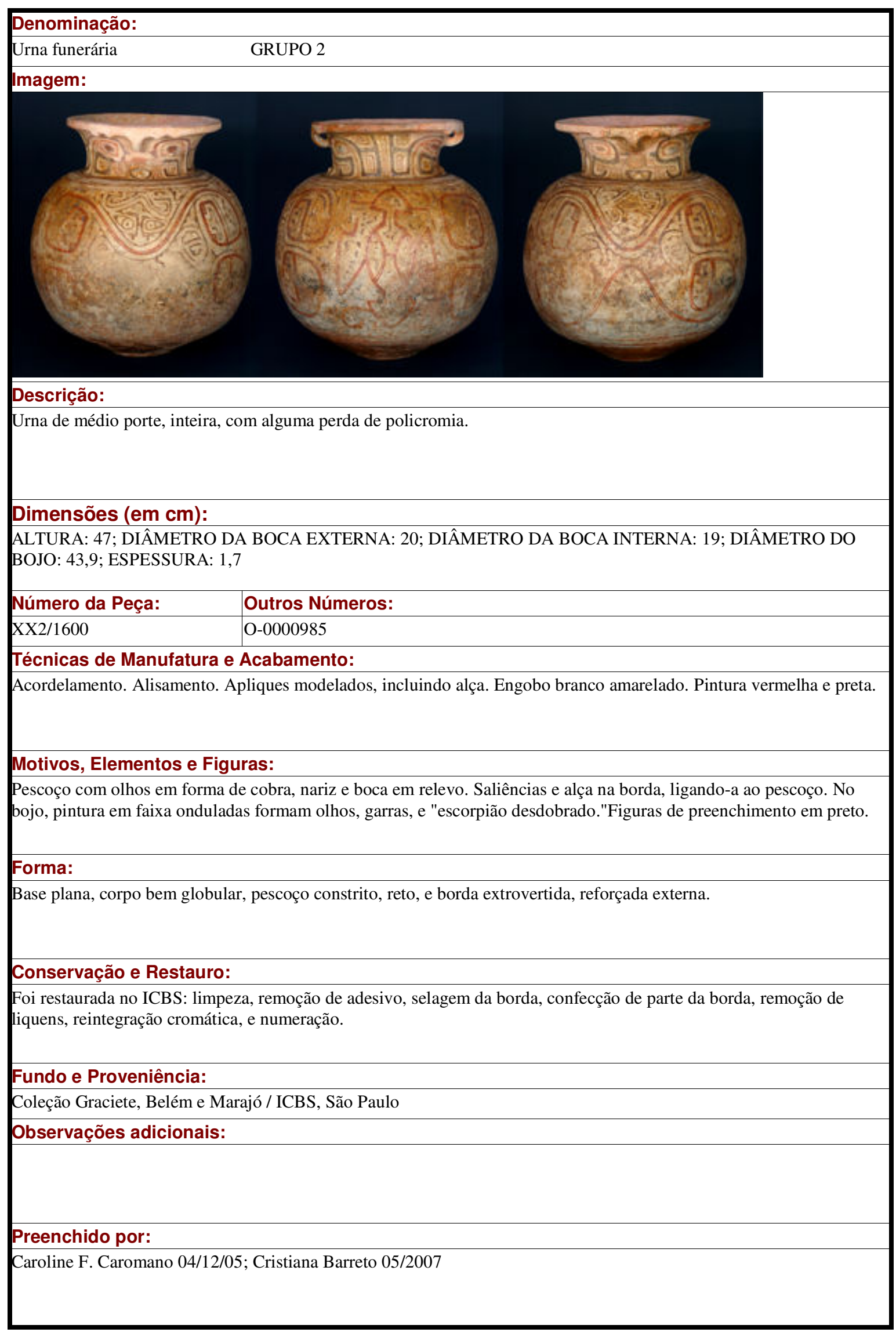




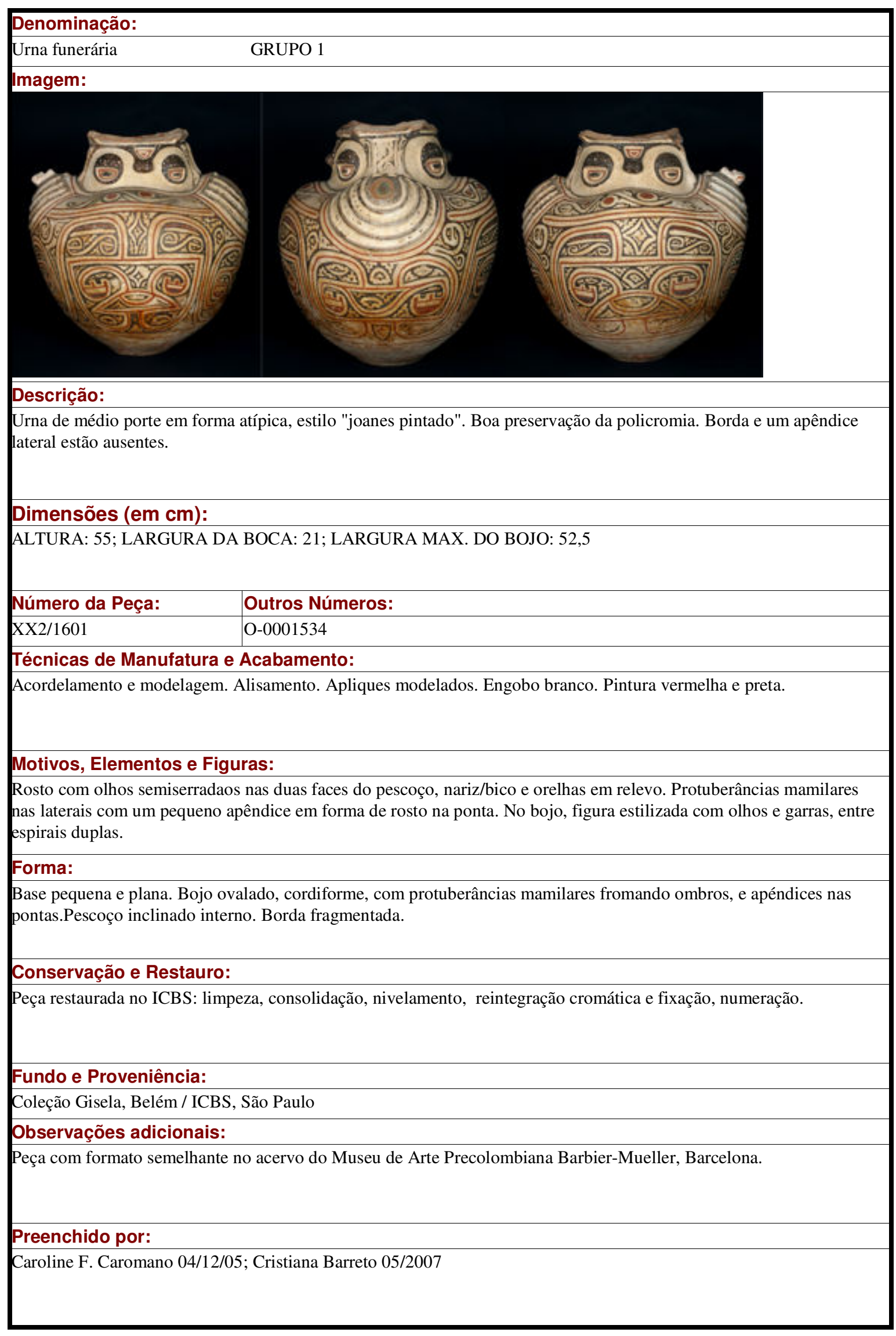




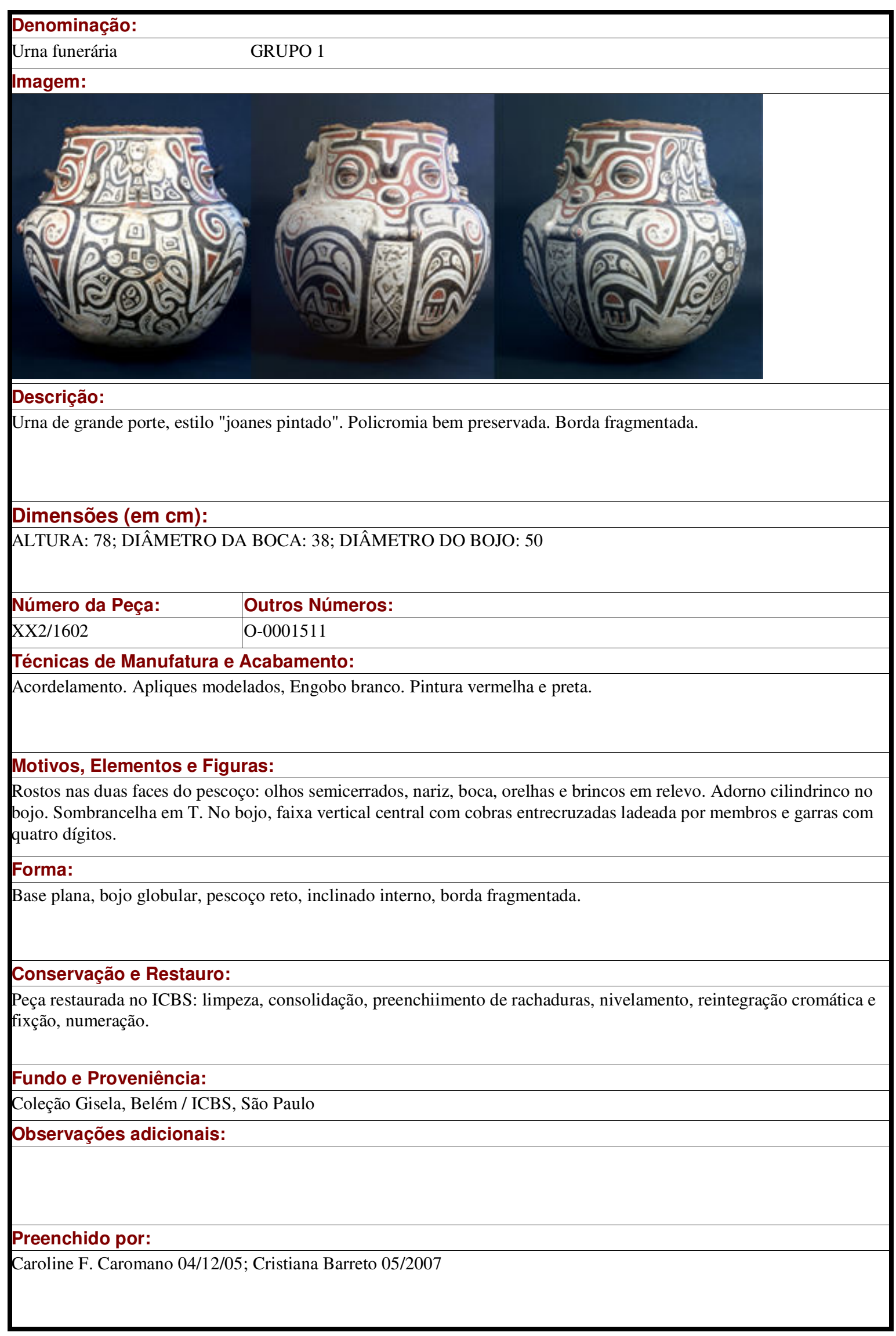




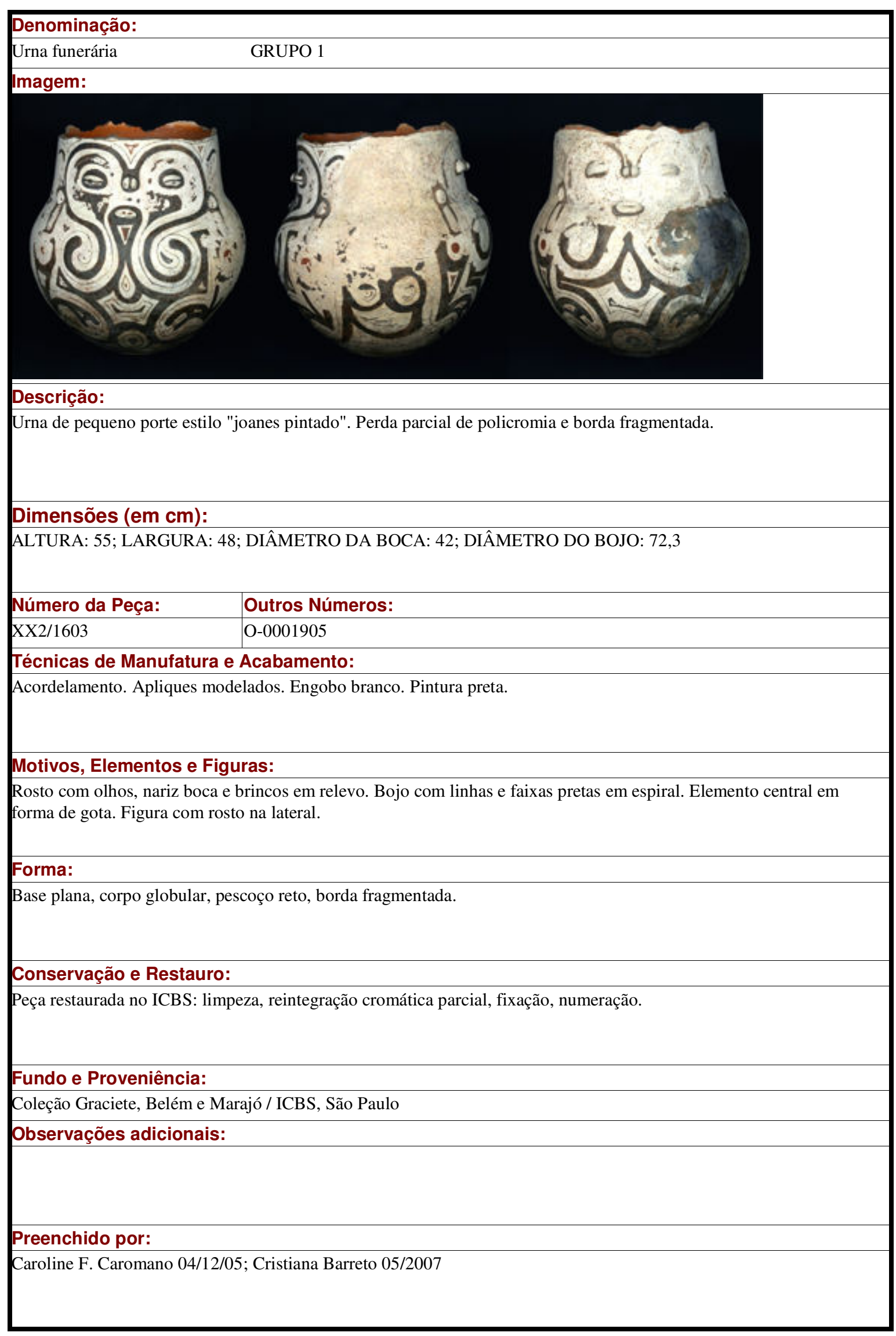




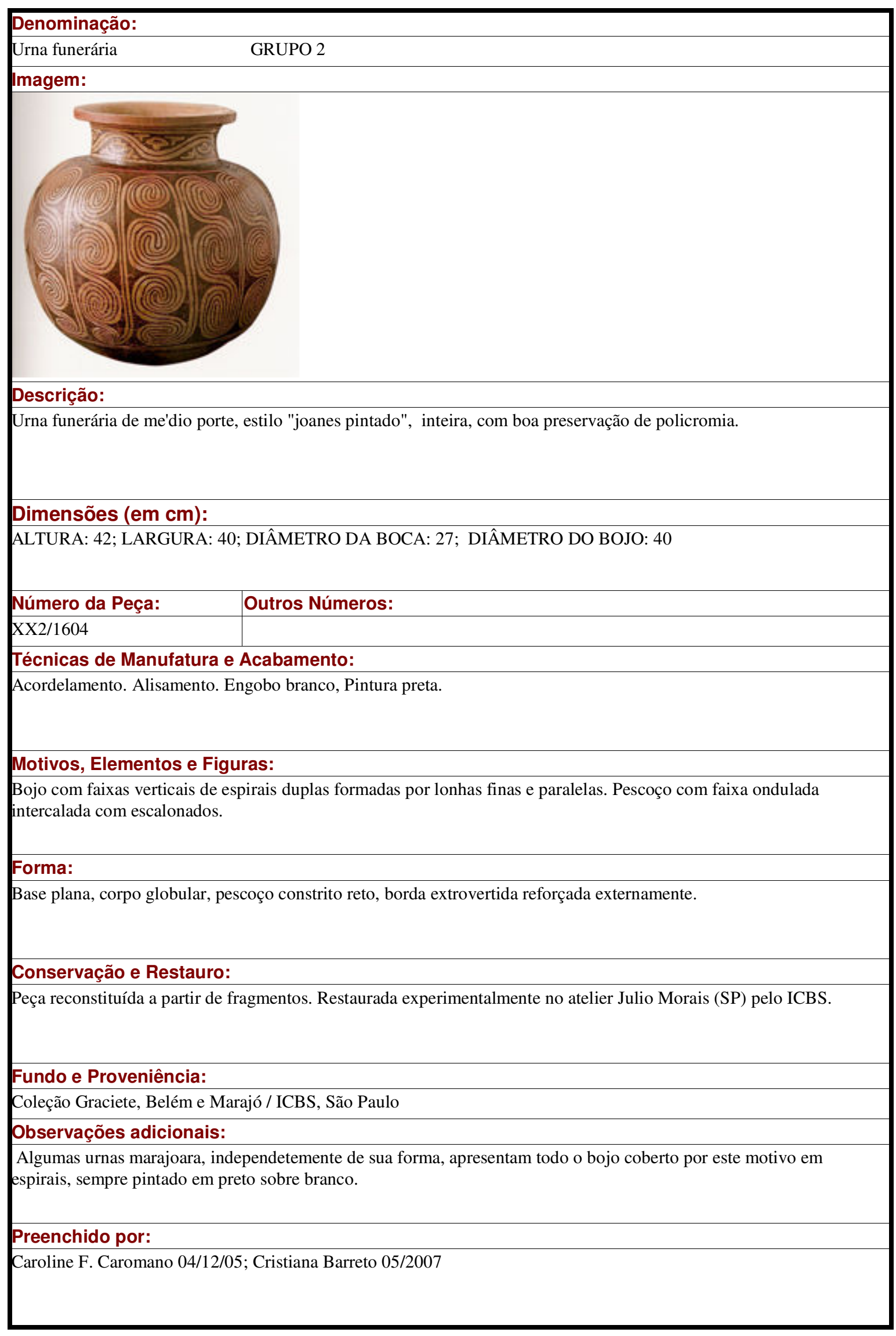




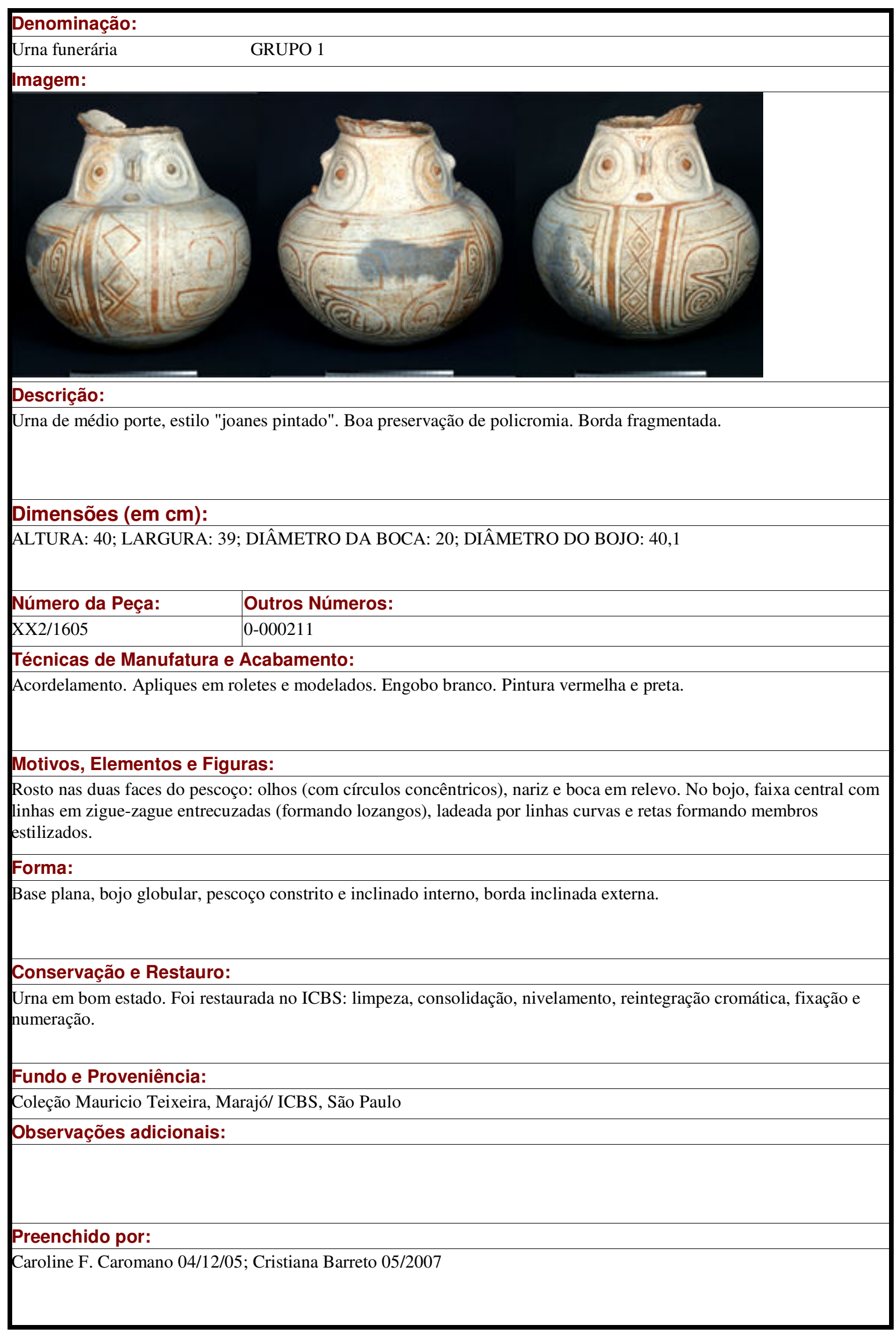




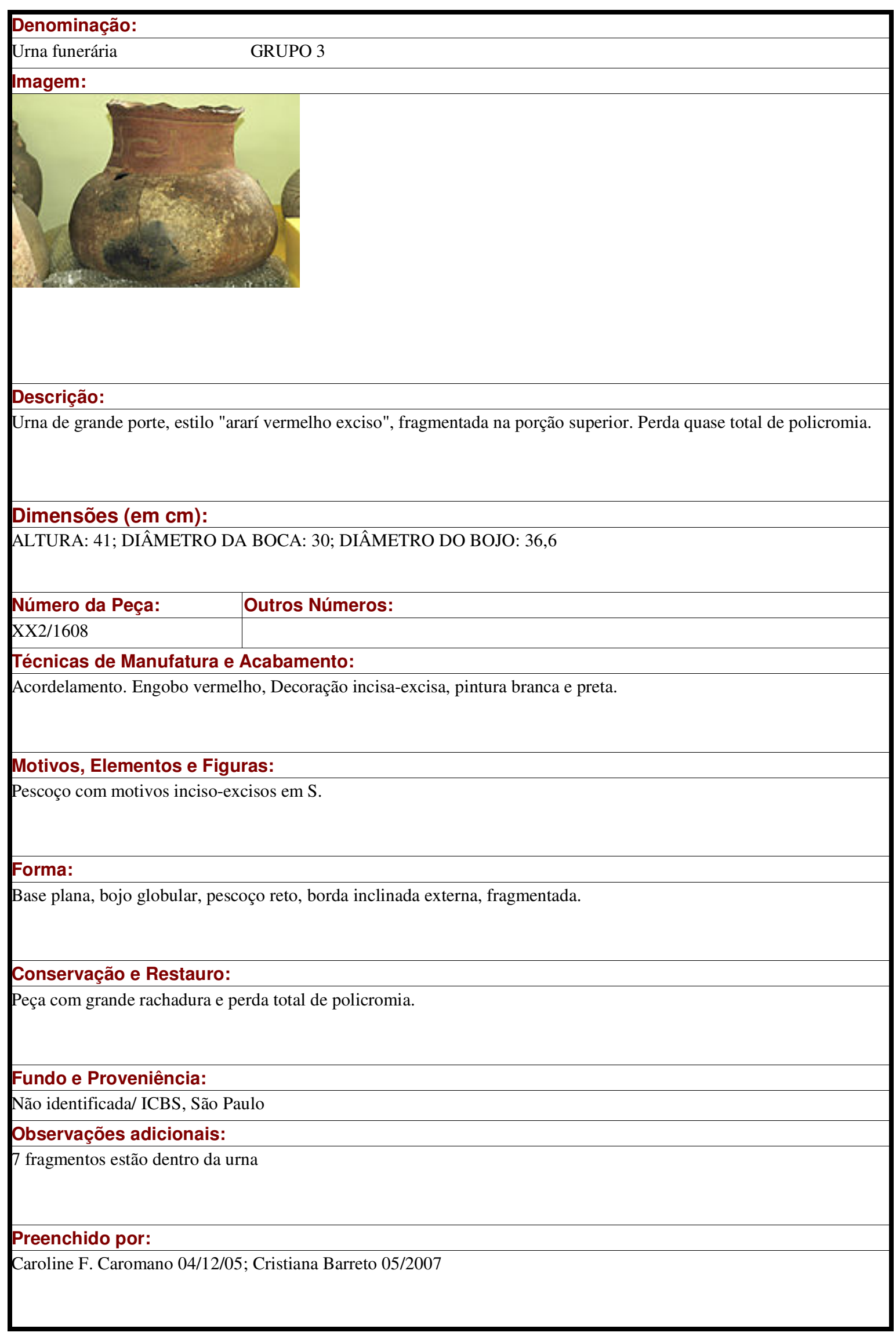




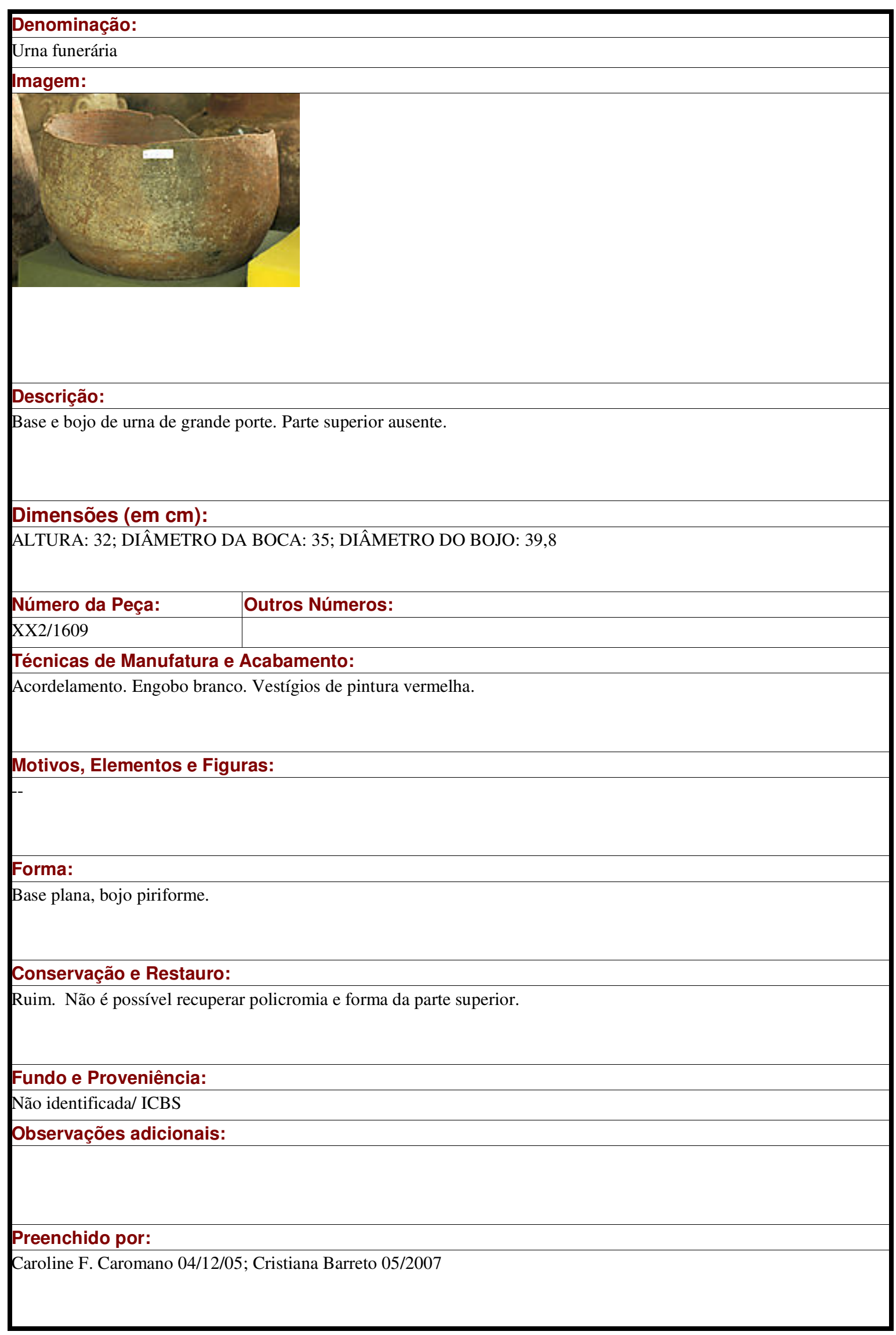




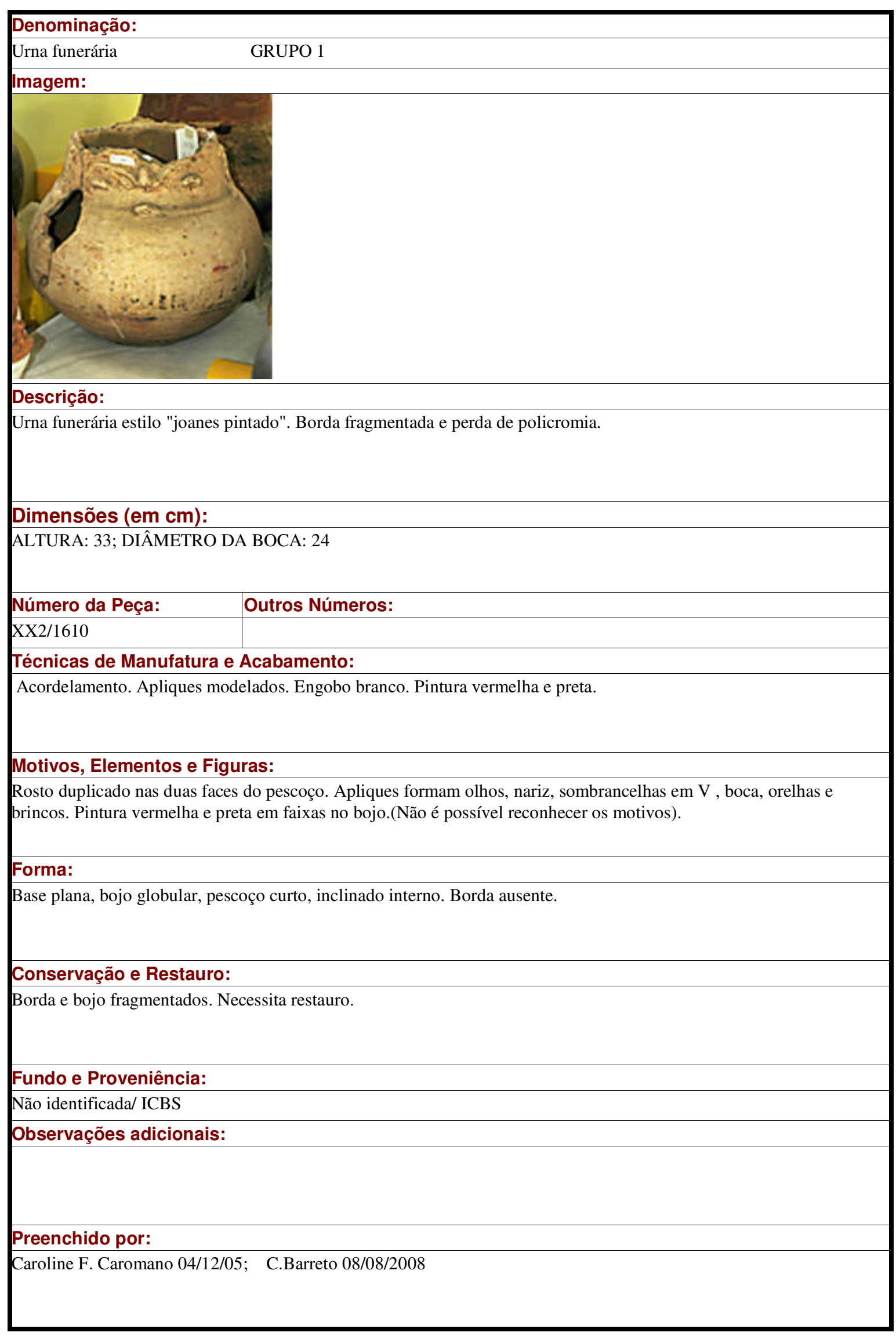




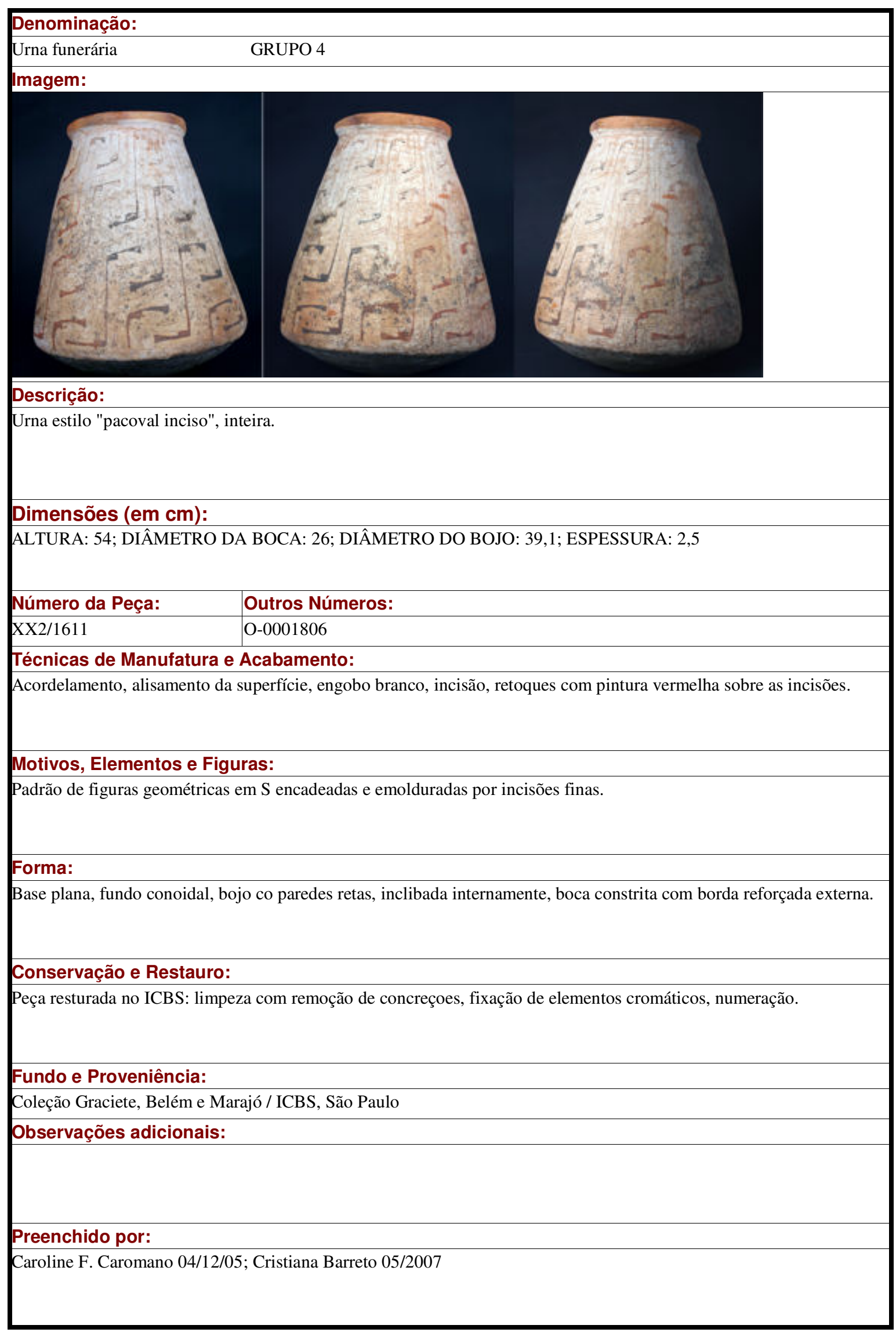




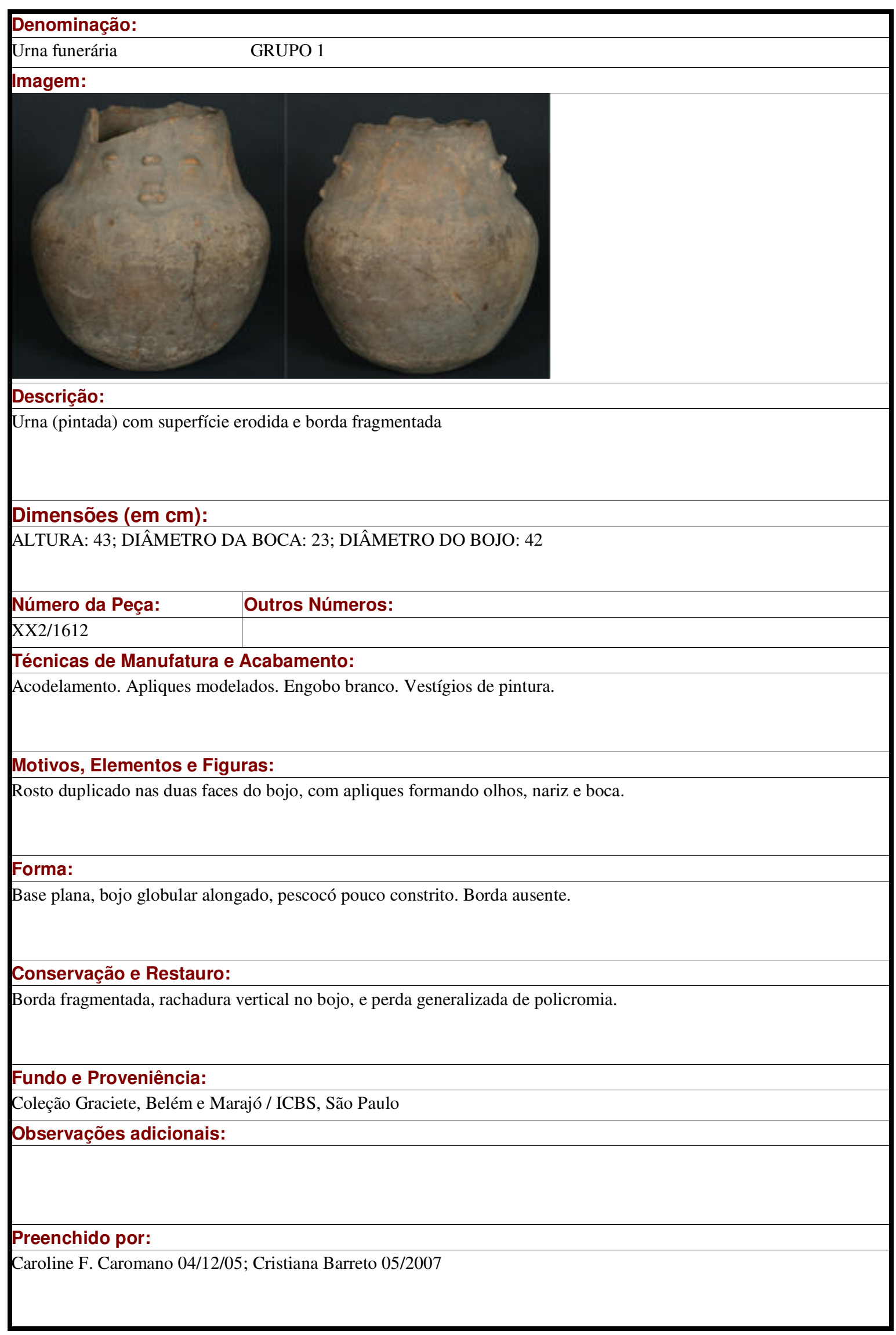




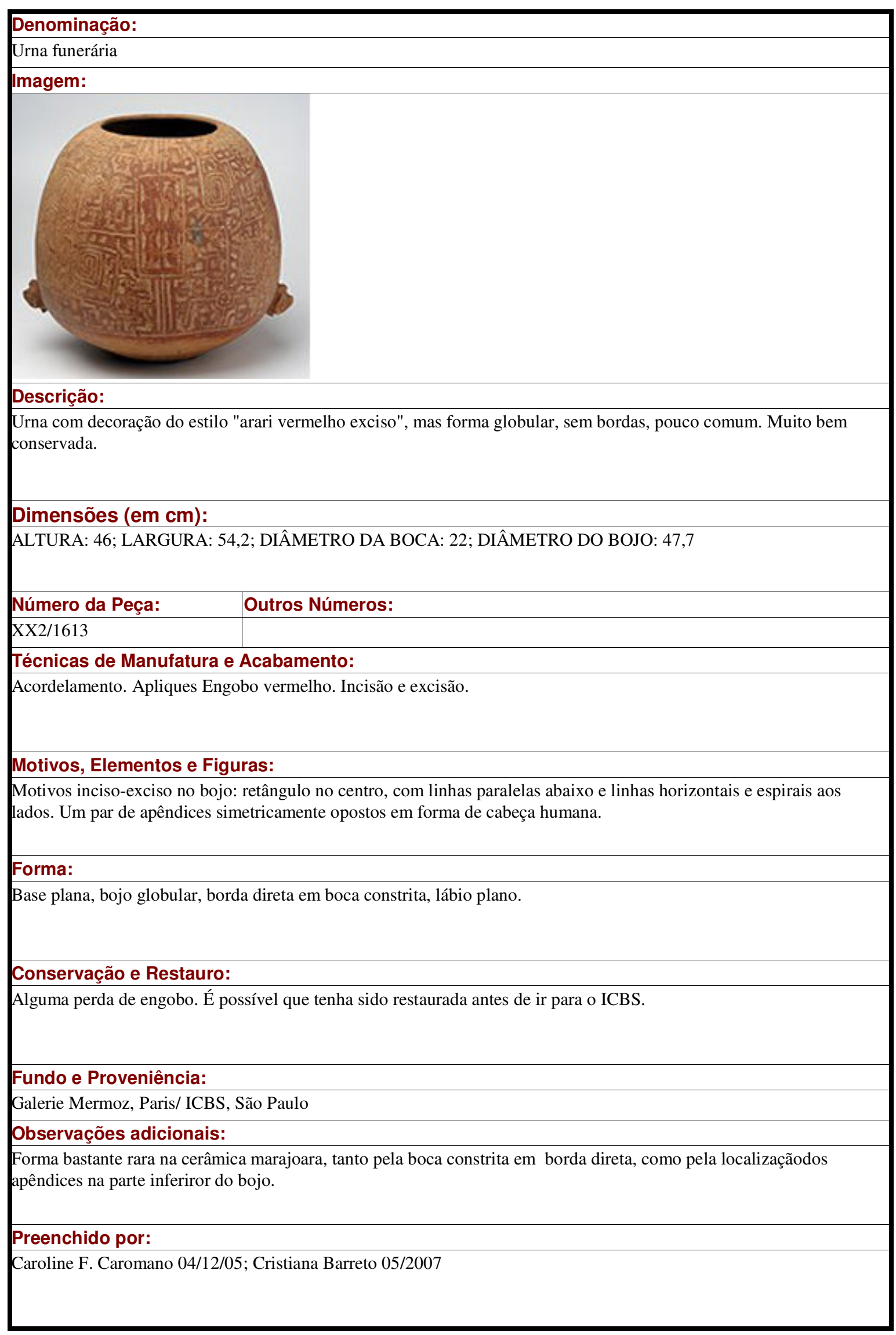




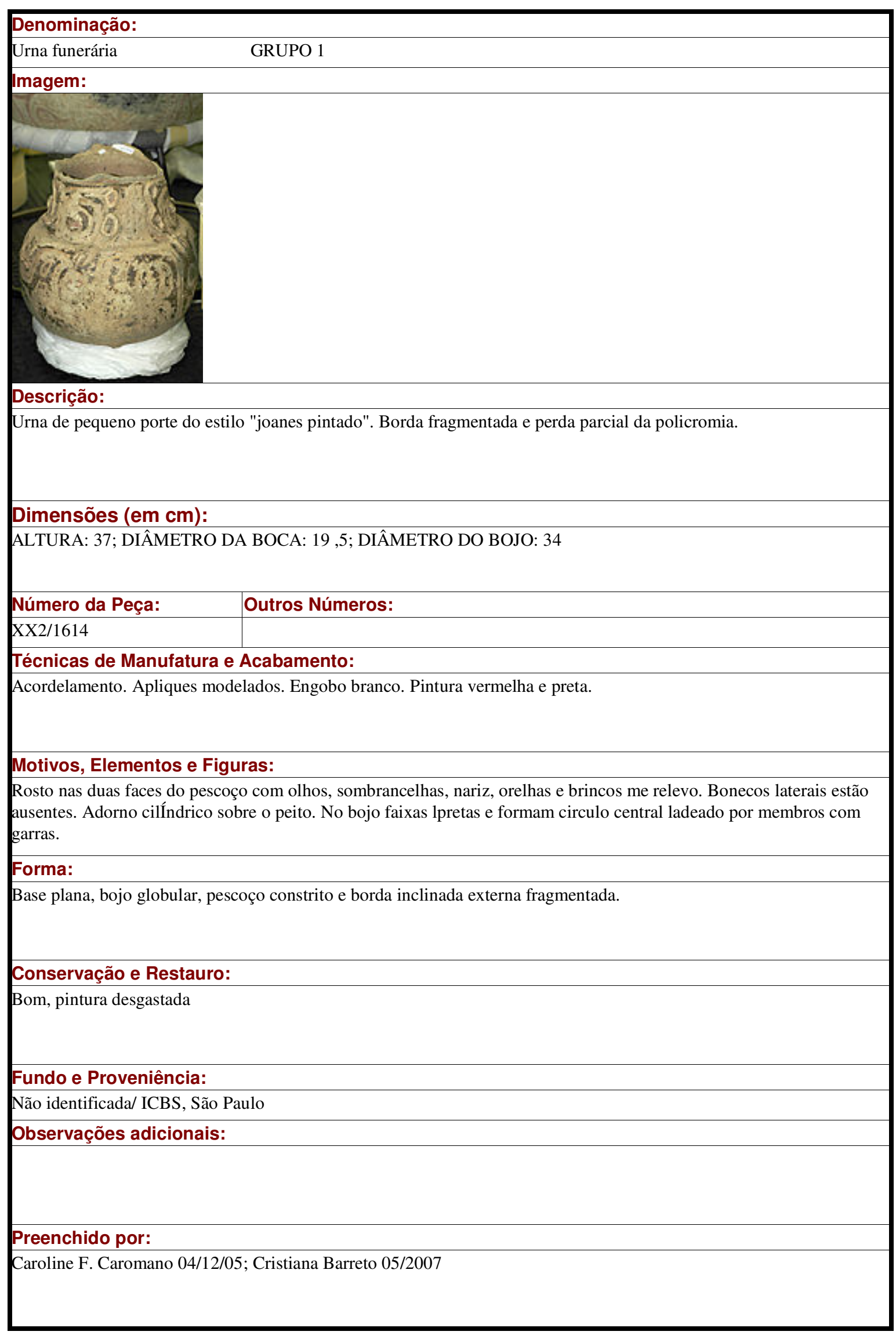




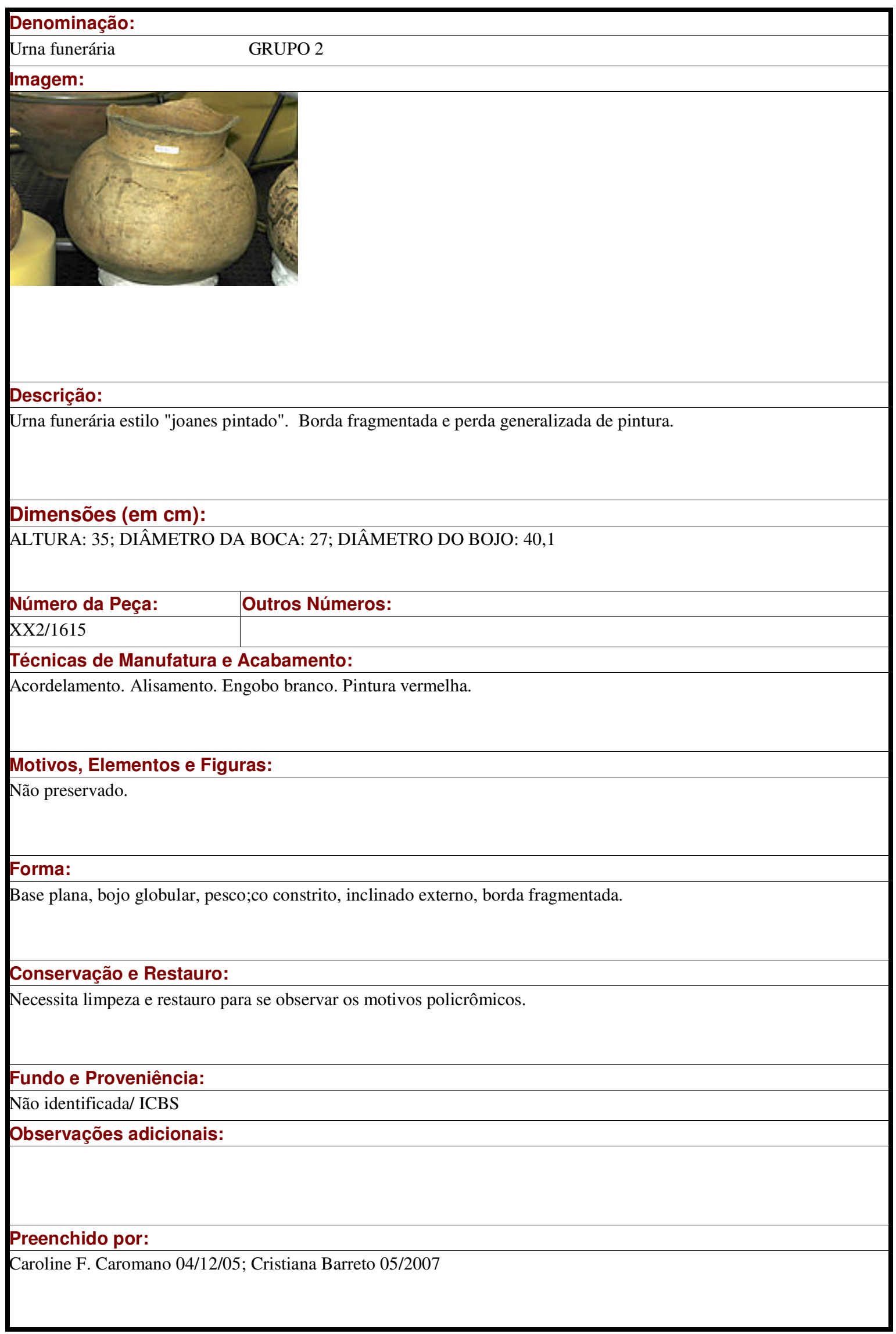




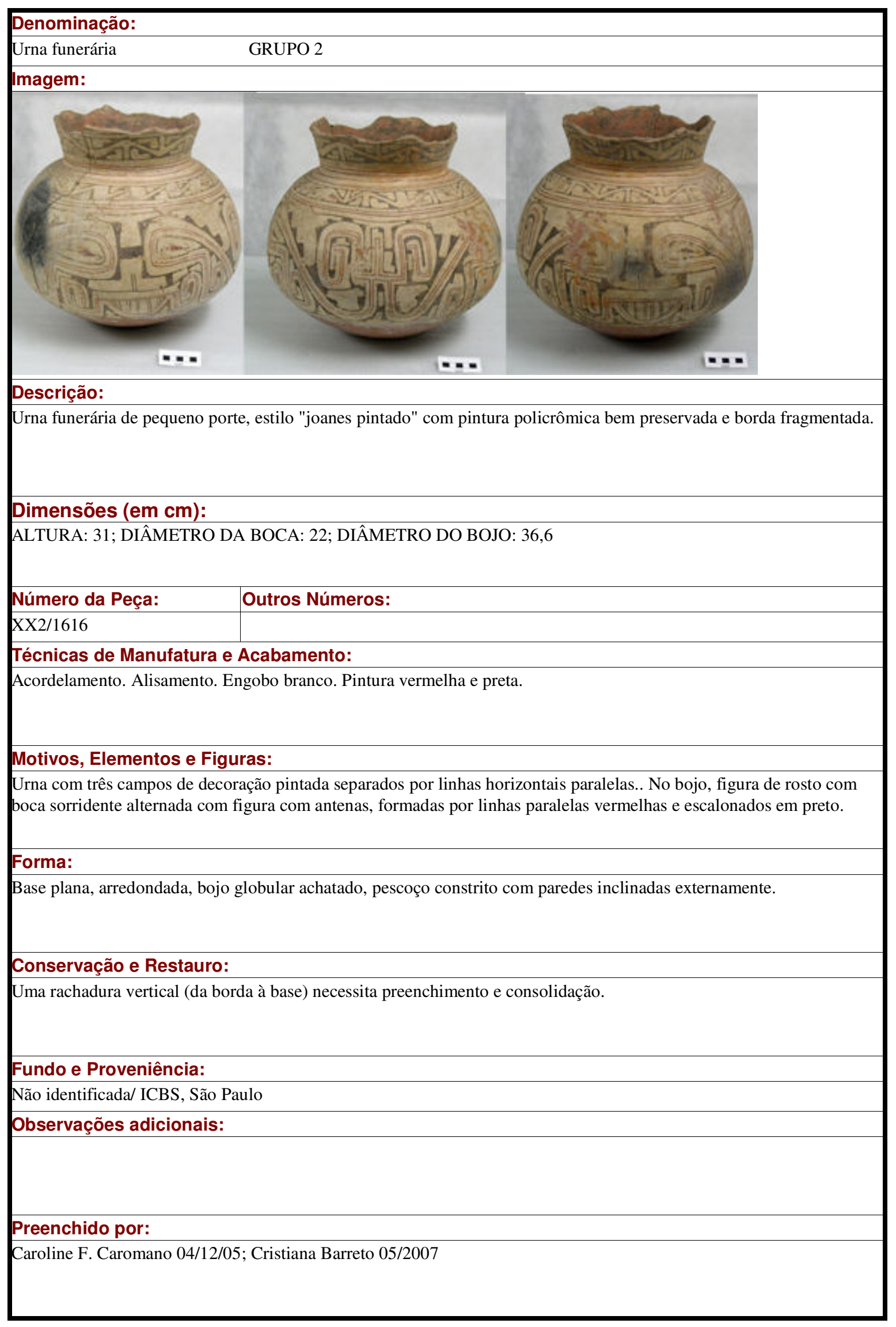




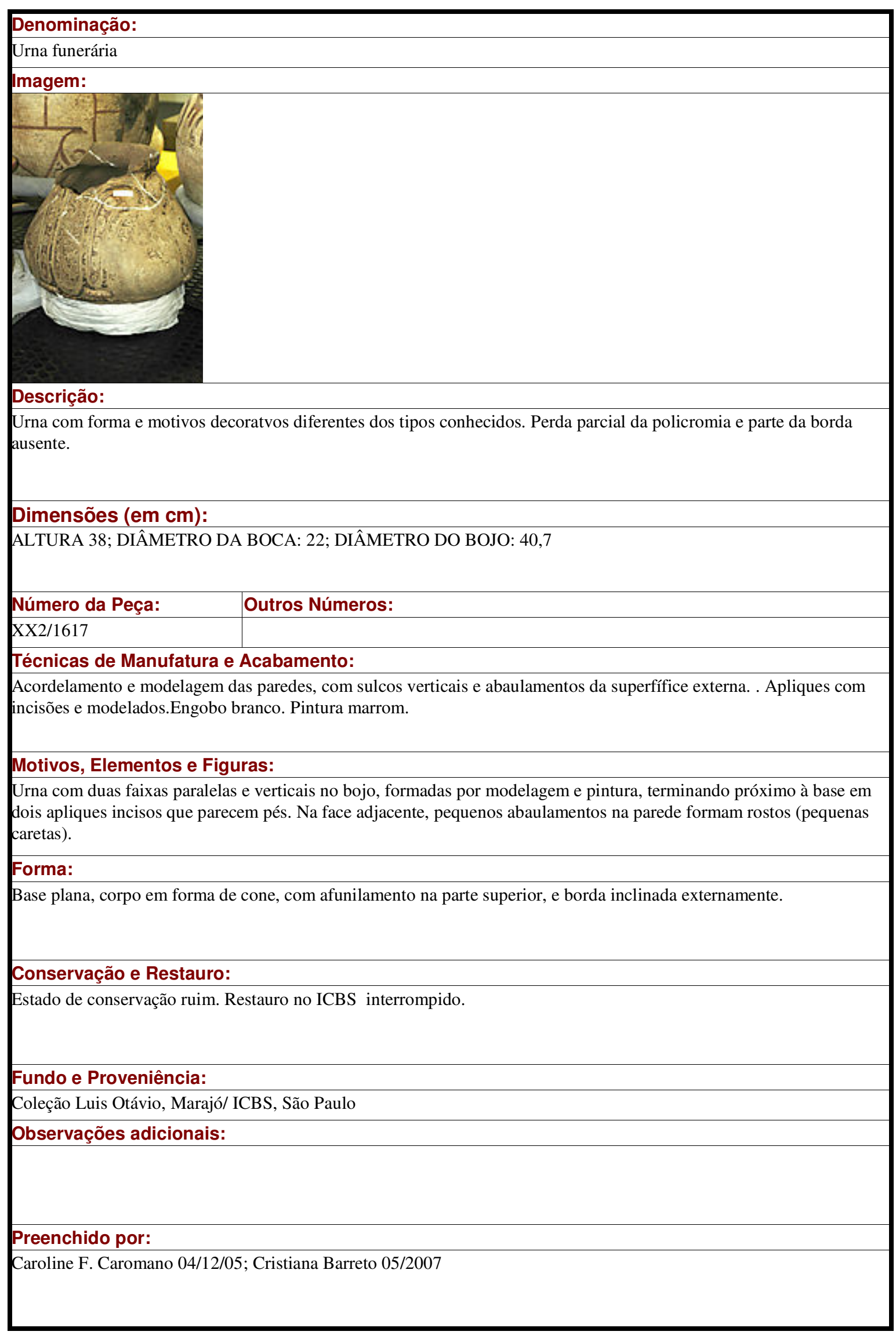




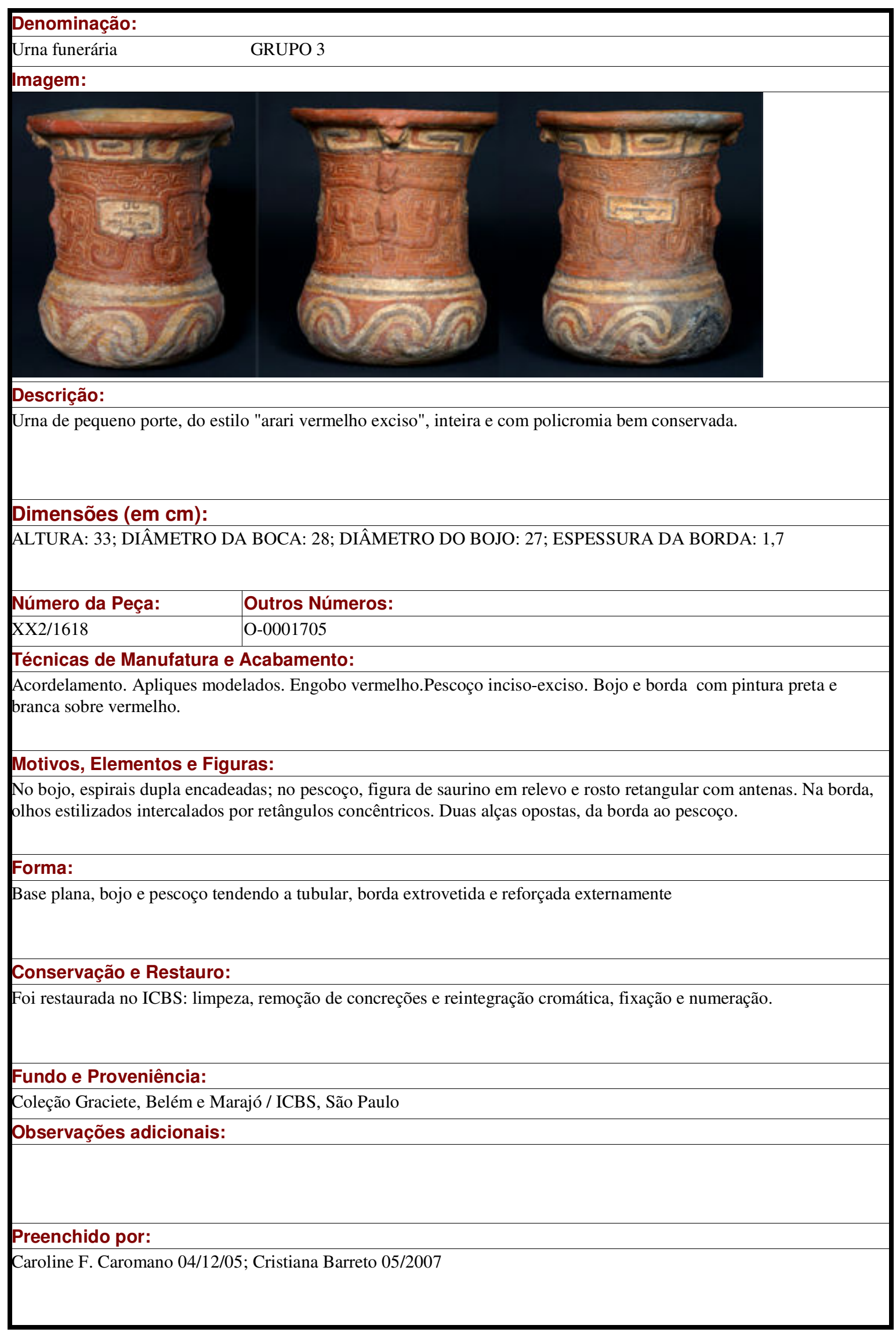




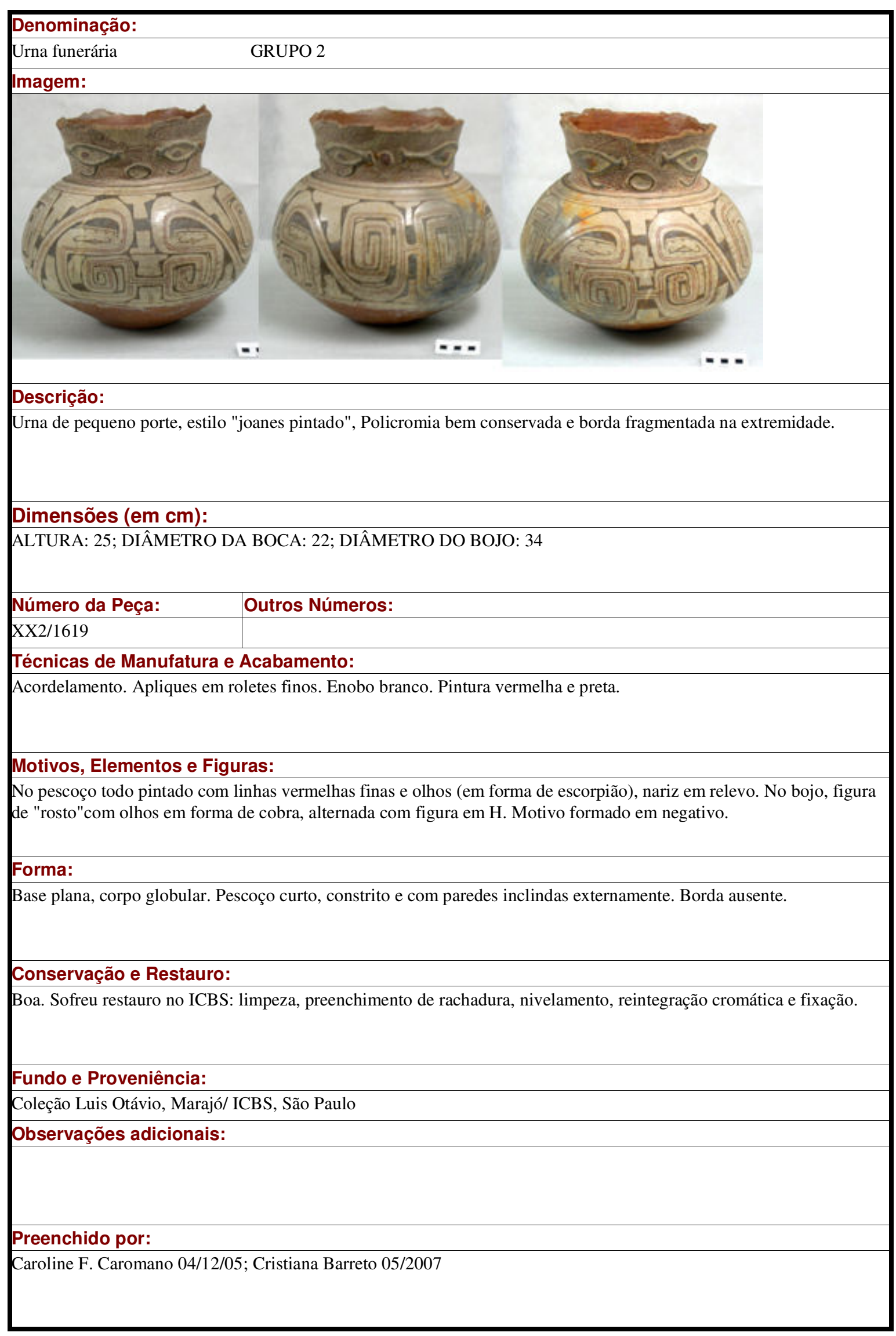




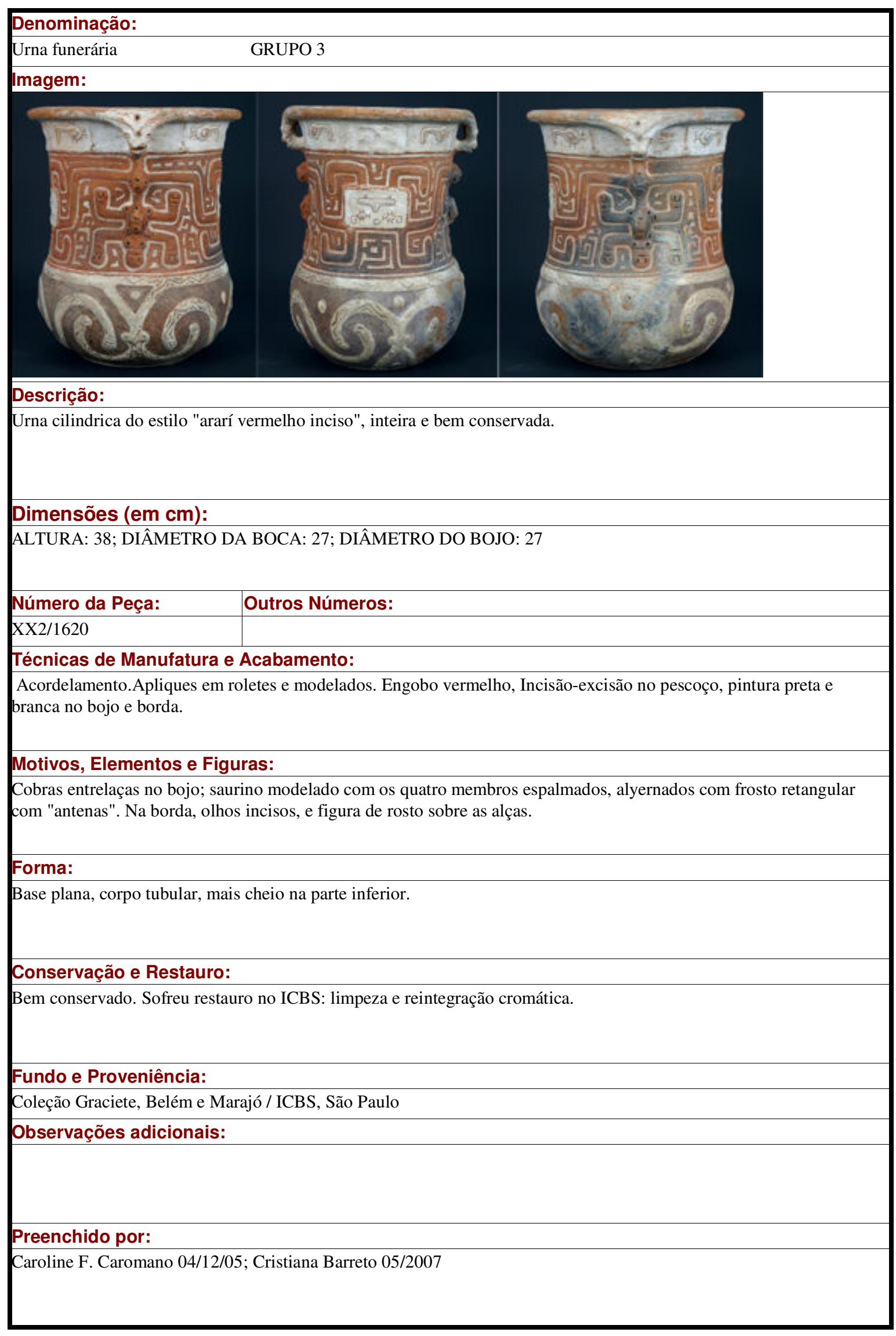




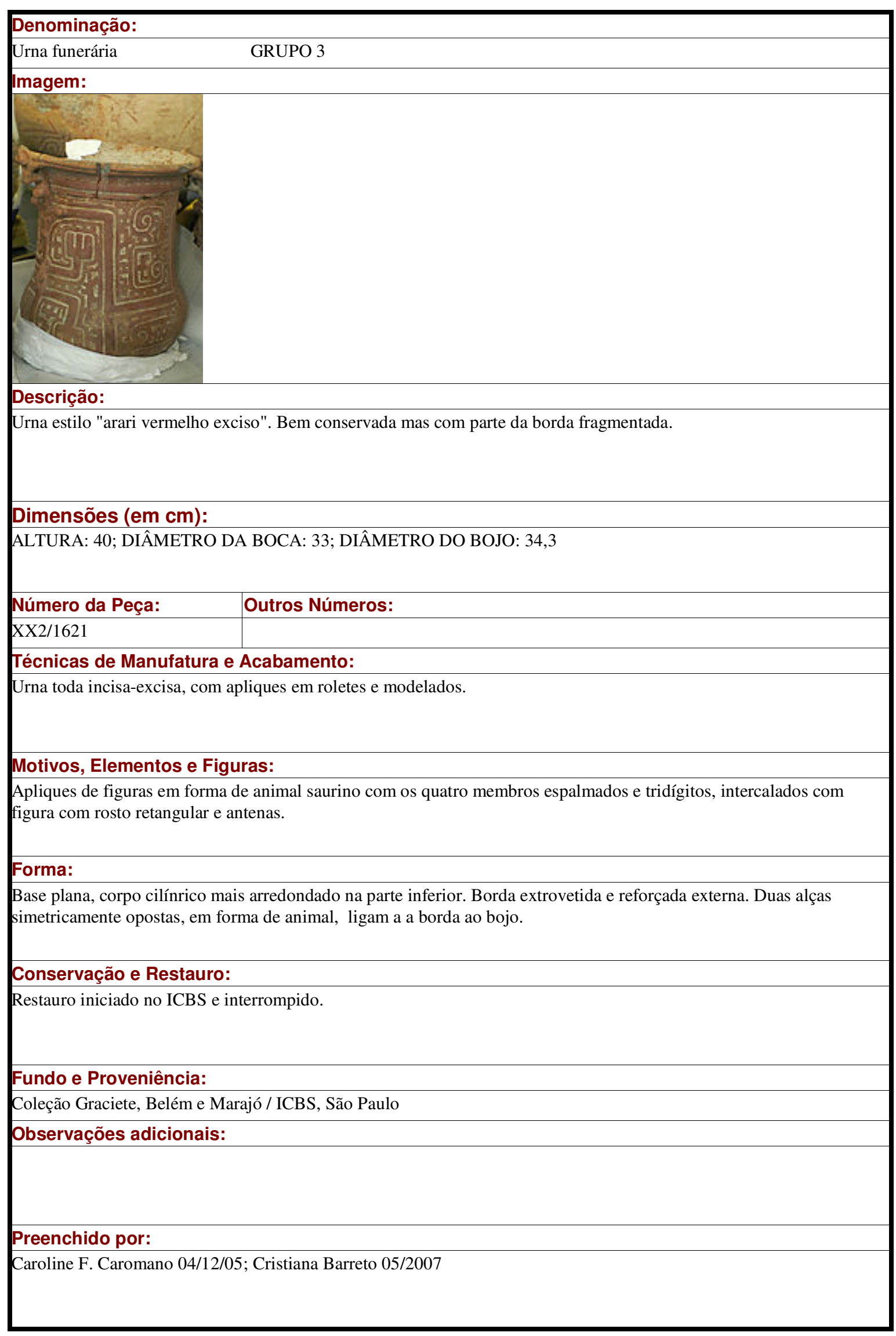




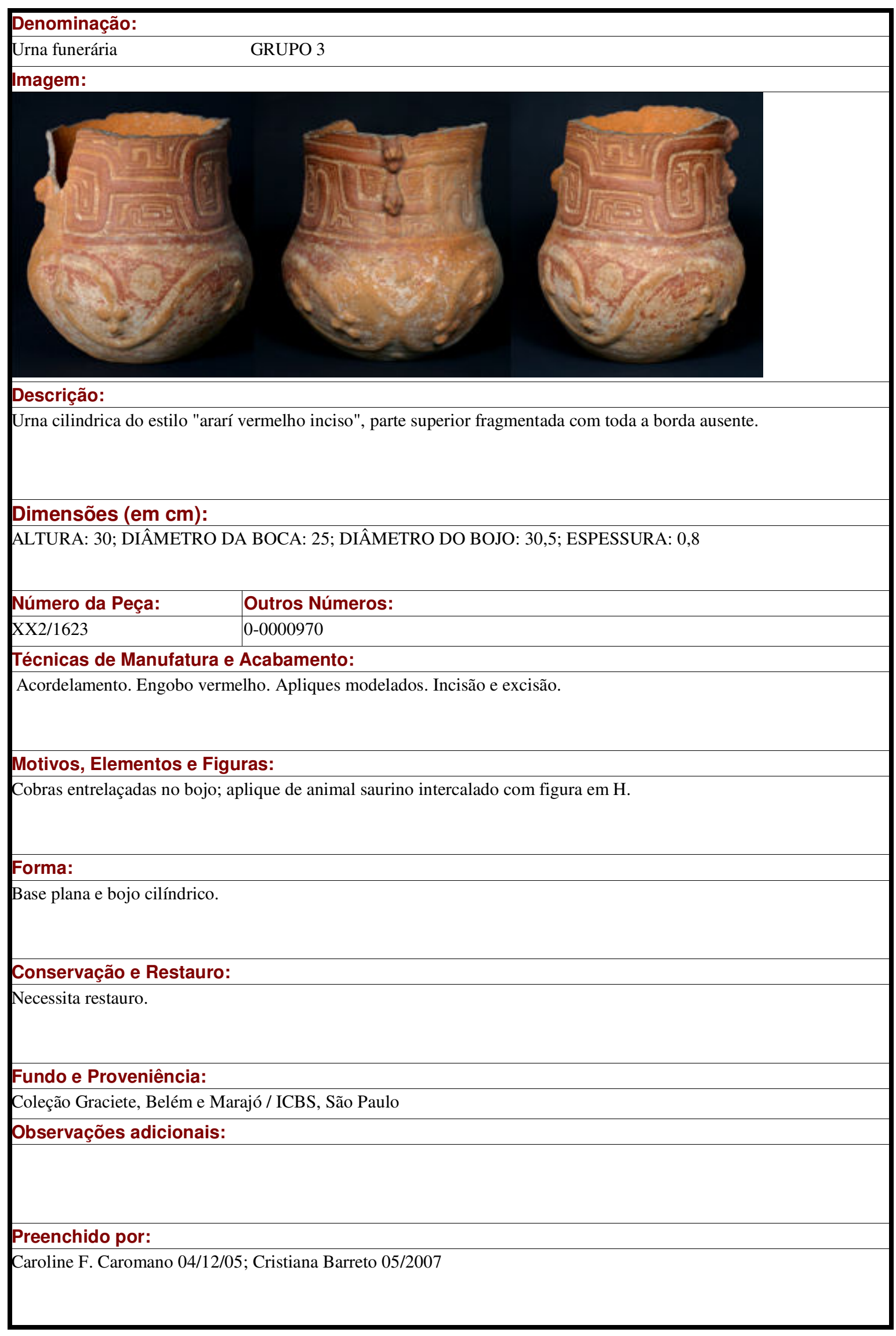




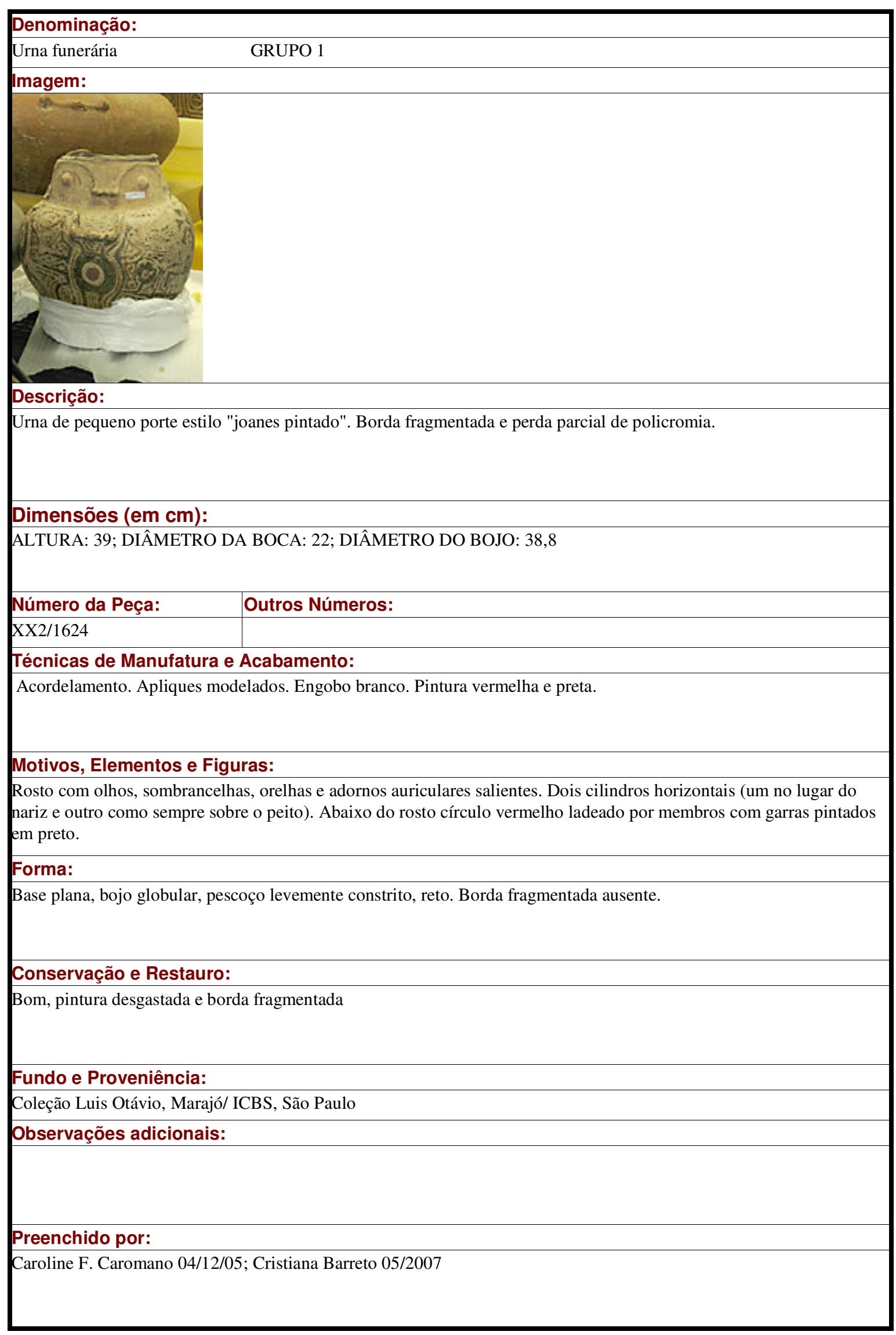




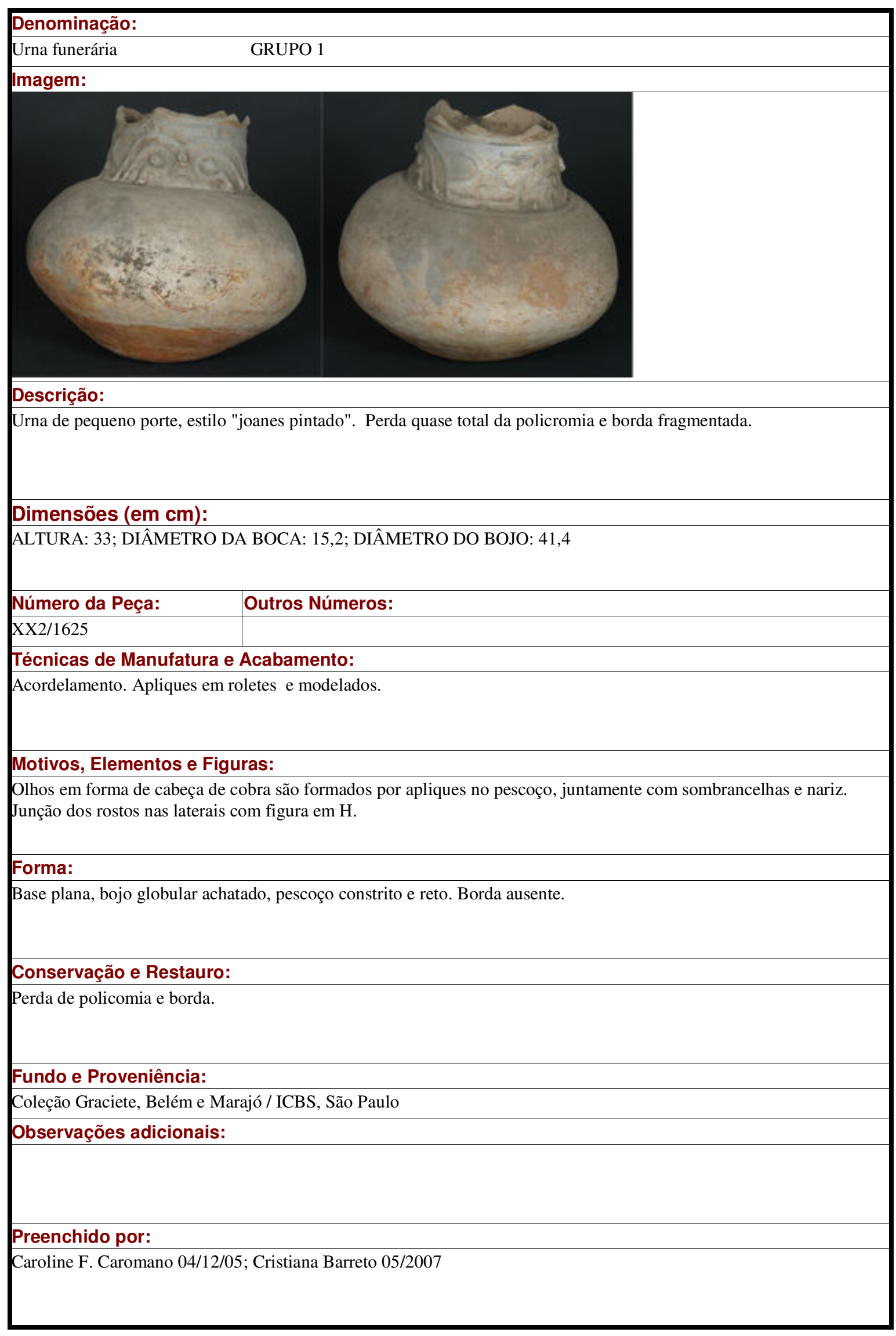




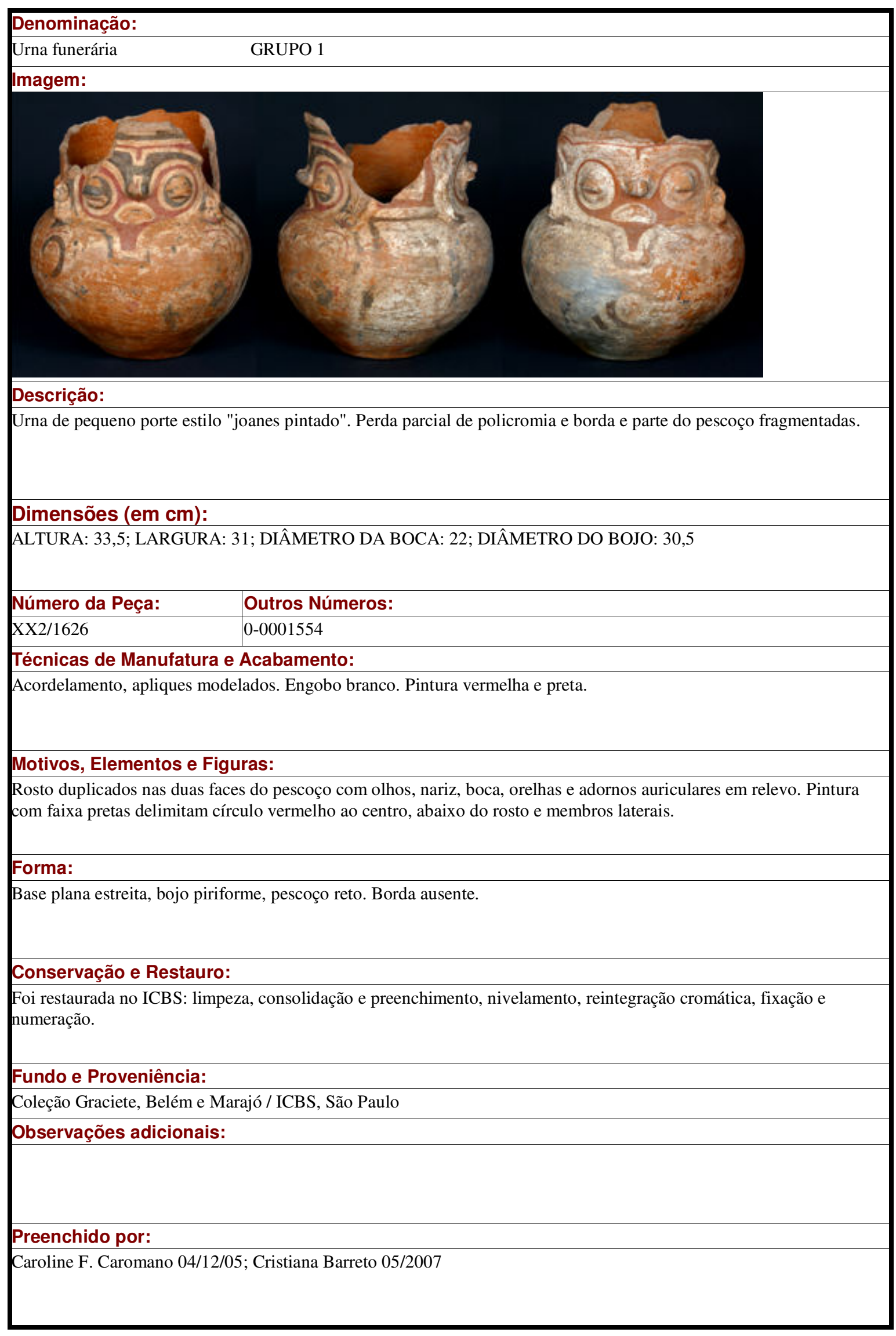




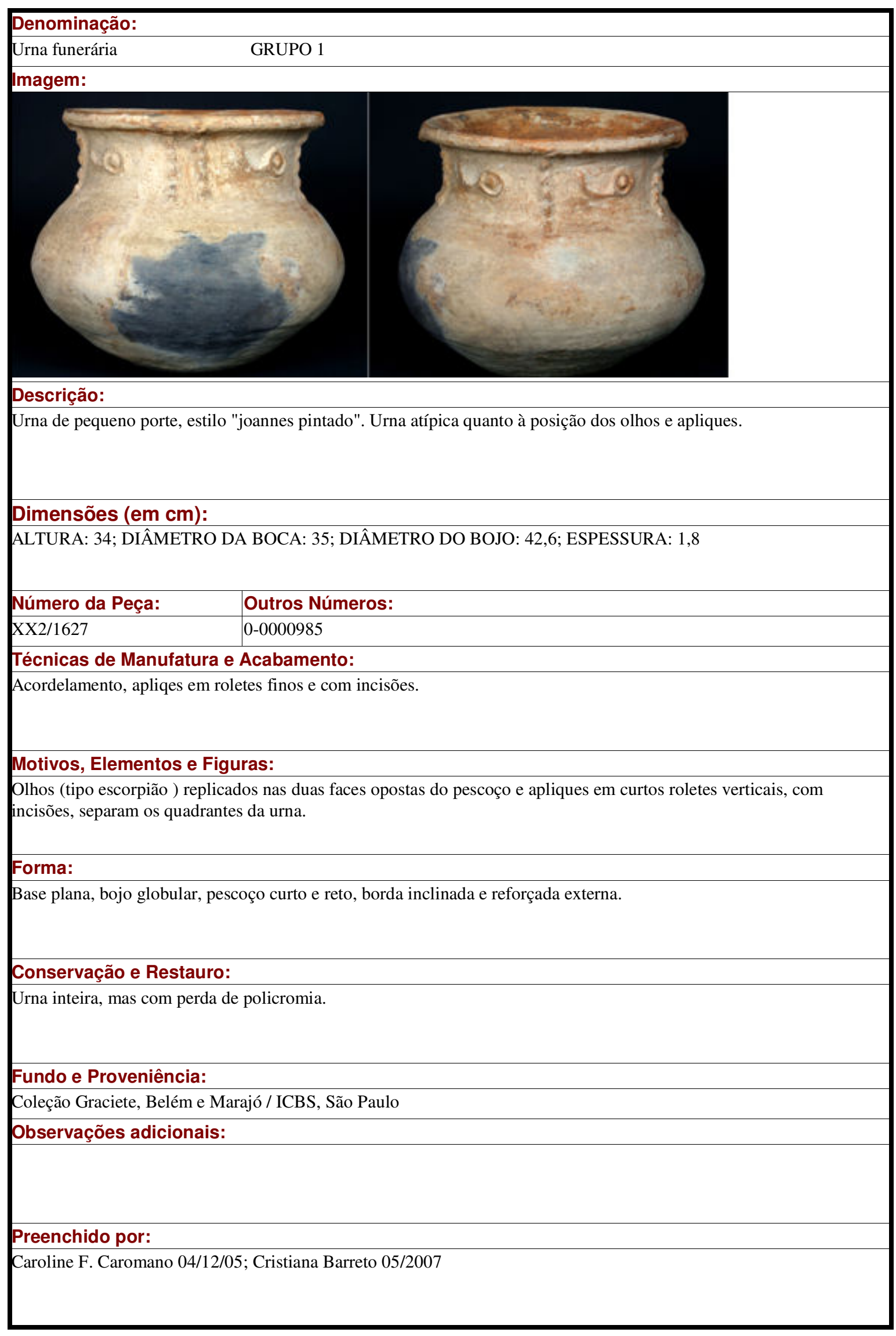




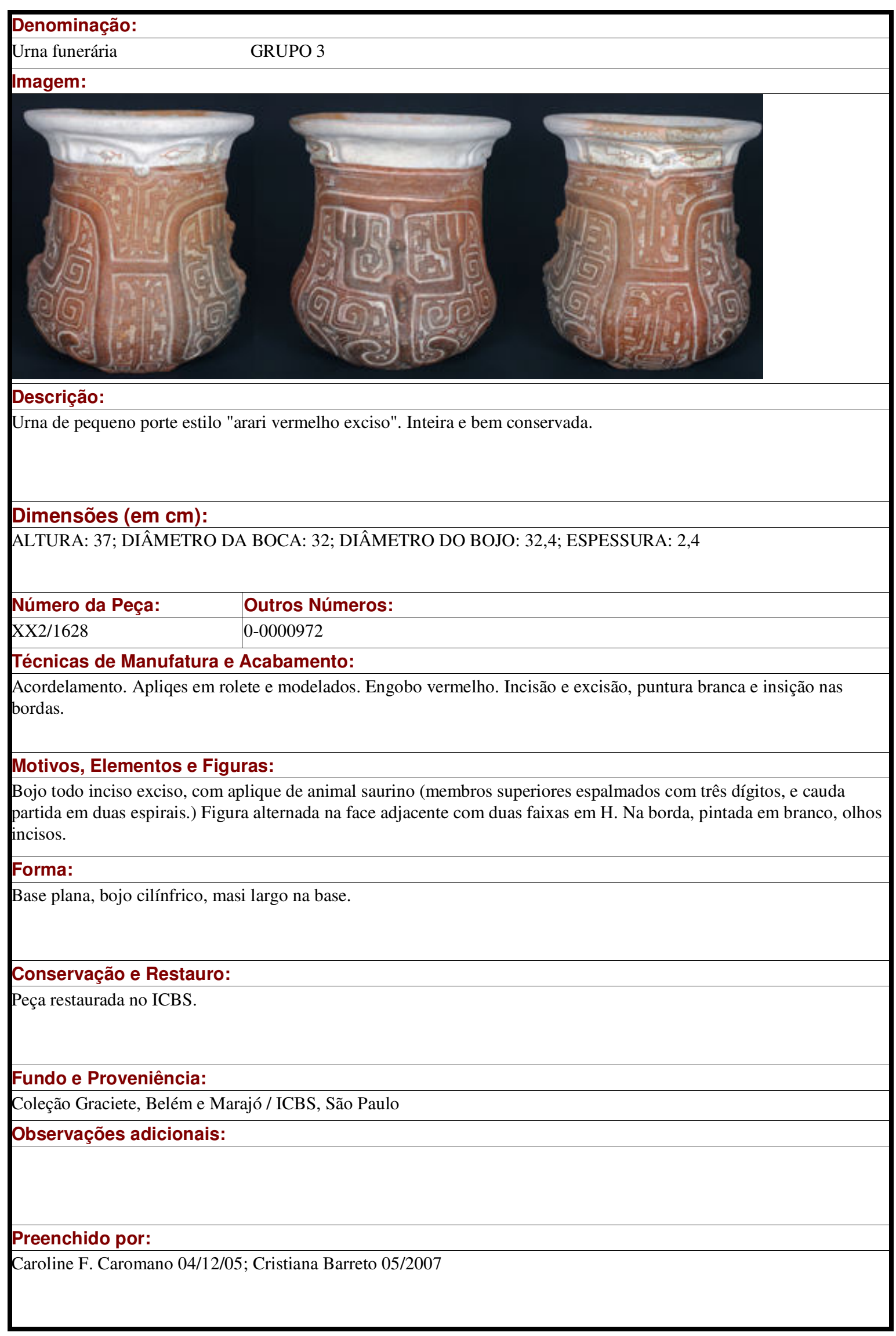




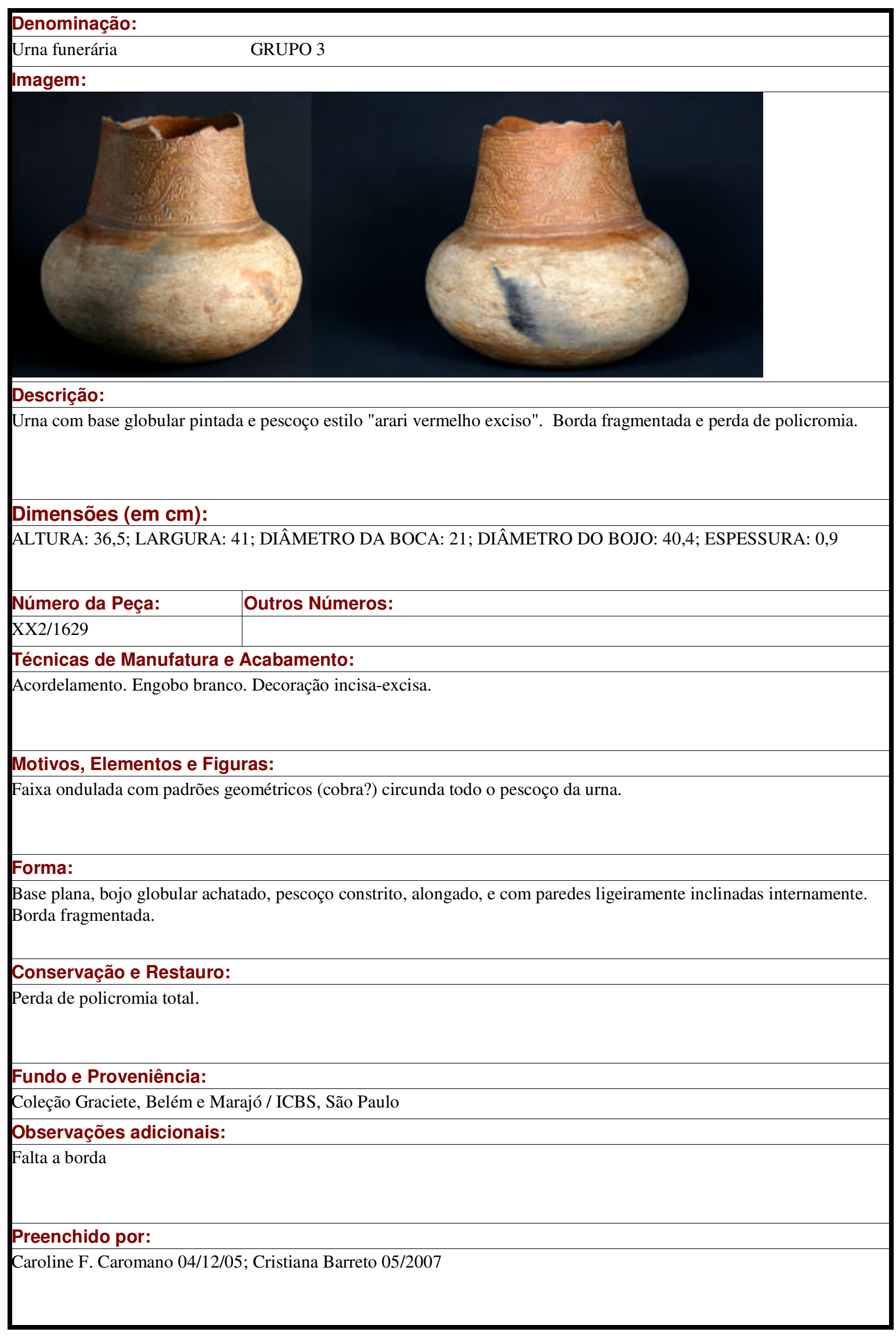




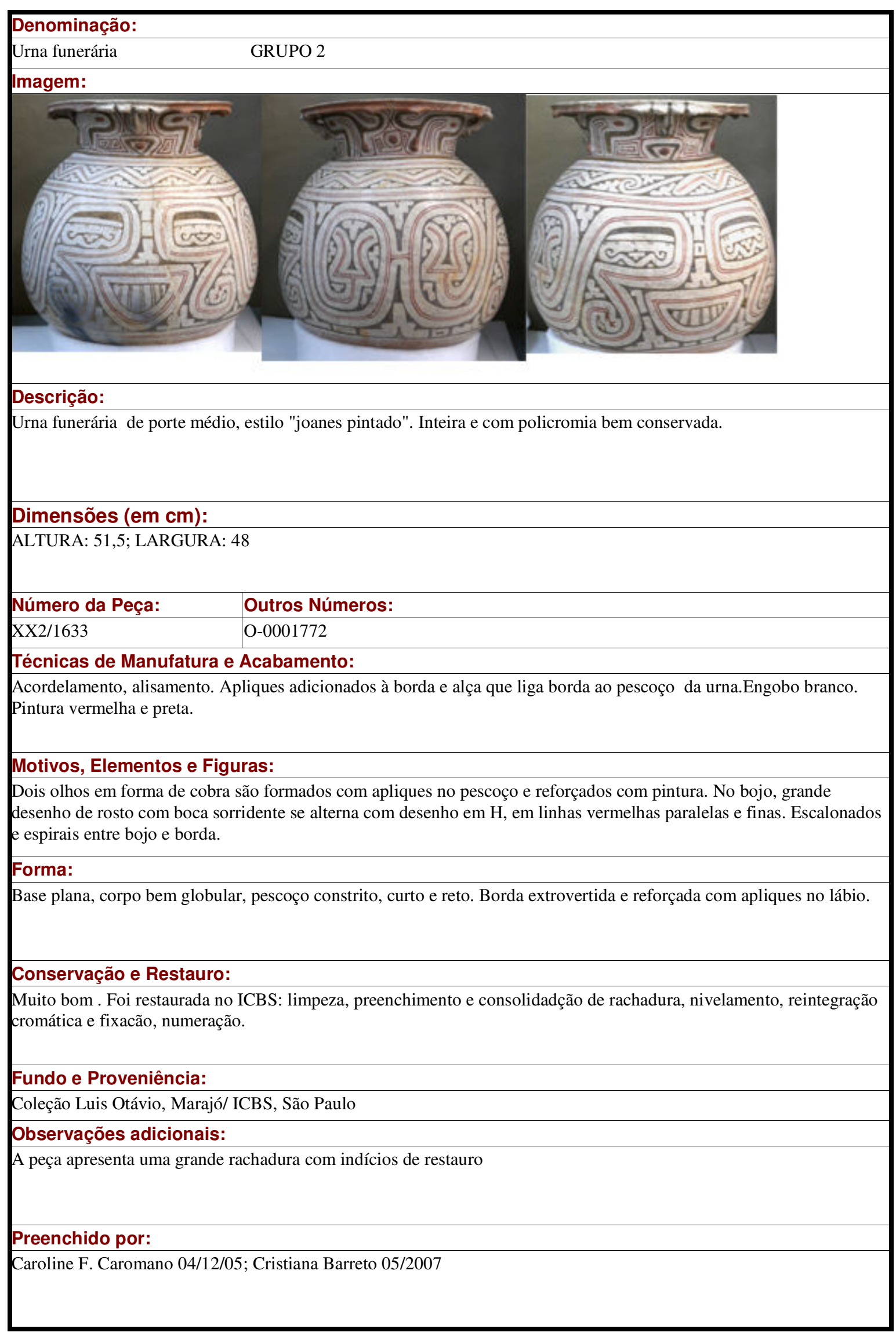




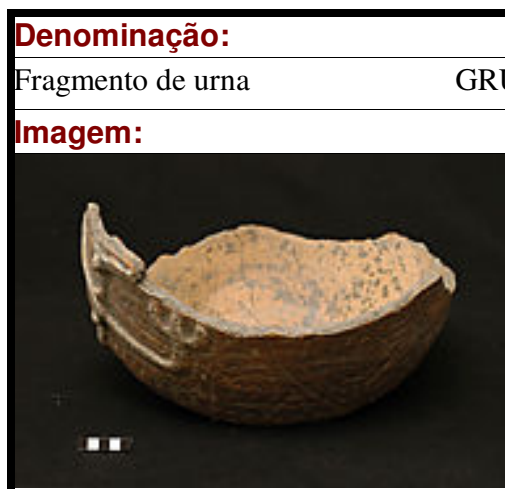

\section{Descrição:}

Fragmento de urna tipo "ararí vermelho exciso". Base plana, carenada, apêndice modelado com figura zoomorfa.

\section{Dimensões (em cm):}

ALTURA PARCIAL: 24,1; DIÂMETRO DA BASE: 13

Número da Peça:

\section{Outros Números:}

XX2/1634

Técnicas de Manufatura e Acabamento:

Incisão, excisão, vestígio de pintura branca sobre engobo vermelho.

Motivos, Elementos e Figuras:

Aplique em forma de figura zoomorfa com garras em tridígitos.

Forma:

Base plana, bojo cilíndrico.

Conservação e Restauro:

Fundo e Proveniência:

Não identificada/ ICBS

Observações adicionais:

Preenchido por:

Sandra L. Campos, 6/12/2005 C. Barreto 03/2007 